\title{
Synthesis of Helical and Bowl-Shaped Polycyclic Aromatic Compounds via Benzannulated Enyne-Allenes
}

\author{
Bo Wen \\ West Virginia University
}

Follow this and additional works at: https://researchrepository.wvu.edu/etd

\section{Recommended Citation}

Wen, Bo, "Synthesis of Helical and Bowl-Shaped Polycyclic Aromatic Compounds via Benzannulated Enyne-Allenes" (2010). Graduate Theses, Dissertations, and Problem Reports. 4671.

https://researchrepository.wvu.edu/etd/4671

This Dissertation is protected by copyright and/or related rights. It has been brought to you by the The Research Repository @ WVU with permission from the rights-holder(s). You are free to use this Dissertation in any way that is permitted by the copyright and related rights legislation that applies to your use. For other uses you must obtain permission from the rights-holder(s) directly, unless additional rights are indicated by a Creative Commons license in the record and/ or on the work itself. This Dissertation has been accepted for inclusion in WVU Graduate Theses, Dissertations, and Problem Reports collection by an authorized administrator of The Research Repository @ WVU.

For more information, please contact researchrepository@mail.wvu.edu. 


\title{
Synthesis of Helical and Bowl-Shaped Polycyclic Aromatic Compounds via Benzannulated Enyne-Allenes
}

\author{
Bo Wen \\ Dissertation submitted to the Eberly College of Arts and Sciences \\ at West Virginia University \\ in partial fulfillment of the requirements \\ for the degree of \\ Doctor of Philosophy \\ in \\ Organic Chemistry
}

Approved by

Kung K. Wang, Ph. D., Chair

Jeffrey L. Petersen, Ph. D.

Björn C. Söderberg, Ph. D.

Peter M. Gannett, Ph. D.

Xiaodong Shi, Ph. D.

C. Eugene Bennett Department of Chemistry

Morgantown, West Virginia

2010

Keywords: Enyne-Allene, Schmittel Cyclization, 4,5-Diheteroarylphenanthrene

1,4-Naphthoquinone Methide, Buckybowl

Copyright 2010 Bo Wen 


\section{ABSTRACT \\ Synthesis of Helical and Bowl-shaped Polycyclic Aromatic Compounds via Benzannulated Enyne-Allenes}

\section{BO WEN}

The cascade radical cyclization of the benzannulated enyne-allenes provides an efficient synthetic pathway to a variety of polycyclic aromatic hydrocarbons. Three indeno-fused 4,5-diheteroarylphenanthrenes were synthesized by thermolysis of corresponding benzannulated enyne-allenes. Its X-ray structure shows that the substituents at C4 and C5 positions of the phenanthryl system are essentially parallel to each other and cause severe helical twist of the structures. The presence of two terpyridyl units in 2.2c allowed it to be used as a ligand for the synthesis of dinuclear ruthenium(II) bis(terpyridine) complexes possessing severe helical twists.

Several 1,4-naphthoquinone methides were synthesized via an unusual acid-catalyzed cascade cyclization sequence followed by two-carbon ring expansion of benzannulated enediynyl alcohols. The simplicity of the synthetic sequence and the mildness of the reaction condition make this pathway especially attractive.

A new synthetic route to a bowl-shaped aromatic hydrocarbon 4.87 was developed. The key steps of this efficient pathway include a cascade cyclization of the corresponding enyne-allene and subsequent palladium-catalyzed intramolecular arylation reactions of the aromatic dibromides. Sever attempts were made to synthesize a precursor of buckybowl 4.54. The suitable precursor will bear a framework of 4.54 and could be fully aromatized to form 4.54. Further exploration is required to overcome difficulties encountered toward the synthesis of buckybowl 4.54. 


\title{
DEDICATED TO
}

\author{
My wife, Ting Zhao, My daughter, Hannah \\ and My Parents
}




\section{Acknowledgements}

I am heartily thankful to my advisor Professor Kung K. Wang. His guidance equipped me with skills and abilities to accomplish this dissertation and pursue a chemistry career as an independent synthetic chemist.

I wish to express my gratitude to Dr. Jeffrey L. Petersen, Dr. Björn C. Söderberg, Dr. Peter M. Gannett, and Dr. Xiaodong Shi for taking time to serve as faculty members in my committee. They have challenged me to expand my knowledge and think in a logical way. My special thanks go to Dr. Jeffrey L. Petersen for his help with the X-ray structure analyses of the compounds synthesized in my research.

I would like to thank the former and present members of the Professor Wang's group for their friendship and assistance throughout these years. Special thanks to Dr Weixiang Dai, Dr Hua Yang, and Dr. Daehwan Kim for their time and efforts to help me with my research.

I also appreciate all the other faculties, staff, and students at WVU who have taught me and helped me during my Ph.D. studies. I wish to thank Dr. Novruz Akhmedov for assistance in NMR experiments for structural characterization in my research. I also want to express my gratitude to Dr Mingde Shan for his assistance.

I wish to acknowledge financial support from the Eberly College of Arts and Sciences at WVU and C. Eugene Bennett Chemistry Department at WVU.

Finally, I would like to express my appreciation to the support from my family. My parents and my little brother give me endless love and encouragement over my life. My daughter, Hannah Wen, brings a lot of happiness to my life. My wife, Ting Zhao, has given me boundless love, constant help, and encouragement throughout my chemistry career. Without their love and encouragement, I would not be where I am today. 


\section{TABLE OF CONTENTS}

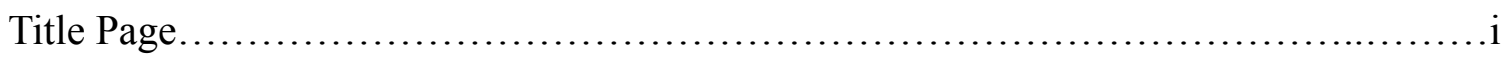

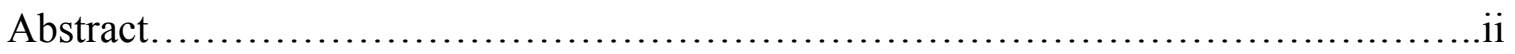

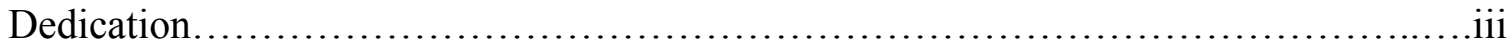

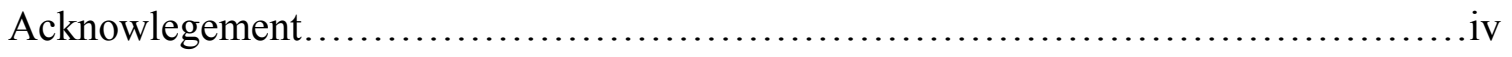

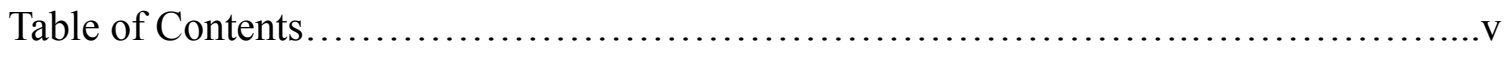

List of Figures...................................................................

List of ${ }^{1} \mathrm{H}$ and ${ }^{13} \mathrm{C}$ NMR Spectra..........................................................

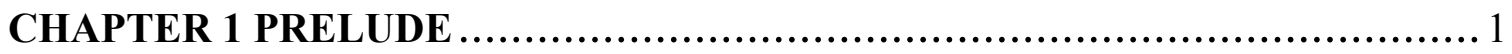

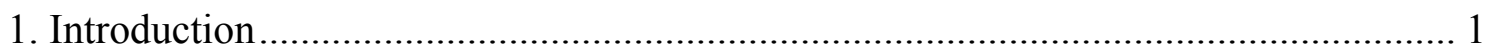

2. The thermal cyclization of enediynes and enyne-allenes............................................ 1

3. The synthetic methodologies for the preparation of benzannulated enyne-allenes ...... 5

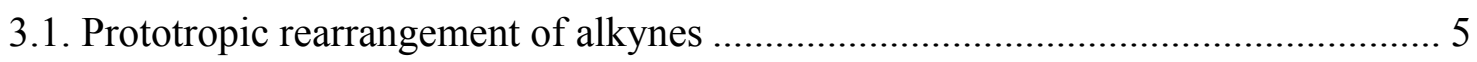

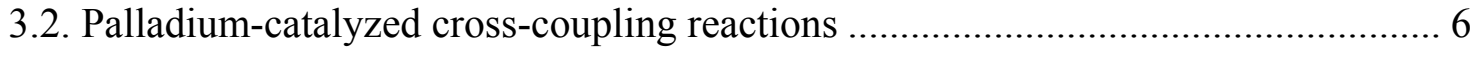

3.3. Rearrangement of propargylic alcohol derivatives..................................................... 7

4. Construction of novel polycyclic aromatic hydrocarbons via the Schmittel cyclization

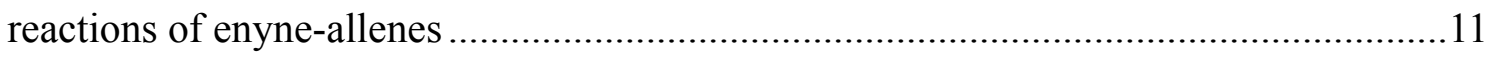

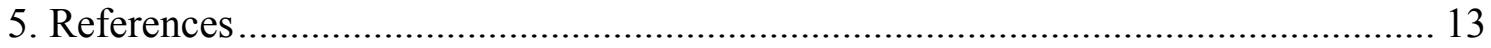

CHAPTER 2 SYNTHESIS OF 4,5-DIHETEROARYLPHENANTHRENES AND THEIR DINUCLEAR RU(II) BIS(2,2':6',2"-TERPYRIDINE) COMPLEXES POSSESSING SEVERE HELICAL TWISTS ..................................... 16 
1. Synthesis and structure characterization of 4,5-diheteroaryl-phenanthrenes compounds that possess sever helical twists........................................................ 16

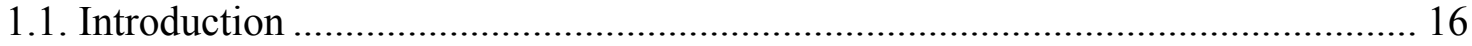

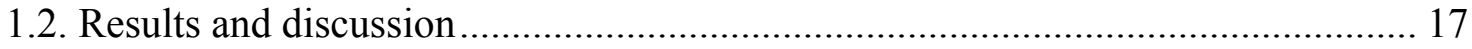

2. Synthesis and structure analysis of dinuclear ruthenium(II) bis(terpyridine) complexes 21

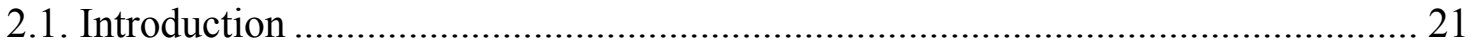

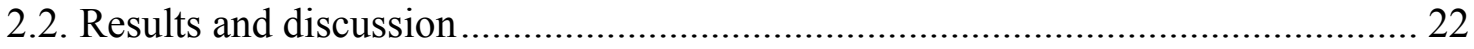

3. Synthesis of pyridine, bipyridine, terpyridine ligands used in the helical twist compounds. 26

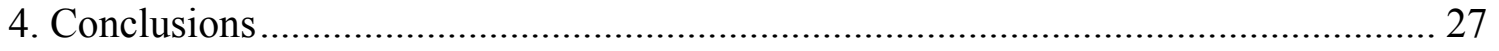

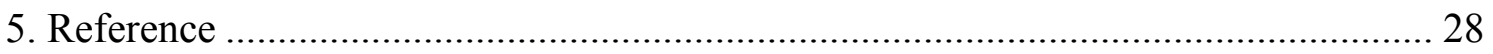

CHAPTER 3 SYNTHETHESIS OF 1,4-NAPHTHOQUINONE METHIDES VIA ACID-CATALYZED CASCADE CYCLIZATIONS OF THE BENZANNULATED

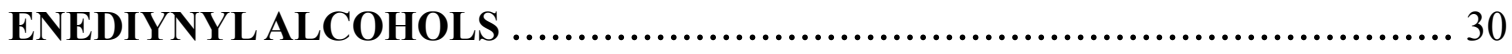

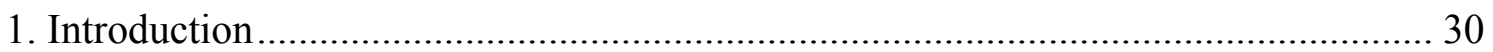

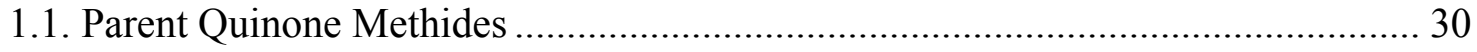

1.2. Properties and Synthetic Applications of Quinone Methides ............................. 31

1.3. Synthetic method used to generate quinone methides ...................................... 33

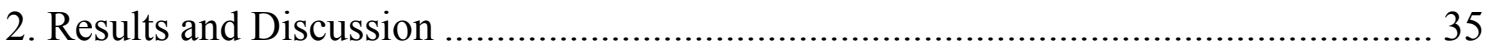

2.1. The synthesis of 1 , 4 -naphthoquinone methides ................................................. 35

2.2. The properties of $1,4-$ naphthoquinone methides .......................................... 39

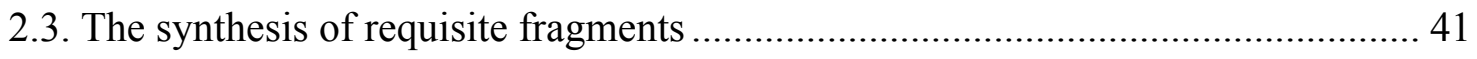


3. Conclusion

4. Reference

\section{CHAPTER 4. SYNTHESIS OF BOWL-SHAPED FULLERENE FRAGMENTS

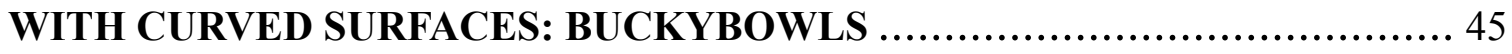

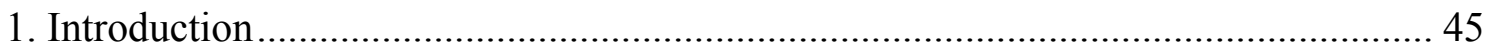

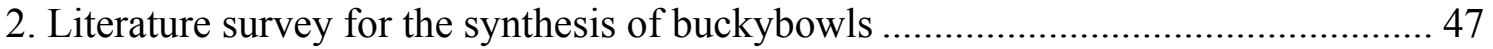

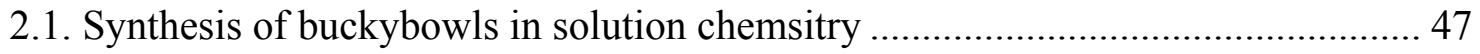

2.2. Synthesis of buckybowls by flash vacuum pyrolysis ....................................... 51

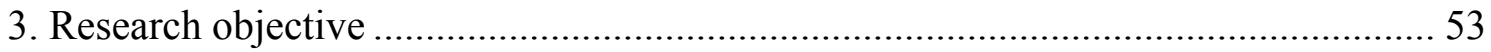

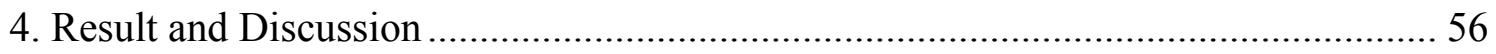

4.1. Retrosynthetic Analysis for Buckybow1 4.54 ............................................... 56

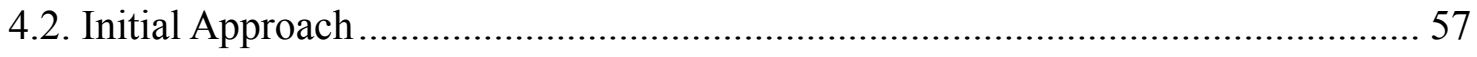

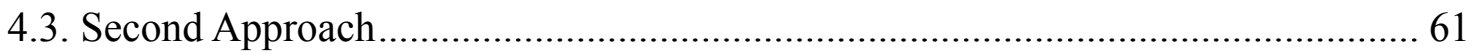

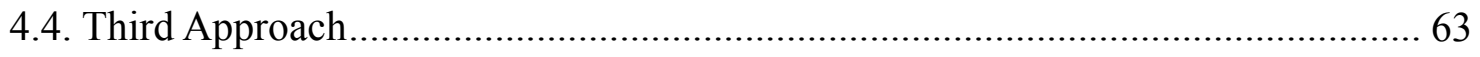

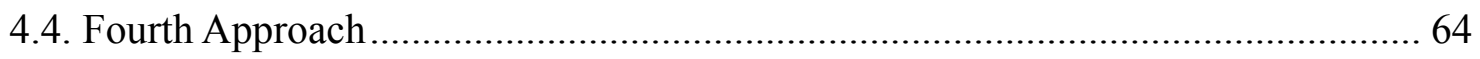

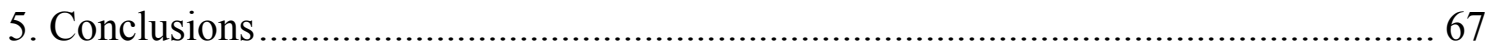

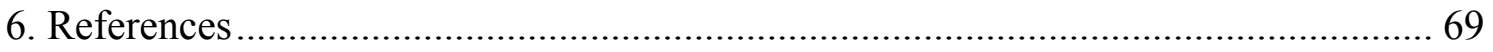

CHAPTER 5. EXPERIMENT SECTION ........................................ 74

Experimental Methods.................................................... 75

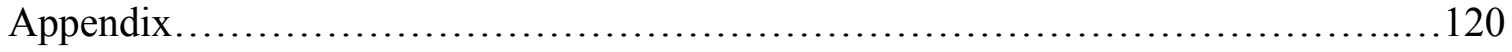

Publications \& Presentations................................................ 280 


\section{LIST OF FIGURES}

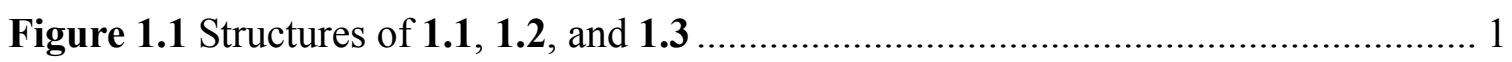

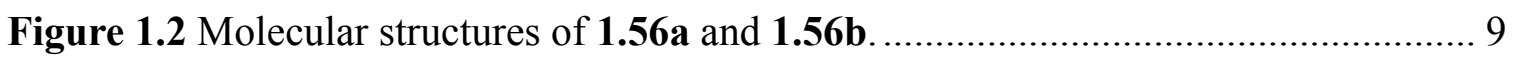

Figure 2.1 Structures of 4,5-disubstituted phenanthrenes ........................................ 17

Figure 2.2 ${ }^{1} \mathrm{H}$ NMR spectrum of the 4,5-di(4-pyridyl)phenanthrene 2.2a...................... 19

Figure 2.3 ORTEP drawings of the crystal structures of 2.2a and 2.2c. ....................... 20

Figure 2.4 (a) UV-vis absorption spectra and (b) luminescence spectra of 2.2a (black), 2.2b (red), and 2.2c (blue) in dichloromethane at room temperature............................. 21

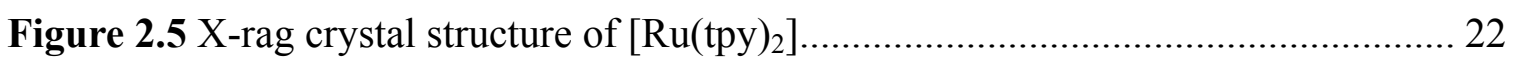

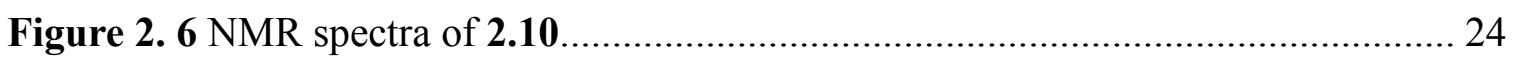

Figure 2.7 UV-vis absorption spectra of $\mathbf{2 . 1 3}$ (black), 2.14 (red), and [Ru(4'-EtOtpy) $)_{2}$ $\left(\mathrm{PF}_{6}\right)_{2}($ blue $)$ in acetonitrile at room temperature..................................................... 25

Figure 3.1 The structures of parent quinone methides.............................................. 30

Figure 3.2 Structures of stabilized $p$-QMs. ........................................................... 35

Figure 3.3 The scope and limitation of the new synthetic pathway for QMs ................ 37

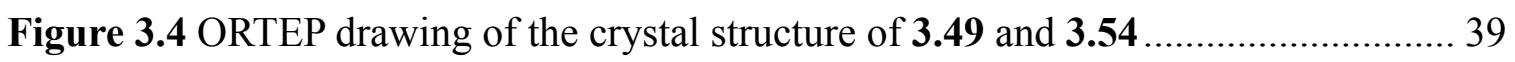

Figure 3.5 UV-vis absorption sepectra of 3.49, 3.50, 3.54, and 3.57 in $\mathrm{CH}_{3} \mathrm{CN}$.......... 40

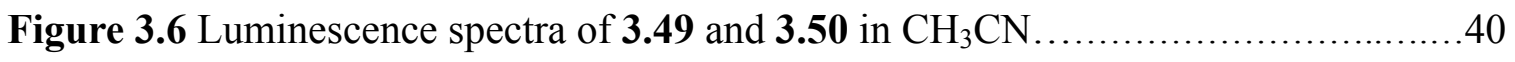

Figure 3.7 UV-vis absorption sepectra of 3.49 in $\mathrm{CH}_{3} \mathrm{CN}$ with varying $\mathrm{H}_{2} \mathrm{SO}_{4}$

concentration. 40

Figure 3.8 UV-vis absorption sepectra of 3.49, 3.50, 3.54, and 3.57 in $\mathrm{CH} 3 \mathrm{CN}$ with acid .40

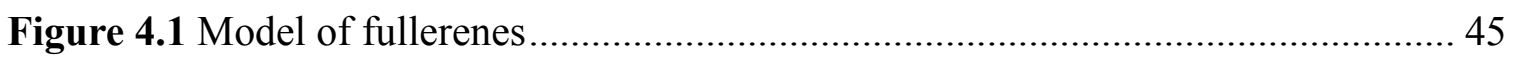

Figure 4.2 Bowl-shaped polycyclic aromatic hydrocarbons.................................... 46

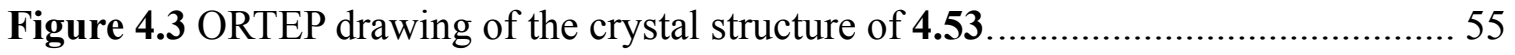

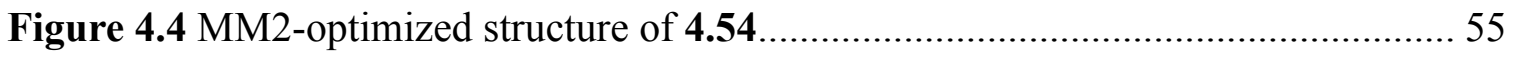


Figure 4.5 POAV angles of fullerene and buckybowls. ........................................... 55

Figure 4.6 Proposed application of buckybowl 4.54............................................. 56

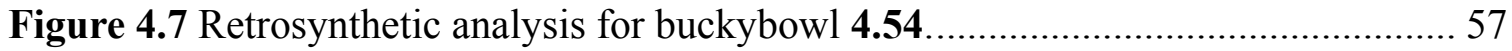

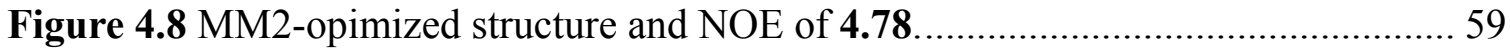

Figure 5.1 ORTEP drawings of the crystal structures of two diastereomers of 2.8a.....118

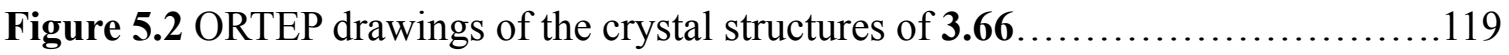

Figure 5.3 ORTEP drawings of the crystal structures of $4.97 \ldots \ldots \ldots \ldots \ldots \ldots \ldots \ldots \ldots \ldots$

\section{LIST OF ${ }^{1} \mathrm{H}$ AND ${ }^{13} \mathrm{C}$ NMR SPECTRA}

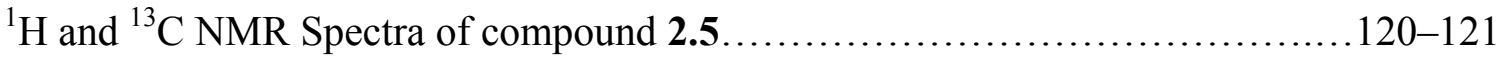

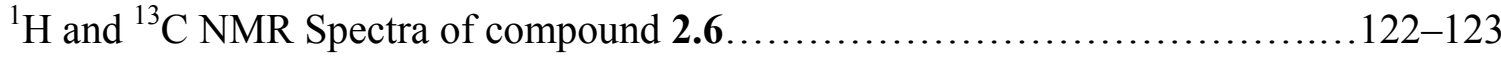

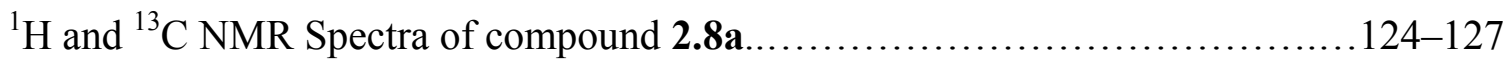

${ }^{1} \mathrm{H}$ and ${ }^{13} \mathrm{C}$ NMR Spectra of compound 2.2a..............................128-129

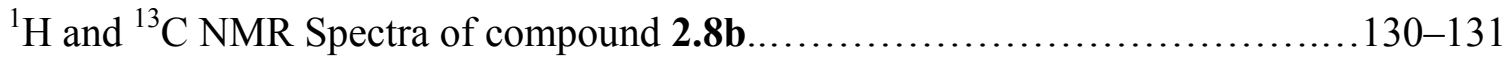

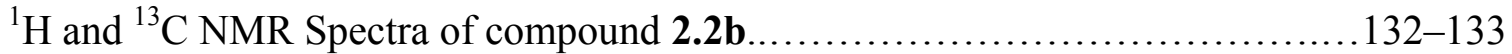

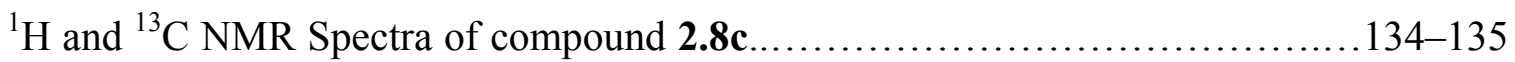

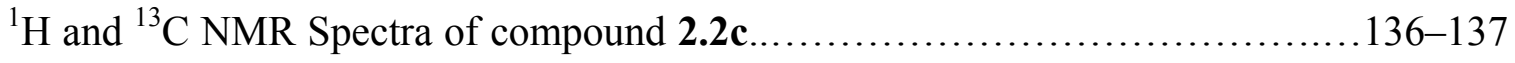

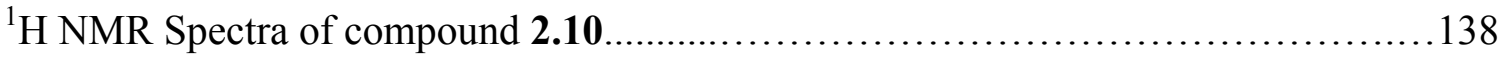

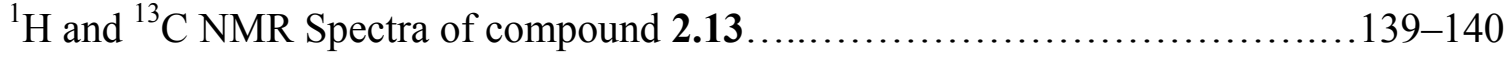

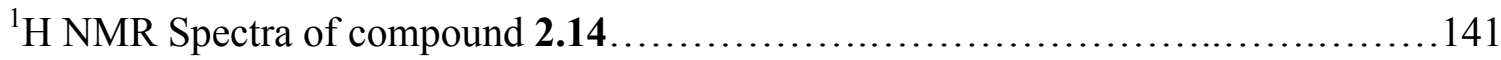

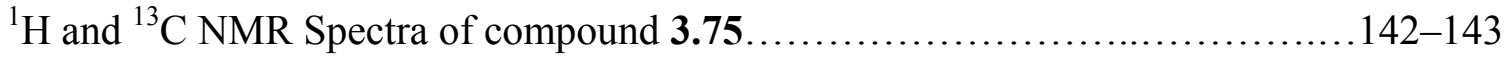

${ }^{1} \mathrm{H}$ and ${ }^{13} \mathrm{C}$ NMR Spectra of compound 3.43 ..............................144-145

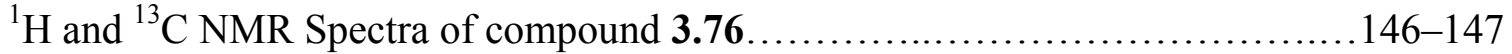

${ }^{1} \mathrm{H}$ and ${ }^{13} \mathrm{C}$ NMR Spectra of compound 3.44 ..................................

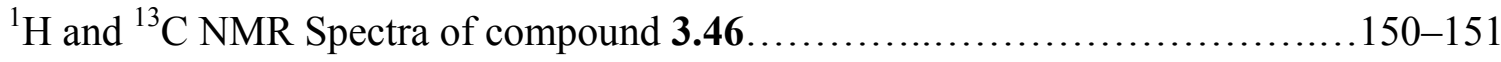

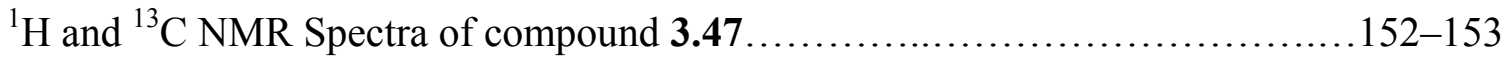


${ }^{1} \mathrm{H}$ and ${ }^{13} \mathrm{C}$ NMR Spectra of compound 3.48..............................154-155

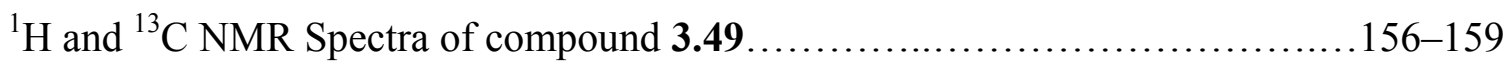

${ }^{1} \mathrm{H}$ and ${ }^{13} \mathrm{C}$ NMR Spectra of compound 3.50.................................

${ }^{1} \mathrm{H}$ and ${ }^{13} \mathrm{C}$ NMR Spectra of compound 3.53 ....................................

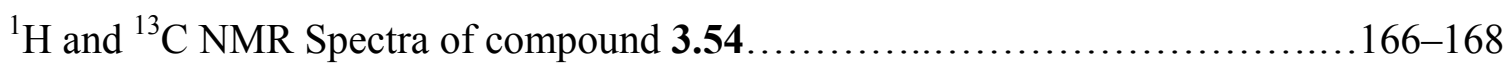

${ }^{1} \mathrm{H}$ and ${ }^{13} \mathrm{C}$ NMR Spectra of compound 3.81 ..................................

${ }^{1} \mathrm{H}$ and ${ }^{13} \mathrm{C}$ NMR Spectra of compound 3.55 .................................

${ }^{1} \mathrm{H}$ and ${ }^{13} \mathrm{C}$ NMR Spectra of compound 3.56...............................173-174

${ }^{1} \mathrm{H}$ and ${ }^{13} \mathrm{C}$ NMR Spectra of compound 3.57...................................

${ }^{1} \mathrm{H}$ and ${ }^{13} \mathrm{C}$ NMR Spectra of compound 3.59.................................

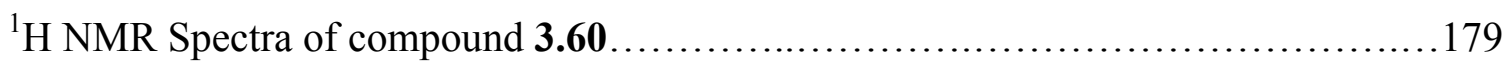

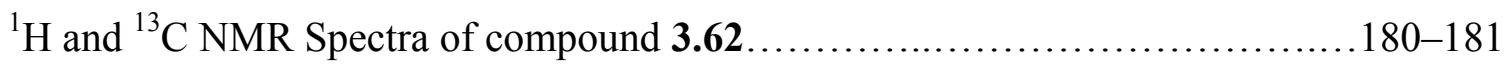

${ }^{1}$ H NMR Spectra of compound 3.63 ........................................... 182

${ }^{1} \mathrm{H}$ and ${ }^{13} \mathrm{C}$ NMR Spectra of compound 3.65 ..................................

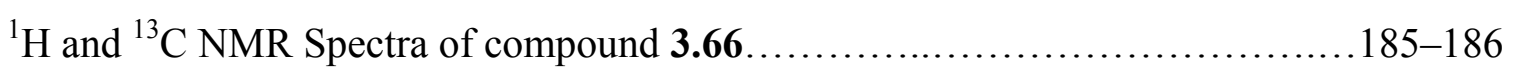

${ }^{1} \mathrm{H}$ and ${ }^{13} \mathrm{C}$ NMR Spectra of compound 3.68 ................................ 187-188

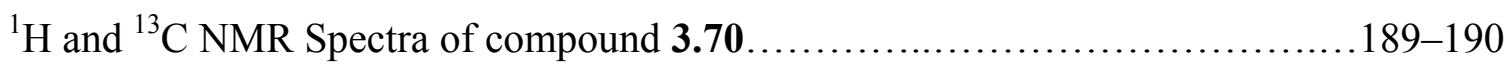

${ }^{1} \mathrm{H}$ and ${ }^{13} \mathrm{C}$ NMR Spectra of compound 3.71 ....................................

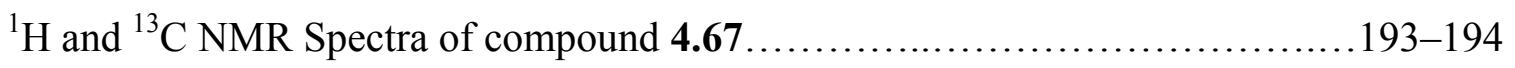

${ }^{1} \mathrm{H}$ and ${ }^{13} \mathrm{C}$ NMR Spectra of compound 4.68.............................. 195-196

${ }^{1} \mathrm{H}$ and ${ }^{13} \mathrm{C}$ NMR Spectra of compound 4.71..................................

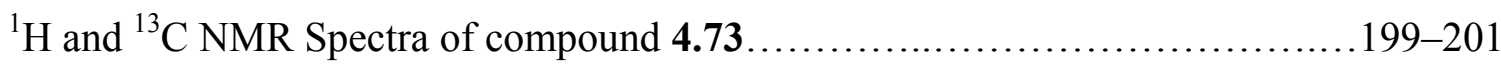

${ }^{1} \mathrm{H}$ and ${ }^{13} \mathrm{C}$ NMR Spectra of compound 4.74 ..............................202-203

${ }^{1} \mathrm{H}$ and ${ }^{13} \mathrm{C}$ NMR Spectra of compound 4.76 ..............................204-205

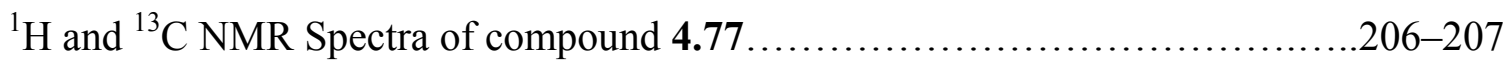

${ }^{1} \mathrm{H}$ and ${ }^{13} \mathrm{C}$ NMR Spectra of compound 4.78 .................................208-209

gCosy and ${ }^{1} \mathrm{H}$ NMR Spectra of compound 4.78 ...............................210-211 


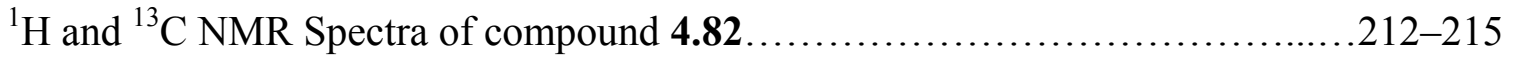

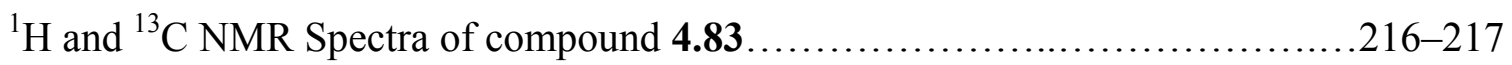

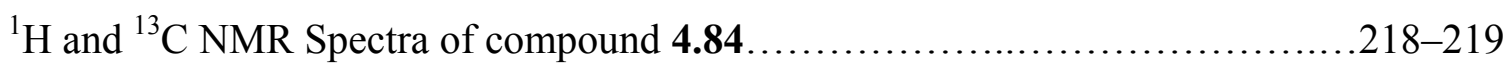

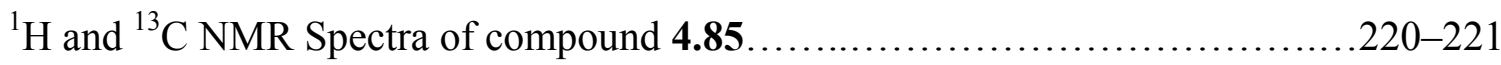

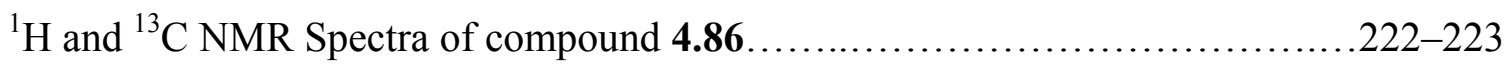

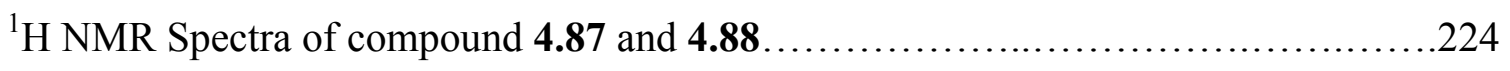

1 D NOESY NMR Spectra of compound 4.87 and $4.88 \ldots \ldots \ldots \ldots \ldots \ldots \ldots . . .225-226$

1 D TOCSY NMR Spectra of compound 4.87 and $4.88 \ldots \ldots \ldots \ldots \ldots \ldots \ldots \ldots . .227-228$

Seldecoupled ${ }^{1} \mathrm{H}$ NMR Spectra of compound 4.87.........................229-232

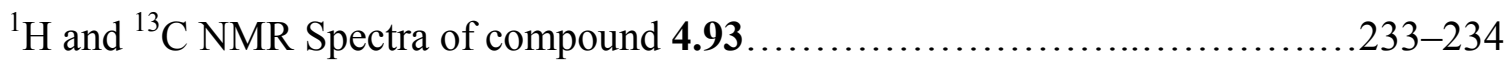

${ }^{1} \mathrm{H}$ and ${ }^{13} \mathrm{C}$ NMR Spectra of compound 4.94 ................................235-238

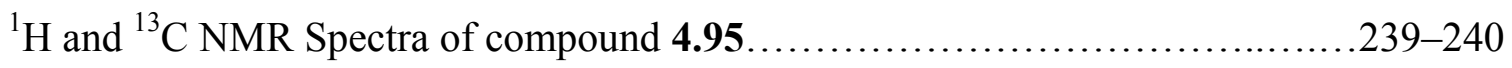

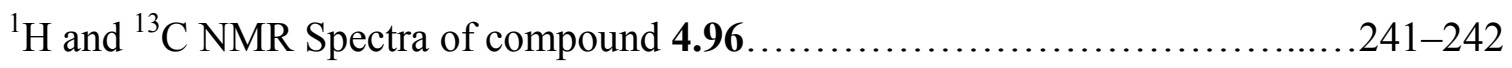

${ }^{1} \mathrm{H}$ and ${ }^{13} \mathrm{C}$ NMR Spectra of compound 4.97...............................243-244

${ }^{1} \mathrm{H}$ and ${ }^{13} \mathrm{C}$ NMR Spectra of compound 4.98 ................................245-246

${ }^{1} \mathrm{H}$ and ${ }^{13} \mathrm{C}$ NMR Spectra of compound 4.99 ...............................247-248

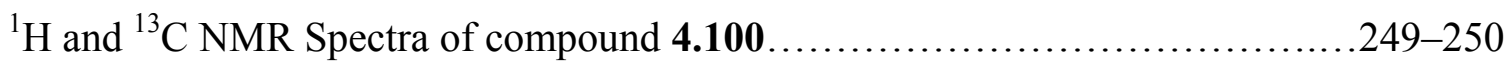

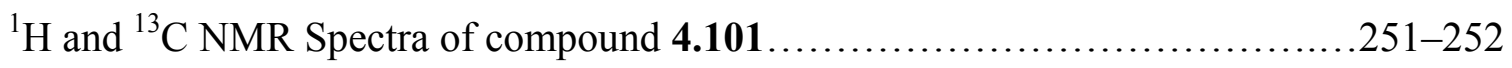

${ }^{1} \mathrm{H}$ and ${ }^{13} \mathrm{C}$ NMR Spectra of compound 4.103 ................................253-254

${ }^{1} \mathrm{H}$ and ${ }^{13} \mathrm{C}$ NMR Spectra of compound 4.104.............................255-256

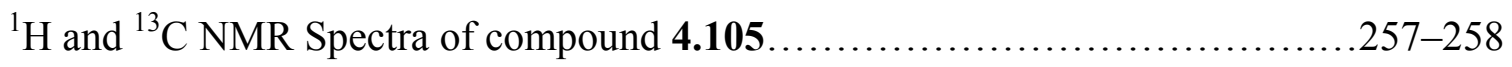

${ }^{1} \mathrm{H}$ and ${ }^{13} \mathrm{C}$ NMR Spectra of compound 4.106...............................259-260

${ }^{1} \mathrm{H}$ and ${ }^{13} \mathrm{C}$ NMR Spectra of compound 4.107................................261-262

${ }^{1} \mathrm{H}$ and ${ }^{13} \mathrm{C}$ NMR Spectra of compound 4.108.............................263-264

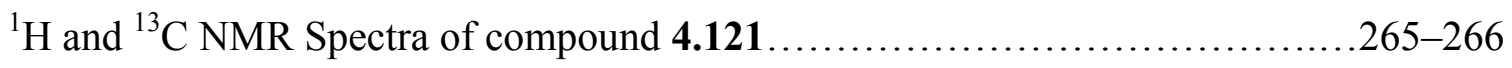

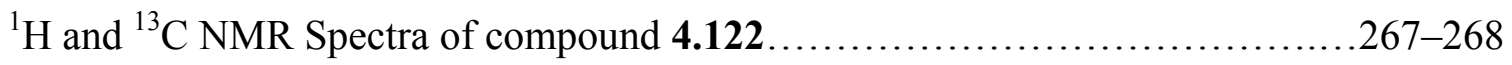

${ }^{1} \mathrm{H}$ and ${ }^{13} \mathrm{C}$ NMR Spectra of compound 4.123 ..............................269-270 


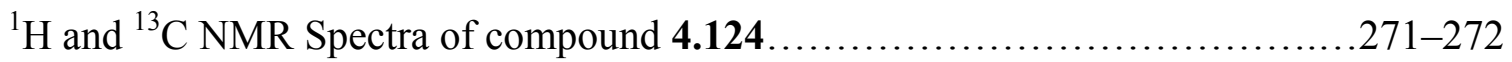

${ }^{1} \mathrm{H}$ and ${ }^{13} \mathrm{C}$ NMR Spectra of compound 4.126...............................273-274

${ }^{1} \mathrm{H}$ and ${ }^{13} \mathrm{C}$ NMR Spectra of compound 4.129................................275-276

${ }^{1} \mathrm{H}$ and ${ }^{13} \mathrm{C}$ NMR Spectra of compound 4.130..............................277-278

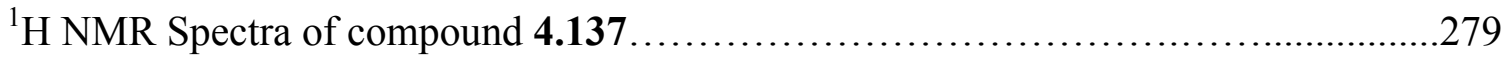




\section{CHAPTER 1}

\section{Prelude}

\section{Introduction}

Allenes have been known for more than 100 years to organic chemists. The correct core structure of allenes was predicted in 1874 by Jacobus H. Van'tHoff, ${ }^{1}$ the first Nobel laureate in chemistry. Interestingly, the aim in the first documented synthesis of an allene was to prove the non-existence of this class of "highly unstable" organic compounds. ${ }^{2,3}$ The cumulated diene system of allenes has been described as consisting of two double bonds with two $\pi$-orbitals perpendicular to each other. Over the past 20 years, the chemistry of allenes has developed rapidly because of their unusual properties, such as the axial chirality of the elongated tetrahedron and the various functionality. With multi-reactivity, an allene can serve as a powerful candidate for synthetic manipulations. Hence, allenes hold great potential for the discovery of new and exciting organic reactions for a variety of chemical transformations. ${ }^{4-10}$

The focus of this dissertation is the preparation of benzannulated enyne-allenes as precursors for use in the synthesis of helical polycyclic aromatic hydrocarbons 1.1, bowl-shaped fullerene fragments 1.2, and 1,4-naphthoquinone methides $\mathbf{1 . 3}$ (Figure 1.1).

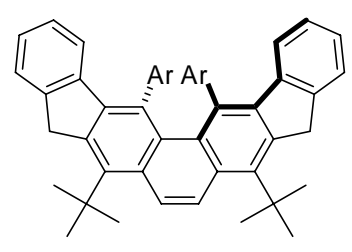

1.1

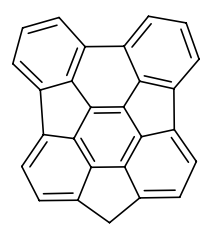

1.2

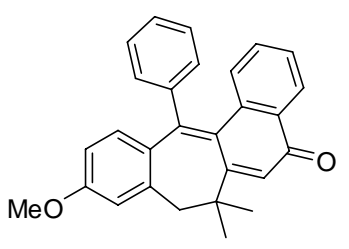

1.3

Figure 1.1 Structures of 1.1, 1.2, and 1.3

\section{The thermal cyclization of enediynes and enyne-allenes}


Because allenes have a hybrid character of an olefin and an acetylene, most of the reactions that simple alkenes and alkynes undergo are also available to the allenes. The reactive diradical intermediates $\mathbf{1 . 5}$ and $\mathbf{1 . 8}$ were formed in the thermal cyclizations of enediynes 1.4 (Bergman, $\left.C^{1}-C^{6}\right)^{11-13}$ and enyne-allenes 1.7 (Myers-Saito, $\left.C^{2}-C^{7}\right)^{14-17}$ (Scheme 1.1).

Scheme 1.1. Thermal cyclization of enediynes and enyne-allenes
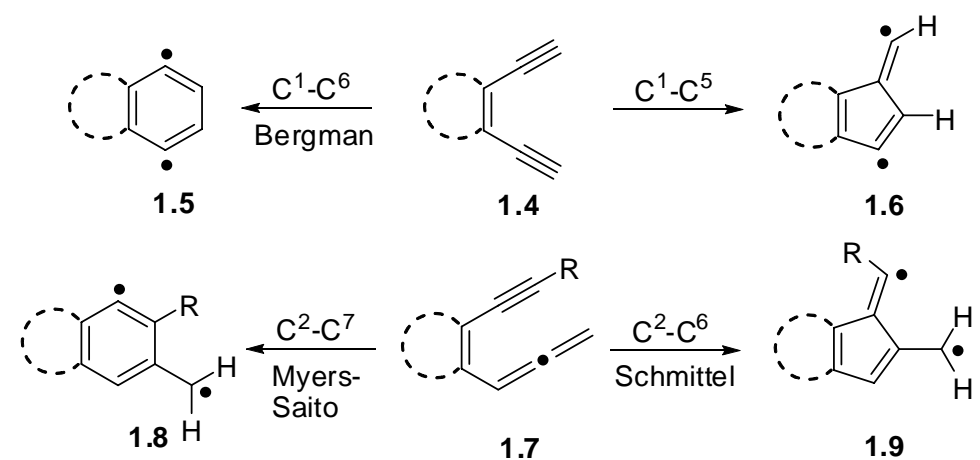

Both of the intermediates were of great interest for organic chemist and they also could be used to simulate antitumor antibiotics for natural enediynes in biology. ${ }^{18}$ The biological activity of the enediynes is attributed to their ability to cleave DNA irreversibly. For example, a thermal $\mathrm{C}^{2}-\mathrm{C}^{7}$ cyclization was proposed to be a key step for the DNA damage action of neocarzinostatin A by Myers (Scheme 1.2). ${ }^{19}$

Scheme 1.2. Mechanism of DNA cleavage by $\mathbf{1 . 1 0}$

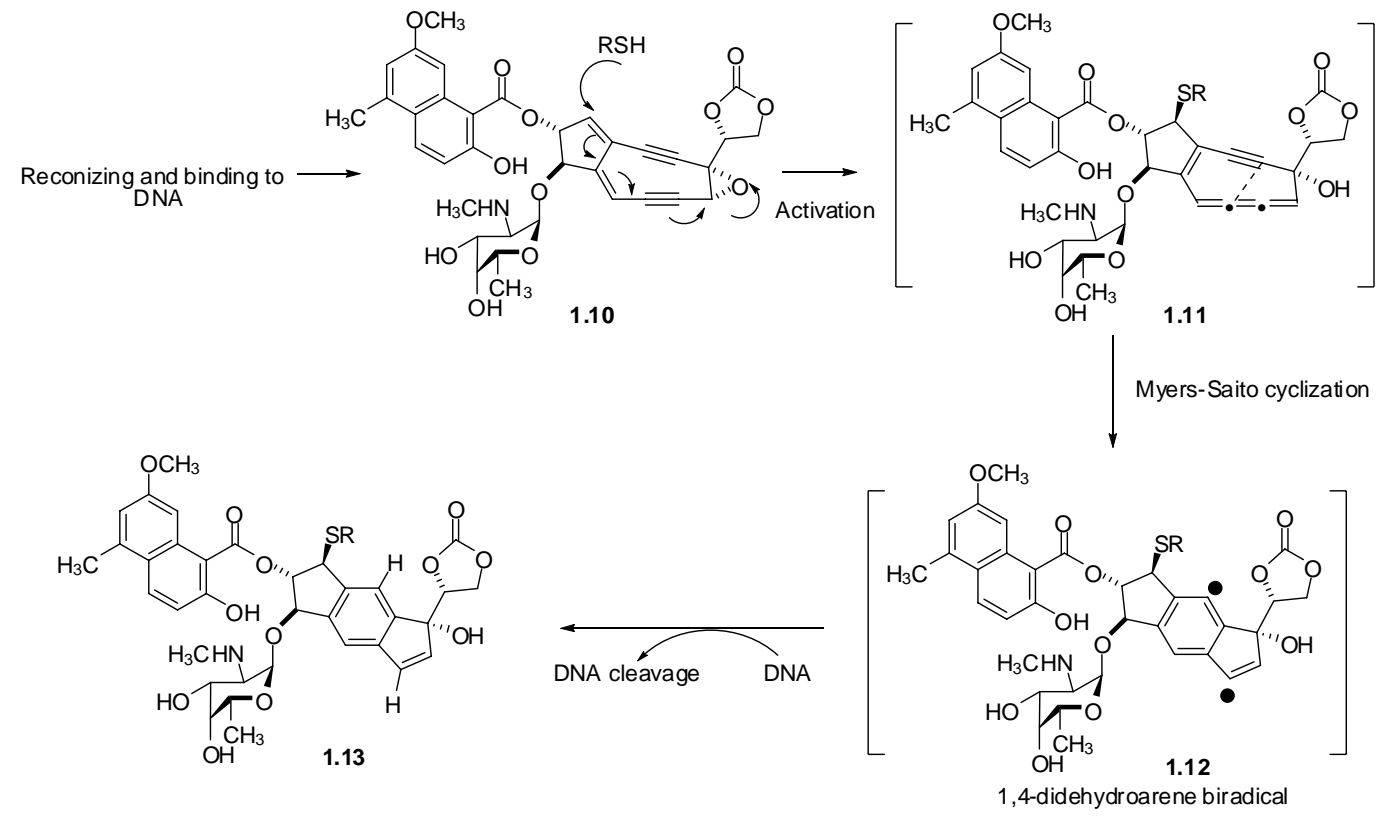


In Scheme 1.2, stereospecific nucleophilic attack at C12 initiated the DNA damage. Subsequently, the ring skeleton was rearranged with epoxide opening and a cumulene was formed in a labile intermediate 1.11. Afterward, biradical 1.12 was formed by a rapid Myers-Saito cyclization, which extracted two hydrogen atoms from the sugar-phosphate backbone of DNA, leading to the formation of $\mathbf{1 . 1 3}$ and DNA cleavage. The occurrence of the Myers-Saito cyclization to form highly reactive intermediates is due in part to the aromaticity gained on cyclization.

The thermal $C^{1}-C^{5}$ diradial cyclization of parent enediyne 1.4 (Scheme 1.1), a variant of the Bergman cyclization, is unlikely because the high energy barrier for cyclization (41.0 vs $25.2 \mathrm{kcal} / \mathrm{mol}$ at the BLYP/6-31G(d) level of theory). ${ }^{20-22}$ In 2008 , Robert A. Pascal reported that benzannulated enediyne $\mathbf{1 . 1 4}$ with the 2,4,6-trichlorophenyl group at both alkyne termini gave indene derivatives $\mathbf{1 . 1 5}$ and $\mathbf{1 . 1 6}$ (Scheme 1.3) in $19 \%$ and $50 \%$ isolated yields, respectively. ${ }^{23}$ The pathway switch from $\mathrm{C}^{1}-\mathrm{C}^{6}$ to $\mathrm{C}^{1}-\mathrm{C}^{5}$ is attributed to the increased steric conflict between substituents on the alkyne termini in the Bergman TS and the stabilization of the diradical intermediate in the $C^{1}-C^{5}$ pathway.

Scheme 1.3. Thermal $C^{1}-C^{5}$ cyclization of enediyne $\mathbf{1 . 1 4}$

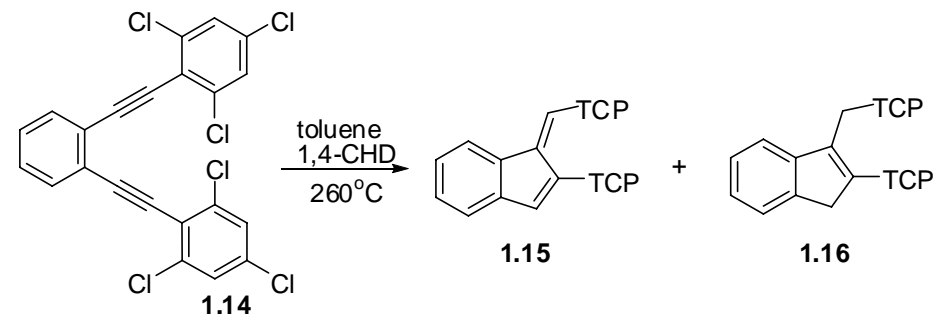

Similar studies of the thermal $C^{2}-C^{6}$ cyclizaion of enyne-allenes 1.7 were reported by Schmittel in 1995 (Scheme 1.1). ${ }^{24-28}$ The aromaticity was not gained in this cyclization, but it is still promoted by the formation of a strong $\operatorname{sp}^{2}-\mathrm{sp}^{2} \sigma$ bond from sp-hybridized carbons. Since then, this second reaction motif for enyne-allenes has proven valuable in synthesis and has been studied mechanistically and theoretically. ${ }^{21,22,29-31}$ Through theoretical studies, the $C^{2}-C^{7}$ cyclization of the parent $(Z)-1,2,4$-heptatrien-6-yne is 
predicted to be favored over $\mathrm{C}^{2}-\mathrm{C}^{6}$ by about $10 \mathrm{kcal} / \mathrm{mol}^{32}$ However, substantial evidence showed that two competing thermal reaction modes of enyne-allenes can be most conveniently controlled through the proper choice of substituents at the alkyne terminus (Scheme 1.4). The $\mathrm{C}^{2}-\mathrm{C}^{6}$ cyclization of $\mathbf{1 . 1 7}$ is favored by radical stabilizing groups or bulky groups at $\mathrm{C}^{7}$. Whereas, the $\mathrm{C}^{2}-\mathrm{C}^{7}$ reaction mode is observed with $\mathrm{R}^{1}=\mathrm{H}$ or an n-alkyl group.

Scheme 1.4. A switch from $C^{2}-C^{7}$ cyclization to $C^{2}-C^{6}$ cyclization

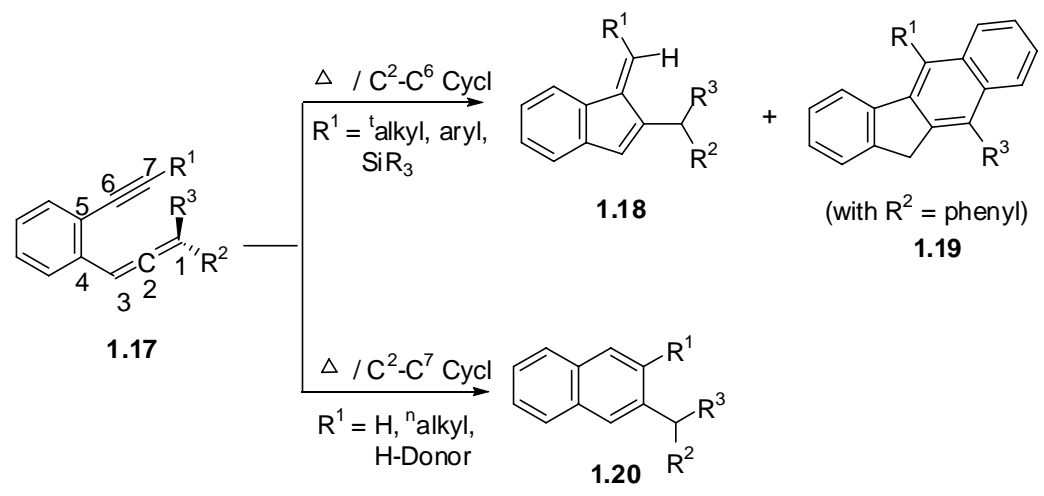

The $\mathrm{C}^{2}-\mathrm{C}^{6}$ cyclizaion can proceed through a stepwise diradical mechanism or a concerted pericyclic pathway (Scheme 1.5). ${ }^{33}$ Some mechanistic and theoretical evidence showed this reaction involves a fulvenyl diradical intermediates. However, a formal ene reaction was used to explain the overall conversation when the substituent is an alkyl group at $C^{1} \cdot{ }^{34,35}$ Due to multiple bonding changes and the wide variation of substituents tolerated in the Schmittel cyclization, there may be a changeover from the stepwise to the

Scheme 1.5. Possible mechanism of the $C^{2}-C^{6}$ cyclizaion

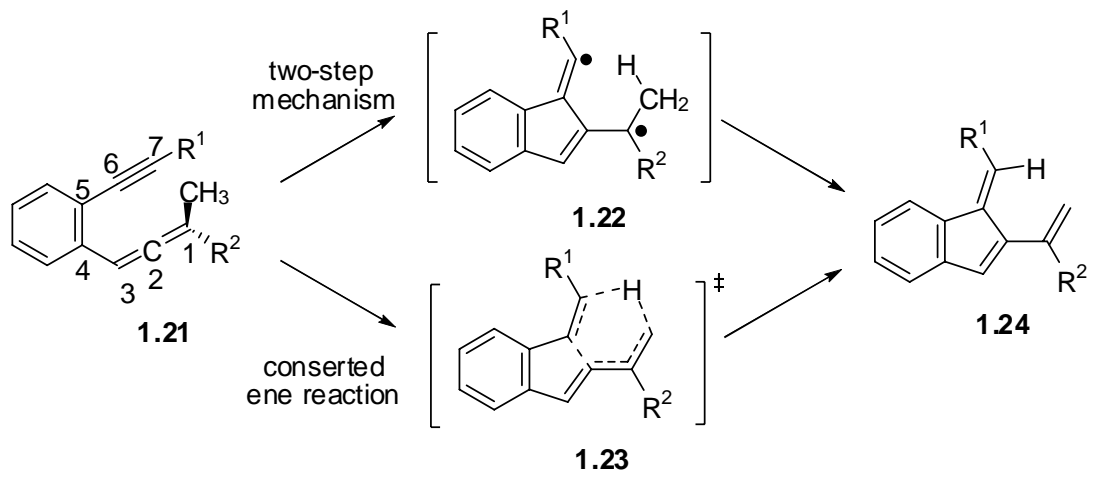


concerted pathway. The considerations of both kinetic isotope effects and dynamic effects, even for complex reactions in solution, are necessary to understand the mechanism.

\section{The synthetic methodologies for the preparation of benzannulated enyne-allenes}

As mentioned in the introduction, the cyclization reactions of benzannulated enyne-allenes can be used to construct polycyclic ring systems. Several synthetic methods were developed to prepare benzannulated enyne-allenes with diverse structural features.

\subsection{Prototropic rearrangement of alkynes}

The 1,3-Prototropic rearrangement of alkynes is the most important isomerization reaction used for preparation of allenes. Depending on the substituted substrates of the alkyne, the reaction can provide a good yield when the migrating $\pi$-bond moves into conjugation with a neighboring alkene or arene. The prototype of this reaction leading to

allene $\mathbf{1 . 2 6}$ and $\mathbf{1 . 2 8}$ has been described (Scheme 1.6). ${ }^{36-38}$ The isomerizations have also been successfully used in the synthesis of a series of 1,3-diarylallenes, which even tolerate other functional groups.

Scheme 1.6. 1,3-Prototropic rearrangement of alkynes to allenes

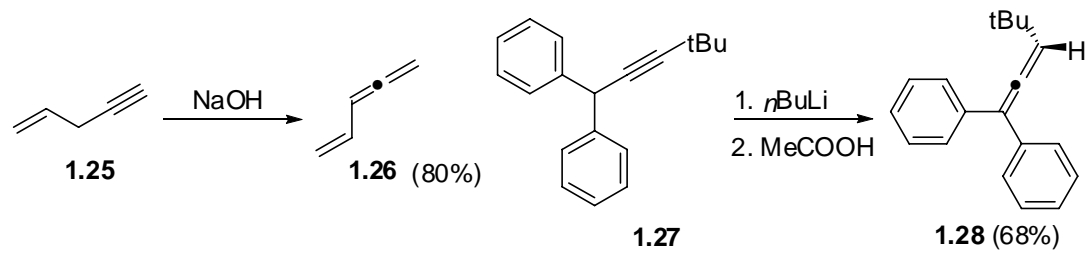

Recently, our research group reported a convenient pathway to prepare the benzannulated enyne-allene $\mathbf{1 . 3 3}$ in situ by a prototropic rearrangement of the 
benzannulated enediyne 1.32 (Scheme 1.7). ${ }^{39,40}$ This method involves the condensation of 1.29 and the lithium acetylide $\mathbf{1 . 3 0}$, followed by protonation to produce the propargylic alcohol 1.31. Reduction of $\mathbf{1 . 3 1}$ with triethylsilane in the presence of trifluoroacetic acid provides the benzannulated enediyne 1.32. 1,3-Prototropic rearrangement, promoted by potassium tert-butoxide in refluxing toluene at $110{ }^{\circ} \mathrm{C}$, produces the benzannulated enyne-allene $\mathbf{1 . 3 3}$ in situ. It undergoes the cascade cyclization sequence via biradical 1.34, derived from $C^{2}-C^{6}$ cyclizaion, followed by a prototropic rearrangement to regain aromaticity to produce 5-aryl-11H-benzo[b] fluorenyl derivative $\mathbf{1 . 3 5}$ in excellent yield.

Scheme 1.7. Synthesis of benzannulated enyne-allene.
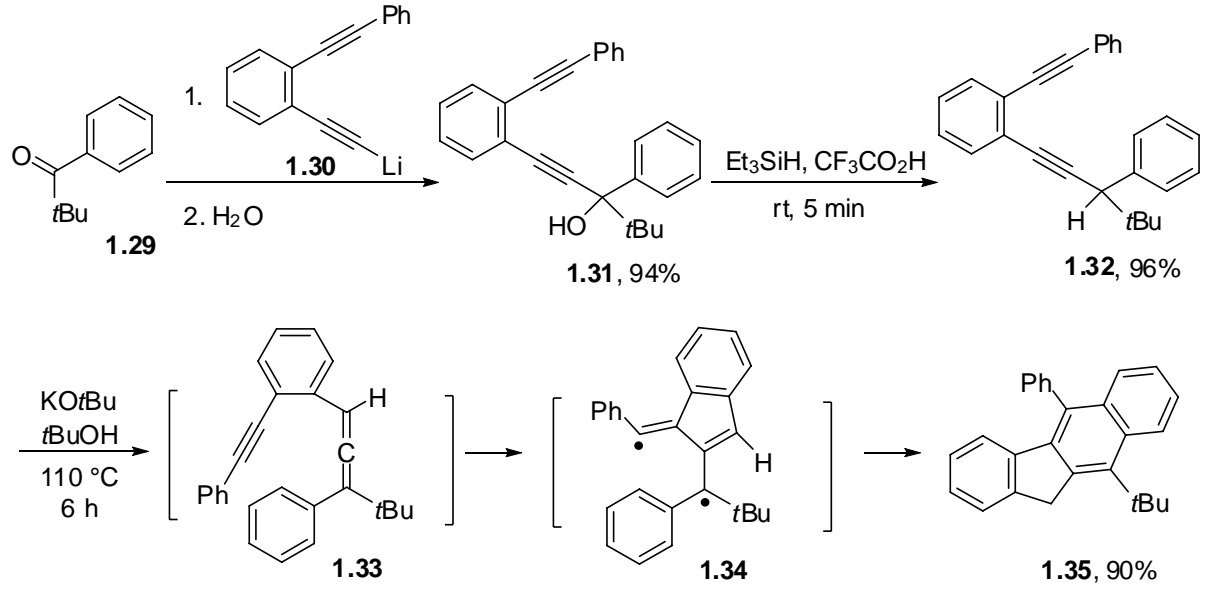

\subsection{Palladium-catalyzed cross-coupling reactions}

The palladium-catalyzed cross-coupling reactions have been developed and used for the construction of a wide range of simple and complex molecules. A series of preparations of substituted allenes were reported by cross coupling of allenes with suitable halogen or metal substituents at one of the $\mathrm{sp}^{2}$-hybridized carbons. Two examples are outlined in Scheme 1.8. 
Scheme 1.8. Palladium catalyzed cross coupling reactions to benzannulated enyne-allene.

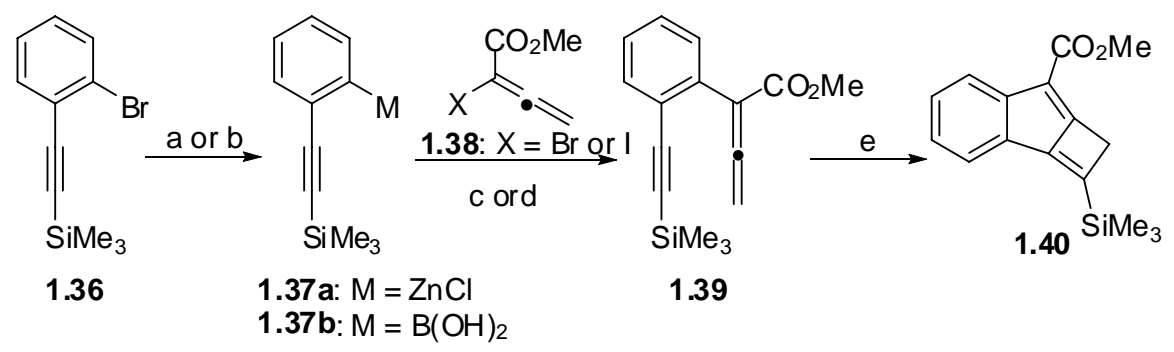

(a) $n$-BuLi, THF, $-90^{\circ} \mathrm{C}, 10 \mathrm{~min} ; \mathrm{ZnCl}_{2},-90^{\circ} \mathrm{C}$ to $-20^{\circ} \mathrm{C}$; (b) $n$-BuLi, THF, $-90^{\circ} \mathrm{C}, 10 \mathrm{~min}$; $\mathrm{B}\left(\mathrm{OCH}_{3}\right)_{3},-90^{\circ} \mathrm{C}$ to $0^{\circ} \mathrm{C} ; \mathrm{Ag}_{2} \mathrm{O}, \mathrm{H}_{2} \mathrm{O}$; (c) coupling of 1.37a: $\mathrm{Pd}\left(\mathrm{PPh}_{3}\right)_{4}(5 \mathrm{~mol} \%), \mathrm{AsPh}_{3}$ (40mol\%), THF, rt; (d) coupling of $1.37 \mathrm{~b}: \mathrm{Pd}_{2}(\mathrm{dba})_{3} \mathrm{CHCl}_{3}$ (5mol\%), $\mathrm{AsPh}_{3}(40 \mathrm{~mol} \%)$, THF, rt; (e)1,4-CHD, $70^{\circ} \mathrm{C}, 3 \mathrm{~h}$

Gillmann and his co-workers described an efficient Negishi coupling reaction between haloallene carboxylates 1.38 and arylzinc halide $1.37 \mathbf{a}$, generated from the corresponding aryl bromides 1.36, which led to the construction of benzannulated enyne-allene ester 1.39. ${ }^{41}$ Saalfrank's group reported a second method to prepare $\mathbf{1 . 3 9}$ by a Suzuki coupling of allenyl bromide 1.38 with boronic acid $1.37 \mathbf{b} .{ }^{42}$ When 1.39 was heated in the presence of 1,4-CHD at $70{ }^{\circ} \mathrm{C}$ for $3 \mathrm{~h}, 1 H$-cyclobut $[a]$ indene $\mathbf{1 . 4 0}$ was produced by the Schmittel cyclizaiton reaction.

\subsection{Rearrangement of propargylic alcohol derivatives}

One of the most useful methods for the asymmetric synthesis of allenes was the rearrangement of propargylic precursors from the corresponding propargylic alcohols. Treatment of the chiral propargylic alcohol 1.41 with thionyl bromide gave a 9:1 mixture of 1.43 and $1.44 .^{43}$ A rearrangement reaction from 1.42 was proposed to be responsible for the formation of $\mathbf{1 . 4 3}$ (Scheme 1.9). 
Scheme 1.9. Rearrangement of propargyl alcohol derivatives

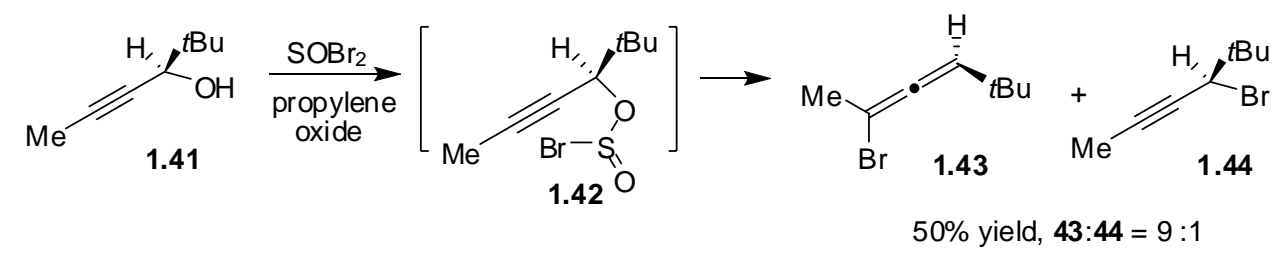

Our group developed a new synthetic pathway to generate the chlorinated benzoenyne-allene system 1.48 in situ by the $\mathrm{S}_{\mathrm{N}} i^{\prime}$ reaction of the corresponding benzannulated propargylic alcohol $\mathbf{1 . 4 6}$ with thionyl chloride (Scheme 1.10). ${ }^{39,44}$ The subsequent rapid cascade radical cyclization sequence leads to the chlorinated benzofluorenyl derivative 1.50. The hydrolysis of $\mathbf{1 . 5 0}$, on exposure to water/silica gel, furnishes alcohol 1.51 in $74 \%$ overall yield from 1.46. A minor amount of 1.52, derived from the intramolecular [2+2] cycloaddition reaction of $\mathbf{1 . 4 8}$, is also produced in $12 \%$ yield.

Scheme 1.10. Treatment of a propargylic alcohol with thionyl chloride to form an enyne-allene.

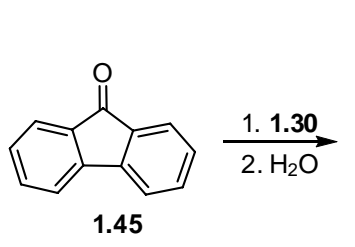

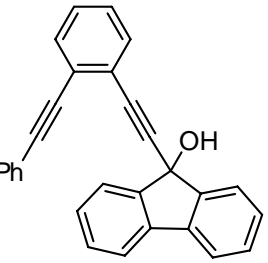

1.46, $100 \%$

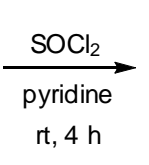

$4 \mathrm{~h}$

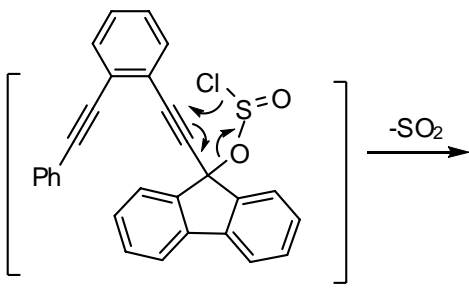

1.47

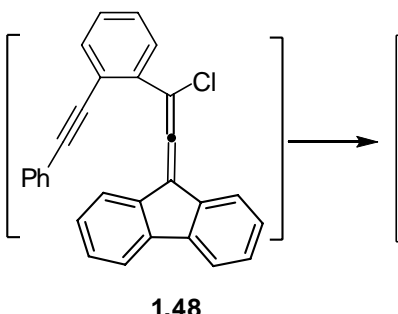

1.48

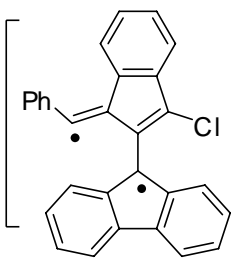

1.49

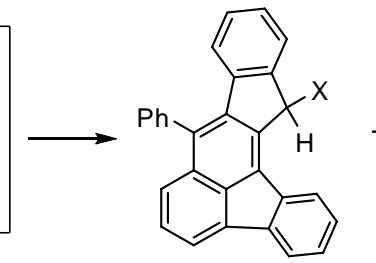

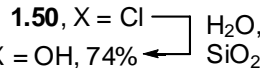

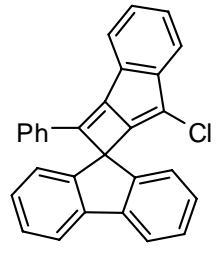

$1.52,12 \%$

Interestingly, the intramolecular $[2+2]$ cycloaddition reaction of the chlorinated benzoenyne-allene intermediates occurred preferentially in certain cases to form $1 H$-cyclobut $[a]$ indenes (Scheme 1.11). Condensation between benzannulated enediynes 
Scheme 1.11. Intramolecular $[2+2]$ cycloaddition reaction
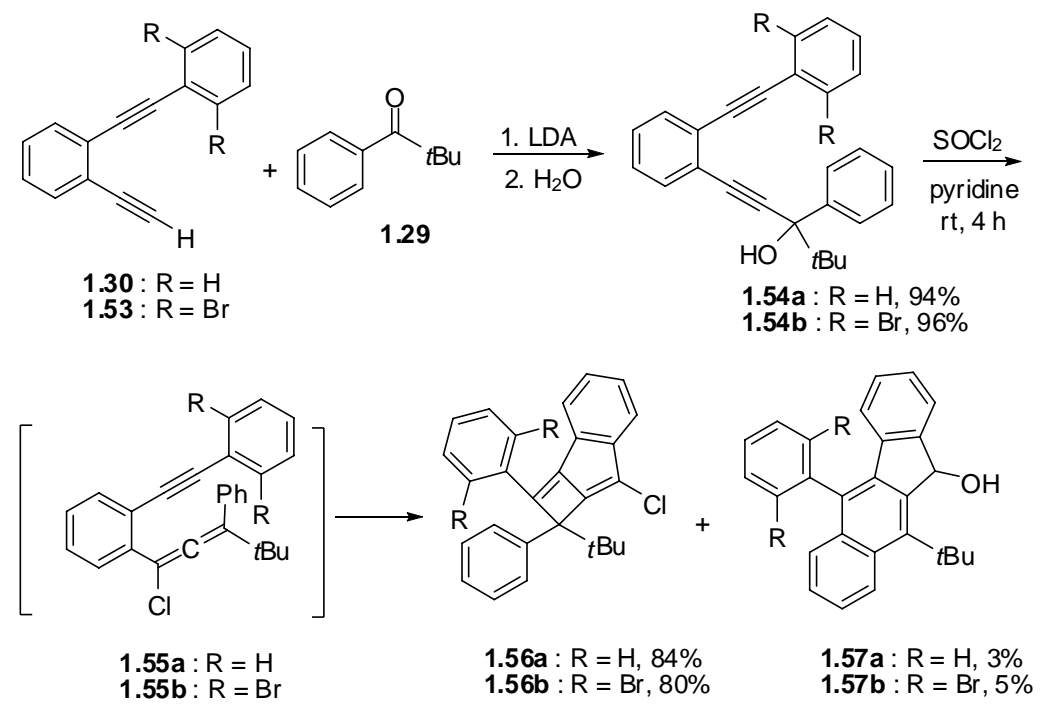

(1.30 or 1.53) and pivalophenone (1.29) as reported previously furnished the corresponding benzannulated enediynyl propargylic alcohol 1.54. Treatment of 1.54 with thionyl chloride gave the $[2+2]$ cycloaddition adduct 1.56 predominately. The competition between [4+2] and [2+2] cycloaddition may be attributed to the emergence of the nonbonded steric interactions between the chloro substituent and the tert-butyl group.
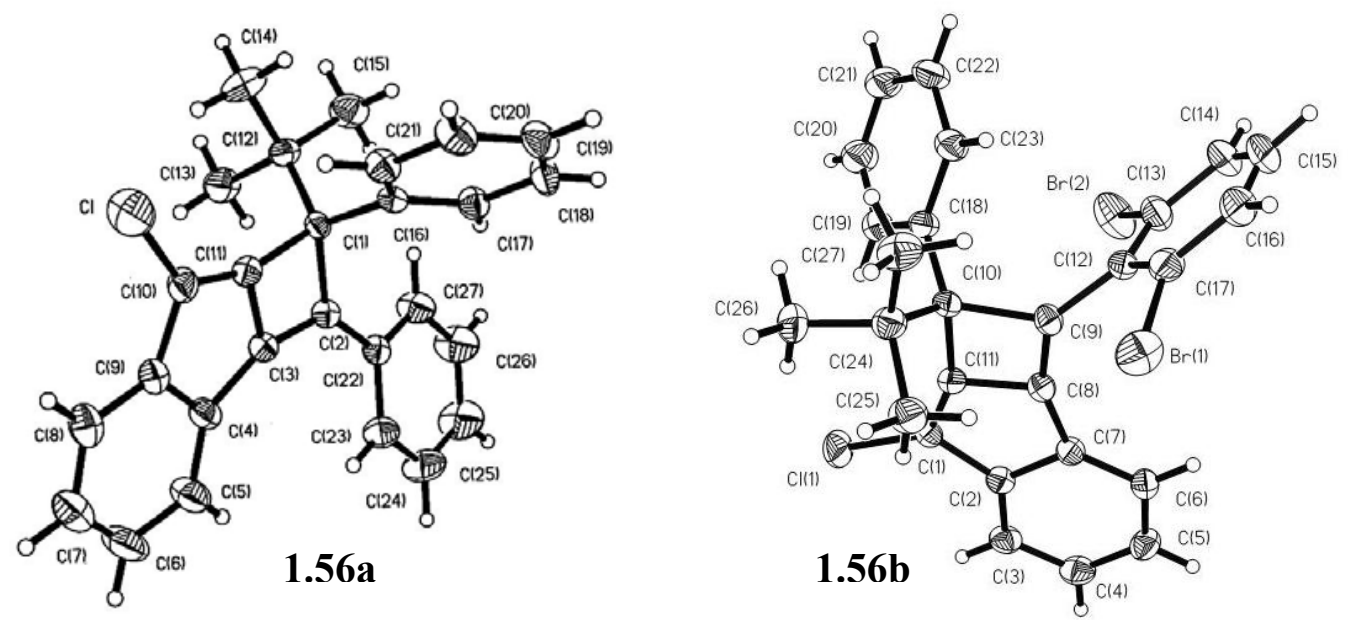

Figure 1.2 Molecular structures of $1.56 \mathrm{a}$ and $1.56 \mathrm{~b}$.

Selected bond lengths $(\AA)$ and angles (deg): 1.56a C(1)-C(2), 1.594(4); C(1)-C(11), 1.543(4); $\mathrm{C}(2)-\mathrm{C}(3), \quad 1.363(4) ; \mathrm{C}(3)-\mathrm{C}(11), 1.430(4) ; \mathrm{C}(11)-\mathrm{C}(1)-\mathrm{C}(2), 81.7(2) ; \mathrm{C}(1)-\mathrm{C}(2)-\mathrm{C}(3), 92.1(2)$; 
$\mathrm{C}(2)-\mathrm{C}(3)-\mathrm{C}(11), 94.5(2) ; \quad \mathrm{C}(3)-\mathrm{C}(11)-\mathrm{C}(1)$ 91.7(2). 1.56b $\mathrm{C}(9)-\mathrm{C}(10), 1.619(5) ; \mathrm{C}(10)-\mathrm{C}(11)$, 1.563(5); $\mathrm{C}(8)-\mathrm{C}(9), 1.356(6) ; \mathrm{C}(8)-\mathrm{C}(11), 1.458(5) ; \mathrm{C}(11)-\mathrm{C}(10)-\mathrm{C}(9), 81.1(3) ; \mathrm{C}(8)-\mathrm{C}(9)-\mathrm{C}(10)$, 92.8(3); C(9)-C(8)-C(11), 94.6(3); C(8)-C(11)-C(10), 91.4(3).

Single crystals of $\mathbf{1 . 5 6 a}$ and $1.56 \mathrm{~b}$ were isolated by crystallization from a hexanes-ether mixture, from which the solid-state structure of the compounds were determined by X-ray diffraction (Figure 1.2). From the X-ray analysis of the four membered ring compounds obtained by the $[2+2]$ cycloaddition reaction of the chlorinated benzoenyne-allene intermediates, it is apparent that one of the $\mathrm{C}\left(\mathrm{sp}_{3}\right)-\mathrm{C}\left(\mathrm{sp}_{2}\right)$ bond distance in the cyclobutene ring of 1.56a $(1.594 \AA)$ and $\mathbf{1 . 5 6 b}(1.619 \AA)$ is significantly longer than the $1.50 \AA$ expected for a normal $\mathrm{C}(\mathrm{sp} 3)-\mathrm{C}\left(\mathrm{sp}_{2}\right)$ single bond. The existence of the longer $\mathrm{C}-\mathrm{C}$ bond most likely is due to the steric repulsion between the bulky substituents on the four member ring. Comparison of these two cyclobutene compounds, $\mathbf{1 . 5 6 b}$ with a more bulky dibromide benzene substituent gave a longer C-C bond than 1.56a with a benzene substituent on the four member ring. The longer $\mathrm{C}-\mathrm{C}$ bond distance will result in lower bond dissociation energy.

The activation of carbon-carbon bonds for cleavage has long been an area of great interest to synthetic chemists. To facilitate selective $\mathrm{C}-\mathrm{C}$ bond cleavage, the potential for the relief of ring strain in substrates has been employed as a driving force. ${ }^{45,46}$ Recently, we found that thermolysis of $\mathbf{1 . 5 6 a}$ and $\mathbf{1 . 5 6 b}$ at $150-210{ }^{\circ} \mathrm{C}$ in the high boiling point solvents led to a homolytic carbon-carbon bond cleavage in the cyclobutene ring (Scheme 1.12). Instead of undergoing ring-opening polymerization, the products resulting from the thermolysis of $1.56 \mathbf{a}$ and $\mathbf{1 . 5 6} \mathbf{b}$ were the more stable [ $4+2]$ adducts $1.59 \mathbf{a}$ and $\mathbf{1 . 5 9 b}$, which furnished 1.57a and 1.57b after hydrolysis on exposure to water/silica gel. Both results may be explained by the formation of the diradical intermediates $\mathbf{1 . 5 8} \mathbf{a}$ and $\mathbf{1 . 5 8 b}$, which are the reverse reactions of the $[2+2]$ cycloaddition reactions. The corresponding 1.58b underwent thermal homolytic $\mathrm{C}-\mathrm{C}$ bond cleavage more readily, consistent with a higher degree of ring strain. 
Scheme 1.12. Thermal opening of cyclobutene ring

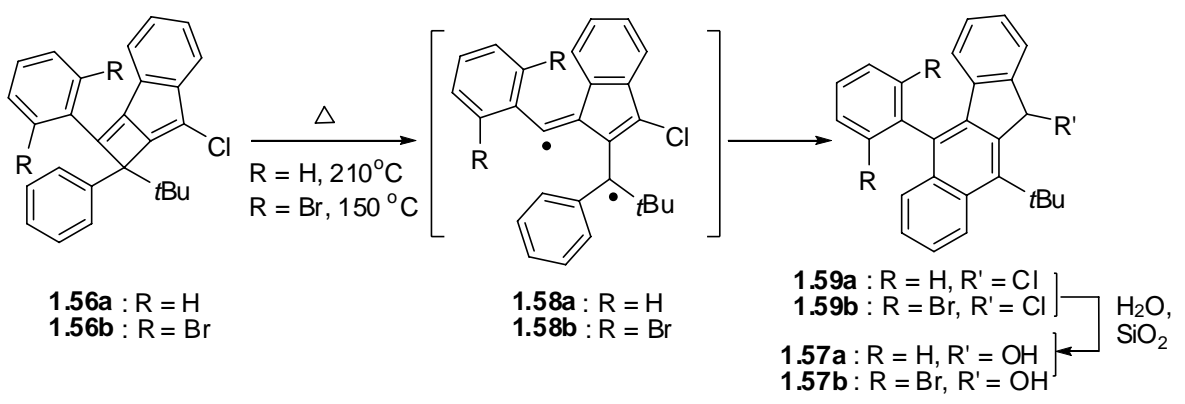

\section{Construction of novel polycyclic aromatic hydrocarbons via the Schmittel cyclization reactions of enyne-allenes}

A new synthetic pathway was developed by our group to generate a $\mathrm{C}_{44} \mathrm{H}_{26}$ hydrocarbon 1.68 bearing a 44-carbon framework of $\mathrm{C}_{60}$ (Scheme 1.13). ${ }^{44}$ The key steps in this route included two Schmittel cyclizations of chlorosubstituted benzanulated enyne-allenes. Condensation of mono-ketal 1.60 with lithium acetylide 1.30 followed by cyclization with thionyl chloride and reduction with sodium borohydride produced 1.63.

Scheme 1.13. Synthesis of a 44-carbon framework of $\mathrm{C}_{60}$
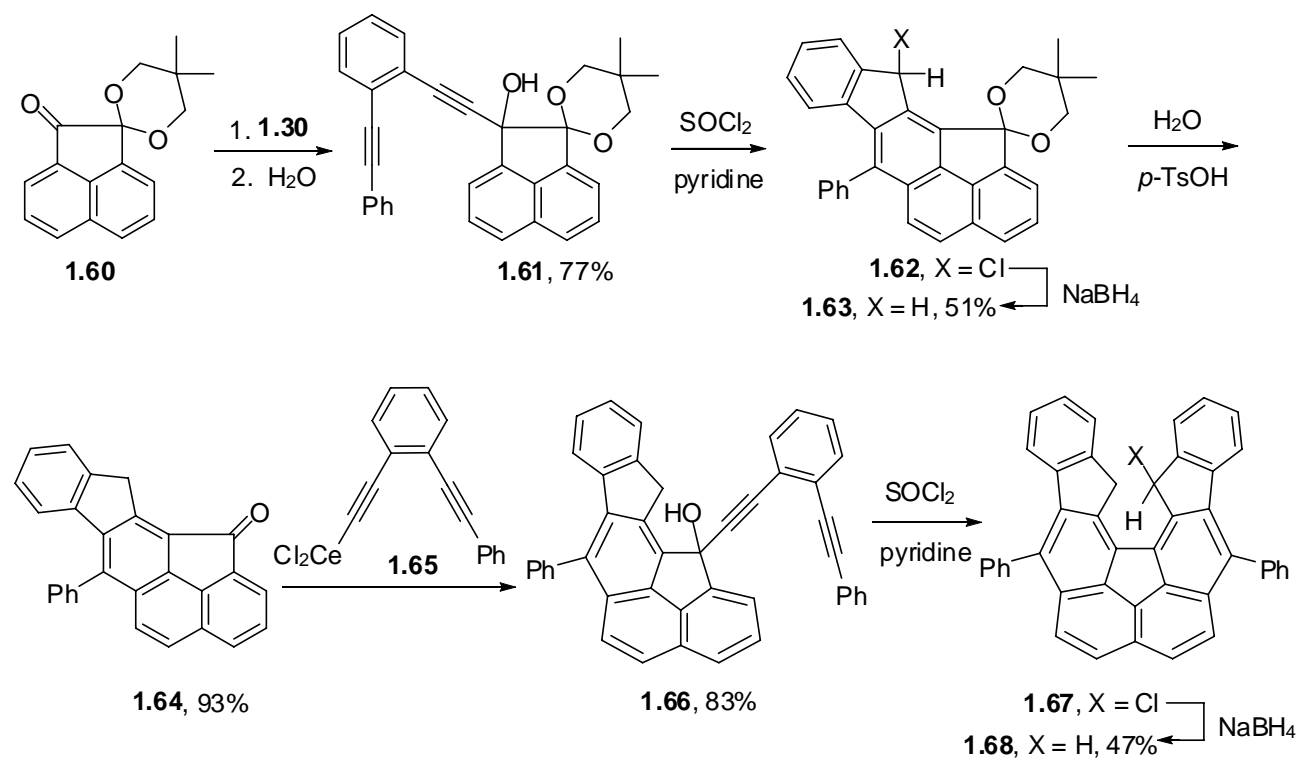
Hydrolysis of the ketal group in $\mathbf{1 . 6 3}$ led to $\mathbf{1 . 6 4}$ having a carbonyl group to allow a repeat of the condensation, cascade cyclization, and reduction sequence. In all, the polycyclic aromatic hydrocarbon $\mathbf{1 . 6 8}$ was synthesized in 8 steps with a $12.8 \%$ overall yield.

Several helical 4,5-diaryldiindenophenanthrenes have been prepared in our group (Scheme 1.14). ${ }^{40,47,48}$ The synthetic sequence started with the condensation of the p-dipivaloylbenzene $\mathbf{1 . 6 9}$ with 2 equiv of the lithium acetylide, derived from 1.30 and was followed by reduction of the resulting propargylic alcohol $\mathbf{1 . 7 0}$ to give the requisite benzannulated enediyne $\mathbf{1 . 7 1}$ for subsequent cascade cyclization reactions. Treatment of 1.71 with potassium tert-butoxide in refluxing toluene at $110{ }^{\circ} \mathrm{C}$ produced benzofluorene 1.72. Interestingly, the final products have twisted aromatic frameworks because of the nonbonded steric interactions between the two substituents at the $\mathrm{C} 4$ and $\mathrm{C} 5$ positions, which cause them to bend away from the mean plane of the aromatic system.

Scheme 1.14. Synthesis of helical polycyclic aromatic hydrocarbon
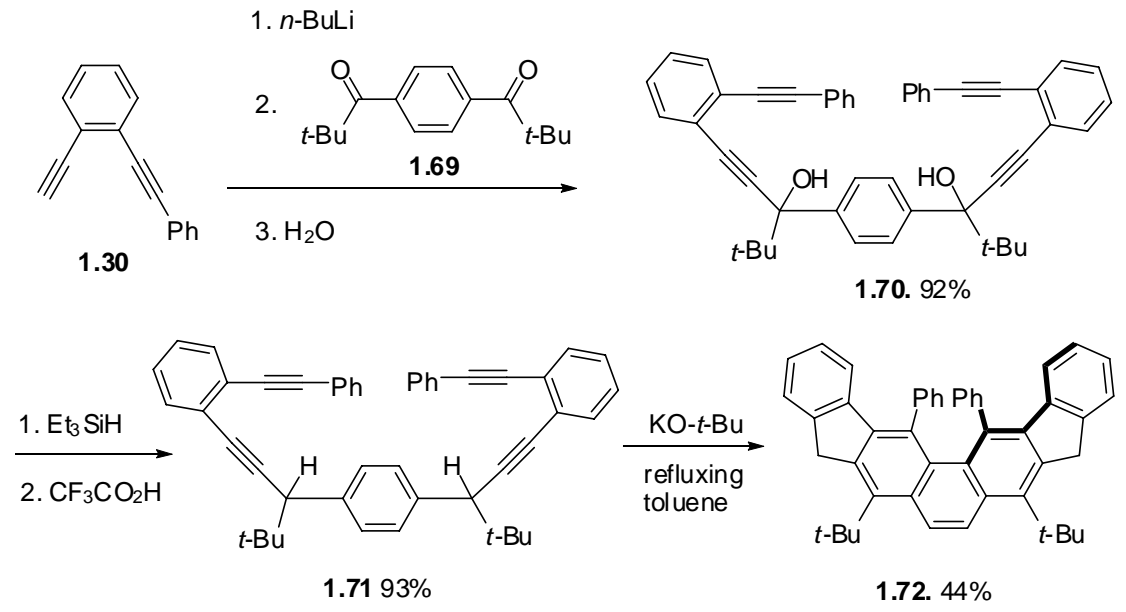


\section{References}

(1) Van'tHoff, J. H. La Chimie dans L'Espace; Bazendijk, P. M. (publisher): Rotterdam, 1875.

(2) Burton, B. S.; Pechman, H. V. Chem Ber 1887, 20, 145.

(3) Jones, E. R. H.; Mansfield, G. H.; Whiting, M. L. H. J. Chem. Soc 1954, 3208.

(4) Krause, N.; Hashmi, A. S. K.; Eds.; Modern Allene Chemistry; Wiley-VCH: Weinheim,, 2005; Vol. Vol. 1 and 2.

(5) Hashmi, A. S. K. Angew. Chem., Int. Ed. 2000, 39, 3590.

(6) Zimmer, R.; Dinesh, C. U.; Nandanan, E.; Khan, F. A. Chem. Rev. 2000, 100, 3067-3126.

(7) Marshall, J. A. Chem. Rev. 1996, 96, 31-48.

(8) Sydnes, L. K. Chem. Rev. 2003, 103, 1133-1150.

(9) Wang, K. K. Chem. Rev. 1996, 96, 207-222.

(10) Bates, R. W.; Satcharoen, V. Chem. Soc. Rev. 2002, 31, 12-21.

(11) Jones, R. R.; Bergman, R. G. J. Am. Chem. Soc. 1972, 94, 660-661.

(12) Lockhart, T. P.; Comita, P. B.; Bergman, R. G. J. Am. Chem. Soc. 1981, 103, 4082-4090.

(13) Bergman, R. G. Accounts. Chem. Res. 1973, 6, 25-31.

(14) Myers, A. G.; Kuo, E. Y.; Finney, N. S. J. Am. Chem. Soc. 1989, 111, 8057-8059.

(15) Myers, A. G.; Dragovich, P. S. J. Am. Chem. Soc. 1989, 111, 9130-9132.

(16) Nagata, R.; Yamanaka, H.; Okazaki, E.; Saito, I. Tetrahedron Lett. 1989, 30, 4995-4998.

(17) Nagata, R.; Yamanaka, H.; Murahashi, E.; Saito, I. Tetrahedron Lett. 1990, 31, 2907-2910.

(18) Lee, M. D.; Ellestad, G. A.; Borders, D. B. Accounts. Chem. Res. 1991, 24, 235-243.

(19) Myers, A. G. Tetrahedron Lett. 1987, 28, 4493-4496.

(20) Prall, M.; Wittkopp, A.; Schreiner, P. R. The Journal of Physical Chemistry A 2001, 
$105,9265-9274$.

(21) Stahl, F.; Moran, D.; von Ragué Schleyer, P.; Prall, M.; Schreiner, P. R. J. Org. Chem. 2002, 67, 1453-1461.

(22) Schreiner, P. R.; Navarro-Vázquez, A.; Prall, M. Accounts. Chem. Res. 2004, 38, 29-37.

(23) Vavilala, C.; Byrne, N.; Kraml, C. M.; Ho, D. M.; Pascal, R. A. J. Am. Chem. Soc. 2008, 130, 13549-13551.

(24) Schmittel, M.; Strittmatter, M.; Kiau, S. Tetrahedron Lett. 1995, 36, 4975-4978.

(25) Schmittel, M.; Strittmatter, M.; Vollmann, K.; Kiau, S. Tetrahedron Lett. 1996, 37, 999-1002.

(26) Schmittel, M.; Strittmatter, M.; Kiau, S. Angewandte Chemie International Edition in English 1996, 35, 1843-1845.

(27) Schmittel, M.; Steffen, J.-P.; Auer, D.; Maywald, M. Tetrahedron Lett. 1997, 38, 6177-6180.

(28) Schmittel, M.; Keller, M.; Kiau, S.; Strittmatter, M. Chemistry - A European Journal 1997, 3, 807-816.

(29) Engels, B.; Hanrath, M. J. Am. Chem. Soc. 1998, 120, 6356-6361.

(30) Schreiner, P. R.; Prall, M. J. Am. Chem. Soc. 1999, 121, 8615-8627.

(31) Cramer, C. J.; Kormos, B. L.; Seierstad, M.; Sherer, E. C.; Winget, P. Org. Lett. 2001, $3,1881-1884$.

(32) Myers, A. G.; Dragovich, P. S.; Kuo, E. Y. J. Am. Chem. Soc. 1992, 114, 9369-9386.

(33) Schmittel, M.; Vavilala, C. J. Org. Chem. 2005, 70, 4865-4868.

(34) Musch, P. W.; Engels, B. J. Am. Chem. Soc. 2001, 123, 5557-5562.

(35) Bekele, T.; Christian, C. F.; Lipton, M. A.; Singleton, D. A. J. Am. Chem. Soc. 2005, 127, 9216-9223.

(36) Bertrand, M.; Hebd, C. R. Seances Acad. Sci. 1958, 247, 824-827.

(37) Grimaldi, J.; Bertrand, M. Bull. Soc. Chim. Fr. 1971, 947-957. 
(38) Steinmetz, M. G.; Mayes, R. T. J. Am. Chem. Soc. 1985, 107, 2111-2121.

(39) Li, H.; Zhang, H.-R.; Petersen, J. L.; Wang, K. K. J. Org. Chem. 2001, 66, $6662-6668$.

(40) Li, H.; Petersen, J. L.; Wang, K. K. J. Org. Chem. 2001, 66, 7804-7810.

(41) Gillmann, T.; Hulsen, T.; Massa, W.; Wocadlo, S. Synlett 1995, 1257-1259.

(42) Saalfrank, R. W.; Haubner, M.; Deutscher, C.; Bauer, W.; Clark, T. J. Org. Chem. 1999, 64, 6166-6168.

(43) Corey, E. J.; Boaz, N. W. Tetrahedron Lett. 1984, 25, 3055-3058.

(44) Zhang, H.-R.; Wang, K. K. J. Org. Chem. 1999, 64, 7996-7999.

(45) Matsuya, Y.; Ohsawa, N.; Nemoto, H. J. Am. Chem. Soc. 2005, 128, 412-413.

(46) Herbert, D. E.; Gilroy, J. B.; Staubitz, A.; Haddow, M. F.; Harvey, J. N.; Manners, I. J. Am. Chem. Soc. 2010, 132, 1988-1998.

(47) Dai, W.; Petersen, J. L.; Wang, K. K. Org. Lett. 2004, 6, 4355-4357.

(48) Zhang, Y.; Petersen, J. L.; Wang, K. K. Org. Lett. 2007, 9, 1025-1028. 


\section{CHAPTER 2}

\section{Synthesis of 4,5-Diheteroarylphenanthrenes and Their Dinuclear Ru(II) Bis(2,2':6', 2'-terpyridine) Complexes Possessing Severe Helical Twists}

\section{Synthesis and structure characterization of 4,5-diheteroaryl- phenanthrenes compounds that possess sever helical twists.}

\subsection{Introduction}

The 4,5-disubstituted phenanthrenes are nonplanar and possess a helical twist. ${ }^{1-4}$ The X-ray crystallographic structure of 4,5-dimethylphenanthrene (2.1) shows a $27.9^{\circ}$ twist between the mean planes of the two outer benzene rings. ${ }^{2}$ Such a structural distortion was caused by the nonbonded steric interactions between the two substituents at the $\mathrm{C} 4$ and C5 positions. Several synthetic methods for 4,5-dimethylphenanthrene and related compounds have been reported, including ozonolysis of pyrene, ${ }^{5}$ intramolecular cyclization of $2,2^{\prime}$-bis(halomethy)-6,6'-dimethylbiphenyls, ${ }^{6,7}$ and photochemically induced dehydrocyclization of stilbenes. ${ }^{89}$ Photocyclization of 1-(8-phenyl-2-naphthyl)4-phenyl-1-buten-3-yne was reported to produce 4,5-diphenylphenanthrenes in $65 \%$ yield. ${ }^{10,11}$ We recently reported a new synthetic pathway leading to the diindeno-fused 4,5-diarylphenanthrenes $\mathbf{2 . 2}$ (Ar = phenyl, 3,5-dimethylphenyl, or 4-biphenylyl) via cascade cyclization reactions of the corresponding benzannulated enyne-allenes. ${ }^{3}$ The twist angle of the outer benzene rings (rings $\mathrm{A}$ and $\mathrm{C}$ ) of the phenanthryl system in $\mathbf{2 . 2}$ $\left(\mathrm{Ar}=\right.$ phenyl) is a more pronounced $46.1^{\circ}$. Our continued interest in nonplanar polycyclic aromatic compounds led us to apply this synthetic sequence to construct several 
4,5-diheteroarylphenanthrene compounds. We now have used a modified and efficient pathway for the synthesis of 4,5-diheteroarylphenanthrenes $2.2 \mathbf{a}, \mathbf{2 . 2 b}$, and 2.2c bearing pyridyl, 2,2'-bipyridyl, and 2,2':6',2' -terpyridyl substituents, respectively. The distorted structures of 2.2a and 2.2c were established by X-ray structure analyses. The presence of two units of pyridyl, bipyridyl, or terpyridyl substituents allows them to serve as potential building blocks for complex formation with transition metals to produce supramolecular systems. $^{12-14}$
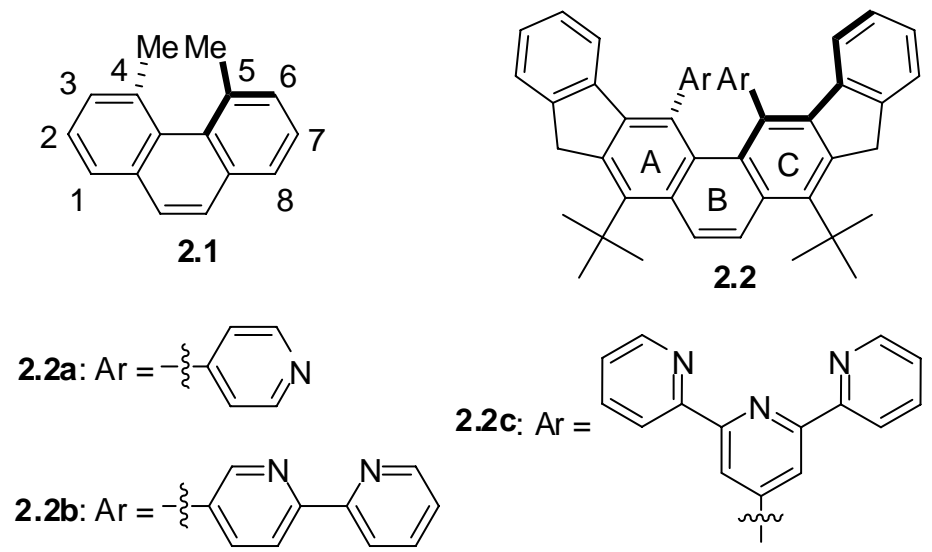

Figure 2.1 Structures of 4,5-disubstituted phenanthrenes

\subsection{Results and discussion}

Synthesis of 4,5-diheteroarylphenanthrenes possessing severe helical twists. The synthetic sequence outlined in Scheme 2.1 for $\mathbf{2 . 2 a}, \mathbf{2 . 2 b}$, and $2.2 \mathrm{c}$ involved initial condensations between 2 equiv of the lithium acetylide derived from $2.3^{15}$ and diketone 2.4 $4^{3}$ to give the corresponding propargylic alcohol $\mathbf{2 . 5}$ as an essentially $1: 1$ mixture of two diastereomers. Reduction of $\mathbf{2 . 5}$ with triethylsilane in the presence of trifluoroacetic acid furnished 2.6 also as an essentially 1:1 mixture of diastereomers. The subsequent Sonogashira reactions ${ }^{16,17}$ with 4-ethynylpyridine $(\mathbf{2 . 7 a})^{18,19}$ produced $\mathbf{2 . 8 a}$. The structures of the two diastereomers of 2.8a were established by X-ray structure analyses. Similarly, 2.8b and $\mathbf{2 . 8 c}$ were synthesized by coupling with 5-ethynyl-2,2'-bipyridine $(\mathbf{2 . 7 b})^{20,21}$ and $4^{\prime}$-ethynyl-2,2':6', $2^{\prime \prime}$-terpyridine $(\mathbf{2 . 7 c}),{ }^{20,22-24}$ respectively. Treatment of 
2.8a with potassium tert-butoxide in refluxing toluene produced 4,5-diheteroarylphenanthrene 2.2a bearing a helical twist in a single operation. Presumably, the transformation from 2.8a to 2.2a proceeded through a cascade sequence of reactions involving two prototropic rearrangements to form the corresponding benzannulated enyne-allene units in 2.9. ${ }^{3}$ The subsequent Schmittel cyclization reactions ${ }^{25,26}$ generate the corresponding biradicals followed by the intramolecular radical-radical couplings and two prototropic rearrangements to regain aromaticity then gave 2.2a as reported previously. ${ }^{3}$ Because the relative reaction rates of the steps of the cascade sequence have not been determined, it is also possible that the first benzannulated enediyne unit in $\mathbf{2 . 8 a}$ could undergo the cascade transformation before the second unit would begin its cyclization sequence. Similarly, 2.2b and 2.2c were obtained from $2.8 b$ and $2.8 c$, respectively.

\section{Scheme 2.1}
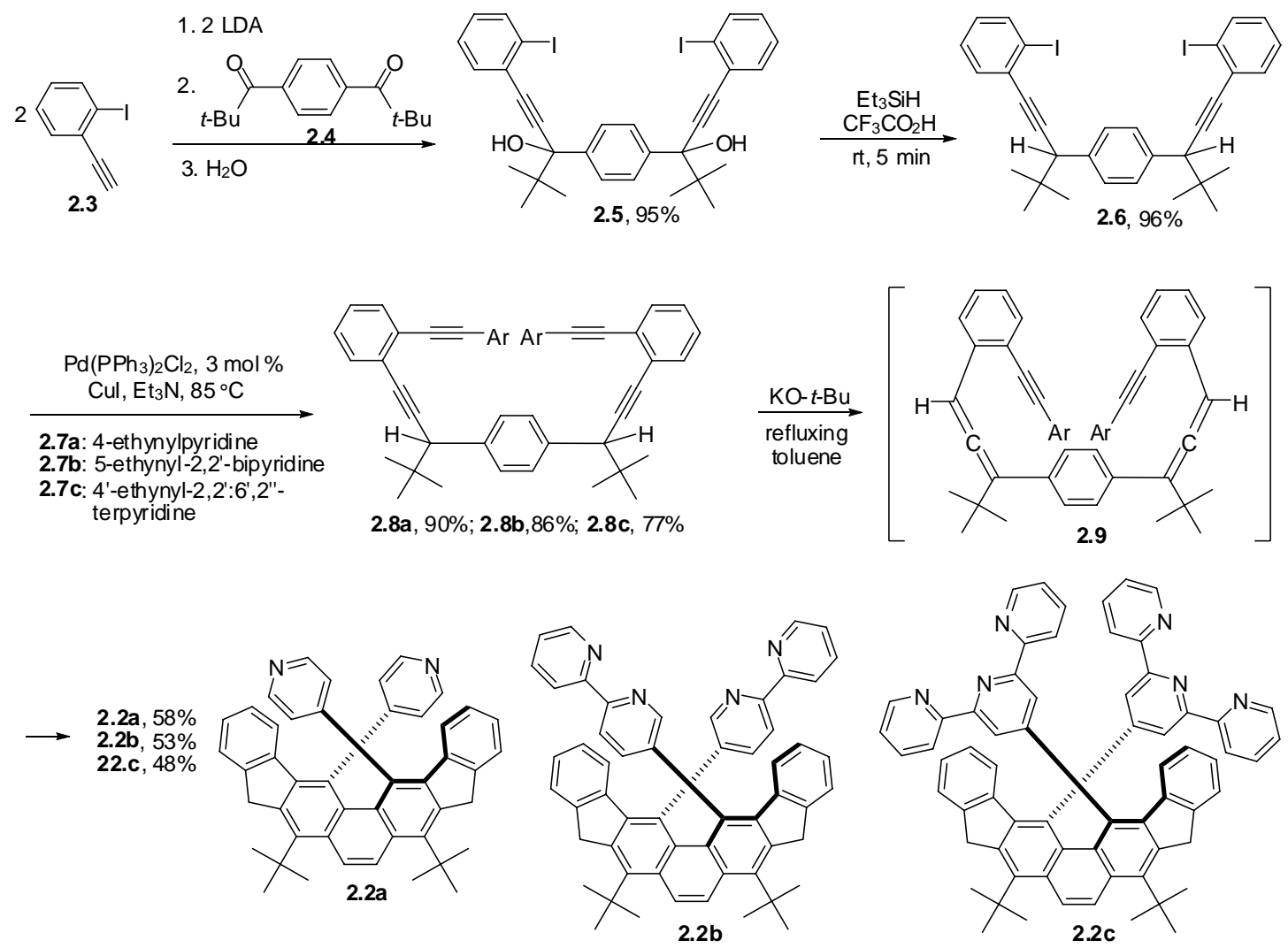
The ${ }^{1} \mathrm{H}$ NMR spectrum of 2.2a show a set of AB quartet signals at $\delta 4.42$ and $\delta 4.20$ $(J=21.0 \mathrm{~Hz})$ from the diastereotopic methylene hydrogens on the five-membered rings, manifesting the presence of a helical twist (Figure 2.2). Such an AB pattern was also observed for 2.2b and 2.2c. Indeed, the X-ray crystallographic structures of 2.2a and 2.2c (Figure 2.3) reveal severe structural distortion due to nonbonded steric interactions between the two heteroaromatic substituents. The two heteroaromatic substituents are bent away from each other, causing a pronounced $45.1^{\circ}$ helical twist between the mean planes of rings $\mathrm{A}$ and $\mathrm{C}$ of 2.2a and a $55.8^{\circ}$ twist of that of 2.2c. As observed in the case of 2.2 (Ar = phenyl), the two heteroaromatic substituents are oriented in essentially twisted parallel positions, but are at a $55.8^{\circ}$ angle from the mean plane of either ring A or $\mathrm{C}$ of 2.2a and at a $47.0^{\circ}$ angle from those of 2.2c. The orientations of the heteroaromatic substituents also place several aromatic hydrogens in the magnetic shielding regions of the aromatic ring currents, causing significant upfield shifts. In the crystal structures, the perpendicular distance between the planes of the two heteroaromatic substituents is ca. $2.80 \AA$ for $2.2 \mathrm{a}$ and ca. $3.03 \AA$ for $2.2 \mathrm{c}$, much shorter than the usual $\pi$ system van der Waals contact distance of ca. $3.4 \AA$ between parallel aromatic hydrocarbons in crystals ${ }^{10}$ and the graphite layer distance of $3.35 \AA$.

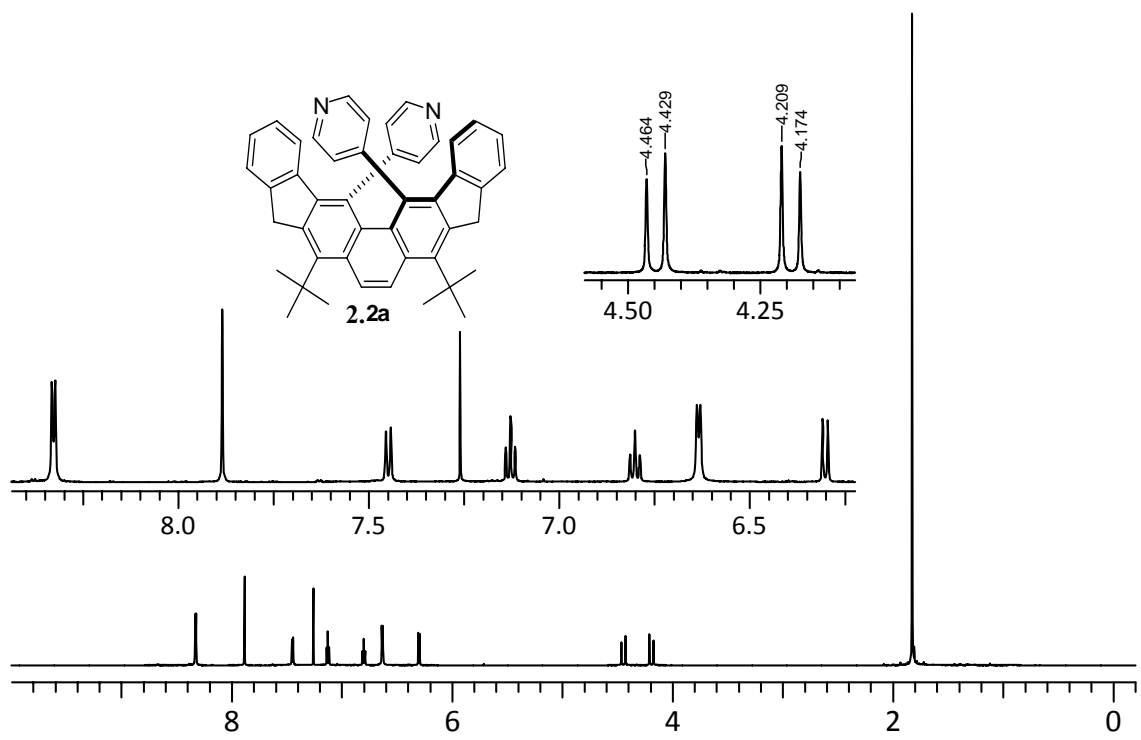

Figure 2.2 ${ }^{1} \mathrm{H}$ NMR spectrum of the 4,5-di(4-pyridyl)phenanthrene 2.2a 
At $28{ }^{\circ} \mathrm{C}$, the ${ }^{1} \mathrm{H}$ NMR spectrum of $2.2 \mathrm{c}$ exhibits broad humps for the aromatic hydrogens on the terpyridyl substituents. At $60{ }^{\circ} \mathrm{C}$, these signals are less broad and a singlet at $\delta 7.91$ attributable to the four hydrogens at the $3^{\prime}$ and $5^{\prime}$ positions of the two central pyridyl rings could be clearly discerned. At $-20{ }^{\circ} \mathrm{C}$, multiple signals of the terpyridyl substituents start to appear. These observations suggest restricted rotations around the carbon-carbon single bonds connecting the terpyridyl substituents to the C4
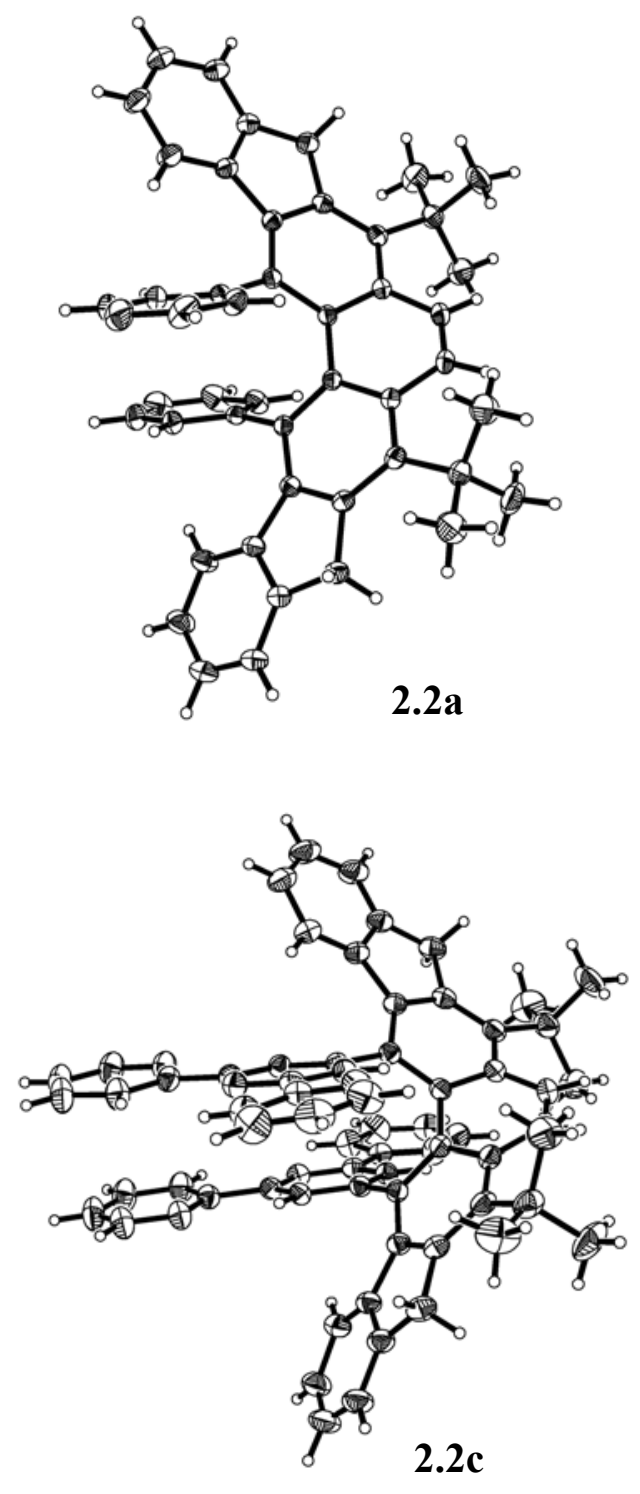

Figure 2.3 ORTEP drawings of the crystal structures of 2.2a and 2.2c. 
or the $\mathrm{C} 5$ position of the central phenanthryl system. Similarly, at $28{ }^{\circ} \mathrm{C}$ broad signals in the aromatic region attributable to the hydrogens on the bipyridyl substituents of $\mathbf{2 . 2 b}$ were also observed. The rates of racemization of $\mathbf{2 . 2 a}-\mathbf{c}$ can be expected to be slow as observed previously for $2.2\left(\mathrm{Ar}=\right.$ phenyl). ${ }^{3}$

The UV-vis absorption spectra of 2.2a, 2.2b, and 2.2c, recorded in dichloromethane, show absorption bands in the near-UV region from ca. 235 to $305 \mathrm{~nm}$ and less intense bands in the visible region with maxima at ca. $405 \mathrm{~nm}$ (Figure 2.4). The dichloromethane solutions of 2.2a-c show bright yellow color. Upon excitation at $360 \mathrm{~nm}$, they exhibit blue emission with maxima at ca. $460 \mathrm{~nm}$.

(a)

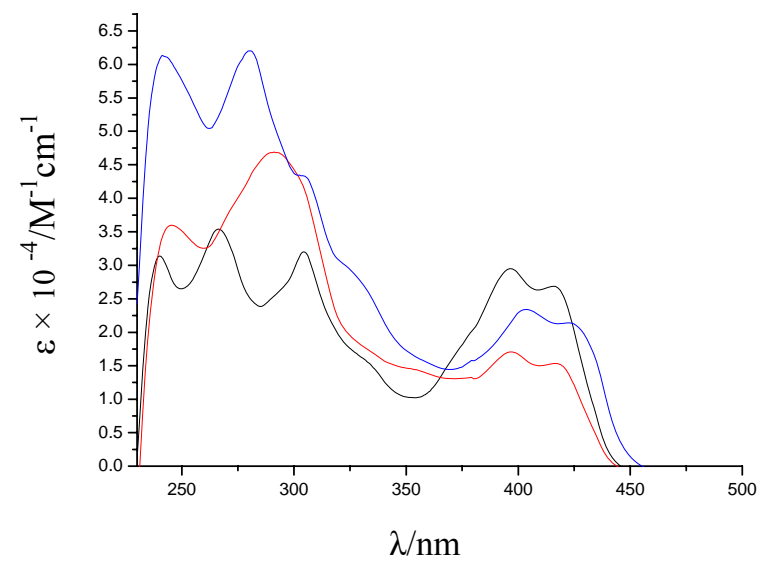

(b)

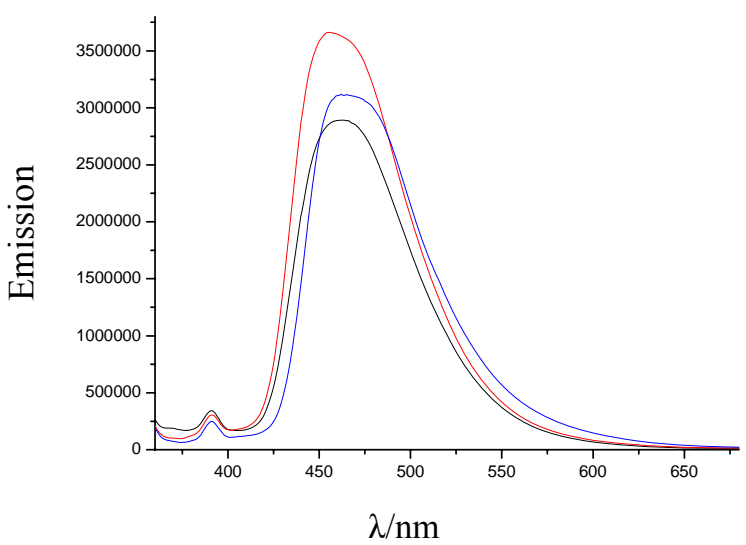

Figure 2.4 (a) UV-vis absorption spectra and (b) luminescence spectra of 2.2a (black), 2.2b (red), and 2.2c (blue) in dichloromethane at room temperature.

\section{Synthesis and structure analysis of dinuclear ruthenium(II) bis(terpyridine) complexes.}

\subsection{Introduction}

Because metal-ligand coordination has been applied extensively in supramolecular chemistry, there is an increasing interest in developing chelating ligands and their 
transition metal complexes. ${ }^{12}$ For instance, 2,2',6', $2^{\prime \prime}$-terpyridine and its $4^{\prime}$-substituted derivatives are common ligands that can coordinate to many different transition metal ions and form metal complexes. The resultant metal complexes have linear or rod-like structures, which have potential applications in the fields of macromolecular chemistry, nanoscience, and photophysics. ${ }^{27} \mathrm{~A}$ wide variety of ruthenium-terpyridine complexes have been reported, which exhibit interesting photophysical, photochemical, and electrochemical properties. Ruthenium-bis(terpyridine) complexes of the type $\left[\mathrm{Ru}(\mathrm{tpy})_{2} \mathrm{X}_{2}\right]\left(\mathrm{X}=\right.$ e.g. $\left.\mathrm{Cl}^{-}, \mathrm{ClO}_{4}^{-}, \mathrm{PF}_{6}^{-}\right)$has been well-known for the strength of their metal-ligand bond, arising from the strong metal-ligand (d- $\left.\pi^{*}\right)$ back donation. Arrangement of the ligands around the ruthenium atom contributes to a distorted octahedral geometry of the formed bis(terpyridine) $\mathrm{Ru}$ complexes, determined by a single crystal X-ray structure analysis of $\left[\mathrm{Ru}(\mathrm{tpy})_{2}\right]$, shown in Figure $2.5 .^{28}$ Herein, two dinuclear ruthenium(II) bis(terpyridine) complexes of 2.2c possessing severe helical twists were successfully synthesized.

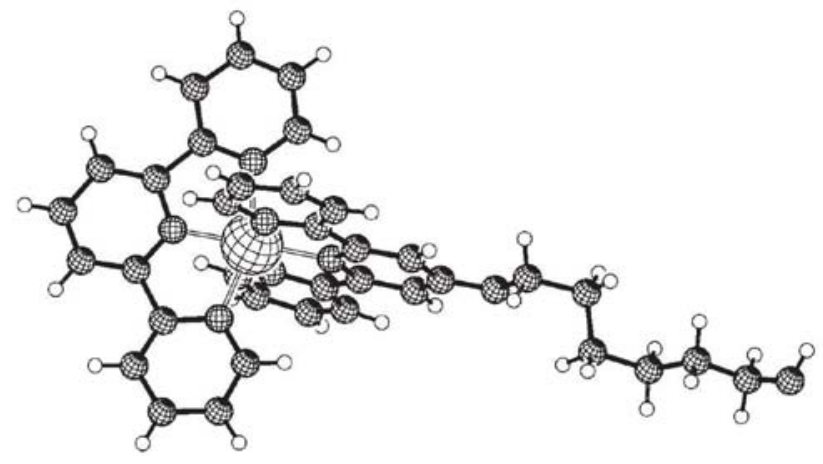

Figure 2.5 X-rag crystal structure of $\left[\mathrm{Ru}(\mathrm{tpy})_{2}\right]$

\subsection{Results and discussion}

Synthesis of dinuclear ruthenium(II) bis(terpyridine) complexes The presence of two terpyridyl substituents in 2.2c provides opportunities for the formation of dinuclear ruthenium(II) bis(terpyridine) complexes possessing helical twists. A reported procedure for the synthesis of $\mathrm{Ru}(\mathrm{II})$ bis(terpyridine) complexes ${ }^{11}$ was adopted by first treating $\mathbf{2 . 2 c}$ 
with ruthenium trichloride to form the $\mathrm{Ru}(\mathrm{III})$ trichloride complex $\mathbf{2 . 1 0}$ (Scheme 2.2). Treatment of $\mathbf{2 . 1 0}$ with $4^{\prime}$-ethoxy-2,2':6',2"-terpyridine (2.11) or $4^{\prime}$-chloro-2,2':6',2"terpyridine (2.12) followed by the addition of a large excess of $\mathrm{NH}_{4} \mathrm{PF}_{6}$ then formed the brown precipitates of $\left[\left(4^{\prime}-E t O t p y\right) R u(2.2 c) R u\left(4^{\prime}-E t O t p y\right)\right]\left(\mathrm{PF}_{6}\right)_{4} \quad \mathbf{( 2 . 1 3 )}$ or $\left[\left(4^{\prime}-\mathrm{Cltpy}\right) \mathrm{Ru}(\mathbf{2 . 2 c}) \mathrm{Ru}\left(4^{\prime}-\mathrm{Cltpy}\right)\right]\left(\mathrm{PF}_{6}\right)_{4}$ (2.14), respectively. ${ }^{1} \mathrm{H}$ NMR studies of the $\mathrm{CD}_{3} \mathrm{CN}$ solutions of the heteroleptic species $\mathbf{2 . 1 3}$ and 2.14 show the presence of minor amounts of the homoleptic species $\left[\mathrm{Ru}\left(4^{\prime}-\text { EtOtpy }\right)_{2}\right]\left(\mathrm{PF}_{6}\right)_{2}$ and $\left[\mathrm{Ru}\left(4^{\prime}-\mathrm{Cltpy}\right)_{2}\right]\left(\mathrm{PF}_{6}\right)_{2}$, respectively, as observed previously in the synthesis of other heteroleptic ruthenium complexes. $^{29}$

\section{Scheme 2.2}

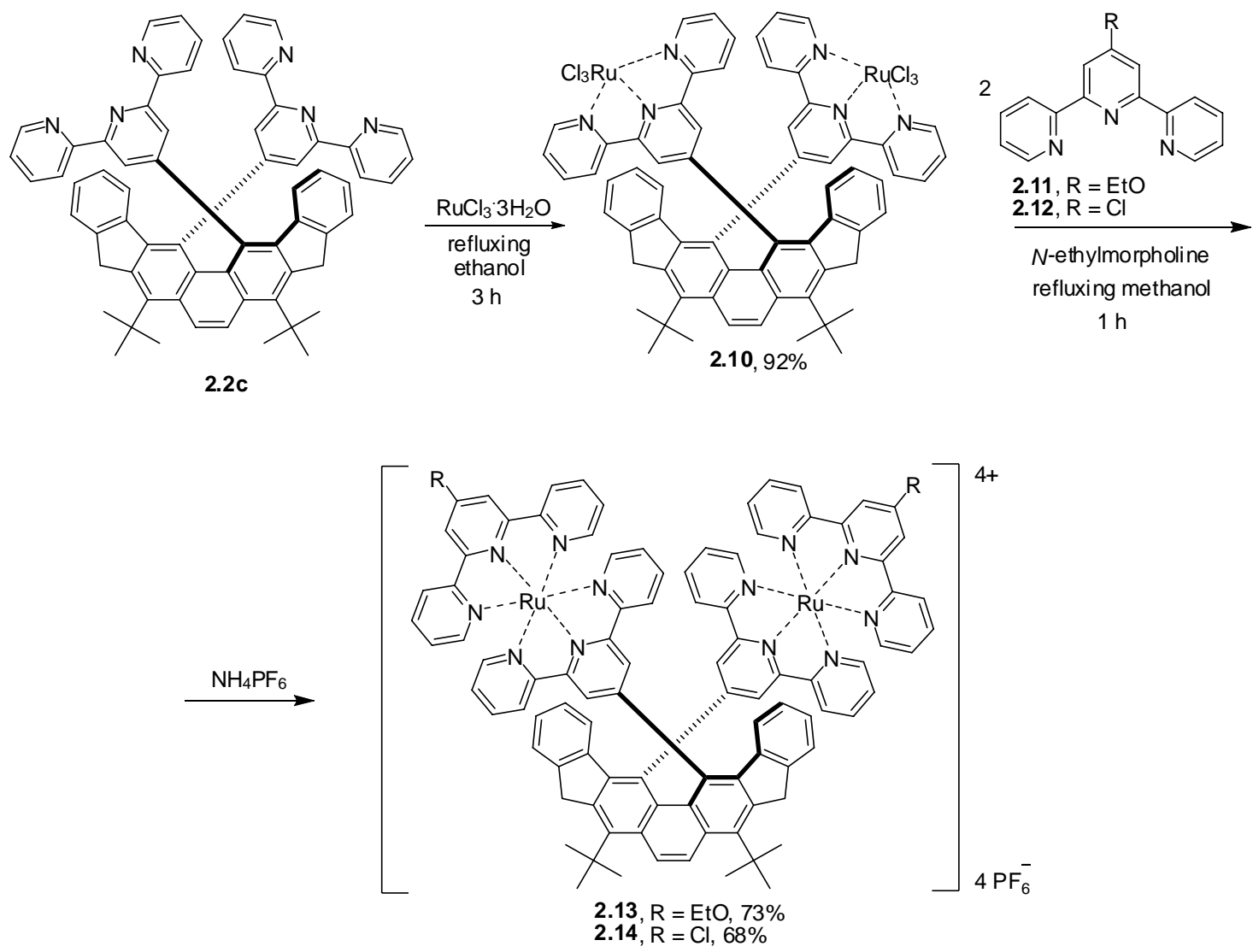

Because of the presence of an unpaired electron in the $t_{2 g}$ orbital of the low-spin $\mathrm{d}^{5}$ $\mathrm{Ru}(\mathrm{III})$ ions, the ${ }^{1} \mathrm{H}$ NMR signals of $\mathbf{2 . 1 0}$ are broadened and shifted dramatically (Figure 2.6). ${ }^{30,31}$ Several signals are shifted upfield or downfield to very large extents. The signals 
at $\delta-32.35$ and -35.56 can be attributed to the hydrogens at the 6 and $6 "$ positions of the terpyridyl system, where they are closest to the paramagnetic $\mathrm{Ru}(\mathrm{III})$ ions. The presence of these two distinct signals also indicates a relatively slow rate of rotation on the NMR time scale around the carbon-carbon single bonds attaching the terpyridyl units to the $\mathrm{C} 4$ or the $\mathrm{C} 5$ position of the central phenanthryl system. The $\mathrm{AB}$ quartet signals of 2.10 appear at $\delta 7.75(J=21.0 \mathrm{~Hz})$ and $4.83(J=21.0 \mathrm{~Hz})$. For 2.13 without the presence of paramagnetic ruthenium ions, the AB quartet signals appear at $\delta 4.46(J=$ $21.6 \mathrm{~Hz})$ and $4.30(J=21.6 \mathrm{~Hz})$. The ${ }^{1} \mathrm{H}$ NMR signals of the ethoxyl groups and the hydrogens on the diindeno-fused phenanthryl system are sharp with well-defined splitting patterns. Similarly, for $\mathbf{2 . 1 4}$ the AB quartet signals appear at $\delta 4.46(J=21.6 \mathrm{~Hz})$ and $4.30(J=21.6 \mathrm{~Hz})$. Again, due to slow rate of rotation around the carbon-carbon single bonds attaching the terpyridyl units to the $\mathrm{C} 4$ or the $\mathrm{C} 5$ position of the central phenanthryl system, the signals of the aromatic hydrogens on the terpyridyl groups of 2.13 and 2.14 are broad.

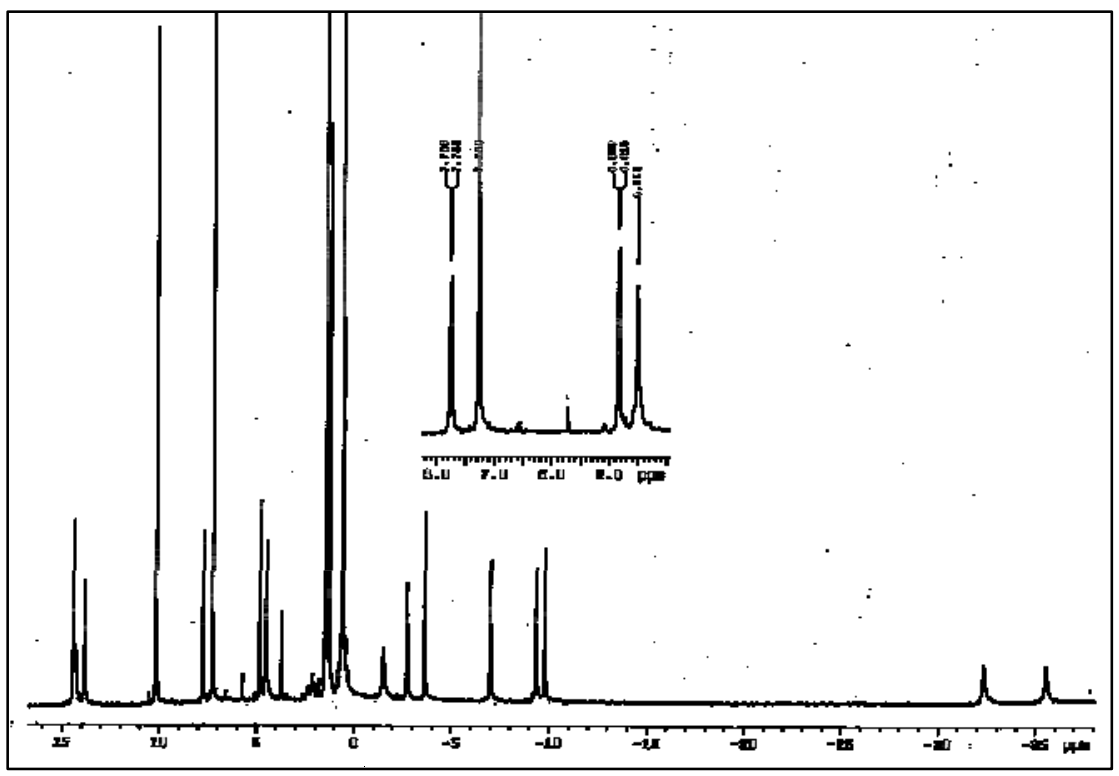

Figure 2.6 NMR spectra of $\mathbf{2 . 1 0}$ 


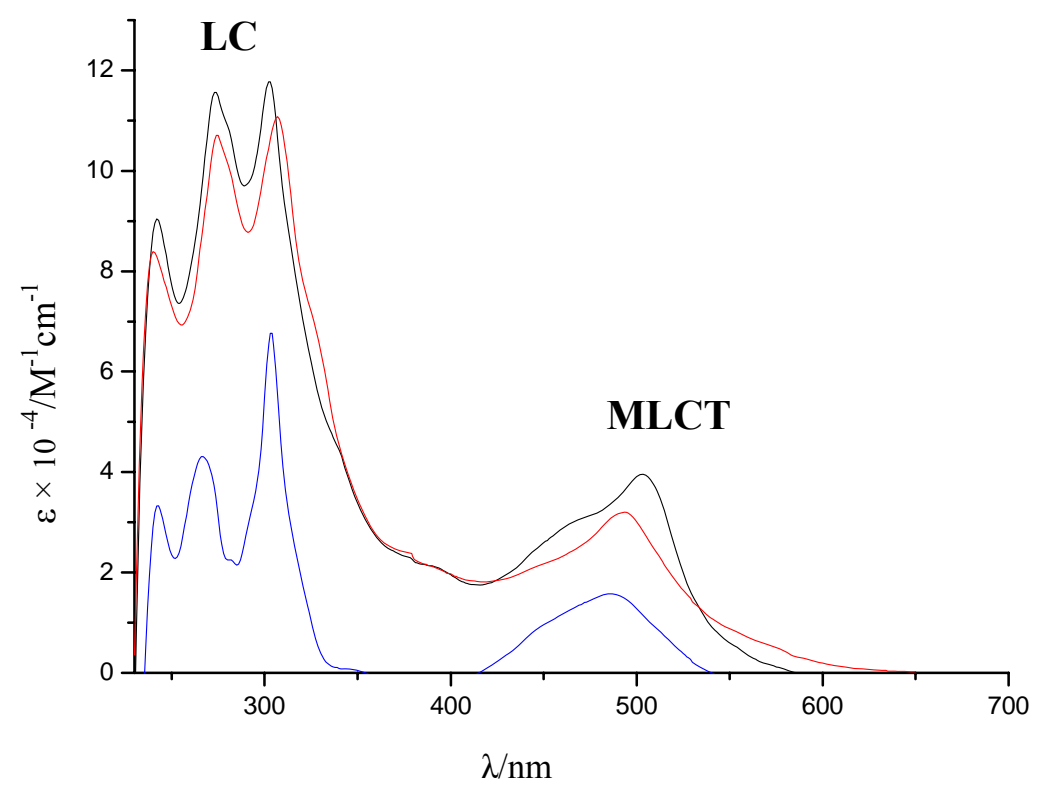

Figure 2.7 UV-vis absorption spectra of 2.13 (black), 2.14 (red), and $\left[\mathrm{Ru}\left(4^{\prime} \text {-EtOtpy }\right)_{2}\right]\left(\mathrm{PF}_{6}\right)_{2}$ (blue) in acetonitrile at room temperature.

The UV-vis absorption spectra of $\mathbf{2 . 1 3}$ and $\mathbf{2 . 1 4}$, recorded in acetonitrile, show intense ligand-centered $\pi-\pi^{*}$ transition bands of the aromatic terpyridyl structures in the near-UV region (Figure 4). ${ }^{32}$ The less intense broad bands in the visible region, which is responsible for the deep red color, can be attributed to the spin-allowed metal-to-ligand charge-transfer (MLCT) transitions involving promotion of an electron from the metal $\mathrm{t}_{2 \mathrm{~g}}$ orbital to a $\pi^{*}$ antibonding orbital of the ligand with absorption maxima at ca. 495 to 505 nm. Compared to the parent $\left[\mathrm{Ru}(\mathrm{tpy})_{2}\right]\left(\mathrm{PF}_{6}\right)_{2}$ complex, which exhibits an absorption maximum at $474 \mathrm{~nm}$, these MLCT bands undergo a red shift. Such a red shift is reminiscent of what was observed in the cases of $\left[\mathrm{Ru}\left(4^{\prime}-\mathrm{EtOtpy}\right)_{2}\right]\left(\mathrm{PF}_{6}\right)_{2}$ complex $(\lambda=$ $485 \mathrm{~nm})$ bearing electron donating ethoxyl groups, $\left[\mathrm{Ru}\left(4^{\prime}-\mathrm{Cltpy}\right)_{2}\right]\left(\mathrm{PF}_{6}\right)_{2}$ complex $(\lambda=$ $480 \mathrm{~nm})$ bearing chloro substituents, and $\left[\mathrm{Ru}\left(4^{\prime}-\mathrm{Phtpy}\right)_{2}\right]\left(\mathrm{PF}_{6}\right)_{2}$ complex $(\lambda=487 \mathrm{~nm})$ bearing phenyl groups. Luminescence was not observed for $\mathbf{2 . 1 3}$ and 2.14 at room temperature. 


\section{Synthesis of pyridine, bipyridine, terpyridine ligands used in the helical twist compounds.}

4-ethynylpyridine $\quad(\mathbf{2 . 7 a})^{18,19}, 5$-ethynyl-2,2'-bipyridine $\quad(\mathbf{2 . 7 b})^{20,21}, \quad 4^{\prime}$-ethynyl$2,2^{\prime}: 6^{\prime}, 2^{\prime \prime}$-terpyridine $\quad(\mathbf{2 . 7 c}),{ }^{20,22-24}, \quad 4^{\prime}$-ethoxy-2,2':6', $2^{\prime \prime}$-terpyridine $\quad(\mathbf{2 . 1 1})^{24}$ and $4^{\prime}$-chloro-2,2':6',2"-terpyridine $(\mathbf{2 . 1 2})^{24}$ were prepared according to the reported procedures. The synthetic procedures for these compounds were summarized in Scheme 2.3 .

Scheme 2.3. Synthesis of bipyridine, terpyridine ligands.

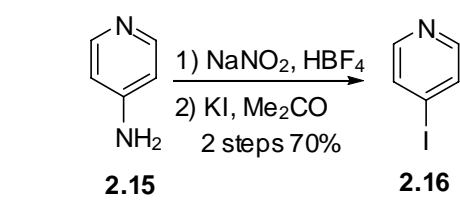

2.172

2.19

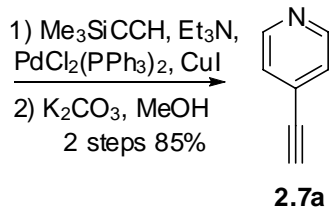

$2.7 a$

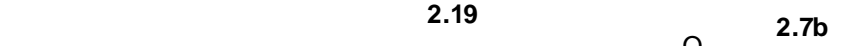

\section{2}<smiles>CCOC(=O)c1ccccn1</smiles>

2.20<smiles>COCCN(O)C(=O)OC(C)=O</smiles>

2.212 steps $60 \%$<smiles>C#Cc1ccc(-c2ccccn2)nc1</smiles>

2.7b

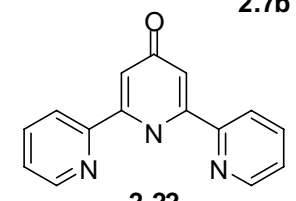

2.22

$\mathrm{Tf}_{2} \mathrm{O}$

Pyridine<smiles>[R]C(C)(C)c1nccc(-c2cc(C#C)cc(-c3ccccn3)n2)n1</smiles>

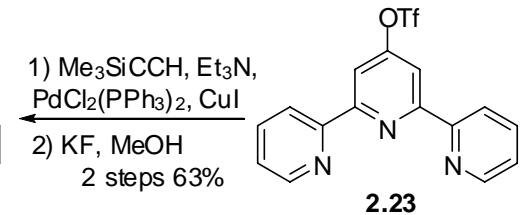<smiles>Clc1cc(-c2ccccn2)nc(-c2ccccn2)c1</smiles>

2.11

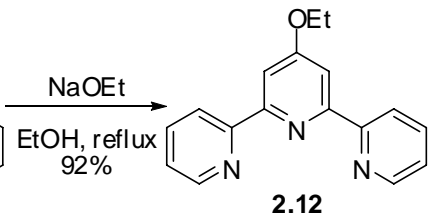




\section{Conclusions}

Three 4,5-diheteroarylphenanthrenes $2.2 \mathbf{a}, \mathbf{2 . 2 b}$, and $\mathbf{2 . 2 c}$ were synthesized via cascade cyclization reactions of the corresponding benzannulated enyne-allenes. The nonbonded steric interactions of the substituents at the $\mathrm{C} 4$ and $\mathrm{C} 5$ positions of the phenanthryl system cause severe helical twist of the structures. The structures of 2.2a and 2.2c were established by X-ray structure analyses, permitting direct measurements of the extent of the structural distortion. The presence of two terpyridyl units in $\mathbf{2 . 2} \mathbf{c}$ allowed it to be used as a ligand for the synthesis of dinuclear ruthenium(II) bis(terpyridine) complexes possessing severe helical twists. The two ruthenium(II) bis(terpyridine) units are in close proximity to each other, making it possible for electronic interactions between the two heteroaromatic $\pi$ systems. 


\section{Reference}

(1) Newman, M. S.; Hussey, A. S. J. Am. Chem. Soc. 1947, 69, 3023-3027.

(2) Armstrong, R. N.; Ammon, H. L.; Darnow, J. N. J. Am. Chem. Soc. 1987, 109, 2077-2082.

(3) Li, H.; Petersen, J. L.; Wang, K. K. J. Org. Chem. 2001, 66, 7804-7810.

(4) Dai, W.; Petersen, J. L.; Wang, K. K. Org. Lett. 2004, 6, 4355-4357.

(5) Newman, M. S.; Whitehouse, H. S. J. Am. Chem. Soc. 1949, 71, 3664-3667.

(6) Newman, M. S.; Lilje, K. C. J. Org. Chem. 1979, 44, 4944-4946.

(7) Karnes, H. A.; Kybett, B. D.; Wilson, M. H.; Margrave, J. L.; Newman, M. S. J. Am. Chem. Soc. 1965, 87, 5554-5558.

(8) Mannschreck, A.; Gmahl, E.; Burgemeister, T.; Kastner, F.; Sinnwell, V. Angewandte Chemie International Edition in English 1988, 27, 270-271.

(9) Grimme, S.; Pischel, I.; Nieger, M.; Vogtle, F. Journal of the Chemical Society, Perkin Transactions 2 1996, 2771-2774.

(10) Tinnemans, A. H. A.; Laarhoven, W. H. Journal of the Chemical Society, Perkin Transactions 2 1976, 1115-1120.

(11) Tinnemans, A. H. A.; Laarhoven, W. H. J. Am. Chem. Soc. 1974, 96, 4617-4622.

(12) Schubert, U. S.; Hofmeier, H.; Newkome, G. R. Modern Terpyridine Chemistry; Wiley-VCH, Weinheim, 2006.

(13)Harriman, A.; Ziessel, R. Carbon-Rich Compounds: From Molecules to Materials; Wiley-VCH, Weinheim, 2006.

(14)Hofmeier, H.; Schubert, U. S. Chem. Soc. Rev. 2004, 33, 373-399.

(15)Li, Y.; Zhang, J.; Wang, W.; Miao, Q.; She, X.; Pan, X. J. Org. Chem. 2005, 70, 3285-3287.

(16) Sonogashira, K.; Tohda, Y.; Hagihara, N. Tetrahedron Lett. 1975, 16, 4467-4470.

(17) Takahashi, S.; Kuroyama, Y.; Sonogashira, K.; Hagihara, N. Synthesis. 1980, 627-630. 
(18)Holmes, B. T.; Pennington, W. T.; Hanks, T. W. Synth. Commun. 2003, 33, 2447 2461.

(19)Coudret, C. Synth. Commun. 1996, 26, 3543 - 3547.

(20) Grosshenny, V.; Romero, F. M.; Ziessel, R. J. Org. Chem. 1997, 62, 1491-1500.

(21)Fang, Y.-Q.; Hanan, G. S. Synlett 2003, 852-854.

(22)Constable, E. C.; Ward, M. D. Journal of the Chemical Society, Dalton Transactions 1990, 1405-1409.

(23) Potts, K. T.; Konwar, D. J. Org. Chem. 1991, 56, 4815-4816.

(24)Constable, E. C.; Cargill Thompson, A. M. W.; Tocher, D. A.; Daniels, M. A. M. New J. Chem. 1992, 16, 855-867.

(25)Schmittel, M.; Strittmatter, M.; Vollmann, K.; Kiau, S. Tetrahedron Lett. 1996, 37, 999-1002.

(26) Schmittel, M.; Strittmatter, M.; Kiau, S. Angewandte Chemie International Edition in English 1996, 35, 1843-1845.

(27)Lainé, P.; Bedioui, F.; Ochsenbein, P.; Marvaud, V.; Bonin, M.; Amouyal, E. J. Am. Chem. Soc. 2002, 124, 1364-1377.

(28)Hofmeier, H.; Andres, P. R.; Hoogenboom, R.; Herdtweck, E.; Schubert, U. S. Aust. J. Chem. 2004, 57, 419-426.

(29) Maestri, M.; Armaroli, N.; Balzani, V.; Constable, E. C.; Thompson, A. M. W. C. Inorg. Chem. 1995, 34, 2759-2767.

(30) Manner, V. W.; Mayer, J. M. J. Am. Chem. Soc. 2009, 131, 9874-9875.

(31)Okamura, T.-a.; Iwamura, T.; Seno, S.; Yamamoto, H.; Ueyama, N. J. Am. Chem. Soc. 2004, 126, 15972-15973.

(32) Winter, A.; Hummel, J.; Risch, N. J. Org. Chem. 2006, 71, 4862-4871. 


\section{Chapter 3}

\section{Synthethesis of 1,4-Naphthoquinone Methides via}

\section{Acid-Catalyzed Cascade Cyclizations of the Benzannulated \\ Enediynyl Alcohols}

\section{Introduction}

Quinone methides (QMs) contain a cyclohexadiene core, to which a carbonyl group and a methylene unit are attached. In terms of structure, QMs are related to benzoquinones and quinone dimethides. However, QMs are highly polarized and quite reactive unlike benzoquinones because QMs have two different function groups. Many QMs are believed to be major intermediates in many different biochemical transformations. Significantly, QMs can serve as ultimate cytotoxins, contributing to the drug efficacy of antitumor drugs, antibiotics, and DNA alkylators. ${ }^{1-3}$

\subsection{Parent Quinone Methides}

In the areas of chemistry and biology, parent ortho (3.1) and para (3.2) quinone methides (QMs) are the most often encountered isomers. Meta-QMs (3.3) are drawn as zwitterionic (3.3a) or biradical (3.3b) structures because they have non-Kekule structures (Figure 3.1). ${ }^{4}$

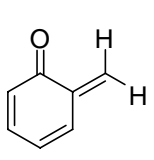

3.1

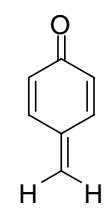

3.2

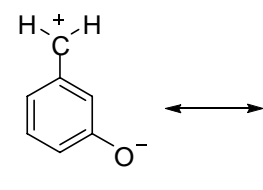

$3.3 a$

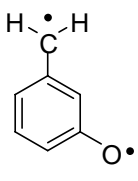

3.3b

Figure 3.1 The structures of parent quinone methides. 
For simple QMs without substituents on the exocyclic methylene group, the QMs molecules are often too reactive to be isolated in pure form because polymerization occurs upon concentrating the dilute solutions. ${ }^{5}$ QMs belong to the antiaromatic Hückel pseudo $4 n \pi$-electron system. However, the reactivity of QMs can be directly measured at a low temperature with the aid of matrix isolation techniques. ${ }^{6,7}$

\subsection{Properties and Synthetic Applications of Quinone Methides}

Both ortho- and para-quinone methides have zwitterionic resonance structures. Therefore, these molecules have both cationic and anionic centers and they can react with both nucleophiles and electrophiles (Scheme 3.1). When nucleophilics attack on a quinone methide, an aromatic phenol ring is usually generated. The quinone methide reactivity is enhanced by the aromatization of the ring. Additionally, rearomatization of the ring can occur when chroman derivatives are produced by formal [4+2] cycloaddition reactions of ortho-quinone methides with electron-rich dienenophiles. ${ }^{8}$

Scheme 3.1. Reactions of ortho- and para-quinone methides.

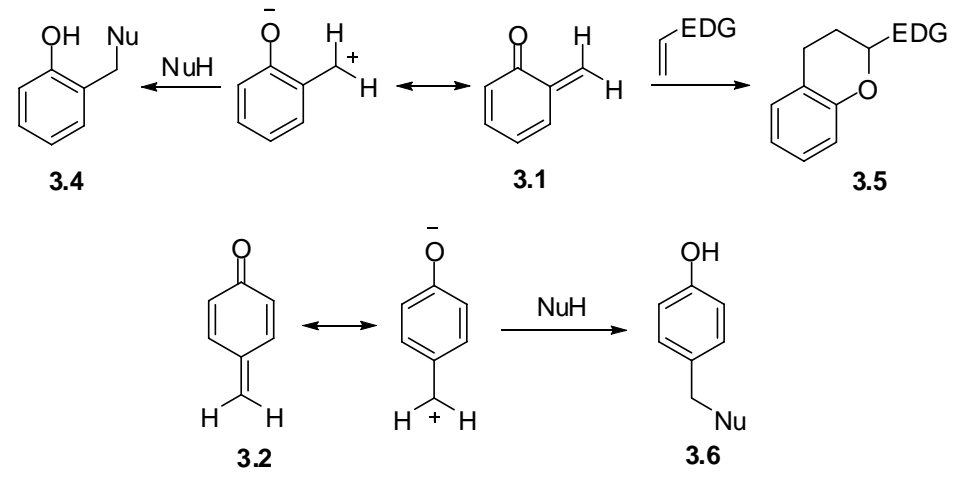

QMs have been reported to be important intermediates in a variety of chemical synthesis and biological processes. $o$-QMs have often been employed in intramolecular or intermolecular [4+2] cycloaddition, dimerization, and electrocyclization reactions (Scheme 3.2). For example, tanzanene $\mathbf{3 . 8}$ was prepared by a diastereoselective cycloaddition reaction between the exocyclic olefin of alloaromadendrene 3.7 and the 
parent $o$-QM. ${ }^{9}$ Pettila reported that Margaspidin 3.11 could be prepared from C-alkylation of a phenol 3.9 with its corresponding $o-\mathrm{QM} \mathrm{3.10} .^{10} \mathrm{~A}$ one-pot synthesis of precocene 3.18 was achieved through a chelation controlled regioselective addition of aldehyde $\mathbf{3 . 1 3}$ ortho to the hydroxyl group in phenol 3.12 and an electrocyclization of $Z o-\mathrm{QM} 3.17$ which is in equilibrium with its $E$ isomer 3.16. ${ }^{11}$ Moore proposed that the formation of an $o$-QM species in vivo upon bio-reductive activation accounted for the anticancer efficacy of several quinone nature products. ${ }^{12}$

Scheme 3.2. Synthetic application of ortho-quinone methid.

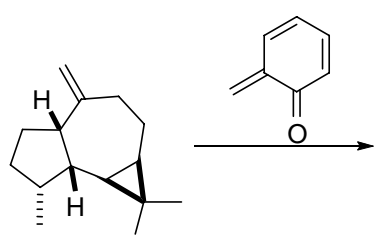

3.7
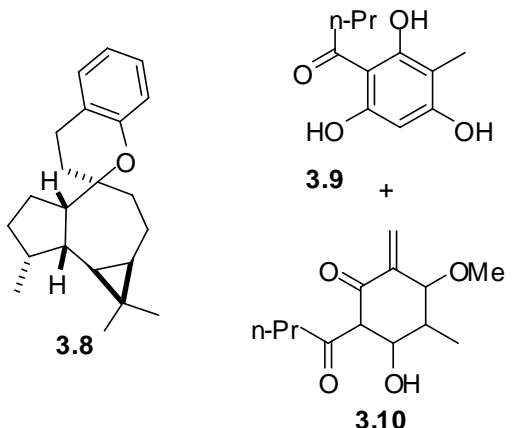

3.10
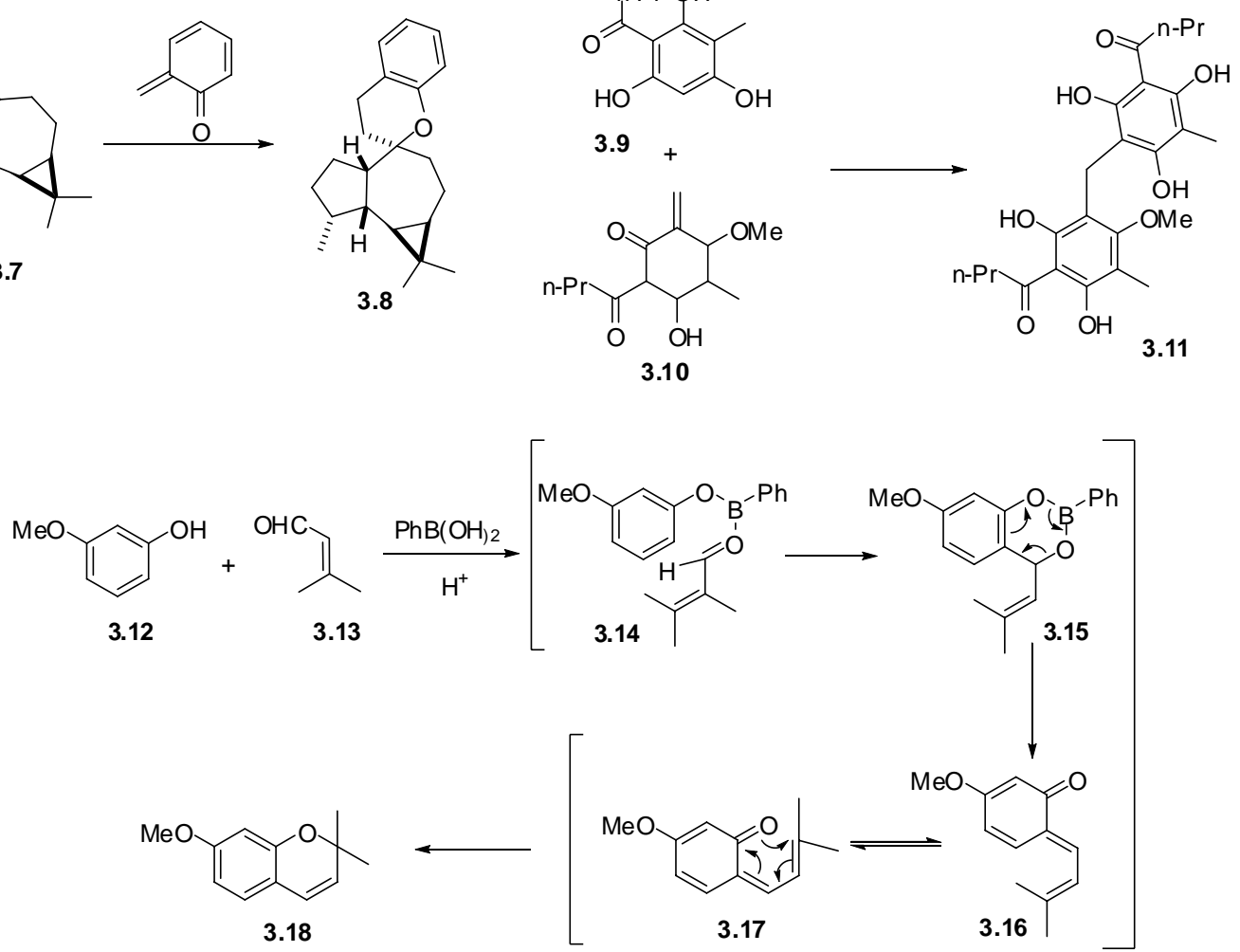

para-Quinone methides have also been used in synthetic chemistry. Generally, $p$-QMs are easily reduced to the corresponding $p$-alkyl phenols. Aromatization of $p$-QMs can occur by nucleophilic 1,6 addition. ${ }^{13,14}$ Angle reported that $p$-QMs could either undergo intramolecular cyclization to produce a variety of $p$-hydroxyphenyl- substituted ring systems or react with an alkene to give indanes through a formal [3+2] cycloaddition 
(Scheme 3.3) ${ }^{15-17}$ In the biosynthesis, $\quad p$-QMs are considered to be crucial intermediates and subsequent chemistry of lignin. ${ }^{18}$ Additionally, $p$-QMs were reported to have useful applications in a variety of areas, such as serving as cationic dyes and $\mathrm{pH}$-sensitive indicators. ${ }^{19-22}$

Scheme 3.3. Synthetic application of para-quinone methid.

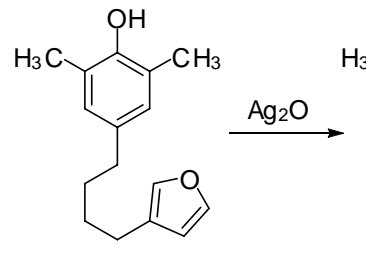

3.19

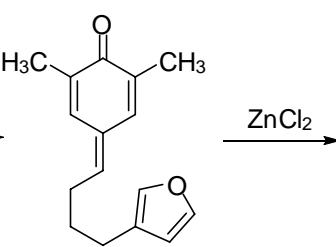

3.20

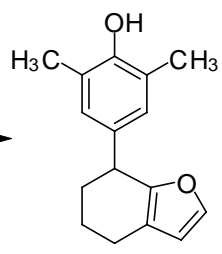

3.21

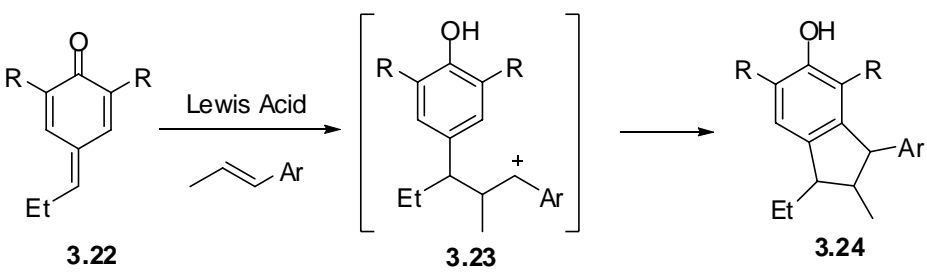

\subsection{Synthetic method used to generate quinone methides}

Due to the wide applications of quinone methides as intermediates in organic synthesis, many different methods have been developed for their preparation. The synthetic methods include (a) tautomerization, (b) oxidation, (c) thermolysis, (d) photolysis, (e) acid promotion, (f) base facilitation and (g) the olefination of quinones.

Jurd firstly demonstrated that tautomerization of benzoquinone 3.25 to an $o-\mathrm{QM}$ could initiate a subsequent reaction (Scheme 3.4) ${ }^{23,24}$ Waters found that a combination of silver(I) oxide with 3.27 generated the $o-\mathrm{QM}$ 3.28 that underwent immediate self-condensation to form a spirodimer. ${ }^{25}$ Many precursors have been selected in the generation of $o-\mathrm{QM}$ by thermolysis. For example, 1-azobenzofuran 3.29 was heated to expel $\mathrm{N}_{2}$ and form an intermediate nitrene, which underwent further rearrangement to afford the nitrile $o$-QM 3.30. ${ }^{26}$ However, only the thermally unstable precursors of $o$-QMs 
can be used in the thermal generation techniques. For the thermally stable QM precursors that possess poor leaving groups such as the hydroxy or alkoxy group, photochemical methods are employed. The best-studied photochemical o-QM precursors are o-hydroxybenzyl and ethers as depicted in 3.31. These compounds could form the corresponding $o$-QM 3.32 easily at room temperature after photolysis at $254 \mathrm{~nm}{ }^{27-29}$

Scheme 3.4. Synthetic methods for ortho-quinone methid.
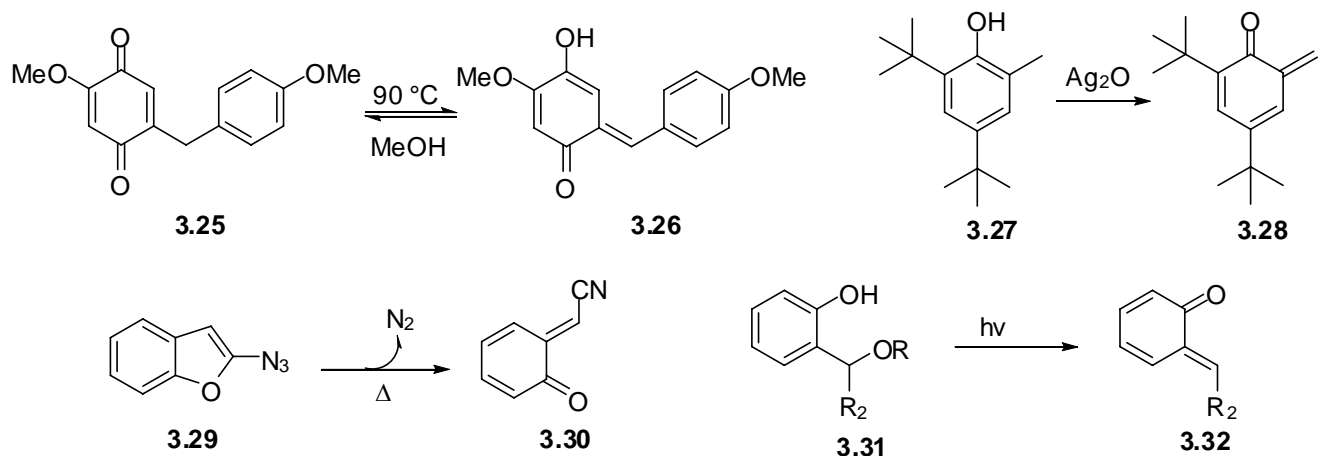

Because para-quinone methides are less polarized and more stable than their corresponding $o$-QMs, $p$-QMs are formed more readily than $o$-QMs. The most often used synthetic methods for $p$-QMs involved the preparation of triarylmethyl precursors for subsequent transformations. The synthesis of diphenylmethylene-substituted $p$-quinone (3.34) by the $O$-demethylation of methoxyphenyl trityl alcohol 3.33 under acidic condition or the photodehydration of para-hydroxytriphenylmethanol $\mathbf{3 . 3 5}$ was reported

Scheme 3.5. Synthetic methods for para-quinone methid.
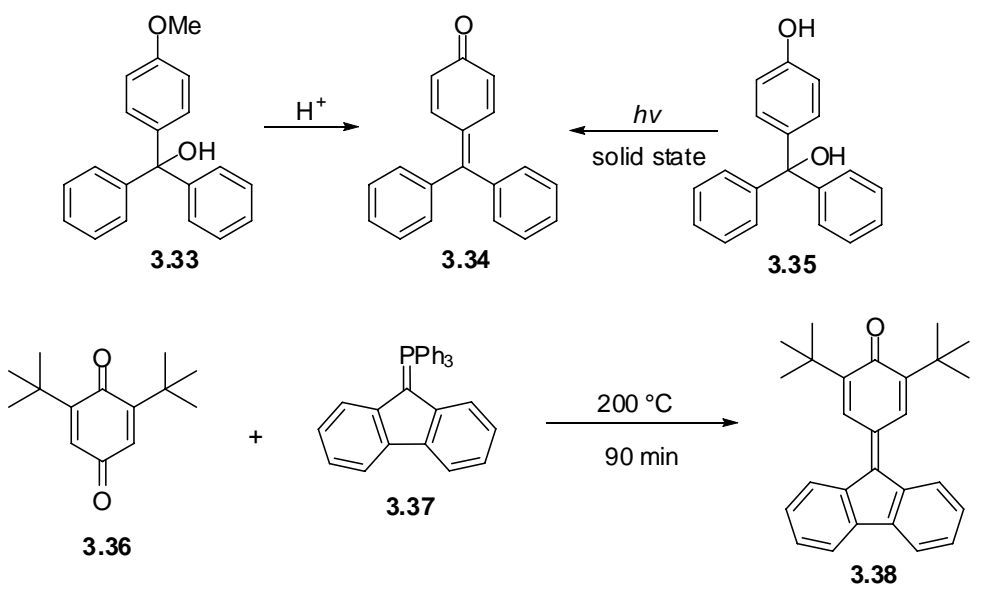
many years ago. ${ }^{30-34}$ The use of the Wittig reaction for condensation with p-benzoquinones ${ }^{13}$ and 1,4-naphthoquinones ${ }^{35}$ has also been reported (Scheme 3.5).

To stabilize the reactive $\pi$-electron system of $p$-QMs and then isolate the pure products, various experiment approaches have been proposed. ${ }^{36-38}$ Figure 3.2 shows the examples for the most successful approach, including (a) introduction of bulky terbutyl substituents in the ortho positions to the carbonyl group (3.39); (b) replacement of exocyclic methylene hydrogen by an electron-donating group (3.40); (c) annelation of an aromatic $\pi$-electron system to the six membered quinonoid ring (3.41); (d) coordination of a metal to the exocyclic methylene group of simple $p$-QMs (3.42).

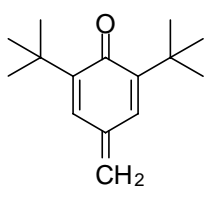

3.39

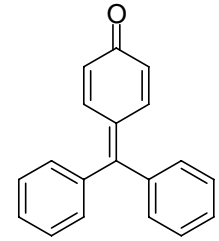

3.40

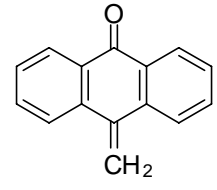

3.41

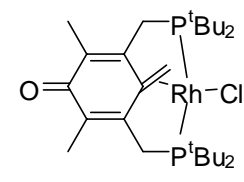

3.42

Figure 3.2 Structures of stabilized $p$-QMs.

\section{Results and Discussion}

\subsection{The synthesis of 1,4-naphthoquinone methides}

In our investigations of the cascade cyclization reactions of benzannulated enediynyl

alcohols, ${ }^{39}$ a serendipitous discovery led to the development of a new synthetic pathway to 1,4-naphthoquinone methides bearing two aryl substituents at the exo-cyclic methylene group under a mild acidic condition at room temperature.

Treatment of the benzannulated enediyne 3.42 with lithium diisopropylamide (LDA) to form the corresponding lithium acetylide followed by condensation with 1-indanone 3.45 produced the benzannulated enediynyl alcohol 3.46 after aqueous workup (Scheme 3.6). On exposure to trifluoroacetic acid at room temperature for $10 \mathrm{~min}, \mathbf{3 . 4 6}$ was 
smoothly transformed to 1,4-naphthoquinone methide $\mathbf{3 . 4 9}$ in $92 \%$ isolated yield. Similarly, 3.50 was obtained from 3.43 and 3.45. However, no quinone methide 3.51 was formed from the corresponding 3.48. Several other examples of using different combinations of benzannulated enediynes and aryl ketones to form 1,4-naphthoquinone methides are shown in Figure 3.3. The transformations from 3.53 to 3.54 and from $\mathbf{3 . 5 6}$ to 3.57 occurred within $20 \mathrm{~min}$ at room temperature. In the cases of $\mathbf{3 . 6 0}$ and $\mathbf{3 . 6 3}$, the reaction mixtures were stirred at room temperature for $60 \mathrm{~min}$. Unexpected, ketone $\mathbf{3 . 6 6}$ was formed under this reaction conditions. The transformation to 1,4-naphthoquinone methides by this method is particularly efficient for cyclic aromatic ketones bearing a methoxyl group at the position para to the keto group and involves an unusual two-carbon ring expansion. It is also worth noting that unlike other reported methods, this new synthetic pathway involves the formation of the $p$-quinone methide ring system from an acyclic precursor.

Scheme 3.6. Synthesis of 1,4-naphthoquinone methides.

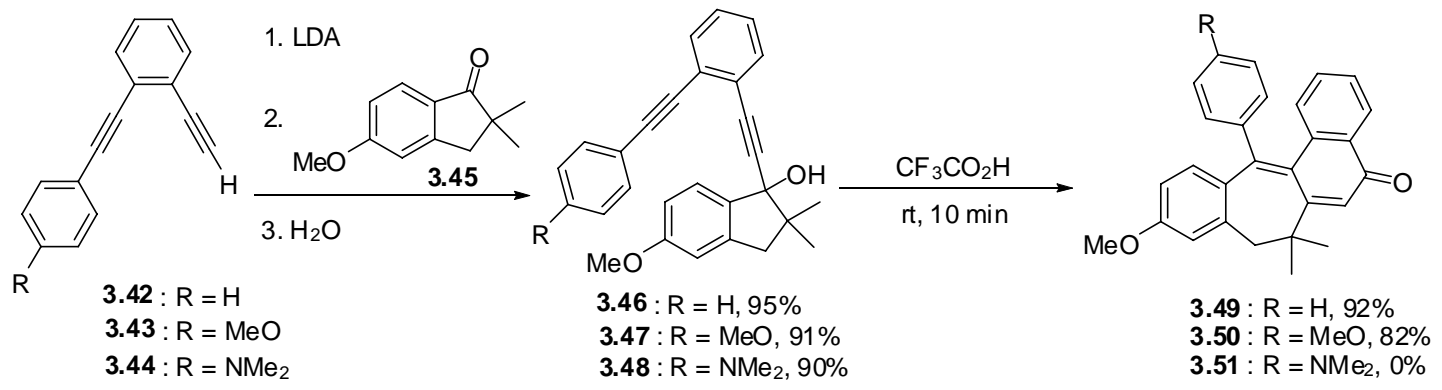

Using the transformation from 3.46 to 3.49 as an example, a proposed reaction mechanism is outlined in Scheme 3.7. The acid-catalyzed transformation of the propargylic alcohol moiety in $\mathbf{3 . 4 6}$ through cationic intermediates $3.46 \mathrm{a}$ and $\mathbf{3 . 4 6 b}$ could produce the $\alpha, \beta$-unsaturated ketone system in 3.46c. A subsequent carbon-carbon bond formation between one of the acetylenic carbons and the $\beta$-carbon of the enone system to form a new six-membered ring could lead to 3.46d. The carbocationic center in $\mathbf{3 . 4 6 d}$ could be captured by an electron-rich $\pi$ bond of the methoxyl-substituted benzene system 


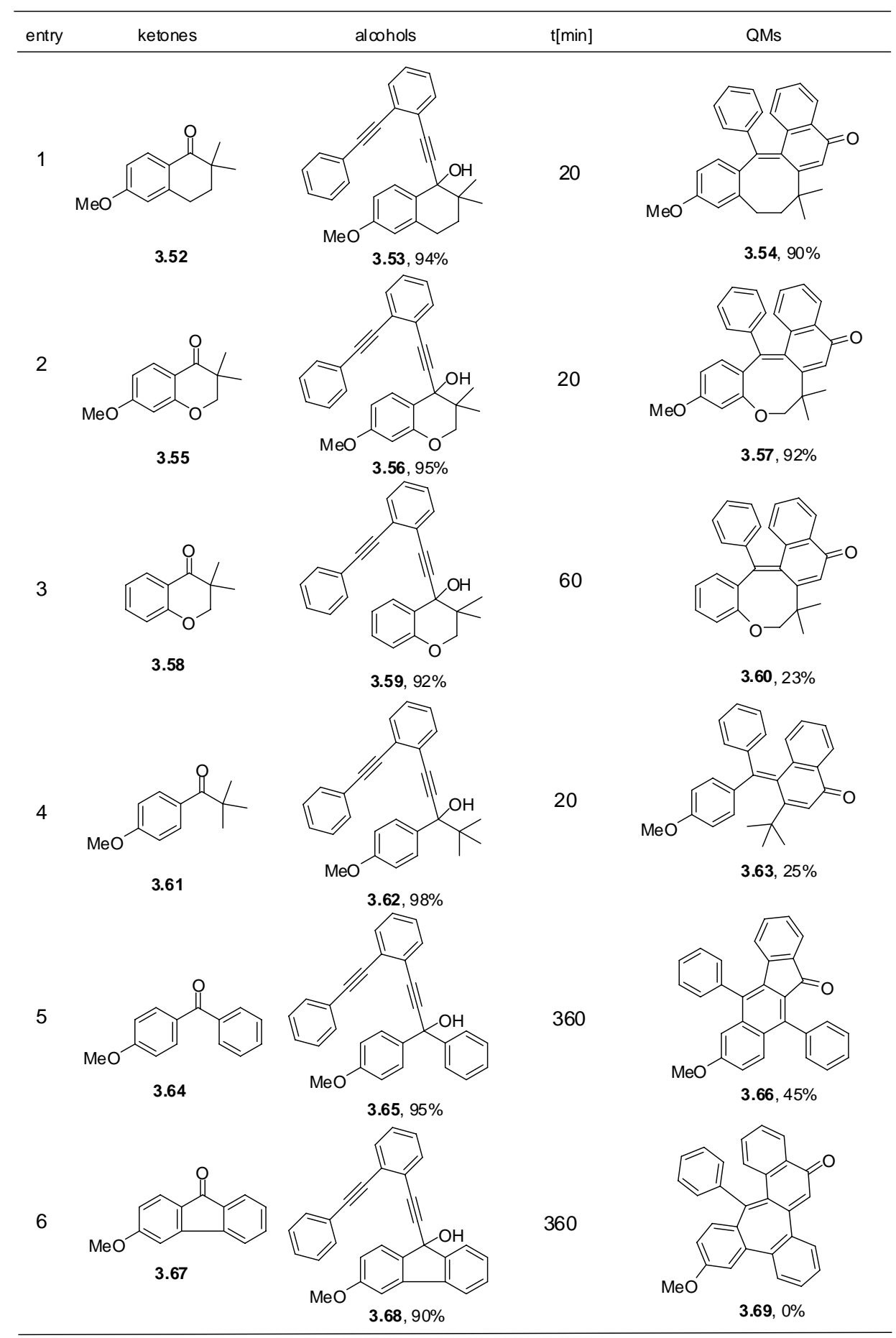

Figure 3.3 The scope and limitation of the new synthetic pathway for QMs

to form 3.46e having a strained cyclobutenyl ring. A subsequent carbon-carbon bond cleavage with the relief of the ring strain could then lead to 1,4-naphthoquinone methide 
3.49 with an unusual two-carbon ring expansion.

Scheme 3.7. Proposed mechanism from 3.46 to 3.49.

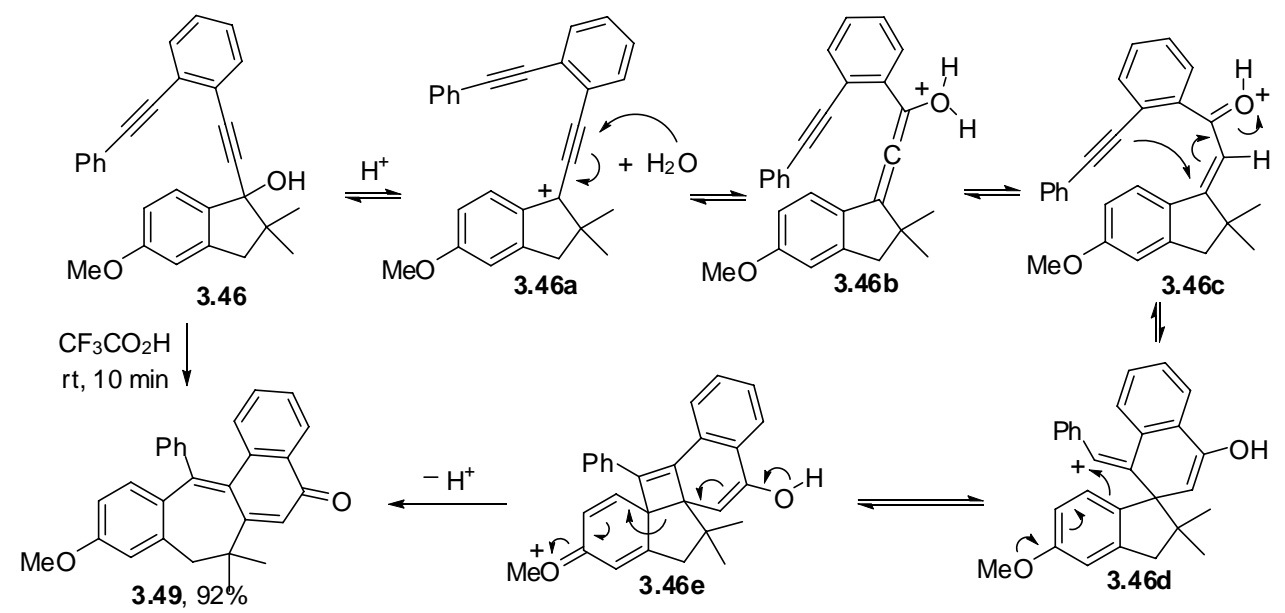

The proposed reaction mechanism is supported by the observation that on exposure to trifluoroacetic acid, the benzannulated enediynyl alcohol $\mathbf{3 . 7 0}$ produced the $\alpha, \beta$-unsaturated ketone 3.71 with the second acetylenic group being hydrated to form a keto group (Scheme 3.8). Apparently, in this case the rate of hydration of the second acetylenic group bearing a 4-methoxyphenyl substituent is faster than that of attacking the $\beta$-carbon of the enone system as shown in 3.46c. The presence of a methoxyl group in 3.46 is crucial to the success of the reaction. Without the methoxyl group, a complex mixture of products was observed. Presumably, the presence of a para-methoxyl group in 3.46a further stabilizes this carbocationic species and may also facilitate the capture of the carbocationic center in 3.46d. In addition, without the $\alpha, \alpha$-dimethyl group in $\mathbf{3 . 4 6}$ simple dehydration occurred to form an indene derivative.

Scheme 3.8. The formation of ketone 3.71.

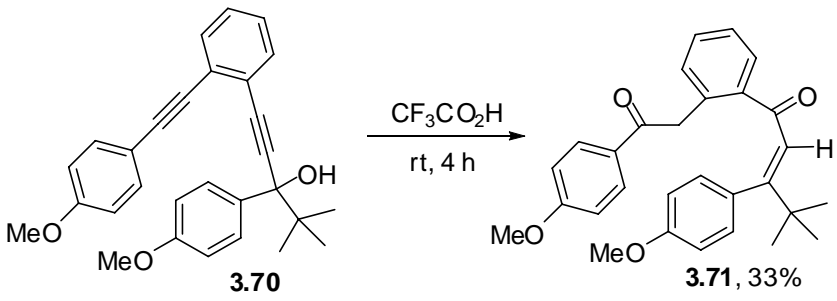




\subsection{The properties of 1,4-naphthoquinone methides}

The X-ray crystal structures of 3.49 and 3.54 indicate that the phenyl substituents are oriented essentially perpendicular to the exocyclic carbon-carbon double bond of the p-quinone methide system (Figure 3.4). In the case of 3.54, the eight-membered ring adopts a tub-like conformation, causing the benzene ring of the $p$-methoxyphenyl group also to orient essentially perpendicular to the exocyclic carbon-carbon double bond. For 3.49, the ${ }^{1} \mathrm{H}$ NMR signals of the aliphatic gem-dimethyl and methylene hydrogens and the aromatic hydrogens on the phenyl substituent are broad at room temperature, indicating a relatively slow rate of ring inversion of the 7-membered ring and a slow rate of rotation of the phenyl substituent on the NMR time scales. At $-20{ }^{\circ} \mathrm{C}$, however, two singlets from the gem-dimethyl group and a distinct $\mathrm{AB}$ coupling pattern of the methylene hydrogens could be clearly discerned. A similar dynamic NMR phenomenon was also observed for 3.54. In addition, the tub-like conformation of the eight-membered ring in 3.54 causes one of the methyls of the gem-dimethyl group to be located in the magnetically shielding region of the $p$-methoxyphenyl group. As a result, its ${ }^{1} \mathrm{H}$ NMR signal exhibits a significant upfield shift, appearing at $\delta=0.43$.
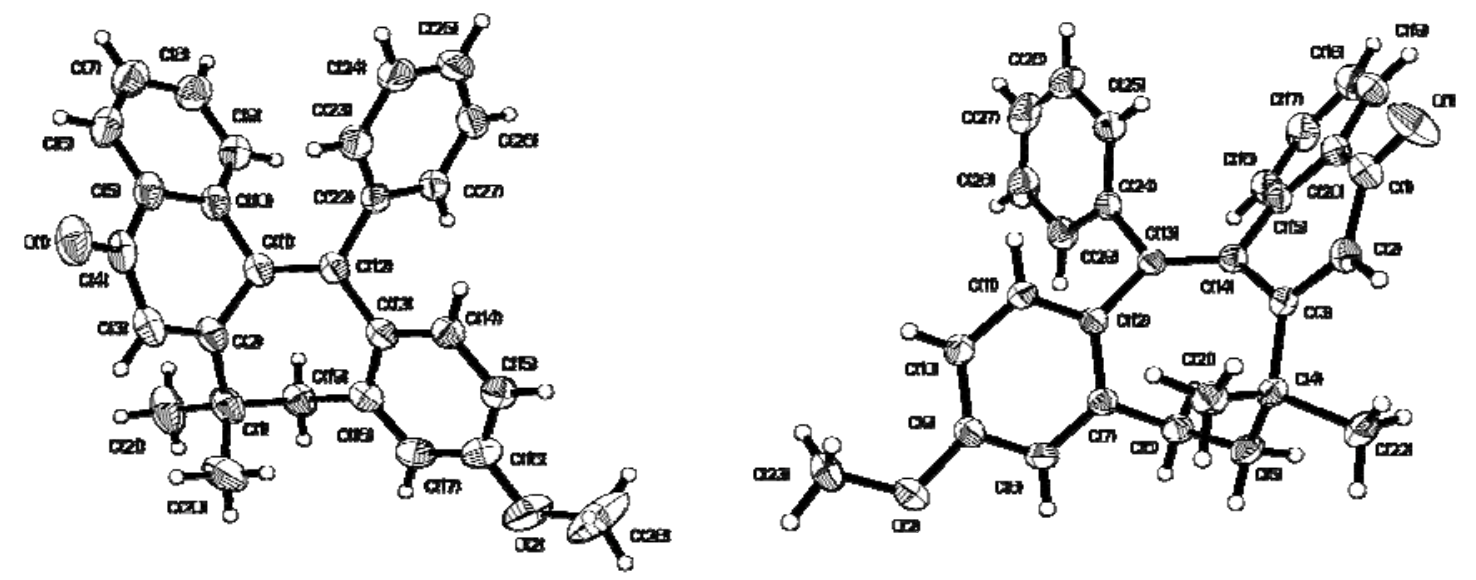

Figure 3. 4 ORTEP drawing of the crystal structure of 3.49 and 3.54 
The UV-vis absorption spectra of $\mathbf{3 . 4 9}$ and 3.54, recorded in $\mathrm{CH}_{3} \mathrm{CN}\left(5.0 \times 10^{-5} \mathrm{M}\right)$, reveal absorption bands in the visible region with maxima at 397 and $402 \mathrm{~nm}$, respectively (Figure 3.5). This is similar to what was observed for the 1,4-naphthoquinone methide having two phenyl substituents on the exo-cyclic methylene group, which exhibits an absorption maximum at $400 \mathrm{~nm} .{ }^{4}$ Bathochromic shifts were observed for $\mathbf{3 . 5 0}\left(\lambda_{\max }=410 \mathrm{~nm}\right)$ bearing an additional $p$-methoxyl substituent and $\mathbf{3 . 5 7}$ $\left(\lambda_{\max }=413 \mathrm{~nm}\right)$ having an additional $o$-alkoxyl substituent. Fluorescence spectra of 3.49 and 3.50 were shown in Figure 3.6. On exposure of 3.49 to increasing concentration of sulfuric acid, an absorption band with maximum at $559 \mathrm{~nm}$ emerges with increasing intensity, which is attributable to the formation of the corresponding triarylmethyl cation (Figure 3.7). ${ }^{40}$

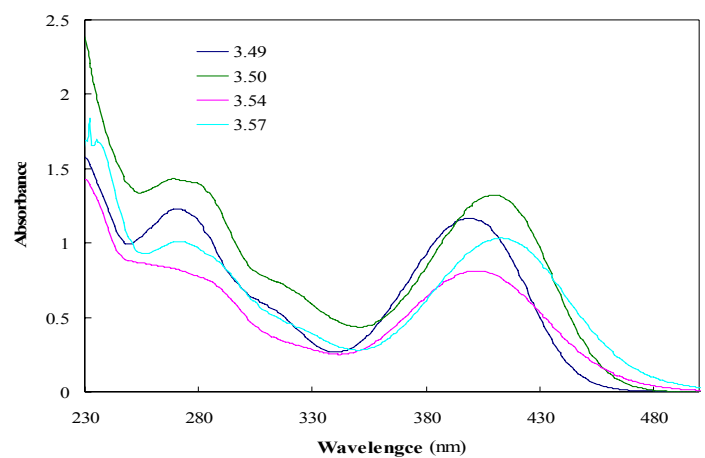

Figure 3.5 UV-vis absorption sepectra of 3.49, 3.50, 3.54, and 3.57 $\left(5.0 \times 10^{-5} \mathrm{M}\right)$ in $\mathrm{CH}_{3} \mathrm{CN}$.

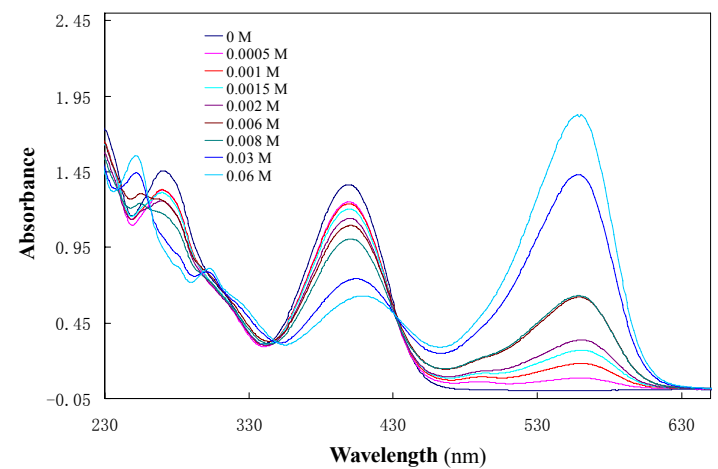

Figure 3.7 UV-vis absorption sepectra of $\mathbf{3 . 4 9}$ (5.0 x $10^{-5} \mathrm{M}$ ) in $\mathrm{CH}_{3} \mathrm{CN}$ with varying $\mathrm{H}_{2} \mathrm{SO}_{4}$ concentration.

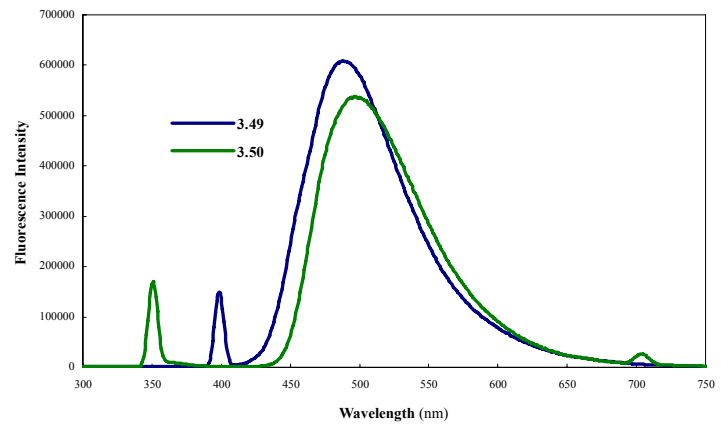

Figure 3.6 Luminescence spectra of $\mathbf{3 . 4 9}$ and 3.50 $\left(5.0 \times 10^{-5} \mathrm{M}\right)$ in $\mathrm{CH}_{3} \mathrm{CN}$.

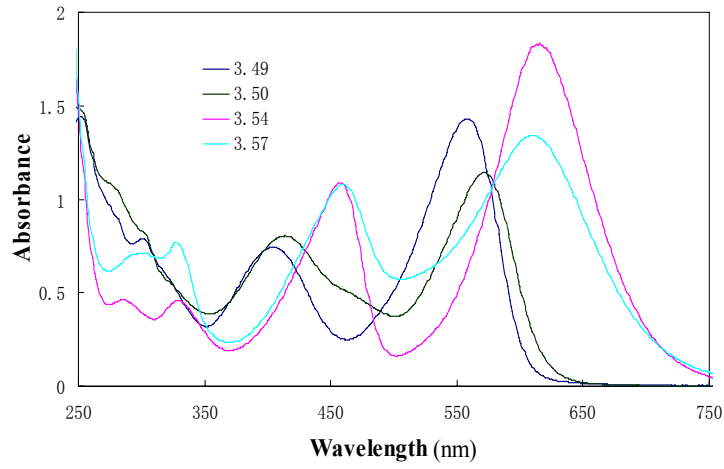

Figure 3.8 UV-vis absorption sepectra of 3.49, 3.50, 3.54, and 3.57 with acid.. 
Similar absorption bands were observed for $\mathbf{3 . 5 0}\left(\lambda_{\max }=570 \mathrm{~nm}\right), \mathbf{3 . 5 4}\left(\lambda_{\max }=615\right.$ $\mathrm{nm})$, and $3.57\left(\lambda_{\max }=609 \mathrm{~nm}\right)$ on exposure to sulfuric acid with pronounced bathochromic shifts for the cases of $\mathbf{3 . 5 4}$ and $\mathbf{3 . 5 7}$ bearing an eight-membered ring (Figure 3.8). As a result, the color of the solution turns red in the cases of $\mathbf{3 . 4 9}$ and $\mathbf{3 . 5 0}$ and turns green in the cases of $\mathbf{3 . 5 4}$ and $\mathbf{3 . 5 7}$.

\subsection{The synthesis of requisite fragments}

Ketones 3.80 and $\mathbf{3 . 8 5}$ were prepared according to the reported procedures. The synthetic procedures for benzannulated enediyne 3.43 and 3.44 , ketone 3.82 and $\mathbf{3 . 8 6}$ were summarized in Scheme 3.9.

Scheme 3.9. synthesis of benzannulated enediynes and ketones

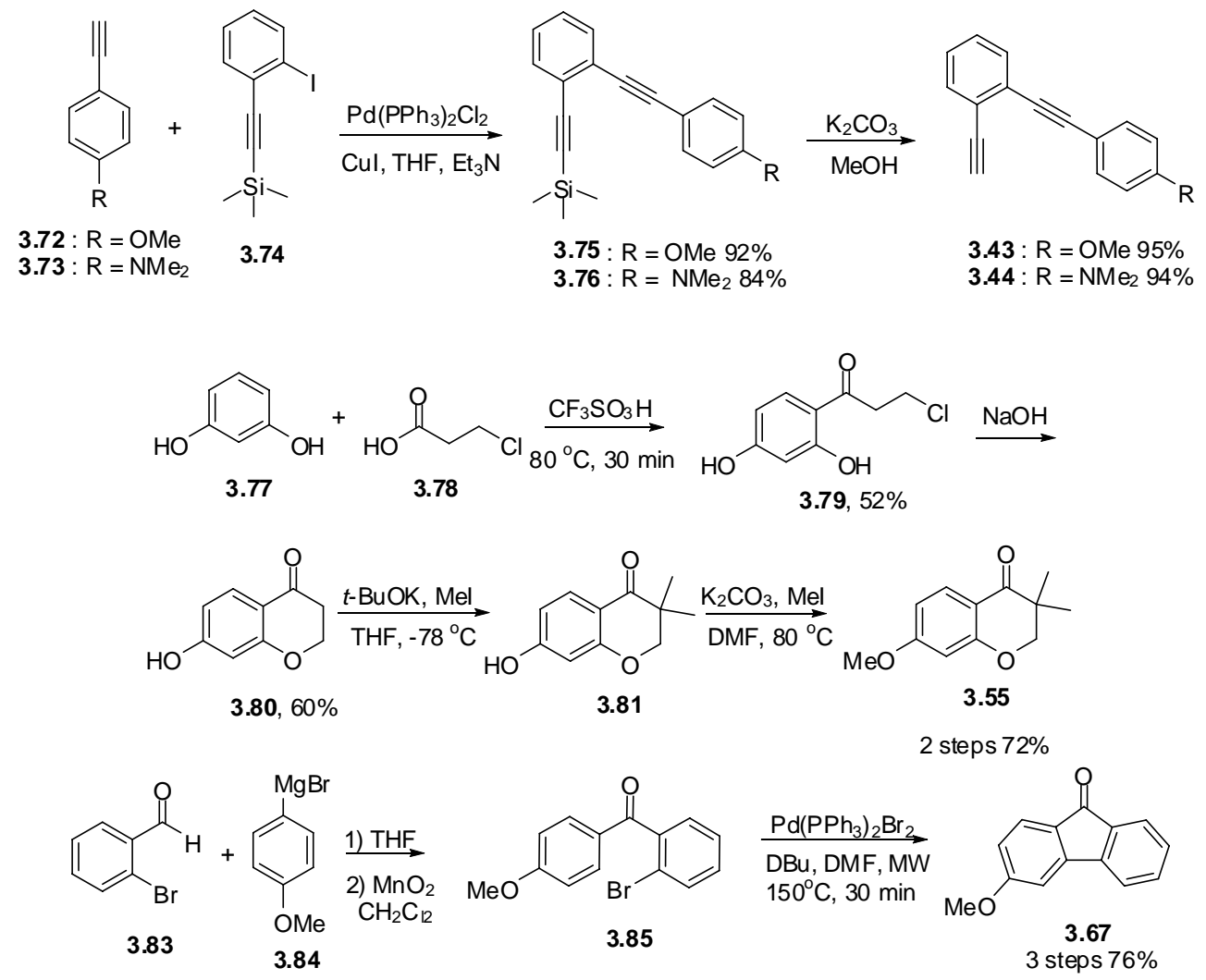




\section{Conclusion}

In conclusion, a new acid-catalyzed cascade cyclization pathway to transform benzannulated enediynyl alcohols to 1,4-naphthoquinone methides was discovered. For cyclic alcohols, the transformation involved an unusual two-carbon ring expansion. In addition, the $p$-quinone methide ring system was constructed from an acyclic precursor. Compared to the Schmittel cyclization reaction of the enyne-allene systems, derived from benzannulated enediynyl alcohols, leading to benzofluorenyl systems via biradical intermediates, the current process proceeds through cationic intermediates, leading to 1,4-naphthoquinone methides. 


\section{Reference}

(1) Rokita, S. E. Quinone Methides; Wiley: New Jersey, 2009.

(2) Thompson, D. C.; Thompson, J. A.; Sugumaran, M.; Moldeus, P.; Chem.-Biol. Interact. 1993, 86, 129-162.

(3) Wagner, H.-U.; Gompper, R. In The Chemistry of the Quinonoid Compounds; Wiley, New York, N. Y., 1974.

(4) Diao, L.; Yang, C.; Wan, P. J. Am. Chem. Soc. 1995, 117, 5369-5370.

(5) Dyall, L. K.; Winstein, S. J. Am. Chem. Soc. 1972, 94, 2196-2199.

(6) Lasne, M. C.; Ripoll, J. L.; Denis, J. M. Tetrahedron 1981, 37, 503-508.

(7) Chapman, O. L.; McIntosh, C. L. Journal of the Chemical Society D: Chemical Communications 1971, 383-384.

(8) Wan, P.; Barker, B.; Diao, L.; Fischer, M.; Shi, Y.; Yang, C. Canadian Journal of Chemistry. 1996, 74, 465-475.

(9) Paknikar, S. K.; Fondekar, K. P.; Mayer, R. Nat. Prod. Lett. 1996, 8, 253 - 256.

(10)Penttila, A.; Kapadia, G. J.; Fales, H. M. J. Am. Chem. Soc. 1965, 87, 4402-4403.

(11)Bissada, S.; Lau, C. K.; Bernstein, M. A.; Dufresne, C. Can. J. Chem. 1994, 72, 1866-1869.

(12) Moore, H. W. Science 1977, 197, 527-532.

(13)Becker, H. D.; Gustafsson, K. J. Org. Chem. 1976, 41, 214-221.

(14)Becker, H. D. J. Org. Chem. 1967, 32, 4093-4095.

(15) Angle, S. R.; Arnaiz, D. O. J. Org. Chem. 1992, 57, 5937-5947.

(16) Angle, S. R.; Rainier, J. D. J. Org. Chem. 1992, 57, 6883-6890.

(17) Angle, S. R.; Arnaiz, D. O.; Boyce, J. P.; Frutos, R. P.; Louie, M. S.; Mattson-Arnaiz, H. L.; Rainier, J. D.; Turnbull, K. D.; Yang, W. J. Org. Chem. 1994, 59, 6322-6337.

(18)Shevchenko, S. M.; Apushkinskii, A. G. Russ. Chem. Rev. 1992, 61, 105-131.

(19) Gomberg, M.; Sullivan, F. W. J. Am. Chem. Soc. 1920, 42, 1864-1870.

(20)Kolthoff, I. M.; Chantooni, M. K.; Bhowmik, S. Anal. Chem. 1967, 39, 315-320. 
(21)Higuchi, T.; Feldman, J. A.; Rehm, C. R. Anal. Chem. 1956, 28, 1120-1130.

(22)Kolthoff, I. M.; Bruckenstein, S. J. Am. Chem. Soc. 1956, 78, 1-9.

(23) Jurd, L. Tetrahedron 1977, 33, 163-168.

(24) Jurd, L.; Roitman, J. N. Tetrahedron 1978, 34, 57-62.

(25)Moore, R. F.; Waters, W. A. J. Chem. Soc. 1954, 243-246.

(26)Foresti, E.; Spagnolo, P.; Zanirato, P. J. Chem. Soc. Perk. T. 1. 1989, 1354-1356.

(27)Padwa, A.; Lee, G. A. J. Am. Chem. Soc. 1973, 95, 6147-6149.

(28)Chiang, Y.; Kresge, A. J.; Zhu, Y. J. Am. Chem. Soc. 2000, 122, 9854-9855.

(29)Huang, C. G.; Beveridge, K. A.; Wan, P. J. Am. Chem. Soc. 1991, 113, 7676-7684.

(30) Gomberg, M. J. Am. Chem. Soc. 1913, 35, 1035-1042.

(31)Lewis, T. W.; Curtin, D. Y.; Paul, I. C. J. Am. Chem. Soc. 1979, 101, 5717-5725.

(32) Gomberg, M.; Jickling, R. L. J. Am. Chem. Soc. 1915, 37, 2575-2591.

(33)Wada, M.; Watanabe, T.; Natsume, S.; Mishima, H.; Kirishima, K.; Erabi, T. Bull. Chem. Sco. Jpn. 1995, 68, 3233-3240.

(34)Taljaard, B.; Taljaard, J. H.; Imrie, C.; Caira, M. R. Eur. J. Org. Chem. 2005, 2005, 2607-2619.

(35) Sullivan, W. W.; Ullman, D.; Shechter, H. Tetrahedron Lett. 1969, 10, 457-461.

(36)Koutek , B.; Pišova , M.; Krupička , J.; Lyčka , A.; Šnobl, D.; Souček, M. Coll. Czech. Chem. Commun. 1982, 47, 1645-1653.

(37) Vigalok, A.; Milstein, D. J. Am. Chem. Soc. 1997, 119, 7873-7874.

(38) Vigalok, A.; Shimon, L. J. W.; Milstein, D. J. Am. Chem. Soc. 1998, 120, 477-483.

(39)Li, H.; Zhang, H.-R.; Petersen, J. L.; Wang, K. K. J. Org. Chem. 2001, 66, $6662-6668$.

(40)Deno, N. C.; Jaruzelski, J. J.; Schriesheim, A. J. Am. Chem. Soc. 1955, 77, 3044-3051. 


\section{CHAPTER 4}

\section{Synthesis of bowl-shaped fullerene fragments with curved surfaces: Buckybowls}

\section{Introduction}

Research in carbon cages has attracted considerable attention in the field of physics, chemistry, and material science since the discovery of the spherical fullerenes and carbon nanotubes (a new form of element carbon). ${ }^{1}$ Fullerenes are cage-like, extremely stable forms of carbon (Figure 4.1). Buckminsterfullerene (or buckyball) have a molecular formula of $\mathrm{C}_{60}$. The three dimensional structure of buckyball consists of twenty six-membered aromatic rings surrounding twelve five-membered rings. Robert Curl, Harold Kroto, and Richard Smalley won the 1996 Nobel Prize in Chemistry for discovering the first fullerene in $1985 .^{2}$ In 1991, Iijima Sumio of Japan introduced the elongated cousins of buckyballs, carbon nanotubes. ${ }^{3}$ Carbon nanotubes have three dimensional structures like cylinders and each cylinder wall consists of a sheet of

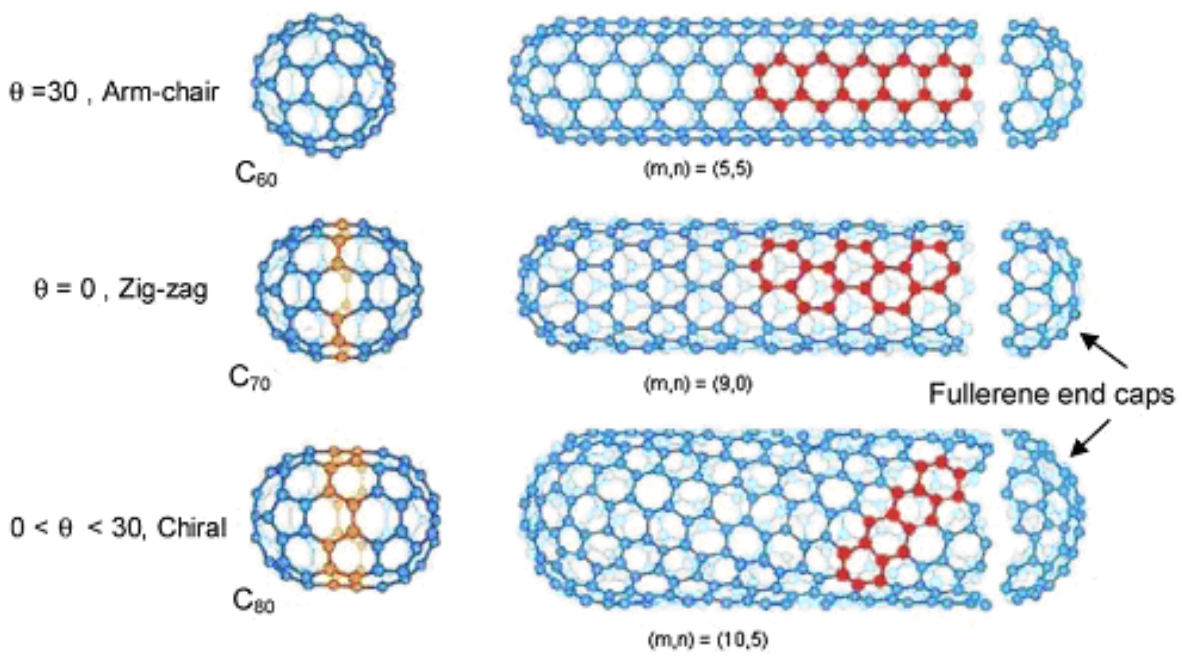

Figure 4.1 Model of fullerenes 
hexagonal rings arranged by the carbon atoms. The structures of cylinders usually have closed-off ends, ranging from 2 to 10 micrometers in length and from 5 to 40 nanometers in diameter. Generally, the ends of carbon nanotubes were capped by fullerene substructure with the existence of pentagonal rings (necessary for closure of the tubes).

Interesting electronic and magnetic behaviors have been observed for buckyballs and carbon nanotubes. These properties allow them to find useful application in structural materials and medicine. The presence of multiple aromatic rings and the superaromacity might account for their unusual electronic and magnetic properties. ${ }^{4}$

Inspired by the discovery and applications of fullerenes, bowl-shaped polyaromatic hydrocarbons (PAHs) with molecular networks that can be mapped on the surface of buckyball $\left(\mathrm{C}_{60}\right)$ are now also considered to be a group of important materials in the science of nonplanar $\pi$-conjugated carbon systems (Figure 4.2 ). ${ }^{5-7}$ These open geodesic polyarenes have commonly been referred to as "fullerene fragments" or "buckybowls". In the past 20 years, synthesis, structural characterization, and properties of buckybowls, such as corannulene (4.1), sumanene (4.2), and tetrabenzopyracylene (4.3), have been actively investigated. All of them are characterized by both concave and convex $\pi$-surfaces as well as by a high degree of strain energy resulting from the pyramidalization of interior trigonal carbon atoms. Corannulene and sumanene possess

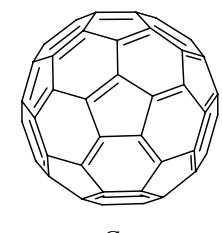

$\mathrm{C}_{60}$

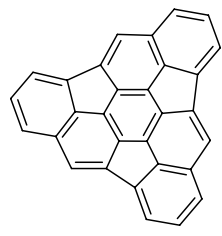$$
\begin{gathered}
\mathrm{C}_{30} \mathrm{H}_{12} \\
\text { Hemifulleren }
\end{gathered}
$$

4.4
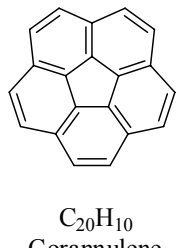

Corannulene

4.1
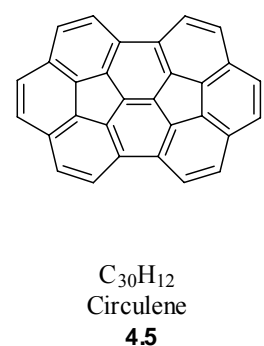
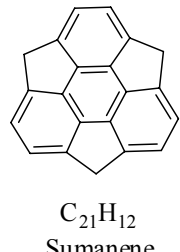

Sumanene
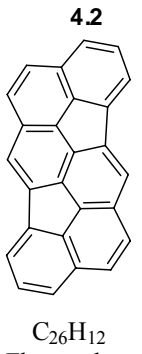

Fluoranthene

4.6
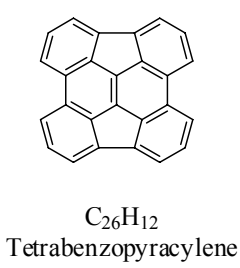

4.3
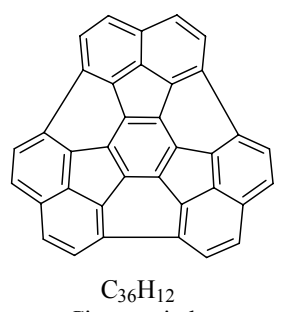

Circumtrindene

Figure 4.2 Bowl-shaped polycyclic aromatic hydrocarbons. 
five- and three-fold symmetry, respectively representing the fundamental structure motifs of buckminsterfullerene.

The synthesis and study of buckybowls are of interest for several reasons. First, appropriate buckybowls can serve as potential substrate for the total synthesis of fullerenes and nanotubes. ${ }^{8-11}$ Second, studies of exo vs. endo preferences of reactivity including metal complex formation can be performed on accessible convex and concave faces of buckybowls.. ${ }^{12-19}$ Third, possessing curved carbon surfaces, buckybowls could be used as scaffolds for molecular systems host/guest chemistry. Fourth, buckybowls could be used as model compounds of fullerenes as well as possible synthetic intermediates for artificially designed fullerene derivatives. ${ }^{20}$

\section{Literature survey for the synthesis of buckybowls}

Since curved buckybowls have strain energy caused by pyramidalization of interior $\mathrm{sp}^{2}$-hybridized carbon atoms, a successful method for buckybowls synthesis must be able to overcome the high degree of the strain energy. ${ }^{21}$ Only limited approaches can be utilized for buckybowl synthesis. Until now, most of the strained fullerene fragments have been successfully synthesized using flash vacuum pyrolysis (FVP) of appropriate

precursors at high temperature. ${ }^{7,22}$ In solution phase, the bulkybowls were prepared by constructing the complete bowl-shaped carbon framework with multiple tetrahedral $\mathrm{sp}^{3}$-hybridized carbons as the precursor, followed by dehydrogenating the bowl precursors in the last step. ${ }^{5,23}$ Recently, the transition metal catalyzed intramolecular coupling of aryl, benzyl, or benzylidene halides has been applied to synthesize the curved buckybowls. ${ }^{24}$

\subsection{Synthesis of buckybowls in solution chemsitry}

In 1966, Barth and Lawton reported the first total synthesis of corannulene from 
acenaphthene (4.8) in 17 steps (Scheme 4.1). ${ }^{25,26}$ They constructed the three-dimensional framework 4.10 using tetrahedral $\mathrm{sp}^{3}$ carbons and subsequent aromatization to synthesize the target compound. Not surprisingly, additional studies of corannulene were stopped in the 1970s because of the length of the synthesis and quite low overall yield $(<1 \%)$. Until the discovery of $\mathrm{C}_{60}$ at 1985 , corannulene was known as the only bowl-shaped polynuclear aromatic hydrocarbon. ${ }^{27}$

Scheme 4.1. Synthesis of corannulene by Bath and Lawton

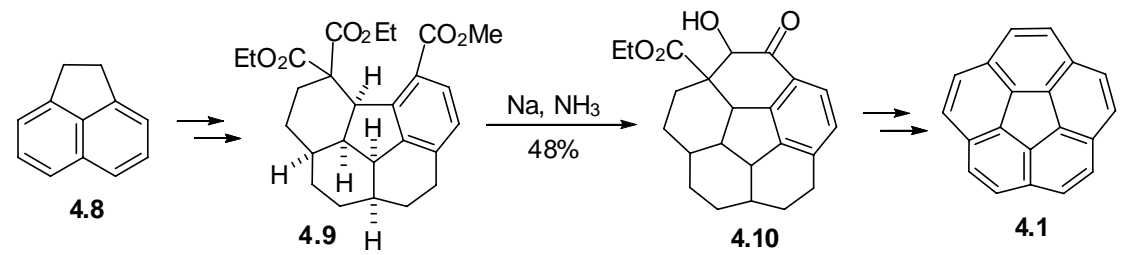

Several synthetic groups attempted to synthesize corannulene using alternative synthetic routes, in which fluoranthene derivatives were served as potential starting materials. $^{28,29}$ However, all of these attempts failed until Siegel reported a successful solution synthesis of methylcorannulene 4.13 from tetrabromide 4.11 in 1996 (Scheme 4.2). ${ }^{30}$ The ring closures of $\mathbf{4 . 1 1}$ were completed by low-valent titanium coupling, and then dehydrogenation were achieved by DDQ oxidation.

Scheme 4.2. Synthesis of methylcorannulene by Siegel.

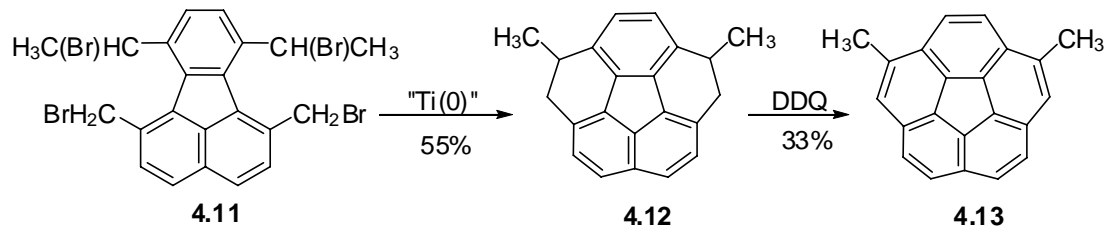

In 1999, a methodology similar to Siegel's approach was employed by Rabideau's group. They discovered that the employment of dibromomethyl groups in $\mathbf{4 . 1 5}$ and the low-valent vanadium coupling led to a single step formation of corannulene in an impressive yield of $70-75 \%$ (Scheme 4.3$).^{31}$ 
Scheme 4.3. Synthesis of corannulene by Rabideau

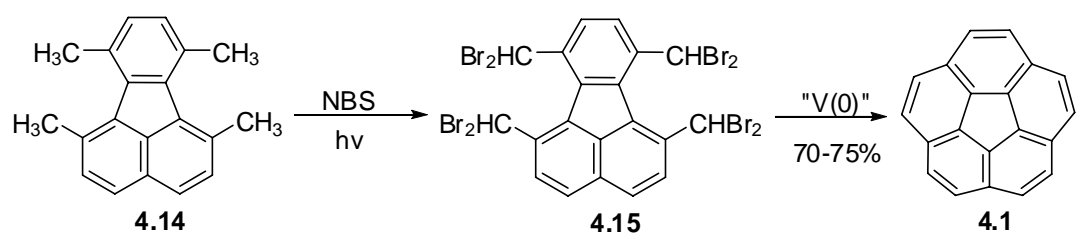

Later, Rabideau's group further improved their synthesis using an alternative method to prepare 1,2,5,6-tetrabromocorannulene $\mathbf{4 . 1 7}$ and a $83 \%$ yield was achieved (Scheme 4.4). ${ }^{32}$ The approach is simpler and less expensive compared to the low-valent metal methods. The parent corannulene can be prepared by debromination of 4.17 under refluxing with $\mathrm{KI}$ and $\mathrm{Zn}$ powder in EtOH. In addition, corannulene derivatives can be obtained from the compound $\mathbf{4 . 1 7}$ by standard coupling procedures..$^{33,34}$

Scheme 4.4. Improved synthesis of corannulene.
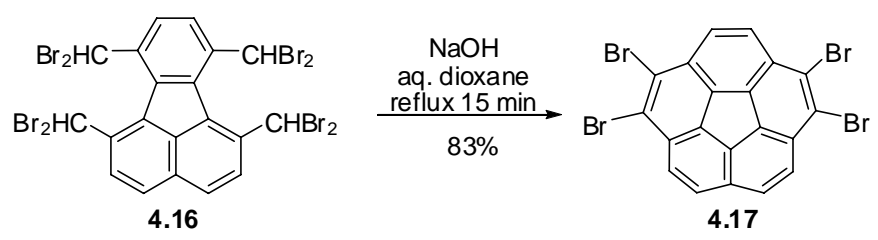

Sumanene, the $\mathrm{C}_{3 \mathrm{v}}$ symmetric subunit of fullerene, was recognized as a potential synthon for the synthesis of fullerene fragment some time ago. ${ }^{35}$ Recently, Hirao's research group successfully synthesized this compound (Scheme 4.5) ${ }^{36}$ In their synthesis, the Ru-catalyzed tandem ring-opening and ring-closing metathesis reaction of syn-benzotris(norbornadiene) 4.19a leading to hexahydrosumanene 4.20 were the key steps. The required $\pi$-conjugated structure of sumanene was achieved by DDQ oxidative aromatization of 4.20 at the last step. Variable-temperature NMR revealed a higher inversion energy barrier of sumanene $(19.6 \mathrm{kal} / \mathrm{mol})$ than corannulene. This result indicates that sumanene is much more rigid than corannulene and the bowl to bowl inversion of sumanene is slower than corannulene at room temperature. 
Scheme 4.5. Synthesis of Sumanene by ROM and RCM.
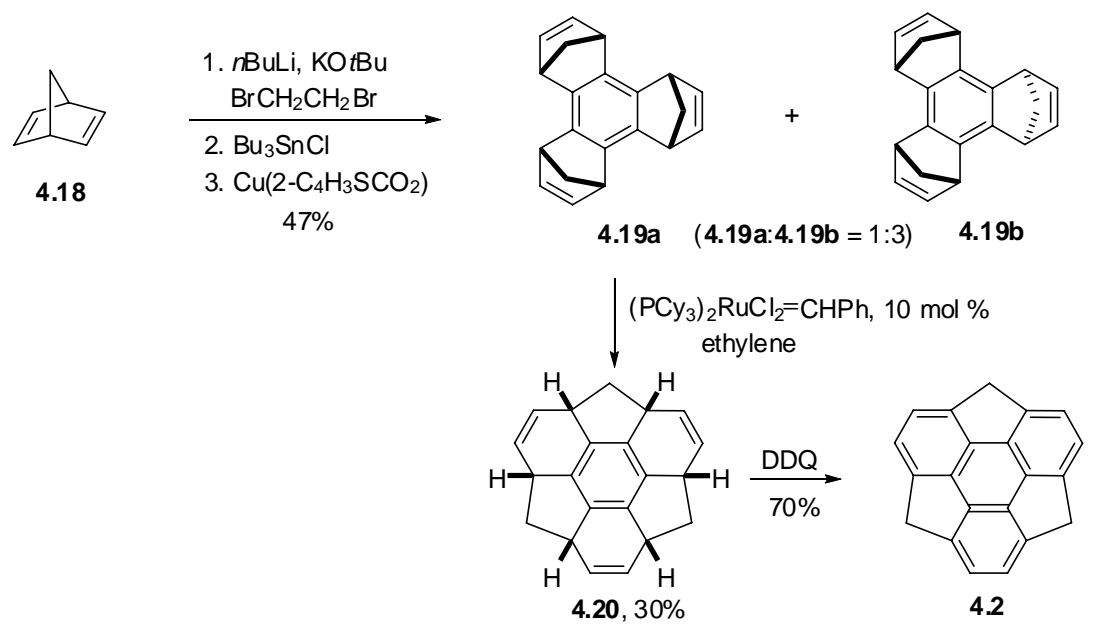

A similar stepwise conversion synthetic rout for sumanene was utilized to synthesize a $\mathrm{C}_{3}$ symmetric chiral buckybowl $\mathbf{4 . 2 2}$ from chiral halonorbornene derivative $(1 S, 4 S)-\mathbf{4 . 2 1} .^{37}$ The final stage of the synthesis was the aromatization step, where the $\mathrm{sp}^{3}$ chirality of the bowl-shaped intermediate $\mathbf{4 . 2 2}$ was converted to the bowl chirality of $\mathbf{4 . 2 3}$ (Scheme 4.6).

Scheme 4.6. Synthesis of chiral buckybowl

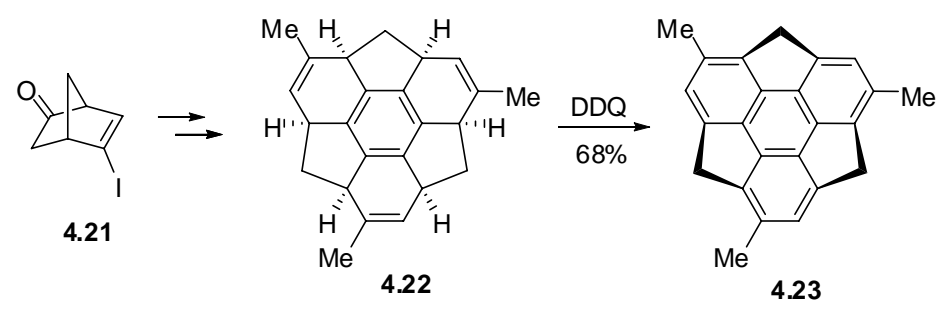

Since 2000, a few strained bowl-shaped ploycyclic aromatic hydrocarbons have been synthesized by palladium-catalyzed intramolecular arylation reactions from relatively simple PAH derivatives (Scheme 4.7). The first successful attempt was achieved by Scott research group in their synthesis of dibenzo[a,g]corannulene $4.25{ }^{38}$ In their research, various palladium catalysts, bases, and reaction conditions were tested to optimize conditions. Later, synthesis of buckybowl 4.27 and 4.29 were completed by two other research groups. ${ }^{24,39}$ More recently, this method has also successfully employed in the preparation of several indeno-fused corannulenes, including pentaindenocorannulene 
4.31. ${ }^{40,41}$

Scheme 4.7. Synthesis of buckybowls by palladium coupling reaction.

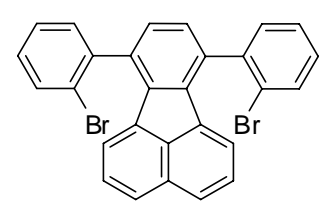

4.24

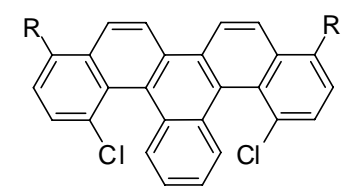

4.26

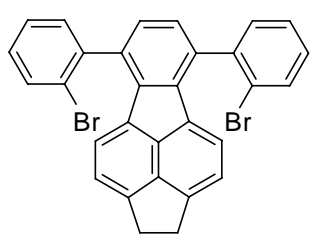

4.28

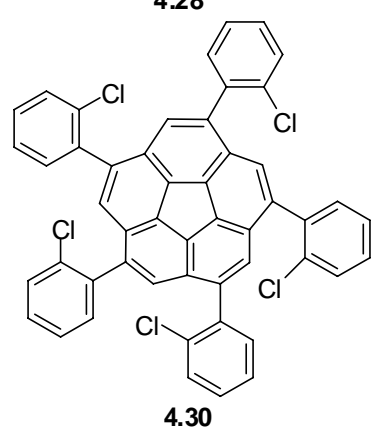

$\mathrm{Pd}\left(\mathrm{PPh}_{3}\right)_{2} \mathrm{Br}_{2}, 10 \mathrm{~mol} \%$

$\mathrm{PPh}_{3}, \mathrm{DBU}, \mathrm{DMF}$

$150^{\circ} \mathrm{C}, 72 \mathrm{~h}$

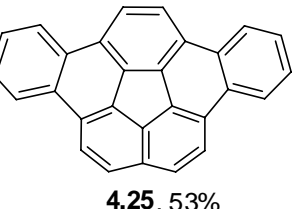

$4.25,53 \%$

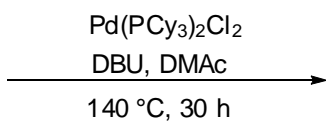

$\mathrm{Pd}\left(\mathrm{PCy}_{3}\right)_{2} \mathrm{Cl}_{2}$ DBU, DMAC

$145^{\circ} \mathrm{C} 48 \mathrm{~h}$

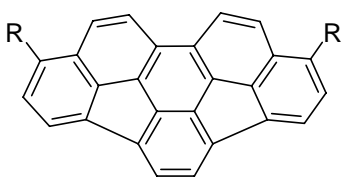

4.27a, $\mathrm{R}=\mathrm{CH}_{3}, 91 \%$

4.27b, $\mathrm{R}=\mathrm{OCH}_{3}, 70 \%$

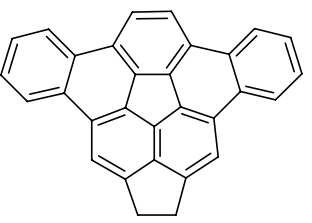

4.29, $36 \%$

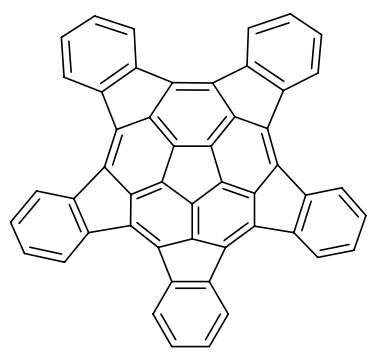

4.31, 35\%

\subsection{Synthesis of buckybowls by flash vacuum pyrolysis}

In 1977, Brown reported that vinylidene 4.33, which was generated thermally from terminal acetylenes $\mathbf{4 . 3 2}$ in gas phase, could be trapped intramolecularly, thereby constructing both five- and six-membered rings (Scheme 4.8). ${ }^{42}$

Scheme 4.8 Cyclization of terminal acetylene under FVP condition

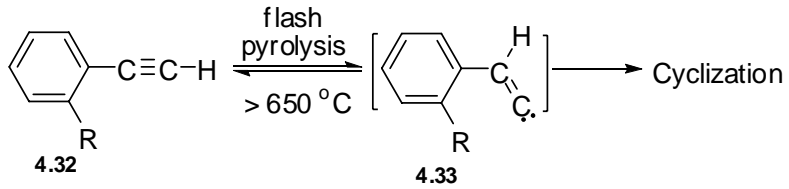


Inspired by Brown's work, Scott's group successfully synthesized corannulene by flash vacuum pyrolysis of diethynylfluoranthene 4.37 which was prepared in six steps from acenaphthenquinone 4.34. ${ }^{43}$ Two more rings were formed under FVP condition from two vinylidene moieties, trapped by insertion into nearby $\mathrm{C}-\mathrm{H}$ bonds. Corannulene was also synthesized by another improved three-step route, in which commercially available chemicals were used as staring materials and a $35-40 \%$ overall yield was achieved in the final FVP step. ${ }^{44}$ In the improved method, the bis(1-chlorovinyl) fluoranthene 4.38 could be easily sublimes cleanly without polymerization because it is more stable than 4.37 at elevated temperatures. 4.38 lose $2 \mathrm{~mol}$ of $\mathrm{HCl}$ in the hot zone to generate $4.37 \mathrm{in} \mathrm{situ,}$ which then cyclizes twice (Scheme 4.9).

Scheme 4.9. Synthesis of corannulene via FVP condition.

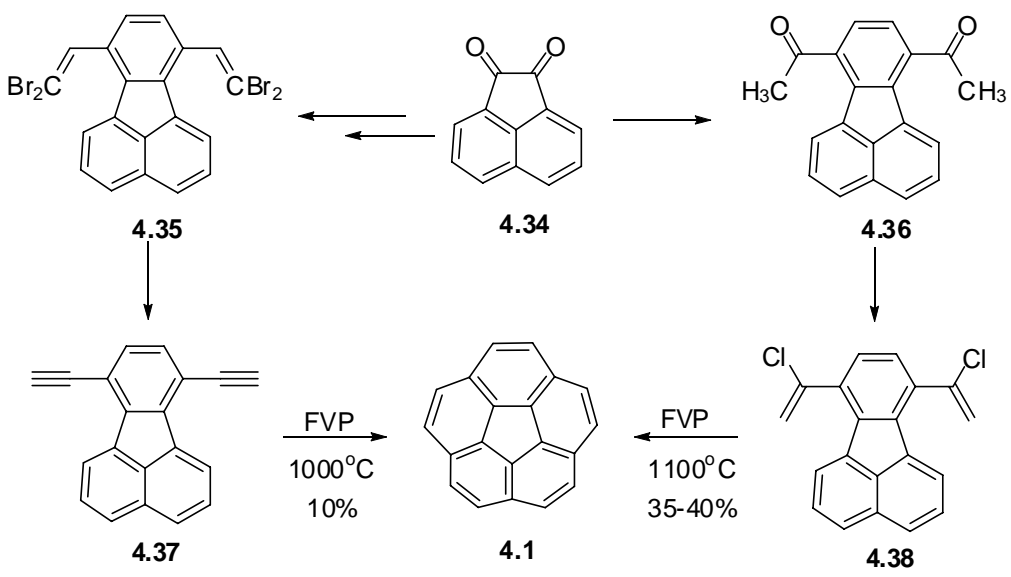

The success of FVP is attributed to two reasons: (1) in pyrolysis, enough thermal energy can be delivered to the molecules to overcome the high energy barriers during intramolecular ring closures; (2) competing intermolecular reactions are avoided by performing the reaction in gas phase.

Since the major breakthrough for the synthesis of corannulene by FVP, ${ }^{45-49}$ several research groups have reported many other FVP based procedures leading to buckybowls from various precursors (Scheme 4.10). ${ }^{50-53}$ The culminating achievement was the use of FVP of $\mathrm{C}_{60} \mathrm{H}_{27} \mathrm{Cl}_{3}$ reported by Scott, de Meijere and coworkers to produce $\mathrm{C}_{60}$ with an 
estimated yield of $0.1-1.0 \% .{ }^{54}$ This work also proved that fullerene could be formed by rational synthetic methods instead of by empirical experiments.

Scheme 4.10 Various buckybowls prepared by FVP.

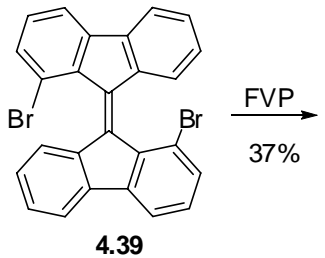

4.39
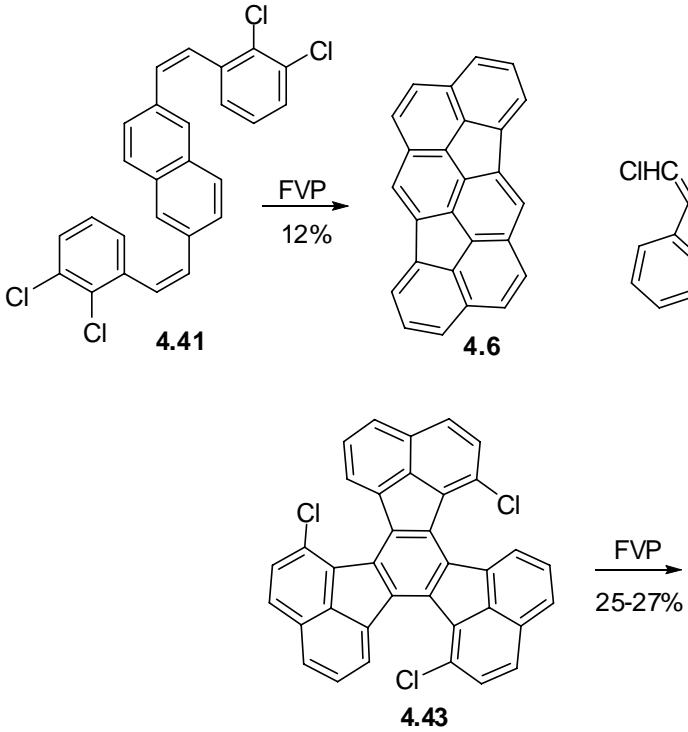

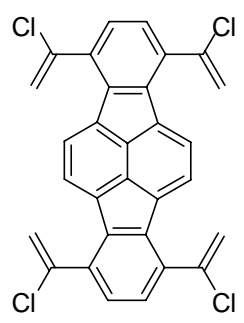

4.40

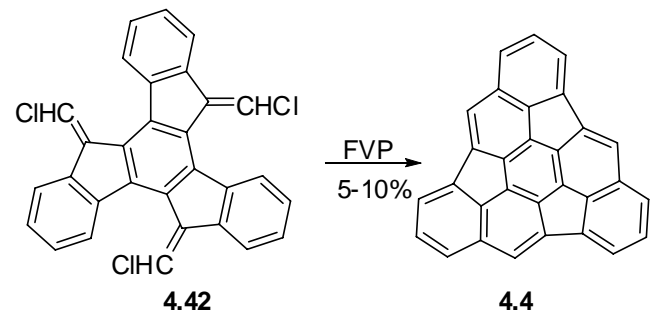

4.4

Although a number of curved molecules have been synthesized by FVP, the FVP method is problematic due to the following limitations: (1) minimum functional group tolerance arising from high temperature applied in FVP, (2) the yield drops dramatically with the increase of the size for buckbowls, (3) scale-up is difficult since FVP is a gas-phase process, and (4) the potential for thermal rearrangement of molecular framework at the high temperatures normally employed $\left(1000-1100^{\circ} \mathrm{C}\right) .{ }^{24}$

\section{Research objective}

Our group has reported a simple and efficient pathway recently to synthesize bowl-shaped polycyclic aromatic hydrocarbons via palladium-catalyzed intramolecular 
arylation reactions. ${ }^{55}$ This synthetic sequence was outlined in Scheme 4.11, involving cascade cyclization reactions of a benzannulated enyne-allene 4.48 formed from the corresponding benzannulated enediyne 4.47. The presence of two properly situated bromo substituents in $\mathbf{4 . 4 9}$ allowed the application of the palladium-catalyzed intramolecular arylation reactions for additional carbon-carbon bond formation. Similarly, dibromides $\mathbf{4 . 5 2}$, readily prepared by the condensation between aryl ketones $\mathbf{4 . 5 1}$ and 4.45, were used to synthesize the corresponding bowl-shaped PAH 4.53. X-ray structural analysis of 4.50 and $\mathbf{4 . 5 3}$ indicates the presence of significant curvatures in their structures (Figure 4.3)

Scheme 4.11 Synthesis of bowl-shaped polycyclic aromatic hydrocarbons via palladium-catalyzed intramolecular arylation reactions.

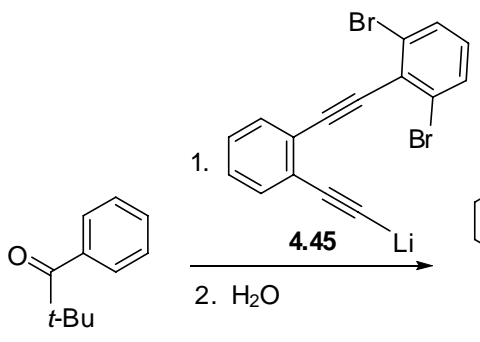

4.44

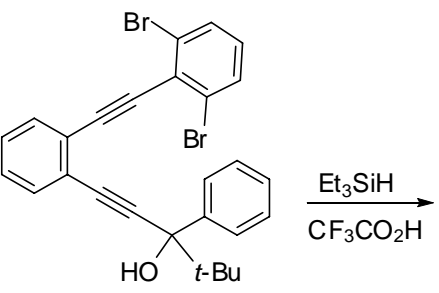

4.46, $74 \%$

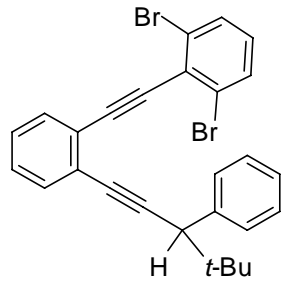

4.47, $93 \%$

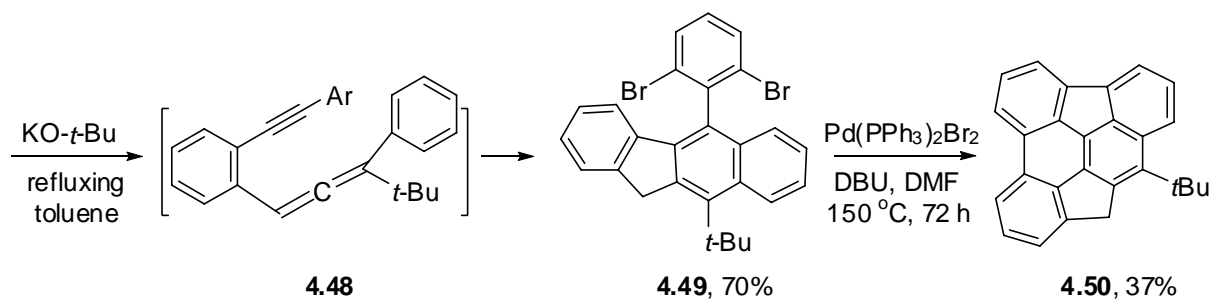

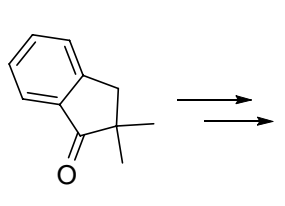

4.51

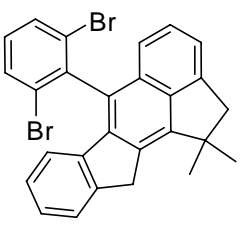

4.52

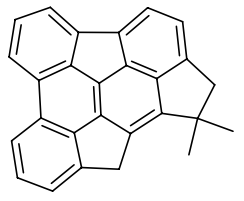

4.53, $11 \%$ 

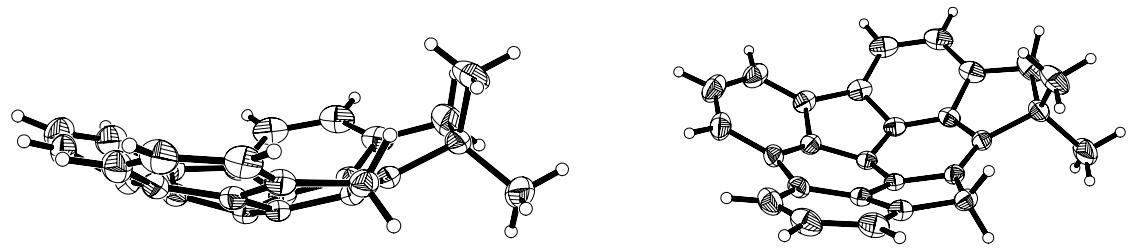

Figure 4.3 ORTEP drawing of the crystal structure of 4.53.

We were interested in further exploring the use of similar strategy to prepare a new bowl-shaped $\pi$-conjugated hydrocarbon 4.54 which has a carbon framework represented on the surface of $\mathrm{C}_{60}$ (Figure 4.4). It is worth noting that the structure of buckybowl 4.54 contains an additional five-membered ring compared to tetrabenzopyracylene (4.3). By comparison with sumanene (4.2), the structure of 4.54 has two additional fused benzene rings.
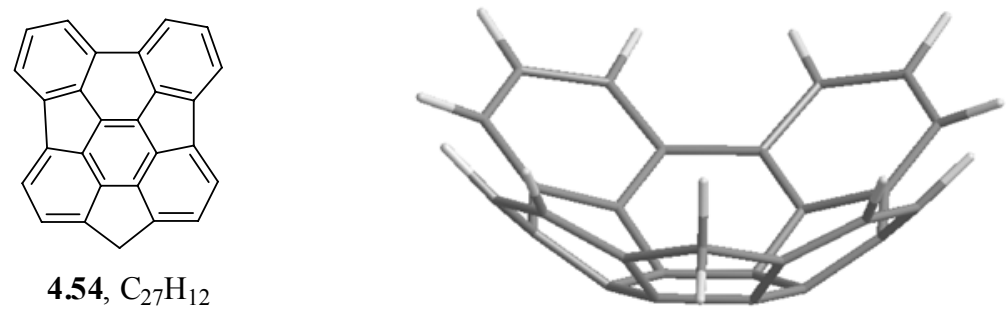

Figure 4.4 MM2-optimized structure of $\mathbf{4 . 5 4}$

Based on the geometry obtained from the X-ray analysis, one of the central ethylene carbon atoms in $\mathbf{4 . 5 3}$ has a pyramidalization angle of $10.3^{\circ}$, defined as $\Theta_{\sigma \pi}-90^{\circ}$ using the $\pi$-orbital axis vector analysis (POAV), which is larger than those of tetrabenzopyracylene (4.3). Apparently, the presence of an additional five-membered ring in $\mathbf{4 . 5 3}$ causes its structure to be more strained and creates a more pronounced curvature (Figure 4.5).
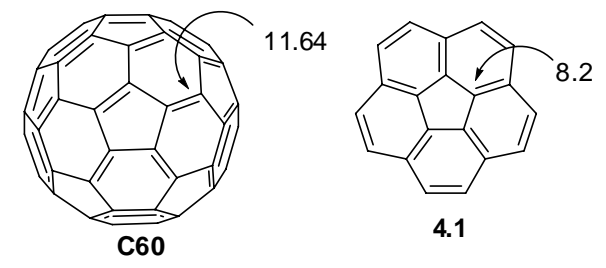

4.1

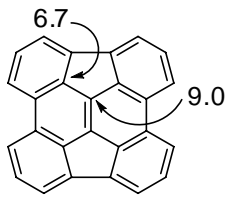

4.3
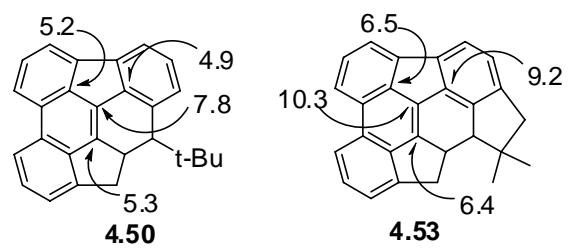
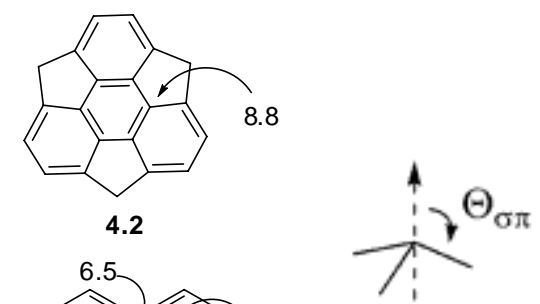

Figure 4.5 POAV angles of fullerene and buckybowls. 
Compared to 4.53 , we can predict that the buckybowl 4.54 will exhibit a larger local curvature because one more fused benzene ring is involved in its carbon framework. This deeper $\pi$-bowl will have some advantages over corannulene and sumanene, including the properties more similar to fullerenes and the presence of a benzylic position that should permit further functionalization to make new bowl-shaped species or dimerization to create a large buckybowl 4.56 having 54 carbons $\left(90 \%\right.$ of $\left.\mathrm{C}_{60}\right)$.

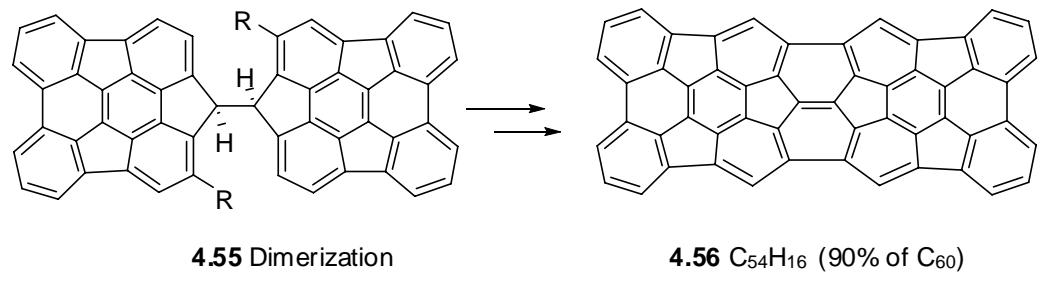

Figure 4. 6 Proposed application of buckybowl 4.54.

\section{Result and Discussion}

\subsection{Retrosynthetic Analysis for Buckybowl 4.54.}

In our retrosynthetic analysis, buckybowl 4.54 can be synthesized from the precursor dibromide hydrocarbon 4.62. The two broken carbon-carbon bond in the northwestern corner in $\mathbf{4 . 5 4}$ could be constructed by palladium-catalyzed intramolecular arylation reactions of 4.62. Further analysis showed the benzene ring in the southeastern corner of 4.54 could be formed from alkyl iodide 4.61 via an intramolecular alkylatioin reaction followed by aromatization. Alkyl iodide 4.61 could be obtained from deprotection of methyl ether 4.60 followed by iodination. The methyl ether 4.60 could be produced from propargylic alcohol 4.59 via reduction and cascade Schmittel cyclization. Propargylic alcohol 4.59 could be synthesiszed from condensation of lithium acetylide $\mathbf{4 . 5 8}$ and the a, a-disubstituted indanone 4.57 (Figure 4.7). 


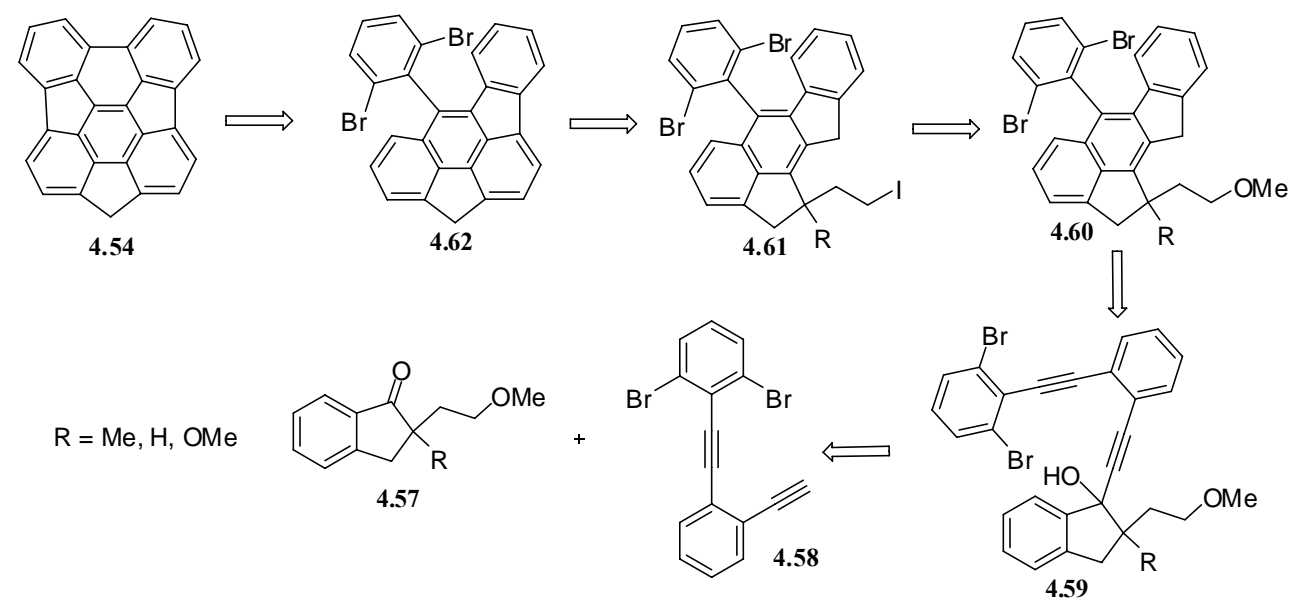

Figure 4. 7 Retrosynthetic analysis for buckybowl 4.54.

Going forward with our retrosynthesis, the substituted indanone 4.57 was prepared from different combinations of indanone and alkylation regents or other simple building block.

\subsection{Initial Approach}

The first approach for the synthesis of buckybowl 4.54 started from a model study of a partially hydrogenated $4 H$-cyclopenta[def]phenanthrene 4.78. As outlined in Scheme 4.12, 1-iodo-2-methoxyethane $\mathbf{4 . 6 5}$ was synthesized from 2-methoxyethanol via mesylation using methanesulfonyl chloride in dichloromethane and triethylamine followed by iodination with sodium iodide in refluxing acetone for 2 days. The crude 4.65 was purified by simple distillation at $90{ }^{\circ} \mathrm{C}$. ${ }^{56}$

\section{Scheme 4.12}

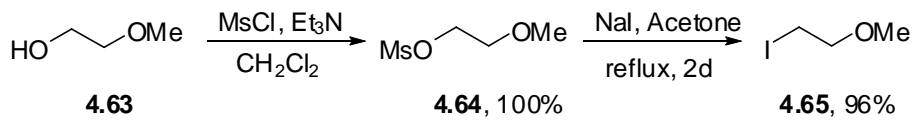

The possibility of preparing 4.67 was investigated by reacting 1-indanone 4.66 with 1-iodo-2-methoxyethane $\mathbf{4 . 6 5}$ under conventional conditions, in which 1 equiv of lithium diisopropylamine (LDA) and $\mathbf{4 . 6 5}$ was introduced to the solution of indanone in THF at $-78{ }^{\circ} \mathrm{C}$. Unfortunately, the alkylation reaction did not take place under low temperature. In refluxing solutions, trace amount of mono- and di-alkylation product were obtained. A 
$15 \%$ yield of the monoalkylation product was achieved when LDA was displaced by sodium hydride.

\section{Scheme 4.13}

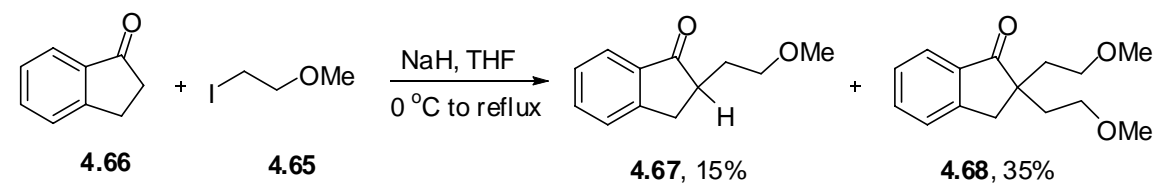

To increase the yield, an alternative approach (Scheme 4.14) was used for preparing 4.71. In this approach, 1-indanone was converted to the corresponding TMS silyl enol ethers 4.69 and alkylated with methyl iodide under mild conditions in the presence of cesium fluoride. In addition to $\mathbf{4 . 7 0}$, the rest of the product mixture consisted of dimethylated material (5-10\%) and hydrolyzed starting material. Subsequently, the alkylated indanone $\mathbf{4 . 7 0}$ was alkylated by refluxing with $\mathrm{NaH}$ and 1-iodo-2methoxyethane (4.65). A 68\% yield was achieved in the second alkylation to produce disubstituted indanone $\mathbf{4 . 7 1}$.

Scheme 4.14
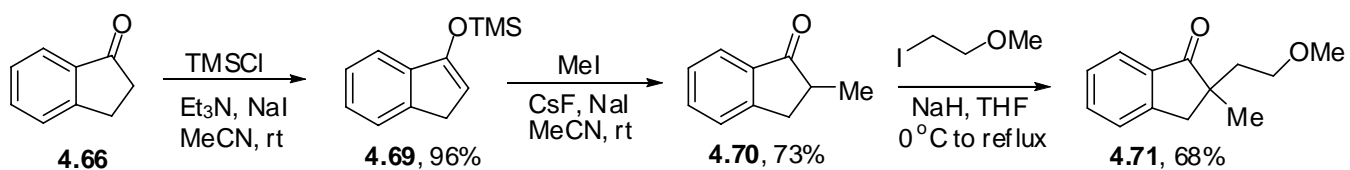

With the alkylation product in hand, condensation of 4.71 and lithium acetylide 4.72, obtained by lithiation of 1-(2-ethynylphenyl)-2-phenylethyne, afforded enediynyl propargylic alcohol $\mathbf{4 . 7 3}$ as a 1:1 diastereomeric pairs (Scheme 4.15). Reduction of $\mathbf{4 . 7 3}$ with triethylsilane in the presence of trifluoroacitic acid then produced 4.74. On exposure to potassium tert-butoxide in refluxing toluene for $6 \mathrm{~h}$, a sequence of cascade reactions occurred, including an initial prototropic rearrangement to form the benzannulated enyne-allene 4.75. A subsequent Schmittel cyclization reaction to generate biradical followed by an intramolecular radical-radical coupling and a prototropic 


\section{Scheme 4.15}
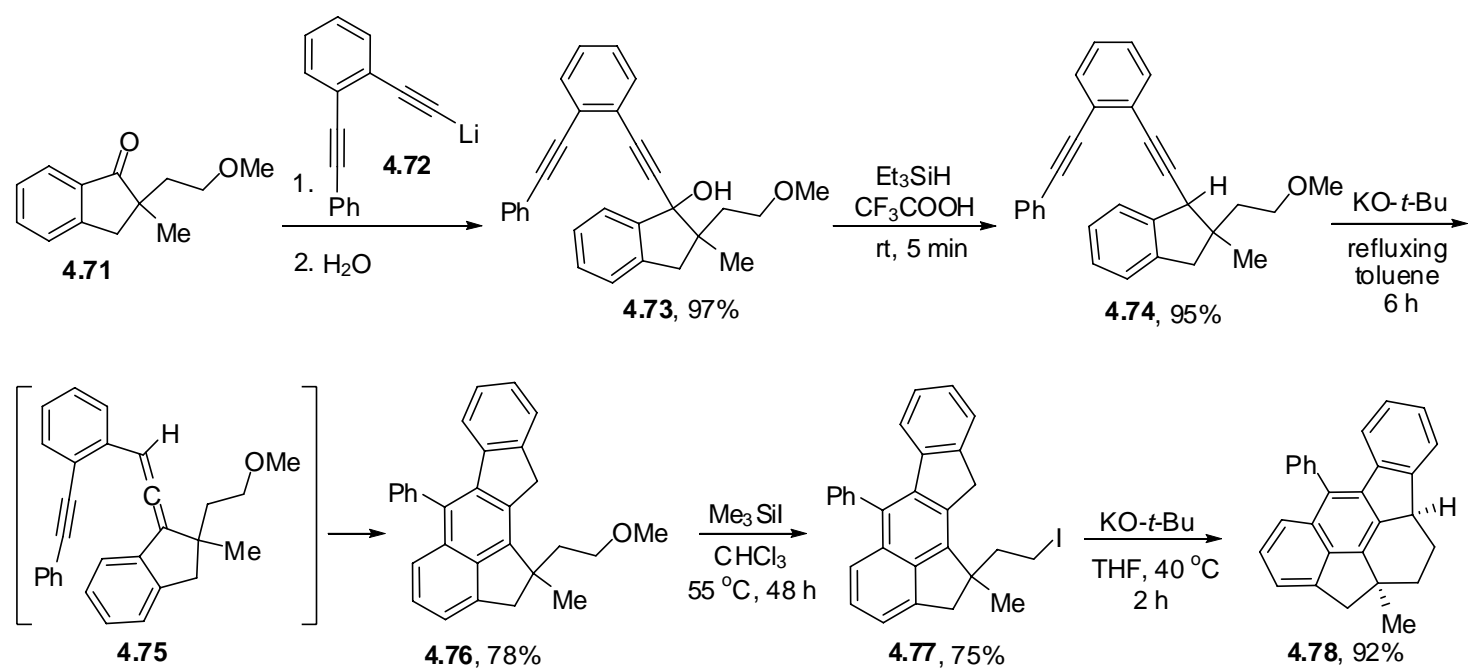

rearrangement to regain aromaticity then led to 4.76. Cleavage of the methyl ether in $\mathbf{4 . 7 6}$ with $\mathrm{Me}_{3}$ SiI produced iodide 4.77..$^{57,58}$ In the presence of potassium tert-butoxide, 4.77 was smoothly converted to the desired hydrocarbon 4.78 in $\mathrm{THF}$ at $40{ }^{\circ} \mathrm{C}$ by an intramolecular alkylation reaction. The structure of 4.78 was confirmed by ${ }^{1} \mathrm{H}$ and ${ }^{13} \mathrm{C}$ NMR spectroscopy. The stereochemistry of $\mathbf{4 . 7 8}$ was confirmed by NOESY experiments (Figure 4.7).
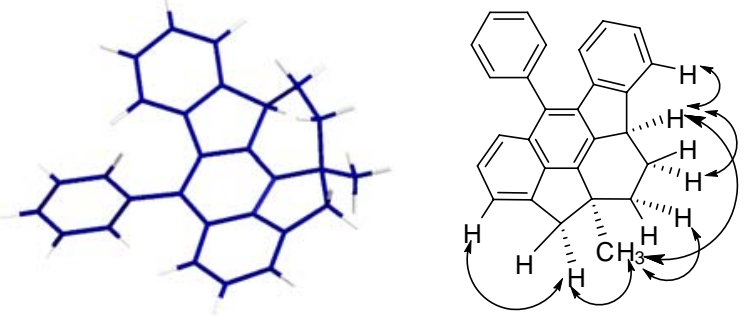

Figure 4. 8 MM2-opimized structure and NOE of 4.78.

Encouraged by the success in obtaining 4.53 and 4.78 , we slightly modified the synthetic Scheme 4.15 to allow for the incorporation of the bromo substituents to give 4.86 (Scheme 4.16). The requisite (2,6-dibromophenyl)ethyne (4.79) was prepared by the Sonogashira coupling reaction between 1,3-dibromo-2-iodobenzene and (trimethylsilyl)- 


\section{Scheme 4.16}
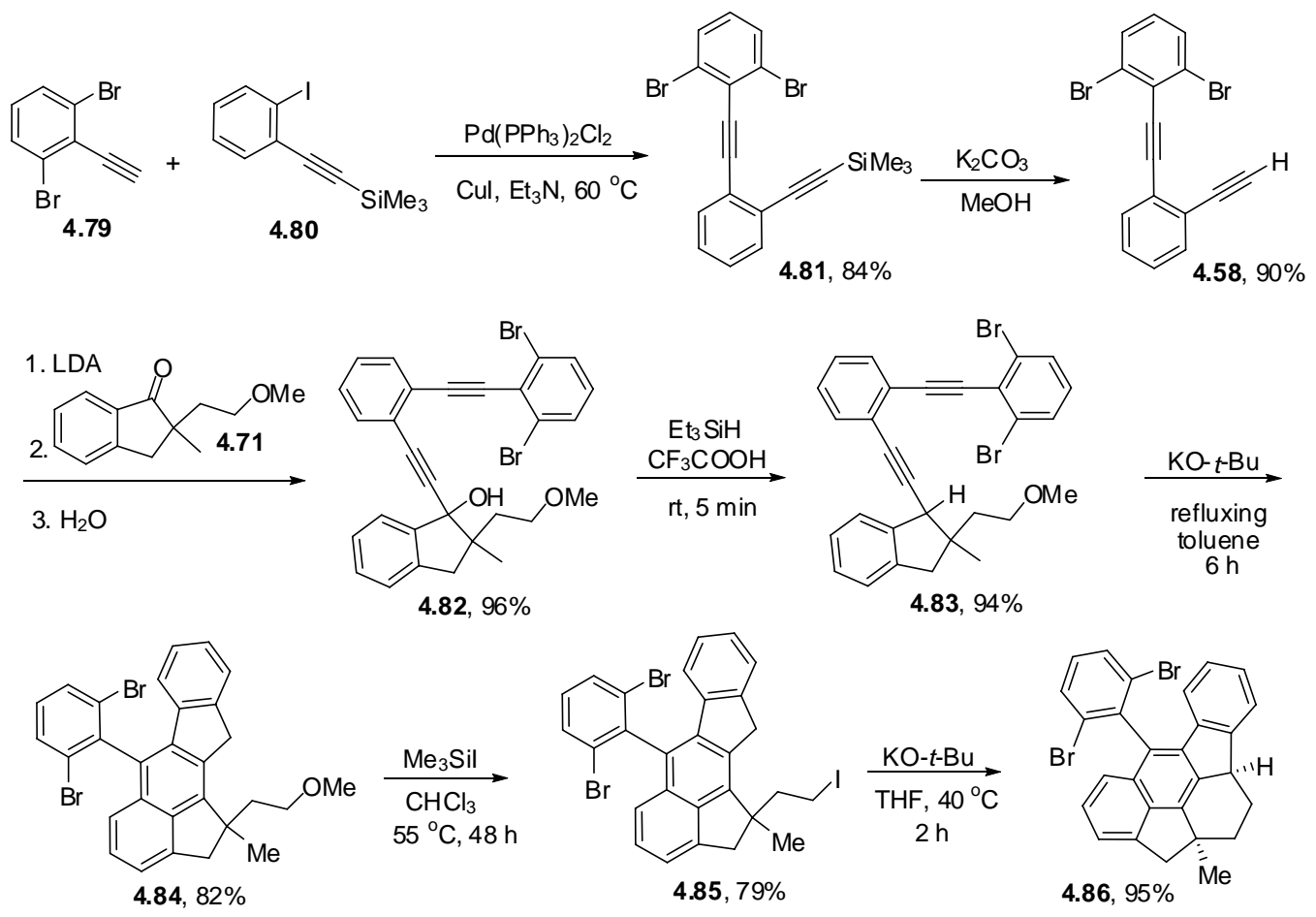

ethyne, followed by desilylation as reported previously. ${ }^{59}$ A second Sonogashira reaction between 4.79 and 1-(2-iodophenyl)-2-(trimethylsilyl)ethyne (4.80) then led to 4.81 , which was readily desilyated to afford the benzannulated enediyne 4.58 .

It is worth noting that compared to $\mathbf{4 . 5 3}$ the subsequent Pd-catalyzed intramolecular arylation reactions were more efficient in producing $\mathbf{4 . 8 7}$ in 30\% yield (Scheme 4.17). Simultaneously, the monocyclized adducts $\mathbf{4 . 8 8}$ and $\mathbf{4 . 8 9}$ were also produced in $3 \%$ and $28 \%$ yields, respectively. Compared to $\mathbf{4 . 5 3}$, the benzofluorene substructure 4.86 is already strained and contains a significant curvature. Apparently, the strain in $\mathbf{4 . 8 6}$ is responsible for the higher efficiency. The strategy of using existing strain in the precursor to promote carbon-carbon bond formation was employed previously to prepare strained compounds. ${ }^{60}$ Unfortunately, attempts for final fully aromatization step to buckybowl 4.54 were unsuccessful by using DDQ for oxidation. 


\section{Scheme 4.17}
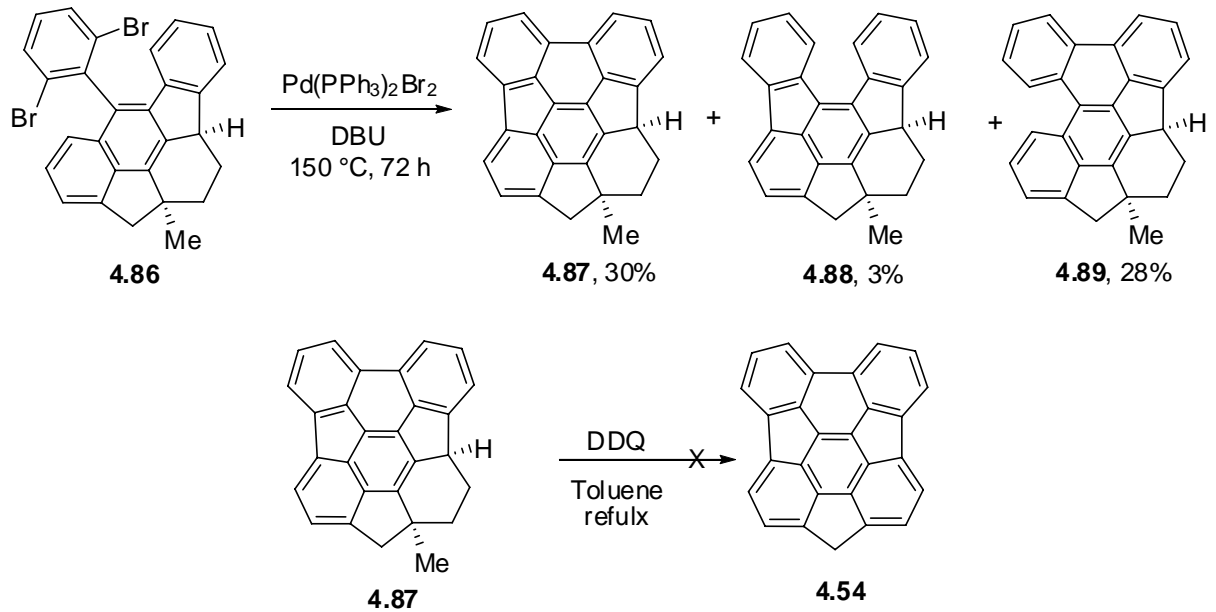

\subsection{Second Approach}

In the second synthetic strategy, the methyl group was displaced with a group that could be removed for the final aromatization step. It was hypothesized that hydrocarbon 4.90 could undergo retro-ene reaction under high temperature, and form buckybowl 4.54 (Scheme 4.18). To proceed with this proposed route, substituted indanone 4.93 was prepared by allylation and alkylation.

\section{Scheme 4.18}

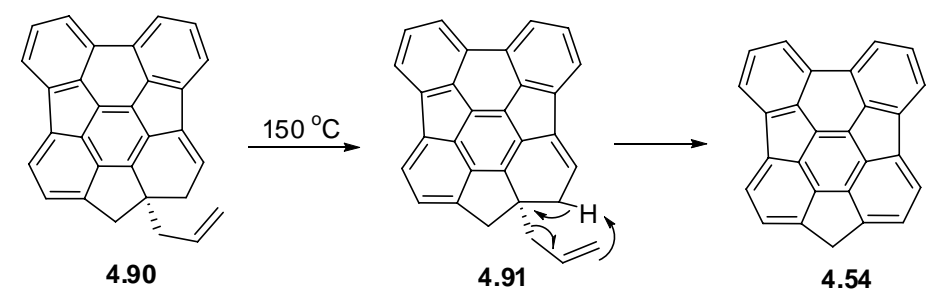

With ketone 4.93 in hand, the synthetic sequence outlined in Scheme 4.19 was adopted for the preparation of hydrocarbon 4.90. From the ketone 4.93, the propargylic alcohol 4.94 was reduced to form 4.95 , which in turn were converted to 4.96 by a cascade cyclization sequence. It is worth mentioning that the cleavage of the methyl ether in 4.96 
with $\mathrm{Me}_{3} \mathrm{SiI}$ is unsuccessful without the 2,6-bis(1,1-dimethylethyl)-4-methyl -pyridine. An intramolecular cyclization reaction led to the major product 4.97 . The structure of 4.97 was confirmed by X-ray analysis. The observed reaction is most likely due to the presence of catalytic amounts of HI in trimethylsilyl iodide. However, alcohol 4.98 was obtained when 2,6-bis(1,1-dimethylethyl)-4-methyl- pyridine was added to the reaction mixture, which trapped the trace amount of HI.

Scheme 4.19
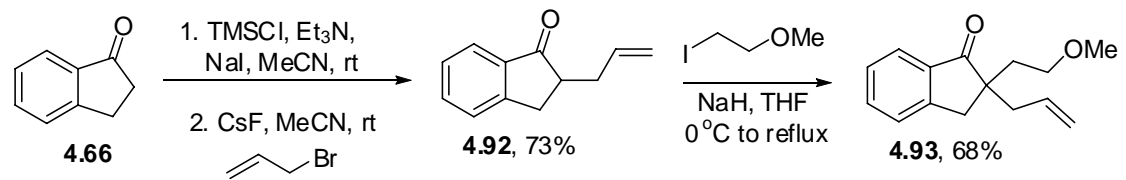

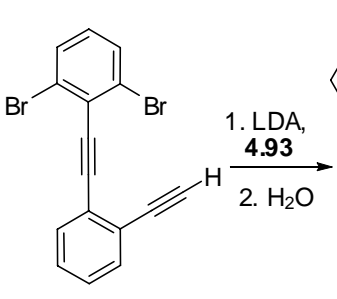

4.58
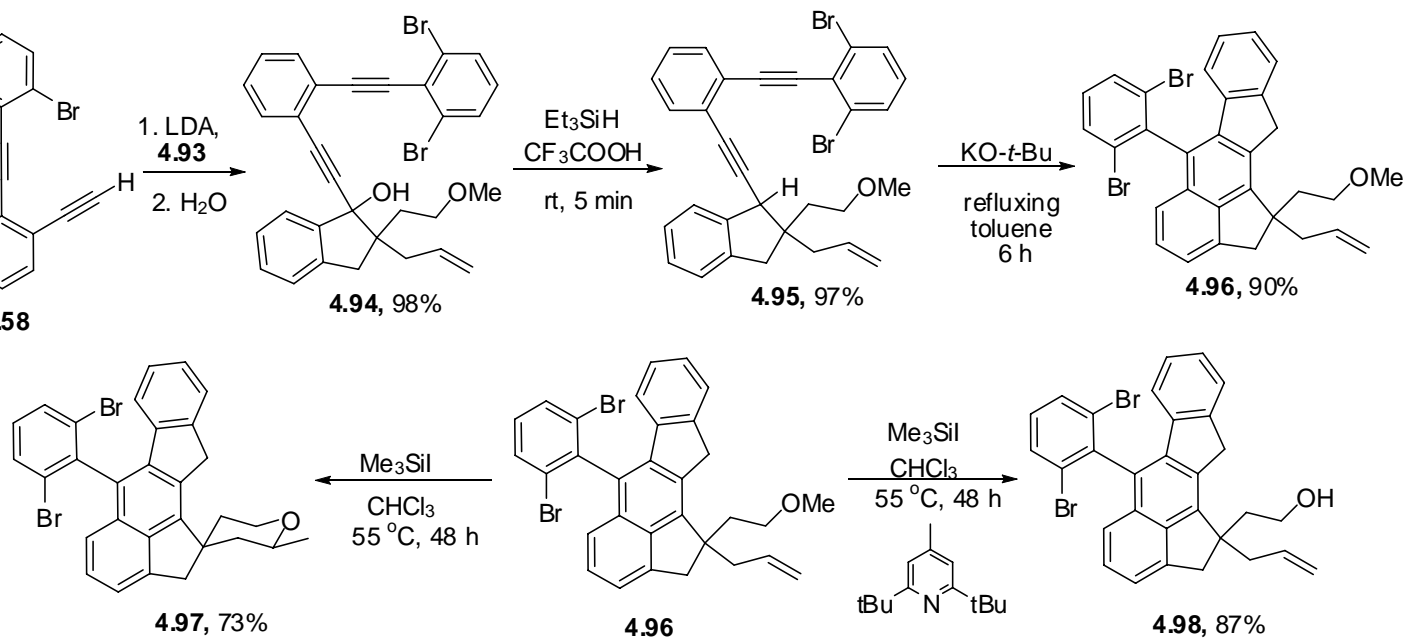

Iodide 4.100 can be conveniently synthesized in two steps from alcohol $\mathbf{4 . 9 8}$ (Scheme 4.20). In the presence of potassium tert-butoxide and iodine, iodide $\mathbf{4 . 1 0 0}$ was transformed into alkene 4.101. Apparently, an intramolecular cyclization of 4.100 occurred initially. The carbon-carbone double bond then was formed by producing the benzofluorenyl anion followed by iodination and dehydroiodination.

The retro-ene reaction of $\mathbf{4 . 1 0 1}$ was performed under high temperature. Unfortunately, this reaction was unsuccessful and ${ }^{1} \mathrm{H}$ NMR spectrum of the crude reaction mixture showed broad peaks in the aromatic region. 
Scheme 4.20
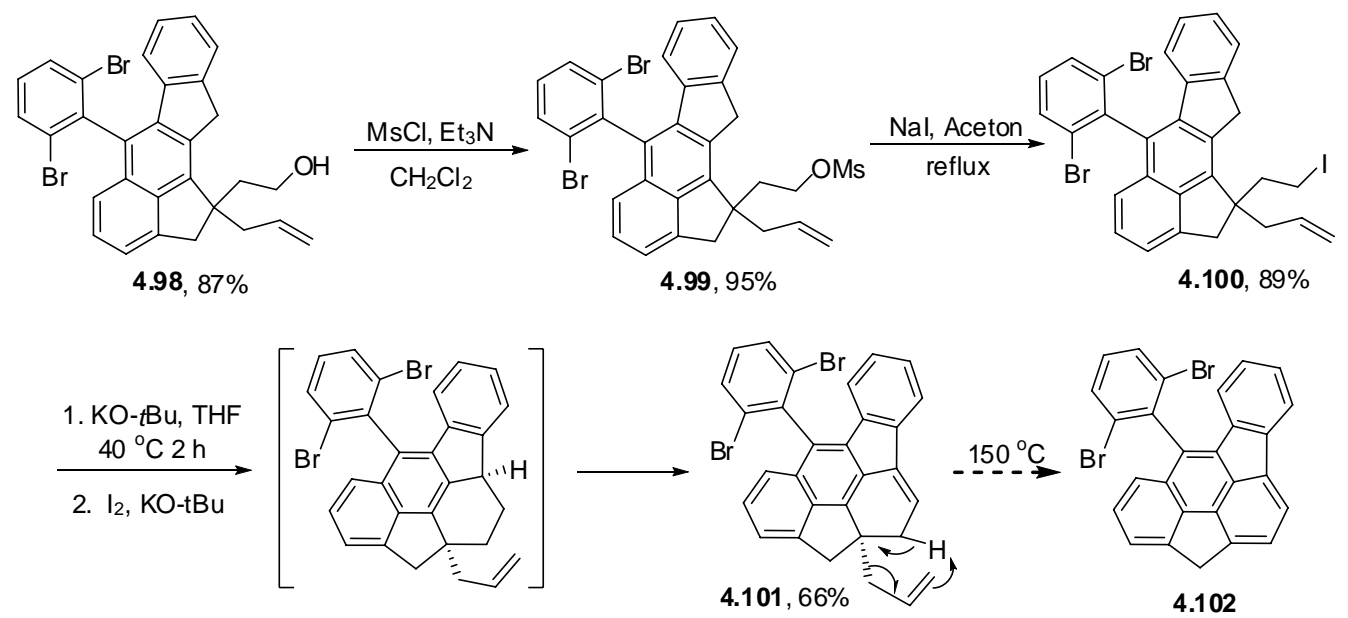

\subsection{Third Approach}

Our third synthetic route to prepare buckybowl 4.54 relied on a similar strategy, except that we decided to displace the methyl group with a proton. However, the alkylation reaction in Scheme 4.13 did not afford monoalkylation product 4.67 in high yield. In an effort to improve the poor yield in this initial route, we investigated the possibility of forming ketone 4.67 from hydrazone 4.103 (Scheme 4.21). 1-Indanone was converted into its hydrazone derivative $\mathbf{4 . 1 0 3}$ in quantitative yield by treatment with $N, N$-dimethylhydrazine in the presence of a catalytic amount of acetic acid. ${ }^{61,62}$ Alkylation with LDA and 1-iodo-2-methoxyethane (4.65) gave product $\mathbf{4 . 6 7}$ in a $61 \%$ yield.

\section{Scheme 4.21}

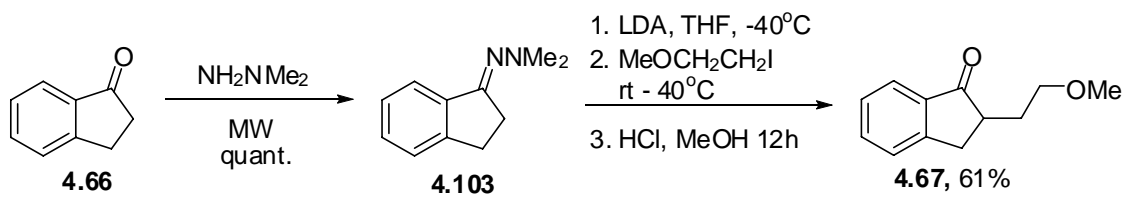

Due to the possibility of producing the dehydration product during the reduction of propargylic alcohol, an alternative route was undertaken (Scheme 4.22). The Wittig olefination of $\mathbf{4 . 6 7}$ afforded $\mathbf{4 . 1 0 4}$ as a mixture of the $E$ and $Z$ isomers, ${ }^{63}$ 
p-Toluenesulfonic acid was used to hydrolyze the enol ether 4.104, thus providing indane aldehyde 4.105 in good yield. ${ }^{64}$ Acetylene 4.106 was prepared by condensation between 4.105 and the Ohira-Bestmann reagent, which was synthesized in two steps. ${ }^{65}$ Bezannulated enediyne 4.107 was accessed through the Sonogashira coupling reaction between acetylene 4.106 and 1,3-dibromo-2-[(2-iodophenyl)ethyny]benzene. However, when 4.107 was treated with potassium tert-butoxide at $80{ }^{\circ} \mathrm{C}$, only $10 \%$ of the Schmittel cyclization product $\mathbf{4 . 1 0 8}$ was obtained as a minor product along with many other unexpected byproducts. The synthetic route was not further investigated because of the low yield in the cyclization step.

Scheme 4.22

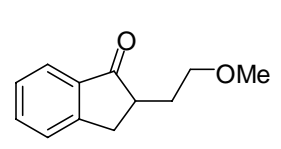

4.67

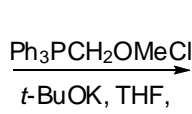

$-20^{\circ} \mathrm{C}, 1 \mathrm{~h}$

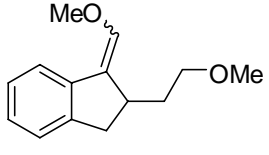

4.104, $88 \%$

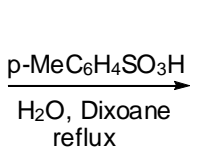

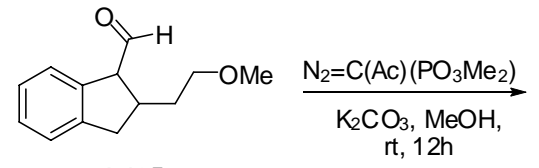

4.105, $80 \%$

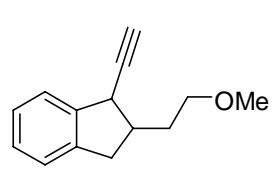

4.106, $72 \%$

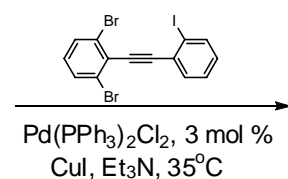

$\mathrm{Cul}, \mathrm{Et}_{3} \mathrm{~N}, 35^{\circ} \mathrm{C}$

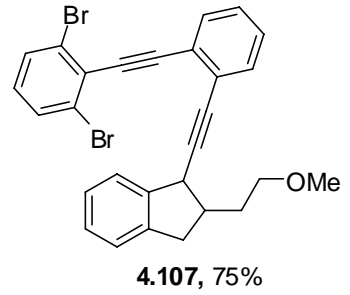

$\underset{\text { Toluene, } 80{ }^{\circ} \mathrm{C}}{\stackrel{\mathrm{KO}-t-\mathrm{Bu}}{\mathrm{C}}}$

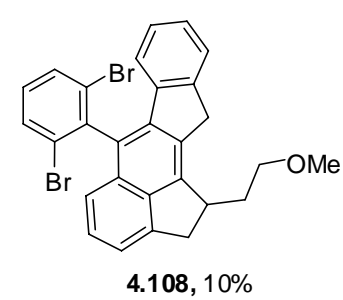

\subsection{Fourth Approach}

With the failure of the previous three routes for the synthesis of buckybowl 4.54, we quickly switched to an alternative approach by starting from ketone 4.123. After literature survey, the synthesis of ketone $\mathbf{4 . 1 2 3}$ could be achieved from the acid catalyzed ring expansion of allenylcyclobutanbenzen-1-ol 4.118 by a Wagner-Meerwein shift (Scheme 4.24). ${ }^{66-69}$ To proceed with this planned route, benzocyclobutenone 4.113 and allene 4.117 were prepared from commercial available starting materials based on the reported procedures (Scheme 4.23). ${ }^{70,71}$ 
Scheme 4.23
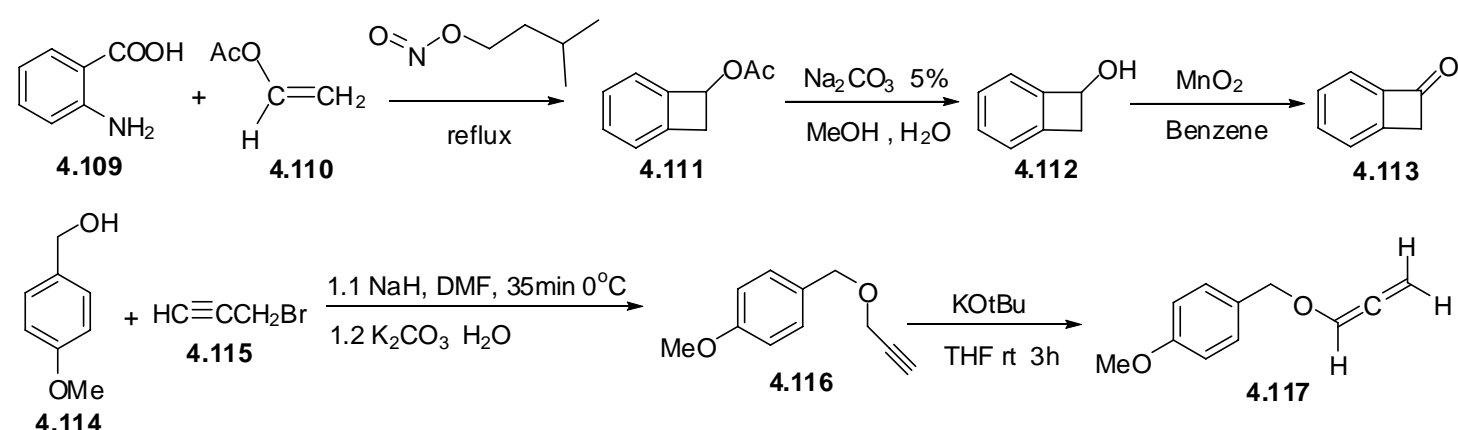

It is important to note that allene $\mathbf{4 . 1 1 7}$ is thermally very unstable and prone to decomposition. This compound decomposed within a matter of hours when refrigerated, results in decomposition. It must be used as soon as it is prepared. The subsequent condensation between benzocyclobutenone 4.113 and allene 4.117 was investigated at -78 ${ }^{\circ} \mathrm{C}$. 1-lithio-1-benzyloxyallene was added to benzocyclobutenone to give $\mathbf{4 . 1 1 8}$ as an intermediate. It is interesting to note that allenyl adduct 4.118 on treatment with trifluoroacetic acid and water at lower or room temperature can provide two totally different products. The production of compound $\mathbf{4 . 1 2 1}$ is due to the [4+2] cycloaddition of allene-diene $4.119,{ }^{72}$ which was obtained by the benzocyclobutene ring opening at room temperature.

Scheme 4.24

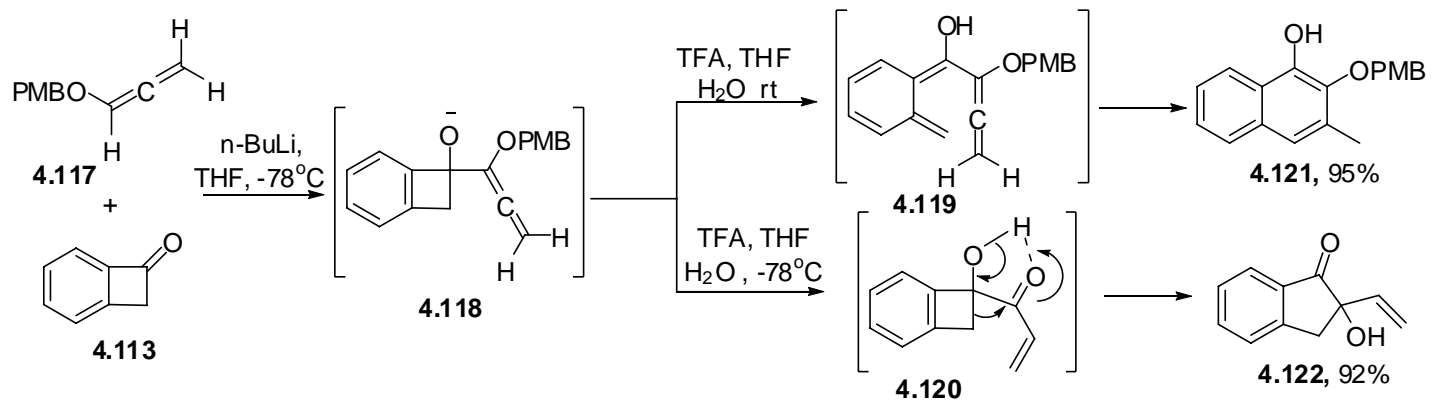

The hydrolysis-ring-expansion reaction of 4.118 was performed under $-78{ }^{\circ} \mathrm{C}$ with acid and water, and led to 2-hydroxy-2-vinyl-2,3-dihydro- $H H$-inden-1-one (4.122) in good isolated yield (92\%). 
With the hydroxyketone 4.122 in hand, our next step was to convert 4.122 into its methyl ether 4.123 by treatment of $\mathbf{4 . 1 2 2}$ with $\mathrm{NaH}$ and iodomethane (Scheme 4.25). Condensation between $\mathbf{4 . 1 2 3}$ and lithium acetylide 4.72 afforded enediynyl propargylic alcohol 4.124 as a single diastereoisomer. However, the following Schimittel cyclization with thionyl chloride was unsuccessful. Alternatively, attempts were made to reduce the propargylic alcohol 4.124 initially to bennzannulated enndiyne 4.126. However, the next cyclization triggered by potassium tert-butoxide also failed because the methoxy group could serve as a leaving group in this reaction.

Scheme 4.25
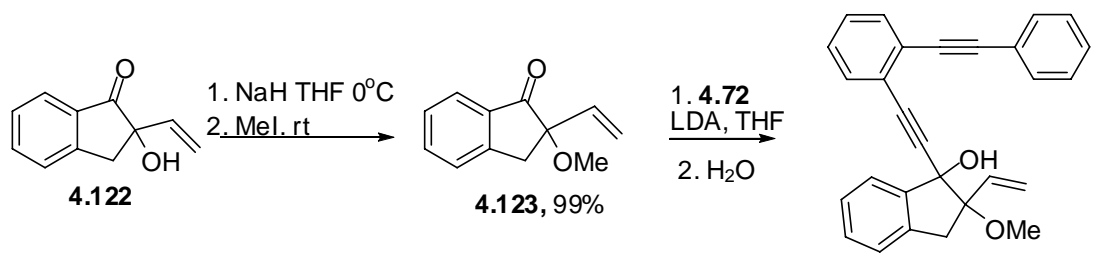

4.124, $98 \%$

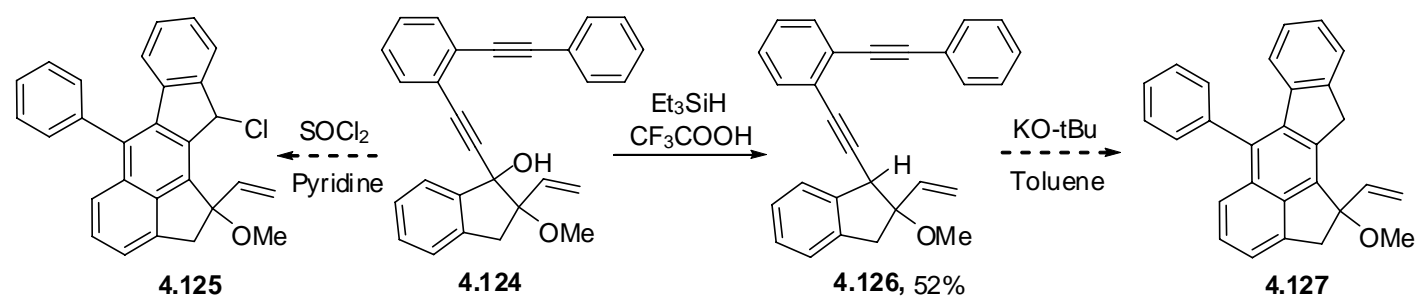

In an attempt to form the Schmittel cyclization product, an alternative synthetic pathway outlined in Scheme 4.26 was pursued. Condensation of ketone 4.123 and lithium trimethylsilylacetylide produced proprgylic alcohol 4.128. Deprotection of trimethylsilyl acetylene was achieved by using a catalytic amount of silver triflate under mild conditions, and afforded 4.129 in a good yield. ${ }^{73}$ Treatment of 4.129 with thionyl bromide produced allenic bromide $\mathbf{4 . 1 3 0}$ as a diastereomeric pairs. ${ }^{74}$ In the next step, we tried to make the benzannulated enyne-allene $\mathbf{4 . 1 3 3}$ with a palladium-catalyzed coupling reaction between 4.130 and arylzinc chloride $4.132 .{ }^{75}$ Interestingly, instead of lithium iodine exchange in compound 4.131, lithium bromine exchange occurred at low temperature. Thus, the palladium-coupling reaction between 4.130 and arylzinc chloride 4.135 led to 
the benzannulated enyne-allene 4.136, which was transformed to the corresponding cyclization product 4.137 through the Schimittel cyclization reaction. The ${ }^{1} \mathrm{H}$ NMR showed that compound 4.137 exists as two atropisomers due to the slow rate of rotation of the iodophenyl substitute in $\mathbf{4 . 1 3 7}$ on the NMR time scale. All attempts to avoid the lithium bromine exchange were unsuccessful. Based on the unexpected results, this synthetic pathway was not investigated further after the hydroboration step.

\section{Scheme 4.26}
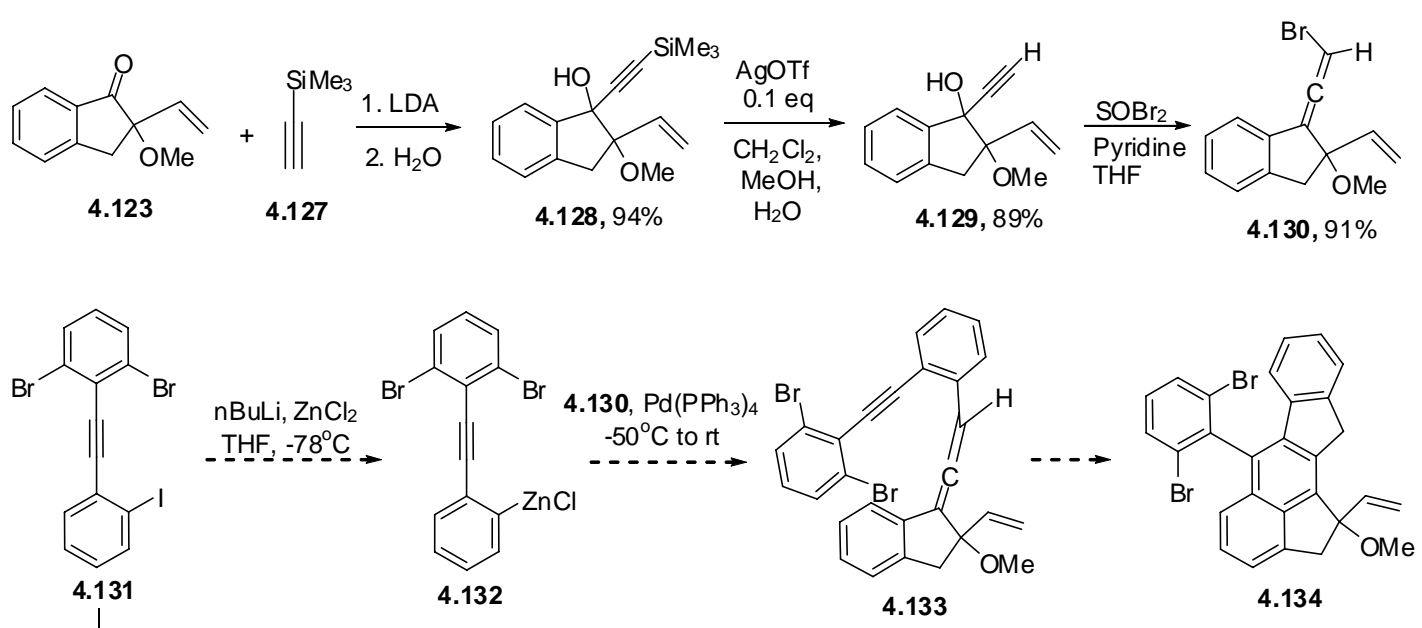

$\mathrm{nBuLi}, \mathrm{ZnCl}_{2}$ THF, $-78^{\circ} \mathrm{C}$

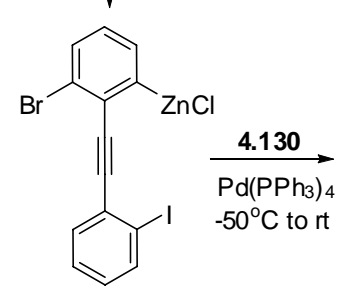

4.135
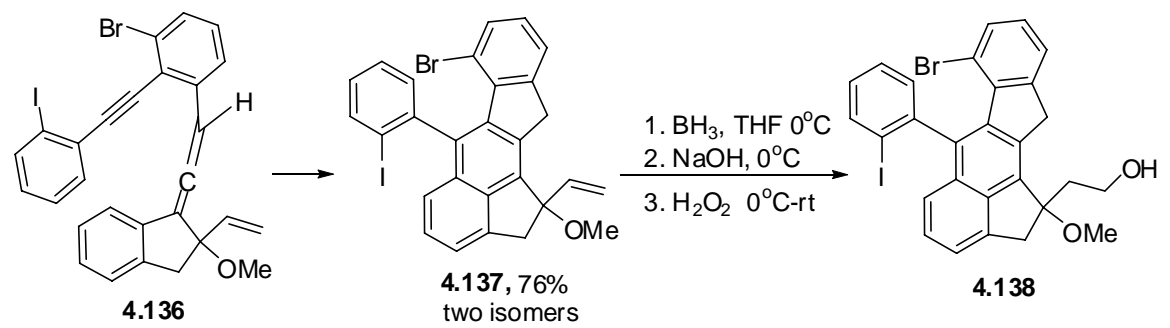

\section{Conclusions}

A bowl-shaped polycyclic aromatic hydrocarbon 4.87, bearing a framework of sumanene, was successfully synthesized from a polycyclic aromatic dibromide. This simple and efficient pathway employed the Schmittel cyclization reaction and palladiumcatalyzed intramolecular arylation reactions as key steps. This overall synthetic strategy 
has found success in producing curved hydrocarbons. Several attempts were made to synthesize the precursor of buckybowl $\mathbf{4 . 5 4}$ by using different combination of benzoenediynes and substituted indanones. Further exploration is required to overcome difficulties encounted toward the synthesis of buckybowl 4.54. 


\section{References}

(1) Kadish, K. M.; Ruoff, R. S. Fullerenes: Chemistry, Physics and Technology; Wiley, New York, 2000.

(2) Kroto, H. W.; Heath, J. R.; O'Brien, S. C.; Curl, R. F.; Smalley, R. E. Nature 1985, $318,162-163$.

(3) Iijima, S. Nature 1991, 354, 56-58.

(4) Cataldo, F.; Ros, T. d. Medicinal Chemistry and Pharmacological Potential of Fullerenes and Carbon Nanotubes Springer, 2008.

(5) Scott, L. T. Angew. Chem. Int. Edit. 2004, 43, 4994-5007.

(6) Wu, Y.-T.; Siegel, J. S. Chem. Rev. 2006, 106, 4843-4867.

(7) Tsefrikas, V. M.; Scott, L. T. Chem. Rev. 2006, 106, 4868-4884.

(8) Faust, R.; Vollhardt, K. P. C. Journal of the Chemical Society, Chemical Communications 1993, 1471-1473.

(9) Diederich, F.; Rubin, Y. Angewandte Chemie International Edition in English 1992, $31,1101-1123$.

(10)McElvany, S. W.; Ross, M. M.; Goroff, N. S.; Diederich, F. Science 1993, 259, 1594-1596.

(11) Sastry, G. N.; Jemmis, E. D.; Mehta, G.; Shah, S. R. Journal of the Chemical Society, Perkin Transactions 2 1993, 1867-1871.

(12)Seiders, T. J.; Baldridge, K. K.; O'Connor, J. M.; Siegel, J. S. J. Am. Chem. Soc. 1997, $119,4781-4782$.

(13) Vecchi, P. A.; Alvarez, C. M.; Ellern, A.; Angelici, R. J.; Sygula, A.; Sygula, R.; Rabideau, P. W. Angew. Chem. Int. Edit. 2004, 43, 4497-4500.

(14)Petrukhina, M. A.; Andreini, K. W.; Tsefrikas, V. M.; Scott, L. T. Organometallics. 2005, 24, 1394-1397.

(15) Vecchi, P. A.; Alvarez, C. M.; Ellern, A.; Angelici, R. J.; Sygula, A.; Sygula, R.; Rabideau, P. W. Organometallics. 2005, 24, 4543-4552. 
(16) Stoddart, M. W.; Brownie, J. H.; Baird, M. C.; Schmider, H. L. J. Organomet. Chem. 2005, 690, 3440-3450.

(17) Amaya, T.; Sakane, H.; Hirao, T. Angew. Chem. Int. Edit. 2007, 46, 8376-8379.

(18) Sakane, H.; Amaya, T.; Moriuchi, T.; Hirao, T. Angew. Chem. Int. Edit. 2009, 48, 1640-1643.

(19) Amaya, T.; Wang, W. Z.; Sakane, H.; Moriuchi, T.; Hirao, T. Angew. Chem. Int. Edit. 2010, 49, 403-406.

(20)Rabideau, P. W.; Sygula, A. Accounts. Chem. Res. 1996, 29, 235-242.

(21) Mehta, G.; Rao, H. S. P. Tetrahedron 1998, 54, 13325-13370.

(22)Brown, R. F. C. Pyrolytic methods in organic chemistry : application of flow and flash vacuum pyrolytic techniques; New York : Academic Press,, 1980.

(23)Chang, H.-F.; Cho, B. P. J. Org. Chem. 1999, 64, 9051-9056.

(24)Wang, L.; Shevlin, P. B. Org. Lett. 2000, 2, 3703-3705.

(25)Barth, W. E.; Lawton, R. G. J. Am. Chem. Soc. 1966, 88, 380-381.

(26)Lawton, R. G.; Barth, W. E. J. Am. Chem. Soc. 1971, 93, 1730-1745.

(27)Hanson, J. C.; Nordman, C. E. Acta Crystallographica Section B 1976, 32, 1147-1153.

(28)Craig, J. T.; Robins, M. D. W. Aust. J. Chem. 1968, 21, 2237-2245.

(29) Davy, J. R.; Iskander, M. N.; Reiss, J. A. Tetrahedron Lett. 1978, 19, 4085-4088.

(30) Seiders, T. J.; Baldridge, K. K.; Siegel, J. S. J. Am. Chem. Soc. 1996, 118, 2754-2755.

(31) Sygula, A.; Rabideau, P. W. J. Am. Chem. Soc. 1999, 121, 7800-7803.

(32) Sygula, A.; Rabideau, P. W. J. Am. Chem. Soc. 2000, 122, 6323-6324.

(33) Sygula, A.; Xu, G.; Marcinow, Z.; Rabideau, P. W. Tetrahedron 2001, 57, 3637-3644.

(34)Xu, G.; Sygula, A.; Marcinow, Z.; Rabideau, P. W. Tetrahedron Lett. 2000, 41, 9931-9934.

(35)Mehta, G.; Shahk, S. R.; Ravikumarc, K. Journal of the Chemical Society, Chemical 
Communications 1993, 1006-1008.

(36) Sakurai, H.; Daiko, T.; Hirao, T. Science 2003, 301, 1878-.

(37)Higashibayashi, S.; Sakurai, H. J. Am. Chem. Soc. 2008, 130, 8592-8593.

(38) Reisch, H. A.; Bratcher, M. S.; Scott, L. T. Org. Lett. 2000, 2, 1427-1430.

(39) Marcinow, Z.; Sygula, A.; Ellern, A.; Rabideau, P. W. Org. Lett. 2001, 3, 3527-3529.

(40)Jackson, E. A.; Steinberg, B. D.; Bancu, M.; Wakamiya, A.; Scott, L. T. J. Am. Chem. Soc. 2007, 129, 484-485.

(41) Steinberg, B. D.; Jackson, E. A.; Filatov, A. S.; Wakamiya, A.; Petrukhina, M. A.; Scott, L. T. J. Am. Chem. Soc. 2009, 131, 10537-10545.

(42)Brown, R. F. C.; Eastwood, F. W.; Jackman, G. P. Aust. J. Chem. 1977, 30, 1757-1767.

(43) Scott, L. T.; Hashemi, M. M.; Meyer, D. T.; Warren, H. B. J. Am. Chem. Soc. 1991, $113,7082-7084$.

(44) Scott, L. T.; Cheng, P.-C.; Hashemi, M. M.; Bratcher, M. S.; Meyer, D. T.; Warren, H. B. J. Am. Chem. Soc. 1997, 119, 10963-10968.

(45) Scott, L. T.; Hashemi, M. M.; Bratcher, M. S. J. Am. Chem. Soc. 1992, 114, 1920.

(46)Borchardt, A.; Fuchicello, A.; Kilway, K. V.; Baldridge, K. K.; Siegel, J. S. J. Am. Chem. Soc. 1992, 114, 1921.

(47)Liu, C. Z.; Rabideau, P. W. Tetrahedron Lett. 1996, 37, 3437.

(48)Zimmerman, G.; Nuechter, U.; Hagen, S.; Nuechter, M. Tetrahedron Lett. 1994, 35, 4747.

(49)Mehta, G.; Panda, G. Tetrahedron Lett. 1997, 38.

(50) Bronstein, H. E.; Choi, N.; Scott, L. T. J. Am. Chem. Soc. 2002, 124, 8870.

(51)Rabideau, P. W.; Abdourazak, A. H.; Folsom, H. E.; Marcinow, Z.; Sygula, A.; Sygula, R. J. Am. Chem. Soc. 1994, 116, 7891-7892.

(52)Abdourazak, A. H.; Marcinow, Z.; Sygula, A.; Sygula, R.; Rabideau, P. W. J. Am. Chem. Soc. 1995, 117, 6410-6411. 
(53) Scott, L. T.; Bratcher, M. S.; Hagen, S. J. Am. Chem. Soc. 1996, 118, 8743-8744.

(54)Scott, L. T.; Boorum, M. M.; McMahon, B. J.; Hagen, S.; Mack, J.; Blank, J.; Wegner, H.; de Meijere, A. Science 2002, 295, 1500.

(55)Kim, D.; Petersen, J. L.; Wang, K. K. Org. Lett. 2006, 8, 2313-2316.

(56) Seidel, G.; Laurich, D.; Fürstner, A. J. Org. Chem. 2004, 69, 3950-3952.

(57)Jung, M. E.; Lyster, M. A. J. Org. Chem. 1977, 42, 3761-3764.

(58)Olah, G. A.; Narang, S. C.; Gupta, B. G. B.; Malhotra, R. J. Org. Chem. 1979, 44, 1247-1251.

(59)Bradshaw, J. D.; Guo, L.; Tessier, C. A.; Youngs, W. J. Organometallics. 1996, 15, $2582-2584$.

(60)Kuo, C.-H.; Tsau, M.-H.; Weng, D. T. C.; Lee, G. H.; Peng, S.-M.; Luh, T.-Y.; Biedermann, P. U.; Agranat, I. J. Org. Chem. 1995, 60, 7380-7381.

(61)Li, X.; Kyne, R. E.; Ovaska, T. V. Org. Lett. 2006, 8, 5153-5156.

(62) Murphy, J. A.; Mahesh, M.; McPheators, G.; Anand, R. V.; McGuire, T. M.; Carling, R.; Kennedy, A. R. Org. Lett. 2007, 9, 3233-3236.

(63) Suri, J. T.; Steiner, D. D.; Barbas, C. F. Org. Lett. 2005, 7, 3885-3888.

(64)Clive, D.; Angoh, A. G.; Bennett, S. M. J. Org. Chem. 1987, 52, 1339-1342.

(65)Bélanger, D.; Tong, X.; Soumaré, S.; Dory, Y.; Zhao, Y. Chemistry - A European Journal 2009, 15, 4428-4436.

(66)Kleinbeck, F.; Toste, F. D. J. Am. Chem. Soc. 2009, 131, 9178-9179.

(67) Trost, B. M.; Xie, J. J. Am. Chem. Soc. 2006, 128, 6044-6045.

(68)Trost, B. M.; Xie, J. J. Am. Chem. Soc. 2008, 130, 6231-6242.

(69) Stone, G. B.; Liebeskind, L. S. J. Org. Chem. 1990, 55, 4614-4622.

(70)Bubb, W. A.; Sternhell, S. Aust. J. Chem. 1976, 29, 1685-1697.

(71)Keck, D.; Vanderheiden, S.; Bräse, S. Eur. J. Org. Chem. 2006, 2006, 4916-4923.

(72)Teller, H.; Flügge, S.; Goddard, R.; Fürstner, A. Angew. Chem. Int. Edit. 2010, 49, 1949-1953. 
(73) Orsini, A.; Vitérisi, A.; Bodlenner, A.; Weibel, J.-M.; Pale, P. Tetrahedron Lett. 2005, $46,2259-2262$.

(74)Conde, J. J.; Mendelson, W. Tetrahedron Lett. 2000, 41, 811-814.

(75)Ruitenberg, K.; Kleijn, H.; Elsevier, C. J.; Meijer, J.; Vermeer, P. Tetrahedron Lett. 1981, 22, 1451-1452. 


\section{Chapter 5}

\section{Experiment Section}

General Experimental Methods. All reactions were conducted in oven-dried $\left(120^{\circ} \mathrm{C}\right)$ glassware under a nitrogen atmosphere. Diethyl ether and tetrahydrofuran (THF) were distilled from benzophenone ketyl prior to use. Commercially available chemicals were of reagent grade and were used as received without further purification. Purification by column chromatography was performed using 32-63 $\mu \mathrm{m}$ silica gel. Melting points were uncorrected. High resolution mass spectra were obtained on a hybrid linear ion trap Fourier transform mass spectrometer system equipped with an ion source. UV-vis spectra of $2.5 \times 10^{-5} \mathrm{M}$ solutions of $\mathbf{2 . 2 a}-\mathbf{c}$ in dichloromethane and $1.0 \times 10^{-5} \mathrm{M}$ solutions of $\mathbf{2 . 1 3}$, 2.14, and $\left[\mathrm{Ru}\left(4^{\prime}-\text {-EtOtpy }\right)_{2}\right]\left(\mathrm{PF}_{6}\right)_{2}$ in acetonitrile were recorded at room temperature. Emission spectra of $1.0 \times 10^{-7} \mathrm{M}$ solutions of $\mathbf{2 . 2 \mathbf { a }}-\mathbf{c}$ in dichloromethane were recorded at room temperature upon excitation at $360 \mathrm{~nm}$. UV-vis spectra of $5.0 \times 10^{-5} \mathrm{M}$ solutions of 3.49, 3.50, 3.54, and 3.57 in acetonitrile were recorded at room temperature. Spectrophotometer cells with an optical path length of $10 \mathrm{~mm}$ were used in recording UV-vis spectra. Emission spectra of $5.0 \times 10^{-5} \mathrm{M}$ solutions of $\mathbf{3 . 4 9}$ and $\mathbf{3 . 5 0}$ in acetonitrile were recorded at room temperature upon excitation at 350 and $400 \mathrm{~nm}$, respectively. 
Propargylic Alcohol 2.5. To $6.00 \mathrm{~g}(26.3 \mathrm{mmol})$ of 1-ethynyl-2-iodobenzene (2.3) in 50 $\mathrm{mL}$ of THF under a nitrogen atmosphere at $0{ }^{\circ} \mathrm{C}$ was added $23.3 \mathrm{~mL}$ of a $1.2 \mathrm{M}$ solution of LDA $(28.0 \mathrm{mmol})$ in hexanes. After $30 \mathrm{~min}$ of stirring, a solution of $3.23 \mathrm{~g}$ of diketone 2.4 (13.1 mmol) in $40 \mathrm{~mL}$ of THF was introduced via cannula, and the reaction mixture was allowed to warm to room temperature. After an additional $2 \mathrm{~h}, 50 \mathrm{~mL}$ of water was introduced, and the reaction mixture was extracted with diethyl ether. The combined organic extracts were washed with brine and water, dried over sodium sulfate, and concentrated. The residue was purified by flash column chromatography (silica gel $/ 20 \%$ THF in hexanes, $\left.R_{f}=0.33\right)$ to produce $8.73 \mathrm{~g}(12.5 \mathrm{mmol}, 95 \%, 1: 1$ mixture of the meso and $\mathrm{rac}$ isomers) of $\mathbf{2 . 5}$ as a white solid: $\mathrm{mp} 227-228{ }^{\circ} \mathrm{C}$; IR 3559, $757 \mathrm{~cm}^{-1} ;{ }^{1} \mathrm{H}$ NMR (mixture of the meso and $\mathrm{rac}$ isomers, $\left.\mathrm{CDCl}_{3}, 600 \mathrm{MHz}\right) \delta 7.85(2 \mathrm{H}, \mathrm{dd}, J=7.8,1.2 \mathrm{~Hz})$, $7.71(4 \mathrm{H}, \mathrm{s}), 7.48(2 \mathrm{H}, \mathrm{dd}, J=7.8,1.2 \mathrm{~Hz}), 7.30(2 \mathrm{H}, \mathrm{td}, J=7.5,1.2 \mathrm{~Hz}), 7.01(2 \mathrm{H}, \mathrm{td}$, $J=8.1,1.8 \mathrm{~Hz}), 2.45(2 \mathrm{H}, \mathrm{br}), 1.12(18 \mathrm{H}, \mathrm{s}) ;{ }^{13} \mathrm{C}$ NMR (mixture of the meso and rac isomers, $\left.\mathrm{CDCl}_{3}, 150 \mathrm{MHz}\right) \delta 141.0,138.8,133.2,129.52,129.49,127.7,126.7,100.4$, 96.1, 87.6, 79.5, 40.0, 25.7; HRMS $m / z$ calcd for $\mathrm{C}_{32} \mathrm{H}_{32} \mathrm{I}_{2} \mathrm{O}_{2} \mathrm{Na}\left(\mathrm{MNa}^{+}\right)$725.0384, found 725.0385 .

Diiodide 2.6. To a mixture of $2.5(8.4 \mathrm{~g}, 11.96 \mathrm{mmol})$ and triethylsilane $(4.17 \mathrm{~g}, 35.9$ $\mathrm{mmol}$ ) in $200 \mathrm{~mL}$ of dichloromethane was added $1.09 \mathrm{~g}$ of trifluoroacetic acid (95.6 $\mathrm{mmol})$. After $1 \mathrm{~h}$ of stirring at room temperature, $5.1 \mathrm{~g}(48.1 \mathrm{mmol})$ of sodium carbonate was added followed by $50 \mathrm{~mL}$ of water. The organic layer was separated, washed with brine and water, dried over sodium sulfate, and evaporated under reduced pressure. The residue was purified by flash column chromatography (silica gel/10\% diethyl ether in hexanes, $\left.R_{f}=0.57\right)$ to provide $7.69 \mathrm{~g}(11.5 \mathrm{mmol}, 96 \%, 1: 1$ mixture of the meso and rac isomers) of 2.6 as a white solid: mp $182-183{ }^{\circ} \mathrm{C}$; IR 2219, 1462, $750 \mathrm{~cm}^{-1}$; ${ }^{1} \mathrm{H}$ NMR (mixture of the meso and rac isomers, $\left.\mathrm{CDCl}_{3}, 600 \mathrm{MHz}\right) \delta 7.83(2 \mathrm{H}, \mathrm{dd}, J=8.1,1.2 \mathrm{~Hz}$ ), $7.43(2 \mathrm{H}, \mathrm{dd}, J=7.8,1.8 \mathrm{~Hz}), 7.38(4 \mathrm{H}, \mathrm{s}), 7.26(2 \mathrm{H}, \mathrm{td}, J=7.5,1.2 \mathrm{~Hz}), 6.96(2 \mathrm{H}, \mathrm{td}$, 
$J=7.8,1.8 \mathrm{~Hz}), 3.68(2 \mathrm{H}, \mathrm{s}), 1.08(18 \mathrm{H}, \mathrm{s}) ;{ }^{13} \mathrm{C}$ NMR (mixture of the meso and rac isomers, $\left.\mathrm{CDCl}_{3}, 150 \mathrm{MHz}\right) \delta 138.6,137.4,133.0,130.6,129.1,128.8,127.6,100.6,95.7$, 85.6, 50.3, 35.7, 27.9; HRMS $m / z$ calcd for $\mathrm{C}_{32} \mathrm{H}_{33} \mathrm{I}_{2}\left(\mathrm{MH}^{+}\right)$671.0666, found 671.0665.

Tetraacetylene 2.8a. The following procedure for 2.8a is representative for the preparation of tetraacetylenes $\mathbf{2 . 8 a}-\mathbf{c}$. To a mixture of $\mathbf{2 . 6}(0.90 \mathrm{~g}, 1.34 \mathrm{mmol})$, $\mathrm{Pd}\left(\mathrm{PPh}_{3}\right)_{2} \mathrm{Cl}_{2}(0.047 \mathrm{~g}, 0.067 \mathrm{mmol})$, and $\mathrm{CuI}(0.0064 \mathrm{~g}, 0.034 \mathrm{mmol})$ in $40 \mathrm{~mL}$ of triethylamine under a nitrogen atmosphere was added via cannula a solution of $\mathbf{2 . 7 a}(0.29$ $\mathrm{g}, 2.81 \mathrm{mmol}$ ) in $20 \mathrm{~mL}$ of triethylamine. The resulting mixture was heated to reflux for $24 \mathrm{~h}$ before it was allowed to cool to room temperature. The mixture was concentrated in vacuo. The black residue was dissolved in $100 \mathrm{~mL}$ of dichloromethane and then washed with brine and water. The organic layer was separated, dried over sodium sulfate, and concentrated. Purification by flash column chromatography (silica gel $/ \mathrm{CH}_{2} \mathrm{Cl}_{2}: \mathrm{MeOH}=$ 19:1, $\left.R_{f}=0.45\right)$ provided $0.75 \mathrm{~g}(1.2 \mathrm{mmol}, 90 \%, 1: 1$ mixture of the meso and rac isomers) of 2.8a as a yellow solid with some fractions contained only the meso or the rac isomer: $\mathrm{mp} 183-185{ }^{\circ} \mathrm{C}$; IR 2218, 1590, 1235, 821, $764 \mathrm{~cm}^{-1}$; meso-2.8a: ${ }^{1} \mathrm{H}$ NMR $\left(\mathrm{CDCl}_{3}, 600 \mathrm{MHz}\right) \delta 8.55(4 \mathrm{H}, \mathrm{br}), 7.56(2 \mathrm{H}, \mathrm{dd}, J=7.8,1.2 \mathrm{~Hz}), 7.53(2 \mathrm{H}, \mathrm{dd}, J=$ 7.8, $1.2 \mathrm{~Hz}), 7.35(2 \mathrm{H}$, td, $J=7.8,1.2 \mathrm{~Hz}), 7.30(2 \mathrm{H}, \mathrm{td}, J=7.8,1.2 \mathrm{~Hz}), 7.297-7.28(8$ $\mathrm{H}, \mathrm{m}), 3.66(2 \mathrm{H}, \mathrm{s}), 1.02(18 \mathrm{H}, \mathrm{s}) ;{ }^{13} \mathrm{C} \mathrm{NMR}\left(\mathrm{CDCl}_{3}, 150 \mathrm{MHz}\right) \delta$ 148.0, 137.6, 133.2, $132.5,132.4,129.3,129.0,127.6,126.8,126.1,124.0,96.4,95.1,89.4,82.2,50.2,35.5$, 27.8. $r a c-2.8 \mathrm{a}:{ }^{1} \mathrm{H} \mathrm{NMR}\left(\mathrm{CDCl}_{3}, 600 \mathrm{MHz}\right) \delta 8.50(4 \mathrm{H}, \mathrm{br} \mathrm{s}), 7.52(2 \mathrm{H}, \mathrm{d}, J=7.8 \mathrm{~Hz})$, $7.46(2 \mathrm{H}, \mathrm{d}, J=6.6 \mathrm{~Hz}), 7.30-7.24(12 \mathrm{H}, \mathrm{m}), 3.67(2 \mathrm{H}, \mathrm{s}), 1.01(18 \mathrm{H}, \mathrm{s}) ;{ }^{13} \mathrm{C} \mathrm{NMR}$ $\left(\mathrm{CDCl}_{3}, 150 \mathrm{MHz}\right) \delta 149.4,137.5,132.3,132.2,131.6,128.9,128.8,127.4,126.7,125.6$, 124.3, 96.3, 93.3, 89.7, 82.1, 50.2, 35.5, 27.7; MS $m / z 621\left(\mathrm{MH}^{+}\right), 254$; HRMS $m / z$ calcd for $\mathrm{C}_{46} \mathrm{H}_{41} \mathrm{~N}_{2}\left(\mathrm{MH}^{+}\right)$621.3264, found 621.3261. Recrystallization of the separated meso-2.8a and rac-2.8a from $\mathrm{CH}_{2} \mathrm{Cl}_{2} / \mathrm{MeOH}$ produced crystals suitable for X-ray structure analyses. 
Tetraacetylene $\mathbf{2 . 8 b}$. The same procedure was repeated as described for $\mathbf{2 . 8 a}$ except that $0.27 \mathrm{~g}(1.5 \mathrm{mmol})$ of $\mathbf{2 . 7 \mathbf { b }}$ was treated with a mixture of $\mathbf{2 . 6}(0.50 \mathrm{~g}, 0.75 \mathrm{mmol})$, $\mathrm{Pd}\left(\mathrm{PPh}_{3}\right)_{2} \mathrm{Cl}_{2}(0.028 \mathrm{~g}, 0.040 \mathrm{mmol})$, and $\mathrm{CuI}(0.0043 \mathrm{~g}, 0.023 \mathrm{mmol})$ in $50 \mathrm{~mL}$ of triethylamine. Purification by flash column chromatography (silica gel/ $\mathrm{CH}_{2} \mathrm{Cl}_{2}: \mathrm{MeOH}$ $\left.=19: 1, R_{f}=0.52\right)$ furnished $0.49 \mathrm{~g}$ of $\mathbf{2 . 8 b}(0.65 \mathrm{mmol}, 86 \%, 1: 1$ mixture of the meso and rac isomers) as a yellow solid: $\mathrm{mp} 189-192{ }^{\circ} \mathrm{C}$; IR 2210, 1739, 1217, $752 \mathrm{~cm}^{-1} ;{ }^{1} \mathrm{H}$ NMR (mixture of the meso and rac isomers, $\left.\mathrm{CDCl}_{3}, 600 \mathrm{MHz}\right) \delta 8.76-8.66(4 \mathrm{H}, \mathrm{m}), 8.50-8.43$ (4 H, m), $7.89(1 \mathrm{H}, \mathrm{t}, J=7.2 \mathrm{~Hz}), 7.83(1 \mathrm{H}, \mathrm{t}, J=7.2 \mathrm{~Hz}), 7.81-7.77(2 \mathrm{H}, \mathrm{m})$, 7.54-7.51 (3 H, m), 7.48-7.46 (1 H, m), 7.39-7.34 (2 H, m), 7.32 and 7.31 (4 H, two singlets), 7.28-7.24 (4 H, m), 3.71 and 3.66 (2 H, two singlets), $1.01(18 \mathrm{H}, \mathrm{s}) ;{ }^{13} \mathrm{C} \mathrm{NMR}$ (mixture of the meso and rac isomers, $\left.\mathrm{CDCl}_{3}, 150 \mathrm{MHz}\right) \delta 154.3,152.9,151.7,151.6$, $147.9,139.74,139.72,138.3,137.54,137.46,132.29,132.23,132.19,132.15,128.99$, 128.97, 128.53, 128.47, 127.4, 126.64, 126.59, 124.71, 124.67, 124.2, 122.1, 121.0, 96.29, 96.27, 93.38, 93.33, 89.3, 82.3, 82.1, 50.2, 35.51, 35.50, 27.8; MS m/z $775\left(\mathrm{MH}^{+}\right), 718$; HRMS $m / z$ calcd for $\mathrm{C}_{56} \mathrm{H}_{47} \mathrm{~N}_{4}\left(\mathrm{MH}^{+}\right)$775.3795, found 775.3789 .

Tetraacetylene 2.8c. The same procedure was repeated as described for 2.8a except that $0.26 \mathrm{~g}(1.0 \mathrm{mmol})$ of $\mathbf{2 . 7 \mathrm { c }}$ was treated with a mixture of $2.6(0.32 \mathrm{~g}, 0.48 \mathrm{mmol})$, $\mathrm{Pd}\left(\mathrm{PPh}_{3}\right)_{2} \mathrm{Cl}_{2}(0.015 \mathrm{~g}, 0.021 \mathrm{mmol})$, and $\mathrm{CuI}(0.005 \mathrm{~g}, 0.026 \mathrm{mmol})$ in $50 \mathrm{~mL}$ of triethylamine. Purification by flash column chromatography (silica gel/ $\mathrm{CH}_{2} \mathrm{Cl}_{2}: \mathrm{MeOH}=$ 9:1, $\left.R_{f}=0.43\right)$ furnished $0.34 \mathrm{~g}$ of $2.8 \mathrm{c}(0.37 \mathrm{mmol}, 77 \%, 1: 1$ mixture of the meso and rac isomers) as a yellow solid: $\operatorname{mp} 251-253{ }^{\circ} \mathrm{C}$; IR 2220, 1738, 1583, 1390, $788 \mathrm{~cm}^{-1} ;{ }^{1} \mathrm{H}$ NMR (mixture of the meso and rac isomers, $\left.\mathrm{CDCl}_{3}, 600 \mathrm{MHz}\right) \delta 8.72(4 \mathrm{H}, \mathrm{d}, J=3.6$ Hz), $8.60(4 \mathrm{H}, \mathrm{d}, J=8.4 \mathrm{~Hz}), 8.59(4 \mathrm{H}, \mathrm{s}), 7.86$ (4 H, t, $J=7.8 \mathrm{~Hz}), 7.54(2 \mathrm{H}, \mathrm{m}), 7.43$ (2 H, m), $7.34(4 \mathrm{H}, \mathrm{t}, J=6.3 \mathrm{~Hz}), 7.32(4 \mathrm{H}, \mathrm{s}), 7.27-7.22(4 \mathrm{H}, \mathrm{m}), 3.64(2 \mathrm{H}, \mathrm{s}), 1.01$ $(18 \mathrm{H}, \mathrm{s}) ;{ }^{13} \mathrm{C} \mathrm{NMR}$ (mixture of the meso and rac isomers, $\left.\mathrm{CDCl}_{3}, 150 \mathrm{MHz}\right) \delta 155.3$, $155.2,148.9,137.3,137.2,133.4,132.4,132.2,129.0,128.6,127.3,126.8,124.7,124.0$, 
123.2, 121.4, 96.5, 93.2, 90.6, 82.1, 50.2, 35.5, 27.7; MS m/z $929\left(\mathrm{MH}^{+}\right), 872,815$; HRMS $m / z$ calcd for $\mathrm{C}_{66} \mathrm{H}_{53} \mathrm{~N}_{6}\left(\mathrm{MH}^{+}\right)$929.4326, found 929.4319 .

4,5-Diheteroarylphenanthrene 2.2a. To $0.28 \mathrm{~g}(0.45 \mathrm{mmol})$ of $\mathbf{2 . 8 a}$ in $30 \mathrm{~mL}$ of anhydrous toluene under a nitrogen atmosphere was added $1.0 \mathrm{~mL}$ of a $1.0 \mathrm{M}$ solution of potassium tert-butoxide $(1.0 \mathrm{mmol})$ in 2-methyl-2-propanol. The reaction mixture was then heated under reflux for $6 \mathrm{~h}$. After the reaction mixture was allowed to cool to room temperature, $10 \mathrm{~mL}$ of water and $120 \mathrm{~mL}$ of dichloromethane were introduced, and the organic layer was separated, dried over sodium sulfate, and concentrated. Flash column chromatograph (silica gel $\left./ \mathrm{CH}_{2} \mathrm{Cl}_{2}: \mathrm{MeOH}=19: 1, R_{f}=0.33\right)$ provided $0.16 \mathrm{~g}(0.26 \mathrm{mmol}$, $58 \%)$ of 2.2a as a yellow solid: $\mathrm{mp}>350{ }^{\circ} \mathrm{C}$; IR $1594,830,741 \mathrm{~cm}^{-1} ;{ }^{1} \mathrm{H} \mathrm{NMR}\left(\mathrm{CDCl}_{3}\right.$, $600 \mathrm{MHz}) \delta 8.33(4 \mathrm{H}, \mathrm{d}, J=5.4 \mathrm{~Hz}), 7.89(2 \mathrm{H}, \mathrm{s}), 7.45(2 \mathrm{H}, \mathrm{d}, J=7.8 \mathrm{~Hz}), 7.13(2 \mathrm{H}, \mathrm{t}$, $J=7.5 \mathrm{~Hz}), 6.80(2 \mathrm{H}, \mathrm{t}, J=7.5 \mathrm{~Hz}), 6.63(4 \mathrm{H}, \mathrm{d}, J=6.0 \mathrm{~Hz}), 6.30(2 \mathrm{H}, \mathrm{d}, J=8.4 \mathrm{~Hz})$, $4.45(2 \mathrm{H}, \mathrm{d}, J=21.0 \mathrm{~Hz}), 4.19(2 \mathrm{H}, \mathrm{d}, J=21.0 \mathrm{~Hz}), 1.83(18 \mathrm{H}, \mathrm{s}) ;{ }^{13} \mathrm{C} \mathrm{NMR}\left(\mathrm{CDCl}_{3}\right.$, $150 \mathrm{MHz}) \delta 149.2,147.3,144.4,141.4,140.2,139.8,136.8,132.1,131.8,130.2,127.4$ (br), 127.0, 125.7, 124.1, 122.6, 122.3, 39.7, 38.0, 33.3; HRMS $m / z$ calcd for $\mathrm{C}_{46} \mathrm{H}_{41} \mathrm{~N}_{2}$ $\left(\mathrm{MH}^{+}\right)$621.3264, found 621.3263. Recrystallization of 2.2a from $\mathrm{CH}_{2} \mathrm{Cl}_{2} / \mathrm{MeOH}$ produced a crystal suitable for X-ray structure analysis.

4,5-Diheteroarylphenanthrene 2.2b. To $0.26 \mathrm{~g}(0.33 \mathrm{mmol})$ of $\mathbf{2 . 8 b}$ in $30 \mathrm{~mL}$ of anhydrous toluene under a nitrogen atmosphere was added $0.7 \mathrm{~mL}$ of a $1.0 \mathrm{M}$ solution of potassium tert-butoxide $(0.7 \mathrm{mmol})$ in 2-methyl-2-propanol. The reaction mixture was then heated under reflux for $6 \mathrm{~h}$. After the reaction mixture was allowed to cool to room temperature, $10 \mathrm{~mL}$ of water and $120 \mathrm{~mL}$ of dichloromethane were introduced, and the organic layer was separated, dried over sodium sulfate, and concentrated. Flash column chromatograph (silica gel $\left./ \mathrm{CH}_{2} \mathrm{Cl}_{2}: \mathrm{MeOH}=19: 1, R_{f}=0.4\right)$ provided $0.14 \mathrm{~g}(0.17 \mathrm{mmol}$, $53 \%$ ) of $2.2 \mathrm{~b}$ as a yellow solid: $\mathrm{mp}>350{ }^{\circ} \mathrm{C}$; IR 1707, 1458, $746 \mathrm{~cm}^{-1} ;{ }^{1} \mathrm{H}$ NMR 
$\left(\mathrm{CDCl}_{3}, 600 \mathrm{MHz}\right) \delta 8.70(2 \mathrm{H}, \mathrm{d}, J=3.6 \mathrm{~Hz}), 8.47(2 \mathrm{H}, \mathrm{br} \mathrm{s}), 8.20(2 \mathrm{H}, \mathrm{br}$ s), $7.93(2 \mathrm{H}$, s), 7.89 (4 H, br s), 7.40 (2 H, d, $J=7.2 \mathrm{~Hz}), 7.35(2 \mathrm{H}, \mathrm{t}, J=5.4 \mathrm{~Hz}), 7.06-7.02(4 \mathrm{H}, \mathrm{m})$, $6.72(2 \mathrm{H}, \mathrm{t}, J=7.8 \mathrm{~Hz}), 6.29(2 \mathrm{H}, \mathrm{d}, J=7.8 \mathrm{~Hz}), 4.43(2 \mathrm{H}, \mathrm{d}, J=21.0 \mathrm{~Hz}), 4.19(2 \mathrm{H}, \mathrm{d}$, $J=21.0 \mathrm{~Hz}), 1.85(18 \mathrm{H}, \mathrm{s}) ;{ }^{13} \mathrm{C} \mathrm{NMR}\left(\mathrm{CDCl}_{3}, 150 \mathrm{MHz}\right) \delta 155.6,148.6,144.4,141.1$, $140.2,137.8,137.5,135.7,132.2,131.0,130.3,126.7,125.9,124.1,123.8,122.5,122.4$, 122.0, 121.2, 39.9, 38.0, 33.4; MS m/z $775\left(\mathrm{MH}^{+}\right)$, 760; HRMS $m / z$ calcd for $\mathrm{C}_{56} \mathrm{H}_{47} \mathrm{~N}_{4}$ $\left(\mathrm{MH}^{+}\right)$775.3795, found 775.3788.

4,5-Diheteroarylphenanthrene 2.2c. To $0.32 \mathrm{~g}(0.34 \mathrm{mmol})$ of $2.8 \mathrm{c}$ in $30 \mathrm{~mL}$ of anhydrous toluene under a nitrogen atmosphere was added $0.7 \mathrm{~mL}$ of a $1.0 \mathrm{M}$ solution of potassium tert-butoxide $(0.7 \mathrm{mmol})$ in 2-methyl-2-propanol. The reaction mixture was then heated under reflux for $6 \mathrm{~h}$. After the reaction mixture was allowed to cool to room temperature, $10 \mathrm{~mL}$ of water and $120 \mathrm{~mL}$ of dichloromethane were introduced, and the organic layer was separated, dried over sodium sulfate, and concentrated. Flash column chromatograph (silica gel $\left./ \mathrm{CH}_{2} \mathrm{Cl}_{2}: \mathrm{MeOH}=9: 1, R_{f}=0.32\right)$ provided $0.15 \mathrm{~g}(0.16 \mathrm{mmol}$, $48 \%$ ) of 2.2c as a yellow solid: $\mathrm{mp}>350{ }^{\circ} \mathrm{C}$; IR 1583, 1565, 1466, 793, $735 \mathrm{~cm}^{-1} ;{ }^{1} \mathrm{H}$ $\operatorname{NMR}\left(\mathrm{CDCl}_{3}, 60{ }^{\circ} \mathrm{C}, 600 \mathrm{MHz}\right) \delta 8.44(4 \mathrm{H}, \mathrm{br}), 8.40(4 \mathrm{H}, \mathrm{br}), 7.91(4 \mathrm{H}, \mathrm{br}), 7.90(2 \mathrm{H}$, s), 7.68 (4 H, br), 7.32 (2 H, d, $J=7.2 \mathrm{~Hz}), 7.10$ (4 H, br), 6.97 (2 H, t, J=7.2 Hz), 6.70 $(2 \mathrm{H}, \mathrm{d}, J=7.8 \mathrm{~Hz}), 6.59(2 \mathrm{H}, \mathrm{t}, J=7.5 \mathrm{~Hz}), 4.18(2 \mathrm{H}, \mathrm{d}, J=21.0 \mathrm{~Hz}), 4.13(2 \mathrm{H}, \mathrm{d}, J=$ $21.0 \mathrm{~Hz}), 1.88(18 \mathrm{H}, \mathrm{s}) ;{ }^{13} \mathrm{C} \mathrm{NMR}\left(\mathrm{CDCl}_{3}, 150 \mathrm{MHz}\right) \delta 155$ (very br), 148.4 (br), 148.2 (br), 144.4, 141.0 (br), 140.0, 137 (very br), 136.5, 132.5 (very br), 132.0, 126.6, 126.0 (br), 125.8, 123.9, 123.3 (br), 122.3, 122.2, 121.1 (br), 39.6, 38.1, 33.3; HRMS m/z calcd for $\mathrm{C}_{66} \mathrm{H}_{53} \mathrm{~N}_{6}\left(\mathrm{MH}^{+}\right)$929.4325, found 929.4319. Recrystallization of 2.2c from $\mathrm{CH}_{2} \mathrm{Cl}_{2} / \mathrm{MeOH}$ produced a crystal suitable for X-ray structure analysis.

$\left[\mathrm{Cl}_{3} \mathbf{R u}(\mathbf{2 c}) \mathbf{R u C l}_{3}\right]$ (2.10). To a suspension of $0.066 \mathrm{~g}$ of $\mathrm{RuCl}_{3} \cdot 3 \mathrm{H}_{2} \mathrm{O}(0.25 \mathrm{mmol})$ and 15 $\mathrm{mL}$ of ethanol was added $0.110 \mathrm{~g}$ of $2 \mathrm{c}(0.118 \mathrm{mmol})$. The reaction mixture was heated to reflux for $16 \mathrm{~h}$ before it was allowed to cool to room temperature. The dark brown 
precipitate was collected by filtration, washed thoroughly with methanol, water, and diethyl ether, and dried in vacuo to yield $0.146 \mathrm{~g}$ of $\mathbf{2 . 1 0}(92 \%)$ as a dark brown solid: $\mathrm{mp}$ $>350{ }^{\circ} \mathrm{C}$; IR 1599, 1469, 790, $752 \mathrm{~cm}^{-1} ;{ }^{1} \mathrm{H}$ NMR $\left(\mathrm{CDCl}_{3}, 600 \mathrm{MHz}\right) \delta 14.40(2 \mathrm{H}, \mathrm{s})$, $14.28(2 \mathrm{H}, \mathrm{s}), 13.82(2 \mathrm{H}, \mathrm{s}), 10.17(2 \mathrm{H}, \mathrm{s}), 7.75(2 \mathrm{H}, \mathrm{d}, J=21.0 \mathrm{~Hz}), 7.26(2 \mathrm{H}, \mathrm{s})$, $4.83(2 \mathrm{H}, \mathrm{d}, J=21.0 \mathrm{~Hz}), 4.51(2 \mathrm{H}, \mathrm{s}), 1.24(2 \mathrm{H}, \mathrm{s}), 0.59(18 \mathrm{H}, \mathrm{s}),-1.53(2 \mathrm{H}, \mathrm{s})$, $-2.75(2 \mathrm{H}, \mathrm{s}),-3.64(2 \mathrm{H}, \mathrm{s}),-7.02(2 \mathrm{H}, \mathrm{s}),-9.35(2 \mathrm{H}, \mathrm{s}),-9.80(2 \mathrm{H}, \mathrm{s}),-32.35(2 \mathrm{H}$, s), $-35.56(2 \mathrm{H}, \mathrm{s})$; HRMS $\mathrm{m} / \mathrm{z}$ calcd for $\mathrm{C}_{66} \mathrm{H}_{52} \mathrm{Cl}_{6} \mathrm{~N}_{6} \mathrm{Ru}_{2}\left(\mathrm{M}^{+}\right)$1342.0471, found 1342.0531.

[(4'-EtOtpy)Ru(2c)Ru(4'-EtOtpy)](PF $)_{4}$ (2.13). A mixture of 2.10 (0.084 g, 0.062 mmol), 4'-EtOtpy (0.035 g, $0.126 \mathrm{mmol})$, and $N$-ethylmorpholine $(0.043 \mathrm{~g}, 0.37 \mathrm{mmol})$ in $7 \mathrm{~mL}$ of methanol was heated under reflux for $1 \mathrm{~h}$ before it was allowed to cool to room temperature. The mixture was filtered and the filtrate was treated with an excess of $\mathrm{NH}_{4} \mathrm{PF}_{6}(0.10 \mathrm{~g}, 0.62 \mathrm{mmol})$ in $10 \mathrm{~mL}$ of methanol to give a brown precipitate. The brown precipitate was collected by filtration, washed with water, methanol, and diethyl ether, and dried in vacuo to produce $0.102 \mathrm{~g}(0.045 \mathrm{mmol}, 73 \%)$ of $\mathbf{2 . 1 3}$ as a brown solid. The ${ }^{1} \mathrm{H}$ NMR spectrum of the brown solid showed the presence of a small amount of the homoleptic species $\left[\mathrm{Ru}\left(4^{\prime} \text {-EtOtpy }\right)_{2}\right]\left(\mathrm{PF}_{6}\right)_{2}$. The brown solid was further purified by flash column chromatography (silica gel/acetonitrile:saturated aqueous potassium nitrate:water $\left.=7: 1: 0.5, R_{f}=0.48\right)$. The main brown band was collected followed by the addition of excess $\mathrm{NH}_{4} \mathrm{PF}_{6}$. The solution was further concentrated in vacuo to induce precipitation. The precipitate was collected and washed with a small amount of methanol, dried in vacuo, to produce a more homogenous sample of $\mathbf{2 . 1 3}$ as a light brown solid: $\mathrm{mp}>350{ }^{\circ} \mathrm{C}$; IR 1615, 1213, 826, $787 \mathrm{~cm}^{-1}$; ${ }^{1} \mathrm{H}$ NMR $\left(\mathrm{CD}_{3} \mathrm{CN}, 600 \mathrm{MHz}\right) \delta 8.48(4 \mathrm{H}$, br s), $8.33(2 \mathrm{H}$, s), $8.31(4 \mathrm{H}, \mathrm{s}), 7.82(4 \mathrm{H}$, br s), $7.64(2 \mathrm{H}, \mathrm{d}, J=7.2 \mathrm{~Hz}), 7.39(2 \mathrm{H}, \mathrm{td}, J=7.2,1.2 \mathrm{~Hz})$, $7.33(2 \mathrm{H}, \mathrm{d}, J=8.4 \mathrm{~Hz}), 7.15(4 \mathrm{H}, \mathrm{br} \mathrm{s}), 7.02(2 \mathrm{H}, \mathrm{t}, J=7.8 \mathrm{~Hz}), 4.61(4 \mathrm{H}, \mathrm{q}, J=7.2$ $\mathrm{Hz}), 4.46(2 \mathrm{H}, \mathrm{d}, J=21.6 \mathrm{~Hz}), 4.30(2 \mathrm{H}, \mathrm{d}, J=21.6 \mathrm{~Hz}), 1.97(18 \mathrm{H}, \mathrm{s}) 1.64(6 \mathrm{H}, \mathrm{t}, J=$ 
$7.2 \mathrm{~Hz}) ;{ }^{13} \mathrm{C}$ NMR $\left(\mathrm{CD}_{3} \mathrm{CN}, 150 \mathrm{MHz}\right) \delta 167.7,156.6,153.9,147.2,145.9,144.3,142.8$, $139.3,138.9,137.5,134.3,133.8,131.3,129.4,128.9,127.9,126.6,124.6,122.6,112.3$, 67.2, 40.4, 39.3, 33.9, 14.8; HRMS $m / z$ calcd for $\mathrm{C}_{100} \mathrm{H}_{82} \mathrm{~F}_{24} \mathrm{~N}_{12} \mathrm{O}_{2} \mathrm{P}_{4} \mathrm{Ru}_{2}\left(\mathrm{M}^{+}\right)$2266.3338, found 2266.3423 .

[(4'-Cltpy)Ru(2c)Ru(4'-Cltpy)](PF $)_{4}$ (2.14). A mixture of $\mathbf{2 . 1 0}$ (0.025 g, $\left.0.019 \mathrm{mmol}\right)$, 4'-Cltpy (2.12) (0.010 g, $0.038 \mathrm{mmol})$, and $N$-ethylmorpholine $(0.014 \mathrm{~g}, 0.12 \mathrm{mmol})$ in 5 $\mathrm{mL}$ of methanol was heated under reflux for $1 \mathrm{~h}$ before it was allowed to cool to room temperature. The mixture was filtered and the filtrate was treated with an excess of $\mathrm{NH}_{4} \mathrm{PF}_{6}(0.033 \mathrm{~g}, 0.20 \mathrm{mmol})$ in $10 \mathrm{~mL}$ of methanol to give a brown precipitate. The brown precipitate was collected by filtration, washed with water, methanol, and diethyl ether, and dried in vacuo to produce $0.028 \mathrm{~g}(0.013 \mathrm{mmol}, 68 \%)$ of $\mathbf{2 . 1 4}$ as a brown solid: ${ }^{1} \mathrm{H}$ NMR (CD $\left.{ }_{3} \mathrm{CN}, 600 \mathrm{MHz}\right) \delta 8.87(4 \mathrm{H}, \mathrm{s}), 8.50(4 \mathrm{H}, \mathrm{m}), 8.34(2 \mathrm{H}, \mathrm{s}), 7.9-7.85(4 \mathrm{H}$, br), $7.65(2 \mathrm{H}, \mathrm{d}, J=7.8 \mathrm{~Hz}), 7.40(2 \mathrm{H}, \mathrm{t}, J=6.6 \mathrm{~Hz}), 7.36(2 \mathrm{H}, \mathrm{d}, J=8.4 \mathrm{~Hz}), 7.19(4$ $\mathrm{H}, \mathrm{t}, J=6.0 \mathrm{~Hz}), 7.04(2 \mathrm{H}, \mathrm{t}, J=7.2 \mathrm{~Hz}), 4.46(2 \mathrm{H}, \mathrm{d}, J=21.6 \mathrm{~Hz}), 4.30(2 \mathrm{H}, \mathrm{d}, J=$ $21.6 \mathrm{~Hz}), 1.96(18 \mathrm{H}, \mathrm{s})$; HRMS $m / z$ calcd for $\mathrm{C}_{96} \mathrm{H}_{72} \mathrm{Cl}_{2} \mathrm{~N}_{12} \mathrm{Ru}_{2}\left(\mathrm{M}-4 \mathrm{PF}_{6}\right)^{+}$1666.3467, found 1666.3552. The ${ }^{1} \mathrm{HNMR}$ spectrum showed that the sample contains minor amount of the homoleptic species $\left[\mathrm{Ru}\left(4^{\prime}-\mathrm{Cltpy}\right)_{2}\right]\left(\mathrm{PF}_{6}\right)_{2}$.

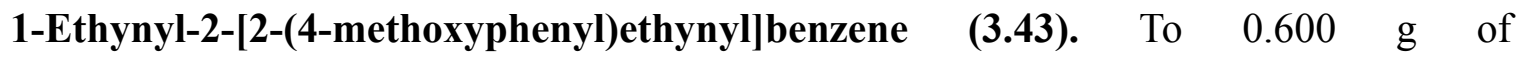
1-[2-(4-methoxyphenyl)ethynyl]-2-[2-(trimethylsilyl)ethynyl]benzene $(1.97 \mathrm{mmol})$ in 90 $\mathrm{mL}$ of methanol was added $1.37 \mathrm{~g}$ of potassium carbonate $(9.91 \mathrm{mmol})$. After $3 \mathrm{~h}$ at room temperature, the mixture was filtered to remove solid particles. Then $20 \mathrm{~mL}$ of a $2 \mathrm{M} \mathrm{HCl}$ solution was added slowly to the filtrate. The reaction mixture was extracted with diethyl ether $(3 \times 30 \mathrm{~mL})$. The combined organic extracts were washed with brine and water, dried over sodium sulfate, and concentrated. Flash column chromatography (silica gel/2\% diethyl ether in hexanes) provided $0.441 \mathrm{~g}$ of $\mathbf{3 . 4 3}$ (1.90 $\mathrm{mmol}, 96 \%$ yield) as a white 
solid: mp 133-134 ${ }^{\circ} \mathrm{C}$; IR 3299, 2216, 1509, $1247 \mathrm{~cm}^{-1} ;{ }^{1} \mathrm{H}$ NMR $\left(\mathrm{CDCl}_{3}, 600 \mathrm{MHz}\right) \delta$ 7.54-7.50 (4 H, m), 7.32 (1 H, td, $J=7.8,1.8 \mathrm{~Hz}), 7.26(1 \mathrm{H}, \mathrm{td}, J=7.8,1.2 \mathrm{~Hz}), 6.89$ (2 $\mathrm{H}, \mathrm{d}, J=9.0 \mathrm{~Hz}), 3.83(3 \mathrm{H}, \mathrm{s}), 3.36(1 \mathrm{H}, \mathrm{s}) ;{ }^{13} \mathrm{C} \mathrm{NMR}\left(\mathrm{CDCl}_{3}, 150 \mathrm{MHz}\right) \delta 159.8,133.2$, $132.5,131.5,128.5,127.5,126.7,124.4,115.3,114.0,93.7,86.7,82.3,80.9,55.3$; HRMS $m / z$ calcd for $\mathrm{C}_{17} \mathrm{H}_{12} \mathrm{ONa}\left(\mathrm{MNa}^{+}\right)$255.0780, found 255.0784.

4-[(2-ethynylphenyl)ethynyl]-N,N-dimethylaniline $\quad \mathbf{( 3 . 4 4 )}$. $\quad$ To $0.510 \quad \mathrm{~g}$ of 4-(2-((trimethylsilyl)ethynyl)phenyl)ethynyl-N,N-dimethyl-aniline $(1.61 \mathrm{mmol})$ in $70 \mathrm{~mL}$ of methanol was added $0.8 \mathrm{~g}$ of potassium carbonate $(6.90 \mathrm{mmol})$. After $3 \mathrm{~h}$ at room temperature, the mixture was filtered to remove solid particles. Then $20 \mathrm{~mL}$ of a $2 \mathrm{M} \mathrm{HCl}$ solution was added slowly to the filtrate. The reaction mixture was extracted with diethyl ether $(3 \times 30 \mathrm{~mL})$. The combined organic extracts were washed with brine and water, dried over sodium sulfate, and concentrated. Flash column chromatography (silica gel $/ 20 \%$ diethyl ether in hexanes) provided $0.355 \mathrm{~g}$ of $\mathbf{3 . 4 4}$ (1.45 mmol, $90 \%$ yield) as a yellow solid: ${ }^{1} \mathrm{H}$ NMR $\left(\mathrm{CDCl}_{3}, 600 \mathrm{MHz}\right) \delta 7.53-7.51(2 \mathrm{H}, \mathrm{m}), 7.47-7.44(2 \mathrm{H}, \mathrm{m})$, $7.30(1 \mathrm{H}, \mathrm{td}, J=7.8,1.2 \mathrm{~Hz}), 7.23(1 \mathrm{H}, \mathrm{td}, J=7.8,1.2 \mathrm{~Hz}), 6.67(2 \mathrm{H}, \mathrm{d}, J=8.4 \mathrm{~Hz})$, $3.36(1 \mathrm{H}, \mathrm{s}), 2.99(6 \mathrm{H}, \mathrm{s}) ;{ }^{13} \mathrm{C} \mathrm{NMR}\left(\mathrm{CDCl}_{3}, 150 \mathrm{MHz}\right) \delta 150.2,132.9,132.4,131.3$, $128.4,127.2,127.0,124.0,111.8,109.9,95.2,86.1,82.5,80.7,40.1$.

Propargylic Alcohol 3.46. The following procedure is representative for the preparation of propargylic alcohols. To $0.222 \mathrm{~g}(1.10 \mathrm{mmol})$ of $\mathbf{3 . 4 2}$ in $20 \mathrm{~mL}$ of THF under a nitrogen atmosphere at $-78{ }^{\circ} \mathrm{C}$ was added $0.638 \mathrm{~mL}$ of a $1.8 \mathrm{M}$ solution of lithium diisopropylamide (LDA, $1.15 \mathrm{mmol}$ ) in hexanes. After $30 \mathrm{~min}$ of stirring, a solution of $0.190 \mathrm{~g}$ of $3.45(1.00 \mathrm{mmol})$ in $10 \mathrm{~mL}$ of THF was introduced via cannula, and the reaction mixture was allowed to warm to room temperature. After an additional $1 \mathrm{~h}, 30$ $\mathrm{mL}$ of water was introduced, and the reaction mixture was extracted with diethyl ether (3 $\times 30 \mathrm{~mL}$ ). The combined organic extracts were washed with brine and water, dried over 
sodium sulfate, and concentrated. Flash column chromatography (silica gel $/ 20 \%$ diethyl ether in hexanes) provided $0.372 \mathrm{~g}$ of $\mathbf{3 . 4 6}(0.95 \mathrm{mmol}, 95 \%$ yield $)$ as a yellow oil: IR $3465,2201,755 \mathrm{~cm}^{-1} ;{ }^{1} \mathrm{H}$ NMR $\left(\mathrm{CDCl}_{3}, 600 \mathrm{MHz}\right) \delta 7.56-7.52(3 \mathrm{H}, \mathrm{m}), 7.45-7.43(2 \mathrm{H}$, m), 7.32-7.27 (5 H, m), $6.76(1 \mathrm{H}, \mathrm{d}, J=1.8 \mathrm{~Hz}), 6.64(1 \mathrm{H}, \mathrm{dd}, J=8.4,2.4 \mathrm{~Hz}), 3.78(3$ H, s), $3.00(1 \mathrm{H}, \mathrm{d}, J=15.6 \mathrm{~Hz}), 2.63(1 \mathrm{H}, \mathrm{d}, J=15.0 \mathrm{~Hz}), 2.16(1 \mathrm{H}, \mathrm{s}), 1.31(3 \mathrm{H}, \mathrm{s})$, $1.20(3 \mathrm{H}, \mathrm{s}) ;{ }^{13} \mathrm{C} \mathrm{NMR}\left(\mathrm{CDCl}_{3}, 150 \mathrm{MHz}\right) \delta 160.5,144.4,138.1,132.2,132.0,131.8$, $128.3,128.2,128.1,127.9,125.9,125.2,125.1,123.1,112.4,110.8,93.2,93.0,88.2,85.3$, 81.4, 55.4, 49.3, 44.6, 26.5, 21.5; HRMS $m / z$ calcd for $\mathrm{C}_{28} \mathrm{H}_{25} \mathrm{O}_{2}\left(\mathrm{MH}^{+}\right) 393.1849$, found 393.1856 .

1,4-Naphthoquinone Methide 3.49. The following procedure is representative for the preparation of the 1,4-naphthoquinone methides. Propargylic alcohol $\mathbf{3 . 4 6}(0.350 \mathrm{~g}, 0.893$ $\mathrm{mmol})$ in $20 \mathrm{~mL}$ of dichloromethane was treated with trifluoroacetic acid $(0.305 \mathrm{~g}, 2.67$ mmol). After $10 \mathrm{~min}$ of stirring, the reaction mixture was treated with $10 \mathrm{~mL}$ of a saturated $\mathrm{NaHCO}_{3}$ solution and extracted with dichloromethane $(3 \times 20 \mathrm{~mL})$. The combined organic extracts were washed with brine and water, dried over sodium sulfate, and concentrated. Flash column chromatography (silica gel $/ 30 \%$ diethyl ether in hexanes) provided $0.322 \mathrm{~g}$ of $\mathbf{3 . 4 9}(0.820 \mathrm{mmol}, 92 \%$ yield $)$ as a yellow solid: $\mathrm{mp} 152-153{ }^{\circ} \mathrm{C}$; IR 1643, 1607, $765 \mathrm{~cm}^{-1} ;{ }^{1} \mathrm{H}$ NMR $\left(\mathrm{CDCl}_{3}, 600 \mathrm{MHz},-40{ }^{\circ} \mathrm{C}\right) \delta 7.94(1 \mathrm{H}, \mathrm{d}, J=7.8 \mathrm{~Hz})$, $7.34(1 \mathrm{H}, \mathrm{t}, J=7.5 \mathrm{~Hz}), 7.24(1 \mathrm{H}, \mathrm{t}, J=7.5 \mathrm{~Hz}), 7.205(1 \mathrm{H}, \mathrm{t}, J=7.5 \mathrm{~Hz}), 7.11(1 \mathrm{H}, \mathrm{d}$, $J=7.2 \mathrm{~Hz}), 7.02(1 \mathrm{H}, \mathrm{t}, J=7.5 \mathrm{~Hz}), 6.95(1 \mathrm{H}, \mathrm{t}, J=7.8 \mathrm{~Hz}), 6.84(1 \mathrm{H}, \mathrm{d}, J=8.4 \mathrm{~Hz})$, $6.77(1 \mathrm{H}, \mathrm{s}), 6.60(3 \mathrm{H}$, broad $), 6.35(1 \mathrm{H}, \mathrm{s}), 3.83(3 \mathrm{H}, \mathrm{s}), 3.54(1 \mathrm{H}, \mathrm{d}, J=13.2 \mathrm{~Hz})$, $2.53(1 \mathrm{H}, \mathrm{d}, J=13.2 \mathrm{~Hz}), 1.33(3 \mathrm{H} \mathrm{s}), 1.04(3 \mathrm{H}, \mathrm{s}) ;{ }^{13} \mathrm{C} \mathrm{NMR}\left(\mathrm{CDCl}_{3}, 150 \mathrm{MHz},-40\right.$ $\left.{ }^{\circ} \mathrm{C}\right) \delta 187.1,168.2,159.0,144.9,144.2,140.7,140.6,133.4,131.9,131.62,131.58$, 131.52, 131.0, 129.8, 128.7, 128.0, 127.7, 127.2, 126.3, 124.6, 123.4, 114.1, 111.0, 55.2, 47.2, 46.3, 35.5, 26.5; HRMS m/z calcd for $\mathrm{C}_{28} \mathrm{H}_{25} \mathrm{O}_{2}\left(\mathrm{MH}^{+}\right)$393.1849, found 393.1854. Recrystallization of $\mathbf{3 . 4 9}$ from diethyl ether/hexanes produced a crystal suitable for X-ray 
structure analysis.

Propargylic Alcohol 3.47. The same procedure was repeated as described for 3.46 except that $0.130 \mathrm{~g}(0.684 \mathrm{mmol})$ of $\mathbf{3 . 4 5}$ was treated with the lithium acetylide derived from $0.159 \mathrm{~g}$ of $3.43(0.685 \mathrm{mmol})$ and $0.42 \mathrm{~mL}$ of a $1.8 \mathrm{M}$ solution of LDA $(0.754 \mathrm{mmol})$ in hexanes to afford $0.262 \mathrm{~g}$ of propargylic alcohol $\mathbf{3 . 4 7}(0.622 \mathrm{mmol}, 91 \%$ yield) as a yellow oil: IR 3500, 2216, 1692, $734 \mathrm{~cm}^{-1} ;{ }^{1} \mathrm{H}$ NMR $\left(\mathrm{CDCl}_{3}, 600 \mathrm{MHz}\right) \delta 7.55(1 \mathrm{H}, \mathrm{d}, J$ $=8.4 \mathrm{~Hz}), 7.52-7.50(2 \mathrm{H}, \mathrm{m}), 7.37-7.35(2 \mathrm{H}, \mathrm{m}), 7.29(1 \mathrm{H}, \mathrm{td}, J=7.8,1.8 \mathrm{~Hz}), 7.26(1$ $\mathrm{H}, \mathrm{td}, J=7.2,1.2 \mathrm{~Hz}), 6.83-6.80(2 \mathrm{H}, \mathrm{m}), 6.76(1 \mathrm{H}, \mathrm{d}, J=1.8 \mathrm{~Hz}), 6.65(1 \mathrm{H}, \mathrm{dd}, J=$ 8.4, $2.4 \mathrm{~Hz}), 3.82(3 \mathrm{H}, \mathrm{s}), 3.78(3 \mathrm{H}, \mathrm{s}), 3.01(1 \mathrm{H}, \mathrm{d}, J=15.0 \mathrm{~Hz}), 2.63(1 \mathrm{H}, \mathrm{d}, J=15.0$ $\mathrm{Hz}), 2.17(1 \mathrm{H}, \mathrm{s}), 1.31(3 \mathrm{H}, \mathrm{s}), 1.20(3 \mathrm{H}, \mathrm{s}) ;{ }^{13} \mathrm{C} \mathrm{NMR}\left(\mathrm{CDCl}_{3}, 150 \mathrm{MHz}\right) \delta 160.5$, 159.7, 144.4, 138.1, 133.2, 132.1, 131.8, 128.0, 127.6, 126.3, 125.2, 125.0, 115.3, 113.9, $112.4,110.8,93.4,92.8,87.0,85.5,81.4,55.3,55.2,49.3,44.6,26.6,21.5$; HRMS $m / z$ calcd for $\mathrm{C}_{29} \mathrm{H}_{27} \mathrm{O}_{3}\left(\mathrm{MH}^{+}\right)$423.1955, found 423.1963 .

1,4-Naphthoquinone Methide 3.50. The same procedure was repeated as described for 3.49 except that $0.200 \mathrm{~g}(0.474 \mathrm{mmol})$ of $\mathbf{3 . 4 7}$ was treated with trifluoroacetic acid $(0.162$ $\mathrm{g}, 1.33 \mathrm{mmol})$ in dichloromethane to afford $0.082 \mathrm{~g}$ of $\mathbf{3 . 5 0}(0.389 \mathrm{mmol}, 82 \%$ yield $)$ as a yellow solid: mp 83-84 ${ }^{\circ} \mathrm{C}$; IR $1641,1620,1242 \mathrm{~cm}^{-1} ;{ }^{1} \mathrm{H} \mathrm{NMR}\left(\mathrm{CDCl}_{3}, 600 \mathrm{MHz}\right.$, $\left.-20{ }^{\circ} \mathrm{C}\right) \delta 7.95(1 \mathrm{H}, \mathrm{d}, J=7.8 \mathrm{~Hz}), 7.20(1 \mathrm{H}, \mathrm{t}, J=7.5 \mathrm{~Hz}), 7.00-6.97(2 \mathrm{H}, \mathrm{m}), 6.88(1$ $\mathrm{H}, \mathrm{d}, J=7.8 \mathrm{~Hz}), 6.86(1 \mathrm{H}, \mathrm{dd}, J=8.4,2.4 \mathrm{~Hz}), 6.75(1 \mathrm{H}, \mathrm{d}, J=3.0 \mathrm{~Hz}), 6.64(1 \mathrm{H}, \mathrm{d}, J$ $=9.0 \mathrm{~Hz}), 6.60(1 \mathrm{H}, \mathrm{dd}, J=9.0,2.7 \mathrm{~Hz}), 6.53(1 \mathrm{H}, \mathrm{dd}, J=8.4,2.4 \mathrm{~Hz}), 6.49(1 \mathrm{H}, \mathrm{dd}, J$ $=8.4,1.8 \mathrm{~Hz}), 6.35(1 \mathrm{H}, \mathrm{s}), 3.82(3 \mathrm{H}, \mathrm{s}), 3.79(3 \mathrm{H}, \mathrm{s}), 3.52(1 \mathrm{H}, \mathrm{d}, J=13.2 \mathrm{~Hz}), 2.51$ $(1 \mathrm{H}, \mathrm{d}, J=13.2 \mathrm{~Hz}), 1.32(3 \mathrm{H}, \mathrm{s}), 1.02(3 \mathrm{H}, \mathrm{s}) ;{ }^{13} \mathrm{C} \mathrm{NMR}\left(\mathrm{CDCl}_{3}, 150 \mathrm{MHz},-20{ }^{\circ} \mathrm{C}\right) \delta$ $187.0,168.3,159.2,158.5,145.0,141.0,140.9$, 136.6, 133.6, 133.3, 132.4, 132.1, 131.9, $131.4,129.9,128.8,126.1,124.7,123.2,114.1,113.6,112.6,111.2,55.25,55.17,47.2$, 46.5, 35.5, 26.4; HRMS m/z calcd for $\mathrm{C}_{29} \mathrm{H}_{27} \mathrm{O}_{3}\left(\mathrm{MH}^{+}\right)$423.1955, found 423.1963 . 
Propargylic Alcohol 3.48. The same procedure was repeated as described for 3.46 except that $0.134 \mathrm{~g}(0.705 \mathrm{mmol})$ of $\mathbf{3 . 4 5}$ was treated with the lithium acetylide derived from $0.173 \mathrm{~g}$ of $3.44(0.706 \mathrm{mmol})$ and $0.36 \mathrm{~mL}$ of a $2.0 \mathrm{M}$ solution of LDA $(0.720 \mathrm{mmol})$ in hexanes to afford $0.276 \mathrm{~g}$ of 3.48 (0.634 mmol, 90\% yield) as a yellow oil: ${ }^{1} \mathrm{H}$ NMR $\left(\mathrm{CDCl}_{3}, 600 \mathrm{MHz}\right) \delta 7.58(1 \mathrm{H}, \mathrm{d}, J=8.4 \mathrm{~Hz}), 7.51(2 \mathrm{H}, \mathrm{td}, J=8.4,1.8 \mathrm{~Hz}), 7.33-7.30$ (2 H, m), $7.27(1 \mathrm{H}, \mathrm{td}, J=7.2,1.2 \mathrm{~Hz}), 7.23(1 \mathrm{H}, \mathrm{td}, J=7.2,1.2 \mathrm{~Hz}), 6.77(1 \mathrm{H}, \mathrm{d}, J=$ $2.4 \mathrm{~Hz}), 6.68(1 \mathrm{H}, \mathrm{dd}, J=8.4,2.4 \mathrm{~Hz}), 6.62-6.59(2 \mathrm{H}, \mathrm{m}), 3.78(3 \mathrm{H}, \mathrm{s}), 3.02(1 \mathrm{H}, \mathrm{d}, J$ $=15.6 \mathrm{~Hz}), 2.98(6 \mathrm{H}, \mathrm{s}), 2.65(1 \mathrm{H}, \mathrm{d}, J=15.6 \mathrm{~Hz}), 2.23(1 \mathrm{H}, \mathrm{s}), 1.33(3 \mathrm{H}, \mathrm{s}), 1.23(3 \mathrm{H}$, s); ${ }^{13} \mathrm{C} \mathrm{NMR}\left(\mathrm{CDCl}_{3}, 150 \mathrm{MHz}\right) \delta 160.4,150.1,144.4,138.2,132.9,132.1,131.6,128.0$, $127.0,126.9,125.2,124.6,112.3,111.7,110.7,109.9,94.8,92.6,86.4,85.7,81.4,55.3$, 49.3, 44.6, 40.1, 26.6, 21.48.

Propargylic Alcohol 3.53. The same procedure was repeated as described for $\mathbf{3 . 4 6}$ except that $0.190 \mathrm{~g}(0.931 \mathrm{mmol})$ of $\mathbf{3 . 5 2}$ was treated with the lithium acetylide derived from $0.202 \mathrm{~g}$ of $3.42(1.00 \mathrm{mmol})$ and $0.61 \mathrm{~mL}$ of a $1.8 \mathrm{M}$ solution of LDA $(1.10 \mathrm{mmol})$ in hexanes to afford $0.354 \mathrm{~g}$ of $\mathbf{3 . 5 3}$ (0.873 mmol, 94\% yield) as a yellow solid: $\mathrm{mp}$ 55-56 ${ }^{\circ} \mathrm{C}$; IR 3400, 1695, 1613, $709 \mathrm{~cm}^{-1} ;{ }^{1} \mathrm{H}$ NMR $\left(\mathrm{CDCl}_{3}, 600 \mathrm{MHz}\right) \delta 7.94(1 \mathrm{H}, \mathrm{d}, J=8.4$ Hz), 7.55-7.51 (2 H, m), 7.45-7.44 (2 H, m), 7.33-7.28 (5 H, m), $6.62(1 \mathrm{H}, \mathrm{d}, J=3.0$ Hz), $6.59(1 \mathrm{H}, \mathrm{dd}, J=8.4,3.0 \mathrm{~Hz}), 3.74(3 \mathrm{H}, \mathrm{s}), 2.88-2.76(2 \mathrm{H}, \mathrm{m}), 2.26(1 \mathrm{H}, \mathrm{s}), 2.07$ (1 H, ddd, $J=13.5,10.2,7.2 \mathrm{~Hz}), 1.67(1 \mathrm{H}, \mathrm{ddd}, J=13.5,6.0,4.2 \mathrm{~Hz}), 1.25(3 \mathrm{H}, \mathrm{s})$, $1.16(3 \mathrm{H}, \mathrm{s}) ;{ }^{13} \mathrm{C} \mathrm{NMR}\left(\mathrm{CDCl}_{3}, 150 \mathrm{MHz}\right) \delta 159.1,136.5,132.2,132.0,131.8,131.4$, $130.2,128.3,128.2,128.0,127.9,125.8,125.4,123.1,113.4,112.4,95.5,93.1,88.3,84.8$, 75.0, 55.1, 37.8, 31.0, 26.1, 24.0, 23.7; HRMS $m / z$ calcd for $\mathrm{C}_{29} \mathrm{H}_{26} \mathrm{O}_{2} \mathrm{Na}\left(\mathrm{MNa}^{+}\right)$ 429.1825, found 429.1833 . 
1,4-Naphthoquinone Methide 3.54. The same procedure was repeated as described for 3.49 except that $0.180 \mathrm{~g}(0.443 \mathrm{mmol})$ of propargylic alcohol 3.53 was treated with trifluoroacetic acid $(0.152 \mathrm{~g}, 1.33 \mathrm{mmol})$ in dichloromethane at room temperature for 20 min to afford $0.162 \mathrm{~g}$ of $\mathbf{3 . 5 4}(0.399 \mathrm{mmol}, 90 \%$ yield $)$ as a yellow solid: $\mathrm{mp} 80-81{ }^{\circ} \mathrm{C}$; IR 1649, 1596, $694 \mathrm{~cm}^{-1} ;{ }^{1} \mathrm{H}$ NMR $\left(\mathrm{CDCl}_{3}, 600 \mathrm{MHz},-40{ }^{\circ} \mathrm{C}\right) \delta 7.92(1 \mathrm{H}, \mathrm{dd}, J=7.8$, $1.2 \mathrm{~Hz}), 7.20(2 \mathrm{H}, \mathrm{t}, J=7.5 \mathrm{~Hz}), 7.12(1 \mathrm{H}, \mathrm{t}, J=7.5 \mathrm{~Hz}), 7.05(1 \mathrm{H}, \mathrm{d}, J=7.8 \mathrm{~Hz})$, 6.95-6.89 (3 H, m), $6.86(1 \mathrm{H}, \mathrm{d}, J=2.4 \mathrm{~Hz}), 6.66(1 \mathrm{H}, \mathrm{dd}, J=8.7,2.7 \mathrm{~Hz}), 6.63-6.61$ (2 H, m), $6.59(1 \mathrm{H}, \mathrm{s}), 3.85(3 \mathrm{H}, \mathrm{s}), 3.56(1 \mathrm{H}, \mathrm{td}, J=12.9,6.6 \mathrm{~Hz}), 2.82(1 \mathrm{H}, \mathrm{dd}, J=$ 12.6, $6.0 \mathrm{~Hz}), 2.10(1 \mathrm{H}, \mathrm{dd}, J=14.1,6.3 \mathrm{~Hz}), 1.74(1 \mathrm{H}, \mathrm{td}, J=13.5,6.6 \mathrm{~Hz}), 1.23(3 \mathrm{H}$, s), $0.43(3 \mathrm{H}, \mathrm{s}) ;{ }^{13} \mathrm{C} \mathrm{NMR}\left(\mathrm{CDCl}_{3}, 150 \mathrm{MHz},-40{ }^{\circ} \mathrm{C}\right) \delta 187.3,164.9,159.6,147.4$, $142.7,135.8,134.6,133.4,133.0,132.3,132.2,129.0,127.6,127.23,127.17,126.6$, 124.2, 112.2, 112.0, 55.3, 44.4, 39.9, 36.4, 31.2, 28.4; HRMS m/z calcd for $\mathrm{C}_{29} \mathrm{H}_{27} \mathrm{O}_{2}$ $\left(\mathrm{MH}^{+}\right)$407.2006, found 407.2013. Recrystallization of 9 from diethyl ether/hexanes produced a crystal suitable for X-ray structure analysis.

7-Methoxy-3,3-dimethyl-4-chromanone (3.55). To a solution of 7-hydroxy-3,3-dimethyl-4-chromanone $(0.220 \mathrm{~g}, 1.15 \mathrm{mmol})$ and potassium carbonate $(0.166 \mathrm{~g}, 1.20 \mathrm{mmol})$ in $5 \mathrm{~mL}$ of $N, N$-dimethylformamide was added iodomethane $(0.204$ $\mathrm{g}, 1.44 \mathrm{mmol})$. The mixture was heated at $80^{\circ} \mathrm{C}$ for $1 \mathrm{~h}$, and then the cooled mixture was diluted with $10 \mathrm{~mL}$ of water. The reaction mixture was extracted with diethyl ether $(3 \times$ $10 \mathrm{~mL}$ ). The combined organic extracts were washed with brine and water, dried over sodium sulfate, and concentrated. Flash column chromatography (silica gel/40\% diethyl ether in hexanes) provided $0.203 \mathrm{~g}$ of $\mathbf{3 . 5 5}$ (0.985 mmol, 86\% yield) as a yellow oil: IR $1686,1611,1118 \mathrm{~cm}^{-1} ;{ }^{1} \mathrm{H} \mathrm{NMR}\left(\mathrm{CDCl}_{3}, 600 \mathrm{MHz}\right) \delta 7.83(1 \mathrm{H}, \mathrm{d}, J=9.0 \mathrm{~Hz}), 6.59$ (1 H, dd, $J=9.0,2.4 \mathrm{~Hz}), 6.40$ (1 H, d, $J=2.4 \mathrm{~Hz}), 4.13(2 \mathrm{H}, \mathrm{s}), 3.83(3 \mathrm{H}, \mathrm{s}), 1.19$ (6 H, s); ${ }^{13} \mathrm{C} \mathrm{NMR}\left(\mathrm{CDCl}_{3}, 150 \mathrm{MHz}\right) \delta 196.1,165.7,163.1,129.4,113.4,110.0,100.5,77.1,55.6$, 41.3, 20.6; HRMS m/z calcd for $\mathrm{C}_{12} \mathrm{H}_{14} \mathrm{O}_{3} \mathrm{Na}\left(\mathrm{MNa}^{+}\right)$229.0835, found 229.0839. 
Propargylic Alcohol 3.56. The same procedure was repeated as described for $\mathbf{3 . 4 6}$ except that $0.100 \mathrm{~g}(0.485 \mathrm{mmol})$ of $\mathbf{3 . 5 5}$ was treated with the lithium acetylide derived from $0.101 \mathrm{~g}$ of $3.42(0.500 \mathrm{mmol})$ and $0.31 \mathrm{~mL}$ of a $1.8 \mathrm{M}$ solution of LDA $(0.550 \mathrm{mmol})$ in hexanes to afford $0.188 \mathrm{~g}$ of $\mathbf{3 . 5 6}(0.461 \mathrm{mmol}, 95 \%$ yield $)$ as a yellow oil: IR 3461, 2216, 1617, $754 \mathrm{~cm}^{-1} ;{ }^{1} \mathrm{H} \mathrm{NMR}\left(\mathrm{CDCl}_{3}, 600 \mathrm{MHz}\right) \delta 7.77(1 \mathrm{H}, \mathrm{d}, J=8.4 \mathrm{~Hz}), 7.55(1 \mathrm{H}, \mathrm{dd}, J$ $=7.2,1.8 \mathrm{~Hz}), 7.53(1 \mathrm{H}, \mathrm{dd}, J=7.2,1.8 \mathrm{~Hz}), 7.43(2 \mathrm{H}, \mathrm{dd}, J=8.1,1.5 \mathrm{~Hz}), 7.34-7.28$ $(5 \mathrm{H}, \mathrm{m}), 6.37(1 \mathrm{H}, \mathrm{d}, J=3.0 \mathrm{~Hz}), 6.35(1 \mathrm{H}, \mathrm{dd}, J=8.4,2.4 \mathrm{~Hz}), 4.22(1 \mathrm{H}, \mathrm{d}, J=10.8$ Hz,), $3.84(1 \mathrm{H}, \mathrm{d}, J=10.8 \mathrm{~Hz}), 3.73(3 \mathrm{H}, \mathrm{s}), 2.41(1 \mathrm{H}, \mathrm{s}), 1.21(3 \mathrm{H}, \mathrm{s}), 1.18$ (3 H, s); ${ }^{13} \mathrm{C}$ NMR $\left(\mathrm{CDCl}_{3}, 150 \mathrm{MHz}\right) \delta 186.6,161.0,153.7,132.2,132.1,131.7,130.1,128.4$, $128.3,127.9,126.0,124.9,123.0,117.5,107.7,101.1,93.29,93.28,88.1,85.3,71.6,71.4$, 55.3, 37.1, 22.1, 19.2; HRMS $m / z$ calcd for $\mathrm{C}_{28} \mathrm{H}_{24} \mathrm{O}_{3} \mathrm{Na}\left(\mathrm{MNa}^{+}\right)$431.1618, found 431.1630 .

1,4-Naphthoquinone Methide 3.57. The same procedure was repeated as described for 3.49 except that $0.120 \mathrm{~g}(0.294 \mathrm{mmol})$ of propargylic alcohol 3.56 was treated with trifluoroacetic acid $(0.107 \mathrm{~g}, 0.938 \mathrm{mmol})$ in dichloromethane at room temperature for 20 min to afford $0.110 \mathrm{~g}$ of $3.57(0.270 \mathrm{mmol}, 92 \%$ yield) as a yellow oil: IR 1703, 1655, 1600, 1115, $756 \mathrm{~cm}^{-1} ;{ }^{1} \mathrm{H} \mathrm{NMR}\left(\mathrm{CDCl}_{3}, 600 \mathrm{MHz},\right) \delta 7.95(1 \mathrm{H}, \mathrm{dd}, J=7.8,1.2 \mathrm{~Hz})$, 7.18 (1 H, ddd, $J=8.1,7.2,1.2 \mathrm{~Hz}), 7.13(1 \mathrm{H}, \mathrm{tt}, J=7.2,1.2 \mathrm{~Hz}), 7.09(1 \mathrm{H}, \mathrm{dm}, J=7.8$, $0.6 \mathrm{~Hz}), 7.07(2 \mathrm{H}, \mathrm{t}, J=7.8 \mathrm{~Hz}), 6.92(1 \mathrm{H}, \mathrm{ddd}, J=7.8,7.2,1.2 \mathrm{~Hz}), 6.84(2 \mathrm{H}, \mathrm{d}, J=$ $7.2 \mathrm{~Hz}), 6.79$ (1 H, dd, $J=2.4,0.6 \mathrm{~Hz}), 6.62-6.61(2 \mathrm{H}, \mathrm{m}), 6.59(1 \mathrm{H}, \mathrm{s}), 4.13(2 \mathrm{H}, \mathrm{s})$, $3.85(3 \mathrm{H}, \mathrm{s}), 0.97(6 \mathrm{H}, \mathrm{s}) ;{ }^{13} \mathrm{C} \mathrm{NMR}\left(\mathrm{CDCl}_{3}, 150 \mathrm{MHz},\right) \delta 186.6,162.4,161.7,157.3$, $146.8,142.6,141.9,134.1,133.4,132.8,132.6,132.4,131.2,129.2,127.6,127.4,126.65$, $126.59,124.5,111.2,106.5,83.1,55.5,41.7,29.4$; HRMS $m / z$ calcd for $\mathrm{C}_{28} \mathrm{H}_{25} \mathrm{O}_{3}\left(\mathrm{MH}^{+}\right)$ 409.1798, found 409.1805. 
Propargylic Alcohol 3.59. The same procedure was repeated as described for 3.46 except that $0.160 \mathrm{~g}(0.908 \mathrm{mmol})$ of $\mathbf{3 . 5 8}$ was treated with the lithium acetylide derived from $0.200 \mathrm{~g}$ of $3.42(0.990 \mathrm{mmol})$ and $0.55 \mathrm{~mL}$ of a $1.8 \mathrm{M}$ solution of LDA $(0.99 \mathrm{mmol})$ in hexanes to afford $0.188 \mathrm{~g}$ of $\mathbf{3 . 5 9}(0.827 \mathrm{mmol}, 92 \%$ yield $)$ as a yellow oil: IR 3418, 2218, 1487, $753 \mathrm{~cm}^{-1} ;{ }^{1} \mathrm{H} \mathrm{NMR}\left(\mathrm{CDCl}_{3}, 600 \mathrm{MHz}\right) \delta 7.88(1 \mathrm{H}, \mathrm{dd}, J=7.8,1.2 \mathrm{~Hz}), 7.56(1 \mathrm{H}$, dd, $J=7.8,1.2 \mathrm{~Hz}), 7.54(1 \mathrm{H}, \mathrm{dd}, J=7.2,1.2 \mathrm{~Hz}), 7.42(2 \mathrm{H}, \mathrm{dd}, J=8.1,1.5 \mathrm{~Hz})$, 7.34-7.28 (5 H, m), $7.20(1 \mathrm{H}, \mathrm{ddd}, J=8.1,7.5,1.8 \mathrm{~Hz}), 6.84(1 \mathrm{H}, \mathrm{dd}, J=8.4,1.2 \mathrm{~Hz})$, $6.81(1 \mathrm{H}, \mathrm{td}, J=7.8,1.2 \mathrm{~Hz}), 4.23(1 \mathrm{H}, \mathrm{d}, J=10.2 \mathrm{~Hz}), 3.89(1 \mathrm{H}, \mathrm{d}, J=10.8 \mathrm{~Hz}), 2.47$ $(1 \mathrm{H}, \mathrm{s}), 1.22(3 \mathrm{H}, \mathrm{s}), 1.20(3 \mathrm{H}, \mathrm{s}) ;{ }^{13} \mathrm{C} \mathrm{NMR}\left(\mathrm{CDCl}_{3}, 150 \mathrm{MHz}\right) \delta$ 152.6, 132.2, 132.1, $131.7,130.0,129.1,128.4,128.31,128.29,127.9,126.0,124.8,124.7,123.0,120.8$, 116.7, 93.3, 93.1, 88.1, 85.6, 71.9, 71.3, 36.9, 22.0, 19.2; HRMS $\mathrm{m} / \mathrm{z}$ calcd for $\mathrm{C}_{27} \mathrm{H}_{22} \mathrm{O}_{2} \mathrm{Na}\left(\mathrm{MNa}^{+}\right)$401.1512, found 401.1513.

1,4-Naphthoquinone Methide 3.60. The same procedure was repeated as described for 3.49 except that $0.090 \mathrm{~g}(0.238 \mathrm{mmol})$ of propargylic alcohol $\mathbf{3 . 5 9}$ was treated with trifluoroacetic acid $(0.082 \mathrm{~g}, 0.714 \mathrm{mmol})$ in dichloromethane at room temperature for 60 min to afford $0.028 \mathrm{~g}$ of a yellow oil containing $75 \%$ of 15 ( $0.056 \mathrm{mmol}, 23 \%$ yield) and $25 \%$ of an unidentified inseparable product 3.59: ${ }^{1} \mathrm{H}$ NMR $\left(\mathrm{CDCl}_{3}, 600 \mathrm{MHz}\right.$, $\delta 7.67(1$ H, dd, $J=7.8,0.6 \mathrm{~Hz}), 7.55(1 \mathrm{H}, \mathrm{dd}, J=7.8,0.6 \mathrm{~Hz}), 7.50-7.48(2 \mathrm{H}, \mathrm{m}), 7.41-7.37(2$ H, m), 7.32-7.30 (4 H, m), 7.13 (1 H, ddd, $J=8.4,6.9,1.5 \mathrm{~Hz}), 6.75(1 \mathrm{H}, \mathrm{dd}, J=8.4$, $1.2 \mathrm{~Hz}$ ), $6.67(1 \mathrm{H}$, ddd, $J=7.8,7.2,1.2 \mathrm{~Hz}), 6.47(1 \mathrm{H}, \mathrm{s}), 3.95(2 \mathrm{H}, \mathrm{s}), 1.11(6 \mathrm{H}, \mathrm{s})$; HRMS $m / z$ calcd for $\mathrm{C}_{27} \mathrm{H}_{22} \mathrm{O}_{2} \mathrm{Na}\left(\mathrm{MNa}^{+}\right)$401.1512, found 401.1514 .

Propargylic Alcohol 3.62. The same procedure was repeated as described for 3.46 except that $0.133 \mathrm{~g}(0.692 \mathrm{mmol})$ of $\mathbf{3 . 6 1}$ was treated with the lithium acetylide derived from $0.140 \mathrm{~g}$ of $3.42(0.693 \mathrm{mmol})$ and $0.39 \mathrm{~mL}$ of a $1.8 \mathrm{M}$ solution of LDA $(0.69 \mathrm{mmol})$ in hexanes to afford $0.267 \mathrm{~g}$ of $\mathbf{3 . 6 2}(0.679 \mathrm{mmol}, 98 \%$ yield $)$ as a yellow oil: IR 3403, 2221, 
1382, $1117 \mathrm{~cm}^{-1} ;{ }^{1} \mathrm{H} \mathrm{NMR}\left(\mathrm{CDCl}_{3}, 600 \mathrm{MHz}\right) \delta 7.65(2 \mathrm{H}, \mathrm{d}, J=9.0 \mathrm{~Hz}), 7.56(1 \mathrm{H}, \mathrm{dd}$, $J=7.2,1.8 \mathrm{~Hz}), 7.51(1 \mathrm{H}, \mathrm{dd}, J=7.2,1.8 \mathrm{~Hz}), 7.46(2 \mathrm{H}, \mathrm{dd}, J=7.8,1.8 \mathrm{~Hz}), 7.35-7.27$ $(5 \mathrm{H}, \mathrm{m}), 6.74(2 \mathrm{H}, \mathrm{d}, J=8.4 \mathrm{~Hz}), 3.75(3 \mathrm{H}, \mathrm{s}), 2.37(1 \mathrm{H}, \mathrm{br} \mathrm{s}), 1.08(9 \mathrm{H}, \mathrm{s}) ;{ }^{13} \mathrm{C} \mathrm{NMR}$ $\left(\mathrm{CDCl}_{3}, 150 \mathrm{MHz}\right) \delta 158.8,134.3,132.20,132.17,131.7,128.9,128.4,128.3,128.0$, $127.9,125.8,125.2,123.1,112.4,96.5,93.1,88.3,84.4,79.3,55.2,39.8,25.6$; HRMS $m / z$ calcd for $\mathrm{C}_{28} \mathrm{H}_{26} \mathrm{O}_{2} \mathrm{Na}\left(\mathrm{MNa}^{+}\right)$417.1825, found 417.1826.

1,4-Naphthoquinone Methide 3.63. The same procedure was repeated as described for 3.49 except that $0.030 \mathrm{~g}(0.076 \mathrm{mmol})$ of $\mathbf{3 . 6 2}$ was treated with trifluoroacetic acid $(0.026$ $\mathrm{g}, 0.228 \mathrm{mmol}$ ) in dichloromethane at room temperature for $60 \mathrm{~min}$ to afford $0.008 \mathrm{~g}$ of $3.63(0.019 \mathrm{mmol}, 25 \%$ yield $)$ as a yellow oil: ${ }^{1} \mathrm{H} \mathrm{NMR}\left(\mathrm{CDCl}_{3}, 600 \mathrm{MHz}\right) \delta 7.98(1 \mathrm{H}$, dd, $J=7.5,1.5 \mathrm{~Hz}), 7.31-7.28$ (3 H, m), 7.21-7.17 (5 H, m), 6.98 (1 H, ddd, $J=8.4,7.2$, $1.2 \mathrm{~Hz}), 6.90(1 \mathrm{H}, \mathrm{d}, J=7.8 \mathrm{~Hz}), 6.82(2 \mathrm{H}, \mathrm{d}, J=8.4 \mathrm{~Hz}), 6.72(1 \mathrm{H}, \mathrm{s}), 3.80(3 \mathrm{H}, \mathrm{s})$, 1.00 (9 H, s); HRMS $m / z$ calcd for $\mathrm{C}_{28} \mathrm{H}_{27} \mathrm{O}_{2}\left(\mathrm{MH}^{+}\right)$395.2006, found 395.2007.

Propargylic Alcohol 3.65. The same procedure was repeated as described for $3.46 \mathrm{except}$ that $0.200 \mathrm{~g}(0.943 \mathrm{mmol})$ of $\mathbf{3 . 6 4}$ was treated with the lithium acetylide derived from $0.230 \mathrm{~g}$ of $3.42(1.14 \mathrm{mmol})$ and $0.63 \mathrm{~mL}$ of a $1.8 \mathrm{M}$ solution of LDA $(0.56 \mathrm{mmol})$ in hexanes to afford $0.371 \mathrm{~g}$ of $\mathbf{3 . 6 5}$ ( $0.895 \mathrm{mmol}, 95 \%$ yield) as a yellow oil: IR 3366, 2931, 1707, 1606, $1247 \mathrm{~cm}^{-1} ;{ }^{1} \mathrm{H}$ NMR $\left(\mathrm{CDCl}_{3}, 600 \mathrm{MHz}\right) \delta 7.66(2 \mathrm{H}, \mathrm{dd}, J=8.4,1.2 \mathrm{~Hz})$, $7.64(2 \mathrm{H}, \mathrm{d}, J=9.0 \mathrm{~Hz}), 7.56(1 \mathrm{H}, \mathrm{dd}, J=7.2,1.2 \mathrm{~Hz}), 7.39(1 \mathrm{H}, \mathrm{dd}, J=7.8,1.8 \mathrm{~Hz})$, 7.34-7.21 (8 H, m), $6.73(1 \mathrm{H}, \mathrm{d}, J=6.6 \mathrm{~Hz}), 3.72(3 \mathrm{H}, \mathrm{s}), 2.88(1 \mathrm{H}, \mathrm{s}) ;{ }^{13} \mathrm{C} \mathrm{NMR}$ $\left(\mathrm{CDCl}_{3}, 150 \mathrm{MHz}\right) \delta 159.0,145.1,137.3,132.2,132.0,131.8,128.4,128.3,128.28$, $128.2,128.0,127.55,127.5,126.1,126.0,124.9,123.0,113.6,95.8,93.4,88.2,85.7,74.7$, 55.2; HRMS $m / z$ calcd for $\mathrm{C}_{30} \mathrm{H}_{22} \mathrm{O}_{2} \mathrm{Na}\left(\mathrm{MNa}^{+}\right)$437.1512, found 437.1513 .

Ketone 3.66. The same procedure was repeated as described for 3.49 except that $0.350 \mathrm{~g}$ 
$(0.845 \mathrm{mmol})$ of $\mathbf{3 . 6 5}$ was treated with trifluoroacetic acid $(0.291 \mathrm{~g}, 2.54 \mathrm{mmol})$ in dichloromethane at room temperature for $6 \mathrm{~h}$ to afford $0.156 \mathrm{~g}$ of $\mathbf{3 . 6 6}(0.380 \mathrm{mmol}, 45 \%$ yield) as a yellow solid: IR 2918, 1701, 1603, 1227, $699 \mathrm{~cm}^{-1} ;{ }^{1} \mathrm{H}$ NMR $\left(\mathrm{CDCl}_{3}, 600\right.$ MHz) $\delta 7.66-7.52(8 \mathrm{H}, \mathrm{m}), 7.47(2 \mathrm{H}, \mathrm{d}, J=6.6 \mathrm{~Hz}), 7.41(2 \mathrm{H}, \mathrm{d}, J=6.6 \mathrm{~Hz}), 7.18(1 \mathrm{H}$, $\operatorname{td}, J=7.2,1.2 \mathrm{~Hz}), 7.14(1 \mathrm{H}, \mathrm{td}, J=7.8,1.2 \mathrm{~Hz}), 7.01(1 \mathrm{H}, \mathrm{dd}, J=9.0,2.4 \mathrm{~Hz}), 6.81(1$ $\mathrm{H}, \mathrm{d}, J=2.4 \mathrm{~Hz}), 6.27(1 \mathrm{H}, \mathrm{d}, J=7.8 \mathrm{~Hz}), 3.71(3 \mathrm{H}, \mathrm{s}) ;{ }^{13} \mathrm{C} \mathrm{NMR}\left(\mathrm{CDCl}_{3}, 150 \mathrm{MHz}\right) \delta$ $192.2,159.9,144.1,140.7,138.6,137.9,136.9,136.3,136.0,134.0,133.1,130.6,129.8$, $129.5,129.4,128.6,128.55,128.3,128.1,127.9,126.6,123.7,123.6,117.6,107.2,55.2$; HRMS $m / z$ calcd for $\mathrm{C}_{30} \mathrm{H}_{21} \mathrm{O}_{2}\left(\mathrm{MH}^{+}\right)$413.1536, found 413.1537 .

Propargylic Alcohol 3.68. The same procedure was repeated as described for 3.46 except that $0.170 \mathrm{~g}(0.806 \mathrm{mmol})$ of $\mathbf{3 . 6 7}$ was treated with the lithium acetylide derived from $0.170 \mathrm{~g}$ of $\mathbf{3 . 4 2}(0.842 \mathrm{mmol})$ and $0.0 .48 \mathrm{~mL}$ of a $1.8 \mathrm{M}$ solution of LDA $(0.86 \mathrm{mmol})$ in hexanes to afford $0.298 \mathrm{~g}$ of $\mathbf{3 . 6 8}\left(0.725 \mathrm{mmol}, 90 \%\right.$ yield) as a yellow oil: ${ }^{1} \mathrm{H}$ NMR $\left(\mathrm{CDCl}_{3}, 600 \mathrm{MHz}\right) \delta 7.75(1 \mathrm{H}, \mathrm{d}, J=7.8 \mathrm{~Hz}), 7.65(1 \mathrm{H}, \mathrm{d}, J=7.8 \mathrm{~Hz}), 7.48(2 \mathrm{H}, \mathrm{td}, J$ $=7.8,1.2 \mathrm{~Hz}), 7.36(1 \mathrm{H}, \mathrm{td}, J=7.8,1.2 \mathrm{~Hz}), 7.32-7.21(8 \mathrm{H}, \mathrm{m}), 7.12(1 \mathrm{H}, \mathrm{d}, J=2.4$ $\mathrm{Hz}), 6.73(1 \mathrm{H}, \mathrm{dd}, J=8.4,2.4 \mathrm{~Hz}), 3.83(3 \mathrm{H}, \mathrm{s}), 2.69(1 \mathrm{H}, \mathrm{s}) ;{ }^{13} \mathrm{C} \mathrm{NMR}\left(\mathrm{CDCl}_{3}, 150\right.$ MHz) $\delta 161.2$, 148.1, 140.7, 139.4, 138.8, 132.3, 131.7, 131.69, 129.5, 128.7, 128.24, $128.21,128.18,127.8,126.1,125.4,124.9,124.4,123.1,120.1,113.8,105.9,93.4,93.2$, $87.9,81.7,74.8,55.5$.

Propargylic Alcohol 3.70. The same procedure was repeated as described for 3.46 except that $0.107 \mathrm{~g}(0.557 \mathrm{mmol})$ of $\mathbf{3 . 6 1}$ was treated with the lithium acetylide derived from $0.130 \mathrm{~g}$ of $3.43(0.560 \mathrm{mmol})$ and $0.31 \mathrm{~mL}$ of a $1.8 \mathrm{M}$ solution of LDA $(0.560 \mathrm{mmol})$ in hexanes to afford $0.229 \mathrm{~g}$ of $\mathbf{3 . 7 0}(0.540 \mathrm{mmol}, 97 \%$ yield $)$ as a yellow oil: IR 3475, 2216 1606, 1509, $1247 \mathrm{~cm}^{-1} ;{ }^{1} \mathrm{H} \mathrm{NMR}\left(\mathrm{CDCl}_{3}, 600 \mathrm{MHz}\right) \delta 7.66(2 \mathrm{H}, \mathrm{d}, J=9.0 \mathrm{~Hz}), 7.53(1$ H, dd, $J=7.2,1.2 \mathrm{~Hz}), 7.49(1 \mathrm{H}, \mathrm{dd}, J=7.2,1.2 \mathrm{~Hz}), 7.38(2 \mathrm{H}, \mathrm{d}, J=9.0 \mathrm{~Hz}), 7.29$ (1 
H, td, $J=7.8,1.8 \mathrm{~Hz}), 7.26(1 \mathrm{H}, \mathrm{td}, J=7.5,1.8 \mathrm{~Hz}), 6.83(2 \mathrm{H}, \mathrm{d}, J=9.0 \mathrm{~Hz}), 6.75(2 \mathrm{H}$, d, $J=9.0 \mathrm{~Hz}), 3.82(3 \mathrm{H}, \mathrm{s}), 3.75(3 \mathrm{H}, \mathrm{s}), 2.38(1 \mathrm{H}, \mathrm{br} \mathrm{s}), 1.08(9 \mathrm{H}, \mathrm{s}) ;{ }^{13} \mathrm{C}$ NMR $\left(\mathrm{CDCl}_{3}, 150 \mathrm{MHz}\right) \delta 159.7,158.8,134.3,133.2,132.1,132.0,129.0,128.0,127.6,126.2$, $125.0,115.2,113.9,112.4,96.3,93.3,87.1,84.6,79.3,55.3,55.1,39.8,25.6$; HRMS $m / z$ calcd for $\mathrm{C}_{29} \mathrm{H}_{28} \mathrm{O}_{3} \mathrm{Na}\left(\mathrm{MNa}^{+}\right)$447.1931, found 447.1931.

Ketone 3.71. The same procedure was repeated as described for 3.49 except that $0.086 \mathrm{~g}$ $(0.203 \mathrm{mmol})$ of $\mathbf{3 . 7 0}$ was treated with trifluoroacetic acid $(0.018 \mathrm{~g}, 0.157 \mathrm{mmol})$ in dichloromethane at room temperature for $4 \mathrm{~h}$ to afford $0.029 \mathrm{~g}$ of $\mathbf{3 . 7 1}(0.067 \mathrm{mmol}, 33 \%$ yield) as a yellow liquid: IR 2249, 1675, 1601, 906, $726 \mathrm{~cm}^{-1} ;{ }^{1} \mathrm{H}$ NMR $\left(\mathrm{CDCl}_{3}, 600\right.$ MHz) $\delta 7.93(2 \mathrm{H}, \mathrm{d}, J=9.0 \mathrm{~Hz}), 7.60(1 \mathrm{H}, \mathrm{dd}, J=7.5,1.5 \mathrm{~Hz}), 7.32(1 \mathrm{H}, \mathrm{td}, J=7.8$, $1.8 \mathrm{~Hz}), 7.256(1 \mathrm{H}, \mathrm{td}, J=7.8,1.2 \mathrm{~Hz}), 7.09(1 \mathrm{H}, \mathrm{d}, J=7.8 \mathrm{~Hz}), 6.91(2 \mathrm{H}, \mathrm{d}, J=9.0$ Hz), $6.85(2 \mathrm{H}, \mathrm{d}, J=8.4 \mathrm{~Hz}), 6.66(2 \mathrm{H}, \mathrm{d}, J=9.0 \mathrm{~Hz}), 6.65(1 \mathrm{H}, \mathrm{s}), 4.32(2 \mathrm{H}, \mathrm{s}), 3.86$ $(3 \mathrm{H}, \mathrm{s}), 3.73(3 \mathrm{H}, \mathrm{s}), 1.15(9 \mathrm{H}, \mathrm{s}) ;{ }^{13} \mathrm{C} \mathrm{NMR}\left(\mathrm{CDCl}_{3}, 150 \mathrm{MHz}\right) \delta$ 197.7, 195.9, 163.3, $163.0,158.3,139.5,134.3,131.8,130.8,130.6,130.1,129.8,129.5,126.4,125.3,113.6$, 112.7, 55.4, 55.1, 42.7, 37.3, 29.2; HRMS $m / z$ calcd for $\mathrm{C}_{29} \mathrm{H}_{31} \mathrm{O}_{4}\left(\mathrm{MH}^{+}\right)$443.2217, found 443.2218. The stereochemistry of the carbon-carbon double bond in $\mathbf{2 0}$ was established by NOE measurements.

\section{1-[2-(4-Methoxyphenyl)ethynyl]-2-[2-(trimethylsilyl)ethynyl]benzene 3.75.}

To a flask containing $0.126 \mathrm{~g}$ of dichlorobis(triphenylphosphine)palladium $(0.180 \mathrm{mmol})$ and $0.060 \mathrm{~g}$ of $\mathrm{CuI}(0.32 \mathrm{mmol})$ was added via cannula a solution of $0.900 \mathrm{~g}$ of 1-bromo-2-[2-(trimethylsilyl)ethynyl]benzene $(3.55 \mathrm{mmol})$ in $45 \mathrm{~mL}$ of triethylamine followed by a solution of $0.516 \mathrm{~g}$ of 1-ethynyl-4-methoxybenzene $(3.90 \mathrm{mmol})$ in $30 \mathrm{~mL}$ of triethylamine under a nitrogen atmosphere. The resulting mixture was stirred vigorously at $75^{\circ} \mathrm{C}$ for $12 \mathrm{~h}$. The mixture was then filtered to remove solid particles, and the filtrate was concentrated. The residue was purified by flash column chromatography 
(silica gel/3\% diethyl ether in hexanes) to give $0.693 \mathrm{~g}$ of 1-[2-(4-methoxyphenyl)ethynyl]-2-[2-(trimethylsilyl)ethynyl]benzene (2.28 mmol, 64\% yield) as a yellow oil: IR 2221, 2164, 1512, 1249, $1118 \mathrm{~cm}^{-1} ;{ }^{1} \mathrm{H}$ NMR $\left(\mathrm{CDCl}_{3}, 600\right.$ MHz,) $\delta 7.51-7.48(4 \mathrm{H}, \mathrm{m}), 7.27(1 \mathrm{H}, \mathrm{td}, J=7.5,1.5 \mathrm{~Hz}), 7.23(1 \mathrm{H}, \mathrm{td}, J=7.2,1.8$

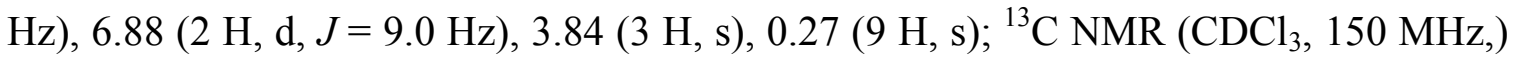
$\delta 159.8,133.2,132.3,131.5,128.2,127.5,126.5,125.4,115.5,114.0,103.6,98.4,93.6$, 87.0, 55.3, 0.07; HRMS m/z calcd for $\mathrm{C}_{20} \mathrm{H}_{20} \mathrm{OSiNa}\left(\mathrm{MNa}^{+}\right)$327.1176, found 327.1182.

\section{4-(2-((trimethylsilyl)ethynyl)phenyl)ethynyl-N,N-dimethyl-aniline 3.76.}

To a flask containing $0.096 \mathrm{~g}$ of dichlorobis(triphenylphosphine)palladium $(0.138 \mathrm{mmol})$ and $0.050 \mathrm{~g}$ of $\mathrm{CuI}(0.089 \mathrm{mmol})$ was added via cannula a solution of $0.840 \mathrm{~g}$ of 1-iodo-2-[2-(trimethylsilyl)ethynyl]benzene $(2.80 \mathrm{mmol})$ in $60 \mathrm{~mL}$ of triethylamine followed by a solution of $0.400 \mathrm{~g}$ of 4-ethynyl-N,N-dimethylaniline $(2.76 \mathrm{mmol})$ in 20 $\mathrm{mL}$ of triethylamine under a nitrogen atmosphere. The resulting mixture was stirred vigorously at $75^{\circ} \mathrm{C}$ for $12 \mathrm{~h}$. The mixture was then filtered to remove solid particles, and the filtrate was concentrated. The residue was purified by flash column chromatography (silica gel $/ 20 \%$ diethyl ether in hexanes) to give $0.542 \mathrm{~g}$ of 4-(2-((trimethylsilyl)ethynyl)phenyl)ethynyl-N,N-dimethyl-aniline. (1.71 mmol, 62\% yield) as a yellow oil; ${ }^{1} \mathrm{H}$ NMR $\left(\mathrm{CD}_{3} \mathrm{OD}, 600 \mathrm{MHz}\right.$, $\delta 7.47(1 \mathrm{H}, \mathrm{d}, J=8.4 \mathrm{~Hz})$, 7.45-7.42 (2 H, m),7.25 (1 H, td, $J=7.8,1.2 \mathrm{~Hz}), 7.19(1 \mathrm{H}, \mathrm{d}, J=7.8,1.2 \mathrm{~Hz}), 6.66(1$ $\mathrm{H}, \mathrm{d}, J=8.4 \mathrm{~Hz}), 2.99(6 \mathrm{H}, \mathrm{s}), 0.29(9 \mathrm{H}, \mathrm{s}) ;{ }^{13} \mathrm{C} \mathrm{NMR}\left(\mathrm{CD}_{3} \mathrm{OD}, 150 \mathrm{MHz},\right) \delta 152.1$, $133.9,133.3,132.4,129.6,128.43,128.4,126.3,113.2,111.4,105.2$, 98.7, 96.2, 87.1, $40.6,0.26$.

\section{7-Hydroxy-3,3-dimethyl-4-chromanone 3.81.}

A solution of 7-hydroxy-4-chromanone $(0.200 \mathrm{~g}, 1.22 \mathrm{mmol})$ and iodomethane $(0.865 \mathrm{~g}$, $6.09 \mathrm{mmol})$ in $20 \mathrm{~mL}$ of THF was added to a solution of potassium tert-butoxide $(0.547 \mathrm{~g}$, 
$4.88 \mathrm{mmol})$ in $60 \mathrm{~mL}$ of THF at $-78{ }^{\circ} \mathrm{C}$ under a nitrogen atmosphere. After $6 \mathrm{~h}$ of stirring at $-78{ }^{\circ} \mathrm{C}$, the resulting white slurry was allowed to warm to room temperature slowly and was filtered through a celite cake. The reaction mixture was treated with $50 \mathrm{~mL}$ of a saturated $\mathrm{NH}_{4} \mathrm{Cl}$ solution and extracted with diethyl ether $(3 \times 30 \mathrm{~mL})$. The combined organic extracts were washed with brine and water, dried over sodium sulfate, and concentrated. Flash column chromatography (silica gel $/ 40 \%$ diethyl ether in hexanes) provided $0.245 \mathrm{~g}$ of 7 -hydroxy-3,3-dimethyl-4-chromanone (1.19 mmol, $98 \%$ yield) as a yellow solid: mp $128-129{ }^{\circ} \mathrm{C}$; IR 3137, 1656, $1590,1240 \mathrm{~cm}^{-1} ;{ }^{1} \mathrm{H}$ NMR $\left(\mathrm{CDCl}_{3}, 600\right.$ MHz,) $\delta 8.07(1 \mathrm{H}, \mathrm{br} \mathrm{s}), 7.80(1 \mathrm{H}, \mathrm{d}, J=9.0 \mathrm{~Hz}), 6.60(1 \mathrm{H}, \mathrm{dd}, J=9.0,2.4 \mathrm{~Hz}), 6.45(1$ $\mathrm{H}, \mathrm{d}, J=2.4 \mathrm{~Hz}), 4.12(2 \mathrm{H}, \mathrm{s}), 1.20(6 \mathrm{H}, \mathrm{s}) ;{ }^{13} \mathrm{C} \mathrm{NMR}\left(\mathrm{CDCl}_{3}, 150 \mathrm{MHz},\right) \delta 198.0$, $163.8,163.6,130.0,112.9,111.1,103.0,76.8,41.3,20.7$; HRMS $\mathrm{m} / \mathrm{z}$ calcd for $\mathrm{C}_{11} \mathrm{H}_{12} \mathrm{O}_{3} \mathrm{Na}\left(\mathrm{MNa}^{+}\right)$215.0679, found 215.0682.

Ketone 4.67 and ketone 4.68. A solution of indanone $(0.213 \mathrm{~g}, 1.61 \mathrm{mmol})$ in THF (20 $\mathrm{mL})$ was added dropwise to a stirred suspension of $\mathrm{NaH}(0.064 \mathrm{~g}, 60 \%$ in mineral oil, 1.61 mmol) in $20 \mathrm{~mL}$ THF at $0{ }^{\circ} \mathrm{C}$, and stirring was continued for $1 \mathrm{~h}$. To this solution was added $0.300 \mathrm{~g}$ of 1-iodo-2-methoxyethane $(1.61 \mathrm{mmol})$. After $1 \mathrm{~h}$ at room temperature, the mixture was heated to reflux for $6 \mathrm{~h}$. Then the mixture was cooled to $0{ }^{\circ} \mathrm{C}$ and quenched by ice-water. The reaction mixture was extracted with diethyl ether $(3 \times 50$ $\mathrm{mL}$ ). The combined organic extracts were washed with brine and water, dried over sodium sulfate, and concentrated. Flash column chromatography (silica gel $/ 10 \%$ diethyl ether in hexanes) provided $0.046 \mathrm{~g}$ of $\mathbf{4 . 6 7}(0.242 \mathrm{mmol}, 15 \%$ yield $)$ and $0.140 \mathrm{~g}$ of $\mathbf{4 . 6 8}$ (0.564 mmol, $35 \%$ yield) as yellow oil. 4.67: ${ }^{1} \mathrm{H} \mathrm{NMR}\left(\mathrm{CDCl}_{3}, 600 \mathrm{MHz}\right) \delta 7.50(1 \mathrm{H}, \mathrm{d}$, $J=7.8 \mathrm{~Hz}), 7.57(1 \mathrm{H}, \mathrm{td}, J=7.8,1.2 \mathrm{~Hz}), 7.45(1 \mathrm{H}, \mathrm{d}, J=7.8 \mathrm{~Hz}), 7.36(1 \mathrm{H}, \mathrm{td}, J=7.8$, $1.2 \mathrm{~Hz}), 3.58-3.55(2 \mathrm{H}, \mathrm{m}), 3.39-3.34(1 \mathrm{H}, \mathrm{m}), 3.34(3 \mathrm{H}, \mathrm{s}), 2.87(1 \mathrm{H}, \mathrm{dd}, J=16.8$, $4.2 \mathrm{~Hz}), 2.79-2.75(1 \mathrm{H}, \mathrm{m}), 2.28-2.23(1 \mathrm{H}, \mathrm{m}), 1.75-1.65(1 \mathrm{H}, \mathrm{m}) ;{ }^{13} \mathrm{C} \mathrm{NMR}\left(\mathrm{CDCl}_{3}\right.$, $150 \mathrm{MHz}) \delta 208.5,153.6,136.6,134.6,127.3,126.5,123.9,70.8,58.6,44.8,33.1,31.2$.

4.68: ${ }^{1} \mathrm{H}$ NMR $\left(\mathrm{CDCl}_{3}, 600 \mathrm{MHz}\right) \delta 7.74(1 \mathrm{H}, \mathrm{d}, J=7.8 \mathrm{~Hz}), 7.58(1 \mathrm{H}, \mathrm{td}, J=7.8,1.2$ 
Hz), $7.43(1 \mathrm{H}, \mathrm{d}, J=7.8 \mathrm{~Hz}), 7.36(1 \mathrm{H}, \mathrm{t}, J=7.8, \mathrm{~Hz}), 3.34-3.28(4 \mathrm{H}, \mathrm{m}), 3.17(2 \mathrm{H}, \mathrm{s})$, $3.13(6 \mathrm{H}, \mathrm{s}), 2.03-1.98(2 \mathrm{H}, \mathrm{m}), 1.90-1.85(2 \mathrm{H}, \mathrm{m}) ;{ }^{13} \mathrm{C} \mathrm{NMR}\left(\mathrm{CDCl}_{3}, 150 \mathrm{MHz}\right) \delta$ $209.9,152.9,136.6,134.7,127.3,126.3,123.9,70.0,58.5,50.1,38.1,37.0$.

Ketone 4.71. A solution of ketone $4.70(1.10 \mathrm{~g}, 7.48 \mathrm{mmol})$ in THF $(20 \mathrm{~mL})$ was added dropwise to a stirred suspension of $\mathrm{NaH}(0.390 \mathrm{~g}, 60 \%$ in mineral oil, $9.75 \mathrm{mmol})$ in 30 $\mathrm{mL} \mathrm{THF}$ at $0{ }^{\circ} \mathrm{C}$, and stirring was continued for $1 \mathrm{~h}$. To this solution was added $1.67 \mathrm{~g}$ of 1-iodo-2-methoxyethane $(8.97 \mathrm{mmol})$. After $1 \mathrm{~h}$ at room temperature, the mixture was heated to reflux for $6 \mathrm{~h}$. Then the mixture was cooled to $0{ }^{\circ} \mathrm{C}$ and quenched by ice-water. The reaction mixture was extracted with diethyl ether $(3 \times 50 \mathrm{~mL})$. The combined organic extracts were washed with brine and water, dried over sodium sulfate, and concentrated. Flash column chromatography (silica gel $/ 15 \%$ diethyl ether in hexanes) provided $1.04 \mathrm{~g}$ of $4.71\left(5.09 \mathrm{mmol}, 68 \%\right.$ yield) as yellow oil: ${ }^{1} \mathrm{H} \mathrm{NMR}\left(\mathrm{CDCl}_{3}, 600 \mathrm{MHz}\right) \delta 7.74(1 \mathrm{H}, \mathrm{d}$, $J=7.8 \mathrm{~Hz}), 7.57(1 \mathrm{H}, \mathrm{td}, J=7.2,1.2 \mathrm{~Hz}), 7.42(1 \mathrm{H}, \mathrm{d}, J=7.8 \mathrm{~Hz}), 7.34(1 \mathrm{H}, \mathrm{td}, J=7.8$, $0.6 \mathrm{~Hz}), 3.39-3.33(2 \mathrm{H}, \mathrm{m}), 3.25(1 \mathrm{H}, \mathrm{d}, J=17.4 \mathrm{~Hz}), 3.15(3 \mathrm{H}, \mathrm{s}), 2.88(1 \mathrm{H}, \mathrm{d}, J=$ $16.8 \mathrm{~Hz}), 2.00-1.95(1 \mathrm{H}, \mathrm{m}), 1.87-1.81(1 \mathrm{H}, \mathrm{m}), 1.21(3 \mathrm{H}, \mathrm{s}) ;{ }^{13} \mathrm{C} \mathrm{NMR}\left(\mathrm{CDCl}_{3}, 150\right.$ MHz) $\delta 210.62,152.5,135.7,134.7,127.3,126.5,124.2,69.3,58.4,47.7,40.4,37.4$, 24.3 .

Propargylic alcohol 4.73. To $0.296 \mathrm{~g}(1.46 \mathrm{mmol})$ of $\mathbf{4 . 7 2}$ in $20 \mathrm{~mL}$ of THF under a nitrogen atmosphere at $-78{ }^{\circ} \mathrm{C}$ was added $0.892 \mathrm{~mL}$ of a $1.8 \mathrm{M}$ solution of lithium diisopropylamide (LDA, $1.60 \mathrm{mmol}$ ) in hexanes. After $30 \mathrm{~min}$ of stirring, a solution of $0.250 \mathrm{~g}$ of $4.71(1.22 \mathrm{mmol})$ in $10 \mathrm{~mL}$ of THF was introduced via cannula, and the reaction mixture was allowed to warm to room temperature. After an additional $1 \mathrm{~h}, 30$ $\mathrm{mL}$ of water was introduced, and the reaction mixture was extracted with diethyl ether (3 $\times 30 \mathrm{~mL}$ ). The combined organic extracts were washed with brine and water, dried over sodium sulfate, and concentrated. Flash column chromatography (silica gel $/ 20 \%$ diethyl 
ether in hexanes) provided $0.479 \mathrm{~g}$ of 4.73 (1.18 mmol, 97\% yield, 1:1 mixture of isomers) as a yellow oil. Diastereomer 1: ${ }^{1} \mathrm{H} \mathrm{NMR}\left(\mathrm{CDCl}_{3}, 600 \mathrm{MHz}\right) \delta 7.72(1 \mathrm{H}, \mathrm{d}, J=$ 7.8 Hz), 7.55-7.53 (2 H, m), 7.37-7.35 (2 H, m), 7.30-7.28 (3 H, m), 7.27-7.23 (3 H, m), $7.19(1 \mathrm{H}, \mathrm{d}, J=7.8 \mathrm{~Hz}), 7.14(1 \mathrm{H}, \mathrm{t}, J=7.2 \mathrm{~Hz}), 3.76(1 \mathrm{H}, \mathrm{td}, J=9.6,2.4 \mathrm{~Hz}), 3.55$ (1 H, m), $3.36(3 \mathrm{H}, \mathrm{s}), 3.10(1 \mathrm{H}, \mathrm{d}, J=15.6 \mathrm{~Hz}), 2.65$ (1 H, d, $J=15.6 \mathrm{~Hz}), 2.29-2.25$ (1 $\mathrm{H}, \mathrm{m}), 1.83-1.78(1 \mathrm{H}, \mathrm{m}), 1.53(1 \mathrm{H}, \mathrm{br}, \mathrm{s}), 1.23(3 \mathrm{H}, \mathrm{s})$; Diastereomer $2:{ }^{1} \mathrm{H}$ NMR $\left(\mathrm{CDCl}_{3}, 600 \mathrm{MHz}\right) \delta$ 7.56-7.53 (1 H, m), 7.49-7.43 (4 H, m), 7.36-7.33 (3 H, m), 7.26-7.18 (4 H, m), 7.13 (1 H, d, $J=7.8 \mathrm{~Hz}), 4.21(1 \mathrm{H}, \mathrm{s}), 3.59(1 \mathrm{H}, \mathrm{td}, J=9.6,2.4 \mathrm{~Hz})$, 3.41-3.38 (1 H, m), 3.34 (3 H, s), 3.03 (1 H, d, $J=15.6 \mathrm{~Hz}), 2.76-2.70$ (1 H, m), 2.59 (1 $\mathrm{H}, \mathrm{d}, J=15.6 \mathrm{~Hz}), 1.61-1.55(1 \mathrm{H}, \mathrm{m}), 1.03(3 \mathrm{H}, \mathrm{s}) ;{ }^{13} \mathrm{C} \mathrm{NMR}\left(\mathrm{CDCl}_{3}, 150 \mathrm{MHz}\right) \delta$ $145.7,140.5,132.2,131.9,131.7,128.3,128.2,127.9,127.81,127.8,126.9,125.5,125.4$, $124.9,123.3,123.25,94.3,92.9,88.3,86.4,80.7,69.9,58.7,52.3,44.2,36.2,18.3$.

Diacetylene 4.74. To a mixture of $4.73(0.460 \mathrm{~g}, 1.13 \mathrm{mmol})$ and triethylsilane $(0.395 \mathrm{~g}$, $3.4 \mathrm{mmol}$ ) in $30 \mathrm{~mL}$ of dichloromethane was added $1.03 \mathrm{~g}$ of trifluoroacetic acid (9 $\mathrm{mmol})$. After $0.5 \mathrm{~h}$ of stirring at room temperature, $2.5 \mathrm{~g}(23.5 \mathrm{mmol})$ of sodium carbonate was added followed by $50 \mathrm{~mL}$ of water. The organic layer was separated, washed with brine and water, dried over sodium sulfate, and evaporated under reduced pressure. The residue was purified by flash column chromatography (silica gel $/ 10 \%$ diethyl ether in hexanes) to provide $0.420 \mathrm{~g}(1.07 \mathrm{mmol}, 95 \%, 1: 1$ mixture of the diastereomer) of $\mathbf{4 . 7 4}$ as a white solid: ${ }^{1} \mathrm{H}$ NMR (mixture of diastereomers, $\mathrm{CDCl}_{3}, 600$ MHz) $\delta 7.55-7.48(5 \mathrm{H}, \mathrm{m}), 7.46-7.41(5 \mathrm{H}, \mathrm{m}), 7.32-7.26(10 \mathrm{H}, \mathrm{m}), 7.17-7.15(4 \mathrm{H}, \mathrm{m})$, 7.01-7.07 (2 H, m), 4.16 and 4.06 (2 H, two singlets), 3.61-3.55 (2 H, m), 3.38-3.29 (2 H, m), $3.30(3 \mathrm{H}, \mathrm{s}), 3.15(3 \mathrm{H}, \mathrm{s}), 3.02(1 \mathrm{H}, \mathrm{d}, J=15.0 \mathrm{~Hz}), 2.93(1 \mathrm{H}, \mathrm{d}, J=15.0 \mathrm{~Hz})$, $2.72(1 \mathrm{H}, \mathrm{d}, J=15.0 \mathrm{~Hz}), 2.71(1 \mathrm{H}, \mathrm{d}, J=15.0 \mathrm{~Hz}), 2.09-2.05$ (1 H, m), 2.00-1.85 ( 3 $\mathrm{H}, \mathrm{m}) ;{ }^{13} \mathrm{C} \mathrm{NMR}$ (mixture of diastereomers, $\left.\mathrm{CDCl}_{3}, 150 \mathrm{MHz}\right) \delta 142.9,142.4,141.9$, $141.7,132.2,132.1,132.0 .131 .95,131.8,131.7,128.22,128.21,127.89,127.87,127.5$, 
$127.1,126.9,126.62,126.6,126.2,126.1,125.7,125.65,124.7,124.6,124.5,124.4$, $123.3,123.27,92.93,92.9,92.8,92.3,88.49,88.47,84.0,83.3,70.1,58.6,58.3,49.5$, $48.4,47.7,47.5,45.3,44.0,40.3,36.5,25.9,21.8$.

Hydrocarbon 4.76. To $0.340 \mathrm{~g}(0.87 \mathrm{mmol})$ of 4.74 in $20 \mathrm{~mL}$ of anhydrous toluene under a nitrogen atmosphere was added $1.92 \mathrm{~mL}$ of a $0.5 \mathrm{M}$ solution of potassium tert-butoxide (0.96 mmol) in 2-methyl-2-propanol. The reaction mixture was then heated under $80{ }^{\circ} \mathrm{C}$ for $6 \mathrm{~h}$. After the reaction mixture was allowed to cool to room temperature, $10 \mathrm{~mL}$ of water and $20 \mathrm{~mL}$ of dichloromethane were introduced, and the organic layer was separated, washed with brine and water, dried over sodium sulfate, and concentrated. The residue was purified by flash column chromatography (silica gel/10\% diethyl ether in hexanes) to provide $0.265 \mathrm{~g}(0.68 \mathrm{mmol}, 78 \%)$ of 4.74 as a yellow solid: ${ }^{1} \mathrm{H}$ NMR $\left(\mathrm{CDCl}_{3}, 600 \mathrm{MHz}\right) \delta 7.62-7.59(2 \mathrm{H}, \mathrm{m}), 7.58-7.55(2 \mathrm{H}, \mathrm{m}), 7.48-7.45(2 \mathrm{H}, \mathrm{m})$, 7.38-7.36 (1 H, m), $7.27(2 \mathrm{H}, \mathrm{t}, J=8.4 \mathrm{~Hz}), 7.24(1 \mathrm{H}, \mathrm{td}, J=7.2,1.2 \mathrm{~Hz}), 7.05(1 \mathrm{H}, \mathrm{t}$, $J=8.4 \mathrm{~Hz}), 4.20(1 \mathrm{H}, \mathrm{d}, J=21.6 \mathrm{~Hz}), 4.15(1 \mathrm{H}, \mathrm{d}, J=21.6 \mathrm{~Hz}), 3.60(1 \mathrm{H}, \mathrm{d}, J=17.4$ Hz), 3.40-3.36 (1 H, m), $3.28(1 \mathrm{H}, \mathrm{d}, J=16.8 \mathrm{~Hz}), 3.25-3.20(1 \mathrm{H}, \mathrm{m}), 3.22(3 \mathrm{H}, \mathrm{s})$, 2.47-2.41 (1 H, m), 2.33-2.29 (1 H, m), $1.65(3 \mathrm{H}, \mathrm{s}) ;{ }^{13} \mathrm{C} \mathrm{NMR}\left(\mathrm{CDCl}_{3}, 150 \mathrm{MHz}\right) \delta$ 145.2, 144.1, 142.8, 141.5, 139.7, 138.8, 136.9, 133.3, 131.0, 130.8, 130.2, 130.16, 129.0, $128.9,127.6,127.3,126.9,126.5,124.9,123.7,121.5,119.0,70.3,58.7,46.5,45.5,39.5$, 33.9, 27.5.

Iodide 4.77. To $0.230 \mathrm{~g}(0.588 \mathrm{mmol})$ of 4.76 in $10 \mathrm{~mL}$ of anhydrous chloroform under a nitrogen atmosphere at room temperature was added $1 \mathrm{~mL}$ of trimethylsilyl iodide, and then the reaction mixture was heated to $55^{\circ} \mathrm{C}$. After $48 \mathrm{~h}$ of stirring, the reaction mixture was concentrated in vacuo to remove excess trimethylsily iodide and chloroform. The residure was purified by flash column chromatography (silica gel/5\% diethyl ether in hexanes) to provide $0.215 \mathrm{~g}(0.441 \mathrm{mmol}, 75 \%)$ of 4.77 as a yellow solid: ${ }^{1} \mathrm{H}$ NMR 
$\left(\mathrm{CDCl}_{3}, 600 \mathrm{MHz}\right) \delta$ 7.62-7.54 (4 H, m), 7.46-7.42 (2 H, m), 7.37-7.35 (1 H, m), 7.28-7.23 (3 H, m), $7.04(1 \mathrm{H}, \mathrm{t}, J=7.2 \mathrm{~Hz}), 6.25(1 \mathrm{H}, \mathrm{d}, J=8.4 \mathrm{~Hz}), 4.18(1 \mathrm{H}, \mathrm{d}, J=$ $21 \mathrm{~Hz}), 4.09(1 \mathrm{H}, \mathrm{d}, J=21.6 \mathrm{~Hz}), 3.50(1 \mathrm{H}, \mathrm{d}, J=17.4 \mathrm{~Hz}), 3.27(1 \mathrm{H}, \mathrm{d}, J=16.8 \mathrm{~Hz})$, 3.10-3.05 (1 H, m), 2.82-2.73 (2 H, m), 2.62-2.60 (1 H, m), $1.66(3 \mathrm{H}, \mathrm{s}) ;{ }^{13} \mathrm{C} \mathrm{NMR}$ $\left(\mathrm{CDCl}_{3}, 150 \mathrm{MHz}\right) \delta 143.9,143.5,142.1,141.4,139.8,138.6,137.1,133.5,131.2,131.1$, 130.1, 129.0, 128.99, 127.7, 127.5, 127.0, 126.6, 125.0, 123.8, 121.8, 119.2, 50.2, 45.6, $44.5,33.8,26.9,0.362$.

Hydrocarbon 4.78. To a solution of iodide $4.77(0.070 \mathrm{~g}, 0.144 \mathrm{mmol})$ in THF (20 mL) was added a solution of $t$-BuOK $(0.017 \mathrm{~g}, 0.15 \mathrm{mmol})$ in $5 \mathrm{~mL}$ of THF. The reaction mixture was heated to $40{ }^{\circ} \mathrm{C}$ for $2 \mathrm{~h}$ and quenched with aq satd. $\mathrm{NH}_{4} \mathrm{Cl}$. The reaction mixture was extracted with diethyl ether $(3 \times 30 \mathrm{~mL})$. The combined organic extracts were washed with brine and water, dried over sodium sulfate, and concentrated. Flash column chromatography (silica gel $/ 10 \%$ diethyl ether in hexanes) provided $0.048 \mathrm{~g}$ of $4.78(0.132 \mathrm{mmol}, 92 \%$ yield $)$ as a yellow solid: ${ }^{1} \mathrm{H} \mathrm{NMR}\left(\mathrm{CDCl}_{3}, 600 \mathrm{MHz}\right) \delta 7.72(1 \mathrm{H}$, d, $J=7.2 \mathrm{~Hz}), 7.62(1 \mathrm{H}, \mathrm{br}, \mathrm{s}), 7.56-7.50(2 \mathrm{H}, \mathrm{m}), 7.51(1 \mathrm{H}, \mathrm{d}, J=7.8 \mathrm{~Hz}), 7.44(1 \mathrm{H}$, d, $J=14.4 \mathrm{~Hz}), 7.35(1 \mathrm{H}, \mathrm{t}, J=7.2 \mathrm{~Hz}), 7.32(1 \mathrm{H}, \mathrm{br}, \mathrm{s}), 7.20(2 \mathrm{H}, \mathrm{t}, J=7.2 \mathrm{~Hz}), 7.02$ $(1 \mathrm{H}, \mathrm{t}, J=8.4 \mathrm{~Hz}), 6.77(1 \mathrm{H}, \mathrm{d}, J=7.2 \mathrm{~Hz}), 4.08(1 \mathrm{H}, \mathrm{t}, J=8.4 \mathrm{~Hz}), 3.59(1 \mathrm{H}, \mathrm{d}, J=$ $17.4 \mathrm{~Hz}), 3.24(1 \mathrm{H}, \mathrm{d}, J=16.8 \mathrm{~Hz}), 2.74-2.65(1 \mathrm{H}, \mathrm{m}), 2.31-2.27(1 \mathrm{H}, \mathrm{m}), 1.64(3 \mathrm{H}$, m), 1.52-1.43 (1 H, m), 1.28-1.21 (1 H, m); ${ }^{13} \mathrm{C}$ NMR $\left(\mathrm{CDCl}_{3}, 150 \mathrm{MHz}\right) \delta 151.1,148.0$, $142.9,142.87,139.3,138.45,138.43,136.8,131.6,131.4,131.0,129.9,128.8,128.5$, 127.7, 127.5, 126.8, 126.7, 125.0, 123.1, 121.7, 119.2, 49.2, 43.4, 39.2, 37.5, 27.1, 26.1.

Propargylic alcohol 4.82. To $0.632 \mathrm{~g}(1.77 \mathrm{mmol})$ of $4.58 \mathrm{in} 30 \mathrm{~mL}$ of THF under a nitrogen atmosphere at $-78{ }^{\circ} \mathrm{C}$ was added $1.05 \mathrm{~mL}$ of a $1.8 \mathrm{M}$ solution of lithium diisopropylamide (LDA, $1.90 \mathrm{mmol}$ ) in hexanes. After $30 \mathrm{~min}$ of stirring, a solution of $0.330 \mathrm{~g}$ of $4.71(1.61 \mathrm{mmol})$ in $15 \mathrm{~mL}$ of THF was introduced via cannula, and the 
reaction mixture was allowed to warm to room temperature. After an additional $1 \mathrm{~h}, 30$ $\mathrm{mL}$ of water was introduced, and the reaction mixture was extracted with diethyl ether (3 $\times 50 \mathrm{~mL}$ ). The combined organic extracts were washed with brine and water, dried over sodium sulfate, and concentrated. Flash column chromatography (silica gel/20\% diethyl ether in hexanes) provided $0.868 \mathrm{~g}$ of $\mathbf{4 . 7 3}(1.55 \mathrm{mmol}, 96 \%$ yield, $1: 1$ mixture of isomers) as a yellow oil. Diastereomer 1: ${ }^{1} \mathrm{H} \mathrm{NMR}\left(\mathrm{CDCl}_{3}, 600 \mathrm{MHz}\right) \delta 7.59(2 \mathrm{H}, \mathrm{d}, J=$ 7.8 Hz), 7.58-7.56 (1 H, m), 7.51-7.49 (1 H, m), 7.46-7.44 (1 H, m), 7.29-7.25 (2 H, m), 7.16-7.14 (2 H, m), 7.09-7.07 (1 H, m), $7.05(1 \mathrm{H}, \mathrm{t}, J=8.4 \mathrm{~Hz}), 4.18(1 \mathrm{H}, \mathrm{s})$, 3.59-3.54 (1 H, m), 3.40-3.36 (1 H, m), $3.34(3 \mathrm{H}, \mathrm{s}), 3.01(1 \mathrm{H}, \mathrm{d}, J=15.0 \mathrm{~Hz})$, 2.70-2.64 (1 H, m), $2.55(1 \mathrm{H}, \mathrm{d}, J=15.0 \mathrm{~Hz}), 1.53-1.49(1 \mathrm{H}, \mathrm{m}), 1.01(3 \mathrm{H}, \mathrm{s}) ;{ }^{13} \mathrm{C}$ NMR $\left(\mathrm{CDCl}_{3}, 150 \mathrm{MHz}\right) \delta 145.5,140.6,132.5,132.4,131.2,129.7,128.5,127.9,127.7$, 127.3,126.8, 126.7, 125.6, 124.9, 124.6, 123.3, 97.2, 94.6, 90.4, 86.3, 80.7, 69.9, 58.7, 52.3, 44.2, 36.2, 18.3; Diastereomer $2:{ }^{1} \mathrm{H} \mathrm{NMR}\left(\mathrm{CDCl}_{3}, 600 \mathrm{MHz}\right) \delta 7.68(1 \mathrm{H}, \mathrm{d}, J=$ 13.2 Hz), 7.65-7.63 (1 H, m), 7.58-7.55 (1 H, m), $7.53(2 \mathrm{H}, \mathrm{d}, J=7.8 \mathrm{~Hz}), 7.34-7.32(2$ H, m), $7.21(1 \mathrm{H}, \mathrm{t}, J=7.8 \mathrm{~Hz}), 7.16-7.15(1 \mathrm{H}, \mathrm{m}), 7.11(1 \mathrm{H}, \mathrm{t}, J=7.8 \mathrm{~Hz}), 7.00(1 \mathrm{H}, \mathrm{t}$, $J=7.8 \mathrm{~Hz}), 4.58(3 \mathrm{H}, \mathrm{s}), 3.77-3.72(1 \mathrm{H}, \mathrm{m}), 3.57-3.53(1 \mathrm{H}, \mathrm{m}), 3.36(3 \mathrm{H}, \mathrm{s}), 3.07(1$ H, d, $J=15.0 \mathrm{~Hz}), 2.64(1 \mathrm{H}, \mathrm{d}, J=15.0 \mathrm{~Hz}), 2.26-2.21(1 \mathrm{H}, \mathrm{m}), 1.83-1.79(1 \mathrm{H}, \mathrm{m})$, $1.21(3 \mathrm{H}, \mathrm{s}) ;{ }^{13} \mathrm{C} \mathrm{NMR}\left(\mathrm{CDCl}_{3}, 150 \mathrm{MHz}\right) \delta 145.1,141.7,132.8,132.5,131.2,129.7$, 128.7, 128.6, 127.8, 127.1, 126.7, 126.6, 125.5, 125.1, 124.8, 124.7, 97.1, 94.9, 90.7, 84.2, $80.8,69.1,58.5,50.9,45.4,36.8,24.4$.

Diacetylene 4.83. To a mixture of $4.82(0.843 \mathrm{~g}, 1.50 \mathrm{mmol})$ and triethylsilane $(0.744 \mathrm{~g}$, $6.4 \mathrm{mmol})$ in $30 \mathrm{~mL}$ of dichloromethane was added $0.37 \mathrm{~g}$ of trifluoroacetic acid (3.2 mmol). After $0.5 \mathrm{~h}$ of stirring at room temperature, $1.5 \mathrm{~g}(14.1 \mathrm{mmol})$ of sodium carbonate was added followed by $50 \mathrm{~mL}$ of water. The organic layer was separated, washed with brine and water, dried over sodium sulfate, and evaporated under reduced pressure. The residue was purified by flash column chromatography (silica gel/10\% 
diethyl ether in hexanes) to provide $0.769 \mathrm{~g}(1.41 \mathrm{mmol}, 94 \%, 1: 1$ mixture of the diastereomer) of $\mathbf{4 . 8 3}$ as a white solid: ${ }^{1} \mathrm{H}$ NMR (mixture of diastereomers, $\mathrm{CDCl}_{3}, 600$ MHz) $\delta$ 7.66-7.62 (2 H, m), 7.57-7.54 (4 H, m), 7.52-7.48 (2 H, m), $7.45(1 \mathrm{H}, \mathrm{d}, J=$ $7.2 \mathrm{~Hz}), 7.40$ (1 H, d, J=7.2 Hz), 7.33-7.29 (4H, m), 7.16-7.12 (4 H, m), 7.08-7.05 (2 $\mathrm{H}, \mathrm{m}), 7.03-6.99$ (2 H, m), 4.14 and 4.04 (2 H, two singlets), 3.61-3.51 (2 H, m), 3.38-3.29 (2 H, m), $3.31(3 \mathrm{H}, \mathrm{s}), 3.17(3 \mathrm{H}, \mathrm{s}), 3.02(1 \mathrm{H}, \mathrm{d}, J=15.6 \mathrm{~Hz}), 2.91(1 \mathrm{H}, \mathrm{d}$, $J=15.6 \mathrm{~Hz}), 2.72(1 \mathrm{H}, \mathrm{d}, J=15.6 \mathrm{~Hz}), 2.70(1 \mathrm{H}, \mathrm{d}, J=15.0 \mathrm{~Hz}), 2.07-2.02(1 \mathrm{H}, \mathrm{m})$, 2.05-1.88 ( $3 \mathrm{H}, \mathrm{m}$ ); ${ }^{13} \mathrm{C} \mathrm{NMR}$ (mixture of diastereomers, $\left.\mathrm{CDCl}_{3}, 150 \mathrm{MHz}\right) \delta 142.7$, $142.2,141.9,141.7,132.6,132.56,132.5,132.47,131.3,129.6,128.6,127.5,127.3$, $127.0,126.9,126.6,126.5,126.4,126.3,125.0,124.9,124.8,124.6,124.5,124.46,97.5$, $97.47,93.2,92.8,90.5,90.4,83.8,83.1,70.1,70.07,58.6,58.3,49.6,48.5,47.7,47.5$, $45.3,44.0,40.4,36.5,25.9,21.9$.

Hydrocarbon 4.84. To $0.400 \mathrm{~g}(0.708 \mathrm{mmol})$ of $\mathbf{4 . 8 3}$ in $30 \mathrm{~mL}$ of anhydrous toluene under a nitrogen atmosphere was added $1.55 \mathrm{~mL}$ of a $0.5 \mathrm{M}$ solution of potassium tert-butoxide $(0.77 \mathrm{mmol})$ in 2-methyl-2-propanol. The reaction mixture was then heated under $110^{\circ} \mathrm{C}$ for $6 \mathrm{~h}$. After the reaction mixture was allowed to cool to room temperature, $20 \mathrm{~mL}$ of water and $20 \mathrm{~mL}$ of dichloromethane were introduced, and the organic layer was separated, washed with brine and water, dried over sodium sulfate, and concentrated. The residue was purified by flash column chromatography (silica gel $/ 10 \%$ diethyl ether in hexanes) to provide $0.328 \mathrm{~g}(0.58 \mathrm{mmol}, 82 \%)$ of $\mathbf{4 . 8 4}$ as a yellow solid: ${ }^{1} \mathrm{H}$ NMR $\left(\mathrm{CDCl}_{3}, 600 \mathrm{MHz}\right) \delta 7.82(2 \mathrm{H}, \mathrm{dd}, J=9.0,3.0 \mathrm{~Hz}), 7.57(1 \mathrm{H}, \mathrm{d}, J=7.8 \mathrm{~Hz}), 7.41(1 \mathrm{H}, \mathrm{t}$, $J=8.4 \mathrm{~Hz}), 7.31-7.27(3 \mathrm{H}, \mathrm{m}), 7.13-7.09(2 \mathrm{H}, \mathrm{m}), 6.57(1 \mathrm{H}, \mathrm{d}, J=7.8 \mathrm{~Hz}), 4.21(1 \mathrm{H}$, d, $J=21.0 \mathrm{~Hz}), 4.16(1 \mathrm{H}, \mathrm{d}, J=21.0 \mathrm{~Hz}), 3.58(1 \mathrm{H}, \mathrm{d}, J=17.4 \mathrm{~Hz}), 3.35-3.30(1 \mathrm{H}, \mathrm{m})$, $3.29(1 \mathrm{H}, \mathrm{d}, J=16.8 \mathrm{~Hz}), 3.18-3.13(1 \mathrm{H}, \mathrm{m}), 3.14(3 \mathrm{H}, \mathrm{s}), 2.43-2.38(1 \mathrm{H}, \mathrm{m})$, 2.31-2.27 (1 H, m), $1.68(3 \mathrm{H}, \mathrm{s}) ;{ }^{13} \mathrm{C} \mathrm{NMR}\left(\mathrm{CDCl}_{3}, 150 \mathrm{MHz}\right) \delta 146.4,144.2,143.3$, $140.9,140.0,139.9,137.2,133.3,132.4,132.3,130.5,129.1,128.8,127.8,127.3,127.1$, 
$126.0,125.1,122.3,120.1,119.3,70.2,58.6,46.7,45.6,39.7,34.1,27.5$.

Iodide 4.85. To $0.530 \mathrm{~g}(0.967 \mathrm{mmol})$ of $\mathbf{4 . 8 4}$ in $10 \mathrm{~mL}$ of anhydrous chloroform under a nitrogen atmosphere at room temperature was added $1.1 \mathrm{~mL}$ of trimethylsilyl iodide, and then the reaction mixture was heated to $55^{\circ} \mathrm{C}$. After $48 \mathrm{~h}$ of stirring, the reaction mixture was concentrated in vacuo to remove excess trimethylsily iodide and chloroform. The residure was purified by flash column chromatography (silica gel/5\% diethyl ether in hexanes) to provide $0.492 \mathrm{~g}(0.764 \mathrm{mmol}, 79 \%)$ of $\mathbf{4 . 8 5}$ as a yellow solid: ${ }^{1} \mathrm{H}$ NMR $\left(\mathrm{CDCl}_{3}, 600 \mathrm{MHz}\right) \delta 7.82(2 \mathrm{H}, \mathrm{dd}, J=8.4,0.6 \mathrm{~Hz}), 7.59(1 \mathrm{H}, \mathrm{d}, J=7.8 \mathrm{~Hz}), 7.41(1 \mathrm{H}$, t, $J=7.8 \mathrm{~Hz}), 7.32-7.27(3 \mathrm{H}, \mathrm{m}), 7.12(1 \mathrm{H}, \mathrm{t}, J=7.8 \mathrm{~Hz}), 7.10(1 \mathrm{H}, \mathrm{d}, J=8.4 \mathrm{~Hz})$, $6.56(1 \mathrm{H}, \mathrm{d}, J=7.8 \mathrm{~Hz}), 4.20(1 \mathrm{H}, \mathrm{d}, J=21.6 \mathrm{~Hz}), 4.12(1 \mathrm{H}, \mathrm{d}, J=21.0 \mathrm{~Hz}), 3.50(1 \mathrm{H}$, d, $J=17.4 \mathrm{~Hz}), 3.29(1 \mathrm{H}, \mathrm{d}, J=17.4 \mathrm{~Hz}), 3.09-3.03(1 \mathrm{H}, \mathrm{m}), 2.80-2.75(1 \mathrm{H}, \mathrm{m})$, 2.72-2.67 (1 H, m), 2.62-2.59 (1 H, m), $1.69(3 \mathrm{H}, \mathrm{s}) ;{ }^{13} \mathrm{C} \mathrm{NMR}\left(\mathrm{CDCl}_{3}, 150 \mathrm{MHz}\right) \delta$ 144.6, 143.9, 142.6, 140.7, 140.1, 139.7, 137.4, 133.5, 132.4, 132.3, 130.5, 129.2, 129.1, $128.0,127.5,127.2,125.9,125.8,125.1,122.3,120.4,119.5,50.3,45.7,44.6,34.0,26.8$, 0.23 .

Hydrocarbon 4.86. To a solution of iodide $4.85(0.320 \mathrm{~g}, 0.497 \mathrm{mmol})$ in THF (20 mL) was added a solution of $t$-BuOK $(0.056 \mathrm{~g}, 0.500 \mathrm{mmol})$ in $5 \mathrm{~mL}$ of THF. The reaction mixture was heated to $40{ }^{\circ} \mathrm{C}$ for $2 \mathrm{~h}$ and quenched with aq satd. $\mathrm{NH}_{4} \mathrm{Cl}$. The reaction mixture was extracted with diethyl ether $(3 \times 30 \mathrm{~mL})$. The combined organic extracts were washed with brine and water, dried over sodium sulfate, and concentrated. Flash column chromatography (silica gel $/ 10 \%$ diethyl ether in hexanes) provided $0.243 \mathrm{~g}$ of $4.86(0.472 \mathrm{mmol}, 95 \%$ yield $)$ as a yellow solid: ${ }^{1} \mathrm{H} \mathrm{NMR}\left(\mathrm{CDCl}_{3}, 600 \mathrm{MHz}\right) \delta 7.87(1 \mathrm{H}$, d, $J=7.8 \mathrm{~Hz}), 7.73(1 \mathrm{H}, \mathrm{d}, J=7.8 \mathrm{~Hz}), 7.56(1 \mathrm{H}, \mathrm{d}, J=7.8 \mathrm{~Hz}), 7.39(1 \mathrm{H}, \mathrm{t}, J=8.4$ Hz), 7.29-7.25 (2 H, m), $7.23(1 \mathrm{H}, \mathrm{d}, J=6.6 \mathrm{~Hz}), 7.16(1 \mathrm{H}, \mathrm{d}, J=8.4 \mathrm{~Hz}), 7.12(1 \mathrm{H}, \mathrm{t}$, $J=7.8 \mathrm{~Hz}), 6.66(1 \mathrm{H}, \mathrm{d}, J=8.4 \mathrm{~Hz}), 4.10(1 \mathrm{H}, \mathrm{t}, J=8.4 \mathrm{~Hz}), 3.62(1 \mathrm{H}, \mathrm{d}, J=16.8 \mathrm{~Hz})$, 
$3.27(1 \mathrm{H}, \mathrm{d}, J=16.8 \mathrm{~Hz}), 2.74-2.70(1 \mathrm{H}, \mathrm{m}), 2.34-2.29(1 \mathrm{H}, \mathrm{m}), 1.69(3 \mathrm{H}, \mathrm{m})$, $1.53-1.48(1 \mathrm{H}, \mathrm{m}), 1.22-1.18(1 \mathrm{H}, \mathrm{m}) ;{ }^{13} \mathrm{C} \mathrm{NMR}\left(\mathrm{CDCl}_{3}, 150 \mathrm{MHz}\right) \delta 151.1,148.0$, $142.9,142.87,139.3,138.45,138.43,136.8,131.6,131.4,131.0,129.9,128.8,128.5$, 127.7, 127.5, 126.8, 126.7, 125.0, 123.1, 121.7, 119.2, 49.2, 43.4, 39.2, 37.5, 27.1, 26.1.

Buckybowl 4.87 and 4.89. To a flask containing $0.176 \mathrm{~g}$ of $\mathbf{4 . 8 6}(0.341 \mathrm{mmol})$ and 0.060 $\mathrm{g}$ of dibromobis(triphenylphosphine)palladium $(0.075 \mathrm{mmol})$ under a nitrogen atmosphere were added via cannula $0.559 \mathrm{~mL}$ of DBU $(2.74 \mathrm{mmol})$ in $15 \mathrm{~mL}$ of DMF. The resulting mixture was stirred vigorously at $150{ }^{\circ} \mathrm{C}$ for $72 \mathrm{~h}$. The reaction mixture was then allowed to cool to rt before $30 \mathrm{~mL}$ of water, $15 \mathrm{~mL}$ of a $2 \mathrm{M} \mathrm{HCl}$ solution, and 50 $\mathrm{mL}$ of diethyl ether were introduced. The organic layer was separated, dried over sodium sulfate, and concentrated. The residue was purified by a shot silica gel plug to provide $0.057 \mathrm{~g}$ of $\mathbf{4 . 8 7}$ and $\mathbf{4 . 8 9}$ as yellow solids. Both dicyclization and monocylization products are not stable on silica gel column, so the mixture can not be separated on a flash chromatography column. The crude NMR shows that the mixtures include $0.039 \mathrm{~g}$ of 4.87 and $0.018 \mathrm{~g}$ of 4.89. The structure of cyclization products were analyzed and confirmed by 1D TOCSY and 1D NOESY. All non-aromatic protons were assigned to corresponding products. 4.87: ${ }^{1} \mathrm{H} \mathrm{NMR}\left(\mathrm{CDCl}_{3}, 600 \mathrm{MHz}\right) \delta 4.82(1 \mathrm{H}, \mathrm{dd}), 3.59(1 \mathrm{H}, \mathrm{d})$, 2.59-2.52 (1 H, m), $2.54(1 \mathrm{H}, \mathrm{d}), 1.79(3 \mathrm{H}, \mathrm{s}), 1.60-1.55(1 \mathrm{H}, \mathrm{m}), 1.15-1.10(1 \mathrm{H}, \mathrm{m})$, $(-0.18)-(-0.24)(1 \mathrm{H}, \mathrm{m}) ; 4.89:{ }^{1} \mathrm{H} \mathrm{NMR}\left(\mathrm{CDCl}_{3}, 600 \mathrm{MHz}\right) \delta 4.18(1 \mathrm{H}, \mathrm{dd}), 3.72(1 \mathrm{H}$, d), $3.11(1 \mathrm{H}, \mathrm{d}), 2.76-2.69(1 \mathrm{H}, \mathrm{m}), 2.19-2.14(1 \mathrm{H}, \mathrm{m}), 1.72(3 \mathrm{H}, \mathrm{s}), 1.30-1.20(1 \mathrm{H}$, m), 0.99-0.91 (1 H, m),

Ketone 4.93. A solution of ketone $4.92(0.900 \mathrm{~g}, 5.23 \mathrm{mmol})$ in THF $(20 \mathrm{~mL})$ was added dropwise to a stirred suspension of $\mathrm{NaH}(0.163 \mathrm{~g}, 6.80 \mathrm{mmol})$ in $30 \mathrm{~mL}$ THF at $0{ }^{\circ} \mathrm{C}$, and stirring was continued for $1 \mathrm{~h}$. To this solution was added $1.17 \mathrm{~g}$ of 1-iodo-2-methoxyethane $(6.28 \mathrm{mmol})$. After $1 \mathrm{~h}$ at room temperature, the mixture was 
heated to reflux for $7 \mathrm{~h}$. Then the mixture was cooled to $0{ }^{\circ} \mathrm{C}$ and quenched by ice-water. The reaction mixture was extracted with diethyl ether $(3 \times 50 \mathrm{~mL})$. The combined organic extracts were washed with brine and water, dried over sodium sulfate, and concentrated. Flash column chromatography (silica gel $/ 20 \%$ diethyl ether in hexanes) provided $0.746 \mathrm{~g}$ of 4.93 (3.24 mmol, $62 \%$ yield) as yellow oil: ${ }^{1} \mathrm{H} \mathrm{NMR}\left(\mathrm{CDCl}_{3}, 600 \mathrm{MHz}\right) \delta 7.73(1 \mathrm{H}, \mathrm{d}$, $J=7.8 \mathrm{~Hz}), 7.57(1 \mathrm{H}, \mathrm{td}, J=7.8,1.2 \mathrm{~Hz}), 7.42(1 \mathrm{H}, \mathrm{d}, J=7.8 \mathrm{~Hz}), 7.34(1 \mathrm{H}, \mathrm{td}, J=7.8$, $1.2 \mathrm{~Hz}), 5.65-5.57(1 \mathrm{H}, \mathrm{m}), 5.09-5.05(1 \mathrm{H}, \mathrm{m}), 5.00-4.97(1 \mathrm{H}, \mathrm{m}), 3.34-3.27(2 \mathrm{H}, \mathrm{m})$, $3.12(1 \mathrm{H}, \mathrm{d}, J=16.8 \mathrm{~Hz}), 3.11(3 \mathrm{H}, \mathrm{s}), 3.07(1 \mathrm{H}, \mathrm{d}, J=17.4 \mathrm{~Hz}), 2.44-2.39(1 \mathrm{H}, \mathrm{m})$, 2.34-2.30 (1 H, m), 2.07-2.02 (1 H, m), 1.89-1.84 (1 H, m); ${ }^{13} \mathrm{C}$ NMR $\left(\mathrm{CDCl}_{3}, 150\right.$ MHz) $\delta 209.9,152.8136 .6,134.7,133.4,127.3,126.3,123.8,118.5,68.9,58.4,51.1$, $42.1,36.9,36.6$.

Propargylic alcohol 4.94. To $1.09 \mathrm{~g}(3.06 \mathrm{mmol})$ of 4.58 in $30 \mathrm{~mL}$ of THF under a nitrogen atmosphere at $-78{ }^{\circ} \mathrm{C}$ was added $1.78 \mathrm{~mL}$ of a $1.8 \mathrm{M}$ solution of lithium diisopropylamide (LDA, $3.20 \mathrm{mmol}$ ) in hexanes. After $30 \mathrm{~min}$ of stirring, a solution of $0.640 \mathrm{~g}$ of $4.71(2.78 \mathrm{mmol})$ in $10 \mathrm{~mL}$ of THF was introduced via cannula, and the reaction mixture was allowed to warm to room temperature. After an additional $1 \mathrm{~h}, 30$ $\mathrm{mL}$ of water was introduced, and the reaction mixture was extracted with diethyl ether (3 $\times 40 \mathrm{~mL}$ ). The combined organic extracts were washed with brine and water, dried over sodium sulfate, and concentrated. Flash column chromatography (silica gel $/ 20 \%$ diethyl ether in hexanes) provided $1.60 \mathrm{~g}$ of $\mathbf{4 . 9 4}$ (2.72 $\mathrm{mmol}, 98 \%$ yield, $1: 1$ mixture of isomers) as a yellow oil. Diastereomer 1: ${ }^{1} \mathrm{H} \mathrm{NMR}\left(\mathrm{CDCl}_{3}, 600 \mathrm{MHz}\right) \delta 7.60(2 \mathrm{H}, \mathrm{d}, J=7.8 \mathrm{~Hz})$, 7.59-7.56 (1 H, m), 7.53-7.51 (1 H, m), 7.47-7.44 (1 H, m), 7.29-7.27 (2 H, m), 7.16-7.14 (2 H, m), 7.07-7.03 (2 H, m), 5.84-5.76 (1 H, m), 5.02 (1 H, dd, $J=10.2,1.8$ $\mathrm{Hz}), 4.97(1 \mathrm{H}, \mathrm{dd}, J=16.8,1.8 \mathrm{~Hz}), 4.26(1 \mathrm{H}, \mathrm{s}), 3.58-3.53(1 \mathrm{H}, \mathrm{m}), 3.36-3.32(1 \mathrm{H}$, m), $3.33(3 \mathrm{H}, \mathrm{s}), 2.84(1 \mathrm{H}, \mathrm{d}, J=15.6 \mathrm{~Hz}), 2.79(1 \mathrm{H}, \mathrm{d}, J=15.6 \mathrm{~Hz}), 2.67-2.60(1 \mathrm{H}$, m), 2.49-2.44 (1 H, m), 2.03-1.98 (1 H, m), 1.61-1.56 (1 H, m); ${ }^{13} \mathrm{C} \mathrm{NMR}\left(\mathrm{CDCl}_{3}, 150\right.$ 
MHz) $\delta 145.5,140.2,135.1,132.5,132.4,131.2,129.8,128.5,128.1,127.8,127.2,126.8$, 126.7, 125.6, 124.7, 124.5, 123.2, 117.7, 97.1, 94.6, 90.4, 86.4, 80.9, 69.6, 58.8, 54.8, 40.4, 34.4, 33.3; Diastereomer $2:{ }^{1} \mathrm{H}$ NMR $\left(\mathrm{CDCl}_{3}, 600 \mathrm{MHz}\right) \delta 7.67(1 \mathrm{H}, \mathrm{d}, J=7.8$ Hz), 7.64-7.62 (1 H, m), 7.58-7.55 (1 H, m), 7.52 (2 H, d, $J=7.8 \mathrm{~Hz}), 7.36-7.31(2 \mathrm{H}$, m), $7.19(1 \mathrm{H}$, td, $J=7.2,1.2 \mathrm{~Hz}), 7.13-7.09(2 \mathrm{H}, \mathrm{m}), 6.99(1 \mathrm{H}, \mathrm{t}, J=8.4 \mathrm{~Hz})$, 5.67-5.60 (1 H, m), $4.87(1 \mathrm{H}, \mathrm{s}), 4.86(1 \mathrm{H}, \mathrm{dd}, J=10.2,2.4 \mathrm{~Hz}), 4.76(1 \mathrm{H}, \mathrm{dd}, J=16.8$, $1.8 \mathrm{~Hz}), 3.73(1 \mathrm{H}, \mathrm{td}, J=9.6,2.4 \mathrm{~Hz}), 3.51-3.47(1 \mathrm{H}, \mathrm{m}), 3.31(3 \mathrm{H}, \mathrm{s}), 2.88(1 \mathrm{H}, \mathrm{d}, J=$ $15.6 \mathrm{~Hz}), 2.81(1 \mathrm{H}, \mathrm{d}, J=15.6 \mathrm{~Hz}), 2.73-2.69(1 \mathrm{H}, \mathrm{m}), 2.16-2.08(2 \mathrm{H}, \mathrm{m}), 1.89(1 \mathrm{H}$, ddd, $J=15.0,5.4,1.8 \mathrm{~Hz}) ;{ }^{13} \mathrm{C}$ NMR $\left(\mathrm{CDCl}_{3}, 150 \mathrm{MHz}\right) \delta 145.3,141.2,134.9,132.8$, 132.4, 131.2, 129.7, 128.8, 128.6, 127.8, 127.1, 126.7, 125.6, 124.9, 124.7, 124.5, 117.7, $97.0,94.9,90.7,84.8,81.0,68.7,58.5,54.1,41.0,38.9,33.3$.

Diacetylene 4.95. To a mixture of $4.94(1.33 \mathrm{~g}, 2.27 \mathrm{mmol})$ and triethylsilane $(1.10 \mathrm{~mL}$, $6.80 \mathrm{mmol})$ in $50 \mathrm{~mL}$ of dichloromethane was added $1.34 \mathrm{~mL}$ of trifluoroacetic acid (18.1 $\mathrm{mmol})$. After $0.5 \mathrm{~h}$ of stirring at room temperature, $4.5 \mathrm{~g}(42.3 \mathrm{mmol})$ of sodium carbonate was added followed by $50 \mathrm{~mL}$ of water. The organic layer was separated, washed with brine and water, dried over sodium sulfate, and evaporated under reduced pressure. The residue was purified by flash column chromatography (silica gel $/ 20 \%$ diethyl ether in hexanes) to provide $1.23 \mathrm{~g}(2.16 \mathrm{mmol}, 95 \%$, mixture of the diastereomer $)$ of 4.95 as a white solid: ${ }^{1} \mathrm{H}$ NMR (mixture of diastereomers, $\mathrm{CDCl}_{3}, 600 \mathrm{MHz}$ ) $\delta$ 7.66-7.63 (2 H, m), 7.58-7.55 (4 H, m), 7.52-7.48 (2 H, m), $7.44(1 \mathrm{H}, \mathrm{d}, J=7.2 \mathrm{~Hz})$, $7.41(1 \mathrm{H}, \mathrm{d}, J=7.2 \mathrm{~Hz}), 7.34-7.29$ (4H, m), 7.14-7.11 (4 H, m), 7.09-7.05 (2 H, m), $7.02(1 \mathrm{H}, \mathrm{t}, J=8.4 \mathrm{~Hz}), 7.01(1 \mathrm{H}, \mathrm{d}, J=8.4 \mathrm{~Hz}), 6.00-5.92(1 \mathrm{H}, \mathrm{m}), 5.80-5.73(1 \mathrm{H}$, m), 5.08-5.05 (3 H, m), $4.29(1 \mathrm{H}, \mathrm{s}), 4.22(1 \mathrm{H}, \mathrm{s}), 3.70-3.65(1 \mathrm{H}, \mathrm{m}), 3.59-3.54(1 \mathrm{H}$, m), 3.36-3.30 (1 H, m), 3.26-3.19 (1 H, m), $3.28(1 \mathrm{H}, \mathrm{s}), 3.70-3.65(1 \mathrm{H}, \mathrm{m}), 3.12(1 \mathrm{H}$, s), $2.94(1 \mathrm{H}, \mathrm{d}, J=15.6 \mathrm{~Hz}), 2.93(1 \mathrm{H}, \mathrm{d}, J=16.2 \mathrm{~Hz}), 2.87(1 \mathrm{H}, \mathrm{d}, J=15.6 \mathrm{~Hz}), 2.77$ $(1 \mathrm{H}, \mathrm{d}, J=16.2 \mathrm{~Hz}), 2.51-2.47(1 \mathrm{H}, \mathrm{m}), 2.40-2.38(1 \mathrm{H}, \mathrm{m}), 2.25-2.21(1 \mathrm{H}, \mathrm{m})$, 
2.05-1.87 (5 H, m); ${ }^{13} \mathrm{C}$ NMR (mixture of diastereomers, $\left.\mathrm{CDCl}_{3}, 150 \mathrm{MHz}\right) \delta 142.54$, $142.5,141.5,141.2,135.1,135.0,132.6,132.5,132.46,132.4,131.2,129.6,128.6$, $127.54,127.5,127.3,127.27,127.1,127.05,126.6,126.5,126.47,126.2,125.0,124.9$, $124.5,124.4,124.36,124.3,117.9,117.4,97.5,97.4,93.1,92.9,90.5,90.4,83.7,83.6$, $69.8,69.6,58.6,58.3,50.2,50.0,47.47,46.8,43.7,41.8,39.1,38.0,35.7$.

Hydrocarbon 4.96. To $0.820 \mathrm{~g}(1.44 \mathrm{mmol})$ of $4.95 \mathrm{in} 40 \mathrm{~mL}$ of anhydrous toluene under a nitrogen atmosphere was added $3.16 \mathrm{~mL}$ of a $0.5 \mathrm{M}$ solution of potassium tert-butoxide $(1.58 \mathrm{mmol})$ in 2-methyl-2-propanol. The reaction mixture was then heated under $110^{\circ} \mathrm{C}$ for $6 \mathrm{~h}$. After the reaction mixture was allowed to cool to room temperature, $30 \mathrm{~mL}$ of water and $50 \mathrm{~mL}$ of dichloromethane were introduced, and the organic layer was separated, washed with brine and water, dried over sodium sulfate, and concentrated. The residue was purified by flash column chromatography (silica gel/20\% diethyl ether in hexanes) to provide $0.740 \mathrm{~g}(1.30 \mathrm{mmol}, 90 \%)$ of 4.96 as a yellow solid: ${ }^{1} \mathrm{H}$ NMR $\left(\mathrm{CDCl}_{3}, 600 \mathrm{MHz}\right) \delta 7.82(2 \mathrm{H}, \mathrm{d}, J=8.4 \mathrm{~Hz}), 7.58(1 \mathrm{H}, \mathrm{d}, J=7.2 \mathrm{~Hz}), 7.40(1 \mathrm{H}, \mathrm{t}, J=$ 8.4 Hz), 7.31-7.27 (3 H, m), $7.12(1 \mathrm{H}, \mathrm{t}, J=7.8 \mathrm{~Hz}), 7.09(1 \mathrm{H}, \mathrm{d}, J=8.4 \mathrm{~Hz}), 6.57(1 \mathrm{H}$, d, $J=7.8 \mathrm{~Hz}), 5.62-5.54(1 \mathrm{H}, \mathrm{m}), 5.90(1 \mathrm{H}, \mathrm{dd}, J=17.4,1.8 \mathrm{~Hz}), 4.93(1 \mathrm{H}, \mathrm{d}, J=9.6$ Hz), $4.21(1 \mathrm{H}, \mathrm{d}, J=22.2 \mathrm{~Hz}), 4.17(1 \mathrm{H}, \mathrm{d}, J=22.2 \mathrm{~Hz}), 3.50(1 \mathrm{H}, \mathrm{d}, J=17.4 \mathrm{~Hz})$, $3.42(1 \mathrm{H}, \mathrm{d}, J=16.8 \mathrm{~Hz}), 3.29-3.24(1 \mathrm{H}, \mathrm{m}), 3.11-3.06(1 \mathrm{H}, \mathrm{m}), 3.10(3 \mathrm{H}, \mathrm{s})$, 2.88-2.85 (1 H, m), 2.77-2.72 (1 H, m), 2.47-2.42 (1 H, m), 2.33-2.88 (1 H, m) ; ${ }^{13} \mathrm{C}$ $\mathrm{NMR}\left(\mathrm{CDCl}_{3}, 150 \mathrm{MHz}\right) \delta 144.4,144.1,143.4,140.8,140.0,139.8,138.0,134.3,133.6$, $132.4,132.3,130.5,129.0,128.9,127.9,127.3,127.1,125.9,125.85,125.1,122.3,120.1$, $119.2,118.0,69.9,58.6,50.2,44.5,41.9,38.7,34.3$.

Ether 4.97. To $0.050 \mathrm{~g}(0.088 \mathrm{mmol})$ of $\mathbf{4 . 9 6} \mathrm{in} 10 \mathrm{~mL}$ of anhydrous chloroform under a nitrogen atmosphere at room temperature was added $0.1 \mathrm{~mL}$ of trimethylsilyl iodide, and then the reaction mixture was heated to $55^{\circ} \mathrm{C}$. After $48 \mathrm{~h}$ of stirring, the reaction mixture was concentrated in vacuo to remove excess trimethylsily iodide and chloroform. The 
residue was purified by flash column chromatography (silica gel/20\% diethyl ether in hexanes) to provide $0.036 \mathrm{~g}(0.064 \mathrm{mmol}, 73 \%)$ of 4.97 as a yellow solid: ${ }^{1} \mathrm{H}$ NMR $\left(\mathrm{CDCl}_{3}, 600 \mathrm{MHz}\right) \delta 7.82(2 \mathrm{H}, \mathrm{d}, J=8.4 \mathrm{~Hz}), 7.58(1 \mathrm{H}, \mathrm{d}, J=7.2 \mathrm{~Hz}), 7.42(1 \mathrm{H}, \mathrm{t}, J=$ $7.8 \mathrm{~Hz}), 7.32-7.27(3 \mathrm{H}, \mathrm{m}), 7.12-7.27(2 \mathrm{H}, \mathrm{m}), 6.55(1 \mathrm{H}, \mathrm{d}, J=7.8 \mathrm{~Hz}), 4.27(2 \mathrm{H}, \mathrm{s})$, $4.17(1 \mathrm{H}, \mathrm{dd}, J=11.4,3.6 \mathrm{~Hz}), 3.90-3.82(2 \mathrm{H}, \mathrm{m}), 3.52(2 \mathrm{H}, \mathrm{s}), 2.62(1 \mathrm{H}, \mathrm{td}, J=13.2$, $4.8 \mathrm{~Hz}), 2.26(1 \mathrm{H}, \mathrm{t}, J=13.2 \mathrm{~Hz}), 1.75(1 \mathrm{H}, \mathrm{d}, J=13.8 \mathrm{~Hz}), 1.66(1 \mathrm{H}, \mathrm{dd}, J=13.8,1.8$ $\mathrm{Hz}), 1.32(3 \mathrm{H}, \mathrm{d}, J=6.0 \mathrm{~Hz}) ;{ }^{13} \mathrm{C} \mathrm{NMR}\left(\mathrm{CDCl}_{3}, 150 \mathrm{MHz}\right) \delta 146.6,144.1,142.6,140.7$, $140.3,139.9,136.9,133.4,132.4,130.5,129.2,129.0,127.8,127.4,127.1,126.0,125.1$, $122.3,120.2,119.5,70.8,65.4,47.5,43.2,43.0,35.1,34.2,22.2$.

Alcohol 4.98. To a mixture of $0.180 \mathrm{~g}(0.315 \mathrm{mmol})$ of 4.96 and $0.030 \mathrm{~g}$ of 2,6-bis(1,1-dimethylethyl)-4-methyl-Pyridine in $20 \mathrm{~mL}$ of anhydrous chloroform under a nitrogen atmosphere at room temperature was added $0.1 \mathrm{~mL}$ of trimethylsilyl iodide, and then the reaction mixture was heated to $55^{\circ} \mathrm{C}$. After $48 \mathrm{~h}$ of stirring, the reaction mixture was concentrated in vacuo to remove excess trimethylsily iodide and chloroform. The crude mixture was dissolved in $30 \mathrm{~mL}$ of dichloromethane. The organic solvent was washed with brine and water, dried over sodium sulfate, and concentrated. The residue was purified by flash column chromatography (silica gel $/ 20 \%$ diethyl ether in hexanes) to provide $0.152 \mathrm{~g}(0.274 \mathrm{mmol}, 87 \%)$ of $\mathbf{4 . 9 8}$ as a yellow solid: ${ }^{1} \mathrm{H}$ NMR $\left(\mathrm{CDCl}_{3}, 600\right.$ MHz) $\delta 7.82(2 \mathrm{H}, \mathrm{t}, J=7.8 \mathrm{~Hz}), 7.57(1 \mathrm{H}, \mathrm{d}, J=7.8 \mathrm{~Hz}), 7.40(1 \mathrm{H}, \mathrm{t}, J=7.8 \mathrm{~Hz})$, 7.32-7.27 (3 H, m), 7.13-7.08 (2 H, m), $6.56(1 \mathrm{H}, \mathrm{d}, J=7.8 \mathrm{~Hz}), 5.65-5.57(1 \mathrm{H}, \mathrm{m})$, $5.12(1 \mathrm{H}, \mathrm{d}, J=16.8 \mathrm{~Hz}), 4.96(1 \mathrm{H}, \mathrm{d}, J=10.2 \mathrm{~Hz}), 4.21(2 \mathrm{H}, \mathrm{s}), 3.58-3.53(1 \mathrm{H}, \mathrm{m})$, $3.52(1 \mathrm{H}, \mathrm{d}, J=17.4 \mathrm{~Hz}), 3.41(1 \mathrm{H}, \mathrm{d}, J=17.4 \mathrm{~Hz}), 3.42-3.37(1 \mathrm{H}, \mathrm{m}), 2.92-2.88(1 \mathrm{H}$, m), 2.79-2.75 (1 H, m), 2.49-2.43 (1 H, m), 2.29-2.24 (1 H, m), $1.22(1 \mathrm{H}, \mathrm{br} \mathrm{s}) ;{ }^{13} \mathrm{C}$ NMR $\left(\mathrm{CDCl}_{3}, 150 \mathrm{MHz}\right) \delta 144.3,144.0,143.2,140.7,139.9,139.8,137.9,134.2,133.7$, $132.34,132.32,130.5,129.2,129.0,128.0,127.4,127.2,125.9,125.85,125.1,122.3$, $120.2,119.3,118.1,60.1,50.3,44.4,41.9,41.8,34.4$. 
Methanesulfonate 4.99. To $0.340 \mathrm{~g}(0.619 \mathrm{mmol})$ of 4.98 in $30 \mathrm{~mL}$ of methylene chloride at $0{ }^{\circ} \mathrm{C}$ was added $0.50 \mathrm{ml}(6.19 \mathrm{mmol})$ of triethylamine followed by $0.39 \mathrm{~mL}$ (4.95 mmol) of methanesulfonyl chloride. The solution was stirred for $1 \mathrm{~h}$ before $20 \mathrm{ml}$ of a 1.0 M solution of hydrochloric acid was added. The organic layer was separated, and the aqueous layer was extracted with methylene chloride $(3 \times 20 \mathrm{~mL})$. The combined organic layer was washed with brine and water, dried over sodium sulfate and concentrated in vacuo. The residue was purified by column chromatography (silica gel $/ 10 \%$ ethyl acetate in hexanes) to provide $0.375 \mathrm{~g}(0.588 \mathrm{mmol}, 95 \%)$ of 4.99 as a yellow solid: ${ }^{1} \mathrm{H} \mathrm{NMR}\left(\mathrm{CDCl}_{3}, 600 \mathrm{MHz}\right) \delta 7.82(2 \mathrm{H}, \mathrm{d}, J=7.8 \mathrm{~Hz}), 7.58(1 \mathrm{H}, \mathrm{d}, J=$ $7.8 \mathrm{~Hz}), 7.41(1 \mathrm{H}, \mathrm{t}, J=7.8 \mathrm{~Hz}), 7.33-7.29(3 \mathrm{H}, \mathrm{m}), 7.13(1 \mathrm{H}, \mathrm{t}, J=7.2 \mathrm{~Hz}), 7.10(1 \mathrm{H}$, d, $J=7.8 \mathrm{~Hz}), 6.56(1 \mathrm{H}, \mathrm{d}, J=7.8 \mathrm{~Hz}), 5.64-5.56(1 \mathrm{H}, \mathrm{m}), 5.14(1 \mathrm{H}, \mathrm{d}, J=16.8 \mathrm{~Hz})$, $5.00(1 \mathrm{H}, \mathrm{d}, J=10.2 \mathrm{~Hz}), 4.21(1 \mathrm{H}, \mathrm{d}, J=21.6 \mathrm{~Hz}), 4.13(1 \mathrm{H}, \mathrm{d}, J=21.6 \mathrm{~Hz})$, 4.02-3.94 (2 H, m), $3.57(1 \mathrm{H}, \mathrm{d}, J=17.4 \mathrm{~Hz}), 3.46 \quad(1 \mathrm{H}, \mathrm{d}, J=17.4 \mathrm{~Hz}), 2.92-2.88$ (1 $\mathrm{H}, \mathrm{m}), 2.81-2.76(1 \mathrm{H}, \mathrm{m}), 2.61-2.56(1 \mathrm{H}, \mathrm{m}), 2.54-2.50(1 \mathrm{H}, \mathrm{m}), 2.34(3 \mathrm{H}, \mathrm{s}) ;{ }^{13} \mathrm{C}$ $\mathrm{NMR}\left(\mathrm{CDCl}_{3}, 150 \mathrm{MHz}\right) \delta 143.8,143.0,140.5,140.1,139.6,137.9,133.8,133.6,132.5$, $132.4,130.7,129.5,129.1,128.2,127.6,127.3,125.9,125.7,125.1,122.4,120.3,119.6$, $118.7,67.9,50.1,44.5,41.9,37.9,36.3,34.2$.

Iodide 4.100. To $0.450 \mathrm{~g}(0.0 .708 \mathrm{mmol})$ of 4.99 in $60 \mathrm{~mL}$ of anhydrous chloroform at room temperature was added $0.530 \mathrm{~g}(3.50 \mathrm{mmol})$ of sodium iodide and $0.094 \mathrm{~g}(0.7$ mmol) of lithium iodid, and then the reaction mixture was heated to reflux. After $24 \mathrm{~h}$ of stirring, the reaction mixture was cooled to room temperature and concentrated in vacuo to remove acetone. $50 \mathrm{~mL}$ of water and $50 \mathrm{~mL}$ of methylene chloride was added to the solid mixtures. The organic layer was separated, and the aqueous layer was extracted with methylene chloride $(3 \times 20 \mathrm{~mL})$. the combined organic layer was washed with brine and water, dried over sodium sulfate and concentrated in vacuo. The residue was purified by 
column chromatography (silica gel $/ 10 \%$ diethyl ether in hexanes) to provide $0.422 \mathrm{~g}$ (0.630 mmol, $89 \%)$ of 4.100 as a yellow solid: ${ }^{1} \mathrm{H}$ NMR $\left(\mathrm{CDCl}_{3}, 600 \mathrm{MHz}\right) \delta 7.82(2 \mathrm{H}$, d, $J=8.4 \mathrm{~Hz}), 7.59(1 \mathrm{H}, \mathrm{d}, J=7.2 \mathrm{~Hz}), 7.40(1 \mathrm{H}, \mathrm{t}, J=8.4 \mathrm{~Hz}), 7.32-7.26(3 \mathrm{H}, \mathrm{m})$, $7.13(1 \mathrm{H}, \mathrm{t}, J=7.8 \mathrm{~Hz}), 7.10(1 \mathrm{H}, \mathrm{d}, J=7.8 \mathrm{~Hz}), 6.56(1 \mathrm{H}, \mathrm{d}, J=7.8 \mathrm{~Hz}), 5.61-5.54(1$ H, m), $5.11(1 \mathrm{H}, \mathrm{d}, J=16.8 \mathrm{~Hz}), 4.96(1 \mathrm{H}, \mathrm{d}, J=10.2 \mathrm{~Hz}), 4.19(1 \mathrm{H}, \mathrm{d}, J=16.8 \mathrm{~Hz})$, $4.13(1 \mathrm{H}, \mathrm{d}, J=21.0 \mathrm{~Hz}), 3.49(1 \mathrm{H}, \mathrm{d}, J=17.4 \mathrm{~Hz}), 3.32(1 \mathrm{H}, \mathrm{d}, J=16.8 \mathrm{~Hz})$, 3.03-2.99 (1 H, m), 2.87-2.78 (2 H, m), 2.75-2.71 (1 H, m), 2.66-2.55 (2 H, m); ${ }^{13} \mathrm{C}$ NMR $\left(\mathrm{CDCl}_{3}, 150 \mathrm{MHz}\right) \delta 143.8,142.8,140.7,140.0,139.7,138.2,133.8,133.7,132.4$, $132.35,130.6,129.4,129.1,128.0,127.5,127.3,125.9,125.8,125.2,122.4,120.4,119.4$, 118.4, 53.9, 44.6, 43.9, 40.9, 34.2, 0.026 .

Hydrocarbon 4.101. To a solution of iodide $4.100(0.120 \mathrm{~g}, 0.180 \mathrm{mmol})$ in THF $(20 \mathrm{~mL})$ was added a solution of $t$-BuOK $(0.023 \mathrm{~g}, 0.200 \mathrm{mmol})$ in $2 \mathrm{~mL}$ of THF. The reaction mixture was heated to $40{ }^{\circ} \mathrm{C}$. After $2 \mathrm{~h}$ of stirring, the reaction mixture was added another solution of $t$-BuOK $(0.062 \mathrm{~g}, 0.540 \mathrm{mmol})$ in $5 \mathrm{~mL}$ of THF, followed by a solution of iodine $(0.046 \mathrm{~g}, 0.180 \mathrm{mmol})$ in $2 \mathrm{~mL}$ of THF. With extra $5 \mathrm{~h}$ of stirring, the reaction mixture was quenched with aq satd. $\mathrm{NH}_{4} \mathrm{Cl}$, and then extracted with diethyl ether $(3 \times 40$ $\mathrm{mL}$ ). The combined organic extracts were washed with brine and water, dried over sodium sulfate, and concentrated. Flash column chromatography (silica gel/10\% diethyl ether in hexanes) provided $0.064 \mathrm{~g}$ of 4.101 ( $0.119 \mathrm{mmol}, 66 \%$ yield $)$ as a yellow solid: ${ }^{1} \mathrm{H}$ NMR $\left(\mathrm{CDCl}_{3}, 600 \mathrm{MHz}\right) \delta 7.83(1 \mathrm{H}, \mathrm{dd}, J=8.4,1.2 \mathrm{~Hz}), 7.77-7.73(2 \mathrm{H}, \mathrm{m}), 7.37$ $(1 \mathrm{H}, \mathrm{t}, J=8.4 \mathrm{~Hz}), 7.30-7.25(3 \mathrm{H}, \mathrm{m}), 7.19(1 \mathrm{H}, \mathrm{d}, J=8.4 \mathrm{~Hz}), 7.15(1 \mathrm{H}, \mathrm{t}, J=7.8$ $\mathrm{Hz}), 6.77(1 \mathrm{H}, \mathrm{d}, J=7.8 \mathrm{~Hz}), 6.33-6.31(1 \mathrm{H}, \mathrm{m}), 5.88-5.80(1 \mathrm{H}, \mathrm{m}), 5.07(1 \mathrm{H}, \mathrm{dd}, J=$ 17.4, $1.8 \mathrm{~Hz}), 5.02(1 \mathrm{H}, \mathrm{dd}, J=10.8,2.4 \mathrm{~Hz}), 3.77(1 \mathrm{H}, \mathrm{d}, J=15.6 \mathrm{~Hz}), 3.29(1 \mathrm{H}, \mathrm{dd}, J$ $=18.6,4.8 \mathrm{~Hz}), 3.13(1 \mathrm{H}, \mathrm{d}, J=15.6 \mathrm{~Hz}), 2.83(1 \mathrm{H}, \mathrm{dd}, J=18.6,3.0 \mathrm{~Hz}), 2.58-2.53(1$ $\mathrm{H}, \mathrm{m}), 2.51-2.47(1 \mathrm{H}, \mathrm{m}) ;{ }^{13} \mathrm{C} \mathrm{NMR}\left(\mathrm{CDCl}_{3}, 150 \mathrm{MHz}\right) \delta 143.5,142.6,142.1,139.3$, $138.8,136.9,134.5,134.3,132.8,132.2,132.1,131.1,130.5,130.4,128.4,128.2,128.0$, 
127.5, 126.4, 125.6, 123.1, 122.7, 121.7, 120.5, 120.3, 117.9, 47.0, 43.7, 41.3, 39.4.

Hydrozone 4.103. A mixture of 1-indanone $4.66(0.500 \mathrm{~g}, 3.78 \mathrm{mmol}), \quad N, N-$ dimethylhydrazine $(1.5 \mathrm{~mL})$ and acetic acid (one drop) were placed in a sealed reaction vial equipped with a magnetic bar and heated under microwave irradiation at $140^{\circ} \mathrm{C}$ for 20 minutes. The reaction mixture was then concentrated under reduced pressure to remove excess $N, N$-dimethylhydrazine and the crude on purification over a short pack of basic alumina column using 5\% EtOAc in petroleum ether gave $0.657 \mathrm{~g}$ of hydrazone 4.103 (quant.) as a yellow oil: ${ }^{1} \mathrm{H} \mathrm{NMR}\left(\mathrm{CDCl}_{3}, 600 \mathrm{MHz}\right) \delta 7.55(1 \mathrm{H}, \mathrm{d}, J=7.2 \mathrm{~Hz})$, $7.33(1 \mathrm{H}, \mathrm{t}, J=7.2 \mathrm{~Hz}), 7.29(1 \mathrm{H}, \mathrm{d}, J=7.8 \mathrm{~Hz}), 7.23(1 \mathrm{H}, \mathrm{t}, J=7.8 \mathrm{~Hz}), 3.05-3.02(2$ $\mathrm{H}, \mathrm{m}), 2.91-2.88(2 \mathrm{H}, \mathrm{m}), 2.64(6 \mathrm{H}, \mathrm{s}) ;{ }^{13} \mathrm{C} \mathrm{NMR}\left(\mathrm{CDCl}_{3}, 150 \mathrm{MHz}\right) \delta 148.3,138.7$, $130.5,126.8,125.4,122.0,47.0,28.8$.

Ketone 4.67. A solution of hydrozone $4.103(1.04 \mathrm{~g}, 6.00 \mathrm{mmol})$ in THF $(20 \mathrm{~mL})$ was added dropwise to a solution of LDA $(6.2 \mathrm{mmol})$ in anhydrous THF $(20 \mathrm{~mL})$ via cannula at $-40^{\circ} \mathrm{C}$ and the reaction mixture was slowly warmed to $0^{\circ} \mathrm{C}$ for $2 \mathrm{~h}$. 1-iodo-2-methoxyethane $(1.12 \mathrm{~g}, 6.00 \mathrm{mmol})$ in anhydrous THF $(15 \mathrm{~mL})$ was then added dropwise to it and the reation mixture was slowly warmed to $40^{\circ} \mathrm{C}$ and stirred for additional $6 \mathrm{~h}$. It was quenched by addition of saturated aqueous $\mathrm{NH}_{4} \mathrm{Cl}$ solution and extracted with diethyl ether $(50 \mathrm{ml} \times 3)$. The combined organic layer was washed with saturated brine solution and dried over $\mathrm{Na}_{2} \mathrm{SO}_{4}$. Filtration and solvent evaporation under reduced pressure afforded the crude product which was passed through a short pack of basic alumina column using 5\% EtOAc in hexane to remove the most polar impurities. The product thus obtained was then mixed with $\mathrm{MeOH}(50 \mathrm{~mL})$ and $2 \mathrm{~N}$ aqueous $\mathrm{HCl}(30$ $\mathrm{mL}$ ) solution at room temperature and stirred vigorously for $12 \mathrm{~h}$. MeOH was removed under reduced pressure and the aqueous layer was extracted with diethyl ether. The combined organic layer washed with saturated aqueous sodium bicarbonate solution followed by saturated brine solution and dried over anhydrous $\mathrm{Na}_{2} \mathrm{SO}_{4}$. Evaporation of 
solvent followed by purification over silica gel column using 5\% EtOAc in hexane gave $0.695 \mathrm{~g}$ (3.66 mmol, 61\%) of $\mathbf{4 . 6 7}$ as colorless oil: ${ }^{1} \mathrm{H} \mathrm{NMR}\left(\mathrm{CDCl}_{3}, 600 \mathrm{MHz}\right) \delta 7.50(1$ H, d, $J=7.8 \mathrm{~Hz}), 7.57(1 \mathrm{H}, \mathrm{td}, J=7.8,1.2 \mathrm{~Hz}), 7.45(1 \mathrm{H}, \mathrm{d}, J=7.8 \mathrm{~Hz}), 7.36(1 \mathrm{H}, \mathrm{td}, J$ = 7.8, $1.2 \mathrm{~Hz}), 3.58-3.55(2 \mathrm{H}, \mathrm{m}), 3.39-3.34(1 \mathrm{H}, \mathrm{m}), 3.34(3 \mathrm{H}, \mathrm{s}), 2.87(1 \mathrm{H}, \mathrm{dd}, J=$ 16.8, 4.2 Hz), 2.79-2.75 (1 H, m), 2.28-2.23 (1 H, m), 1.75-1.65 (1 H, m); ${ }^{13} \mathrm{C} \mathrm{NMR}$ $\left(\mathrm{CDCl}_{3}, 150 \mathrm{MHz}\right) \delta 208.5,153.6,136.6,134.6,127.3,126.5,123.9,70.8,58.6,44.8$, $33.1,31.2$.

Enol ether 4.104. A suspension of methoxymethyl(triphenylphosphoniumchloride) $(0.418 \mathrm{~g}, 1.22 \mathrm{mmol})$ in THF $(20 \mathrm{ml})$ was cooled to $-20{ }^{\circ} \mathrm{C}$ and $t$-BuOk $(0.109 \mathrm{~g}, 1.22$ $\mathrm{mmol}$ ) in $10 \mathrm{~mL}$ THF was slowly added dropwise to give an organge solution. After 10 minutes a solution of ketone $4.67(0.100 \mathrm{~g}, 0.478 \mathrm{mmol})$ in THF $(10 \mathrm{~mL})$ was added dropwise and the mixture was stirred for 30 mints and then was warmed to ambient temperature and stirred for an additional hour. The mixture was filtered through a celit plug and the filtrate concentrated in vacuo. The residue was precipitated with EtOAc/hexane $(1: 2,50 \mathrm{~mL})$ and filtrated. The filtrate was concentrated and the residue purified by flash chromatograph (10-15\% EtOAc in hexane gradient elution) to give enol ether $4.104\left(0.92 \mathrm{~g}, 0.420 \mathrm{mmol}, 88 \%\right.$, mixture of $Z / E$ diastereomer) as a yellow oil: ${ }^{1} \mathrm{H}$ NMR (mixture of diastereomers, $\left.\mathrm{CDCl}_{3}, 600 \mathrm{MHz}\right) \delta 7.81(1 \mathrm{H}, \mathrm{d}, J=7.8 \mathrm{~Hz}), 7.25(1 \mathrm{H}$, d, $J=7.2 \mathrm{~Hz}), 7.20-7.16(3 \mathrm{H}, \mathrm{m}), 7.14-7.08$ (3 H, m), $6.65(1 \mathrm{H}, \mathrm{d}, J=1.8 \mathrm{~Hz}), 6.15$ (1 H, d, $J=1.8 \mathrm{~Hz}), 3.75(3 \mathrm{H}, \mathrm{s}), 3.71(3 \mathrm{H}, \mathrm{s}), 3.55-3.50(1 \mathrm{H}, \mathrm{m}), 3.48-3.42(3 \mathrm{H}, \mathrm{m})$, $3.36(3 \mathrm{H}, \mathrm{s}), 3.34(3 \mathrm{H}, \mathrm{s}), 3.32-3.26(1 \mathrm{H}, \mathrm{m}), 3.20-3.12(2 \mathrm{H}, \mathrm{m}), 3.08-3.04(1 \mathrm{H}, \mathrm{m})$, 3.20-3.12 (2 H, m), 2.72-2.65 (2 H, m), 2.09-2.02 (1 H, m), 1.84-1.77 (1 H, m), 1.75-1.70 (1 H, m), 1.67-1.61 (1 H, m); ${ }^{13} \mathrm{C}$ NMR (mixture of diastereomers, $\mathrm{CDCl}_{3}$, $150 \mathrm{MHz}) \delta 143.5,143.2,142.3,140.7,139.9,139.5,126.5,126.4,126.3,126.1,125.2$, $125.17,125.0,124.5,123.2,118.3,71.2,70.5,60.3,60.1,60.08,58.6,58.57,58.4,37.6$, 37.1, 36.8, 36.4, 34.3. 
Aldehyde 4.105. $p$-Toluenesulfonic acid monohydrate (0.026 g, $0.140 \mathrm{mmol})$ was added to a solution of the enol ethers $4.104(0.150 \mathrm{~g}, 0.688 \mathrm{mmol})$ in aqueous dioxane (20 mL, dioxane : $\mathrm{H}_{2} \mathrm{O}=3: 1$ ), and the mixture was stirred under reflux for $14 \mathrm{~h}$. It was then cooled to room temperature, diluted with water $(20 \mathrm{ml})$, and extrated with ether (30 $\mathrm{mL} \times 3$ ). The combined organic extracts were washed with aqueous sodium bicarbonate and brine, dried with $\mathrm{Na}_{2} \mathrm{SO}_{4}$ and evaporated. Flash chromatograph of the residue over silica gel with 15\% EtOAc-hexane gave $0.112 \mathrm{~g}(0.550 \mathrm{mmol}, 80 \%)$ of $\mathbf{4 . 1 0 5}$ as colorless oil: ${ }^{1} \mathrm{H}$ NMR $\left(\mathrm{CDCl}_{3}, 600 \mathrm{MHz}\right) \delta 9.634(1 \mathrm{H}, \mathrm{d}, J=3.6 \mathrm{~Hz}), 7.30-7.25(2 \mathrm{H}, \mathrm{m})$, 7.25-7.20 (2 H, m), $3.72(1 \mathrm{H}, \mathrm{dd}, J=7.8,3.6 \mathrm{~Hz}), 3.54-3.48(2 \mathrm{H}, \mathrm{m}), 3.35$ ( $3 \mathrm{H}, \mathrm{s})$, 3.27-3.22 (1 H, dd, $J=16.2,8.4 \mathrm{~Hz}), 3.00-2.94$ (1 H, m), 2.79-2.74 (1 H, dd, $J=15.6$, 8.4 Hz), 1.96-1.86 (2 H, m); ${ }^{13} \mathrm{C} \mathrm{NMR}\left(\mathrm{CDCl}_{3}, 150 \mathrm{MHz}\right) \delta 200.9,143.9,138.3,128.0$, $126.8,125.0,124.7,70.9,63.7,58.5,38.7,38.0,34.6$.

Alkyne 4.106. $\mathrm{K}_{2} \mathrm{CO}_{3}(0.215 \mathrm{~g}, 1.56 \mathrm{mmol})$ was added to a ice-cooled solution of aldehyde 4.105 (0.160 g, $0.784 \mathrm{mmol})$ and diazophosphonate $(0.224 \mathrm{~g}, 1.17 \mathrm{mmol})$ in $\mathrm{MeOH}(10 \mathrm{~mL})$. The resulting solution was stirred for $1 \mathrm{~h}$ at $0{ }^{\circ} \mathrm{C}$ then for $16 \mathrm{~h}$ at RT. The mixture was treated with a saturated aqueous solution of $\mathrm{NH}_{4} \mathrm{Cl}(10 \mathrm{~mL}) . \mathrm{MeOH}$ was removed under reduced pressure and the aqueous layer was extracted with diethyl ether (3 $\times 30 \mathrm{~mL}$ ). The combined organic layer saturated brine solution and dried over anhydrous $\mathrm{Na}_{2} \mathrm{SO}_{4}$. Evaporation of solvent followed by purification over silica gel column using 5\% EtOAc in hexane gave $0.108 \mathrm{~g}(0.539 \mathrm{mmol}, 72 \%)$ of 4.106 as colorless oil: ${ }^{1} \mathrm{H}$ NMR $\left(\mathrm{CDCl}_{3}, 600 \mathrm{MHz}\right) \delta 7.39(1 \mathrm{H}, \mathrm{d}, J=8.4 \mathrm{~Hz}), 7.25-7.17(3 \mathrm{H}, \mathrm{m})$, 3.67-3.65 (1 H, m), $3.59(1 \mathrm{H}, \mathrm{t}, J=7.2 \mathrm{~Hz}), 3.39(3 \mathrm{H}, \mathrm{s}), 3.12-3.06(1 \mathrm{H}, \mathrm{m})$, 2.64-2.56 (2 H, m), 2.25 (1 H, d, $J=2.4 \mathrm{~Hz}), 2.19-2.14$ (1 H, m), 1.88-1.82 (1 H, m); ${ }^{13} \mathrm{C} \mathrm{NMR}\left(\mathrm{CDCl}_{3}, 150 \mathrm{MHz}\right) \delta 142.7,142.1,127.2,126.7,124.3,123.9,85.3,71.4,69.9$, $58.6,46.6,42.3,37.9,34.0$. 
Diacetylene 4.107. To a mixture of 1,3-dibromo-2-((2-iodophenyl)ethynyl)benzene (0.185 g, $0.402 \mathrm{mmol}), \mathrm{Pd}\left(\mathrm{PPh}_{3}\right)_{2} \mathrm{Cl}_{2}(0.021 \mathrm{~g}, 0.030 \mathrm{mmol})$, and $\mathrm{CuI}(0.010 \mathrm{~g}, 0.053$ $\mathrm{mmol}$ ) in $20 \mathrm{~mL}$ of triethylamine under a nitrogen atmosphere was added via cannula a solution of alkyne $4.106(0.080 \mathrm{~g}, 0.400 \mathrm{mmol})$ in $5 \mathrm{~mL}$ of triethylamine. The resulting mixture was heated to $35^{\circ} \mathrm{C}$ for $12 \mathrm{~h}$ before it was allowed to cool to room temperature. The reaction mixture was concentrated in vacuo. The black residue was dissolved in 100 $\mathrm{mL}$ of dichloromethane and then washed with brine and water. The organic layer was separated, dried over sodium sulfate, and concentrated. Purification by silica gel column using 5\% EtOAc in hexane gave $0.159 \mathrm{~g}(0.300 \mathrm{mmol}, 75 \%)$ of 4.107 as colorless oil: ${ }^{1} \mathrm{H}$ NMR $\left(\mathrm{CDCl}_{3}, 600 \mathrm{MHz}\right) \delta 7.65-7.64(1 \mathrm{H}, \mathrm{m}), 7.55(2 \mathrm{H}, \mathrm{d}, J=8.4 \mathrm{~Hz}), 7.51-7.48(1 \mathrm{H}$, m), $7.46(1 \mathrm{H}, \mathrm{d}, J=7.8 \mathrm{~Hz}), 7.32-7.29(1 \mathrm{H}, \mathrm{m}), 7.17(1 \mathrm{H}, \mathrm{t}, J=7.2 \mathrm{~Hz}), 7.15(1 \mathrm{H}, \mathrm{t}, J$ $=7.2 \mathrm{~Hz}), 7.10(1 \mathrm{H}, \mathrm{t}, J=7.2 \mathrm{~Hz}), 7.00(1 \mathrm{H}, \mathrm{t}, J=8.4 \mathrm{~Hz}), 3.94(1 \mathrm{H}, \mathrm{d}, J=9.6 \mathrm{~Hz})$, $3.56(2 \mathrm{H}, \mathrm{t}, J=6.6 \mathrm{~Hz}), 3.32(3 \mathrm{H}, \mathrm{s}), 3.10(1 \mathrm{H}, \mathrm{dd}, J=15.6,7.8 \mathrm{~Hz}), 2.75-2.68(1 \mathrm{H}$, m), 2.66-2.62 (1 H, m), 2.23-2.17 (1 H, m), 1.89-1.82 (1 H, m); ${ }^{13} \mathrm{C} \mathrm{NMR}\left(\mathrm{CDCl}_{3}, 150\right.$ MHz) $\delta 143.0,142.2,132.6,132.4,131.2,129.6,128.6,127.5,127.3,127.0,126.6,126.5$, $126.2,125.1,124.5,124.2,97.5,95.5,90.6,80.9,71.6,58.5,46.9,43.7,38.0,34.2$.

Hydrocarbon 4.108. To $0.080 \mathrm{~g}(0.150 \mathrm{mmol})$ of $4.107 \mathrm{in} 10 \mathrm{~mL}$ of anhydrous toluene under a nitrogen atmosphere was added $0.33 \mathrm{~mL}$ of a $0.5 \mathrm{M}$ solution of potassium tert-butoxide $(0.15 \mathrm{mmol})$ in 2-methyl-2-propanol. The reaction mixture was then heated under $80{ }^{\circ} \mathrm{C}$ for $2 \mathrm{~h}$. After the reaction mixture was allowed to cool to room temperature, $10 \mathrm{~mL}$ of water and $20 \mathrm{~mL}$ of dichloromethane were introduced, and the organic layer was separated, dried over sodium sulfate, and concentrated. Purification by silica gel column using 5\% EtOAc in hexane gave $0.008 \mathrm{~g}(0.015 \mathrm{mmol}, 10 \%)$ of 4.107 as white solid: ${ }^{1} \mathrm{H}$ NMR $\left(\mathrm{CDCl}_{3}, 600 \mathrm{MHz}\right) \delta 7.83-7.80(2 \mathrm{H}, \mathrm{m}), 7.57(1 \mathrm{H}, \mathrm{d}, J=7.2 \mathrm{~Hz})$, 7.42-7.39 (1 H, m), 7.31-7.26 (2 H, m), 7.13-7.08 (1 H, m), 6.57 (1 H, d, J=7.8 Hz), $4.20(1 \mathrm{H}, \mathrm{d}, J=21 \mathrm{~Hz}), 4.06(1 \mathrm{H}, \mathrm{d}, J=21 \mathrm{~Hz}), 4.07-4.02(1 \mathrm{H}, \mathrm{m}), 3.71(1 \mathrm{H}, \mathrm{dd}, J=$ 
17.4, $8.4 \mathrm{~Hz}), 3.65-3.56(2 \mathrm{H}, \mathrm{m}), 3.40(3 \mathrm{H}, \mathrm{s}), 3.27(1 \mathrm{H}, \mathrm{dd}, J=16.8,3.6 \mathrm{~Hz})$, 2.66-2.60 (1 H, m), 2.00-1.94 (1 H, m); ${ }^{13} \mathrm{C} \mathrm{NMR}\left(\mathrm{CDCl}_{3}, 150 \mathrm{MHz}\right) \delta 144.3,143.6$, $141.0,139.9,138.1,133.9,132.3,130.5,129.1,128.6,127.8,127.3,127.1,126.0,125.9$, $125.2,122.3,120.0,119.3,71.2,58.8,40.2,37.7,34.6,33.7$.

2-(4-methoxybenzyloxy)-3-methylnaphthalen-1-ol (4.121). To a stirred solution of allene $4.117(1.14 \mathrm{~g}, 6.50 \mathrm{mmol})$ in THF $(100 \mathrm{~mL})$ was added dropwise a $1.6 \mathrm{M}$ solution of $\mathrm{n}$-BuLi $(4.06 \mathrm{~mL}, 6.50 \mathrm{mmol})$ in hexane under $\mathrm{N}_{2}$ at $-78{ }^{\circ} \mathrm{C}$. After stirring was continued for $1 \mathrm{~h}$ at $-78{ }^{\circ} \mathrm{C}$, benzocyclobutanone $4.113(0.760 \mathrm{~g}, 6.44 \mathrm{mmol})$ in $5 \mathrm{~mL}$ of THF was added dropwise to this solution. Stirring was continued for $1 \mathrm{~h}$ at $-78^{\circ} \mathrm{C}$ and then warmed up to room temperature. The mixture was quenched with a solution of TFA (12.0 mmol in 1:1THF/water) and extracted with diethyl ether. The combined extracts was washed with brine and water, dried over $\mathrm{Na}_{2} \mathrm{SO}_{4}$, and concentrated in vacuo. The residue was purified by flash chromatography (silica gel $/ 20 \%$ diethyl ether in hexanes) to provide $4.121(1.79 \mathrm{~g}, 6.12 \mathrm{mmol}, 95 \%)$ as a yellow oil: ${ }^{1} \mathrm{H} \mathrm{NMR}\left(\mathrm{CDCl}_{3}, 600 \mathrm{MHz}\right) \delta$ 8.10-8.08 (1 H, m), 7.70-6.68 (1 H, m), 7.41-7.36 (4 H, m), $7.24(1 \mathrm{H}, \mathrm{s}), 6.94(2 \mathrm{H}, \mathrm{d}, J$ $=9.0 \mathrm{~Hz}), 5.91(1 \mathrm{H}, \mathrm{s}), 4.90(2 \mathrm{H}, \mathrm{s}), 3.83(3 \mathrm{H}, \mathrm{s}), 2.52(3 \mathrm{H}, \mathrm{d}, J=0.6 \mathrm{~Hz}) ;{ }^{13} \mathrm{C} \mathrm{NMR}$ $\left(\mathrm{CDCl}_{3}, 150 \mathrm{MHz}\right) \delta 160.0,143.6,140.1,131.2,130.5,130.0,129.1,126.7,125.4,124.3$, $123.2,121.7,120.2,114.3,75.5,55.3,17.1$.

Hydroxyketone 4.122. To a stirred solution of allene 4.117 (1.49 g, $8.47 \mathrm{mmol})$ in THF $(100 \mathrm{~mL})$ was added dropwise a $1.6 \mathrm{M}$ solution of $\mathrm{n}$-BuLi $(5.29 \mathrm{~mL}, 8.47 \mathrm{mmol})$ in hexane under $\mathrm{N}_{2}$ at $-78{ }^{\circ} \mathrm{C}$. After stirring was continued for $1 \mathrm{~h}$ at $-78{ }^{\circ} \mathrm{C}$, benzocyclobutanone $4.113(1.00 \mathrm{~g}, 8.47 \mathrm{mmol})$ in $10 \mathrm{~mL}$ of THF was added dropwise to this solution. The reaction mixture was stirred for $1 \mathrm{~h}$ at $-78{ }^{\circ} \mathrm{C}$, then added a solution of TFA (16.0 mmol in 1:1THF/water). When the reaction is complete, the mixture was extracted with diethyl ether $(3 \times 100 \mathrm{~mL})$. The combined extracts was washed with brine 
and water, dried over $\mathrm{Na}_{2} \mathrm{SO}_{4}$, and concentrated in vacuo. The residue was purified by flash chromatography (silica gel $/ 20 \%$ diethyl ether in hexanes) to provide 4.122 (1.35 g, 7.79 mmol, $92 \%)$ as a yellow oil: ${ }^{1} \mathrm{H}$ NMR $\left(\mathrm{CDCl}_{3}, 600 \mathrm{MHz}\right) \delta 7.78(1 \mathrm{H}, \mathrm{d}, J=7.8$ $\mathrm{Hz}), 7.64(1 \mathrm{H}, \mathrm{td}, J=7.8,1.2 \mathrm{~Hz}), 7.46(1 \mathrm{H}, \mathrm{d}, J=7.8 \mathrm{~Hz}), 7.41(1 \mathrm{H}, \mathrm{t}, J=7.8 \mathrm{~Hz})$, $5.89(1 \mathrm{H}, \mathrm{dd}, J=17.4,10.8 \mathrm{~Hz}), 5.40(1 \mathrm{H}, \mathrm{d}, J=17.4 \mathrm{~Hz}), 5.21(1 \mathrm{H}, \mathrm{d}, J=10.8 \mathrm{~Hz})$, $3.39(1 \mathrm{H}, \mathrm{d}, J=16.8 \mathrm{~Hz}), 3.29(1 \mathrm{H}, \mathrm{d}, J=16.8 \mathrm{~Hz}), 3.12(1 \mathrm{H}, \mathrm{br} \mathrm{s}) ;{ }^{13} \mathrm{C} \mathrm{NMR}\left(\mathrm{CDCl}_{3}\right.$, $150 \mathrm{MHz}) \delta 205.4,150.9,138.0,136.0,133.8,128.1,126.7,125.0,115.1,80.9,41.2$.

Methoxyketone 4.123. A solution of hydroxyketone $4.122(0.200 \mathrm{~g}, 1.15 \mathrm{mmol})$ in anhydrous THF $(10 \mathrm{~mL})$ was added dropwise to a suspension of sodium hydride $[60 \%$ suspension in mineral oil] (55 mg, $1.38 \mathrm{mmol})$ in anhydrous THF $(20 \mathrm{~mL})$ at $0{ }^{\circ} \mathrm{C}$. After being stirred for $1 \mathrm{~h}$, iodo methane $(0.22 \mathrm{~mL}, 3.45 \mathrm{mmol})$ was slowly added to it. The resulting solution was then slowly warmed to room temperature and stirred for $24 \mathrm{~h}$. It was quenched with saturated aqueous $\mathrm{NH}_{4} \mathrm{Cl}$ solution and extracted with diethyl ether (3 x $20 \mathrm{~mL}$ ). The combined extracts was washed with brine and water, dried over $\mathrm{Na}_{2} \mathrm{SO}_{4}$, and concentrated in vacuo. The residue was purified by flash chromatography (silica gel $/ 10 \%$ diethyl ether in hexanes) to provide $0.214 \mathrm{~g}$ of $\mathbf{4 . 1 2 3}(1.14 \mathrm{mmol}, 99 \%)$ as yellow oil: ${ }^{1} \mathrm{H} \mathrm{NMR}\left(\mathrm{CDCl}_{3}, 600 \mathrm{MHz}\right) \delta 7.76(1 \mathrm{H}, \mathrm{d}, J=7.2 \mathrm{~Hz}), 7.61(1 \mathrm{H}, \mathrm{td}, J=7.8$, $1.2 \mathrm{~Hz}), 7.44(1 \mathrm{H}, \mathrm{d}, J=7.8 \mathrm{~Hz}), 7.41(1 \mathrm{H}, \mathrm{t}, J=7.2 \mathrm{~Hz}), 5.93(1 \mathrm{H}, \mathrm{dd}, J=17.4,10.8$ $\mathrm{Hz}), 5.36(1 \mathrm{H}, \mathrm{d}, J=17.4 \mathrm{~Hz}), 5.21(1 \mathrm{H}, \mathrm{d}, J=10.8 \mathrm{~Hz}), 3.37(3 \mathrm{H}, \mathrm{s}), 3.35(1 \mathrm{H}, \mathrm{d}, J=$ $18.0 \mathrm{~Hz}), 3.20(1 \mathrm{H}, \mathrm{d}, J=18.0 \mathrm{~Hz}) ;{ }^{13} \mathrm{C} \mathrm{NMR}\left(\mathrm{CDCl}_{3}, 150 \mathrm{MHz}\right) \delta 202.5,150.5,136.0$, 135.6, 134.7, 127.9, 126.5, 124.8, 118.0, 85.4, 52.5, 37.4 .

Propargylic alcohol 4.124. To $0.392 \mathrm{~g}(1.10 \mathrm{mmol})$ of 4.58 in $30 \mathrm{~mL}$ of THF under a nitrogen atmosphere at $-78{ }^{\circ} \mathrm{C}$ was added $0.67 \mathrm{~mL}$ of a $1.8 \mathrm{M}$ solution of lithium diisopropylamide (LDA, $1.20 \mathrm{mmol}$ ) in hexanes. After $30 \mathrm{~min}$ of stirring, a solution of $0.200 \mathrm{~g}$ of $4.123(1.06 \mathrm{mmol})$ in $5 \mathrm{~mL}$ of THF was introduced via cannula, and the reaction mixture was allowed to warm to room temperature. After an additional $1 \mathrm{~h}, 30$ 
$\mathrm{mL}$ of water was introduced, and the reaction mixture was extracted with diethyl ether (3 $\times 40 \mathrm{~mL}$ ). The combined organic extracts were washed with brine and water, dried over sodium sulfate, and concentrated. Flash column chromatography (silica gel $/ 20 \%$ diethyl ether in hexanes) provided $0.569 \mathrm{~g}$ of $\mathbf{4 . 1 2 4}$ (1.04 mmol, 98\% yield) as a yellow oil; ${ }^{1} \mathrm{H}$ NMR $\left(\mathrm{CDCl}_{3}, 600 \mathrm{MHz}\right) \delta 7.68(1 \mathrm{H}, \mathrm{d}, J=7.8 \mathrm{~Hz}), 7.56-7.52(2 \mathrm{H}, \mathrm{m}), 7.51-7.49(2 \mathrm{H}$, m), 7.32-7.23 (7 H, m), $7.14(1 \mathrm{H}, \mathrm{t}, J=7.2 \mathrm{~Hz}), 6.14(1 \mathrm{H}, \mathrm{dd}, J=17.4,10.8 \mathrm{~Hz}), 5.56$ $(1 \mathrm{H}, \mathrm{d}, J=17.4 \mathrm{~Hz}), 5.51(1 \mathrm{H}, \mathrm{d}, J=10.8 \mathrm{~Hz}), 3.28(1 \mathrm{H}, \mathrm{d}, J=15.6 \mathrm{~Hz}), 3.17(1 \mathrm{H}, \mathrm{d}$, $J=15.6 \mathrm{~Hz}), 3.20(3 \mathrm{H}, \mathrm{s}), 2.45(1 \mathrm{H}, \mathrm{s}) ;{ }^{13} \mathrm{C} \mathrm{NMR}\left(\mathrm{CDCl}_{3}, 150 \mathrm{MHz}\right) \delta 144.0,140.4$, 135.6, 132.3, 131.8, 131.76, 129.1, 128.3, 128.2, 128.1, 127.8, 127.2, 126.1, 125.3, 125.1, $124.4,123.2,120.6,93.3,91.9,91.7,88.2,86.0,81.2,51.9,34.8$.

Diacetylene 4.126. To a mixture of $4.124(0.150 \mathrm{~g}, 0.385 \mathrm{mmol})$ and triethylsilane $(0.19$ $\mathrm{mL}, 1.15 \mathrm{mmol}$ ) in $20 \mathrm{~mL}$ of dichloromethane was added $0.22 \mathrm{~mL}$ of trifluoroacetic acid ( $3.08 \mathrm{mmol})$. After $0.5 \mathrm{~h}$ of stirring at room temperature, $0.500 \mathrm{~g}(4.7 \mathrm{mmol})$ of sodium carbonate was added followed by $20 \mathrm{~mL}$ of water. The organic layer was separated, washed with brine and water, dried over sodium sulfate, and evaporated under reduced pressure. The residue was purified by flash column chromatography (silica gel/10\% diethyl ether in hexanes) to provide $0.075 \mathrm{~g}(0.20 \mathrm{mmol}, 52 \%)$ of $\mathbf{4 . 1 2 6}$ as a white solid: ${ }^{1} \mathrm{H} \mathrm{NMR}\left(\mathrm{CDCl}_{3}, 600 \mathrm{MHz}\right) \delta 7.53-7.49(2 \mathrm{H}, \mathrm{m}), 7.47(1 \mathrm{H}, \mathrm{d}, J=7.2 \mathrm{~Hz}), 7.40(2 \mathrm{H}, \mathrm{d}$, $J=7.2 \mathrm{~Hz}), 7.32-7.25(5 \mathrm{H}, \mathrm{m}), 7.19(2 \mathrm{H}, \mathrm{d}, J=4.2 \mathrm{~Hz}), 7.11-7.08(1 \mathrm{H}, \mathrm{m}), 6.16(1 \mathrm{H}$, dd, $J=17.4,11.4 \mathrm{~Hz}), 5.21(1 \mathrm{H}, \mathrm{d}, J=17.4 \mathrm{~Hz}), 5.51(1 \mathrm{H}, \mathrm{d}, J=10.8 \mathrm{~Hz}), 4.55(1 \mathrm{H}, \mathrm{s})$, $3.36(3 \mathrm{H}, \mathrm{s}), 3.26(1 \mathrm{H}, \mathrm{d}, J=15.6 \mathrm{~Hz}), 3.15(1 \mathrm{H}, \mathrm{d}, J=15.6 \mathrm{~Hz}) ;{ }^{13} \mathrm{C} \mathrm{NMR}\left(\mathrm{CDCl}_{3}\right.$, $150 \mathrm{MHz}) \delta 140.8,139.5,137.2,132.2,131.9,131.8,128.2,128.17,127.8,127.6,127.5$, $127.2,126.0,125.8,124.6,124.1,123.3,117.2,93.0,91.4,90.1,88.4,84.3,52.7,48.3$, 40.5 .

Propargylic alcohol 4.129. To $0.069 \mathrm{~g}(0.700 \mathrm{mmol})$ of ethynyltrimethylsilane 4.128 in 
$10 \mathrm{~mL}$ of THF under a nitrogen atmosphere at $-78^{\circ} \mathrm{C}$ was added $0.38 \mathrm{~mL}$ of a $1.8 \mathrm{M}$ solution of lithium diisopropylamide (LDA, $0.700 \mathrm{mmol}$ ) in hexanes. After $30 \mathrm{~min}$ of stirring, a solution of $0.100 \mathrm{~g}$ of $\mathbf{4 . 1 2 3}(0.532 \mathrm{mmol})$ in $5 \mathrm{~mL}$ of THF was introduced via cannula, and the reaction mixture was allowed to warm to room temperature. After an additional $1 \mathrm{~h}, 10 \mathrm{~mL}$ of water was introduced, and the reaction mixture was extracted with diethyl ether $(3 \times 20 \mathrm{~mL})$. The combined organic extracts were washed with brine and water, dried over sodium sulfate, and concentrated. Flash column chromatography (silica gel/20\% diethyl ether in hexanes) provided $0.143 \mathrm{~g}$ of 4.129 (0.500 mmol, 94\% yield) as a yellow oil; ${ }^{1} \mathrm{H} \mathrm{NMR}$ (major diastereomer, $\left.\mathrm{CDCl}_{3}, 600 \mathrm{MHz}\right) \delta 7.56-7.54(1 \mathrm{H}$, m), 7.30-7.27 (3 H, m), 6.97 (1 H, dd, $J=17.4,10.8 \mathrm{~Hz}), 5.61-7.54(2 \mathrm{H}, \mathrm{m}), 3.24(1 \mathrm{H}$, d, $J=15.6 \mathrm{~Hz}), 3.23(3 \mathrm{H}, \mathrm{s}), 3.15(1 \mathrm{H}, \mathrm{d}, J=15.6 \mathrm{~Hz}), 0.22(9 \mathrm{H}, \mathrm{s}) ;{ }^{13} \mathrm{C} \mathrm{NMR}\left(\mathrm{CDCl}_{3}\right.$, $150 \mathrm{MHz}) \delta 143.8,140.5,135.4,129.2,127.3,125.2,124.1,120.7,92.2,91.6,80.8,67.9$, $51.9,34.8,-0.006$.

Alkyne 4.130. To a solution of trimethylsilyl-alkyne $4.129(0.303 \mathrm{~g}, 1.06 \mathrm{mmol})$ in a premixed mixture of acetone-water-dichloromethane $(4: 1: 7,20 \mathrm{~mL})$ was added silver triflate $(0.038 \mathrm{~g}, 0.150 \mathrm{mmol})$. The resulting mixture was then stirred at room temperature. Once the starting materials disappeared, an aqueous saturated solution of ammonium chloride $(10 \mathrm{~mL})$ was added. The reaction mixture was extracted with dichloromethane (3 $\times 10 \mathrm{~mL}$ ). The combined organic extracts were washed with brine and water, dried over sodium sulfate, and concentrated. Flash column chromatography (silica gel/25\% diethyl ether in hexanes) provided $0.202 \mathrm{~g}$ of 4.130 (0.940 mmol, $89 \%$ yield) as a yellow oil; ${ }^{1} \mathrm{H}$ NMR $\left(\mathrm{CDCl}_{3}, 600 \mathrm{MHz}\right) \delta 7.56(1 \mathrm{H}, \mathrm{dd}, J=6.6,1.8 \mathrm{~Hz}), 7.31-7.25(3 \mathrm{H}, \mathrm{m}), 6.07(1 \mathrm{H}$, dd, $J=17.4,10.8 \mathrm{~Hz}), 5.60(1 \mathrm{H}, \mathrm{dd}, J=10.8,1.2 \mathrm{~Hz}), 5.56(1 \mathrm{H}, \mathrm{dd}, J=17.4,1.2 \mathrm{~Hz})$, $3.26(1 \mathrm{H}, \mathrm{d}, J=16.2 \mathrm{~Hz}), 3.25(3 \mathrm{H}, \mathrm{s}), 3.18(1 \mathrm{H}, \mathrm{d}, J=16.2 \mathrm{~Hz}), 2.72(1 \mathrm{H}, \mathrm{s}) ;{ }^{13} \mathrm{C}$ NMR $\left(\mathrm{CDCl}_{3}, 150 \mathrm{MHz}\right) \delta 143.6,140.2,135.1,129.3,127.3,125.1,124.0,120.9,91.6$, $82.2,80.5,75.3,52.0,34.6$. 
Allenic bromide 4.131. To $0.0130 \mathrm{~g}(0.607 \mathrm{mmol})$ of 4.130 in $20 \mathrm{~mL}$ of THF at $-40{ }^{\circ} \mathrm{C}$ was added $0.5 \mathrm{~mL}(7 \mathrm{mmoL})$ of pyridien followed by $0.1 \mathrm{~mL}(1.3 \mathrm{mmol})$ of thionyl bromide. The solution was allowed to warm to $0{ }^{\circ} \mathrm{C}$ in $1 \mathrm{~h}$ before it was quenched with an aqueous saturated solution of ammonium chloride. The organic layer was separated. The aqueous layer was extracted with diethyl ether $(3 \times 20 \mathrm{~mL})$. The combined organic extracts were washed with brine and water, dried over sodium sulfate, and concentrated. Flash column chromatography (silica gel $/ 15 \%$ diethyl ether in hexanes) provided $0.119 \mathrm{~g}$ of 4.131 ( $0.431 \mathrm{mmol}, 71 \%$ yield) as a yellow oil: ${ }^{1} \mathrm{H} \mathrm{NMR}$ (major diastereomer, $\mathrm{CDCl}_{3}$, $600 \mathrm{MHz}) \delta 7.40-7.38(1 \mathrm{H}, \mathrm{m}), 7.29-7.23(3 \mathrm{H}, \mathrm{m}), 6.52(1 \mathrm{H}, \mathrm{s}), 6.10(1 \mathrm{H}, \mathrm{dd}, J=$ 17.4, $10.8 \mathrm{~Hz}), 5.44(1 \mathrm{H}, \mathrm{dd}, J=17.4,0.6 \mathrm{~Hz}), 5.33(1 \mathrm{H}, \mathrm{dd}, J=10.8,0.6 \mathrm{~Hz}), 3.31(1$ $\mathrm{H}, \mathrm{d}, J=17.4 \mathrm{~Hz}$ ), $3.25(3 \mathrm{H}, \mathrm{s}), 3.23(1 \mathrm{H}, \mathrm{d}, J=17.4 \mathrm{~Hz}) ;{ }^{13} \mathrm{C}$ NMR (major diastereomer, $\left.\mathrm{CDCl}_{3}, 150 \mathrm{MHz}\right) \delta 198.3,141.8,139.0,138.4,135.2,129.8,127.5,125.0$, $124.2,116.3,87.4,77.3,51.5,43.8$.

Hydrocarbon 4.138. To a mixture of $0.280 \mathrm{~g}(0.600 \mathrm{mmol})$ of 4.132 in $10 \mathrm{~mL}$ of THF at $-78^{\circ} \mathrm{C}$ was added dropwise $0.38 \mathrm{~mL}(0.600 \mathrm{mmol})$ of a $1.6 \mathrm{M}$ solution of butyllithium in hexanes. The solution was stirred at $-78^{\circ} \mathrm{C}$ for $10 \mathrm{~min}$ before $0.600 \mathrm{~mL}$ of $1.0 \mathrm{M}$ solution ( $0.600 \mathrm{mmol})$ of zinc chloride in diethyl ether was introduced to form 4.136. The solution was allowed to warm to $-40^{\circ} \mathrm{C}$ and stirred for $1 \mathrm{~h}$. In a separated flask, $0.110 \mathrm{~g}(0.40$ $\mathrm{mmol})$ of 4.131 and $0.020 \mathrm{~g}(0.017 \mathrm{mmol})$ of tetrakis(triphenylphosphine)palladium were dissolved in $10 \mathrm{~mL}$ of THF. The mixture was stirred at room temperature for $15 \mathrm{~min}$ before it was transferred via cannula into the flask containing the zinc reagent 4.136. The reaction mixture was stirred at room temperature for overnight and was quenched with an aqueous saturated solution of ammonium chloride. The organic layer was separated. The aqueous layer was extracted with diethyl ether $(3 \times 20 \mathrm{~mL})$. The combined organic extracts were washed with brine and water, dried over sodium sulfate, and concentrated. 
Flash column chromatography (silica gel $/ 15 \%$ diethyl ether in hexanes) provided $0.176 \mathrm{~g}$ of 4.138 (0.304 mmol, 76\% yield) as a yellow oil: ${ }^{1} \mathrm{H}$ NMR (major diastereomer, $\mathrm{CDCl}_{3}$, $600 \mathrm{MHz}) \delta 7.75(1 \mathrm{H}, \mathrm{d}, J=9.0 \mathrm{~Hz}), 7.50-7.46(2 \mathrm{H}, \mathrm{m}), 7.42-7.37(2 \mathrm{H}, \mathrm{m}), 7.34-7.31$ $(3 \mathrm{H}, \mathrm{m}), 7.27(1 \mathrm{H}, \mathrm{d}, J=8.4 \mathrm{~Hz}), 7.11(1 \mathrm{H}, \mathrm{t}, J=7.8 \mathrm{~Hz}), 6.22-6.16(1 \mathrm{H}, \mathrm{m})$, 5.37-5.33 (1 H, m), 5.22-5.19 (1 H, m), $4.20(1 \mathrm{H}, \mathrm{d}, J=22.2 \mathrm{~Hz}), 4.07(1 \mathrm{H}, \mathrm{d}, J=22.8$ $\mathrm{Hz}), 3.79(1 \mathrm{H}, \mathrm{d}, J=17.4 \mathrm{~Hz}), 3.51(1 \mathrm{H}, \mathrm{d}, J=17.4 \mathrm{~Hz}), 3.15(3 \mathrm{H}, \mathrm{s})$. 

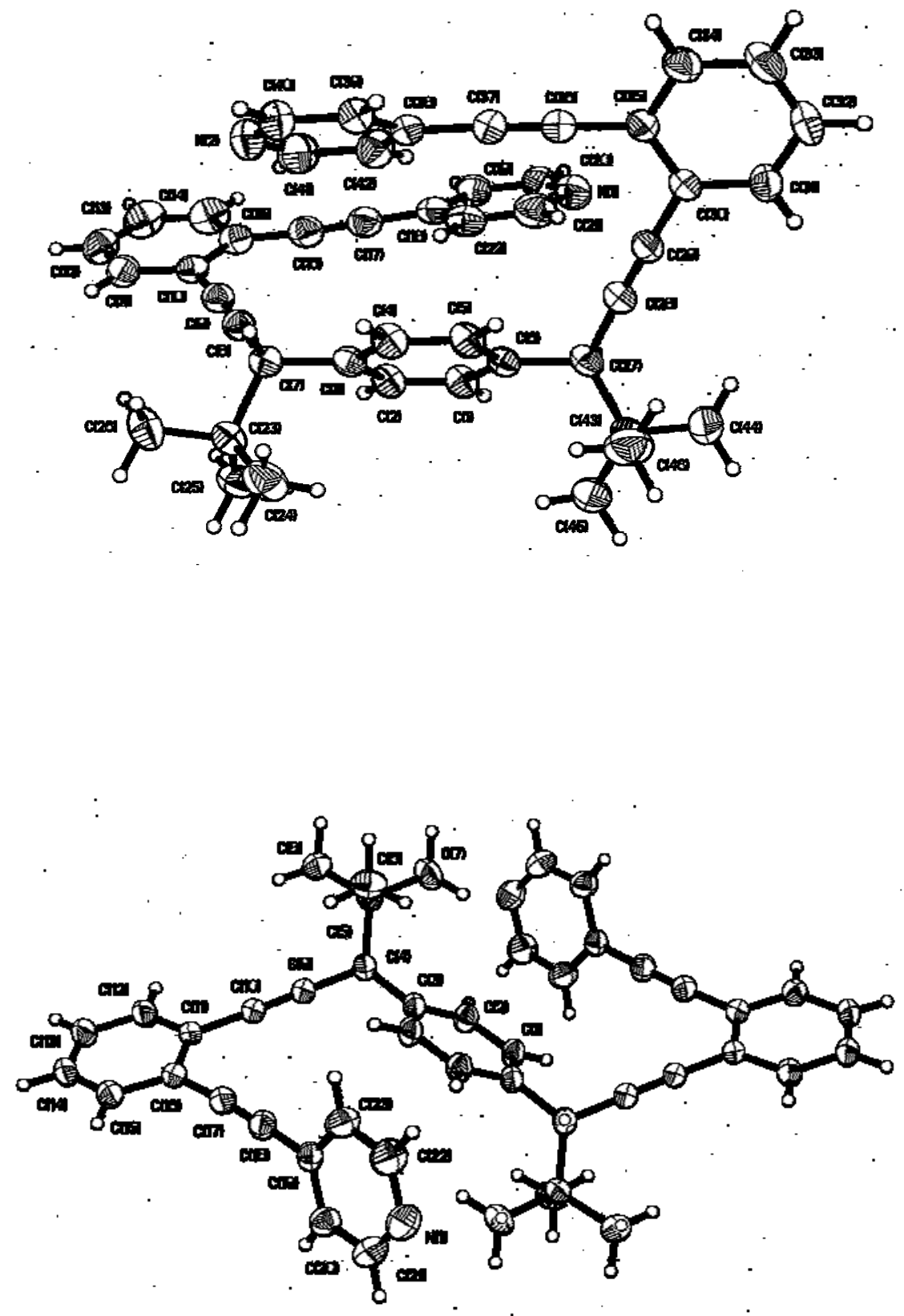

Figure 5.1. ORTEP drawings for the crystal structures of two diastereomers of 2.8a 


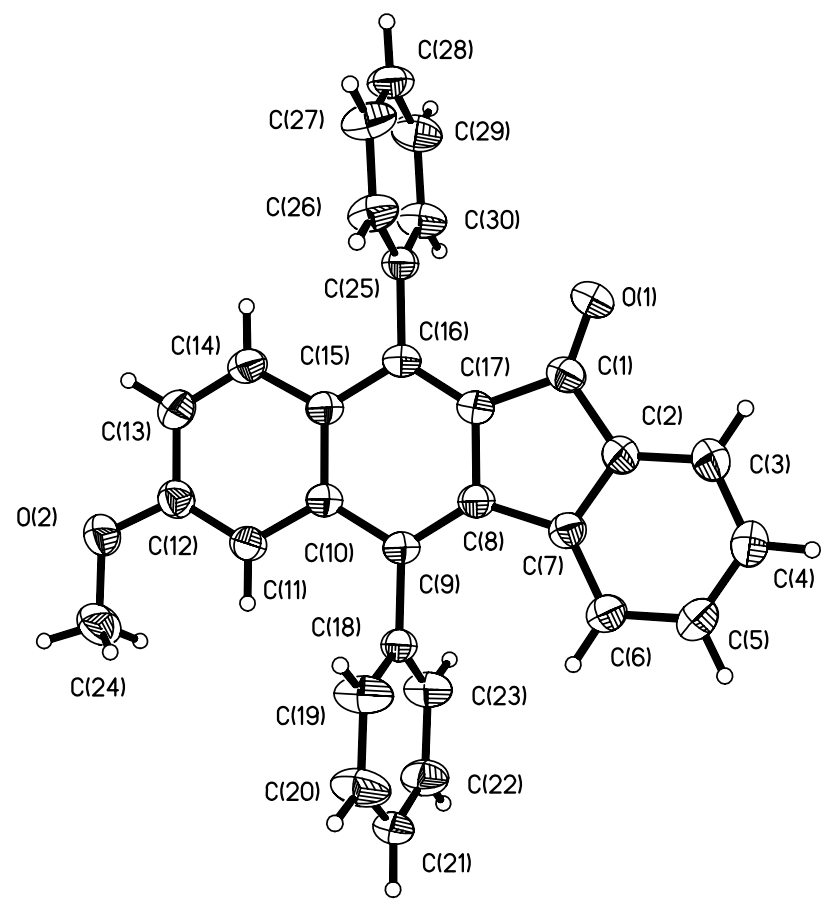

Figure 5.2. ORTEP drawings for the crystal structures of $\mathbf{3 . 6 6}$

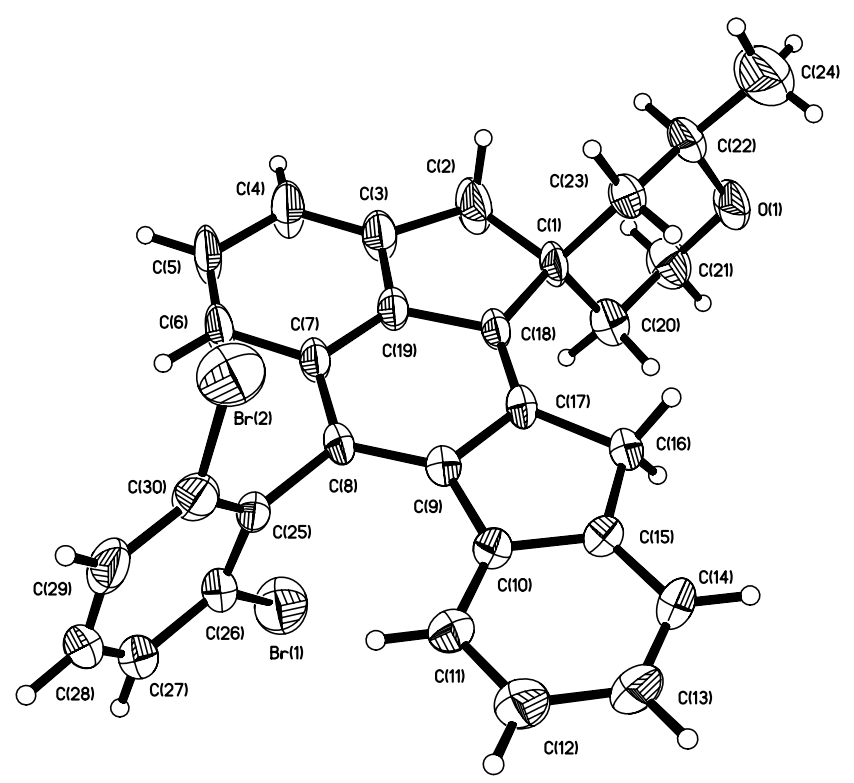

Figure 5.3. ORTEP drawings for the crystal structures of 4.97 

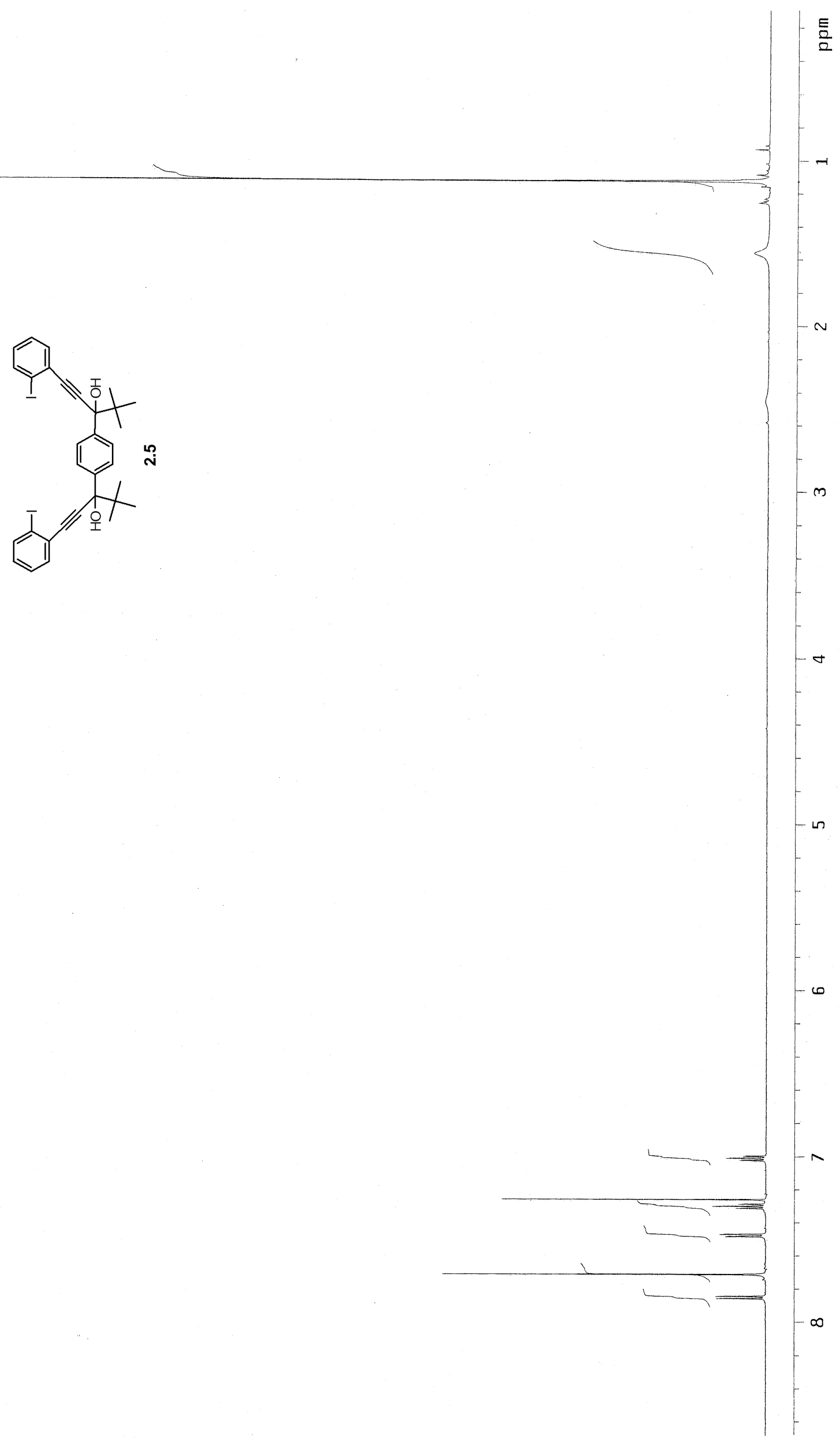


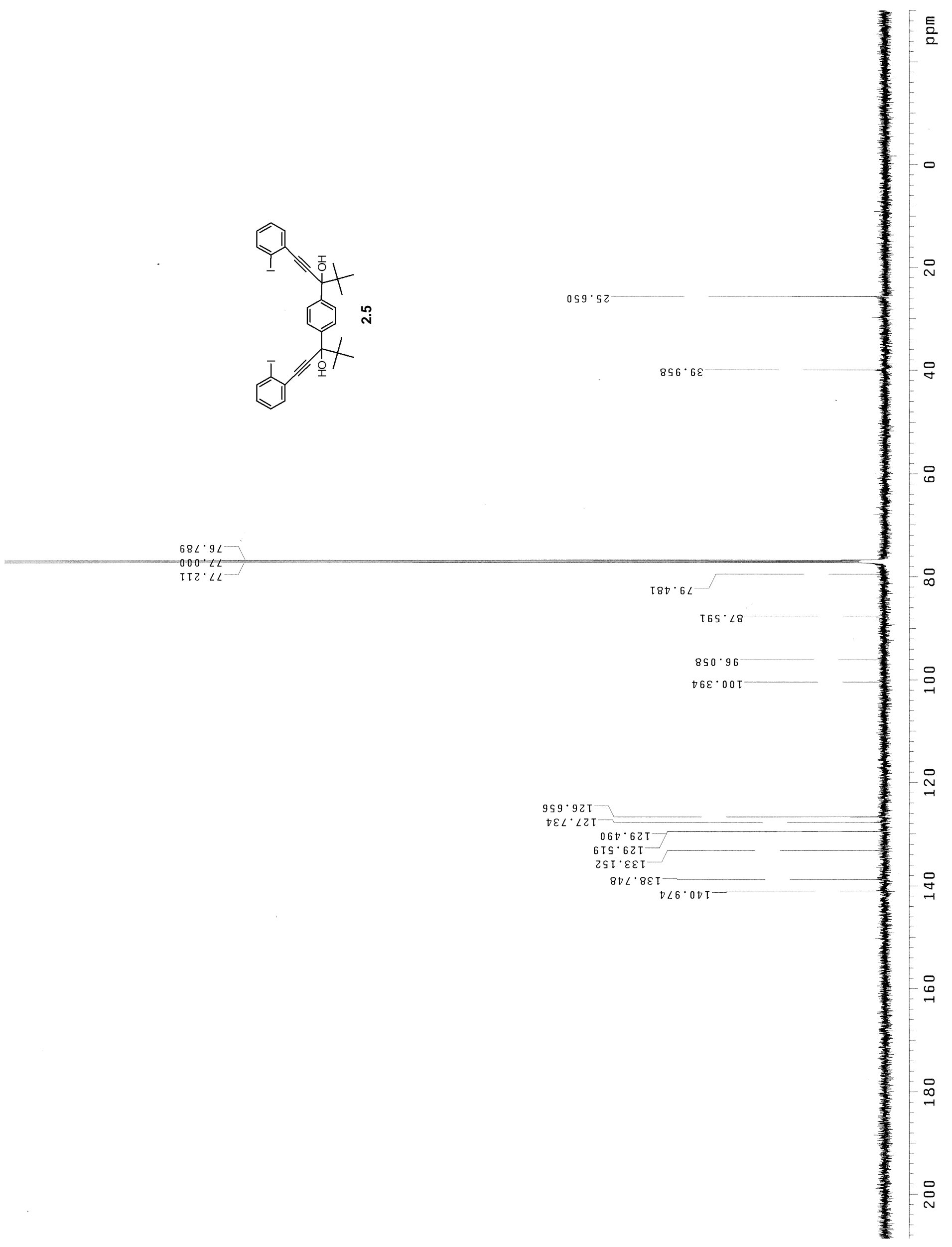




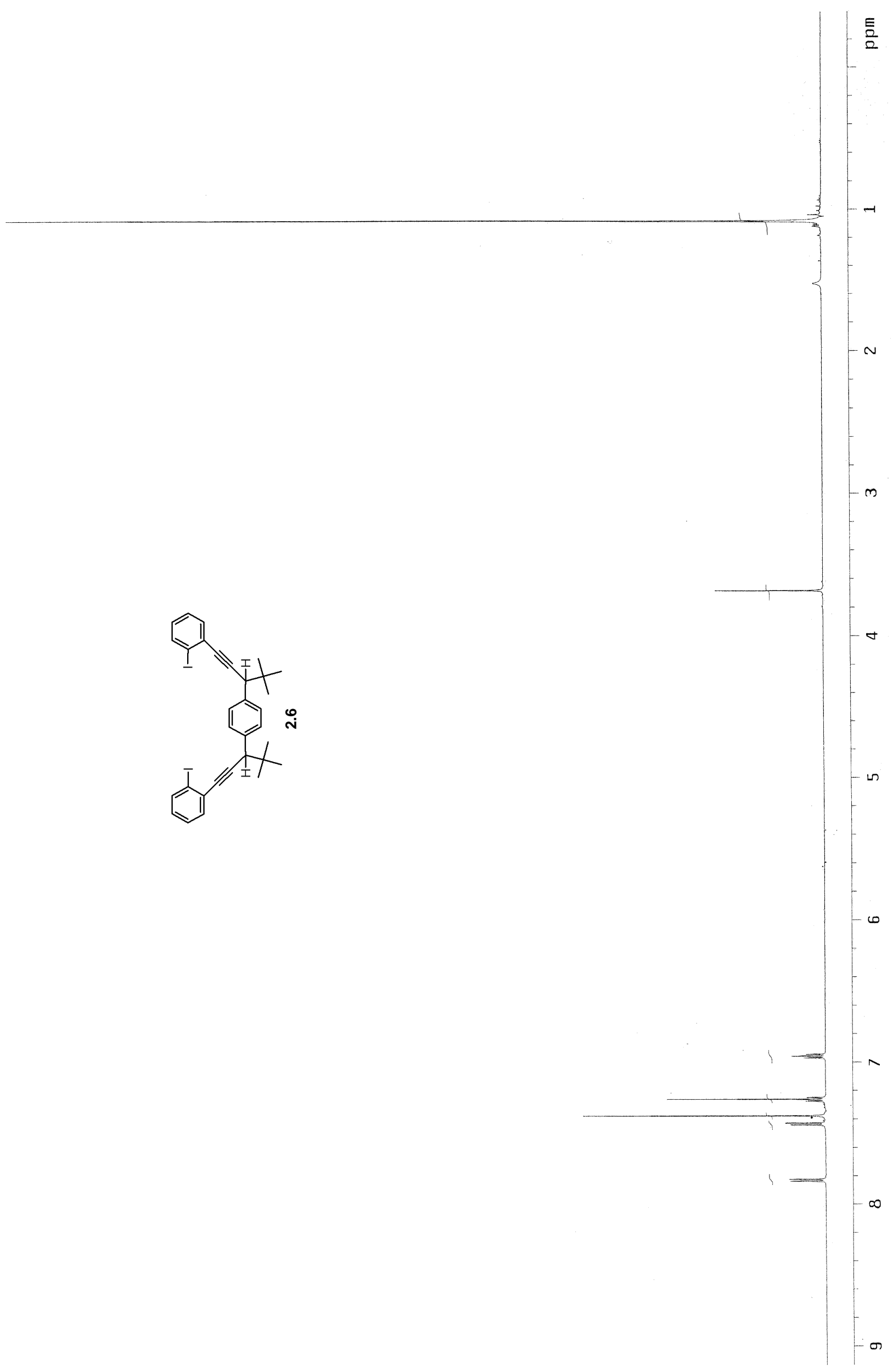




$$
11
$$




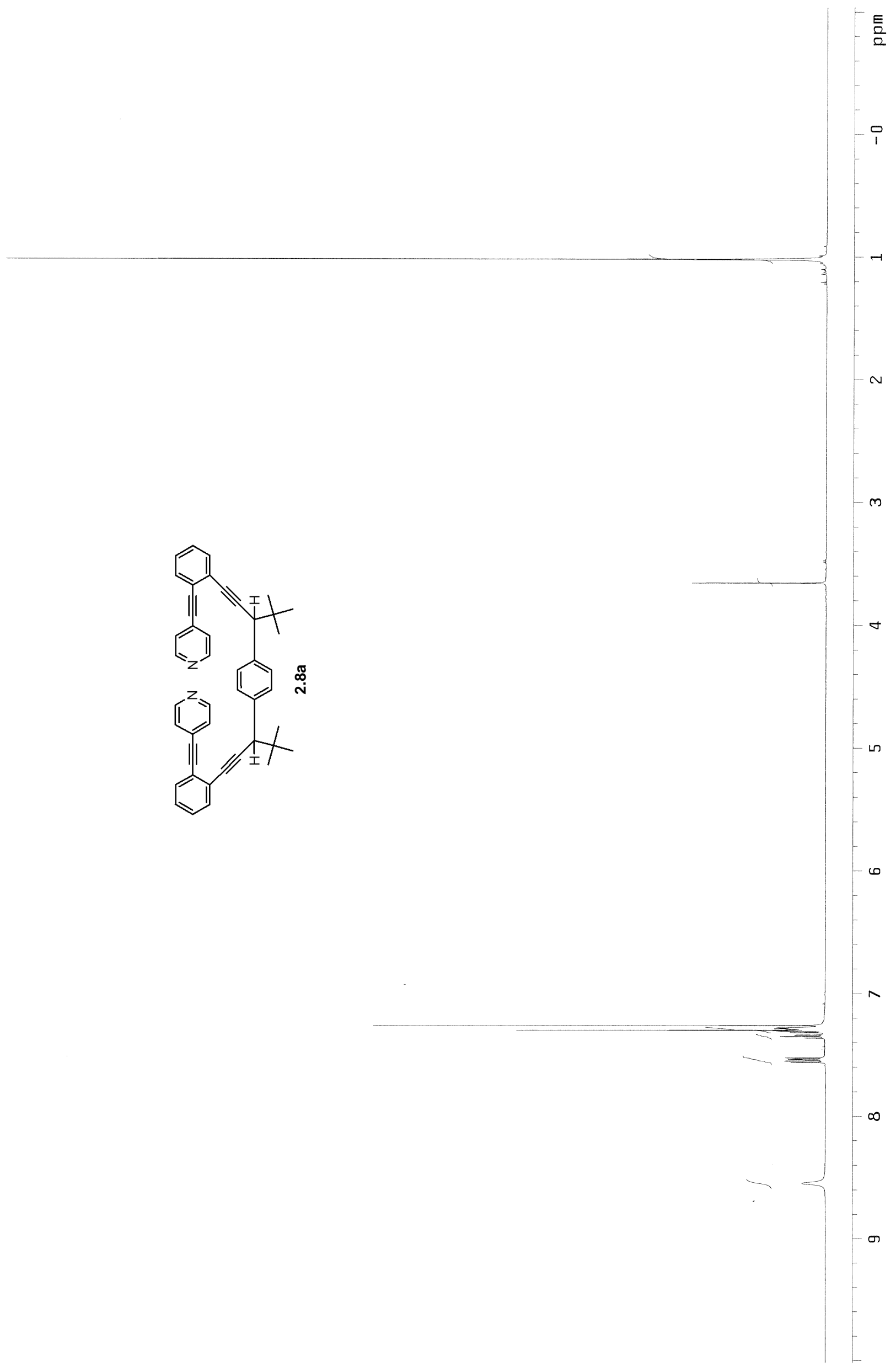



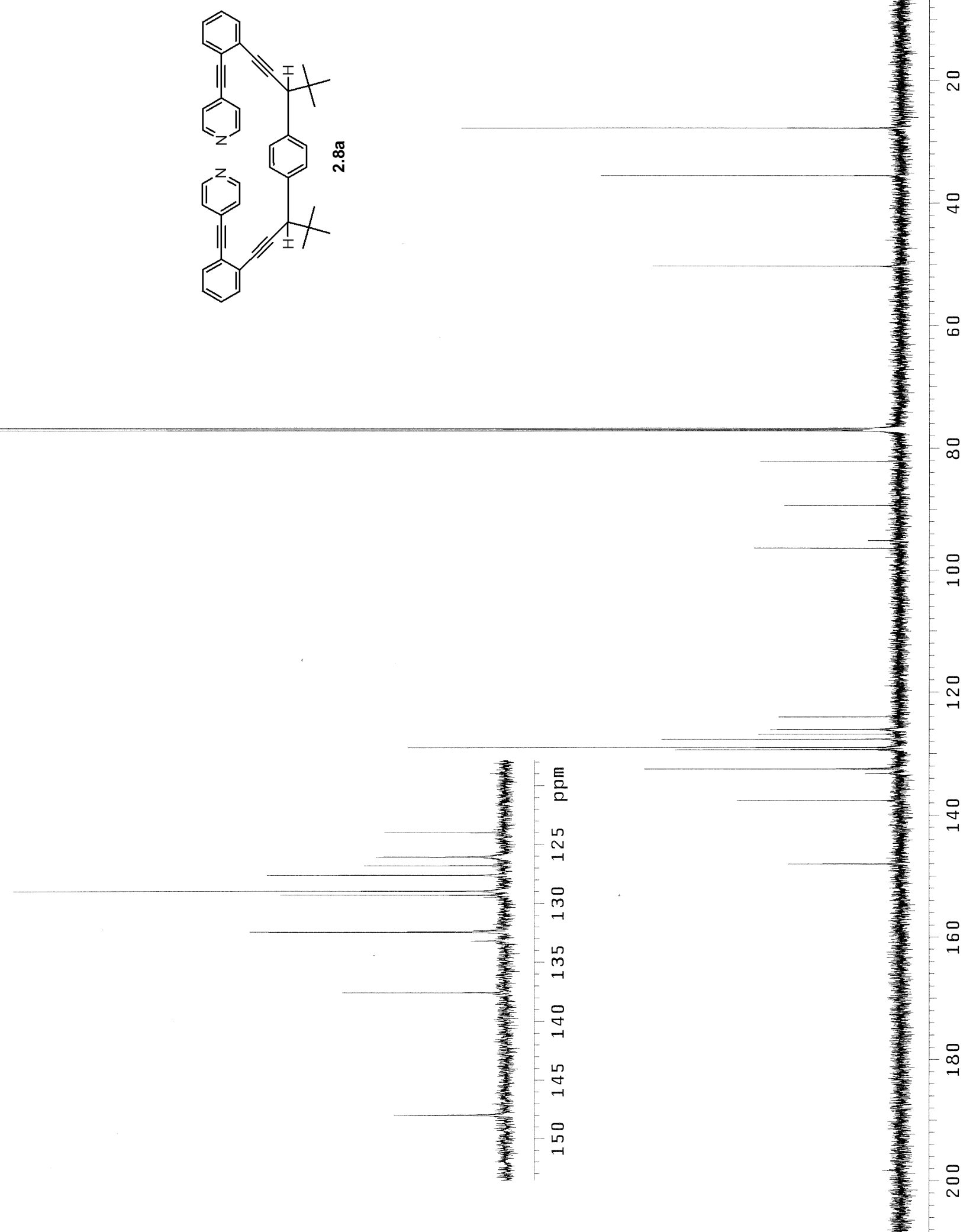


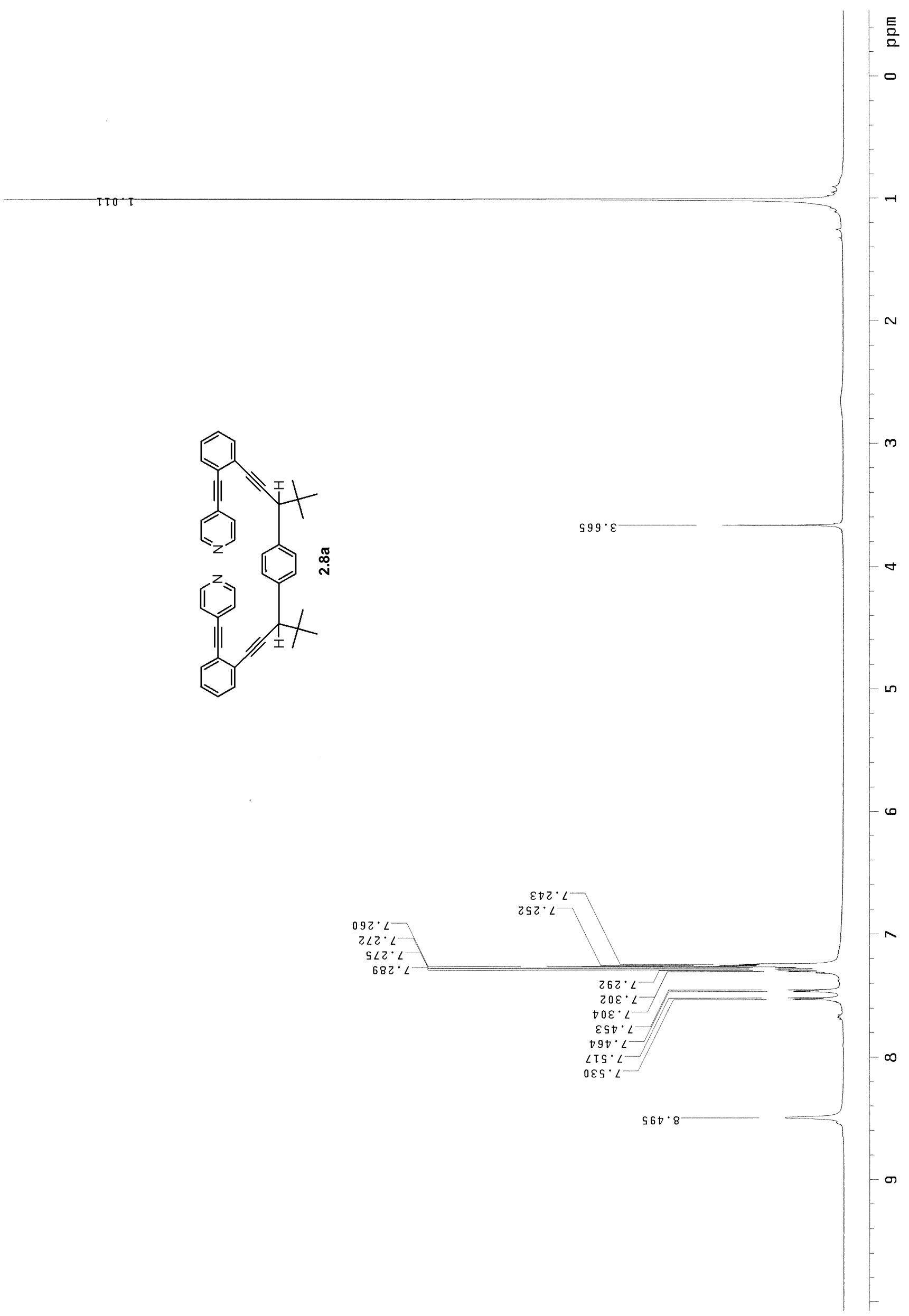




$$
1
$$




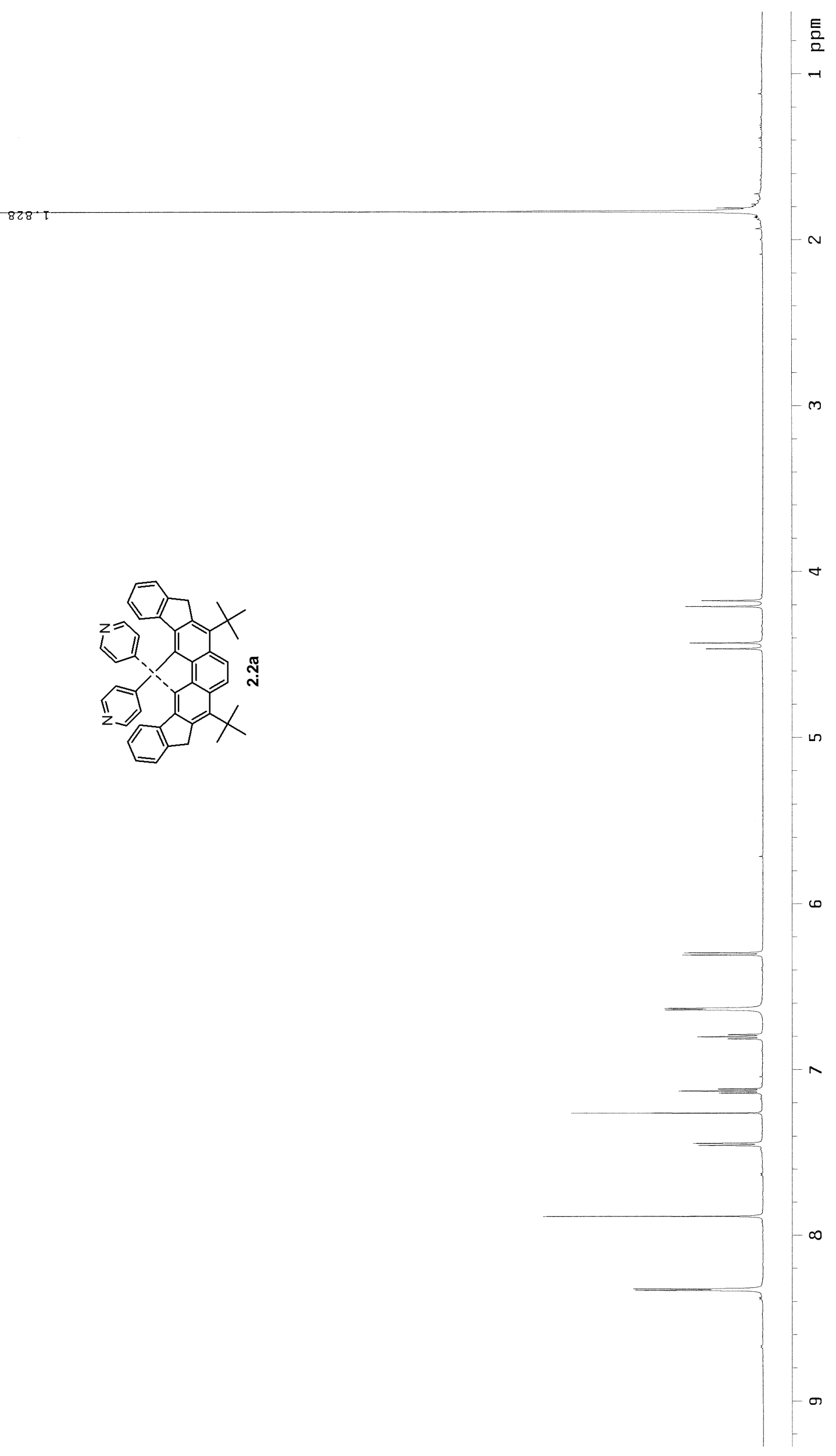




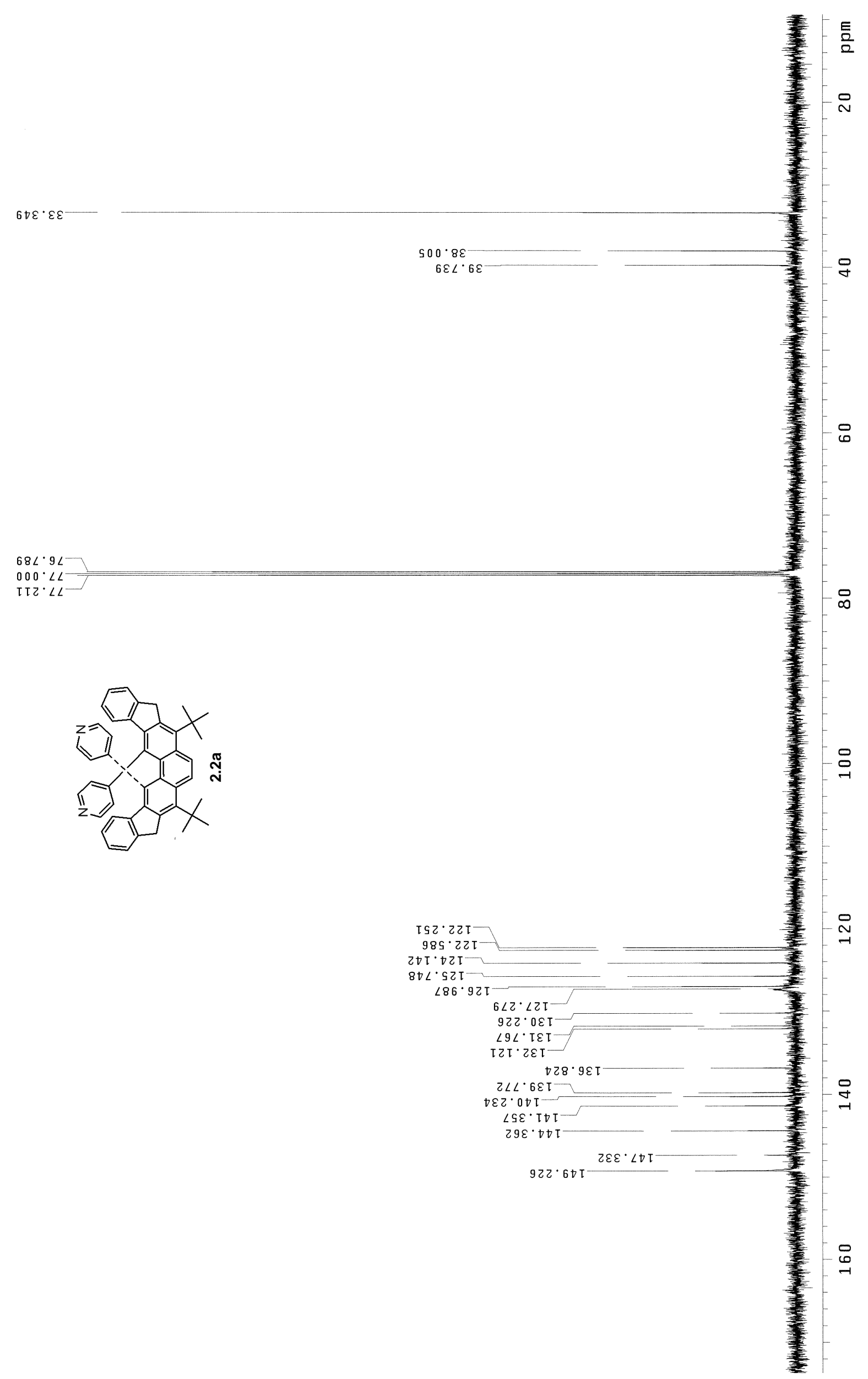




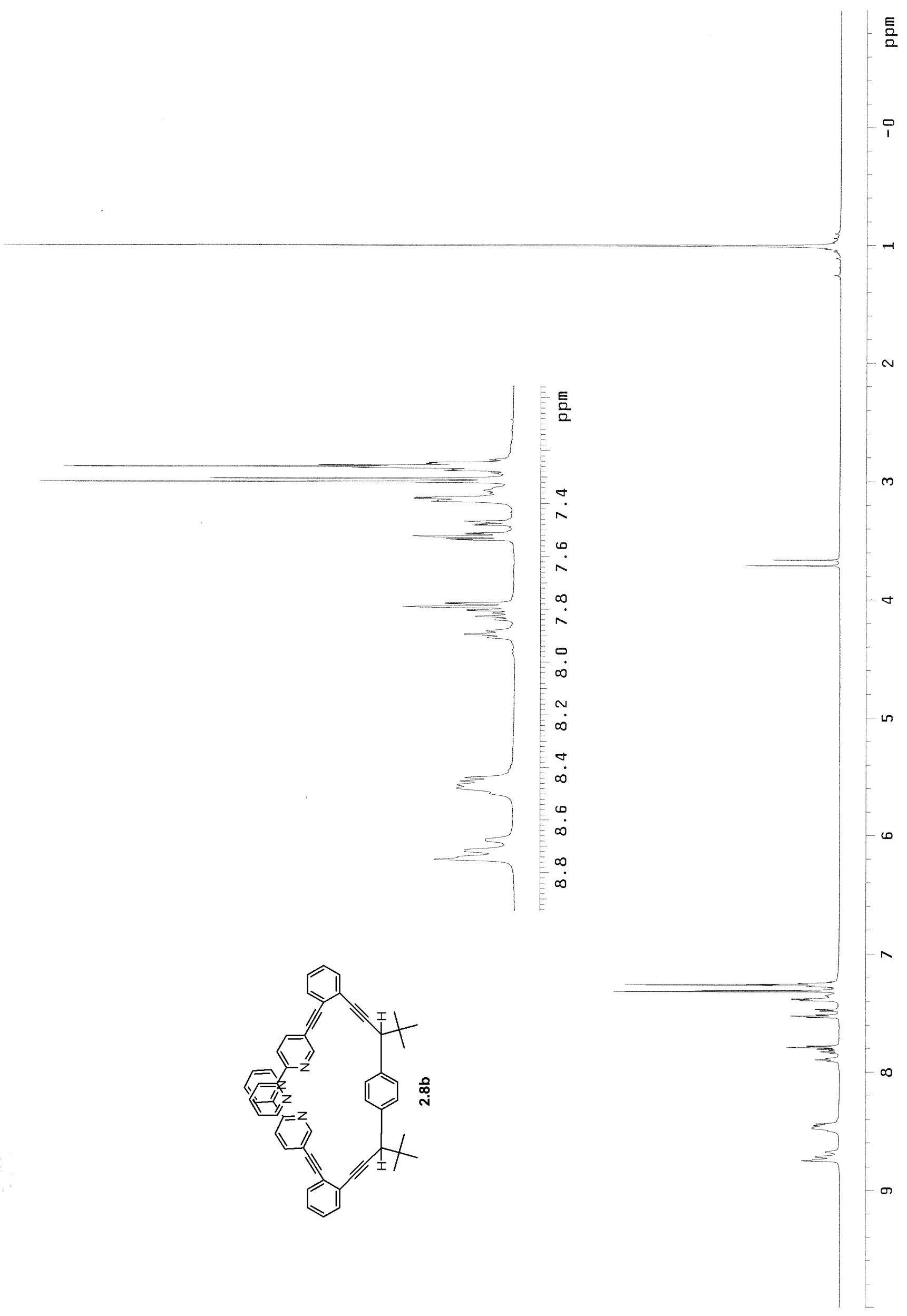




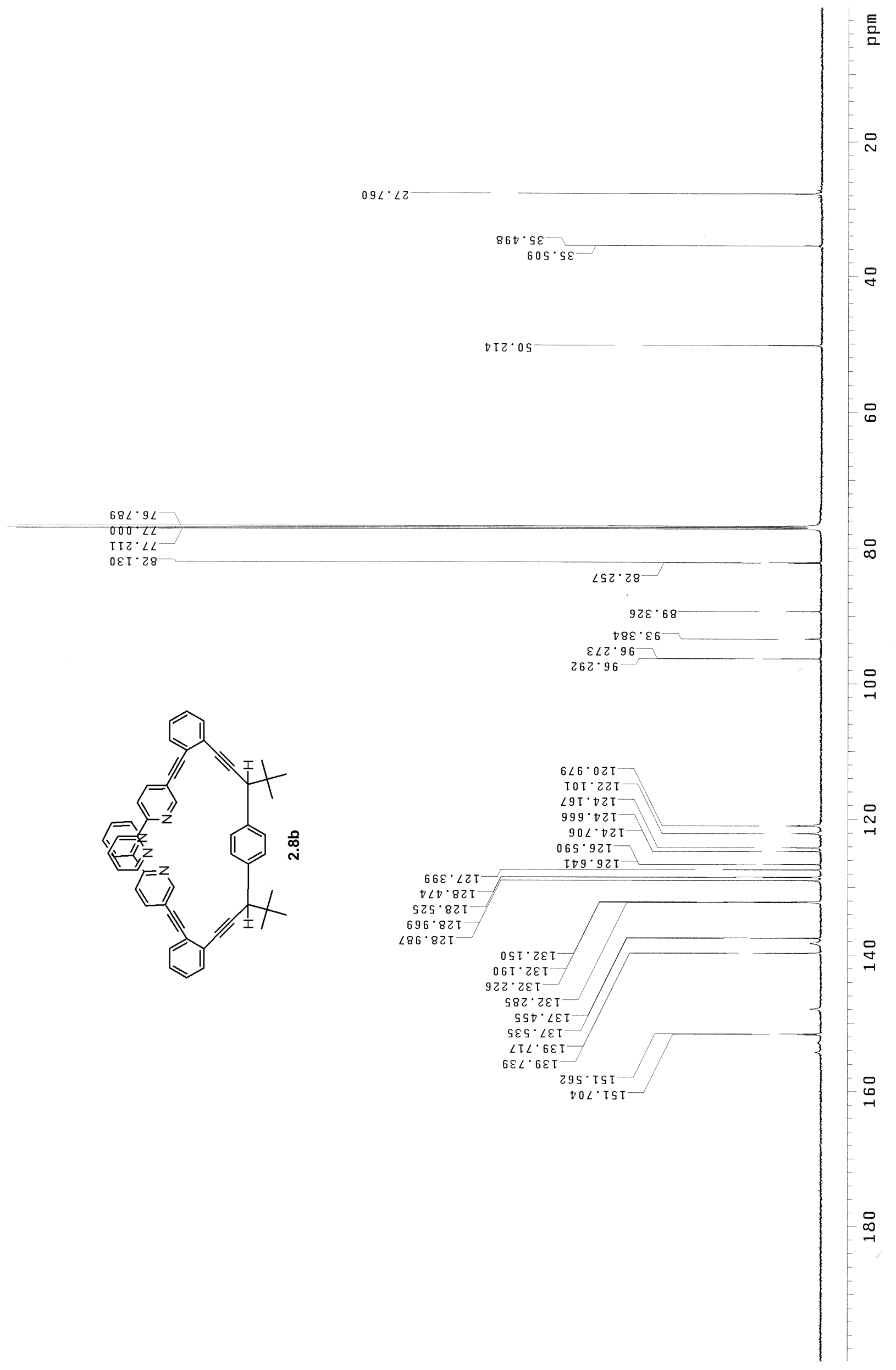




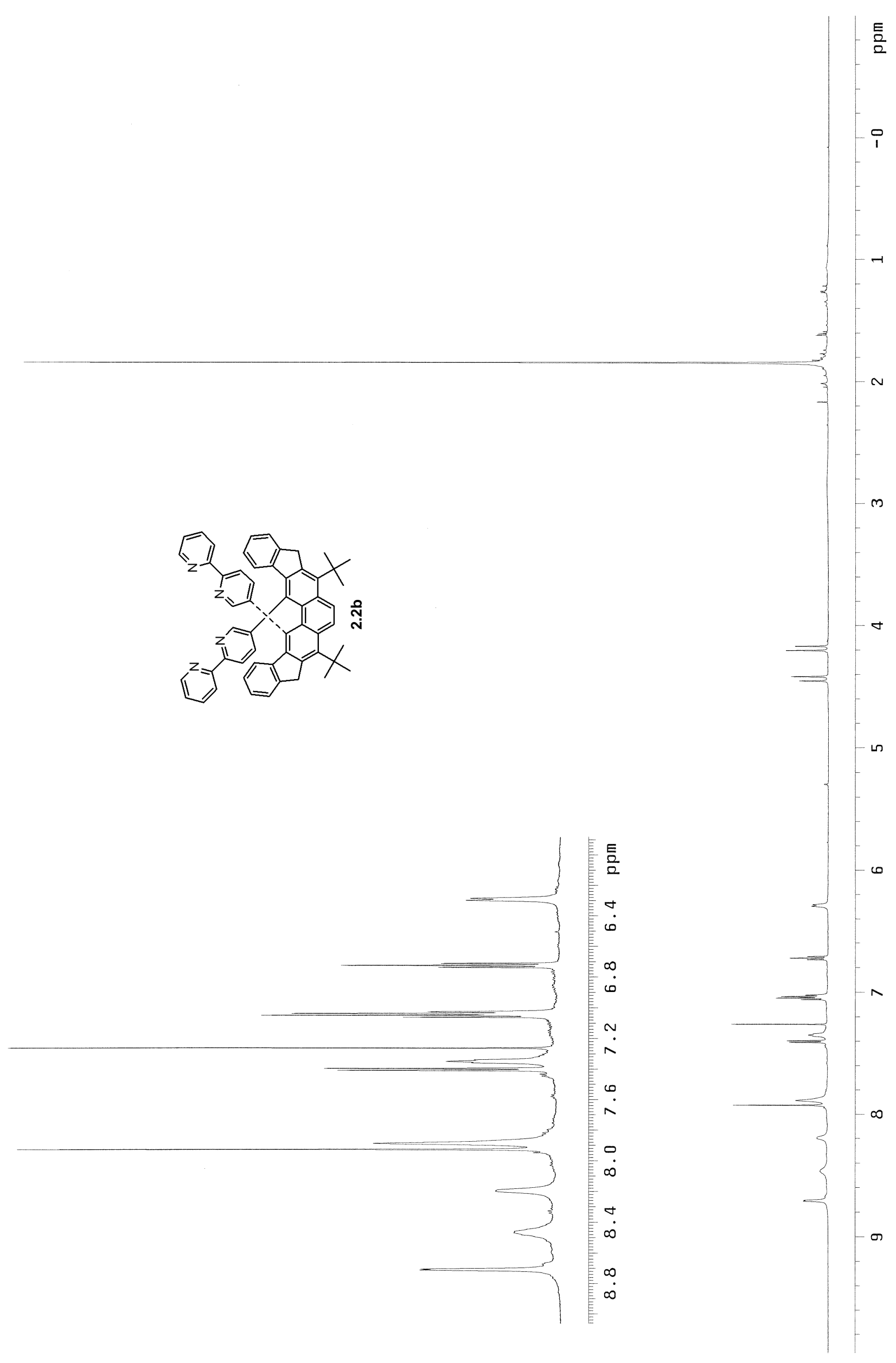




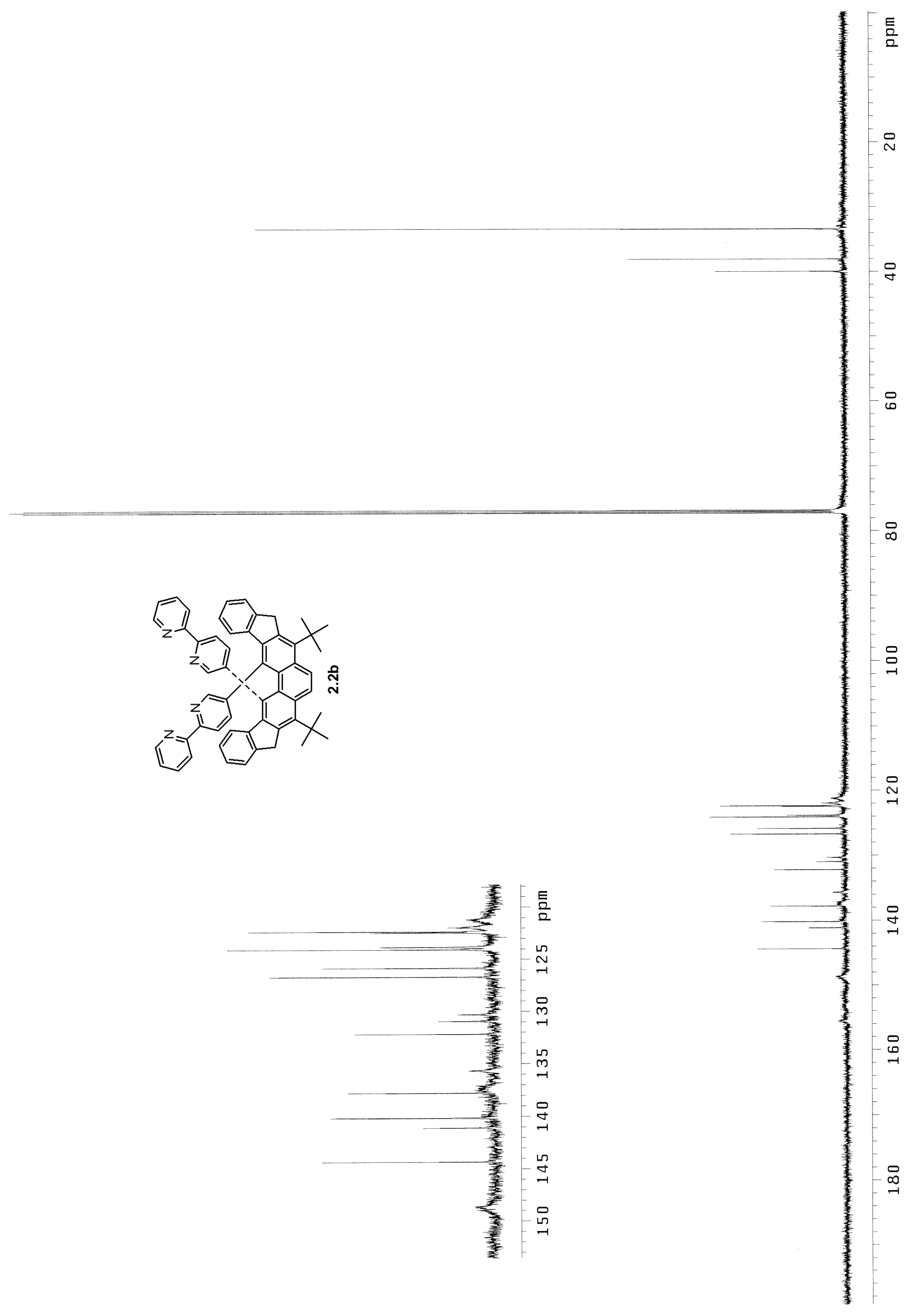



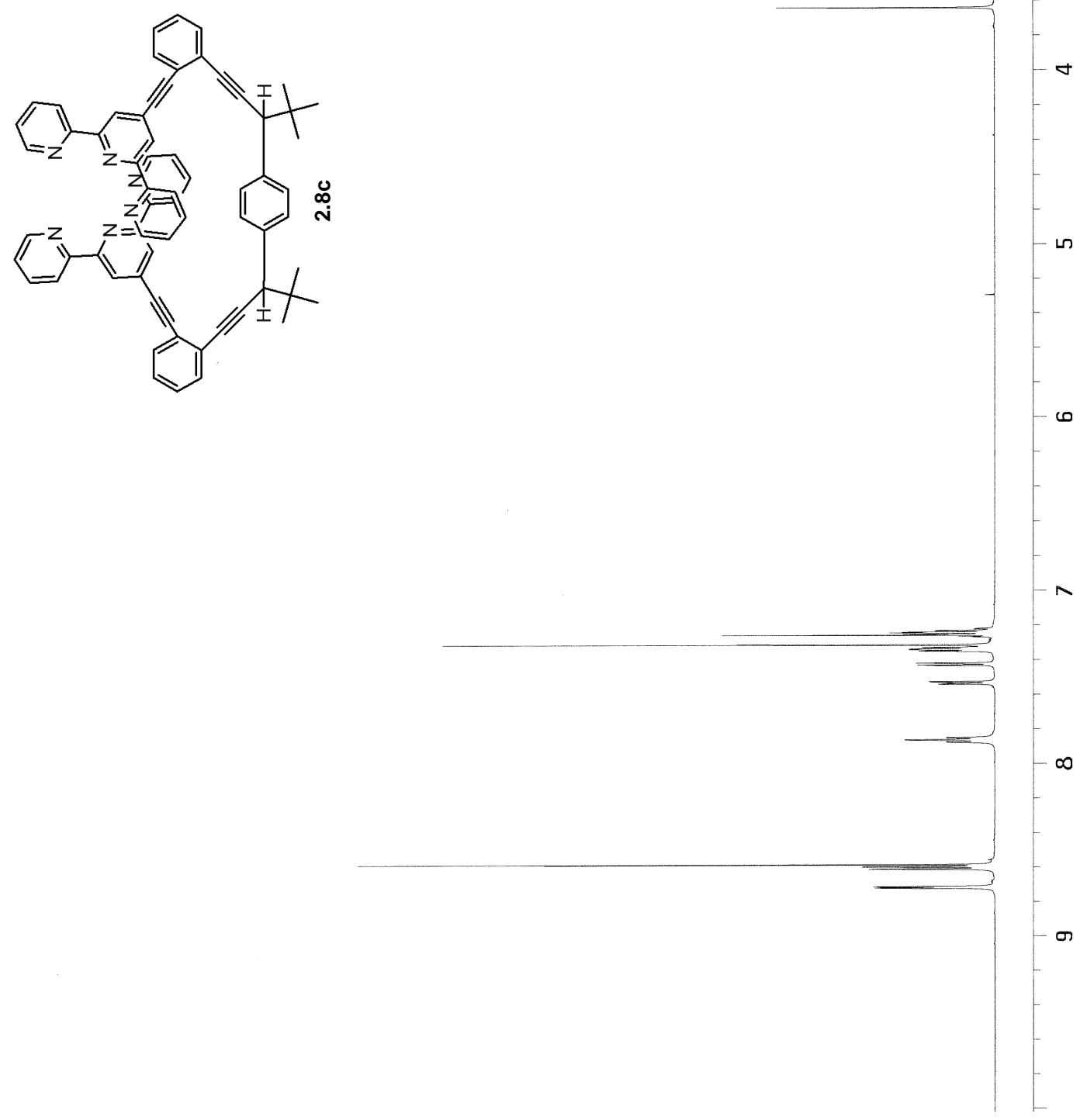


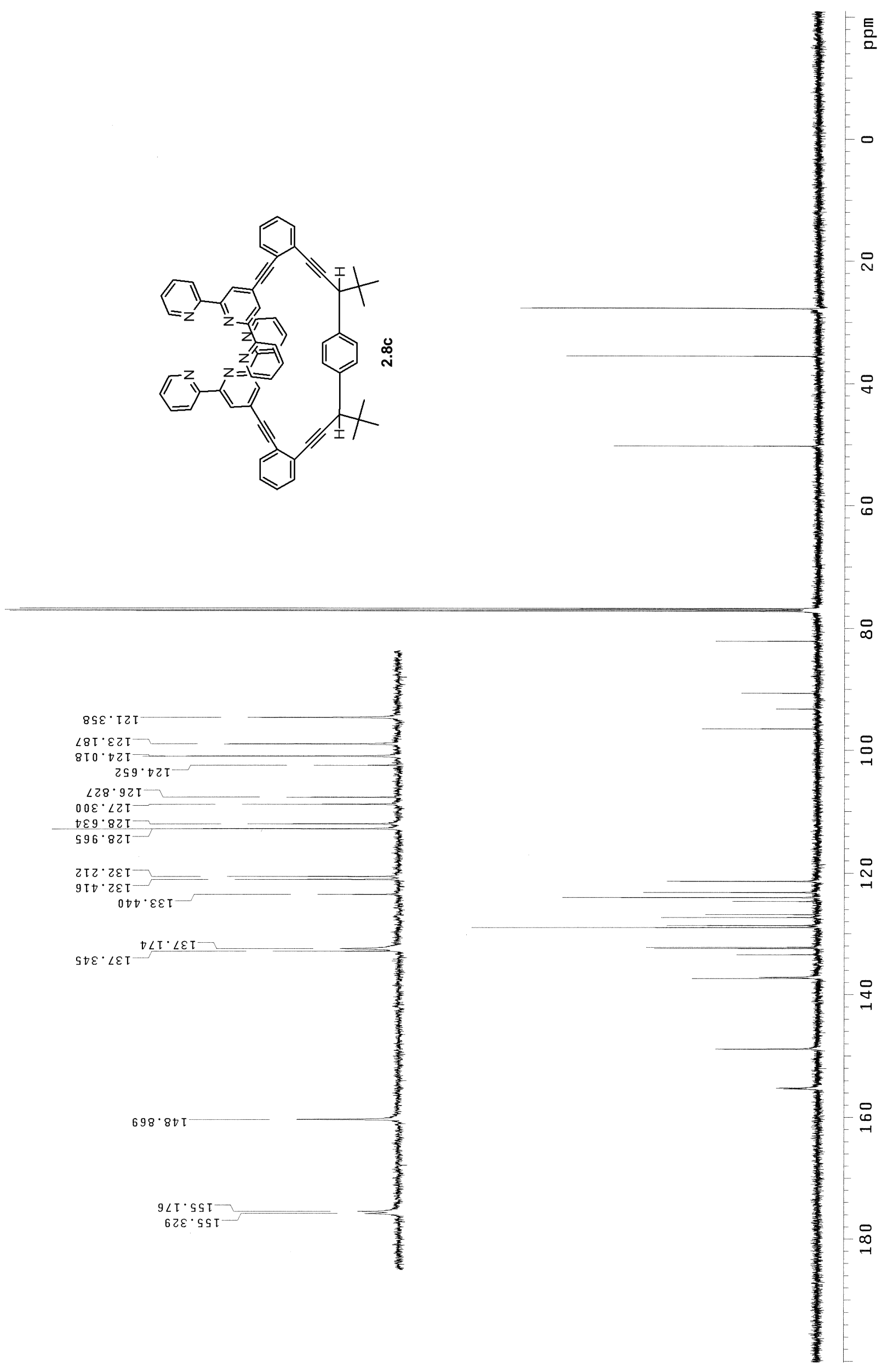




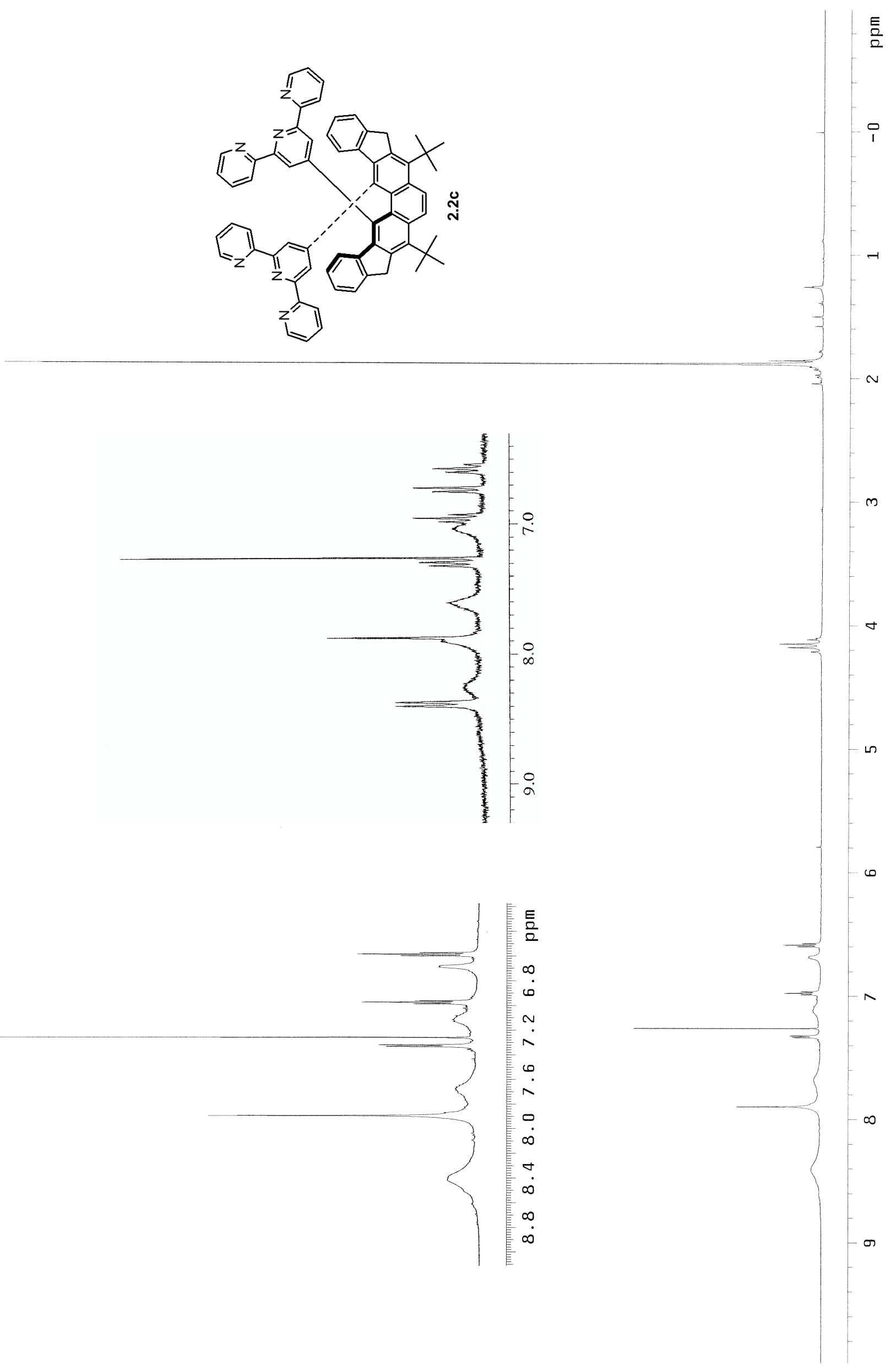




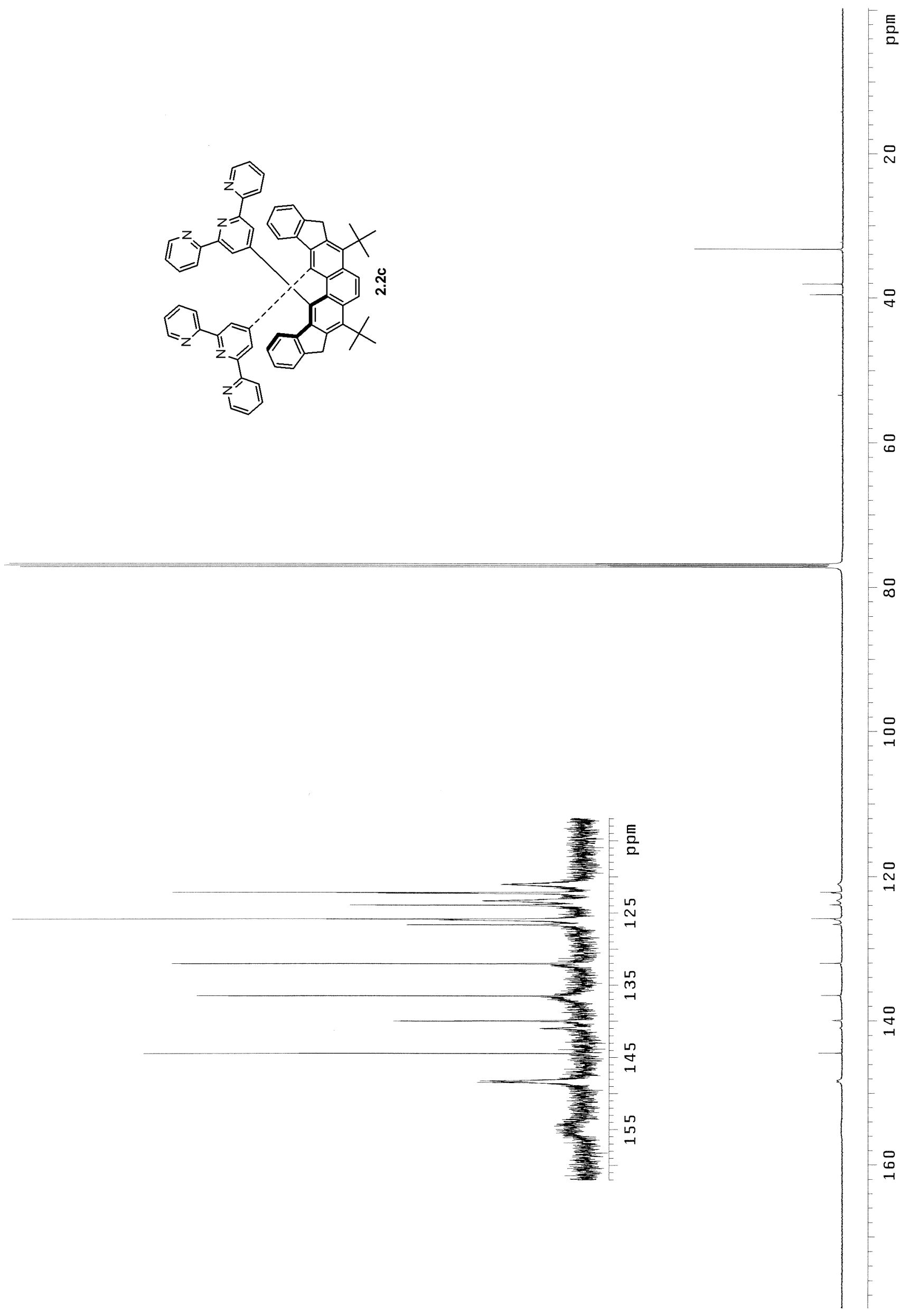




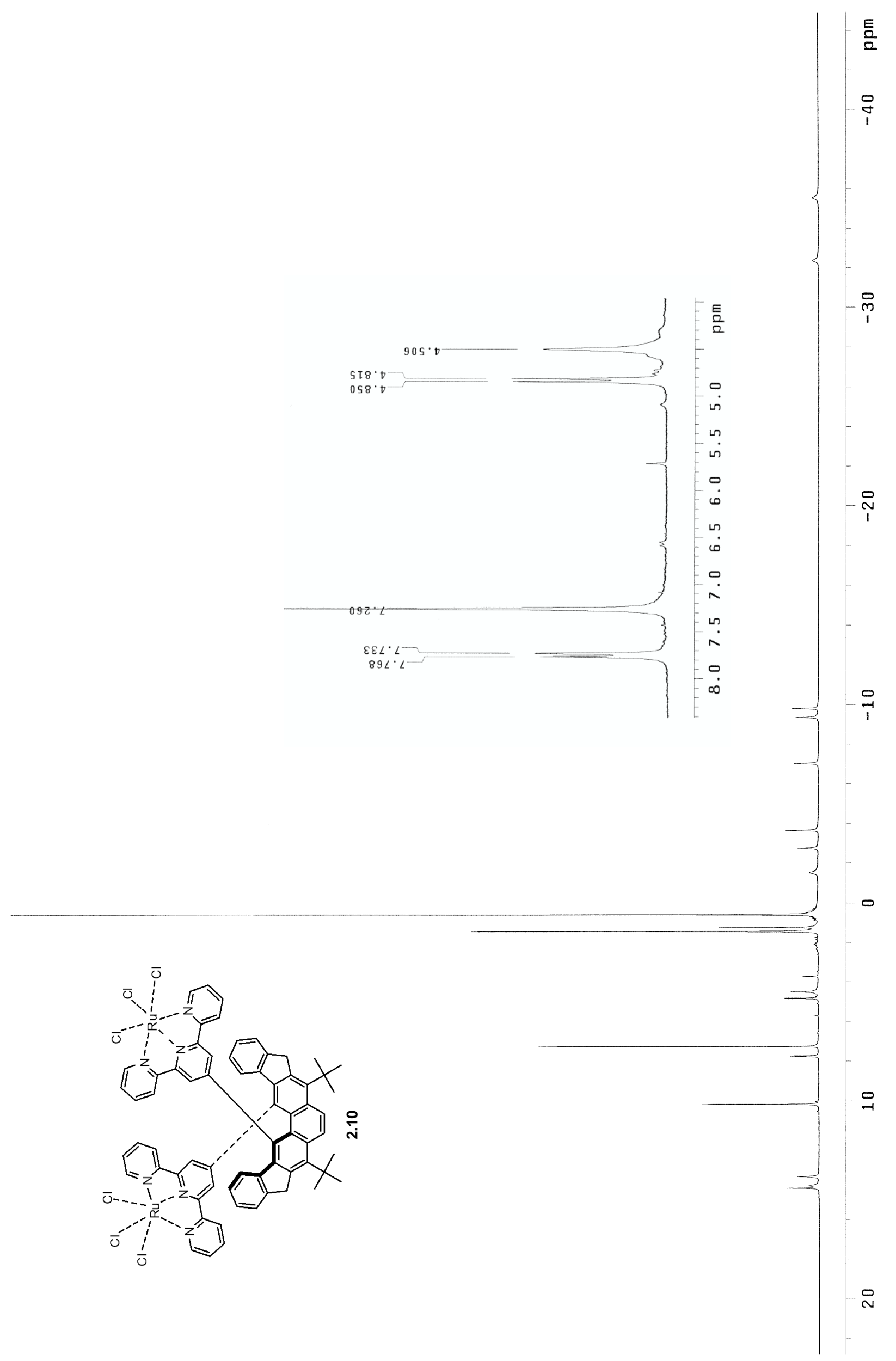




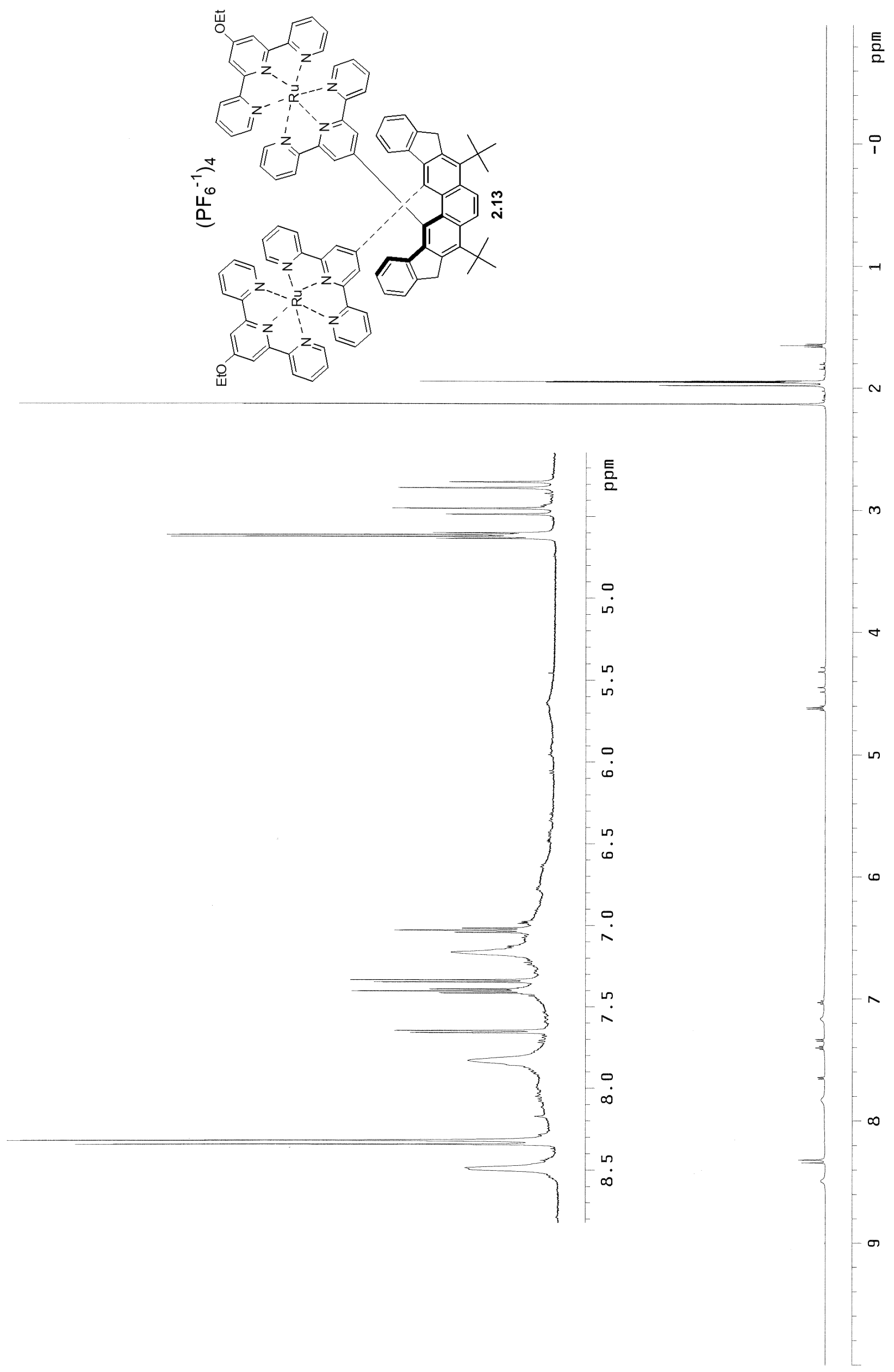




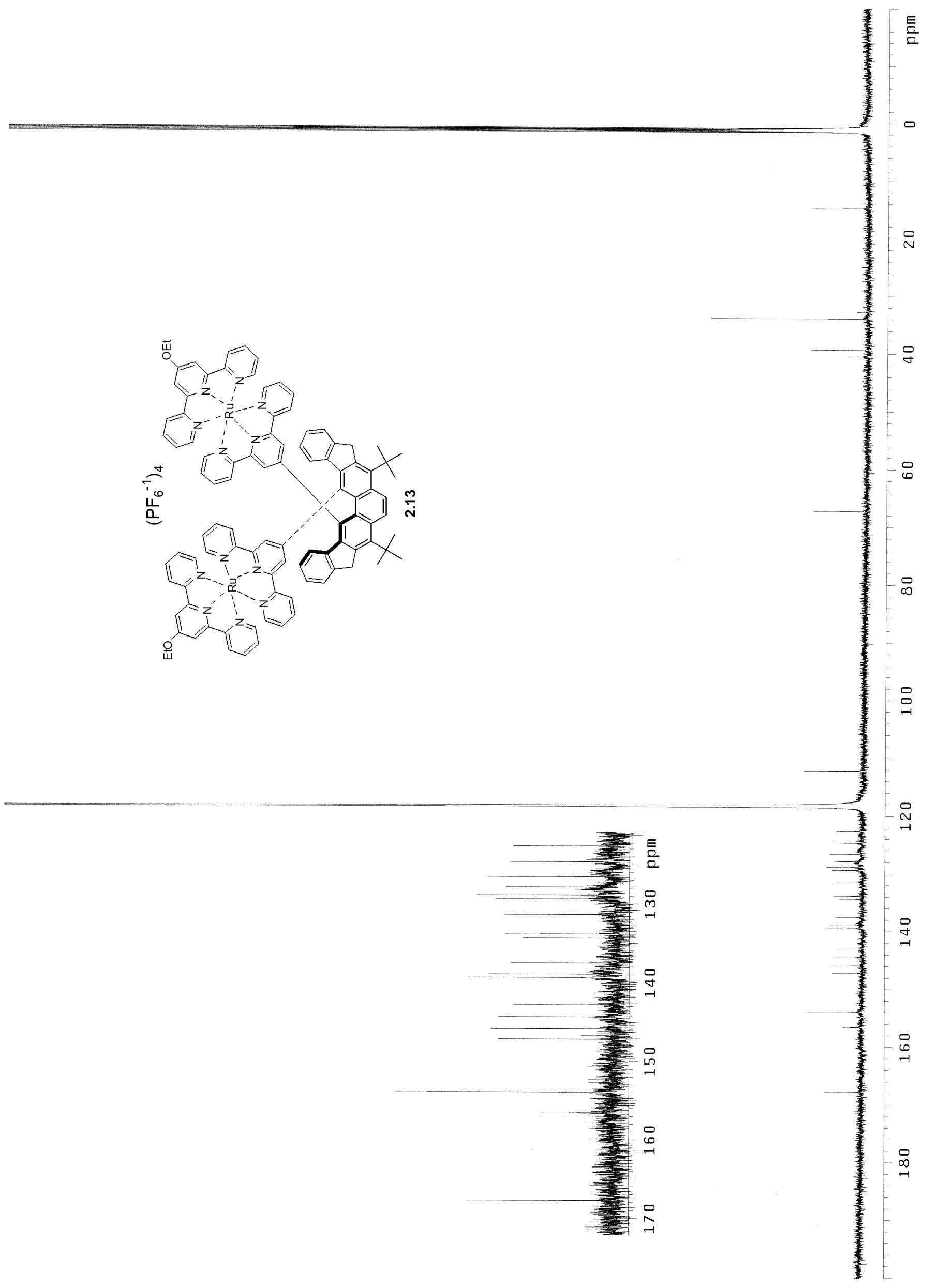

140 


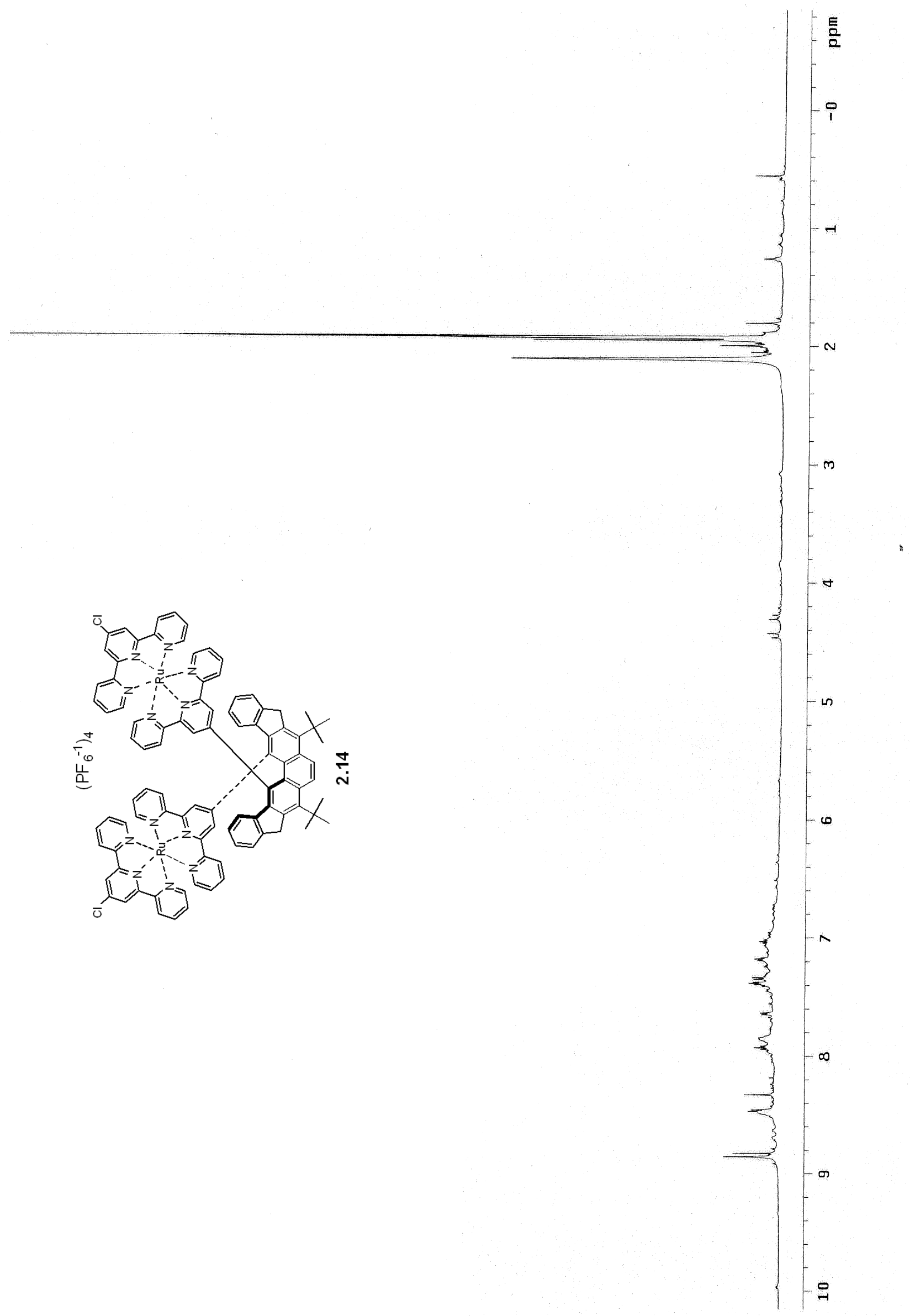




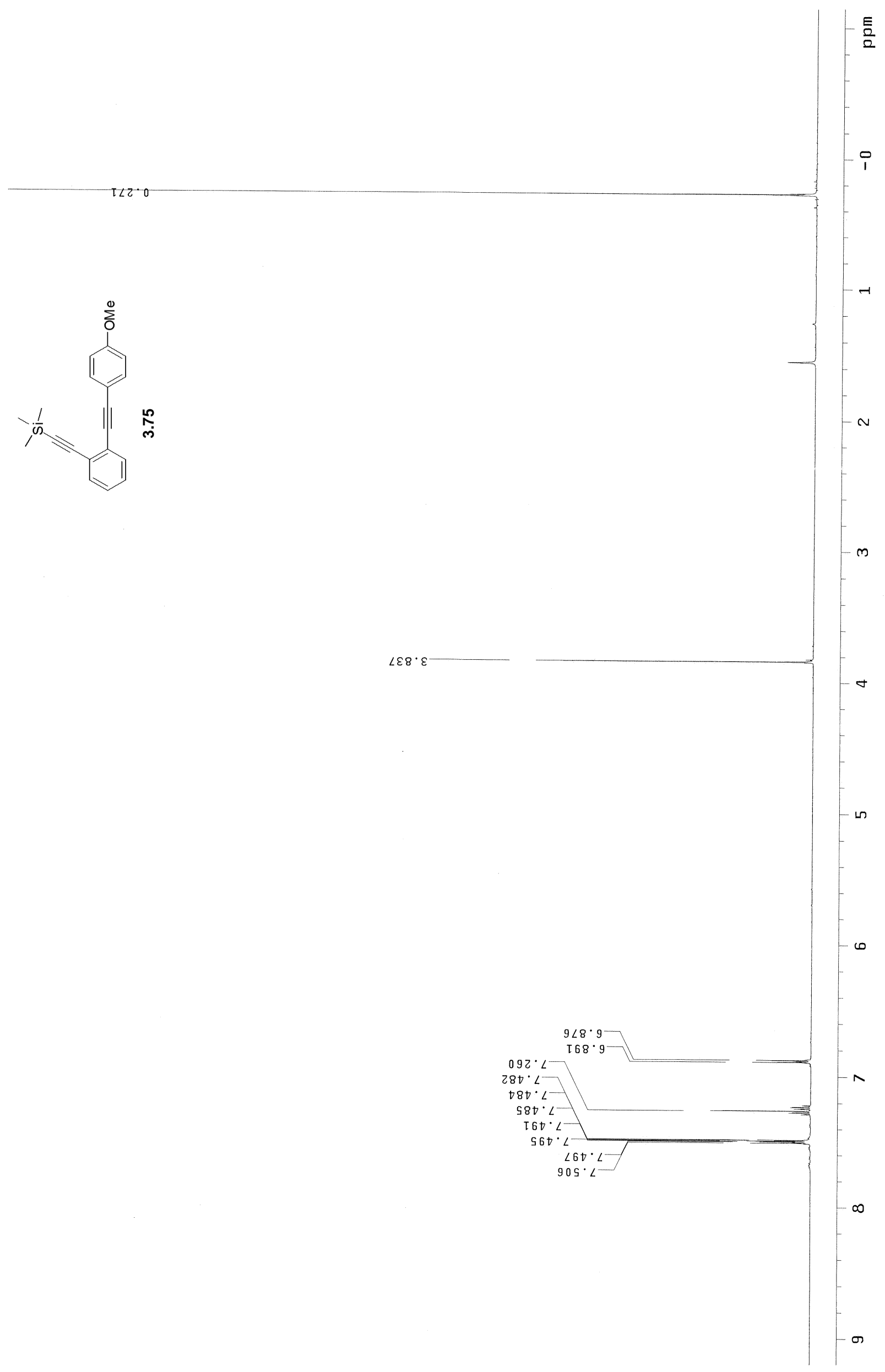



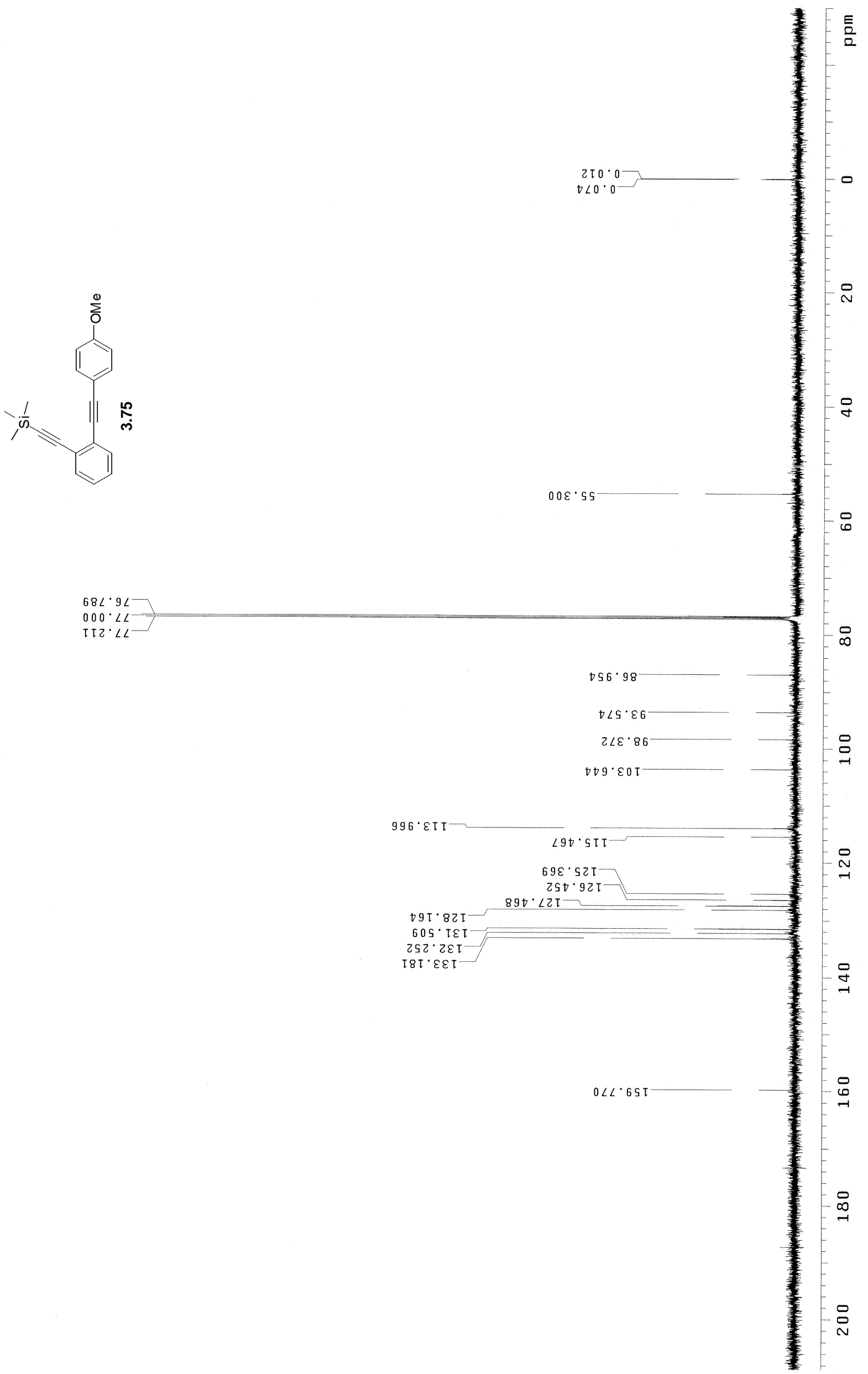


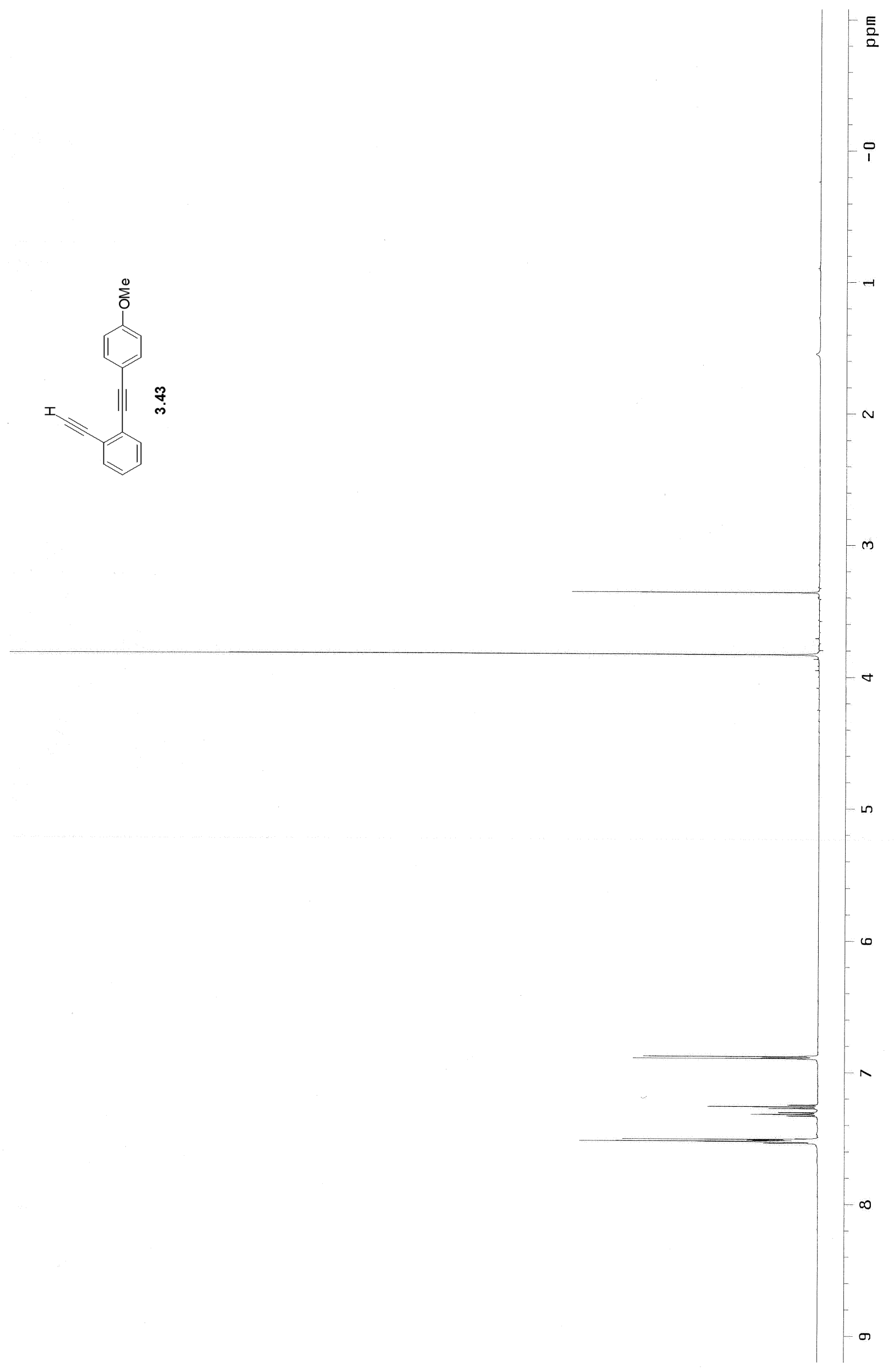




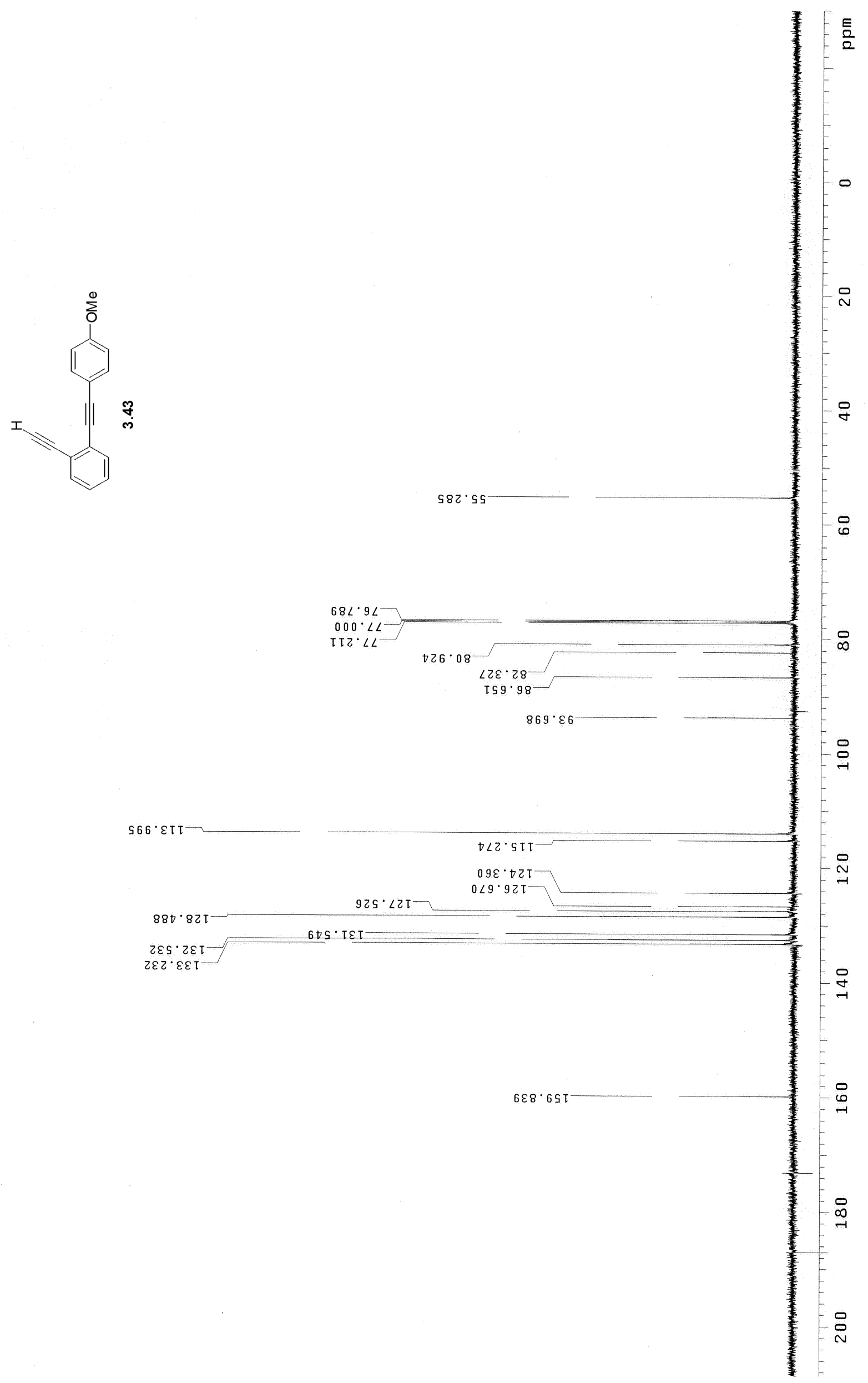




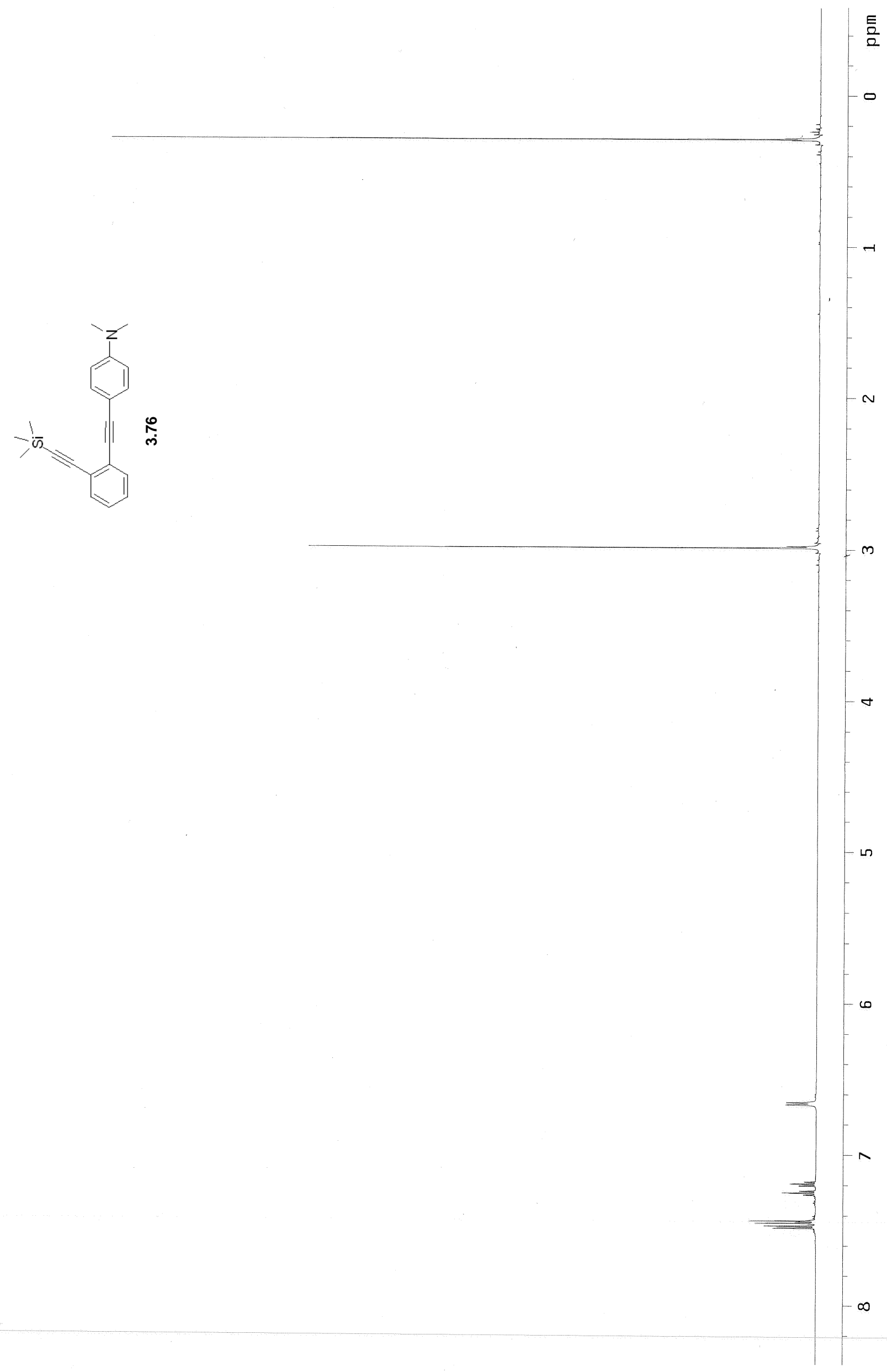




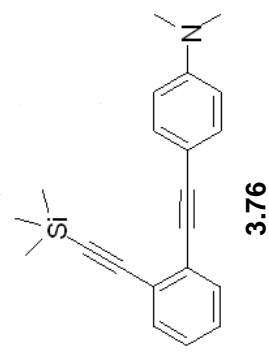

$\varepsilon 92 \cdot 0$
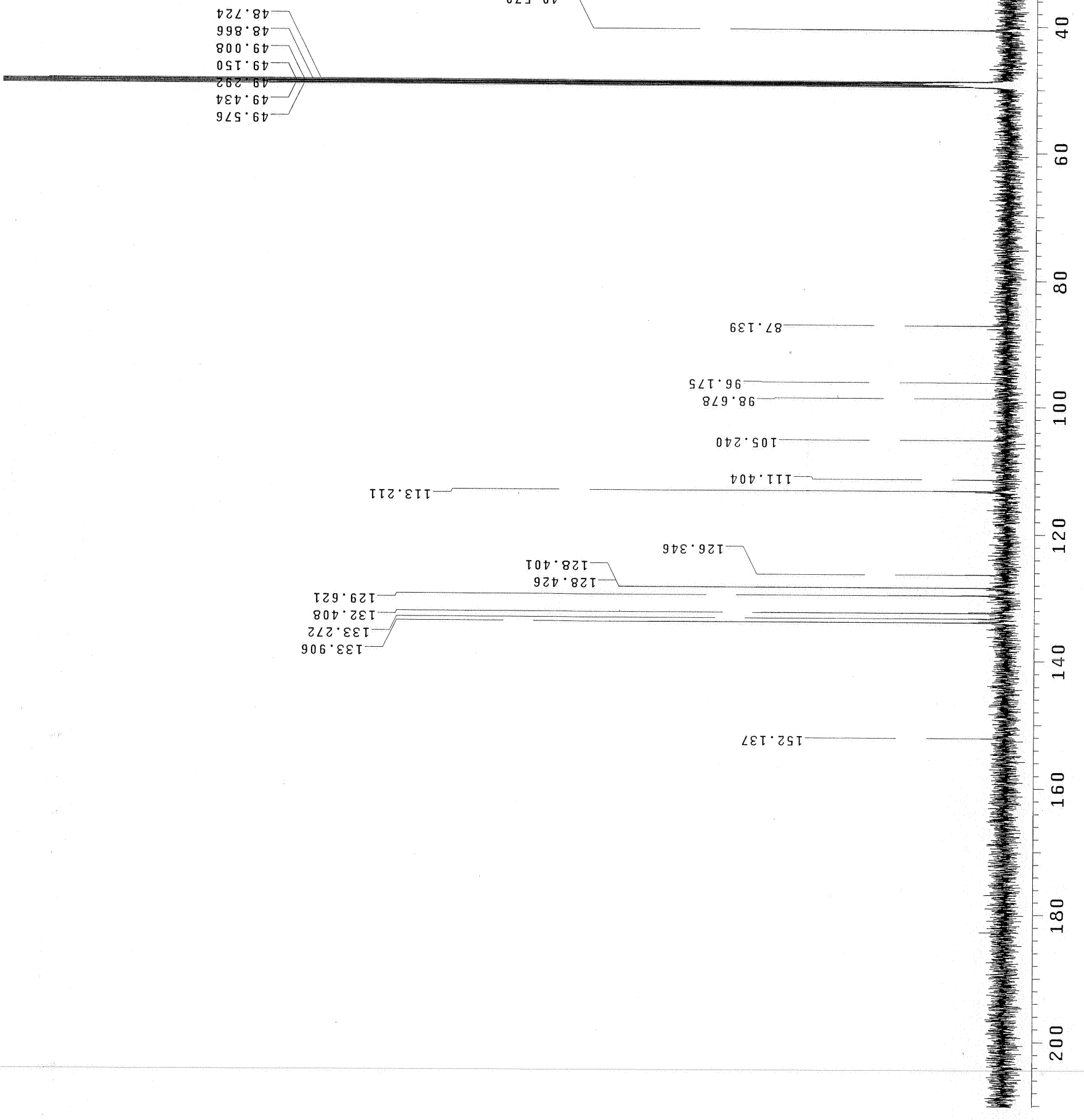

147 


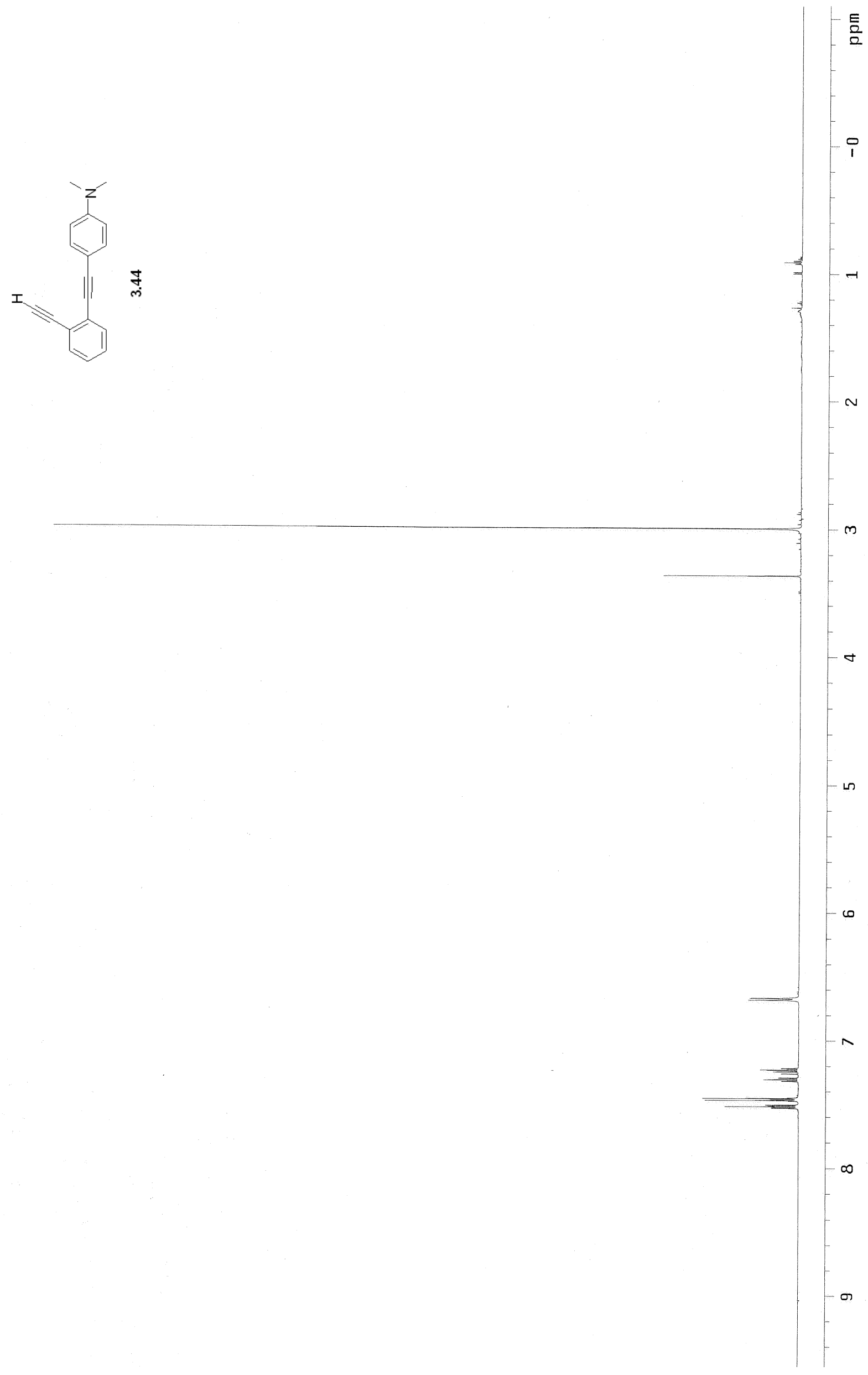




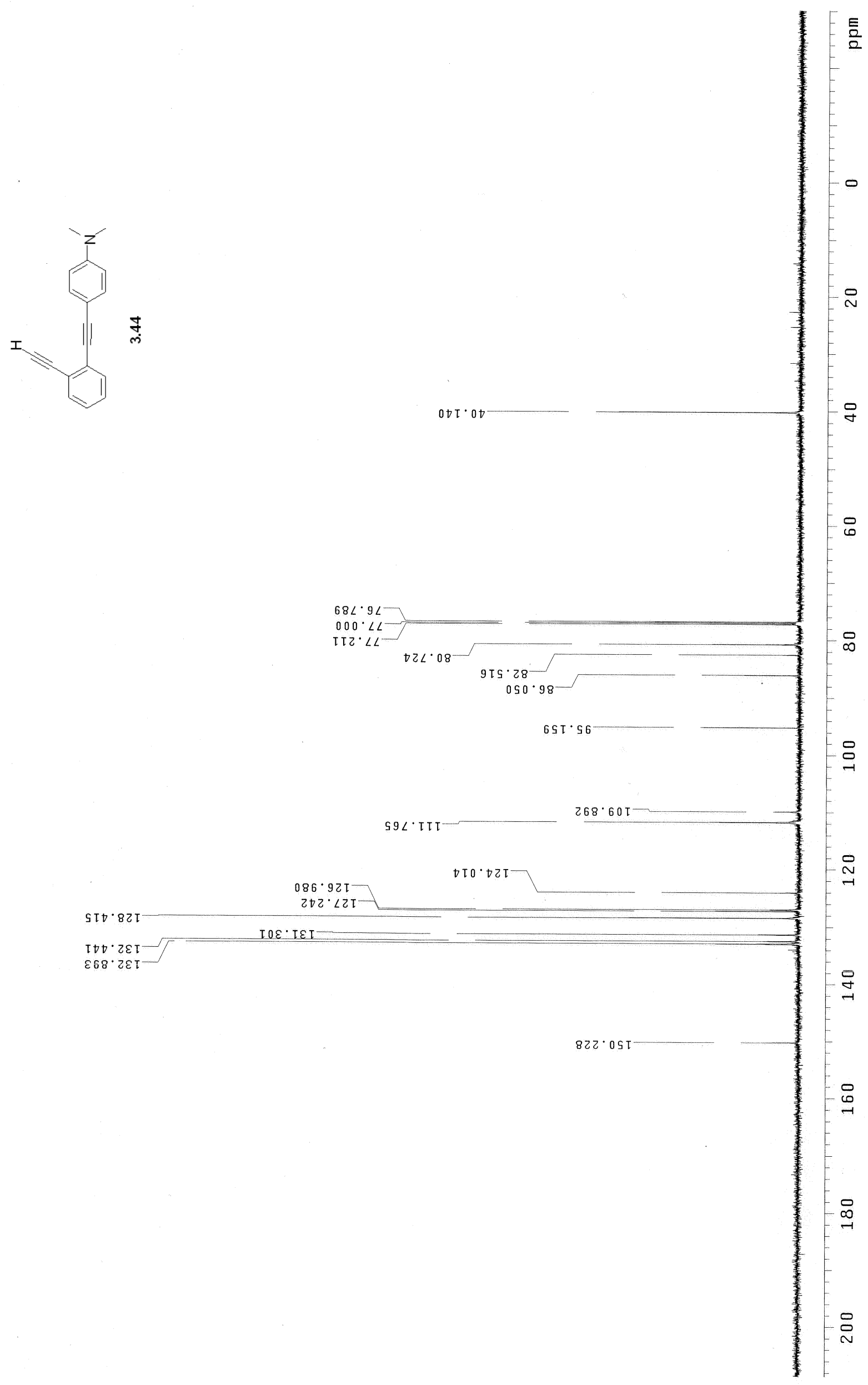




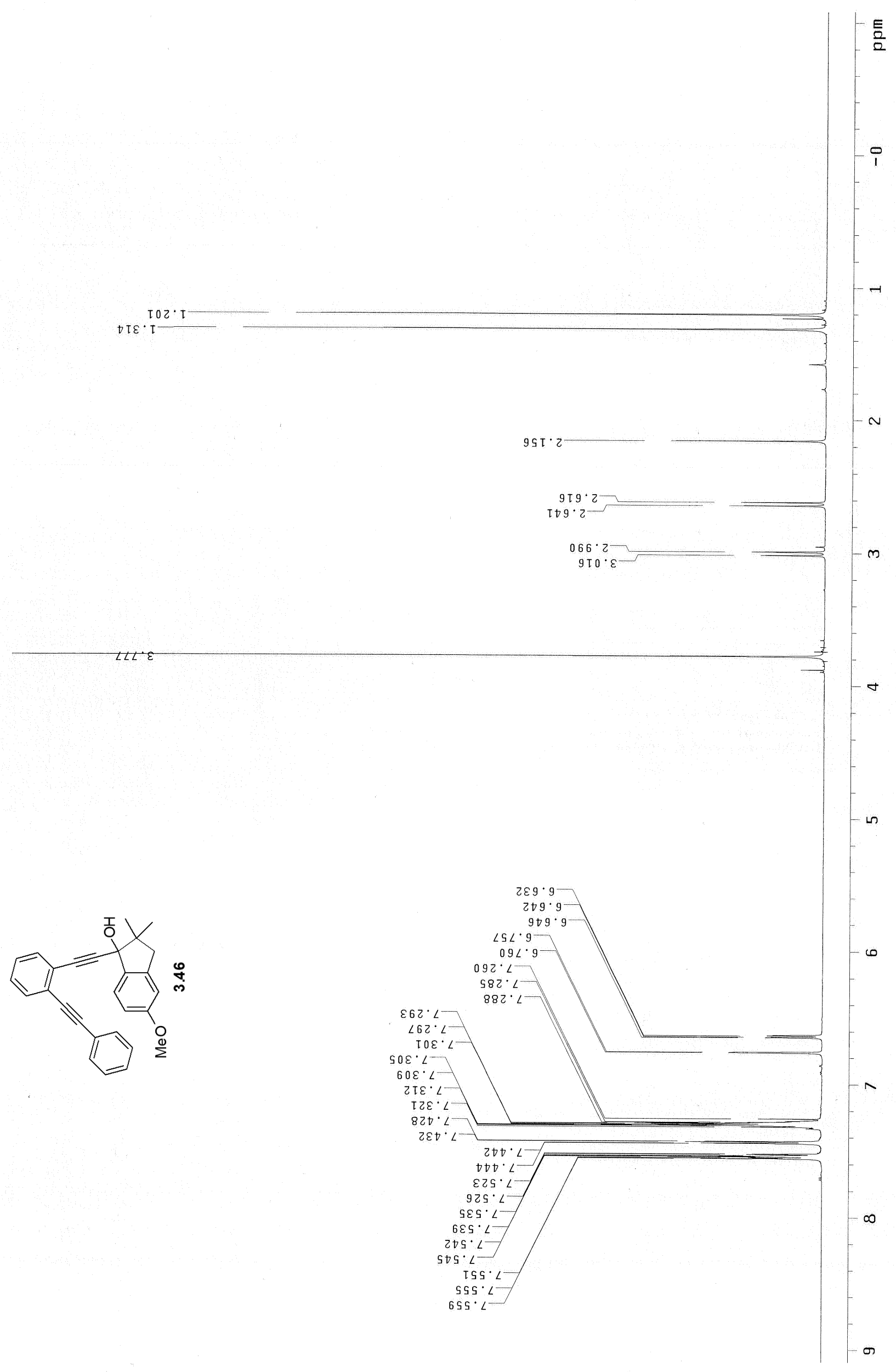




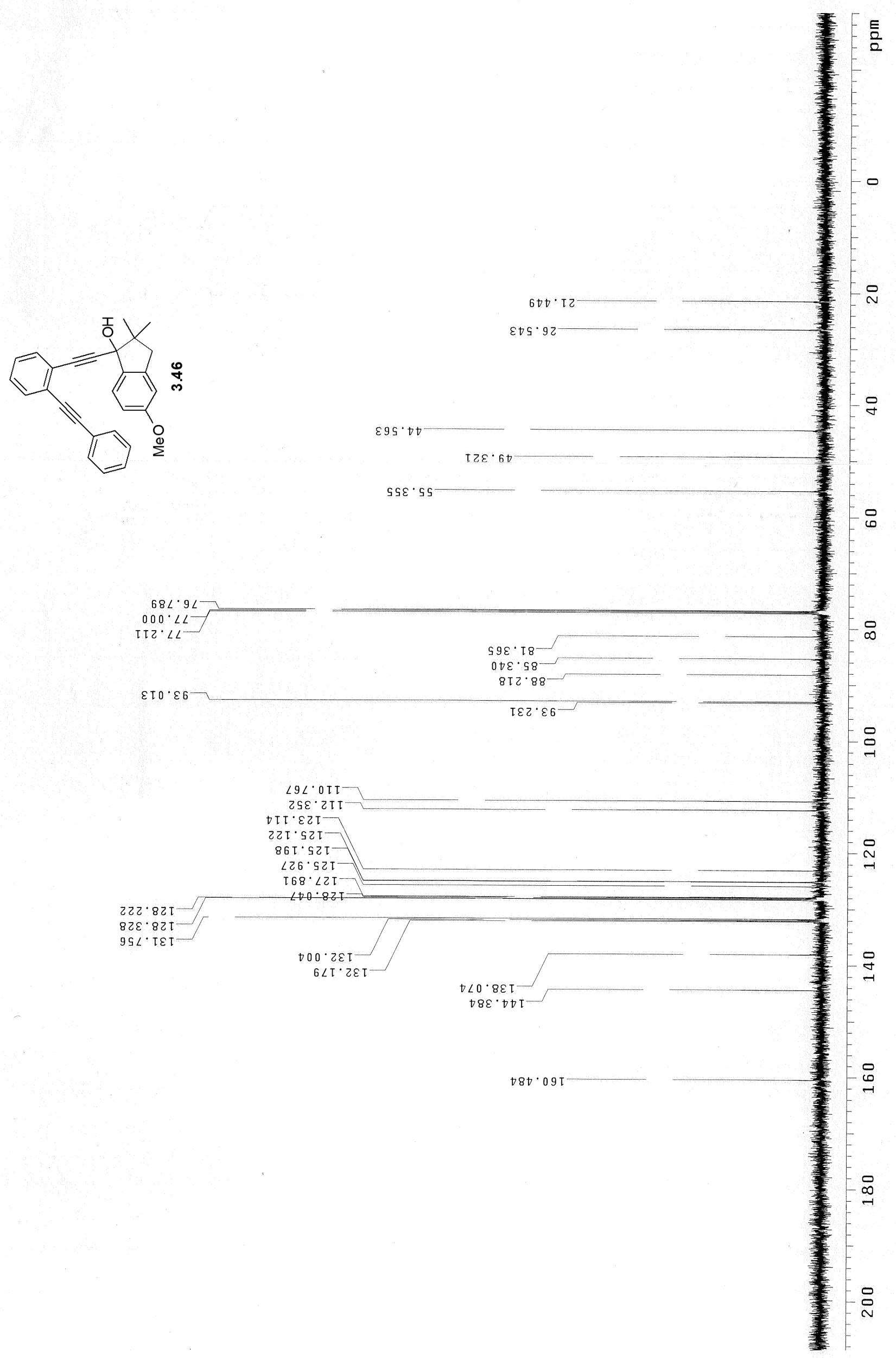




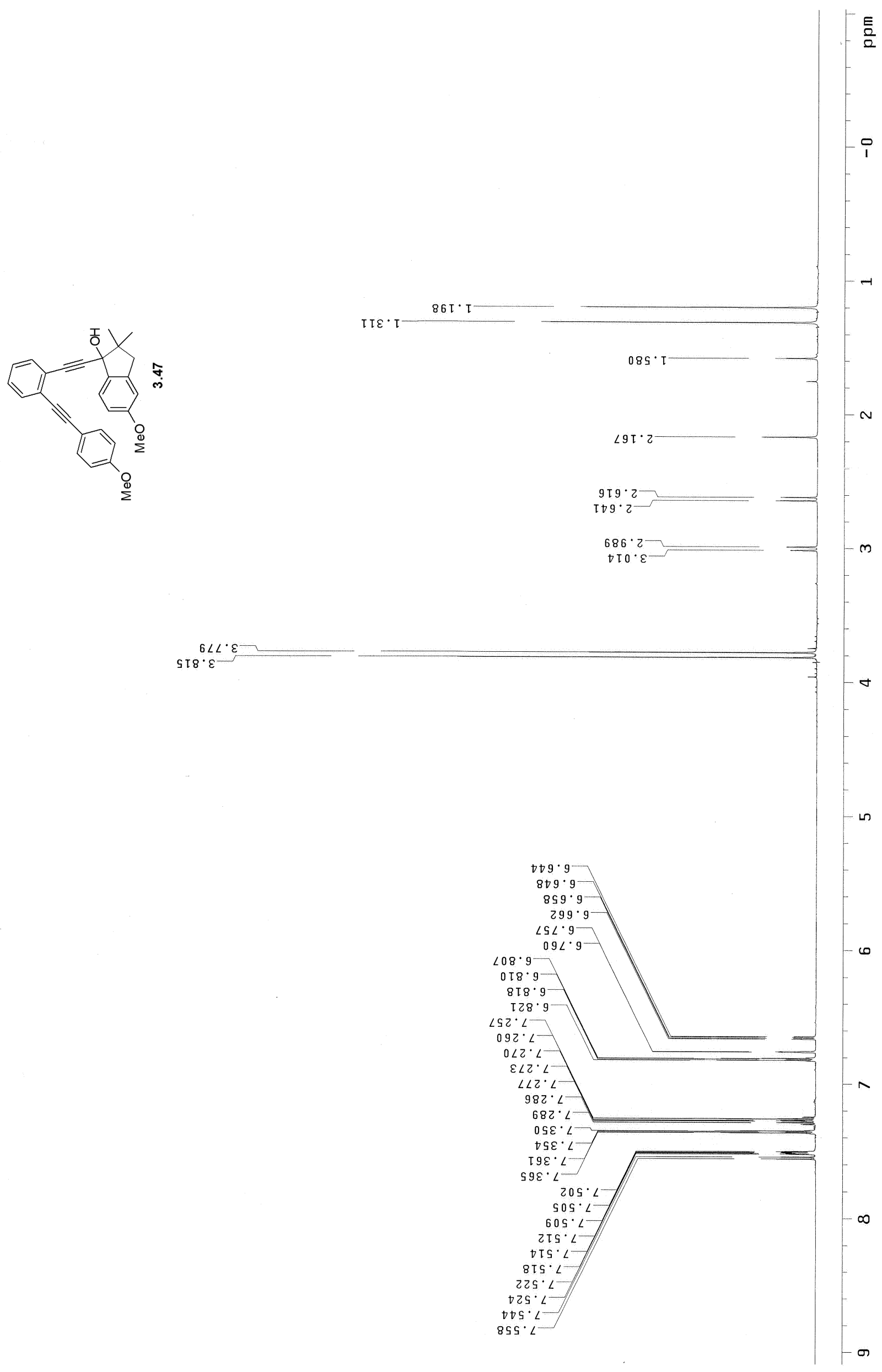




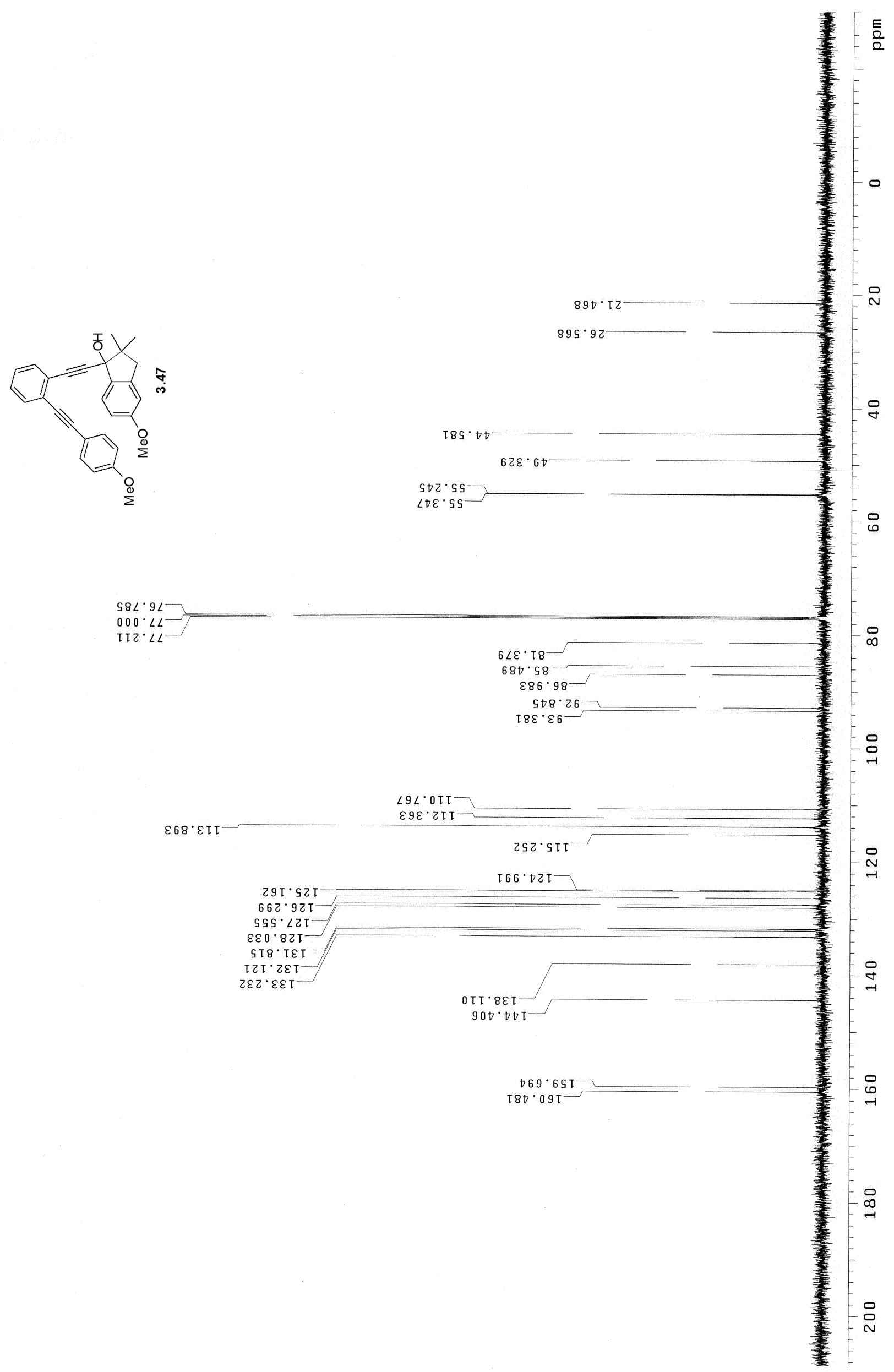




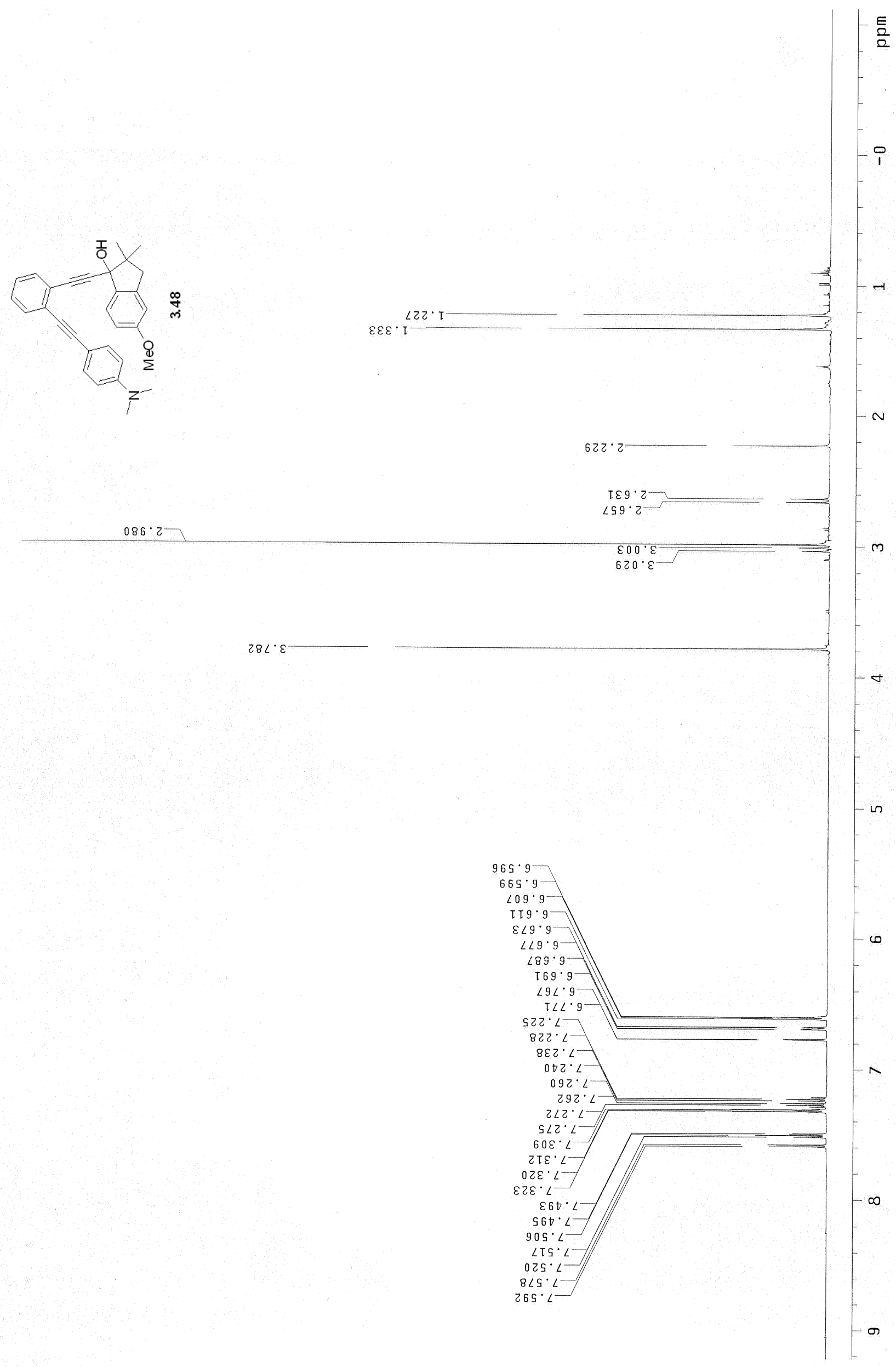




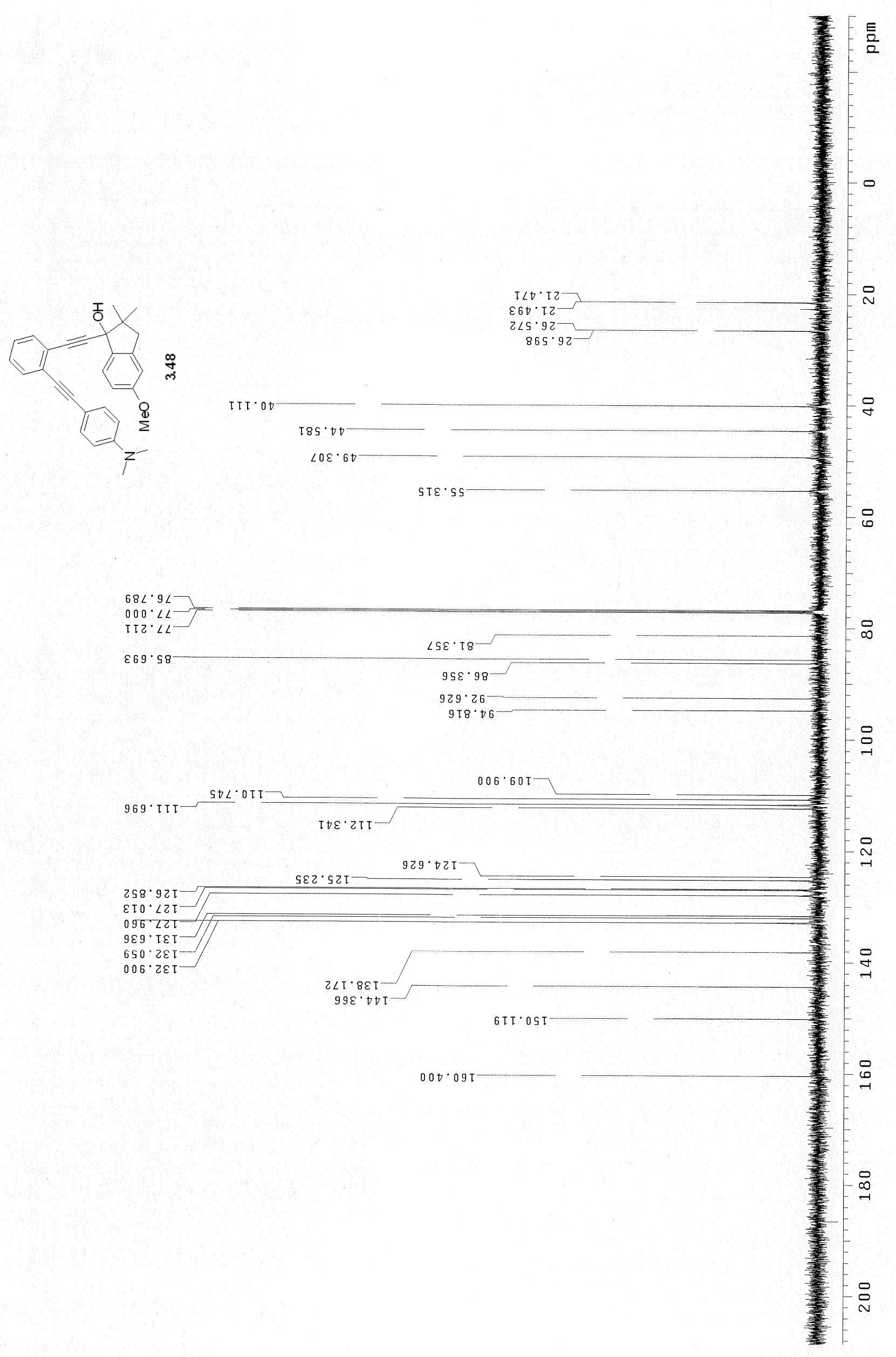




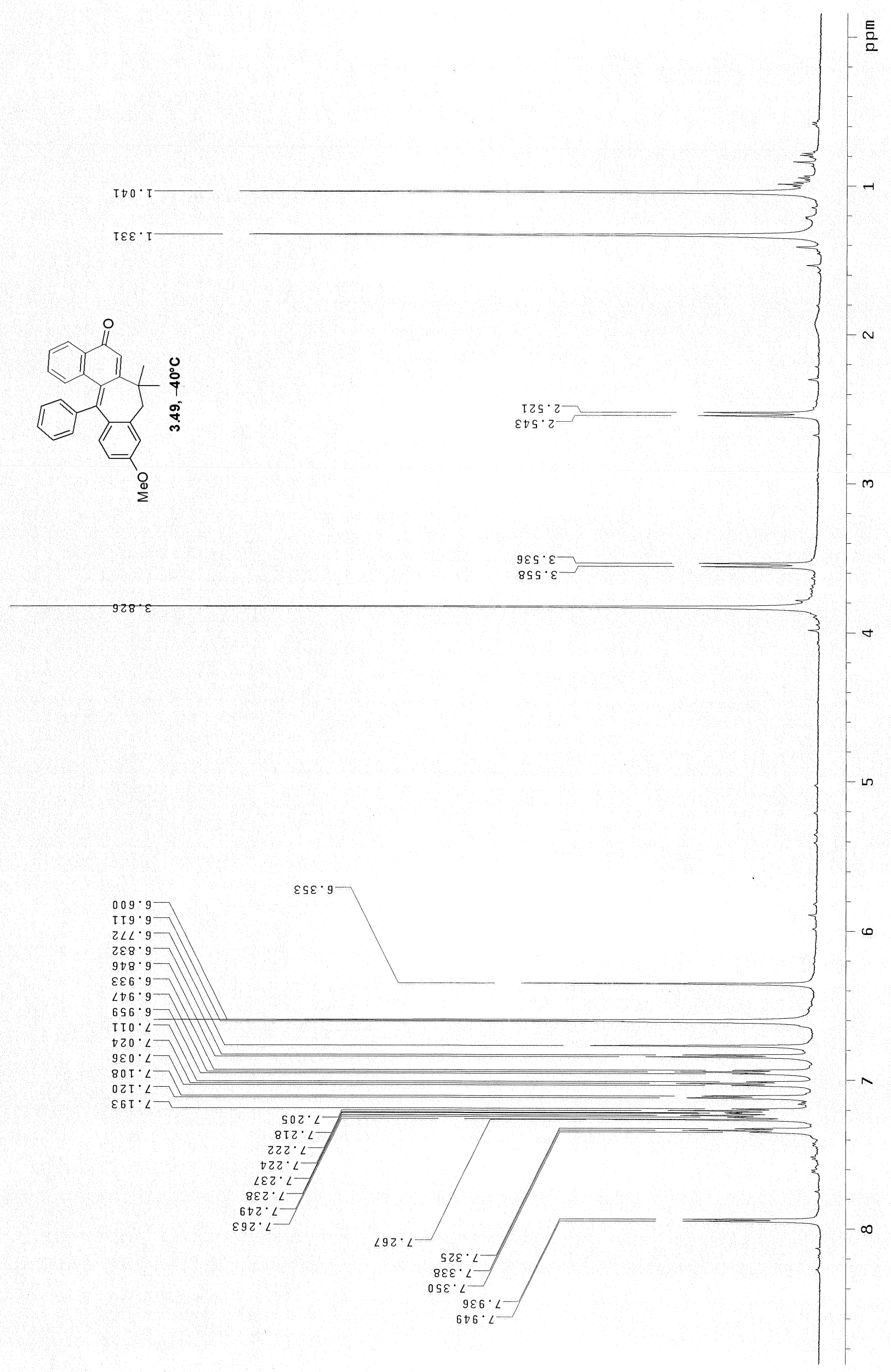




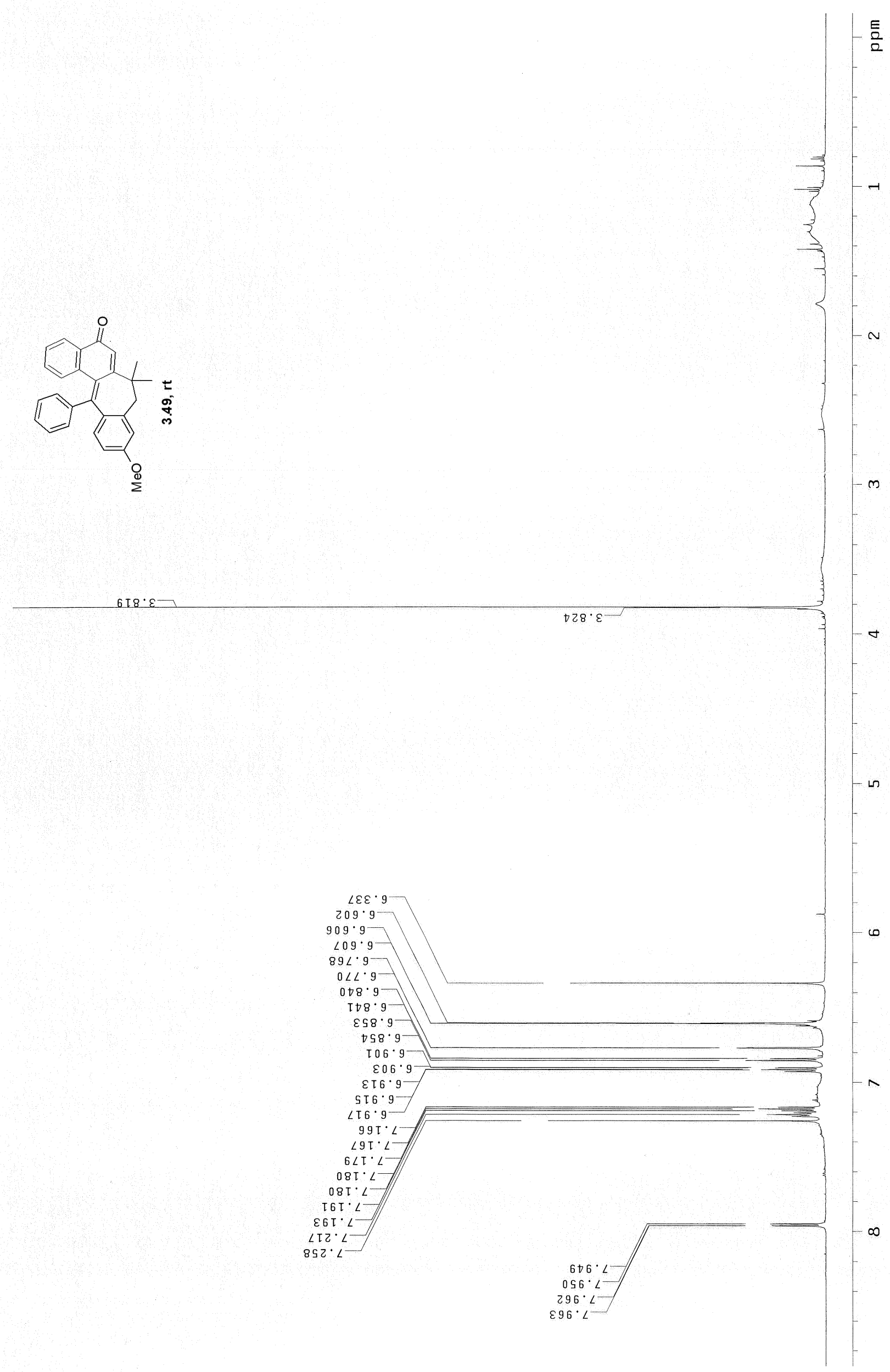




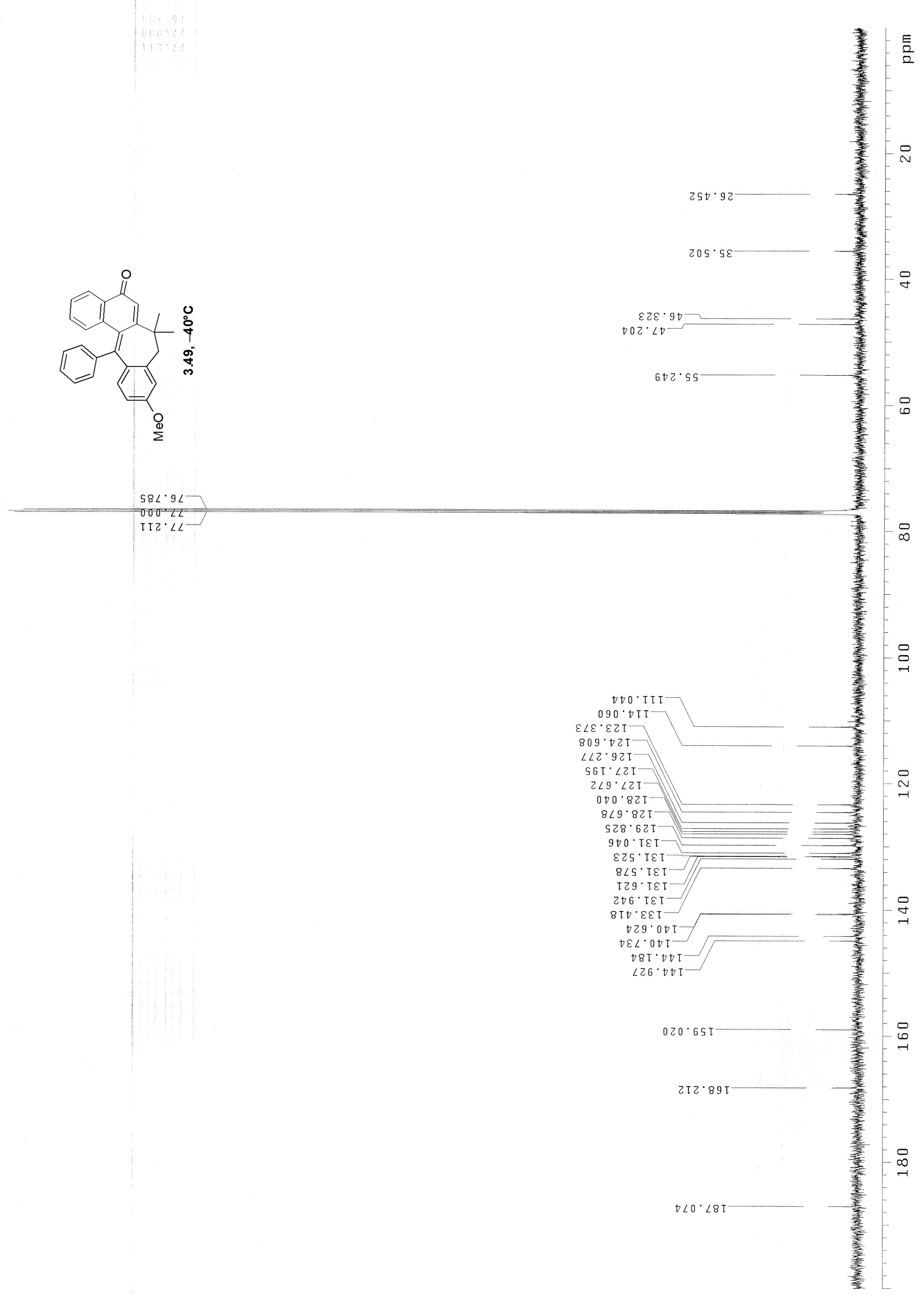




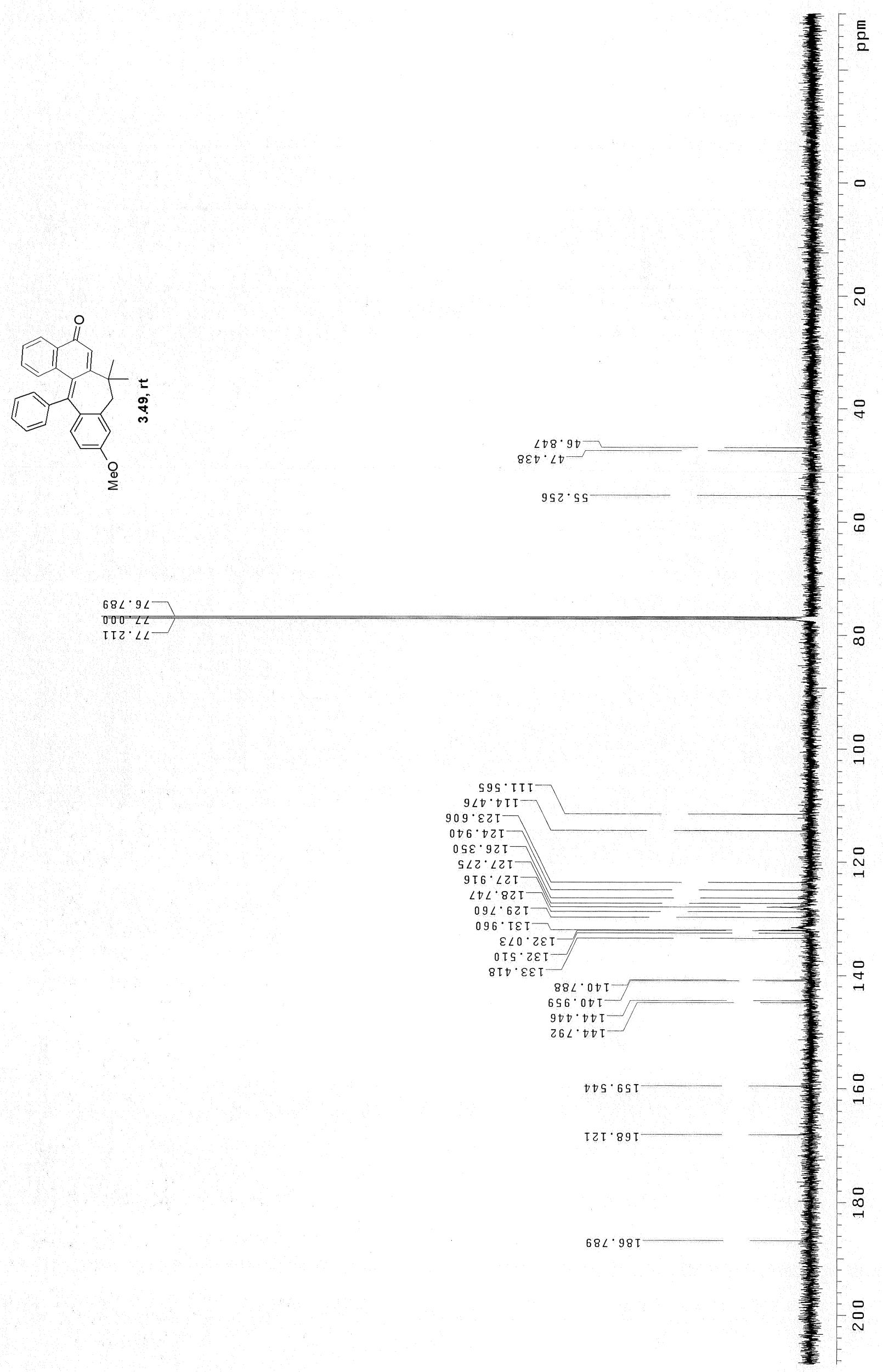



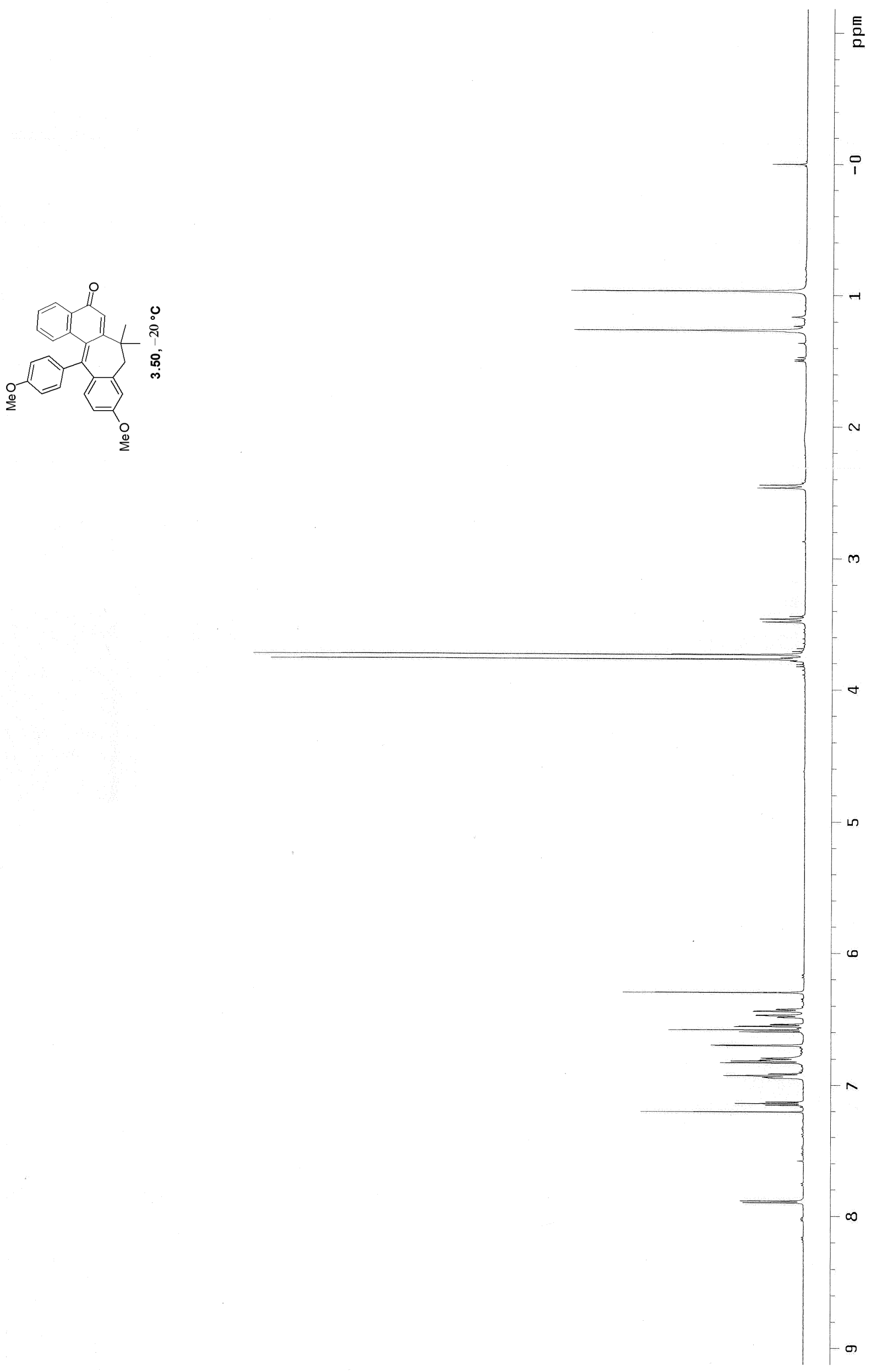


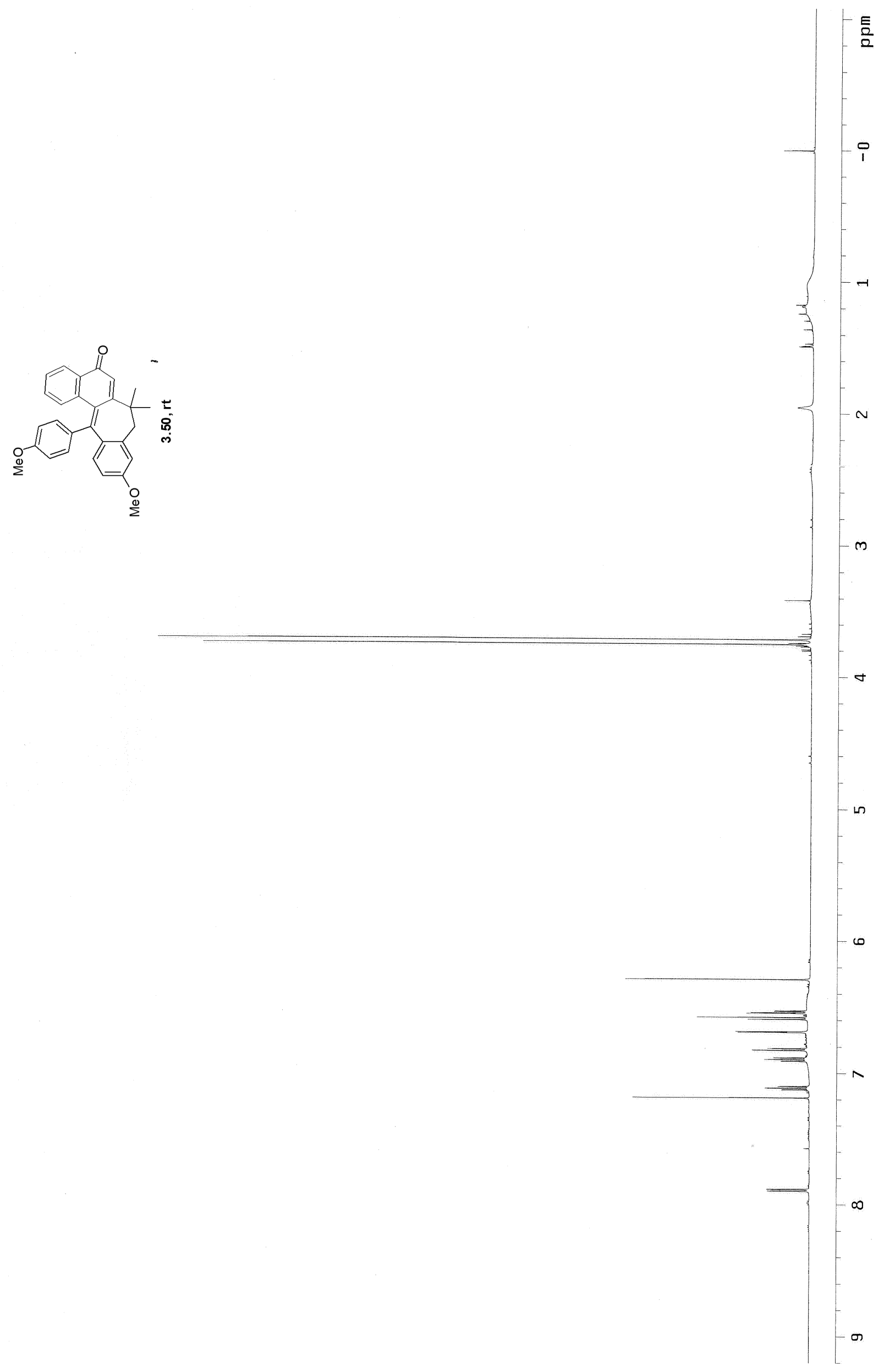




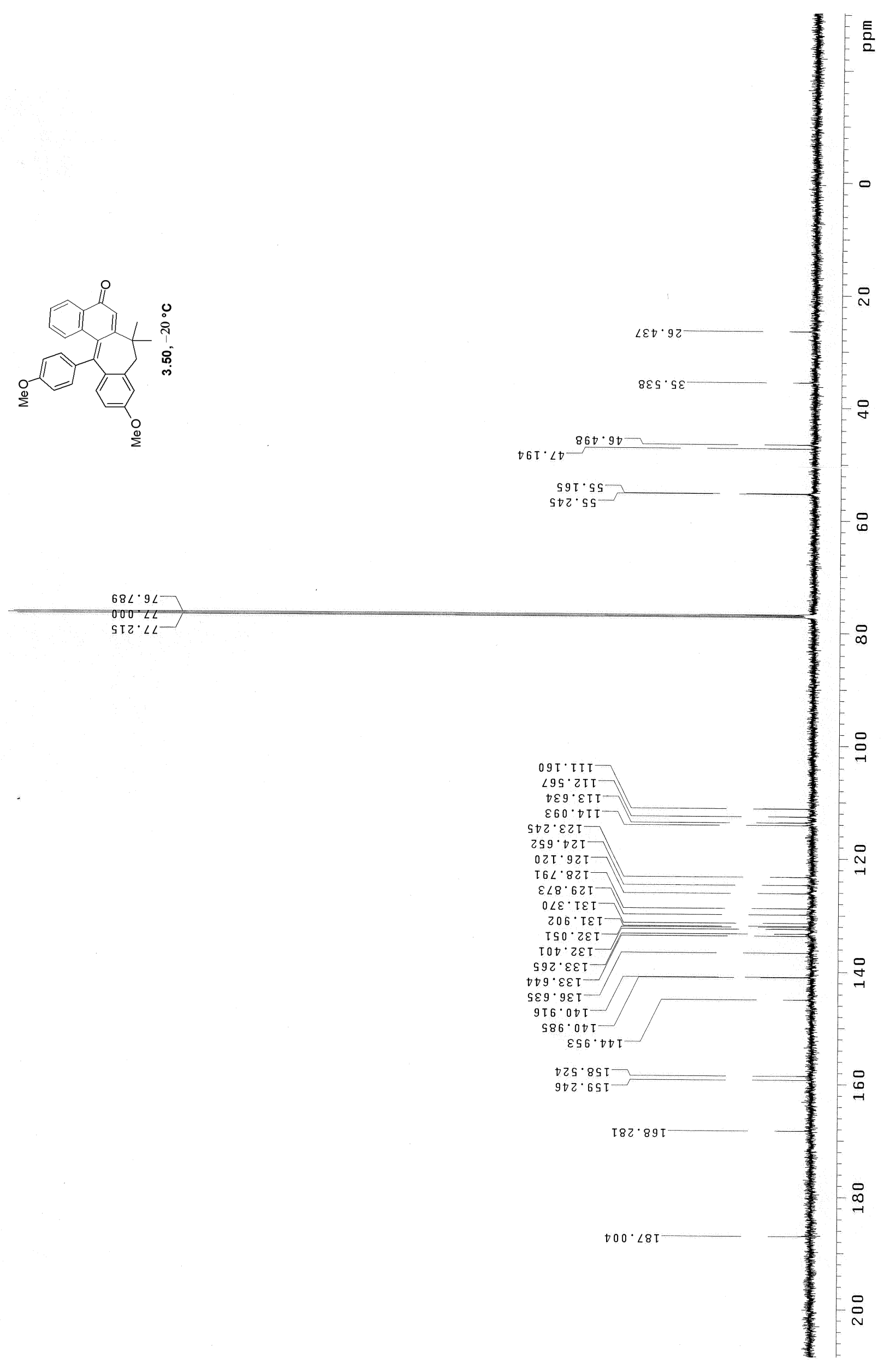




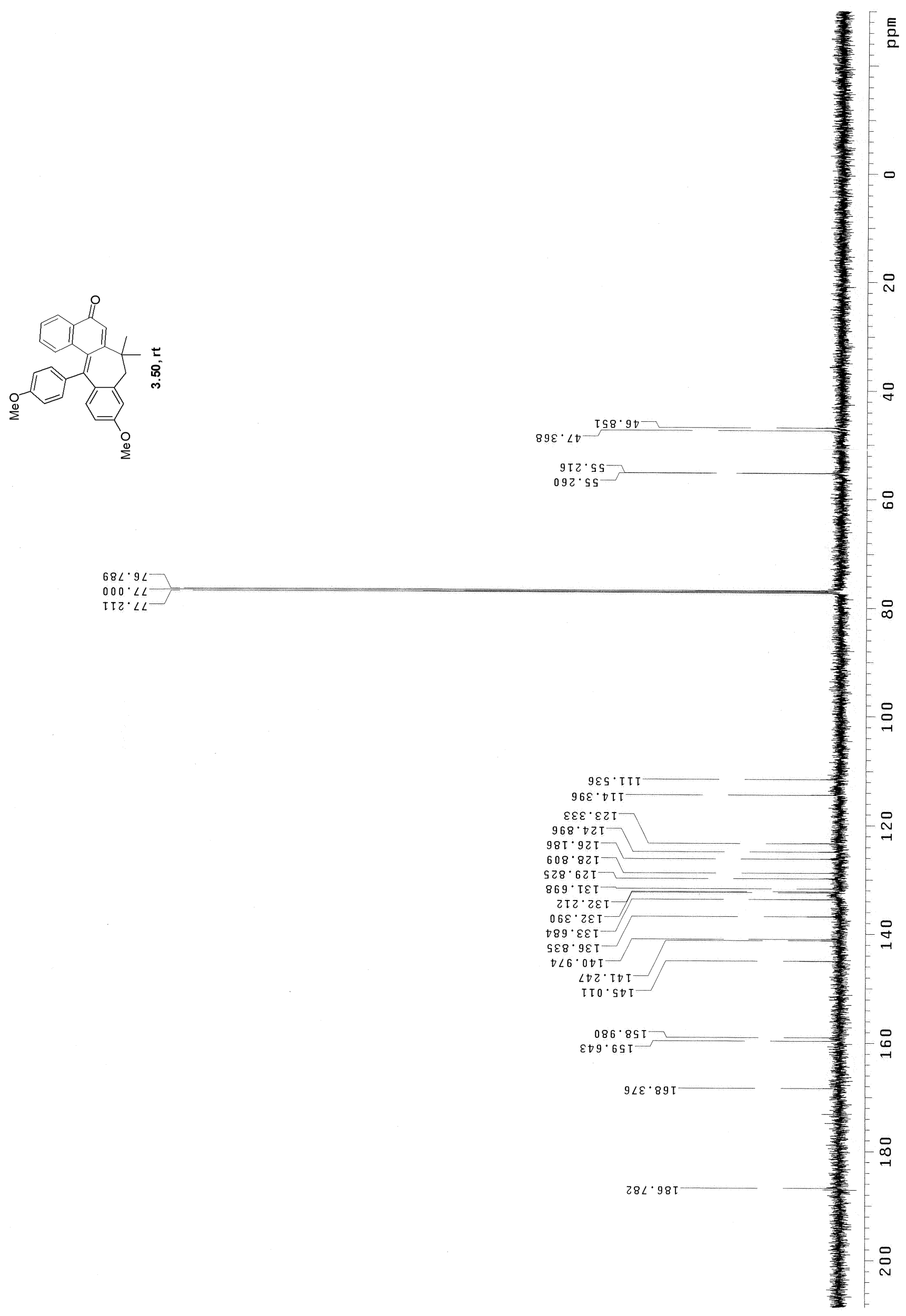




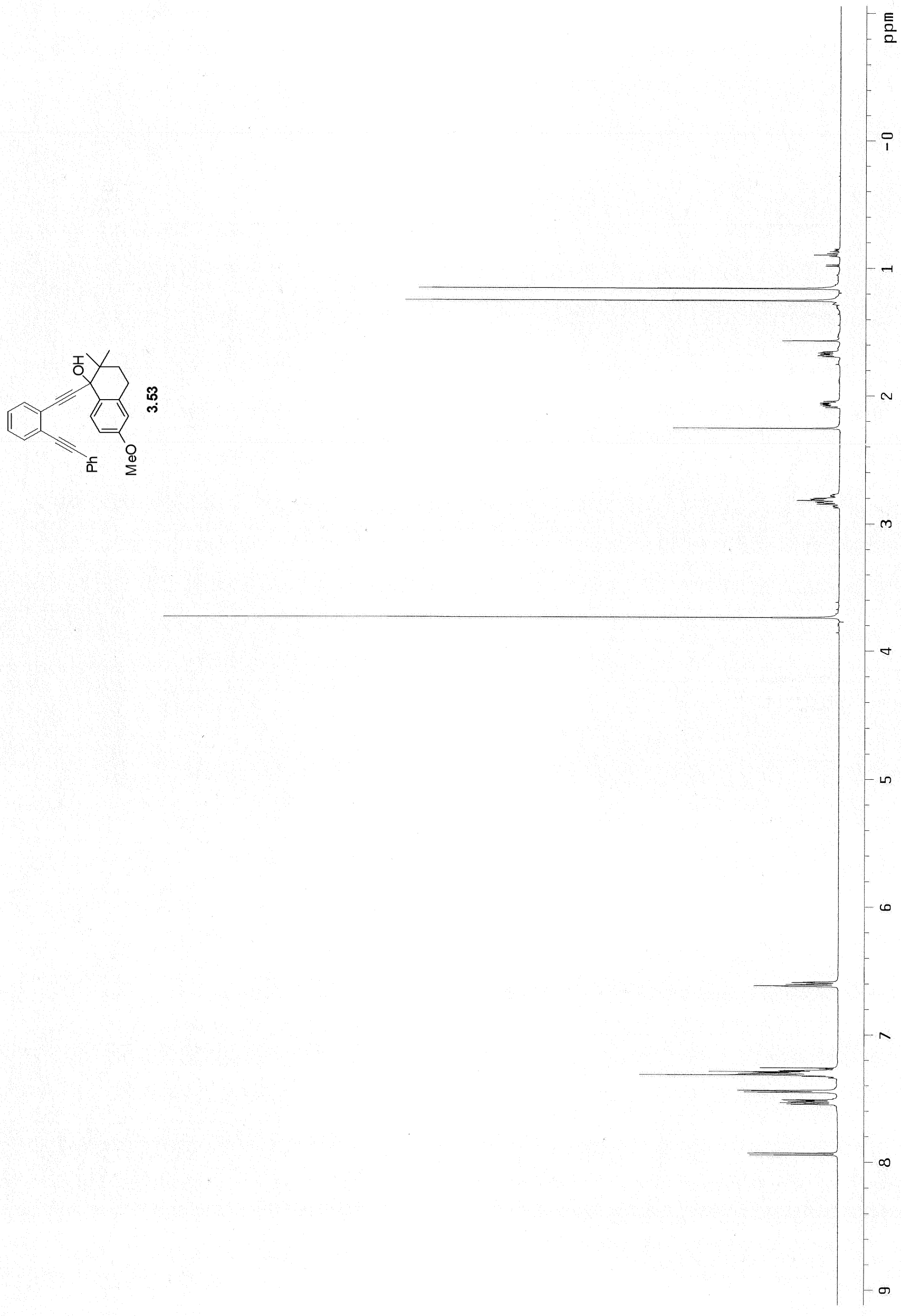



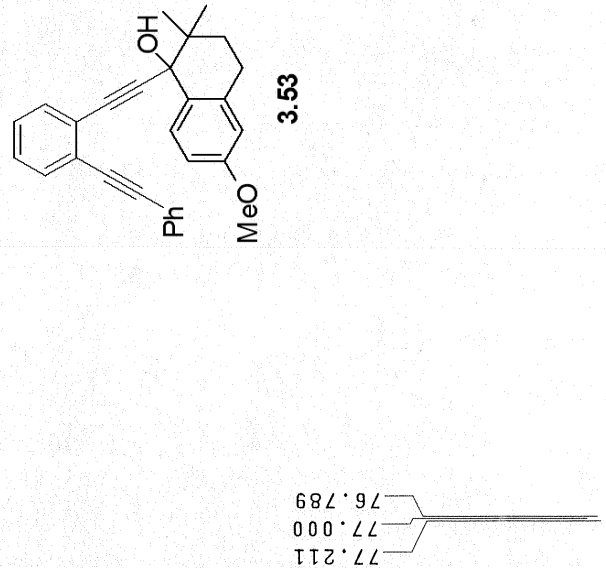

Ttz.
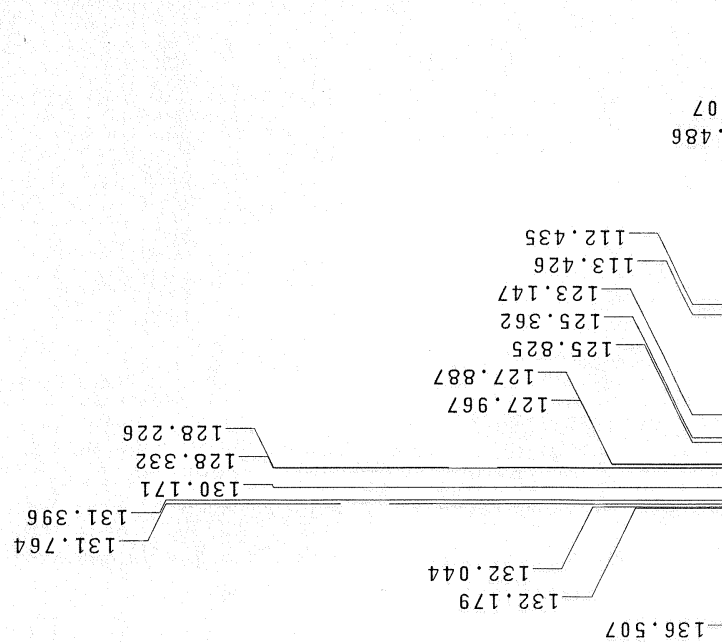

$\angle D T S S$

$286 \cdot t \angle$

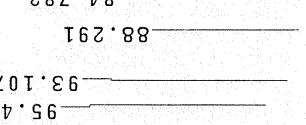

$\angle 0 T \cdot \varepsilon 6$
$980^{\circ} \cdot 96$

$0 \varepsilon L \cdot \varepsilon \tau$

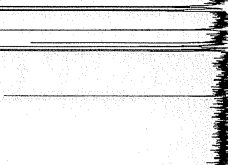




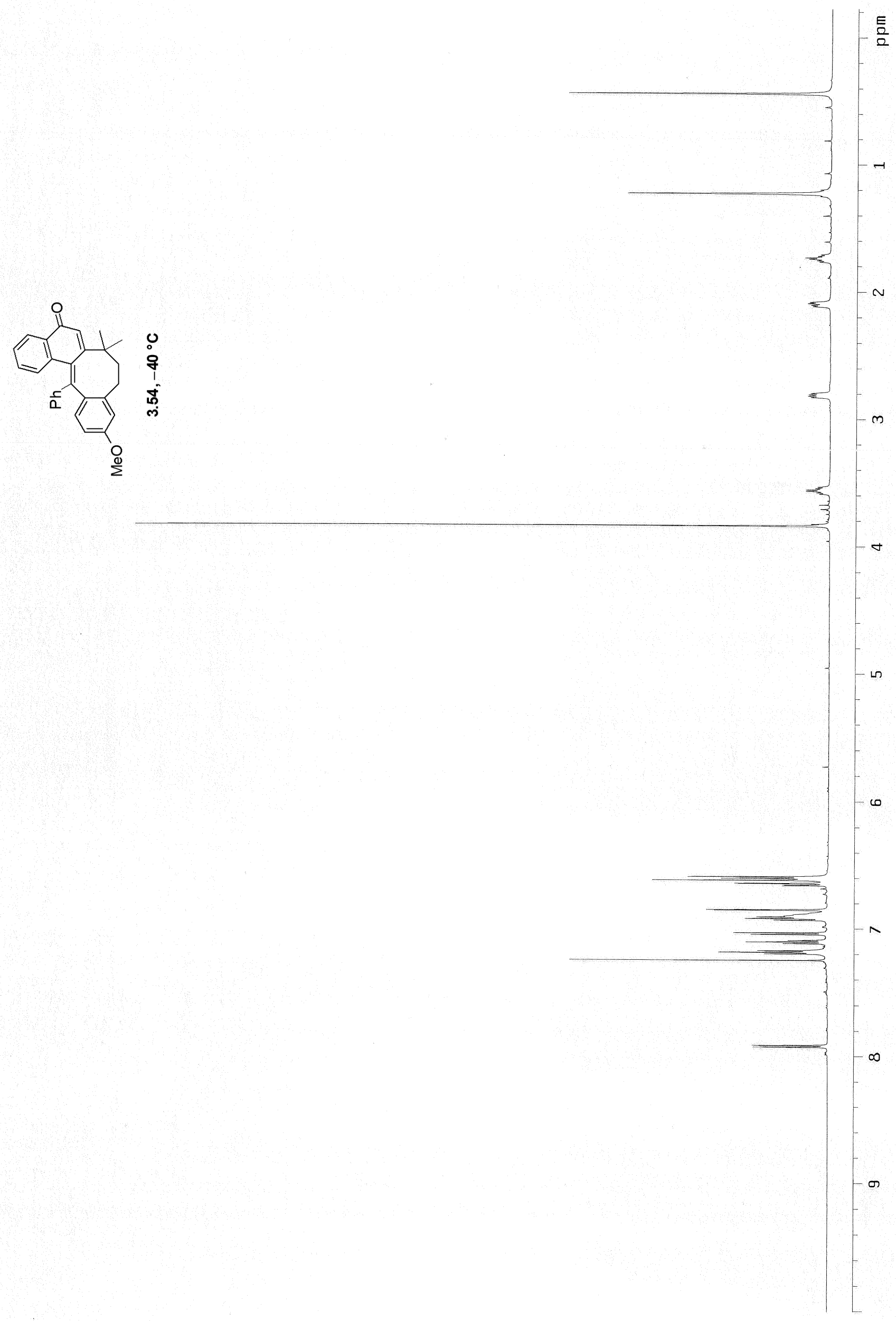




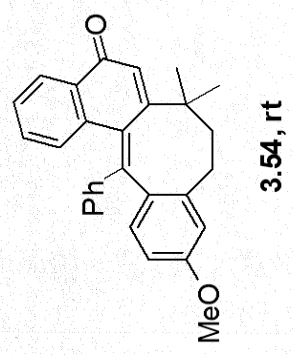




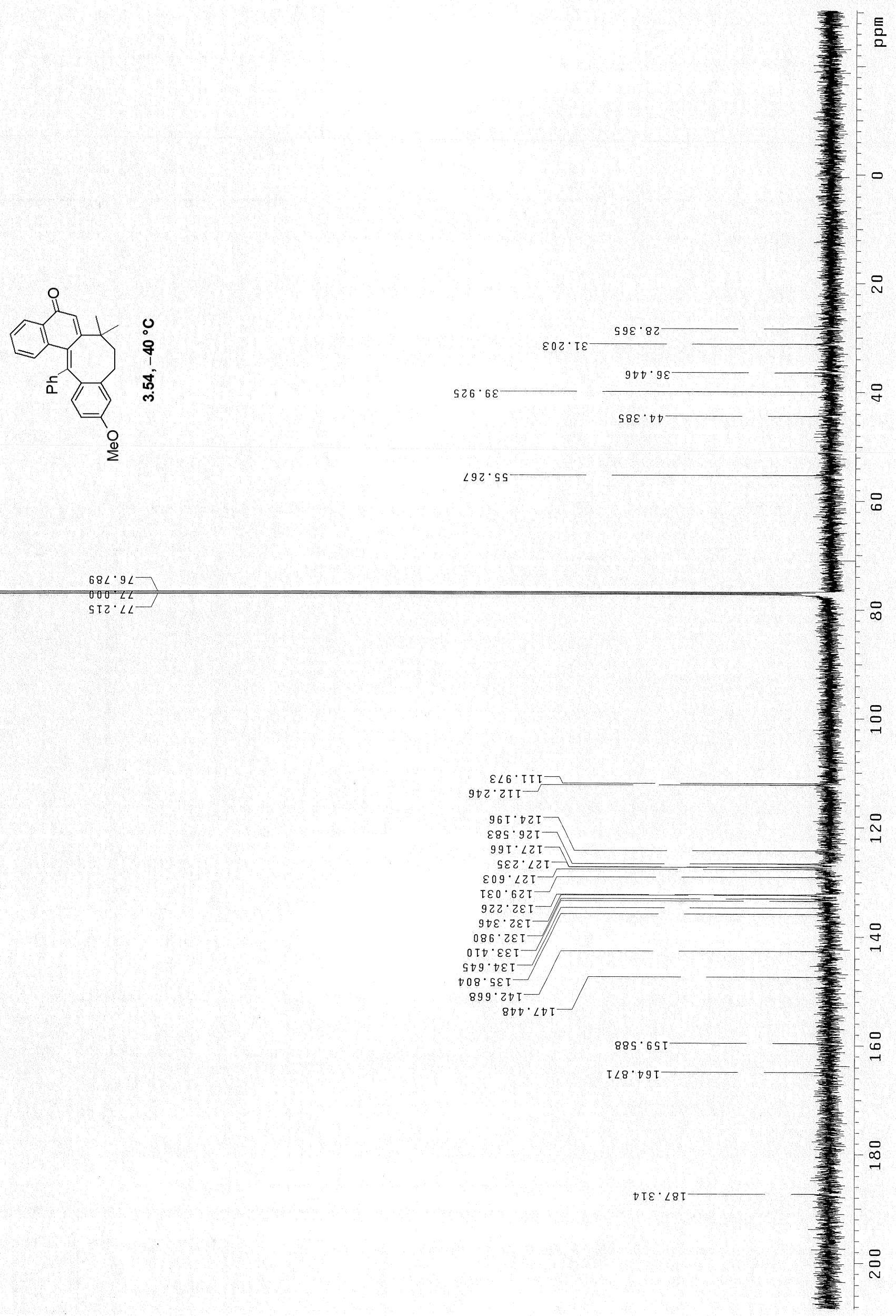




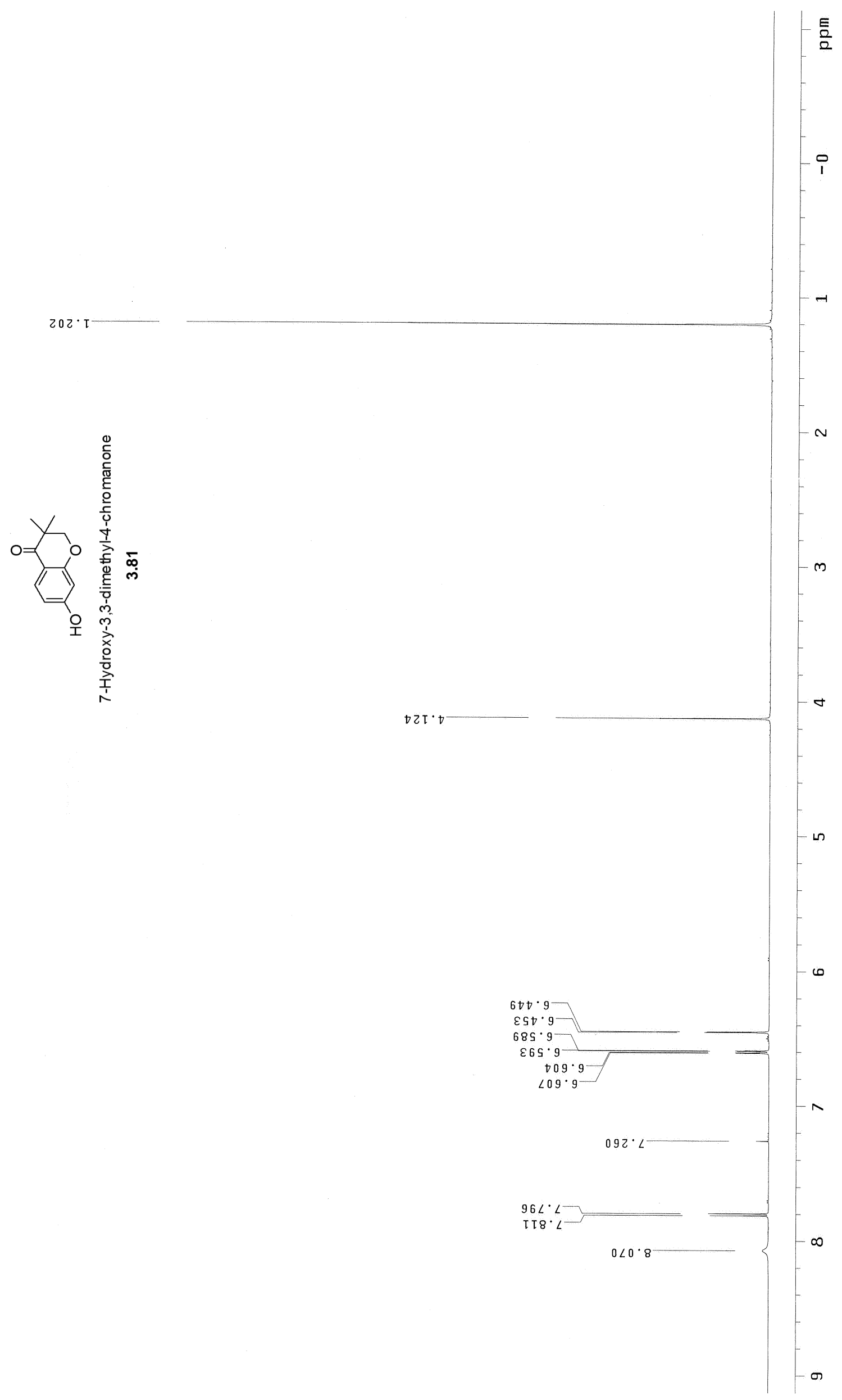




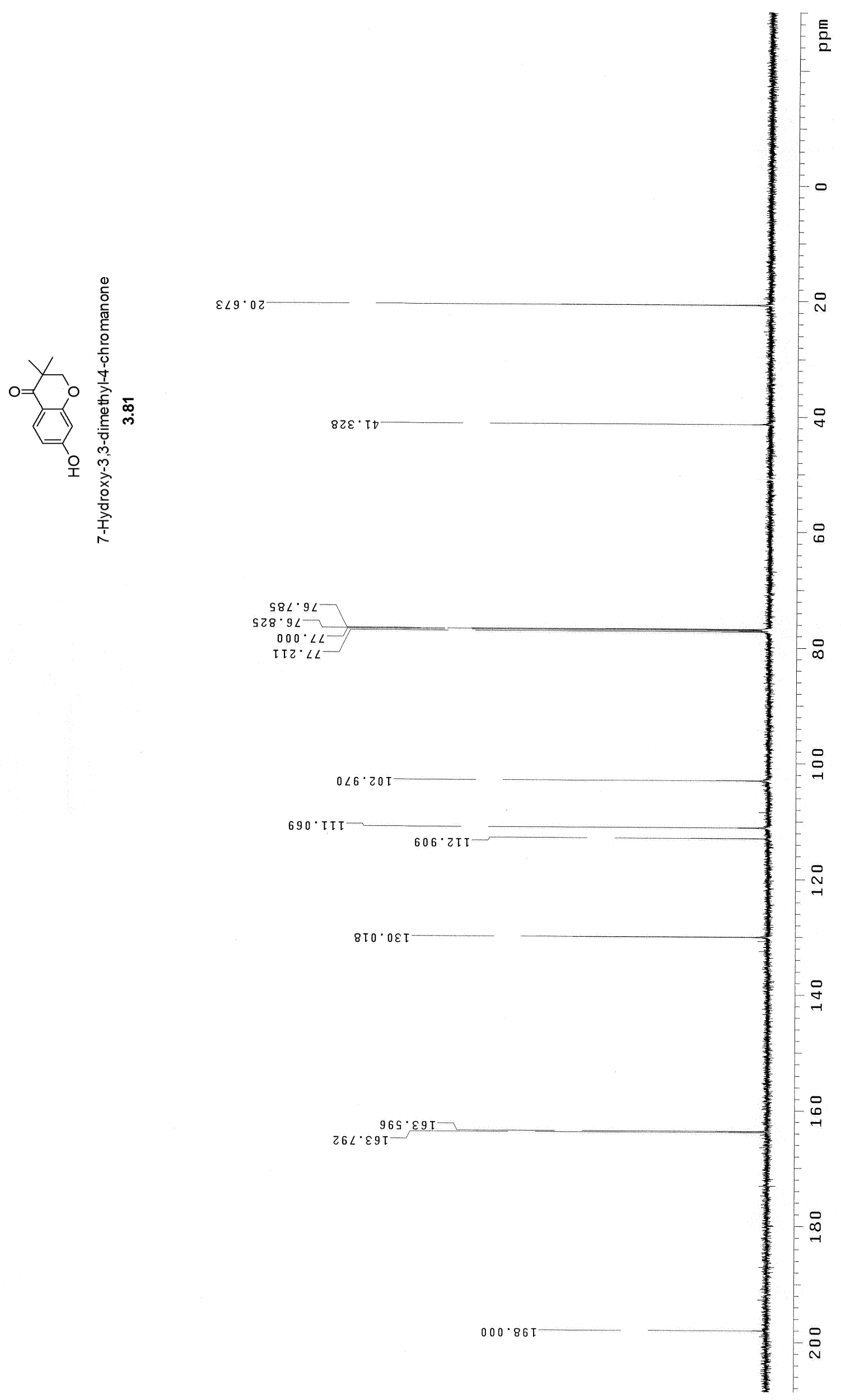




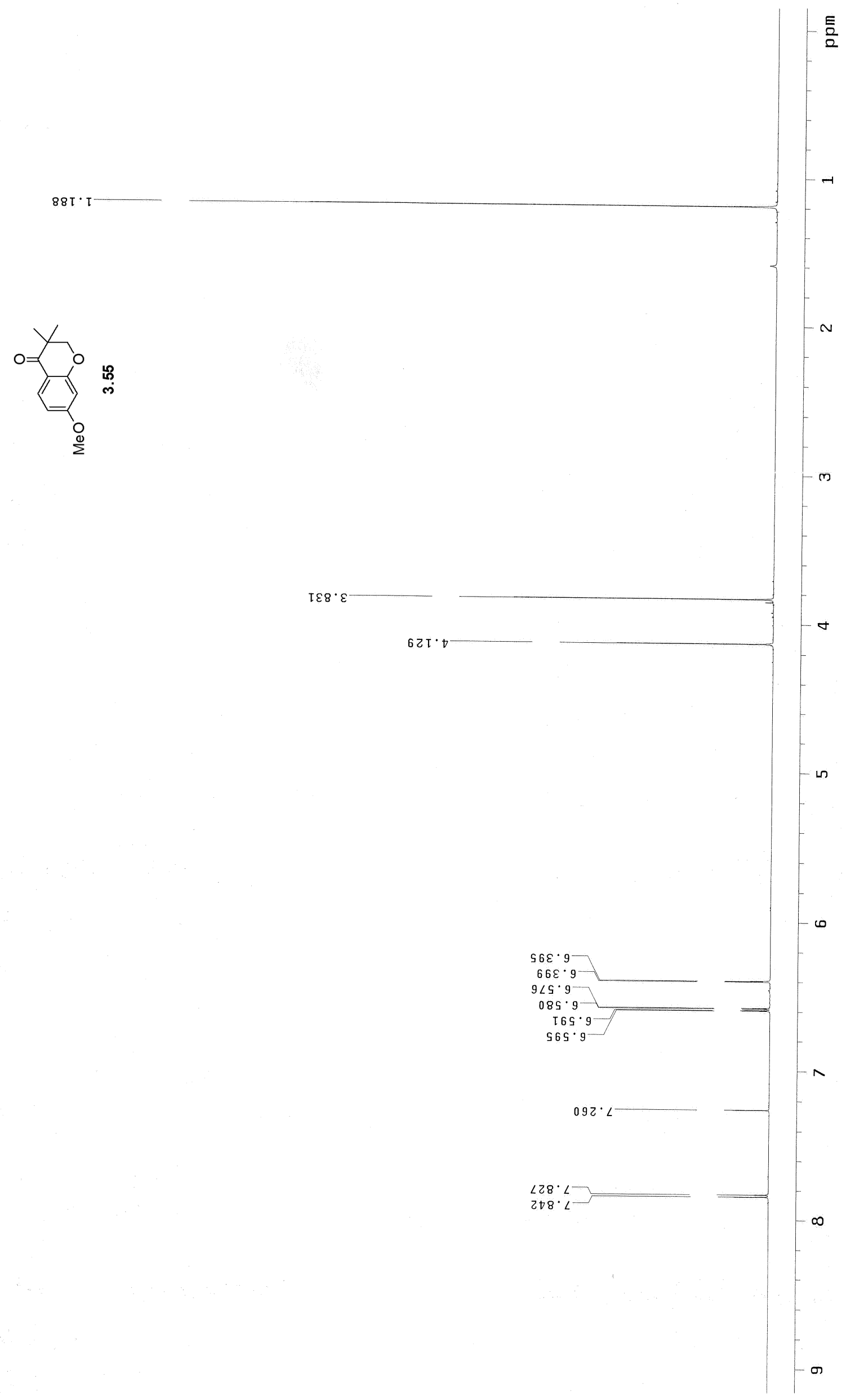



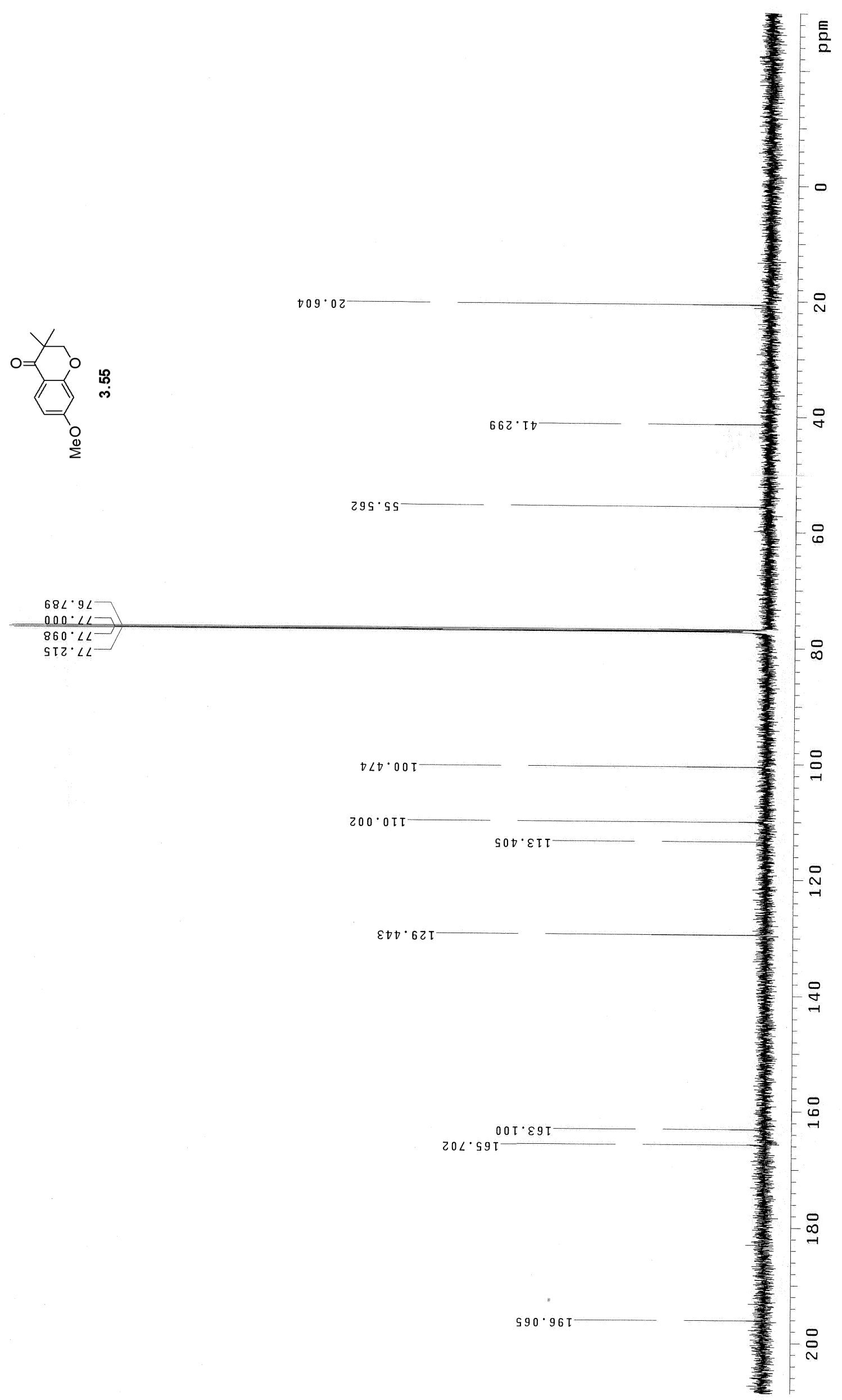


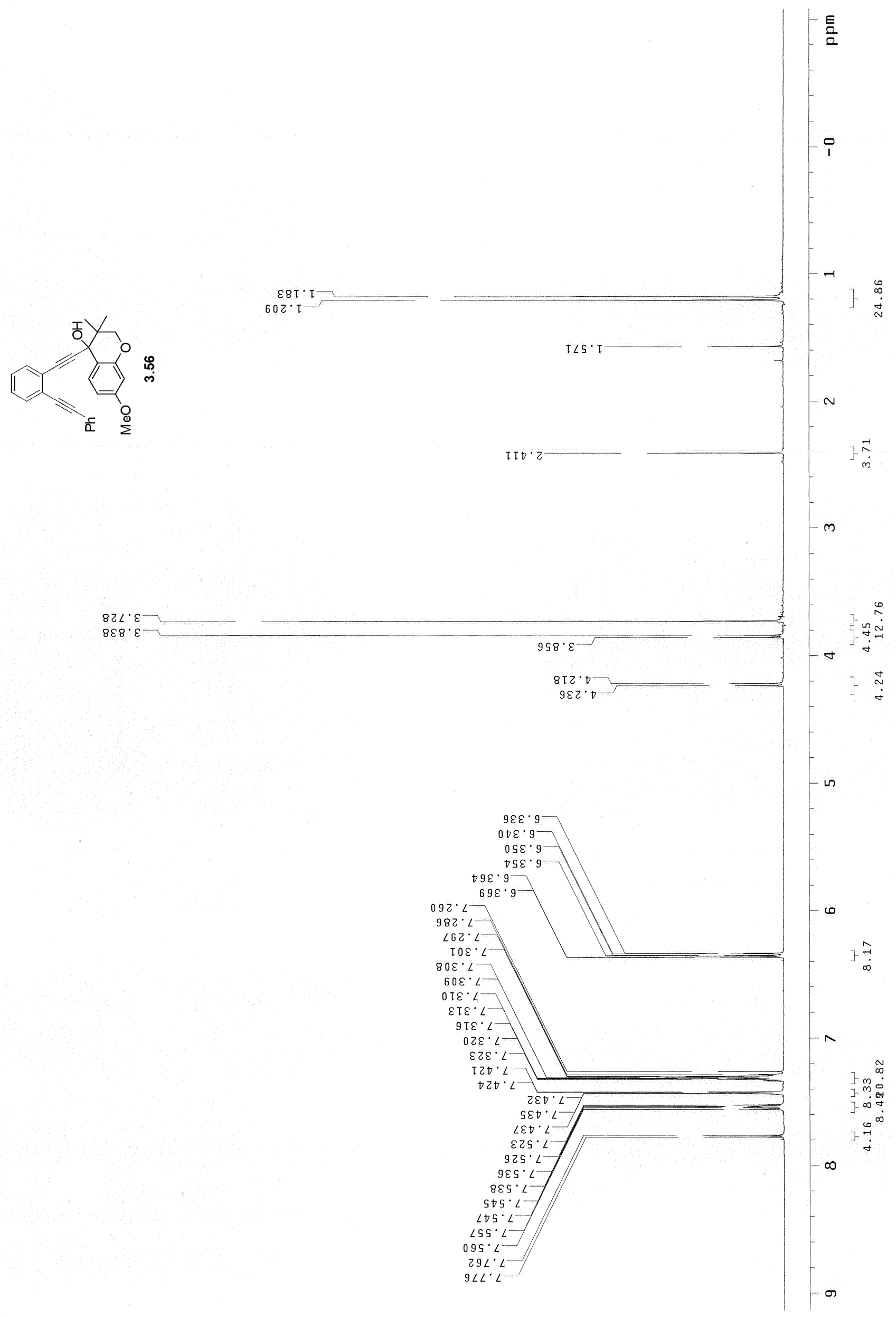




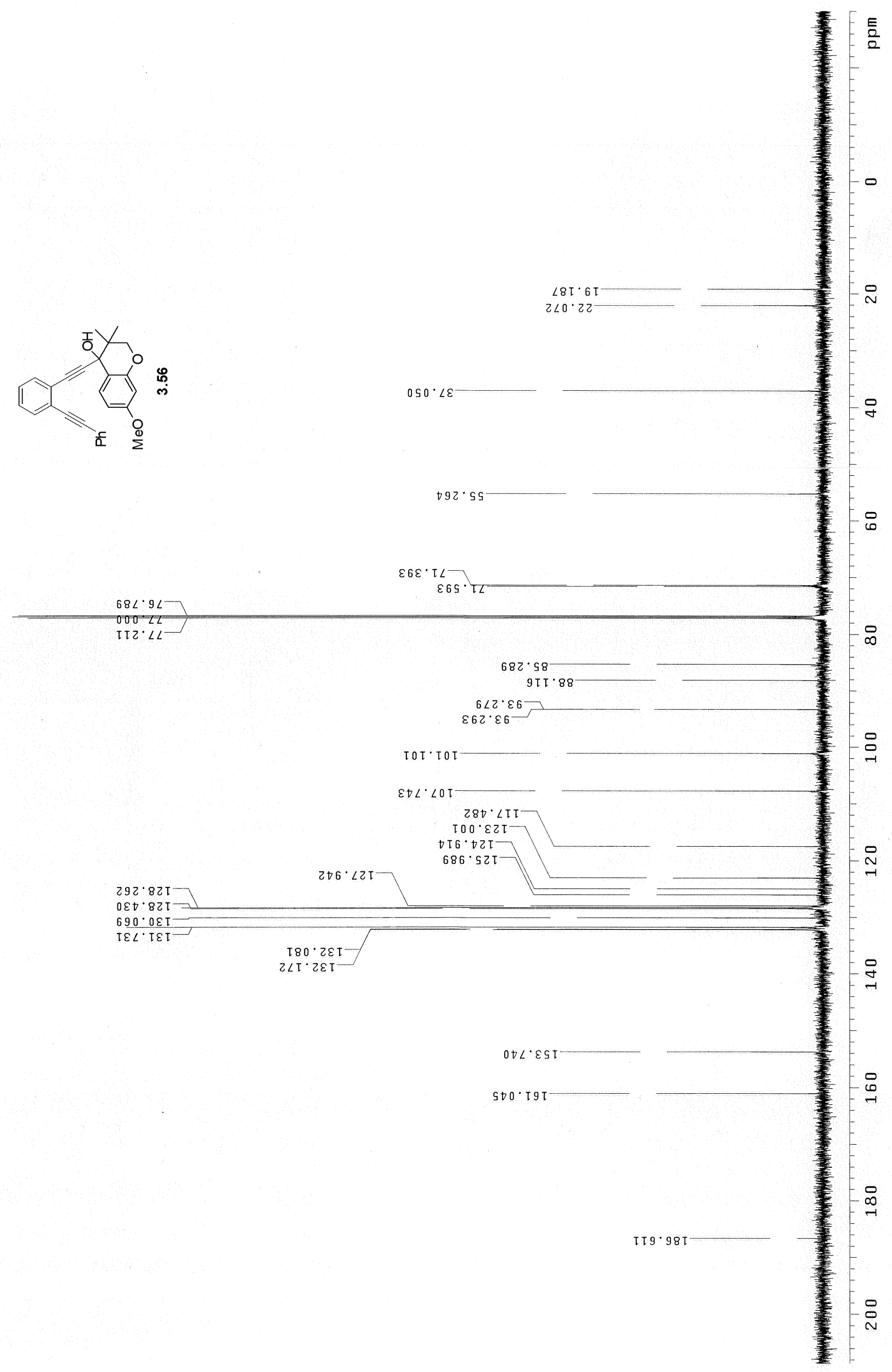




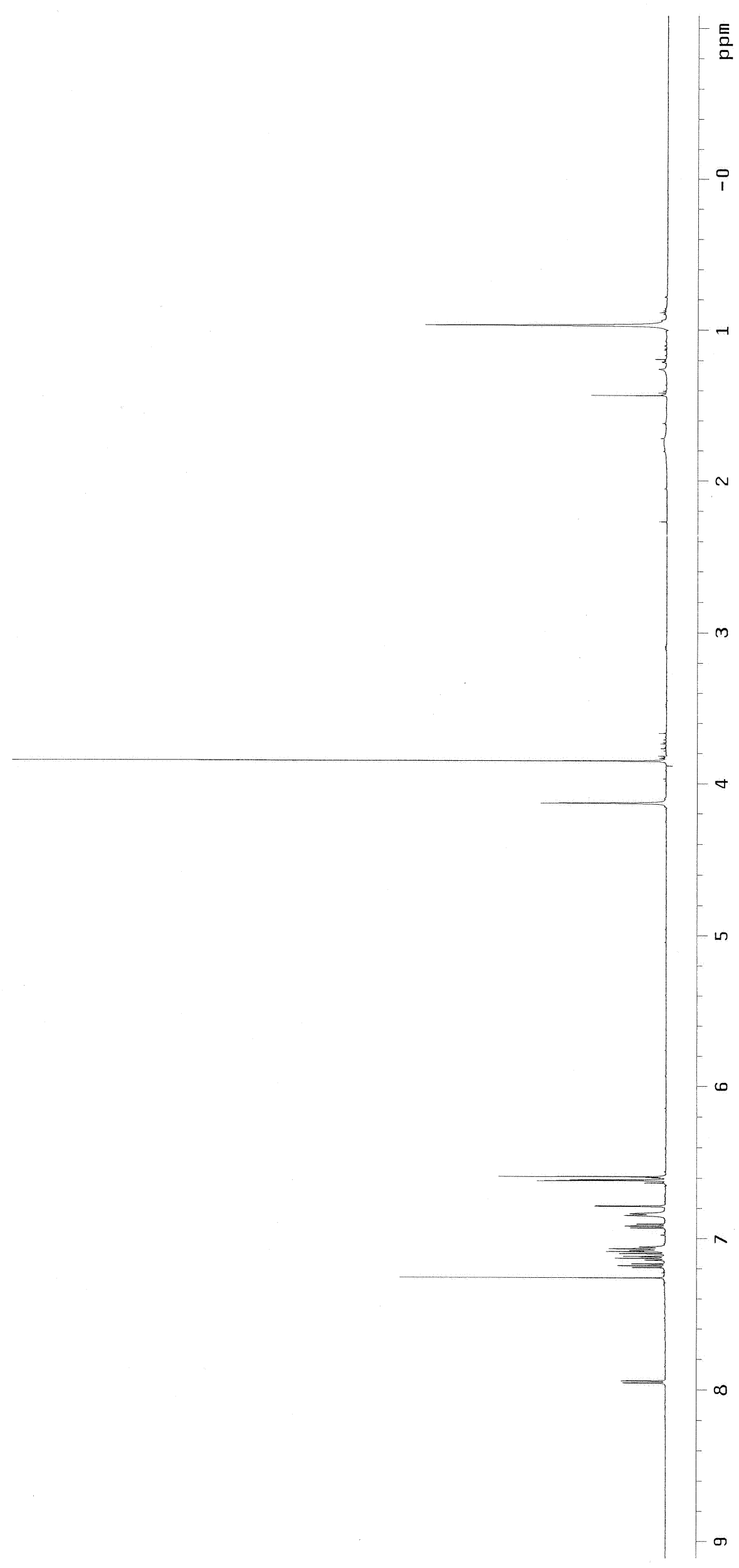




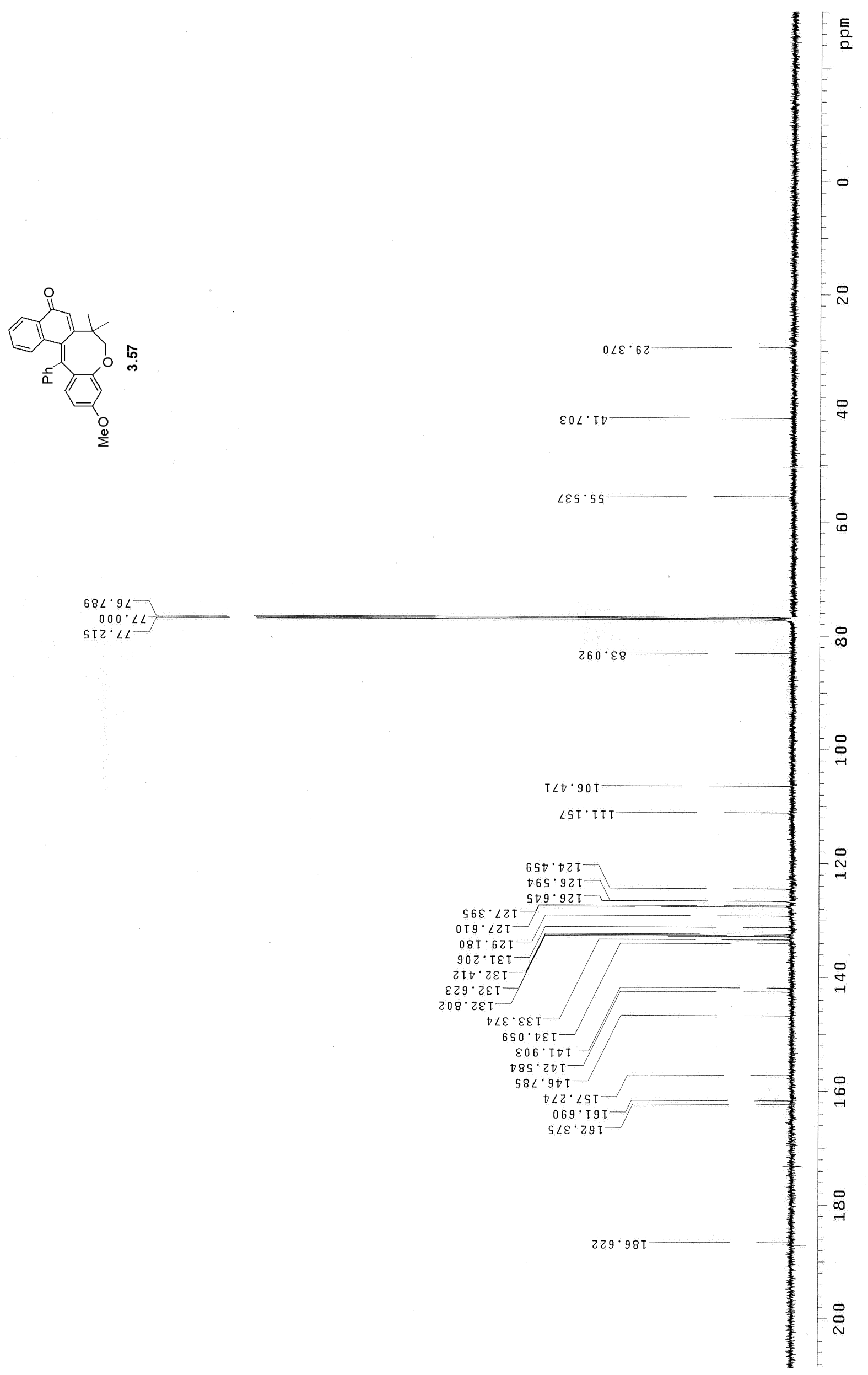




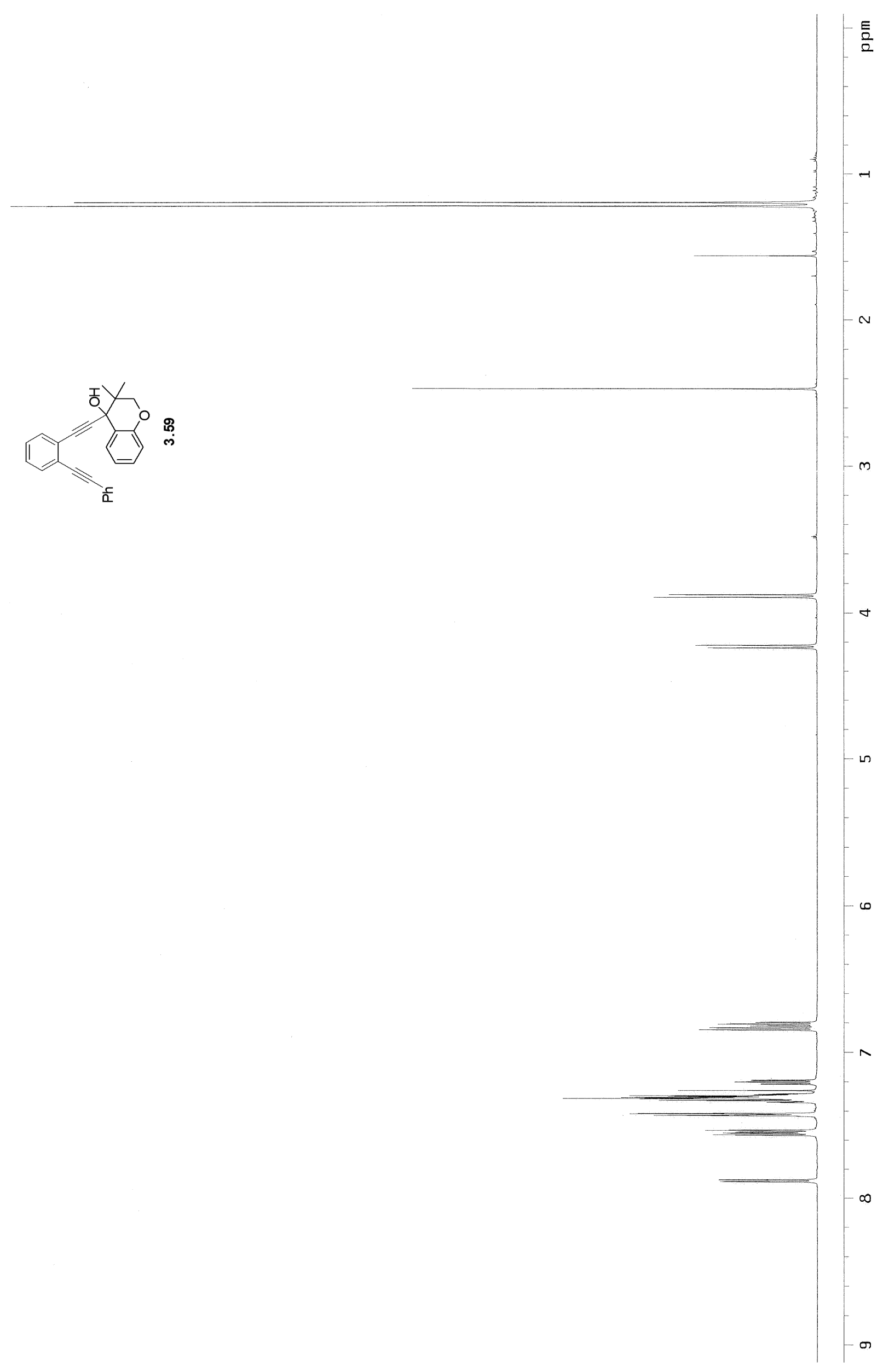



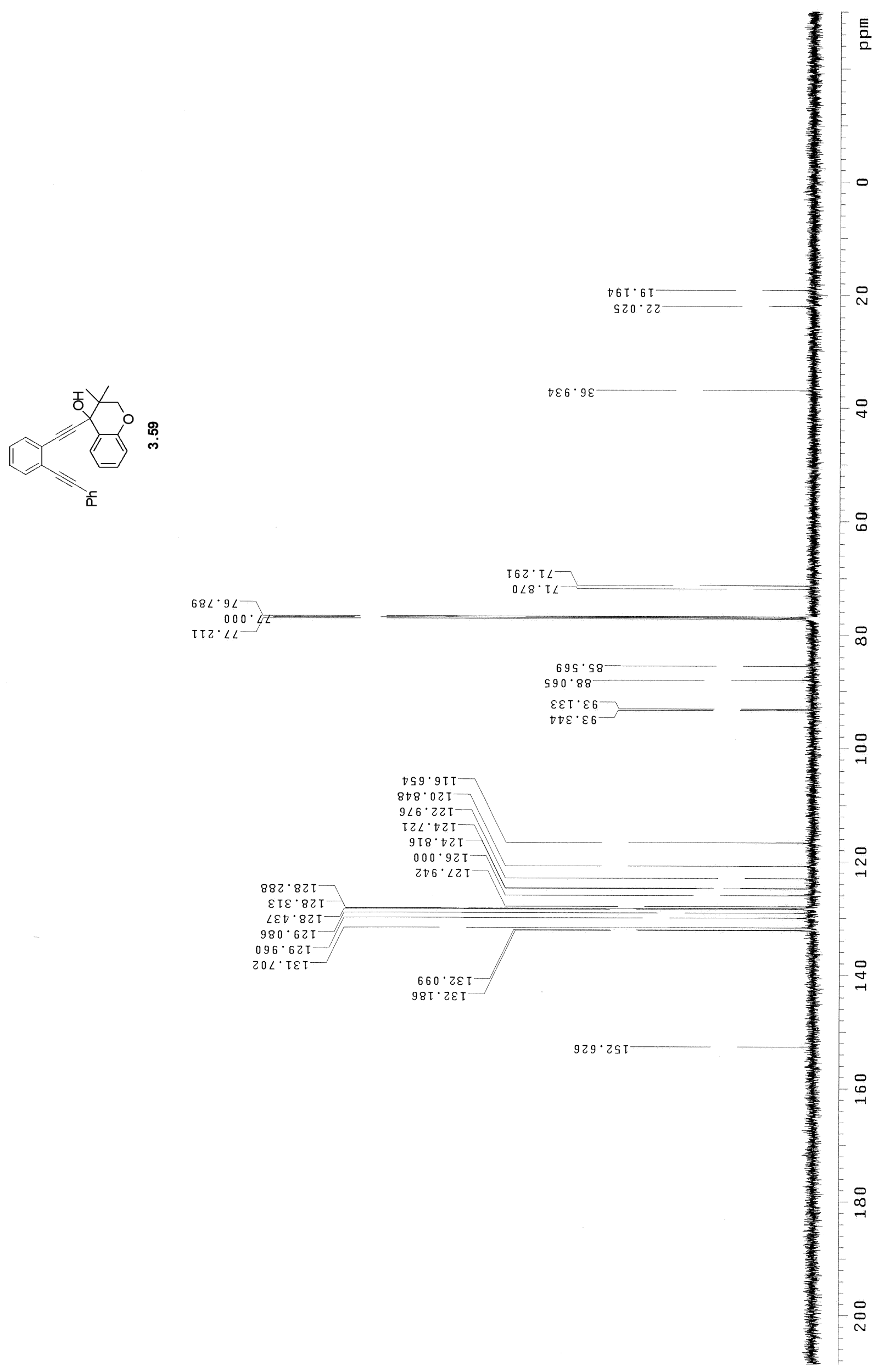


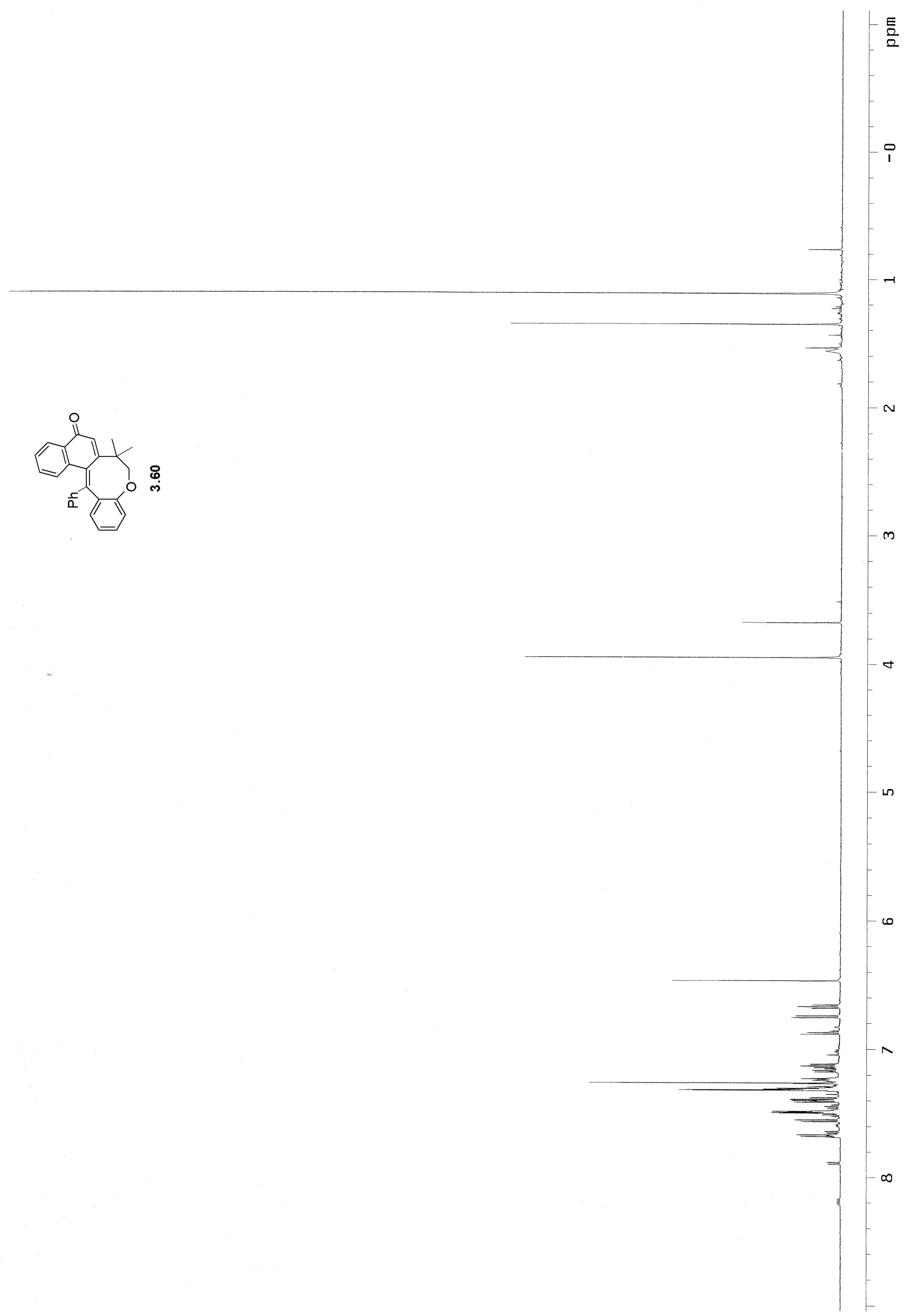




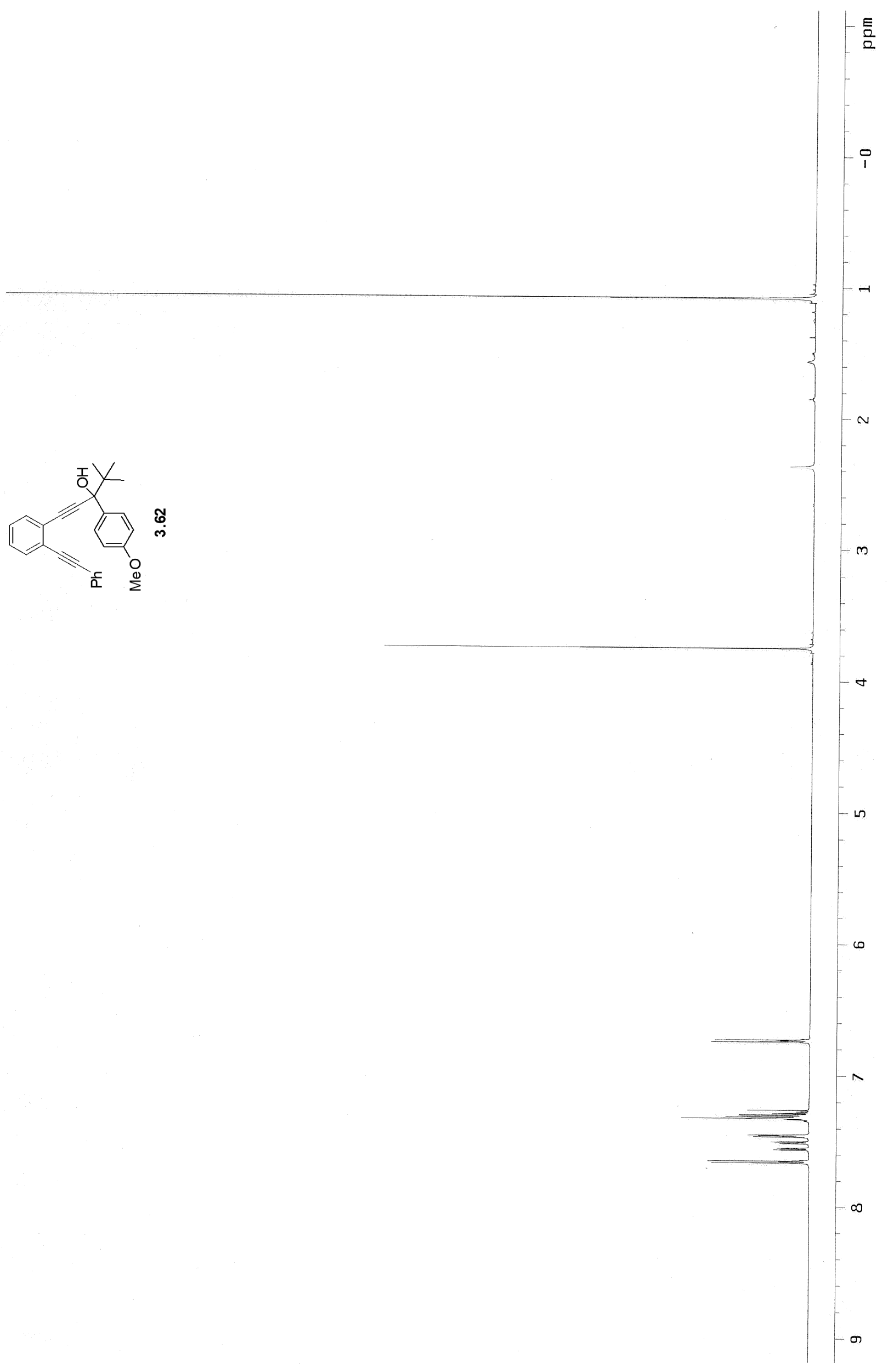



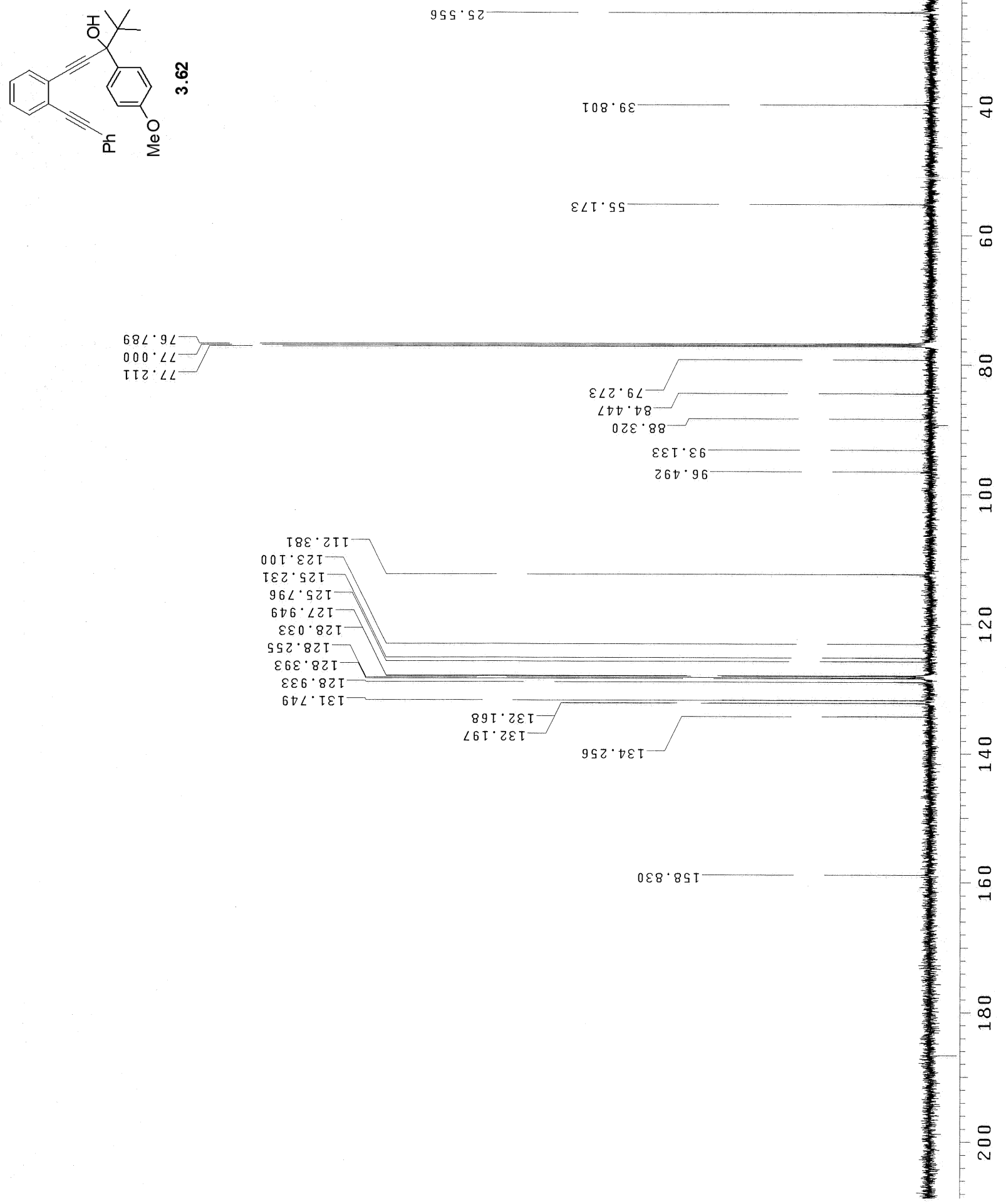


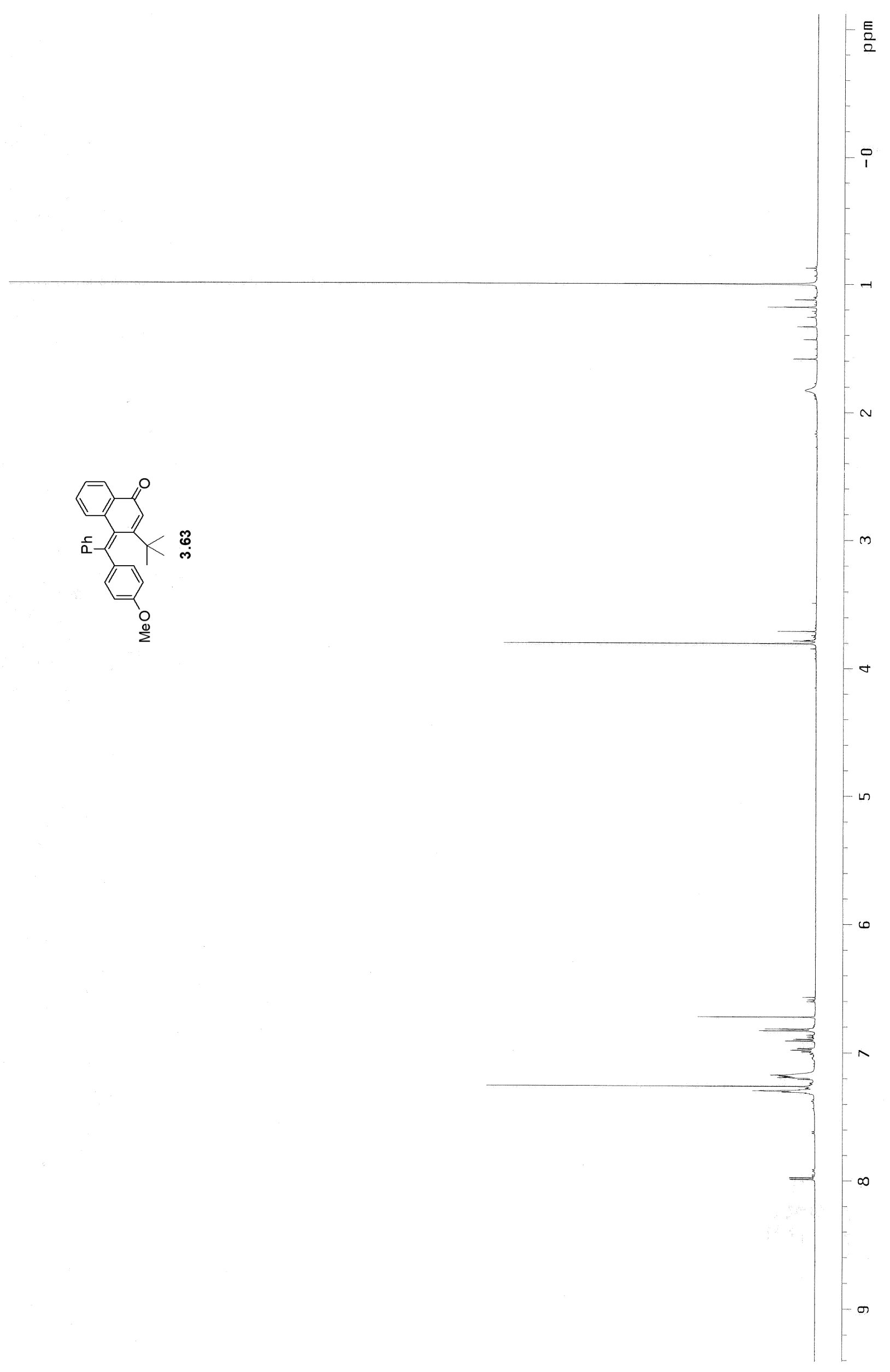




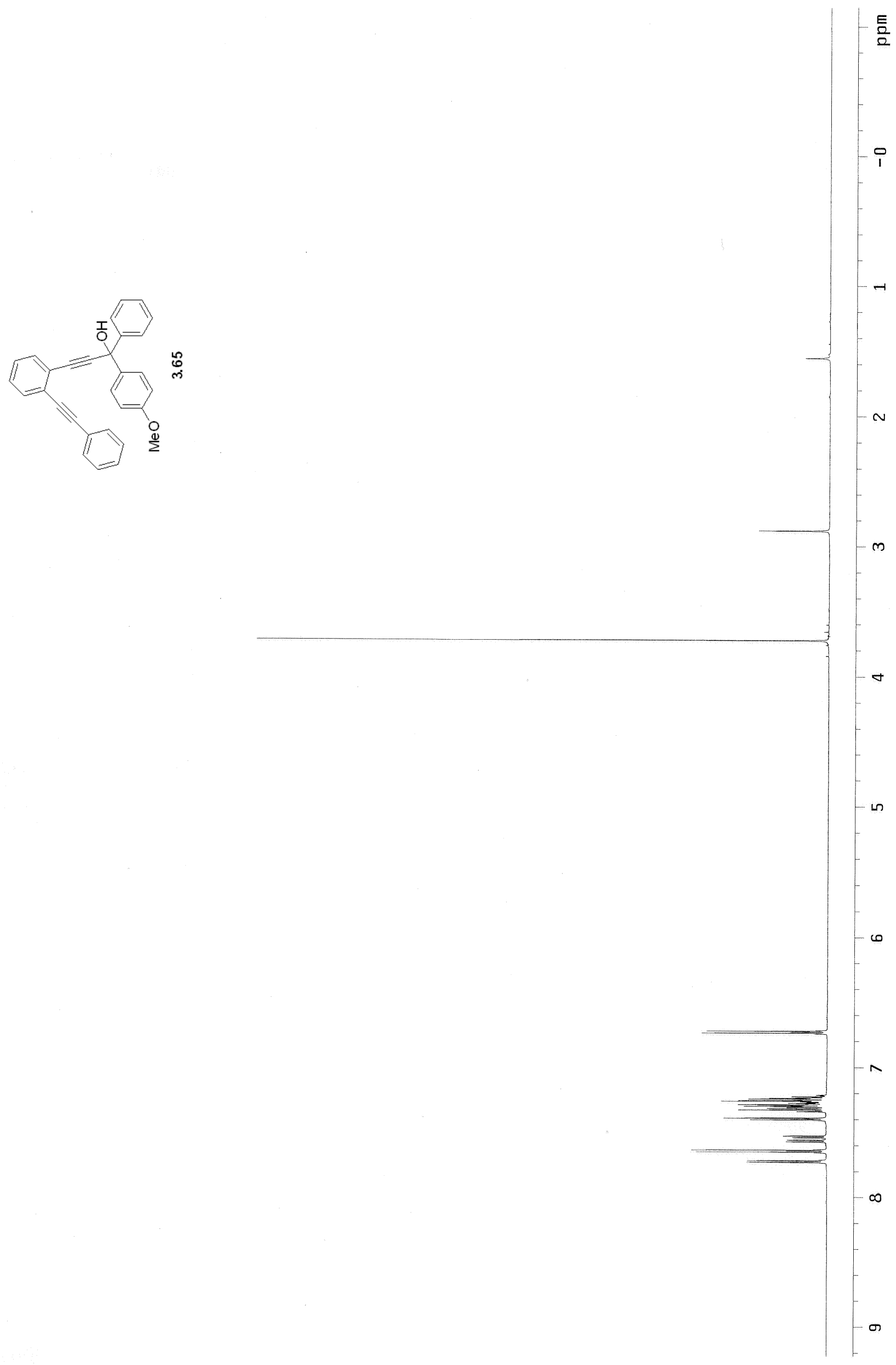




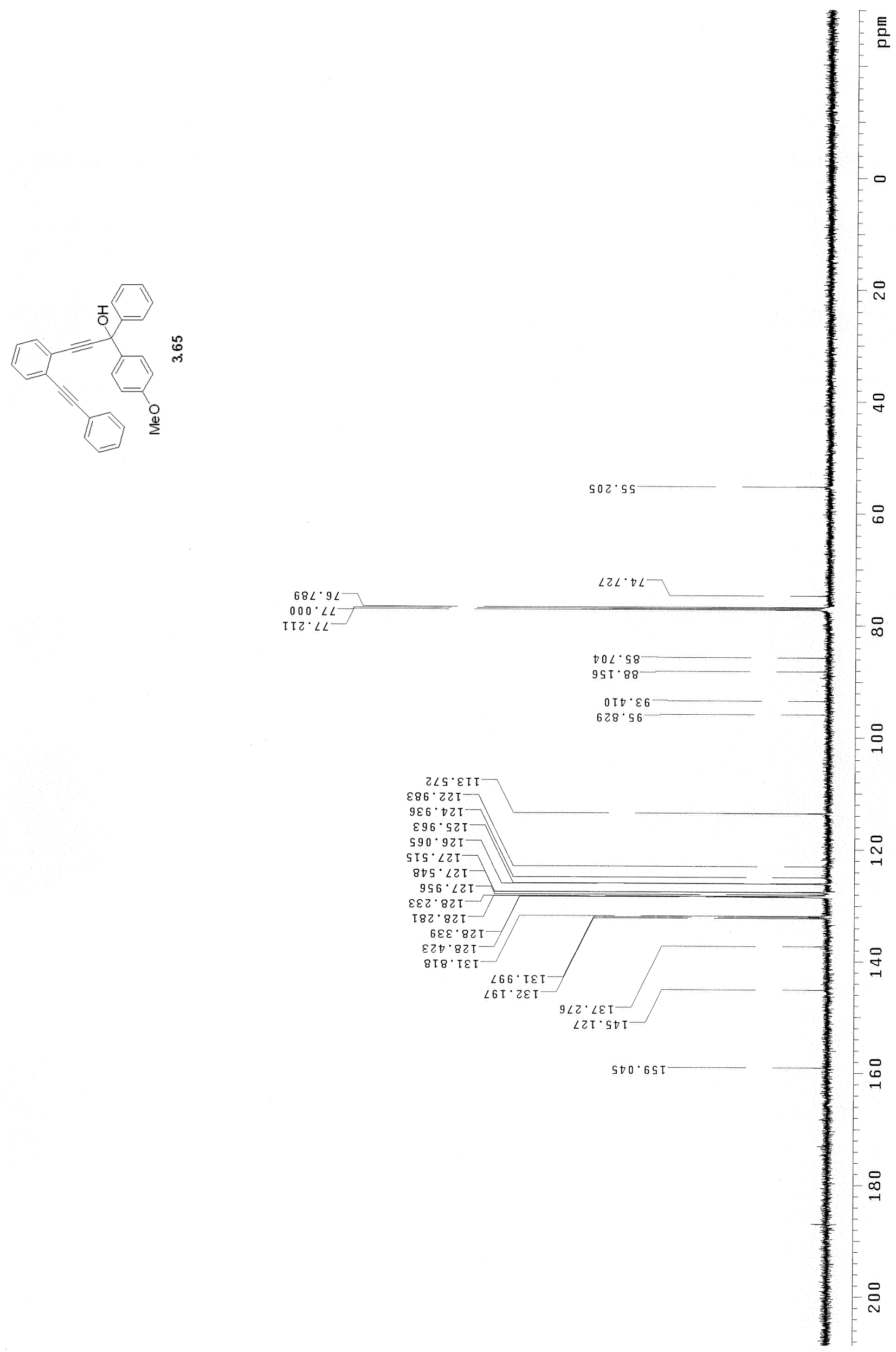




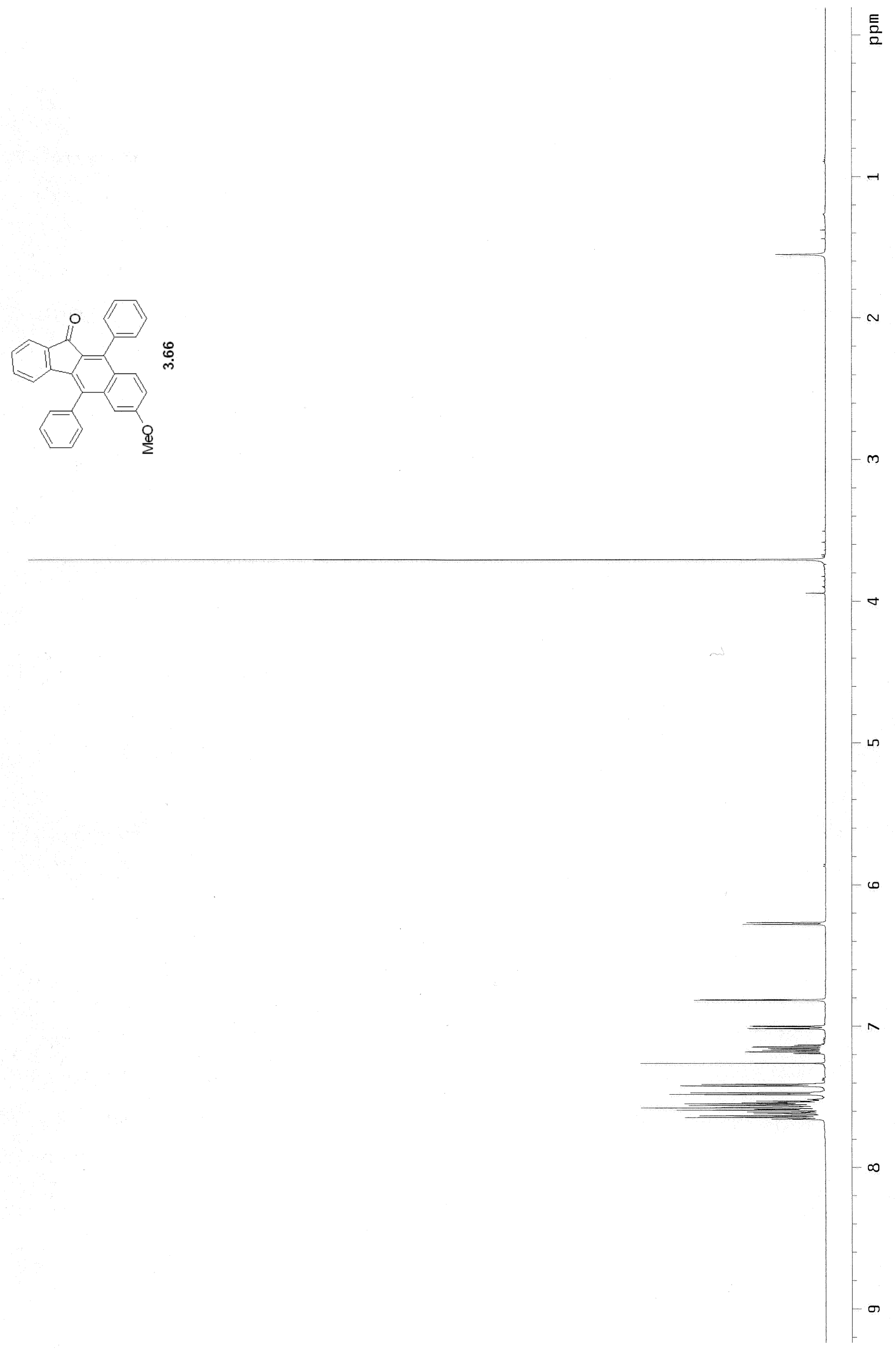




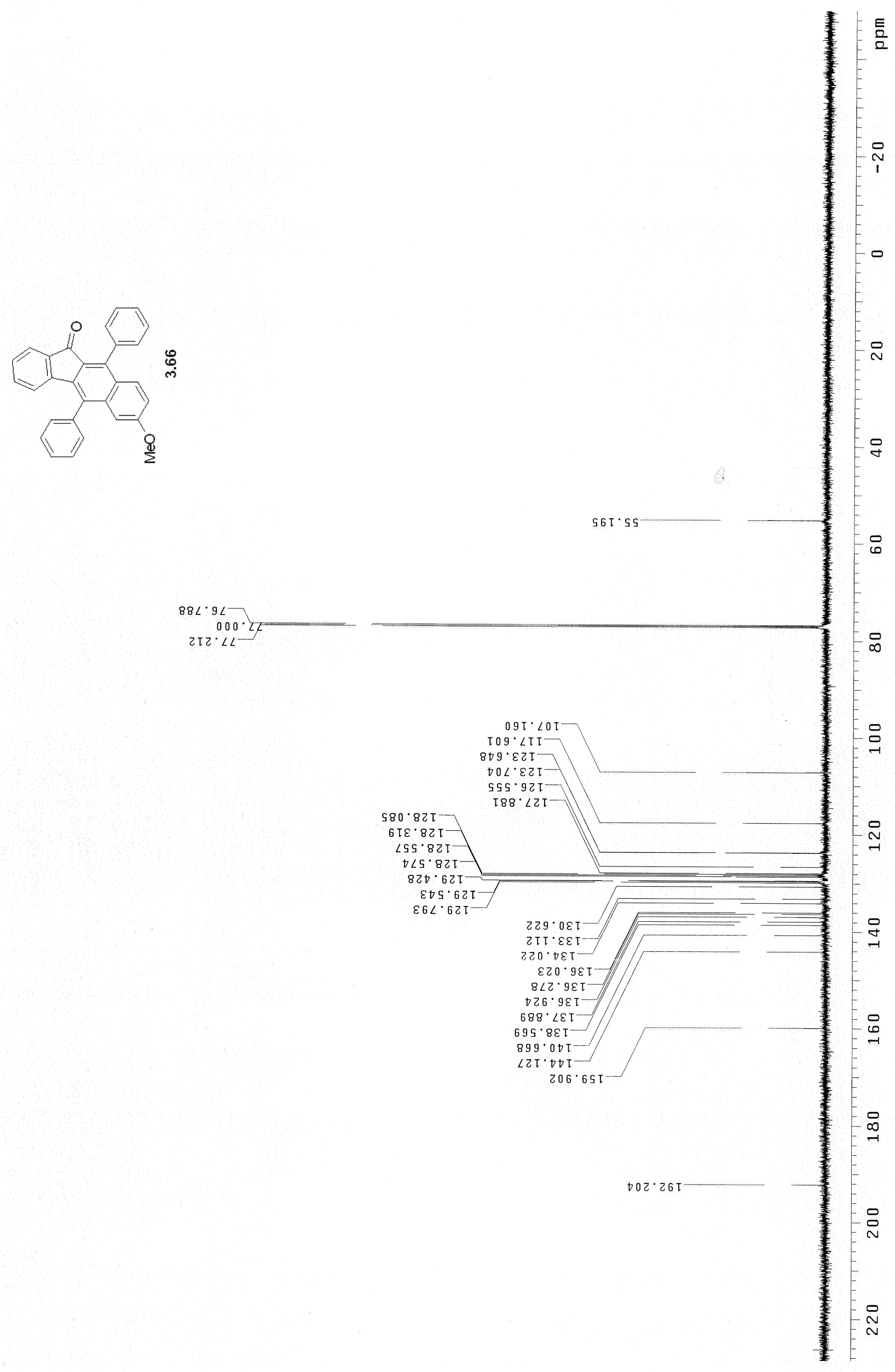




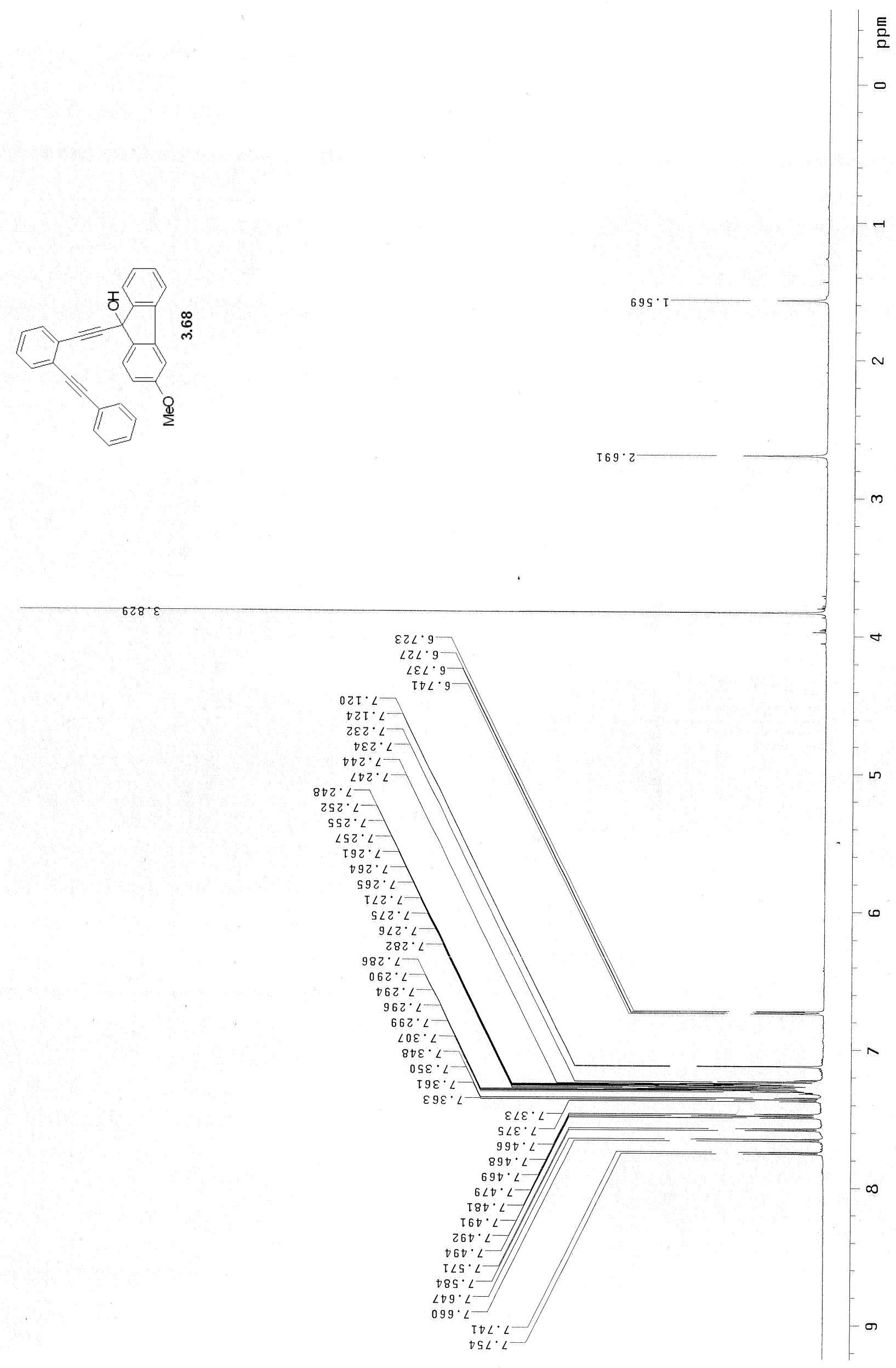



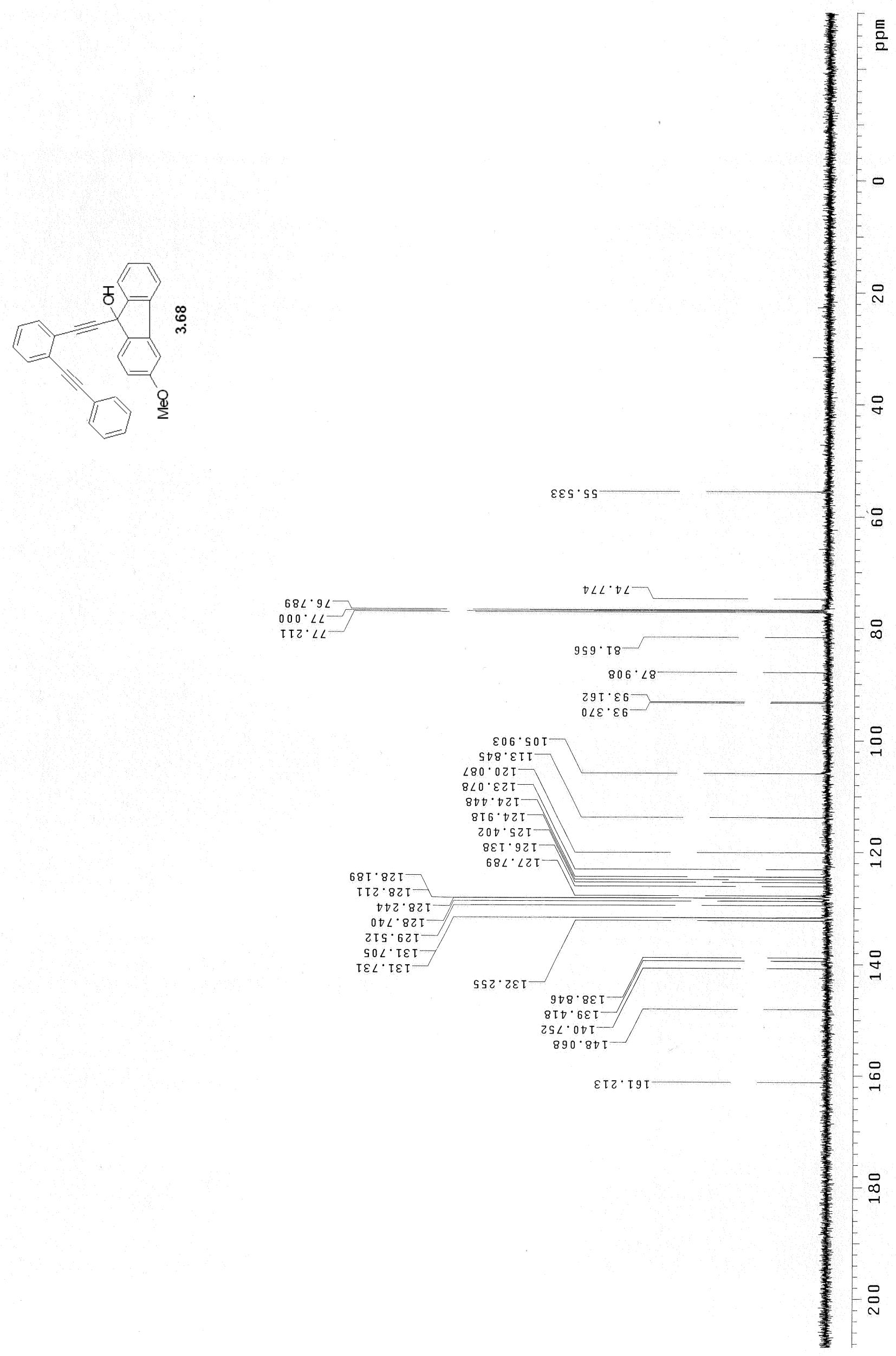


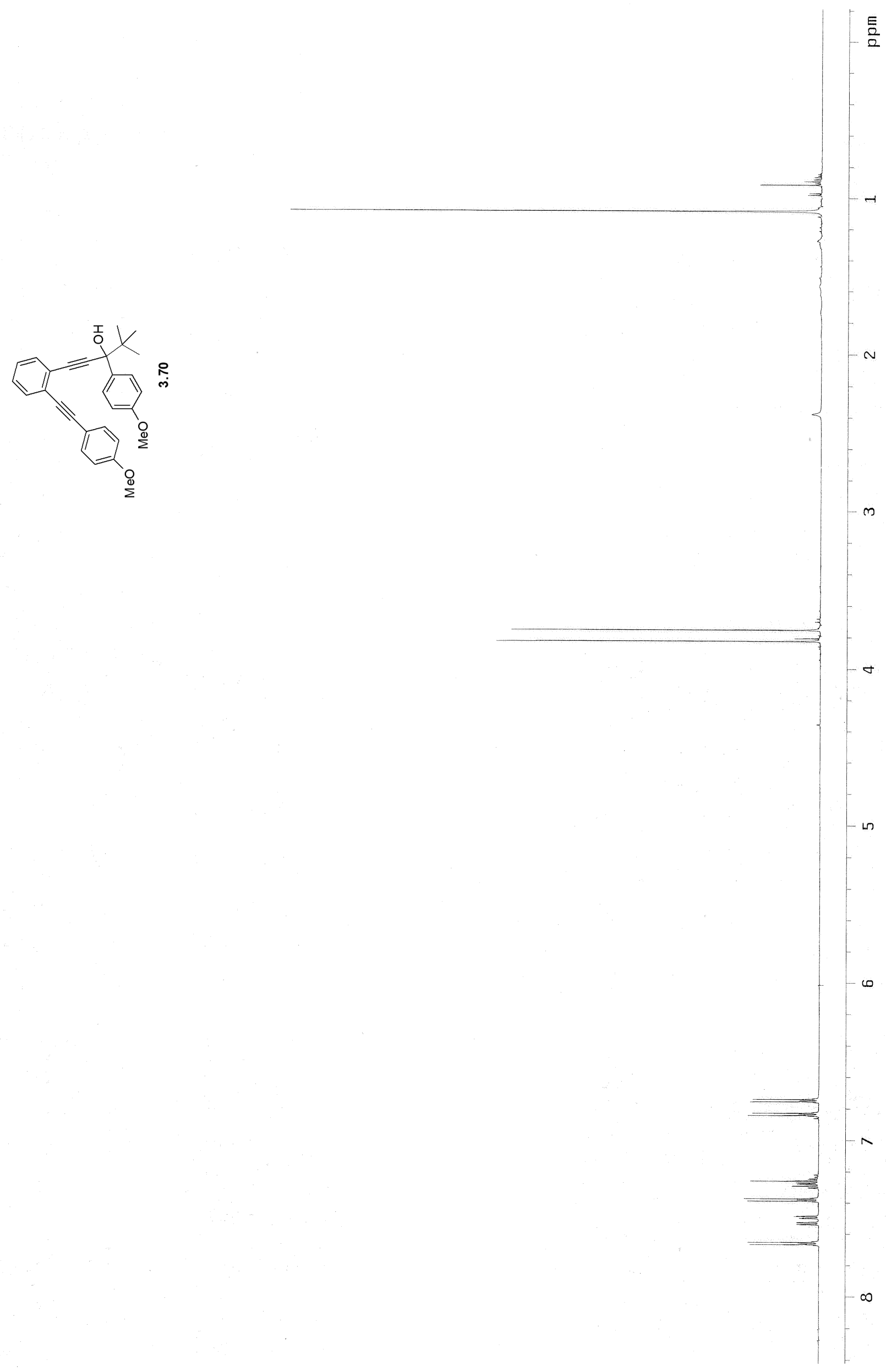




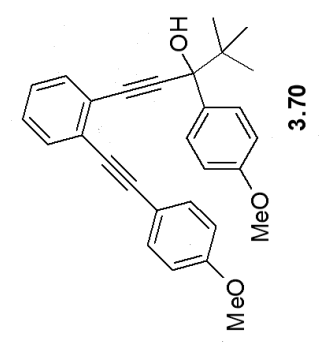

$68 L \cdot 9 L$

$000 \% \angle L$ II $\angle L L$

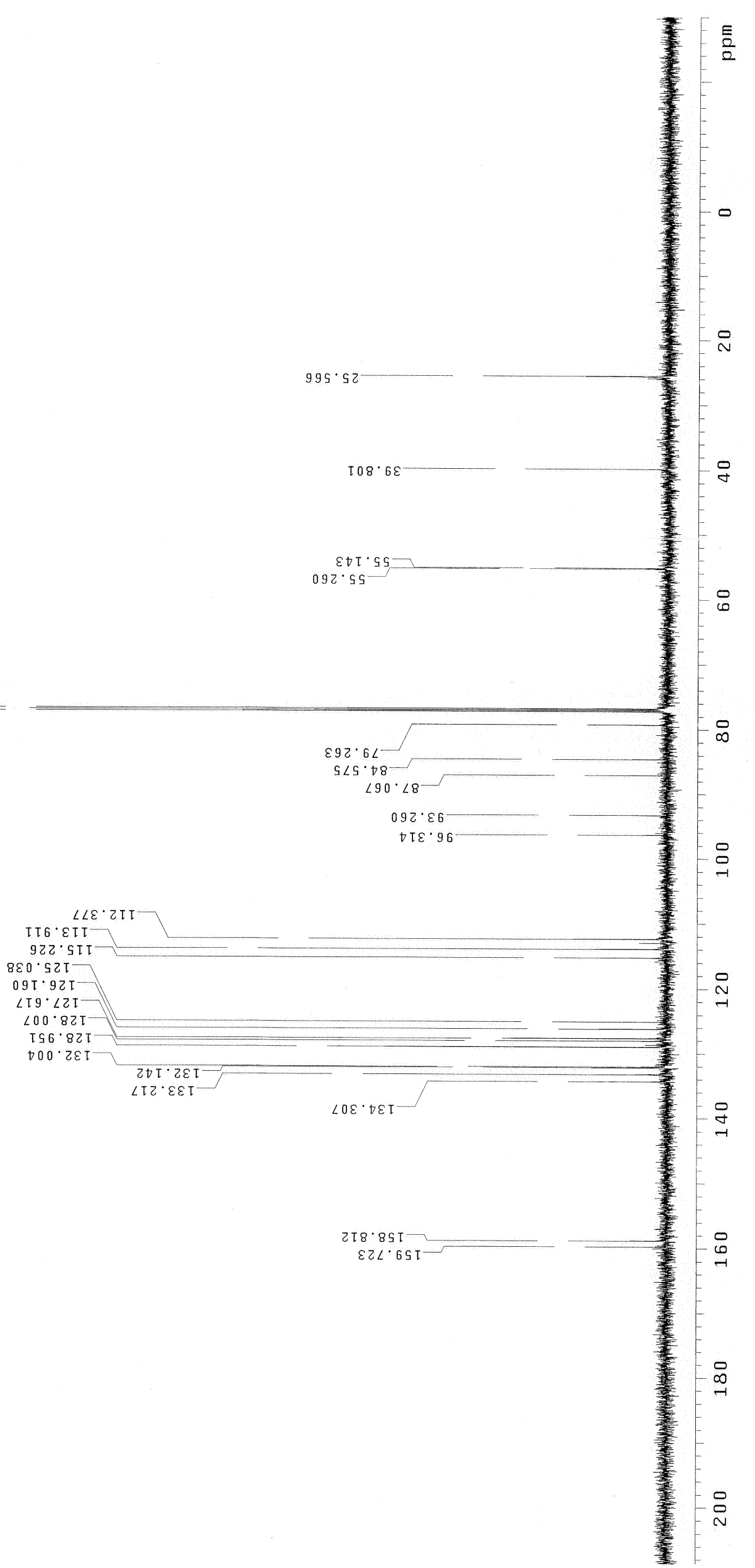




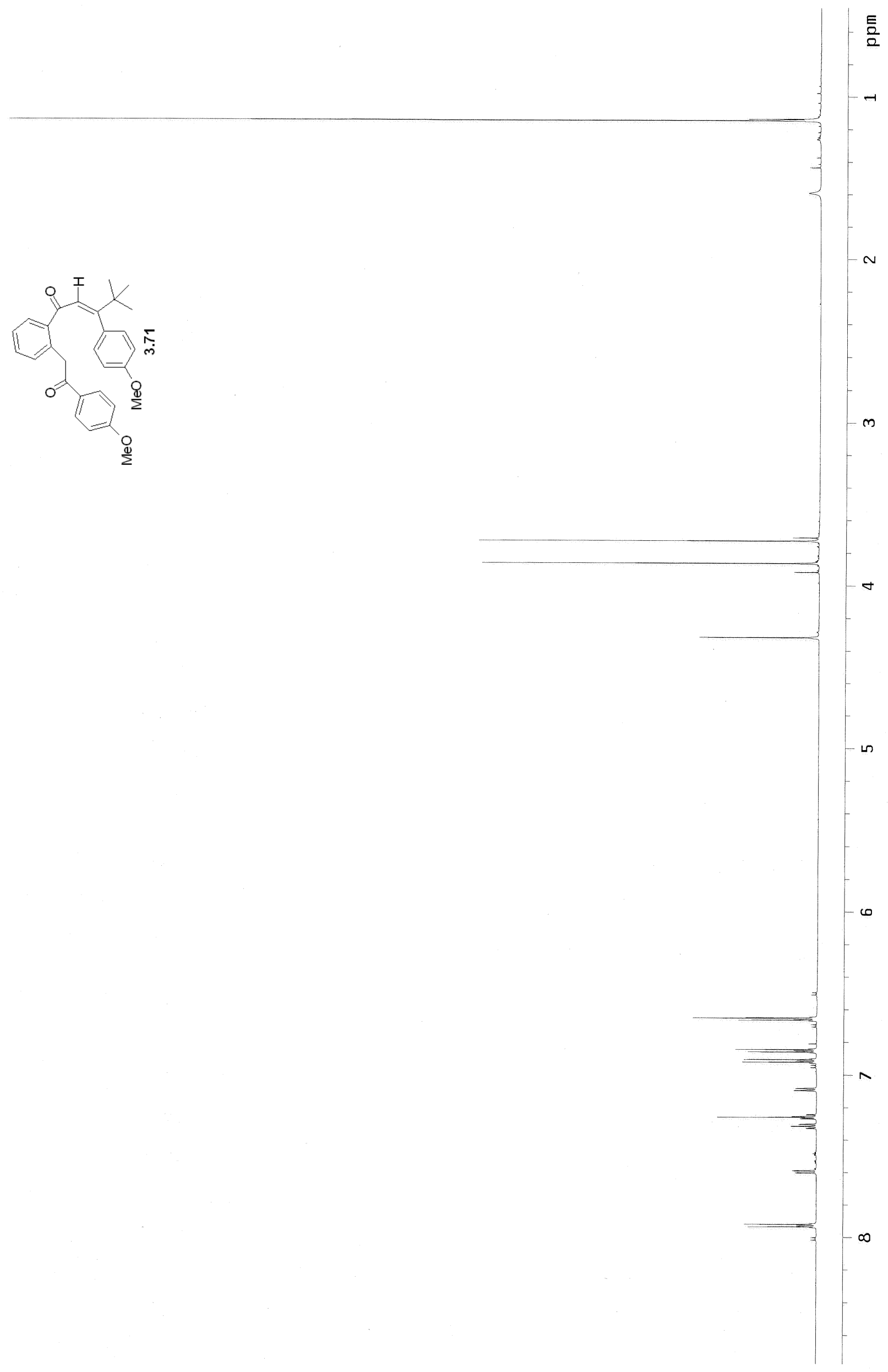



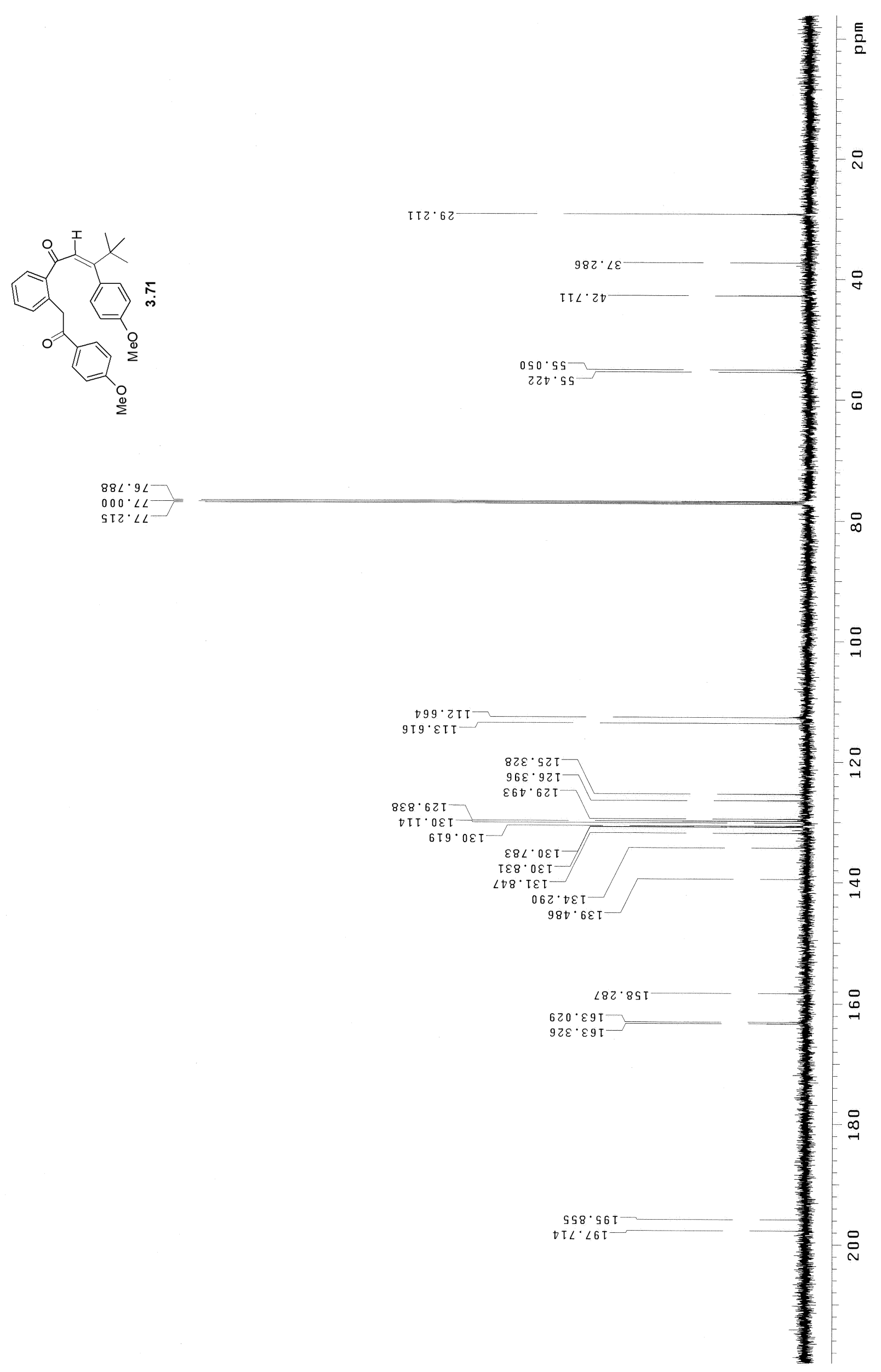


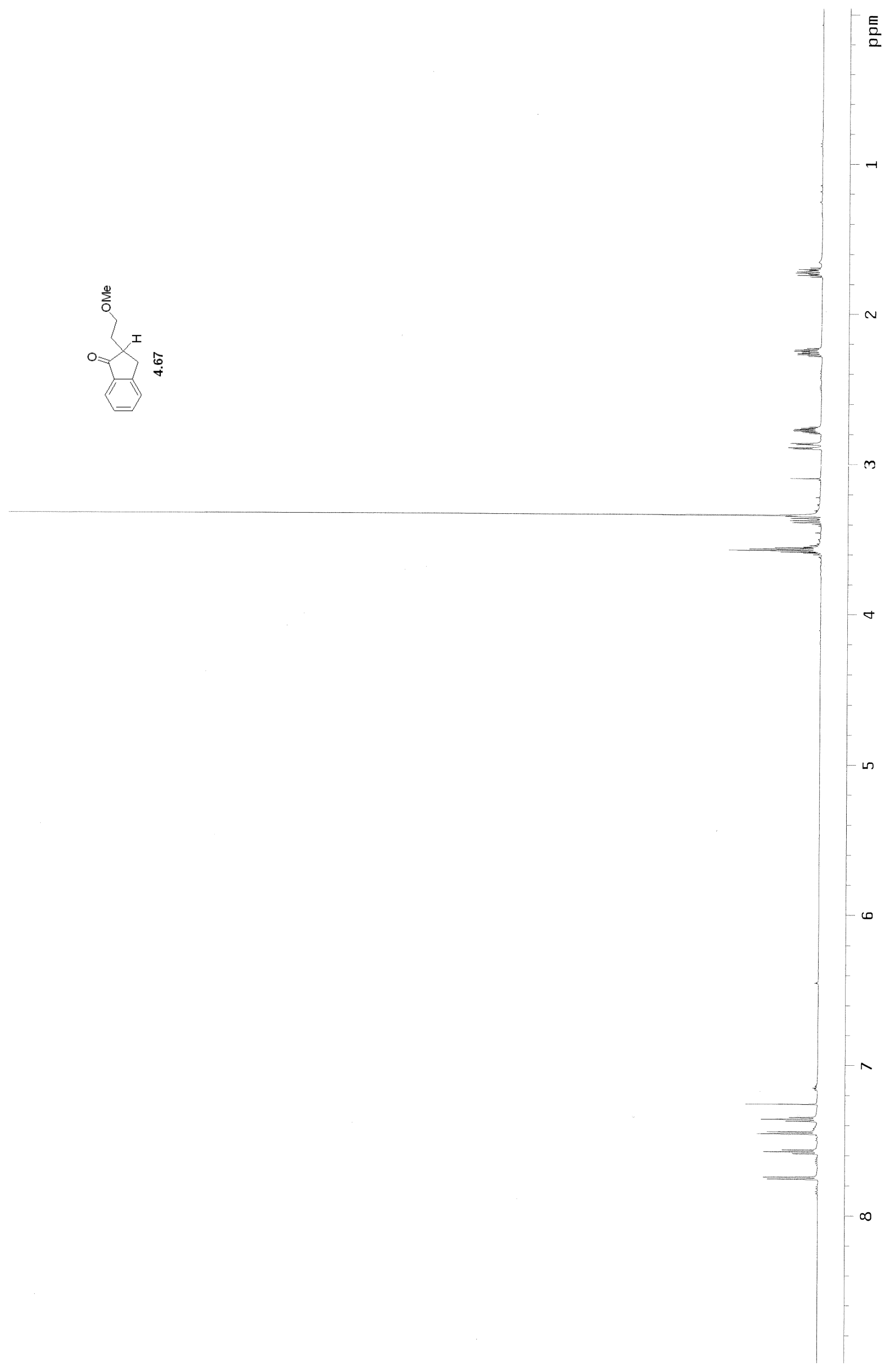



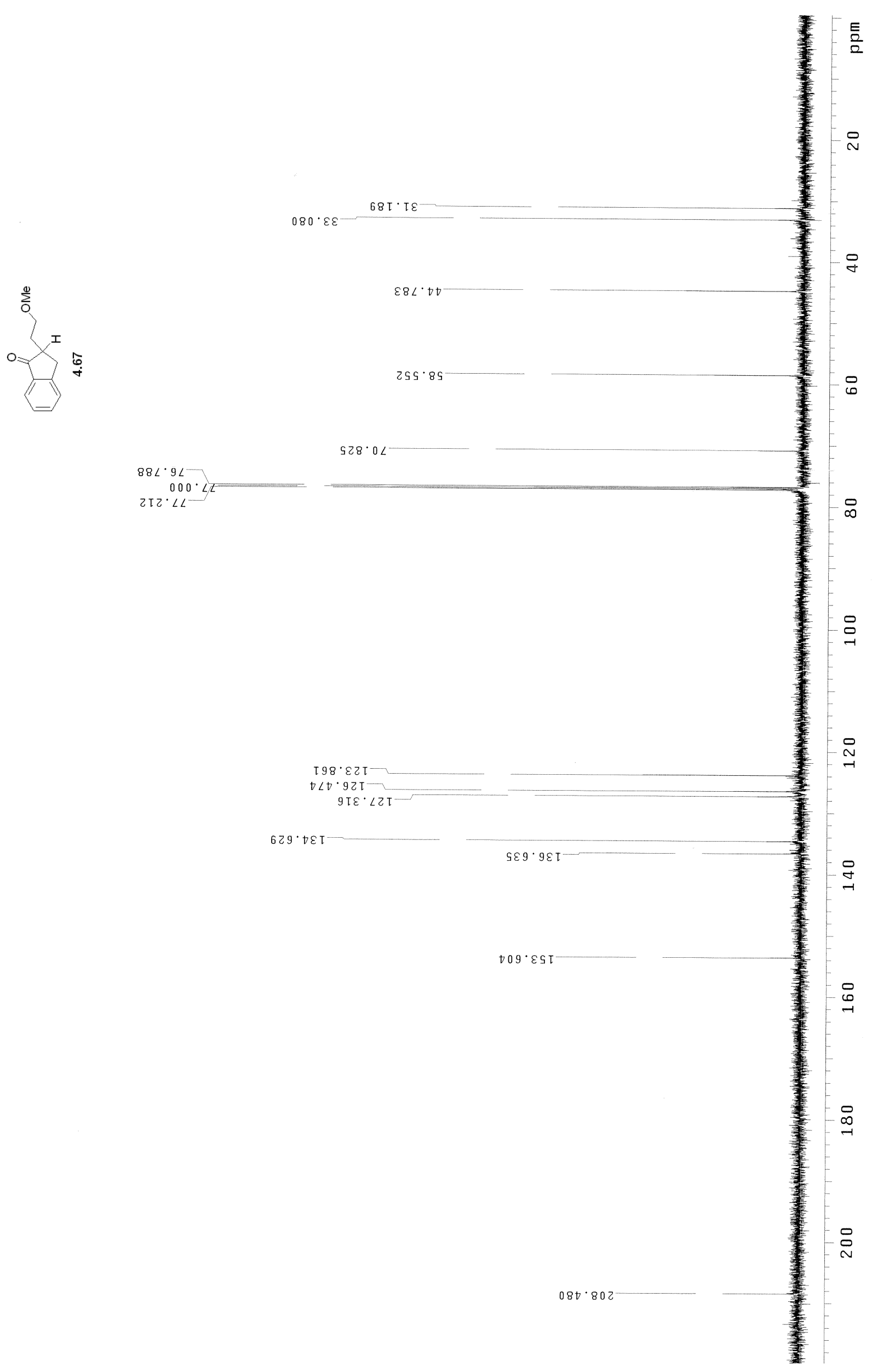


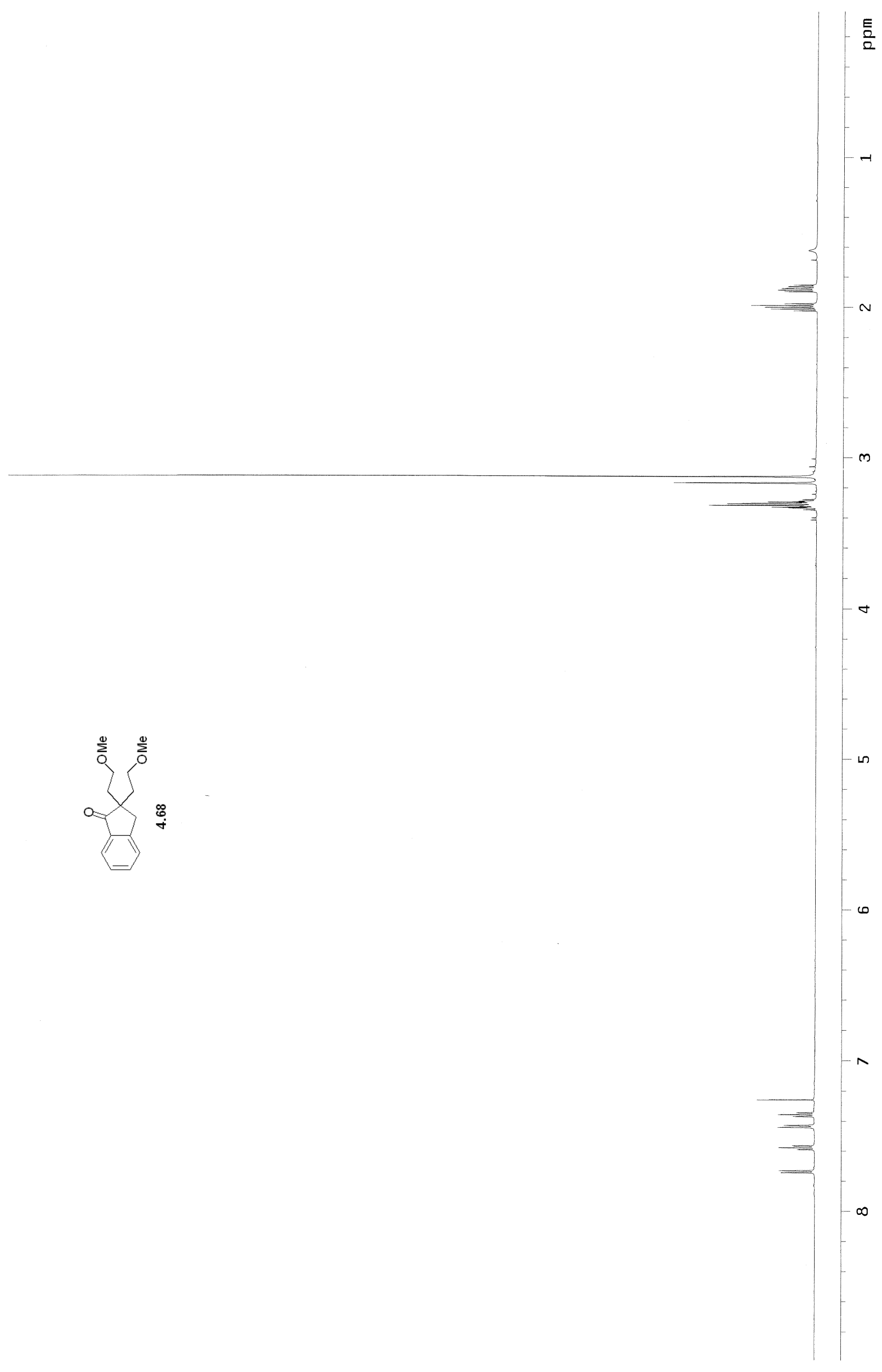




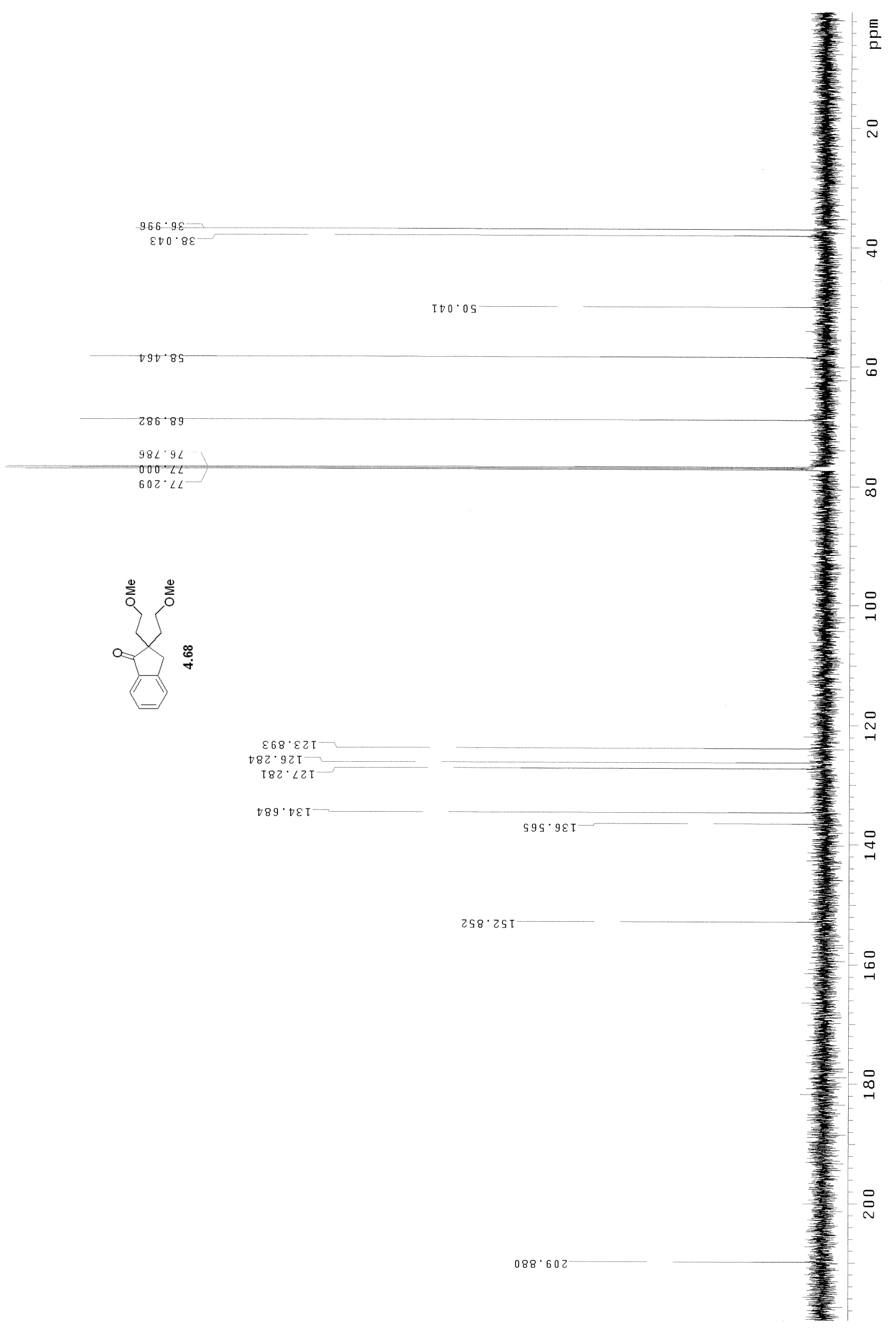



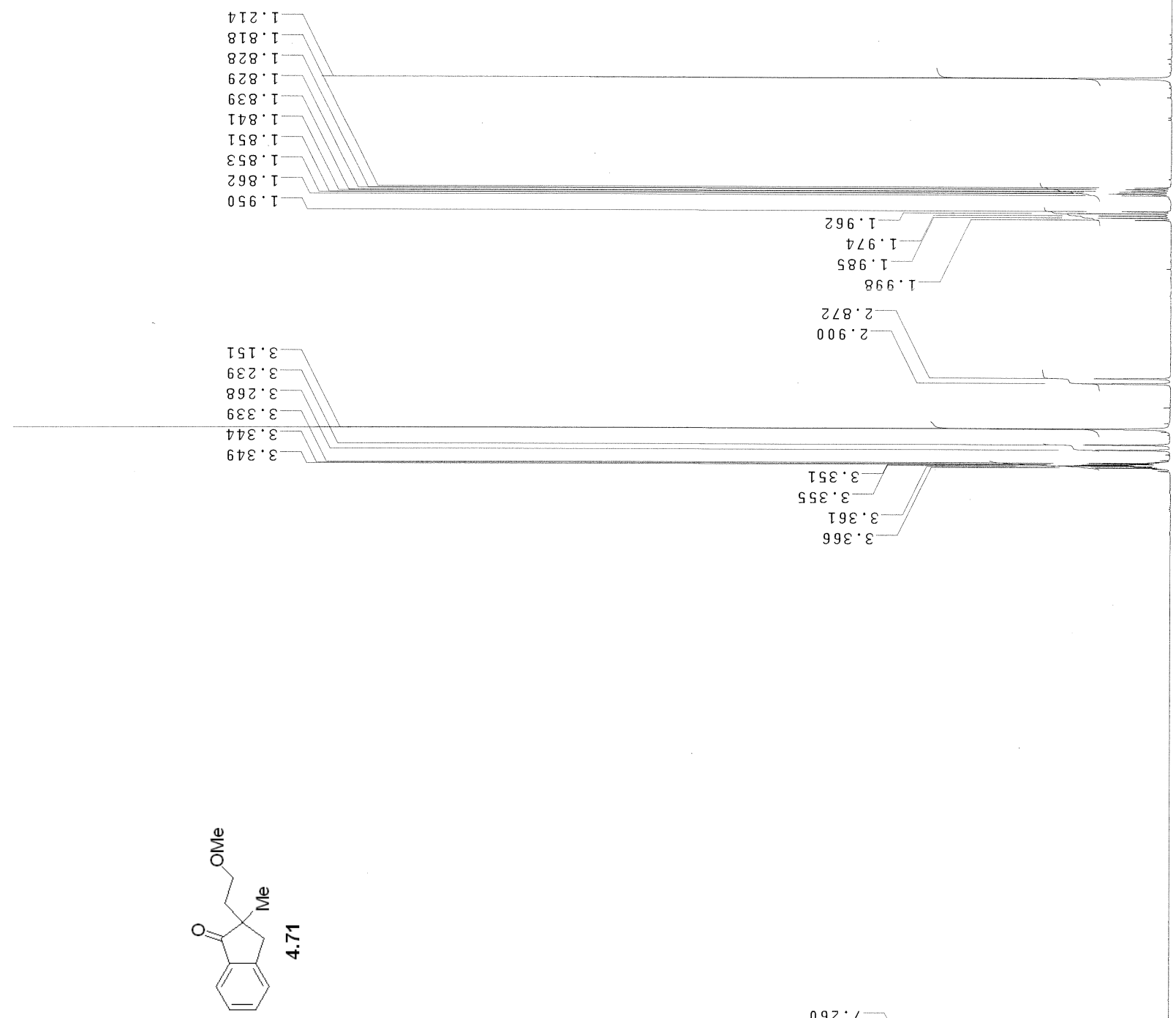

$-$

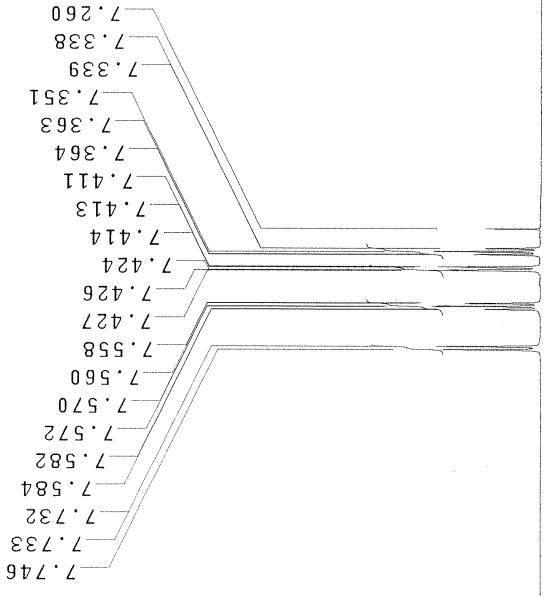

6 
$\sum_{-1}^{0}$

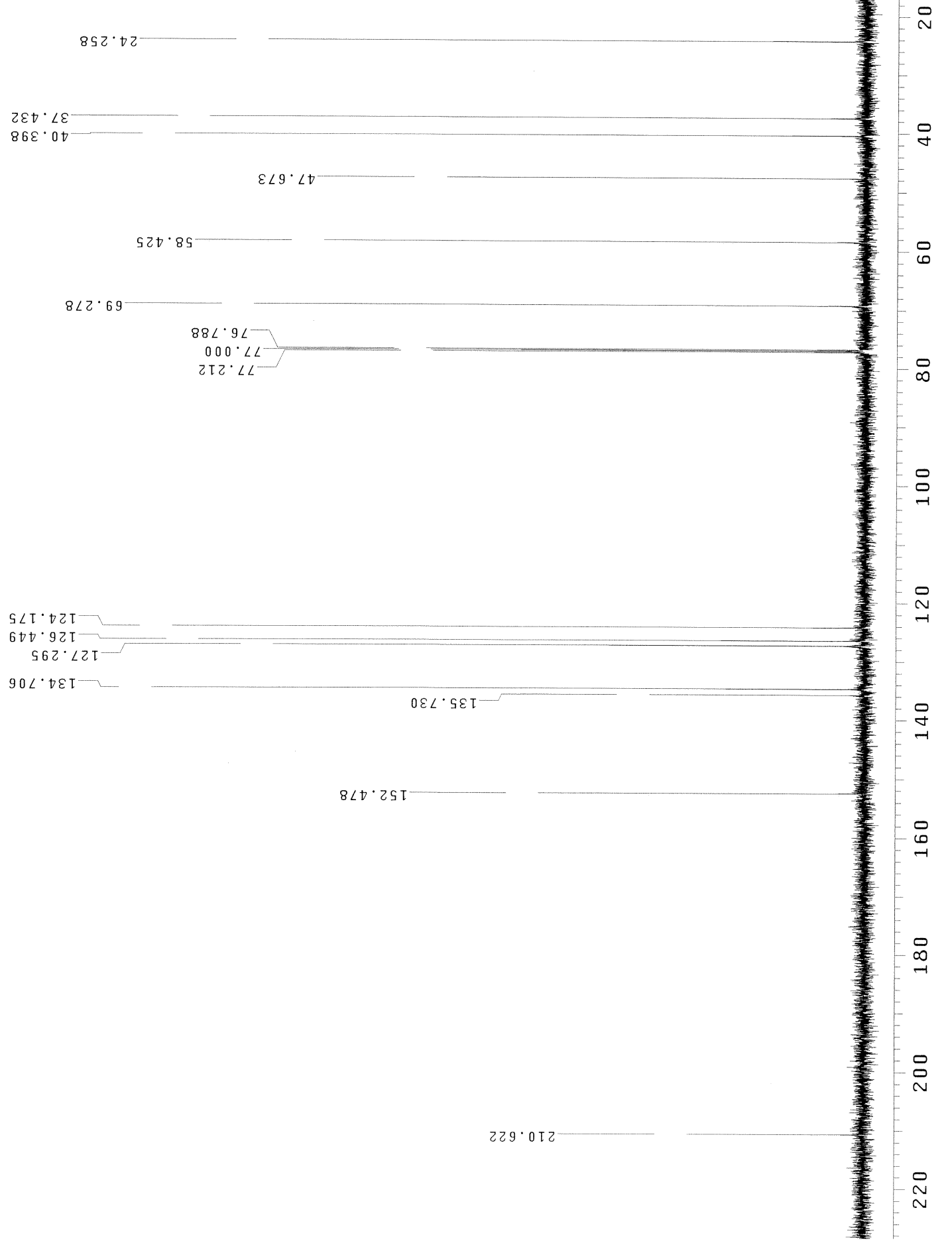




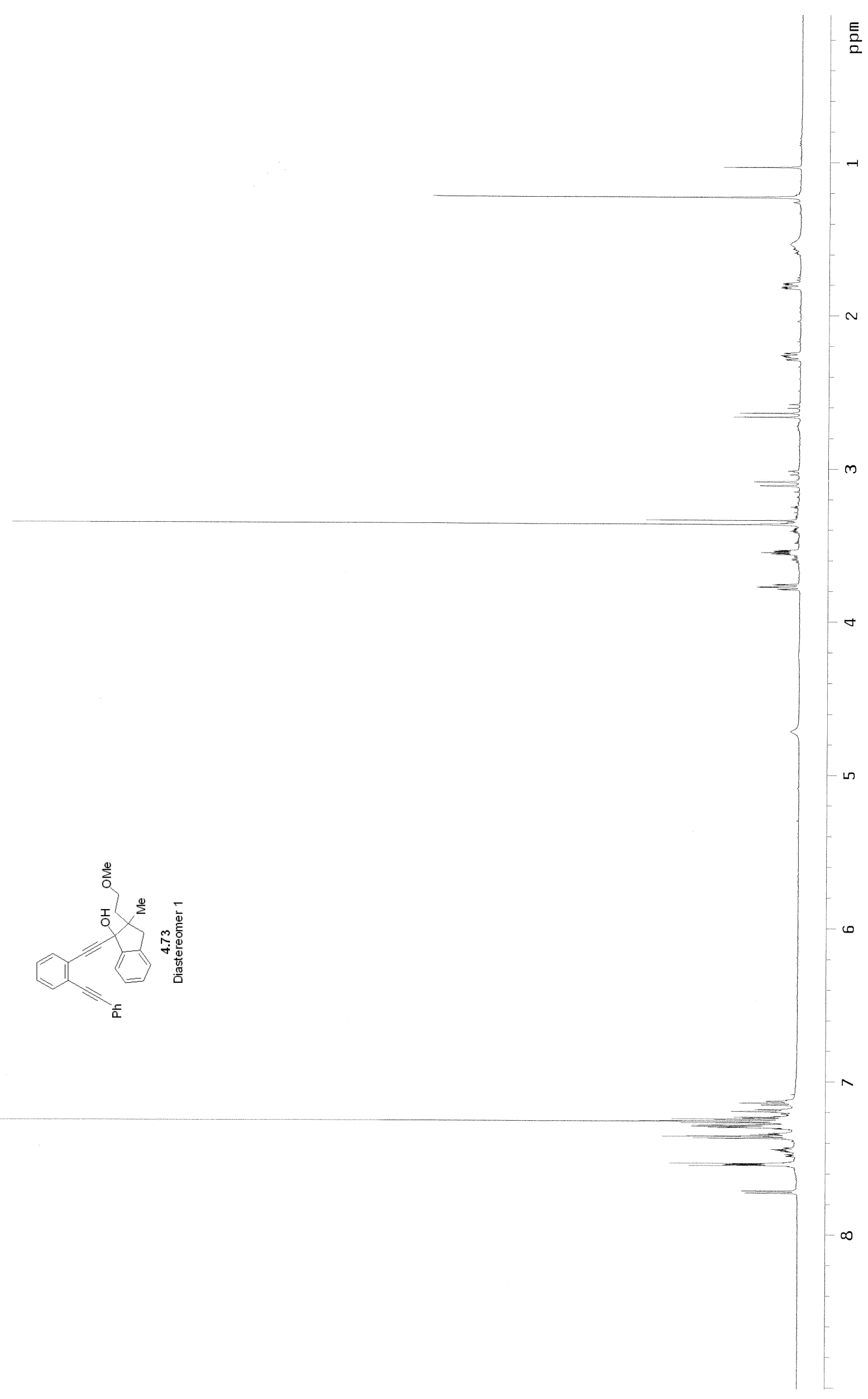




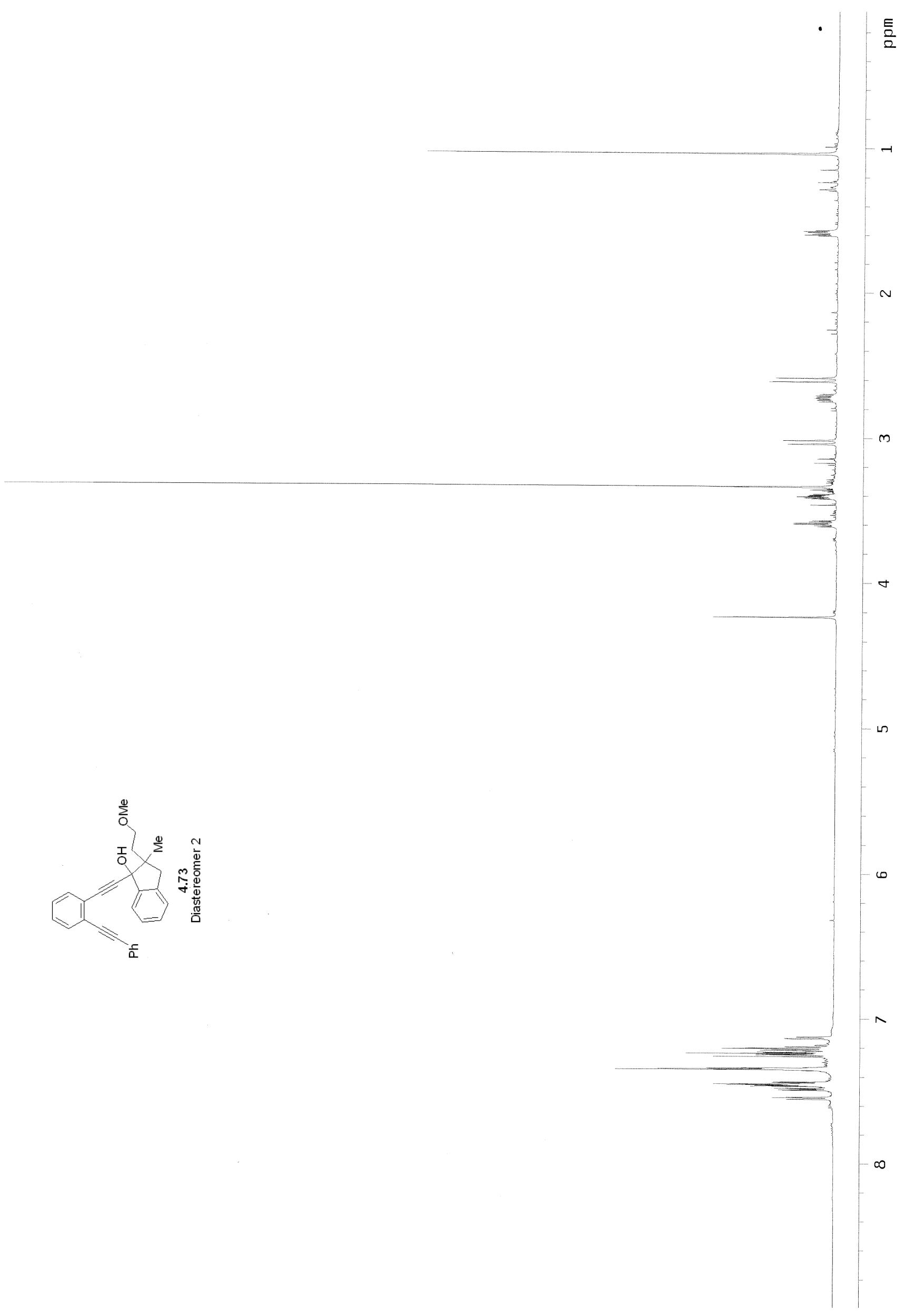




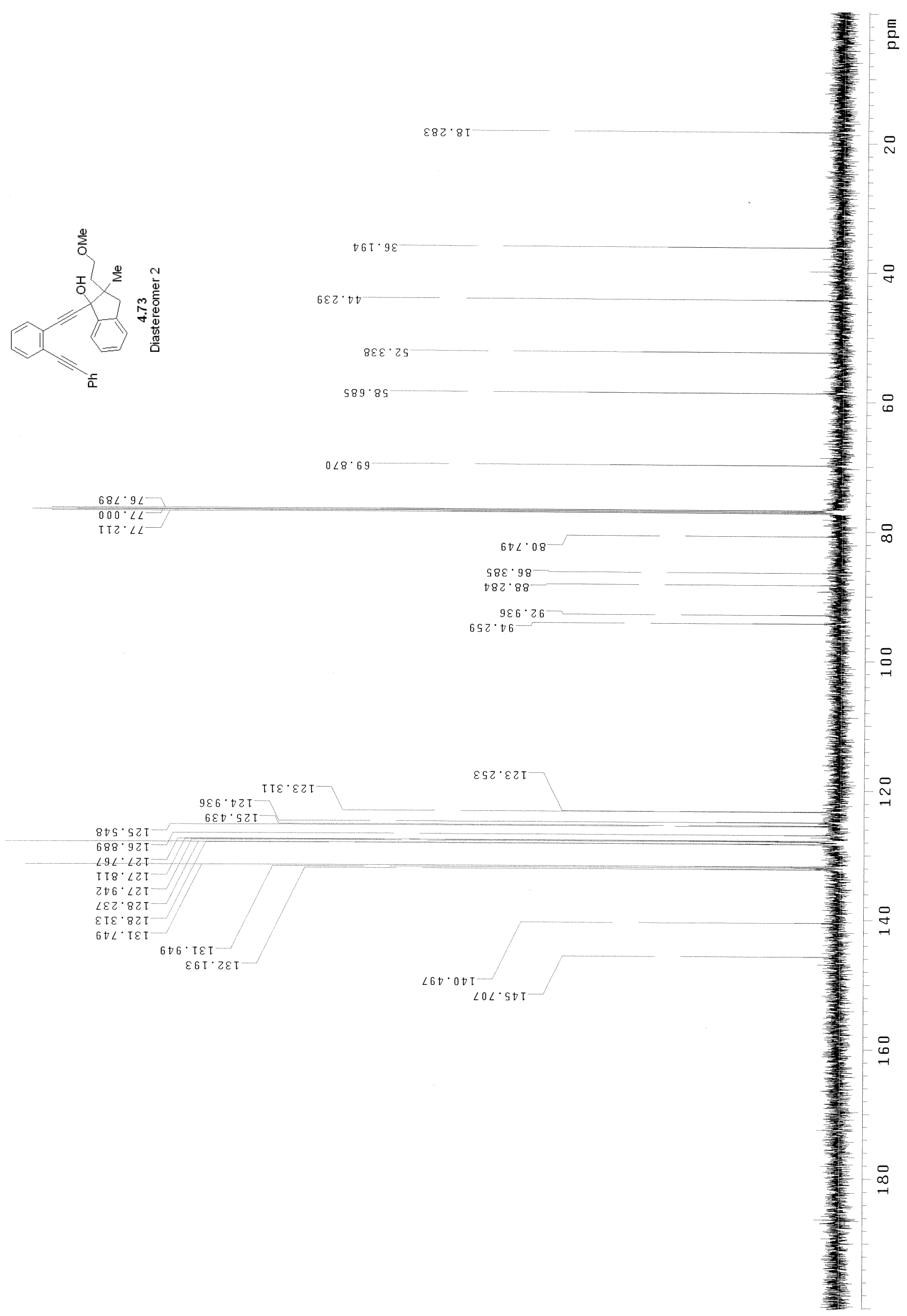



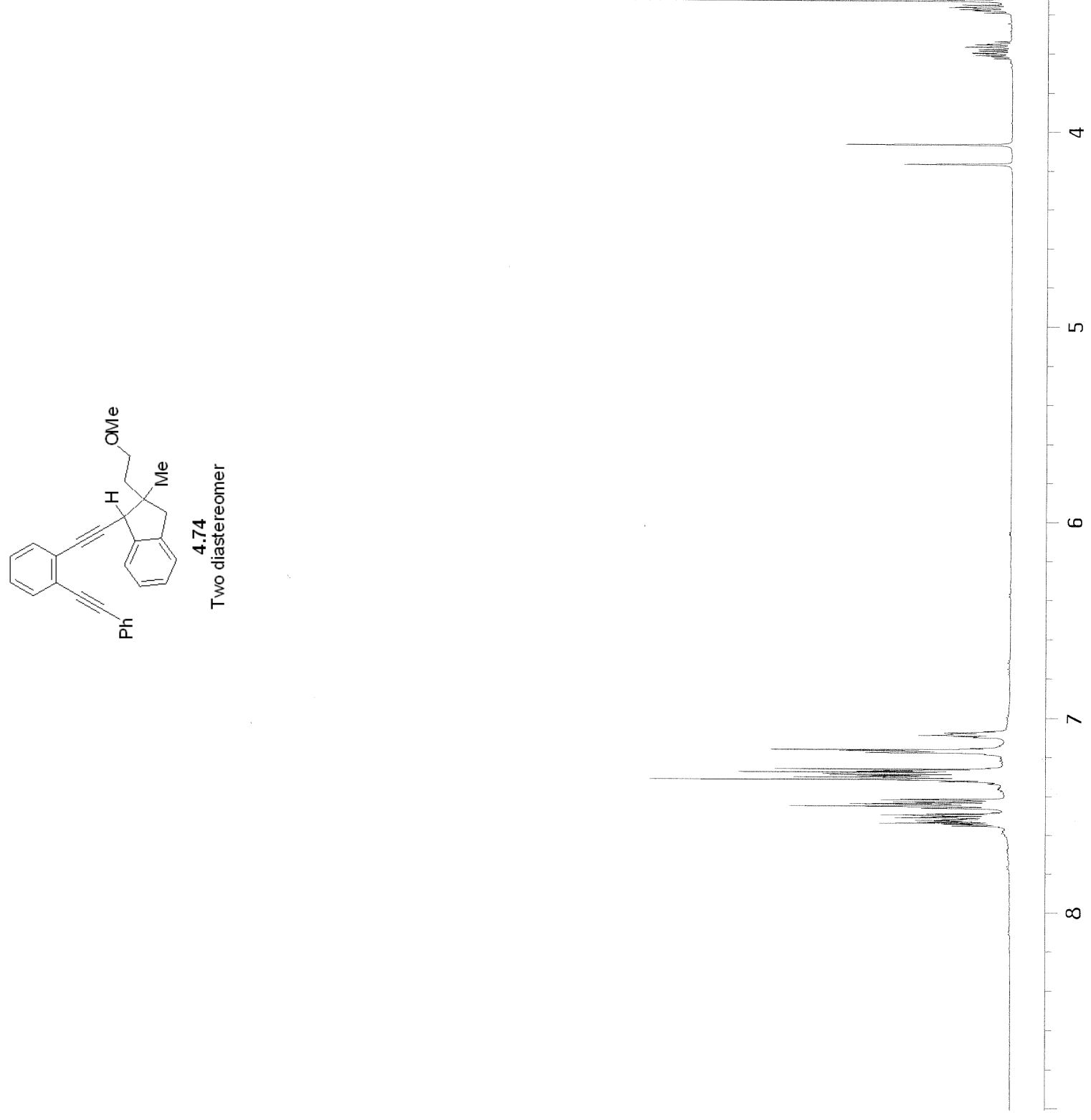


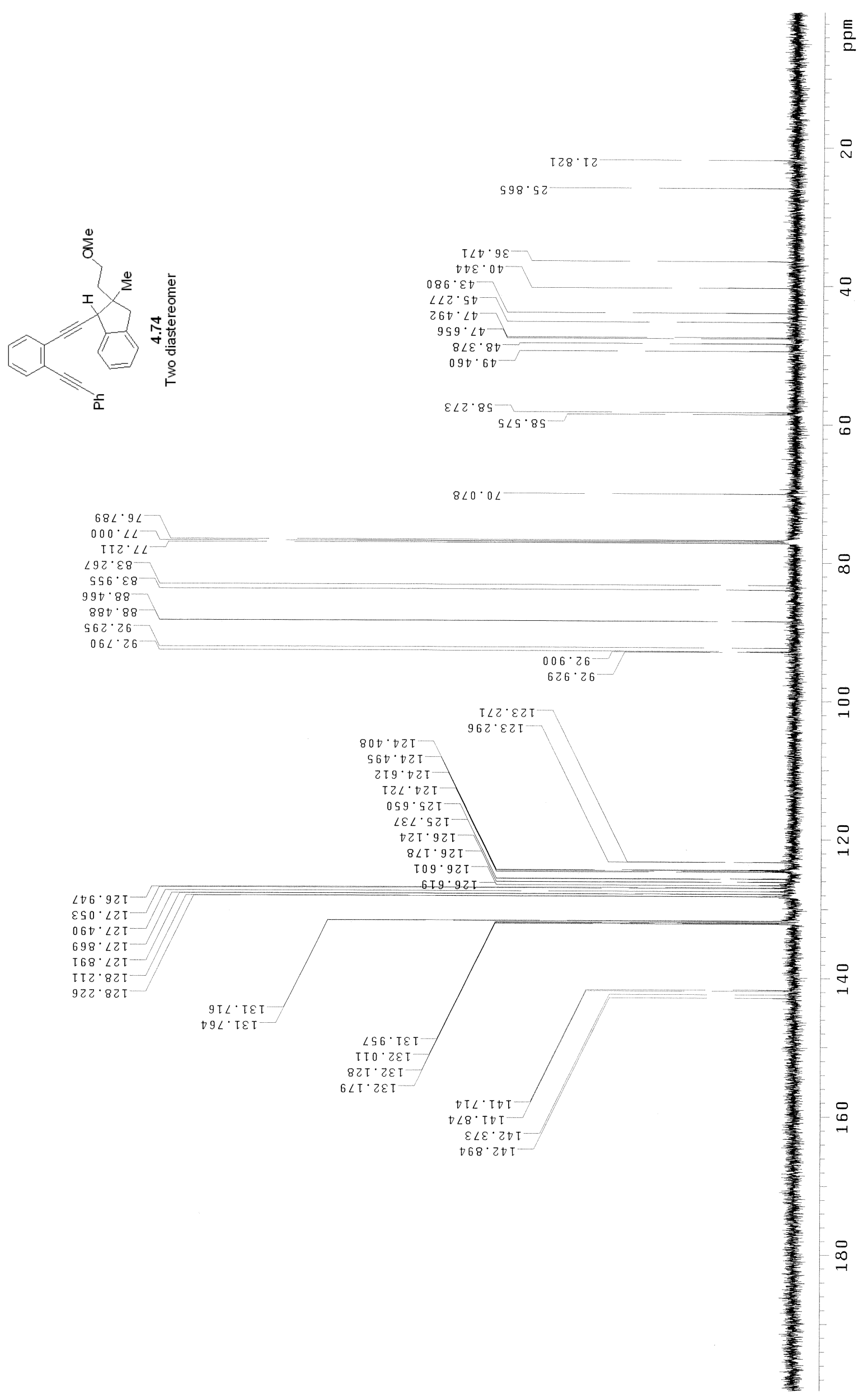




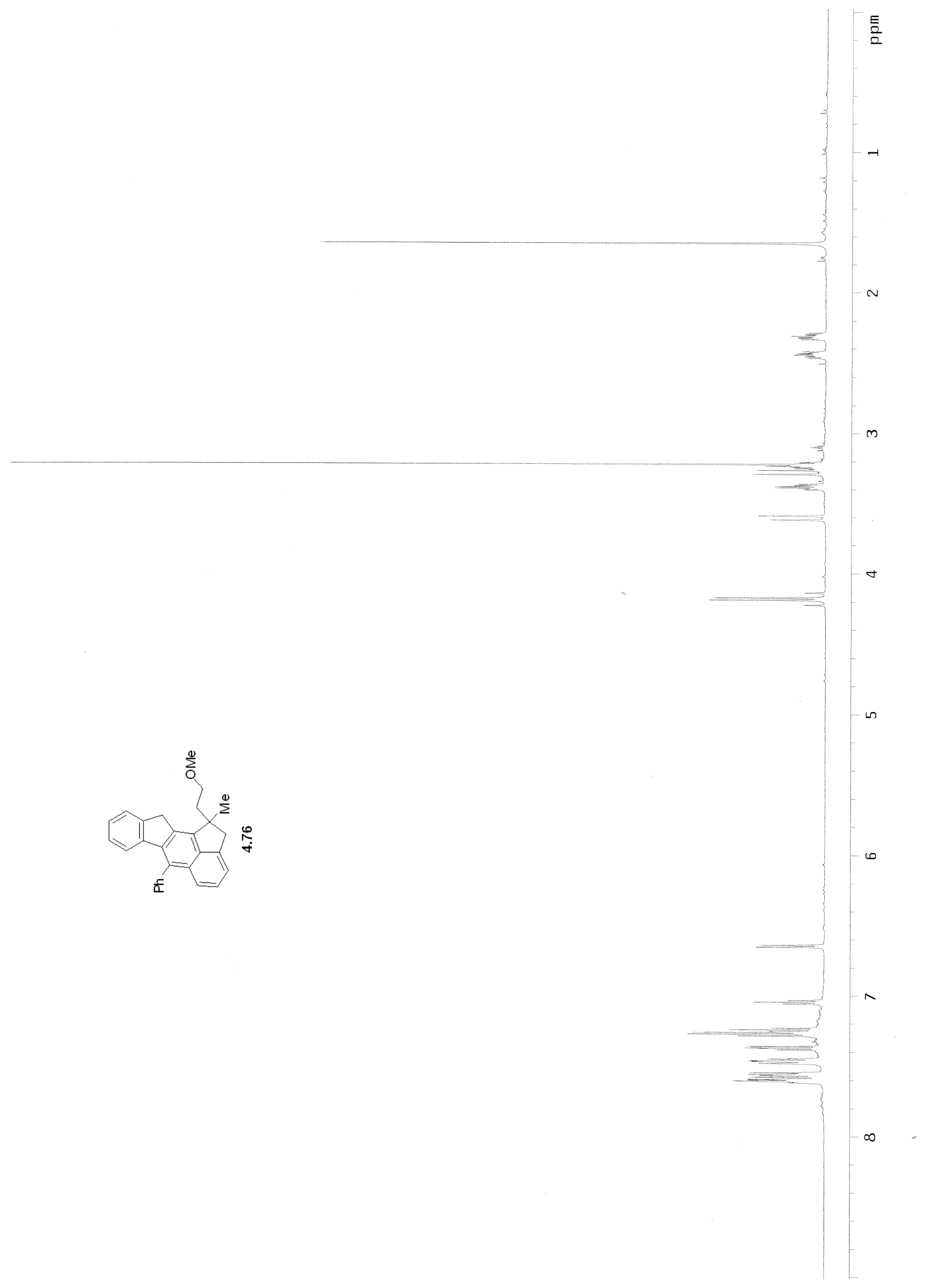




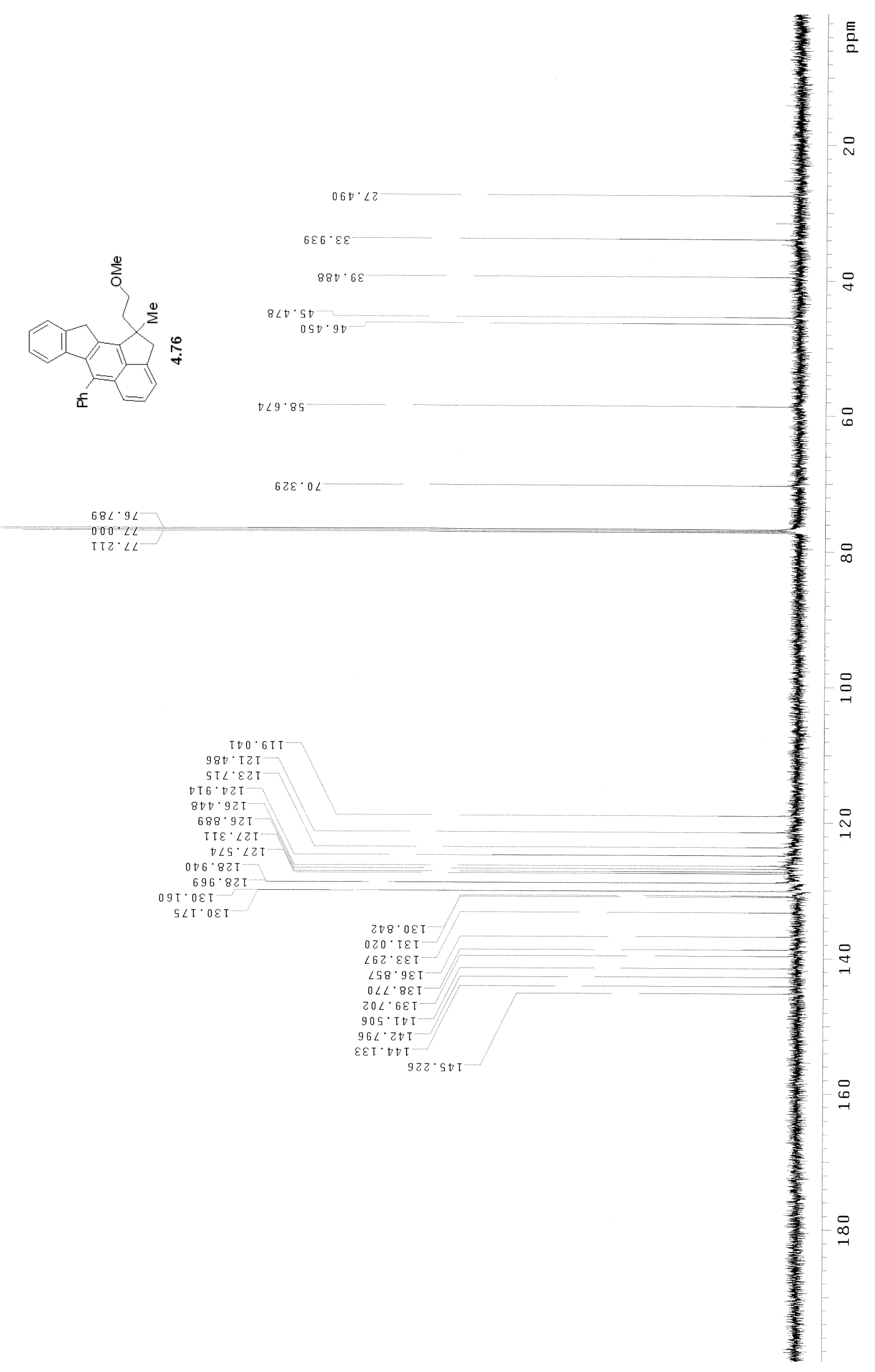




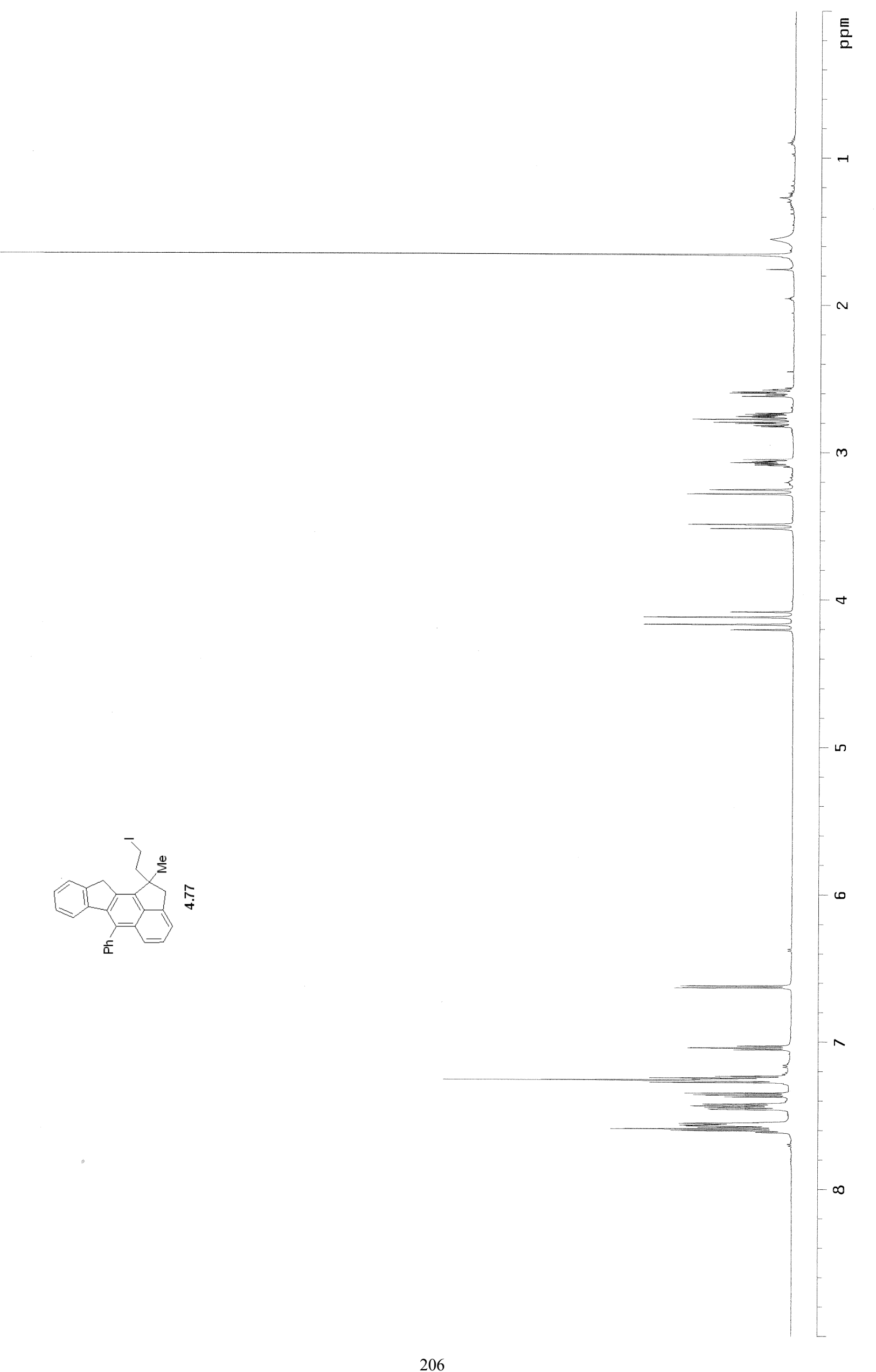




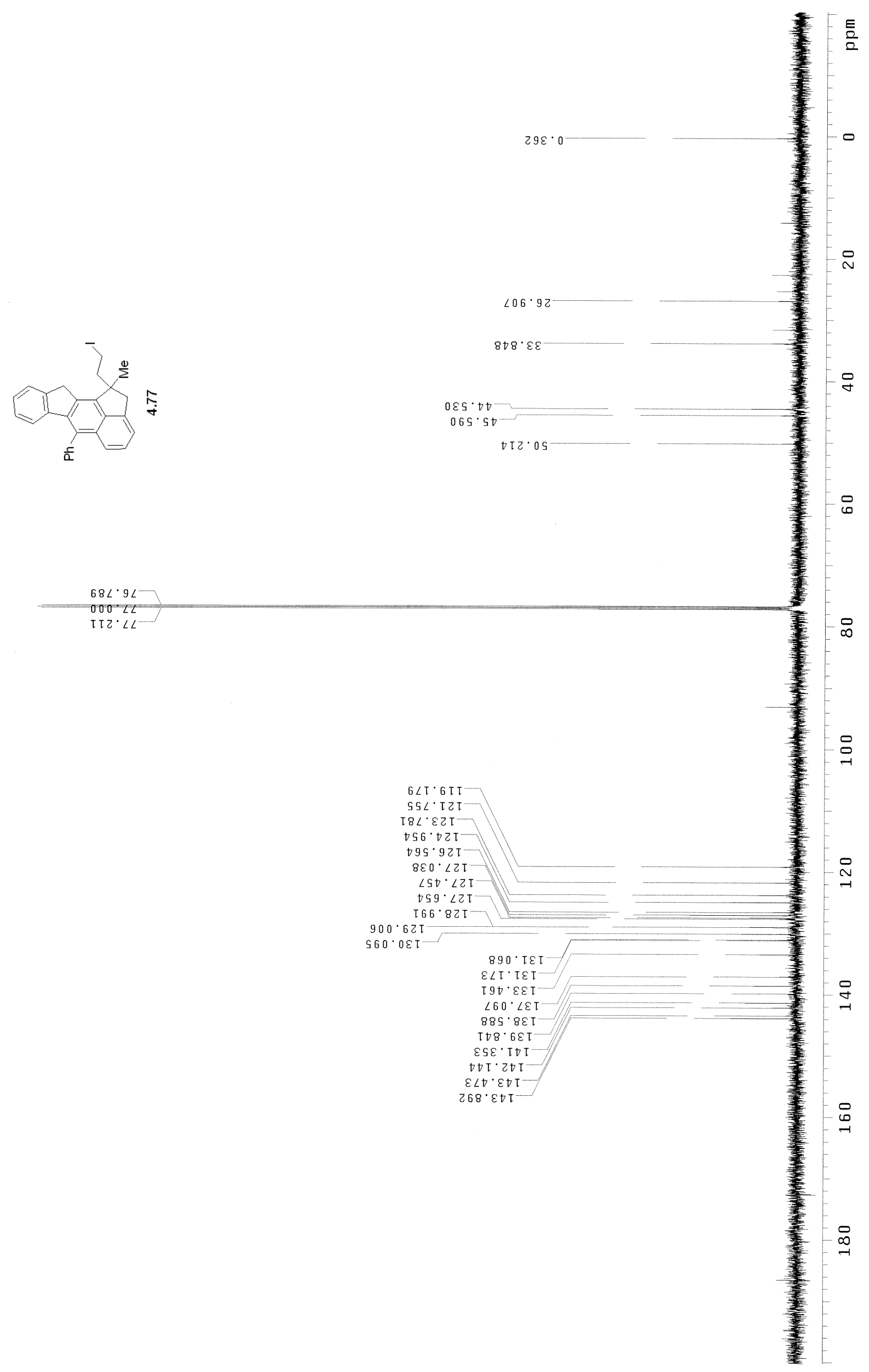




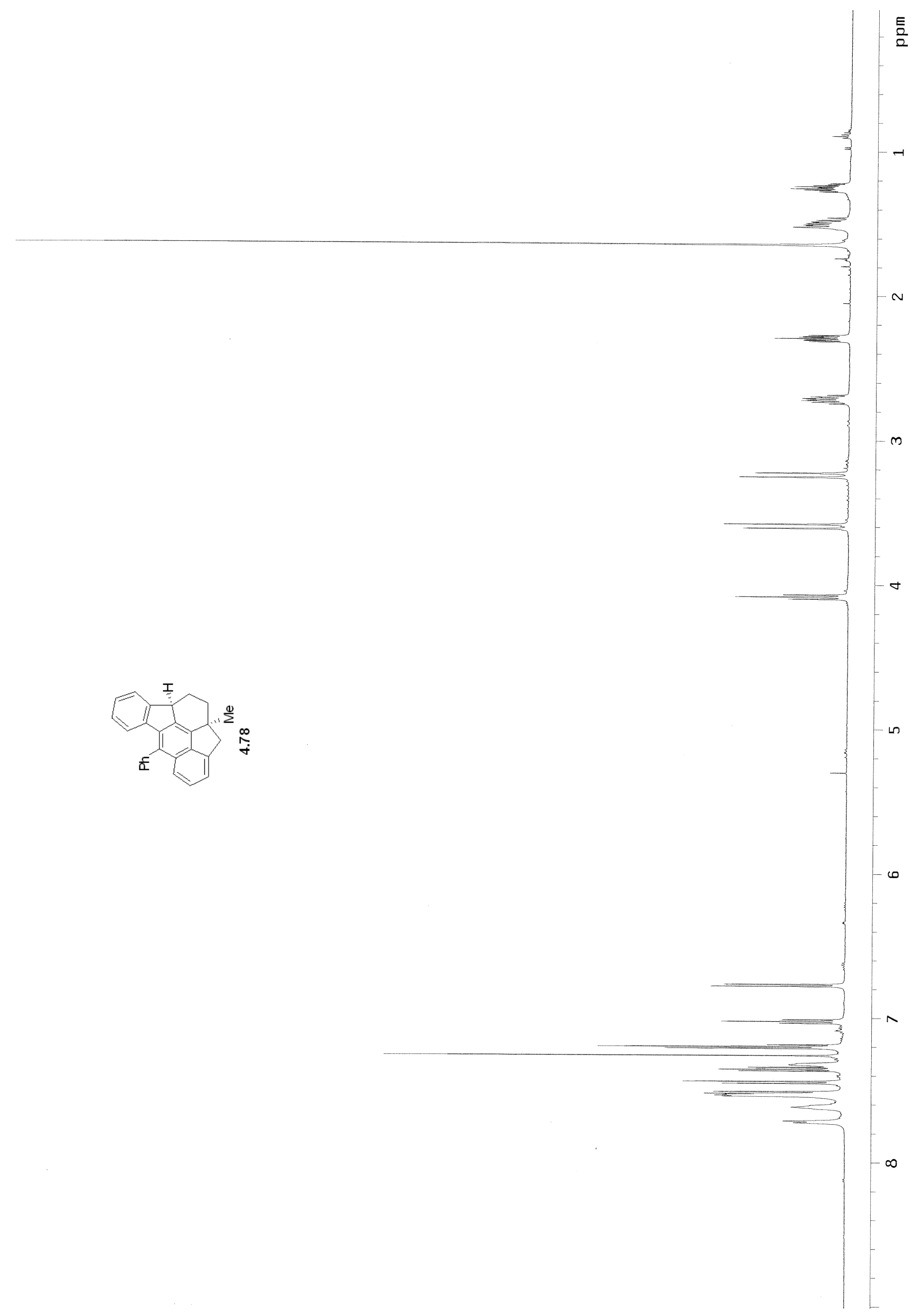




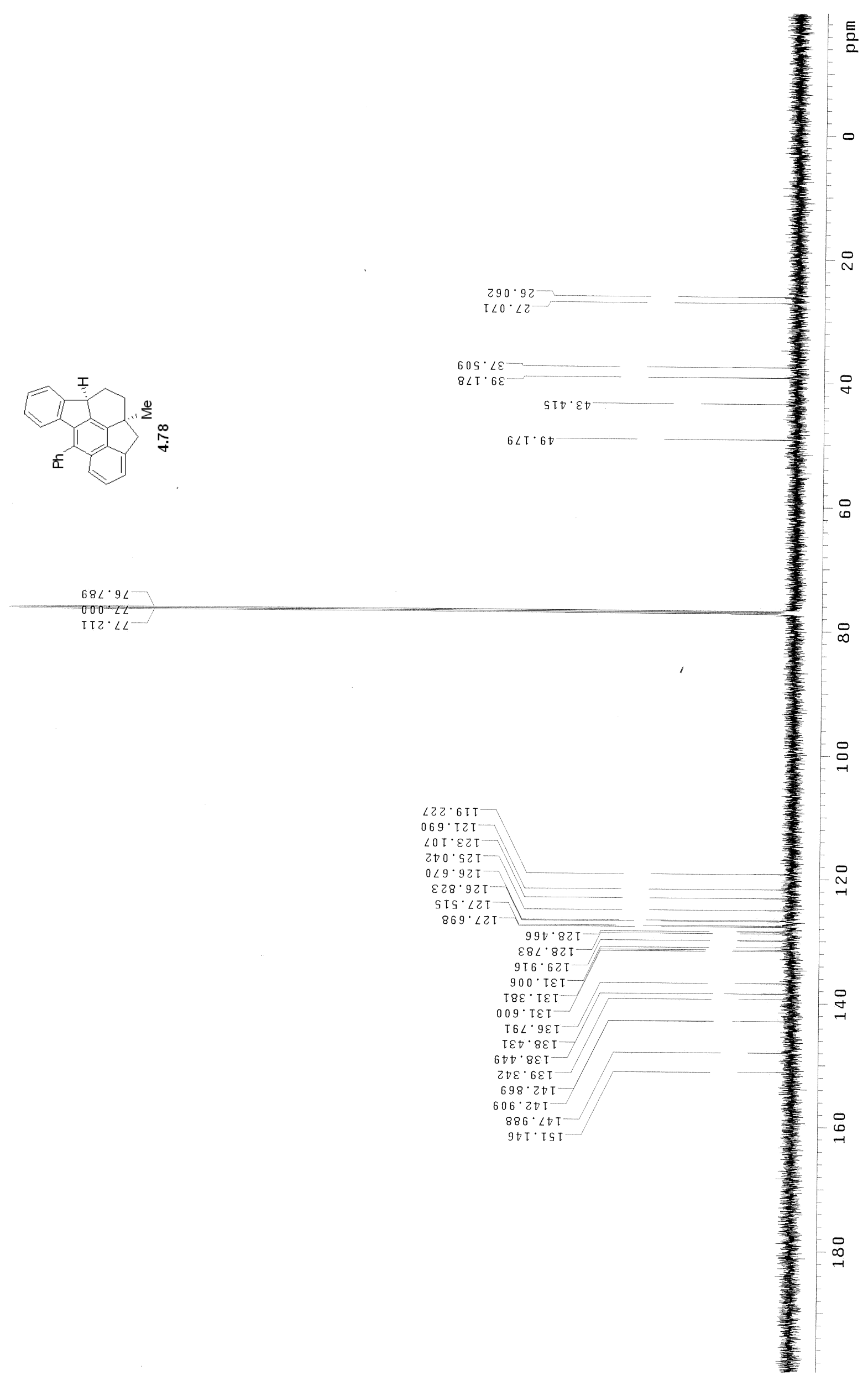




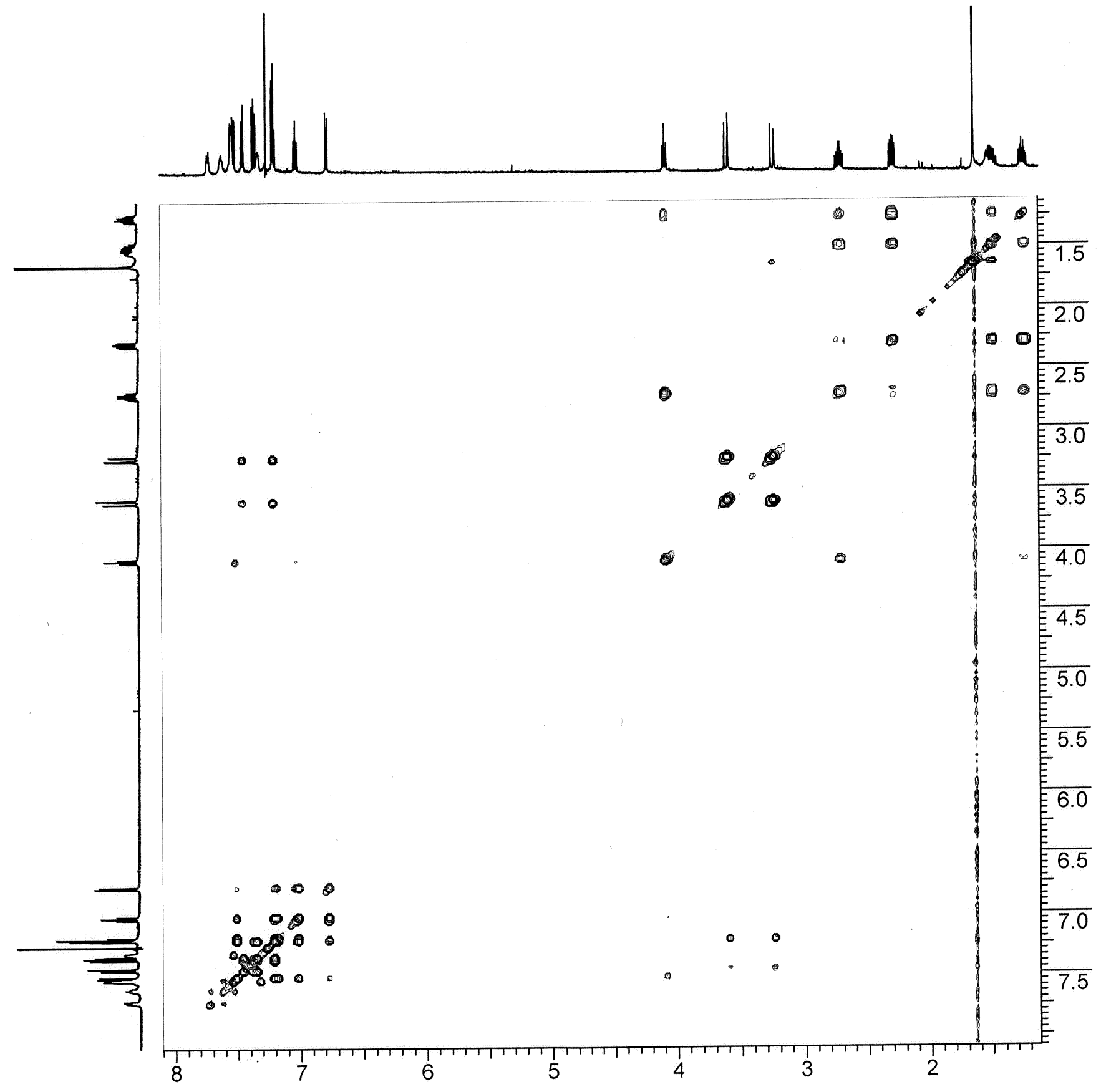




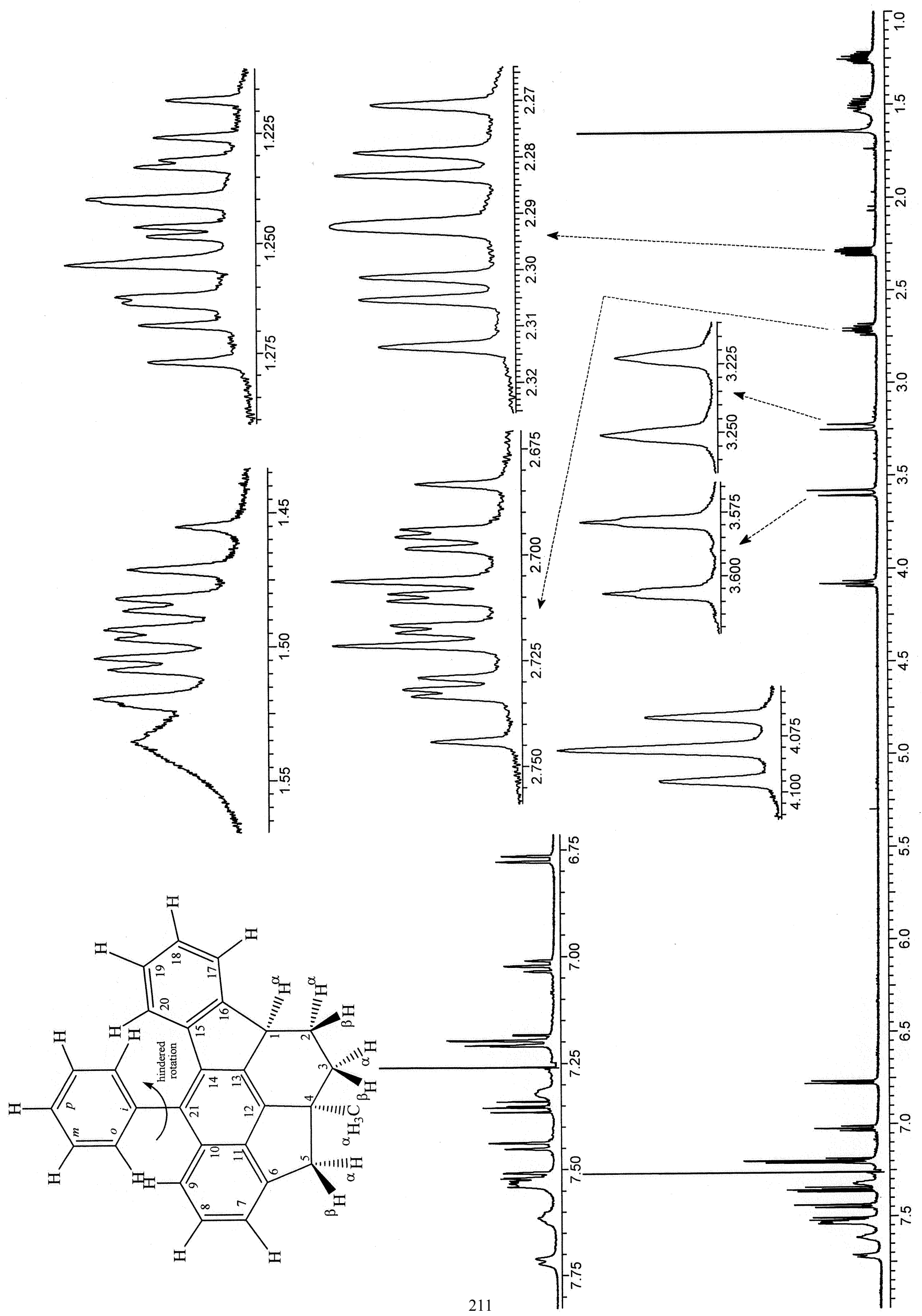




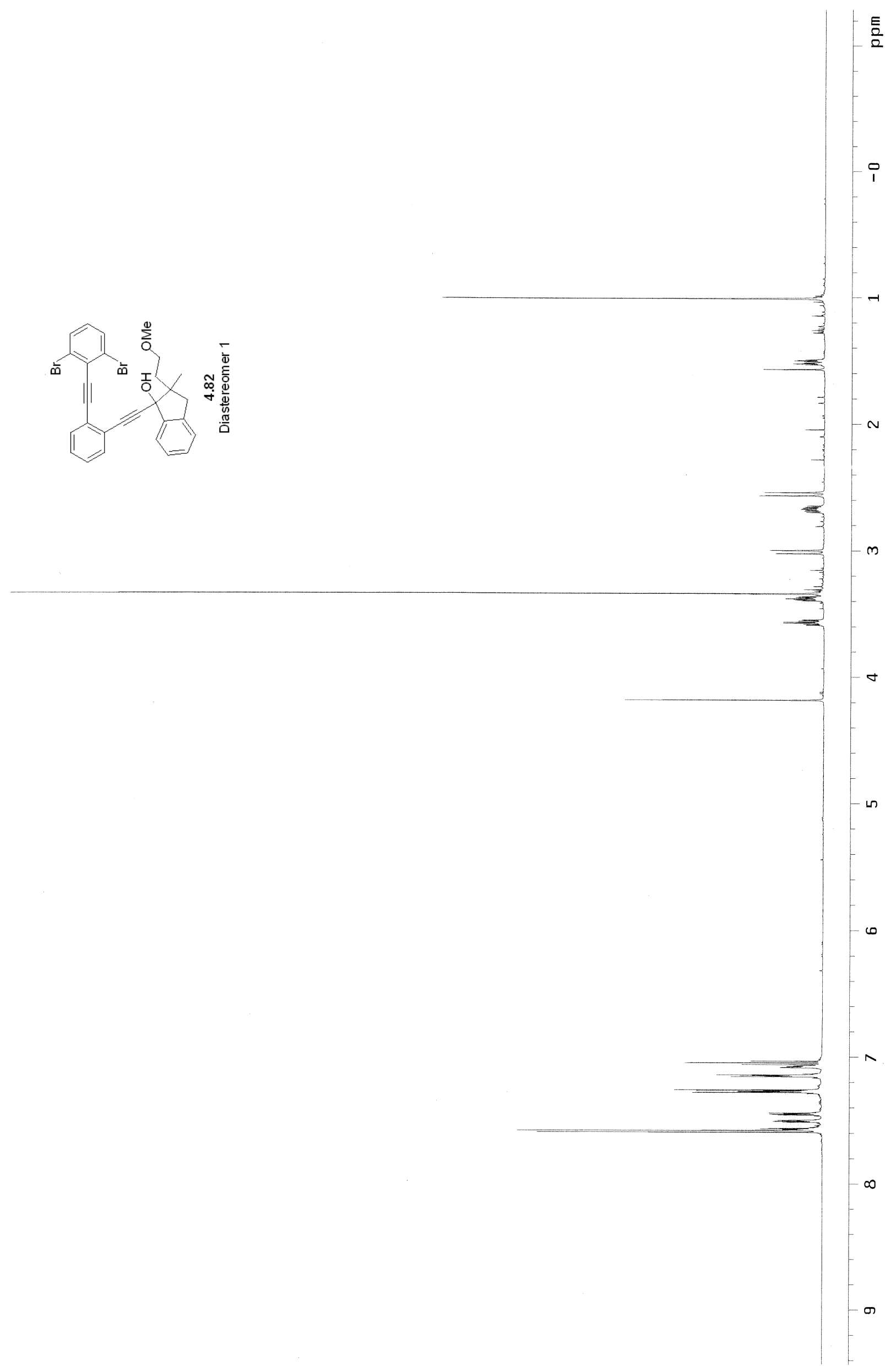




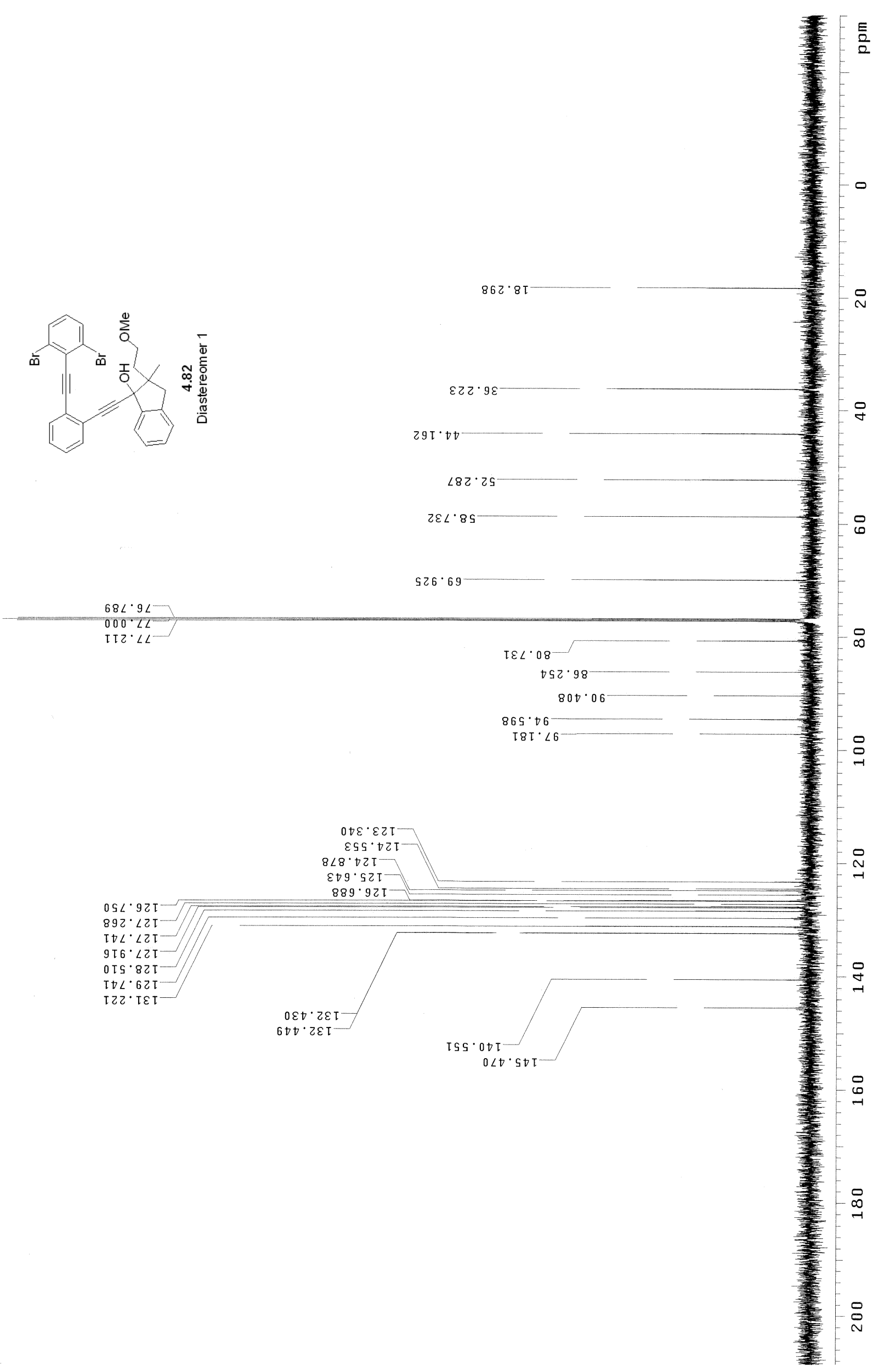




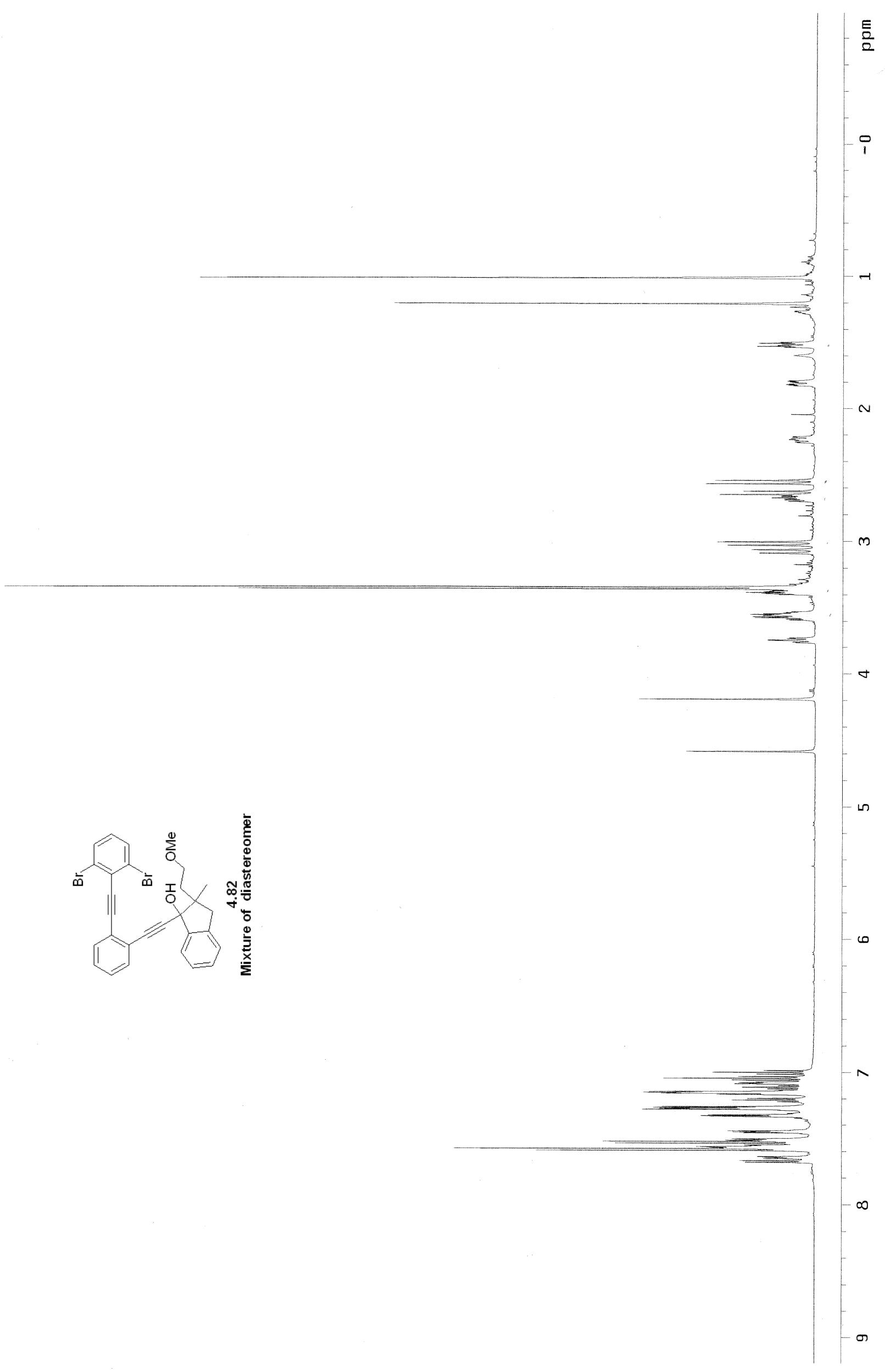



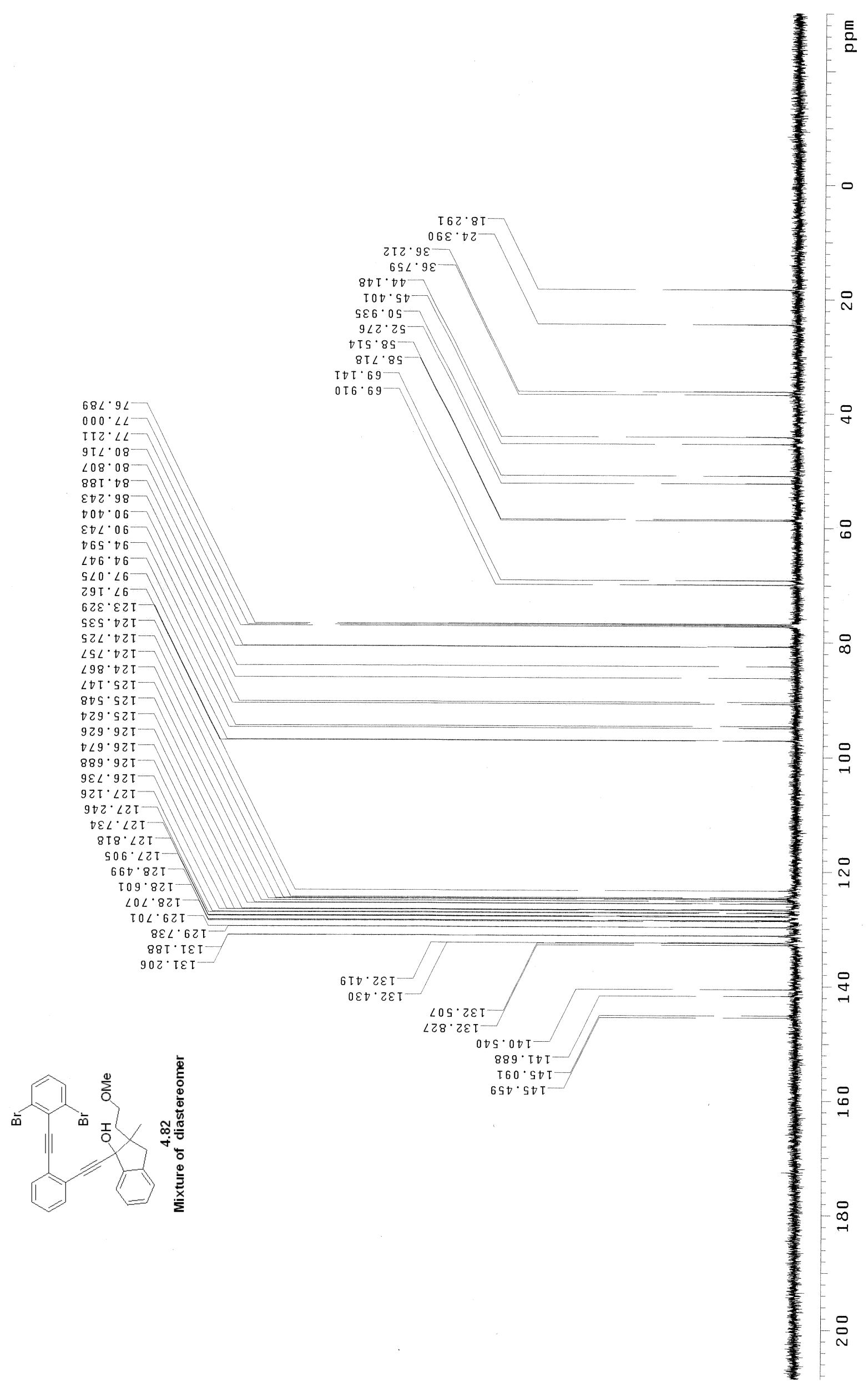

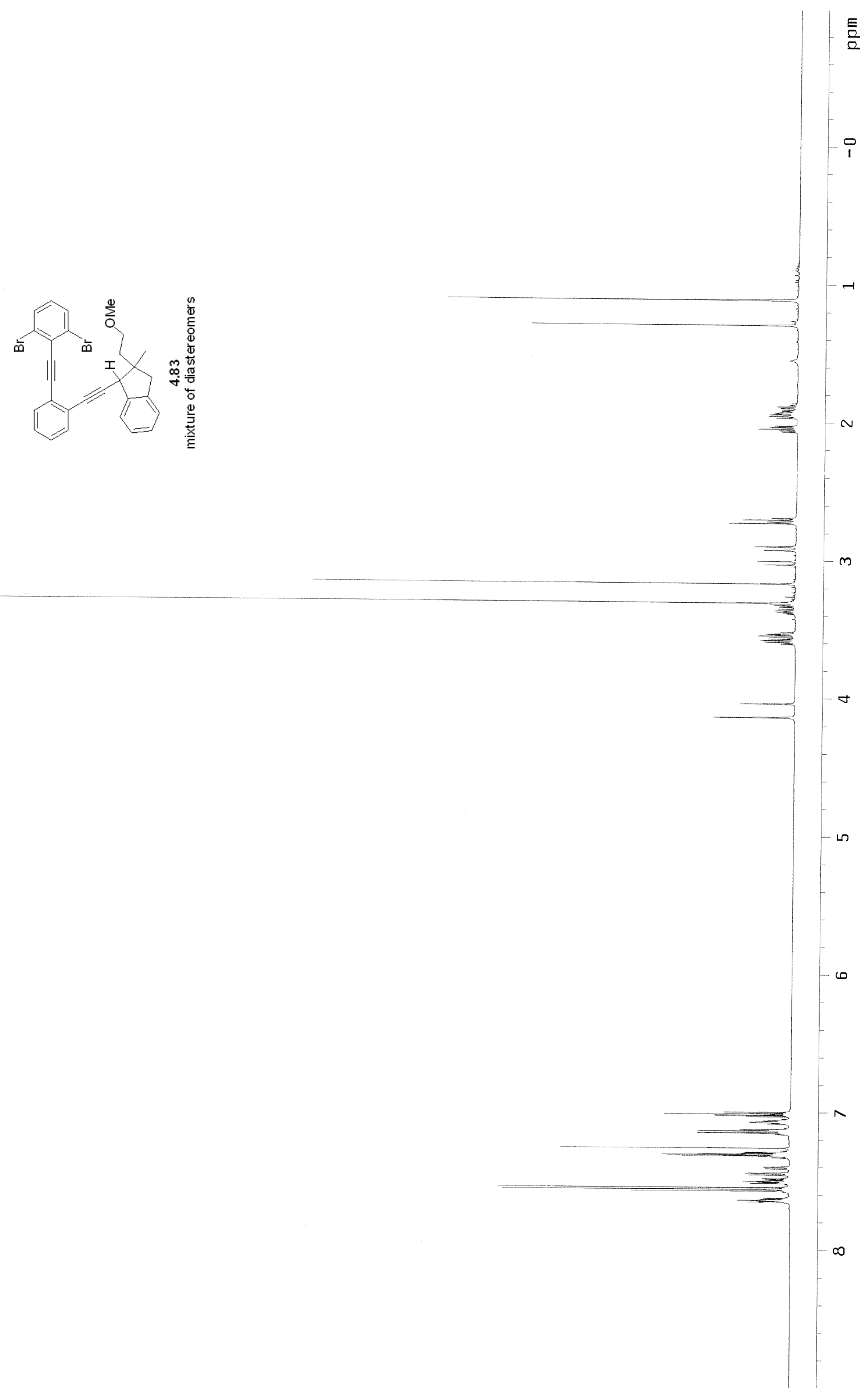


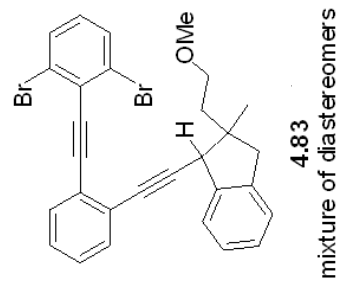

$68 L \cdot 9 L$

II $Z^{\circ} \angle L$

$Z \varepsilon I \cdot O L$

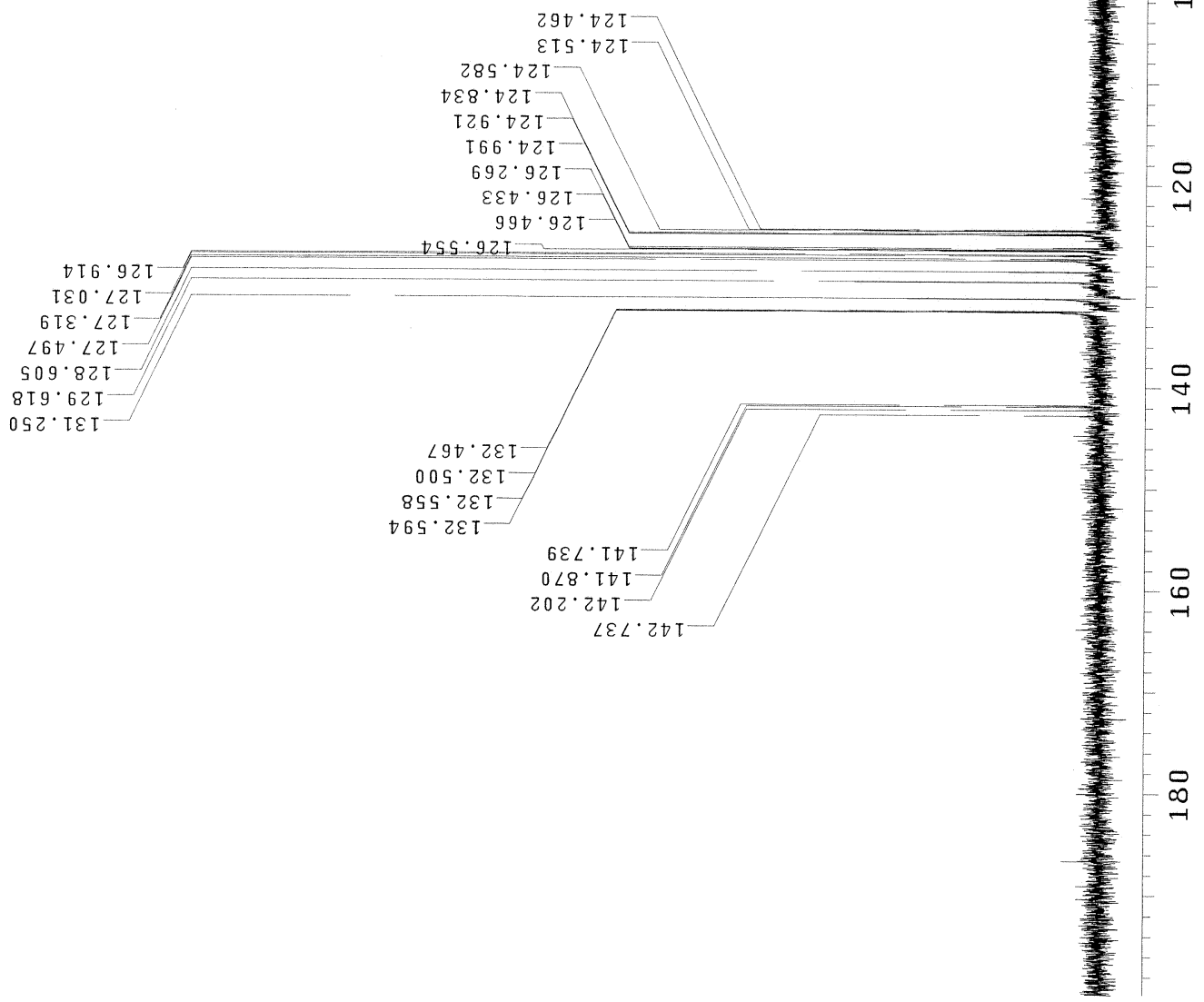




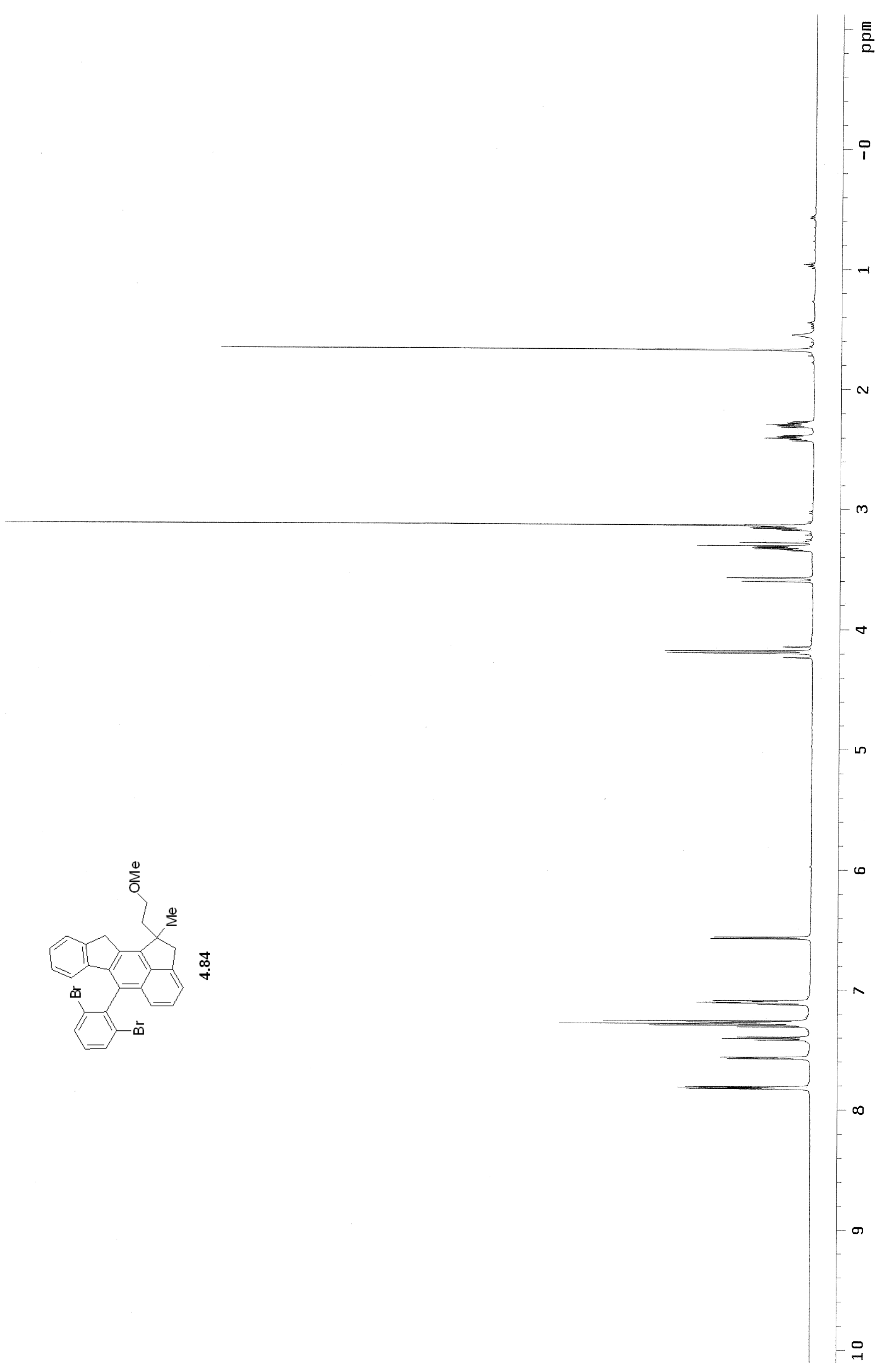




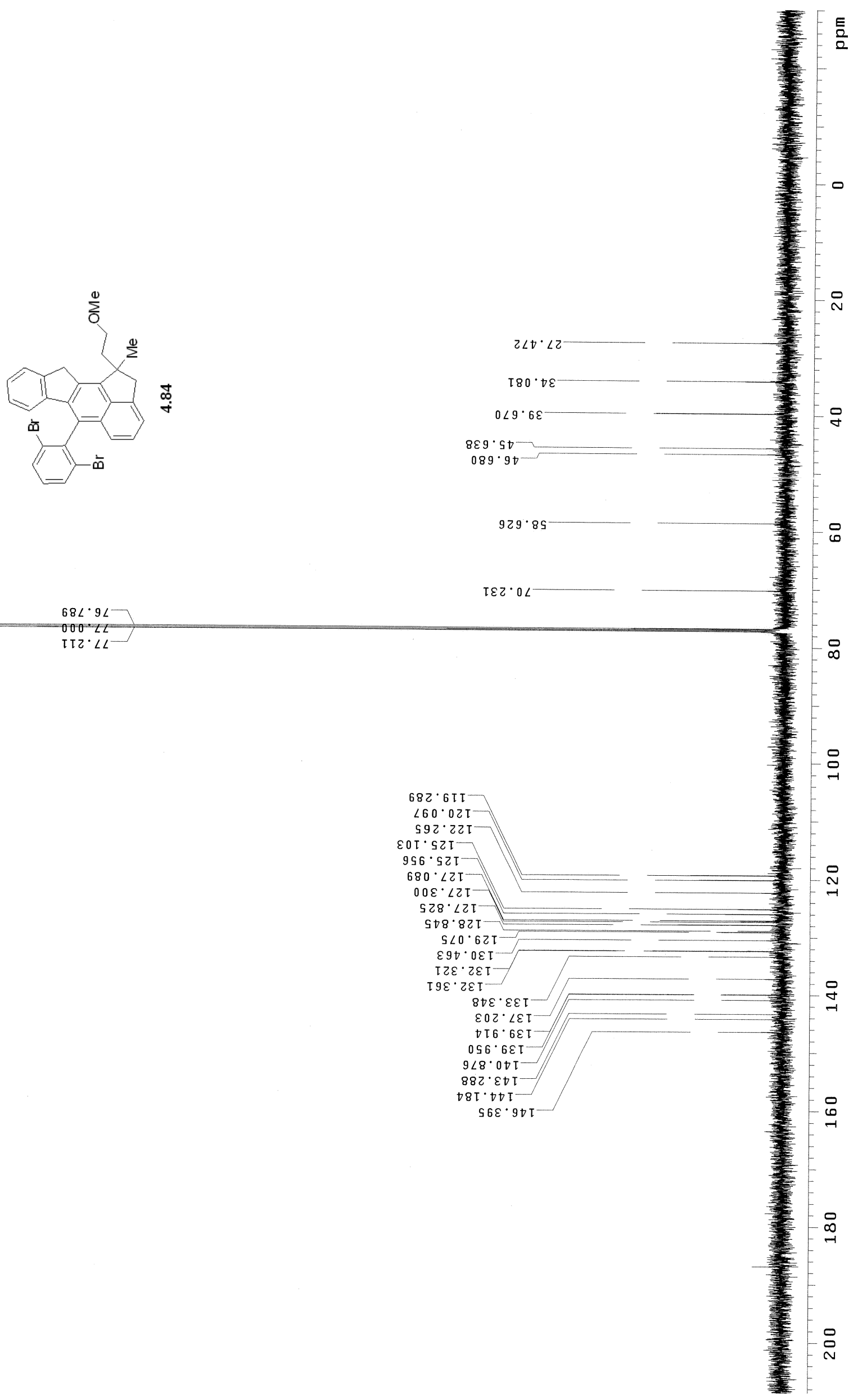




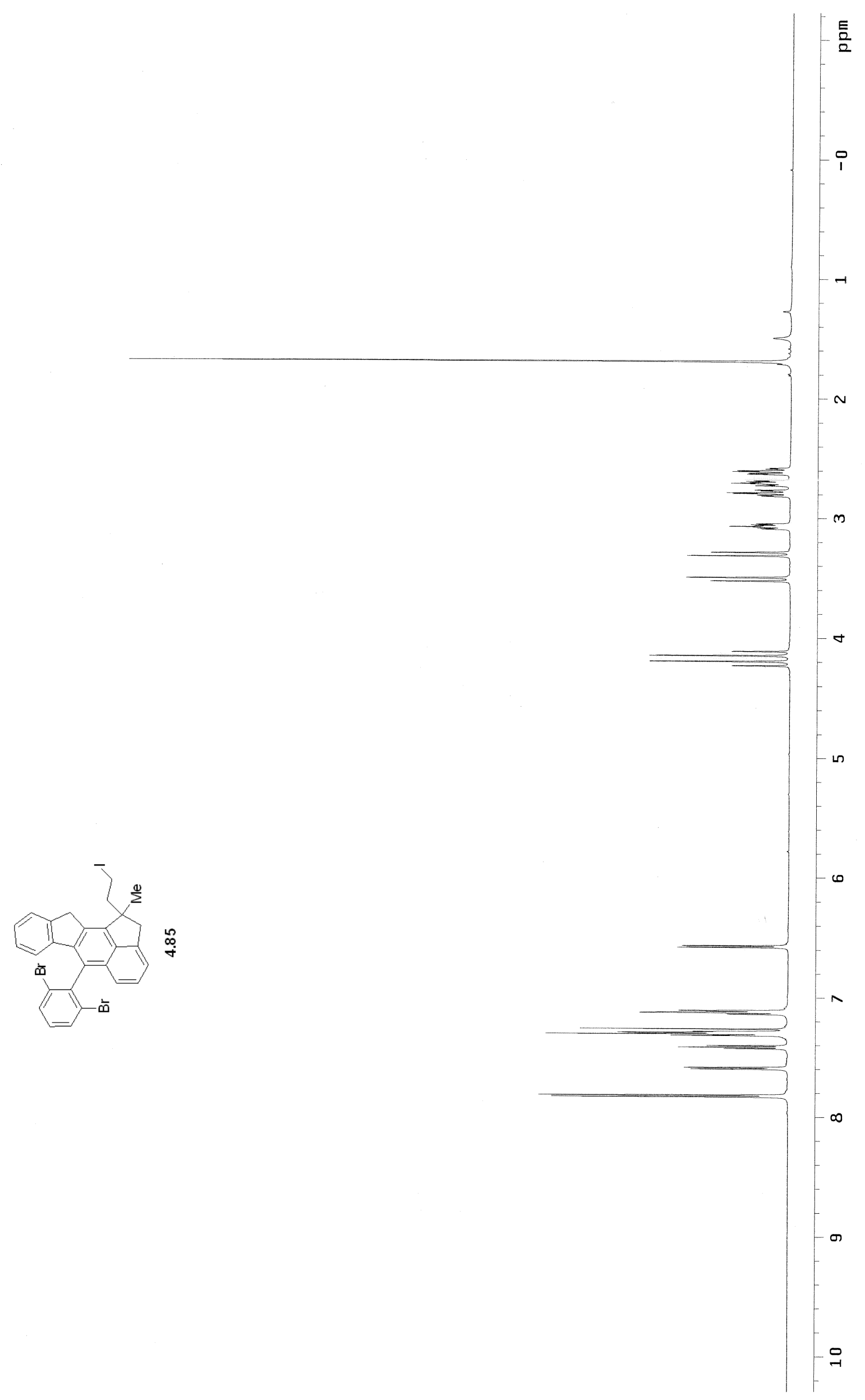



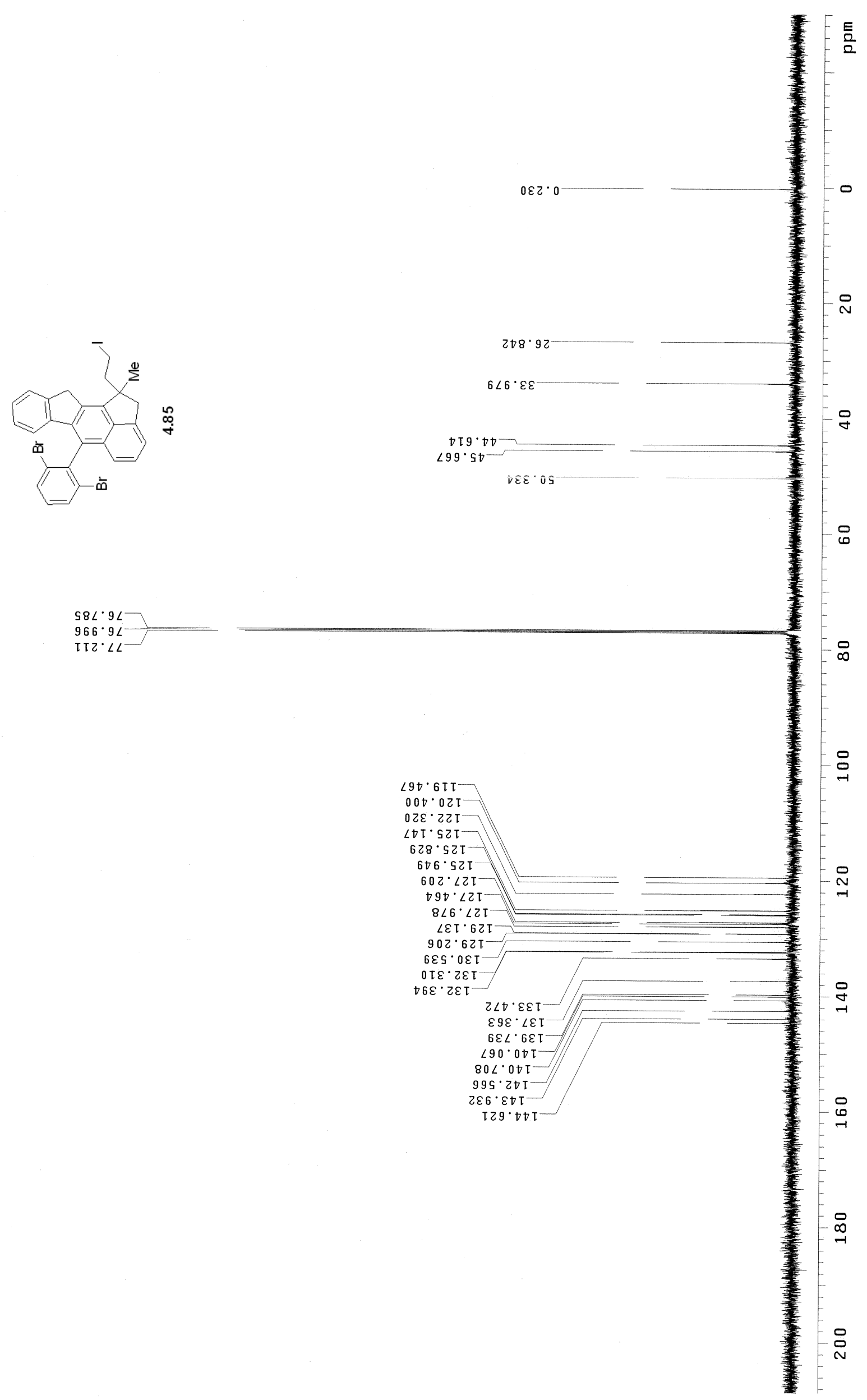


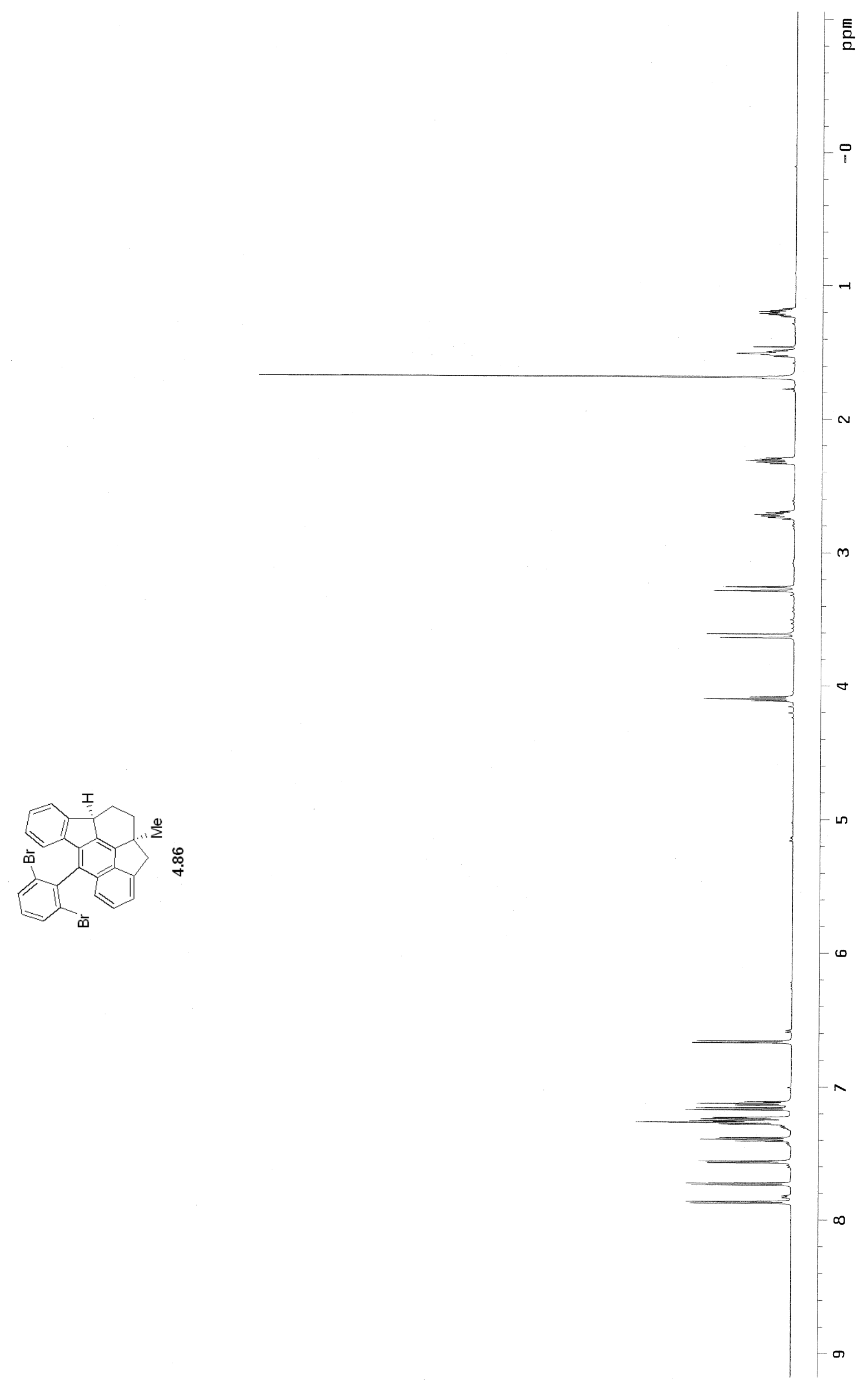




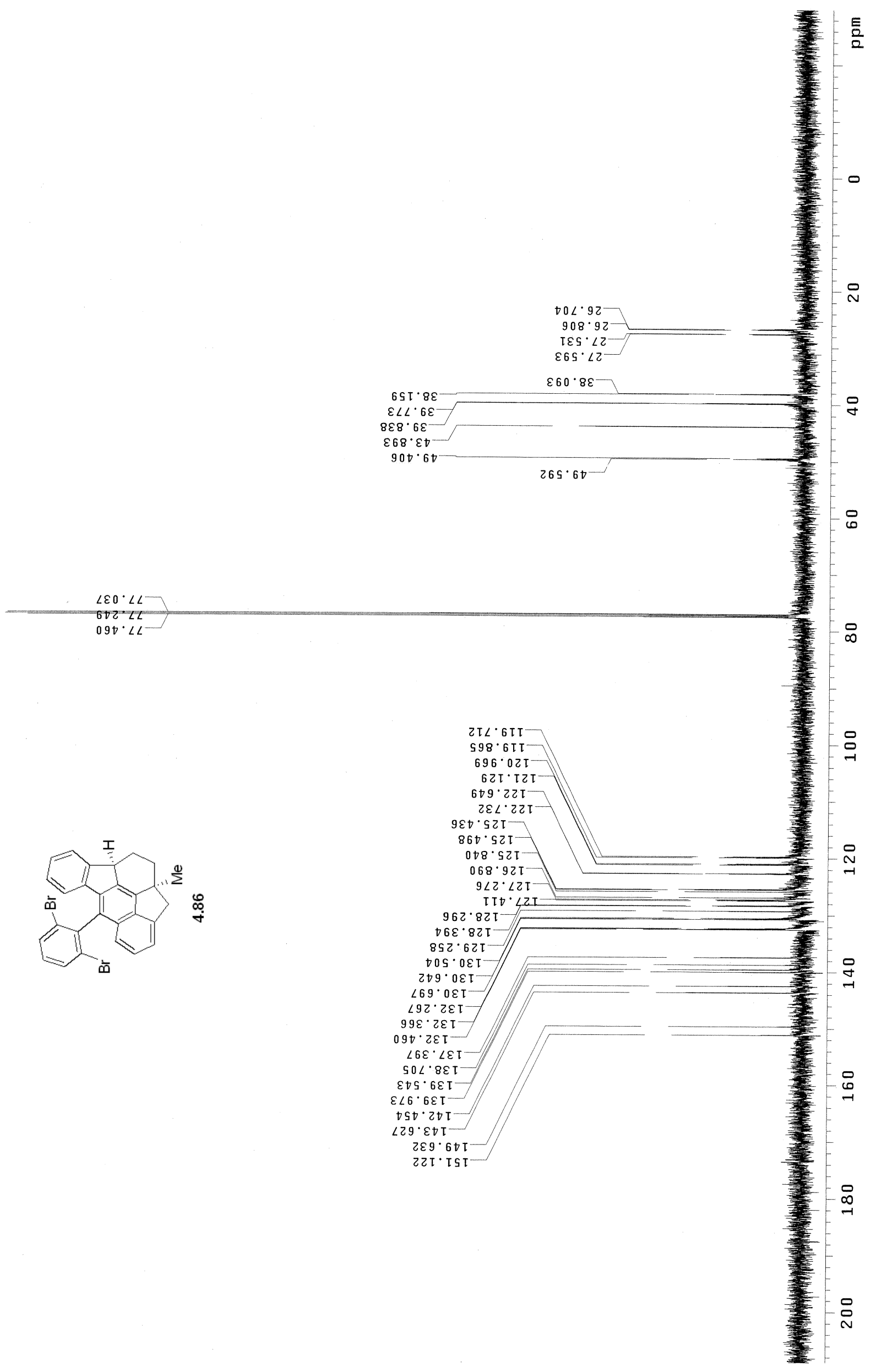




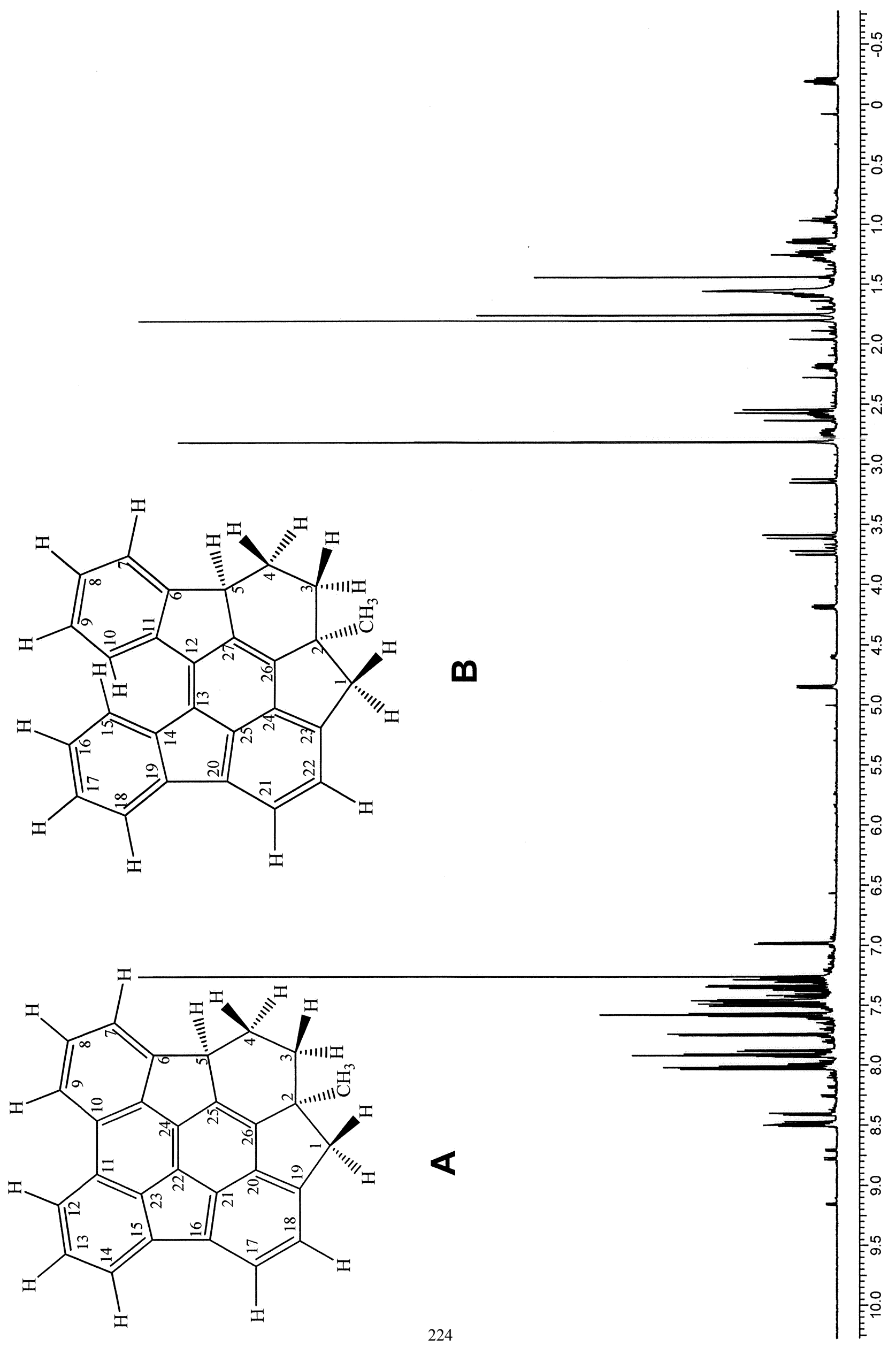




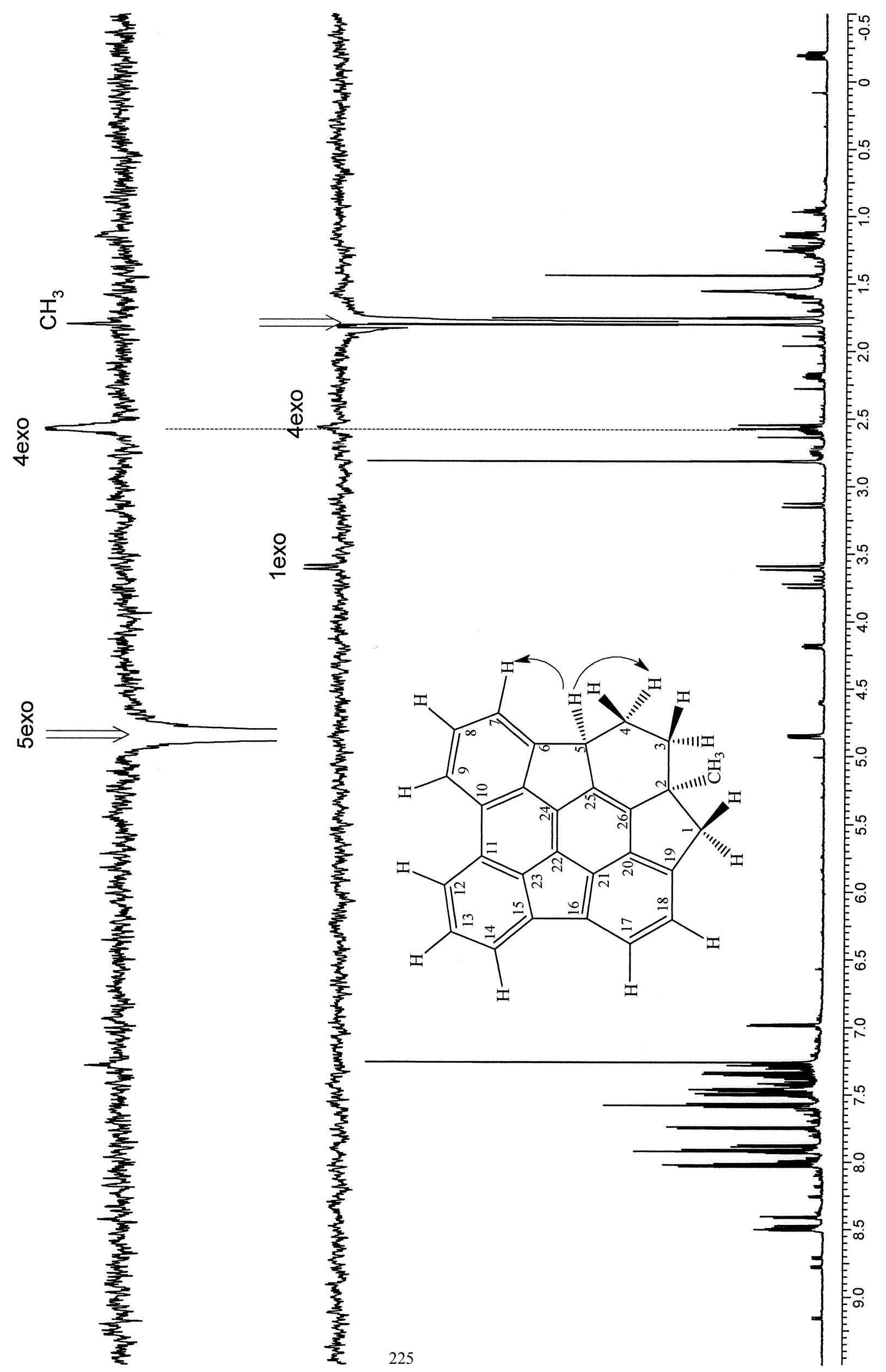




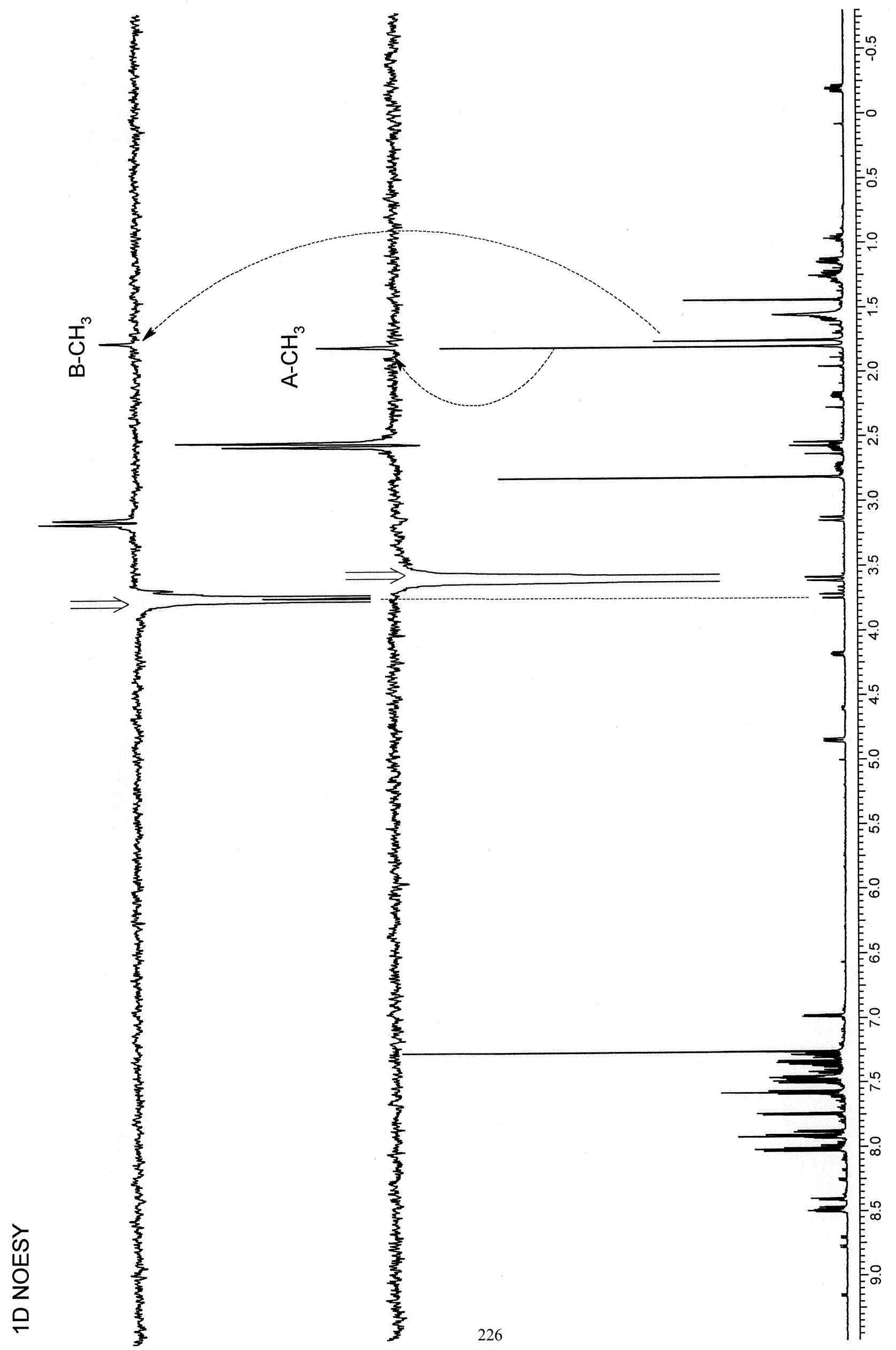




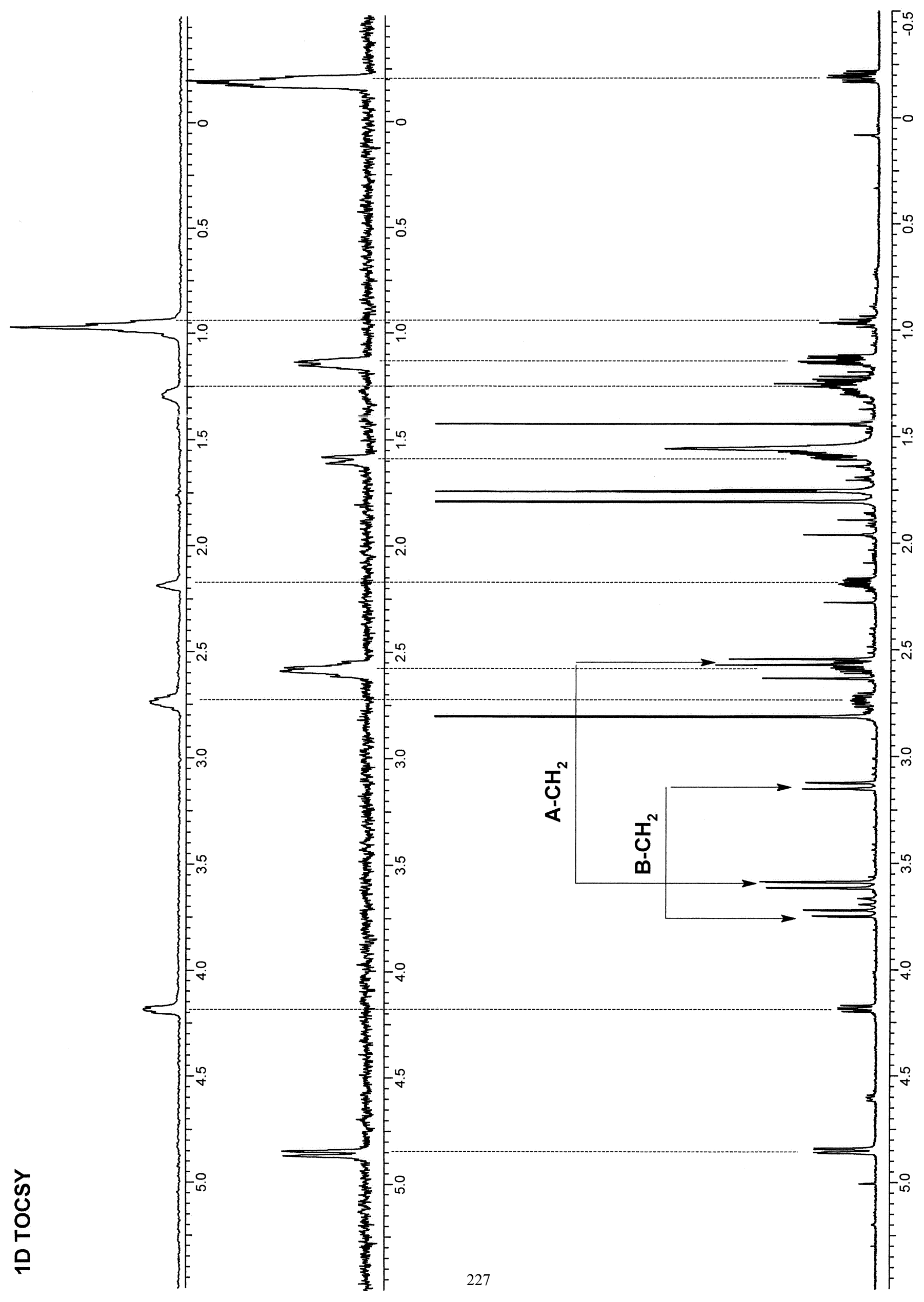




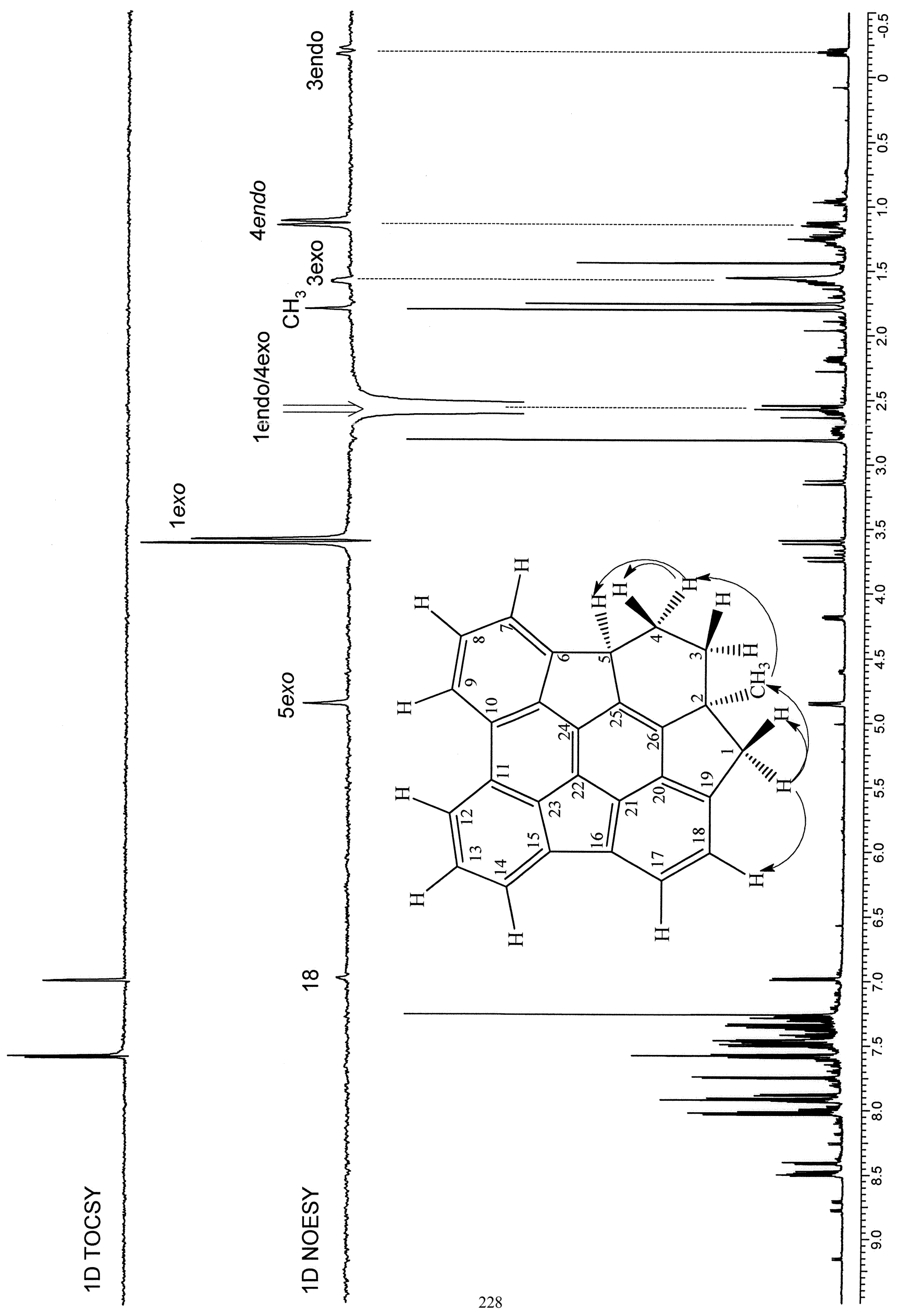




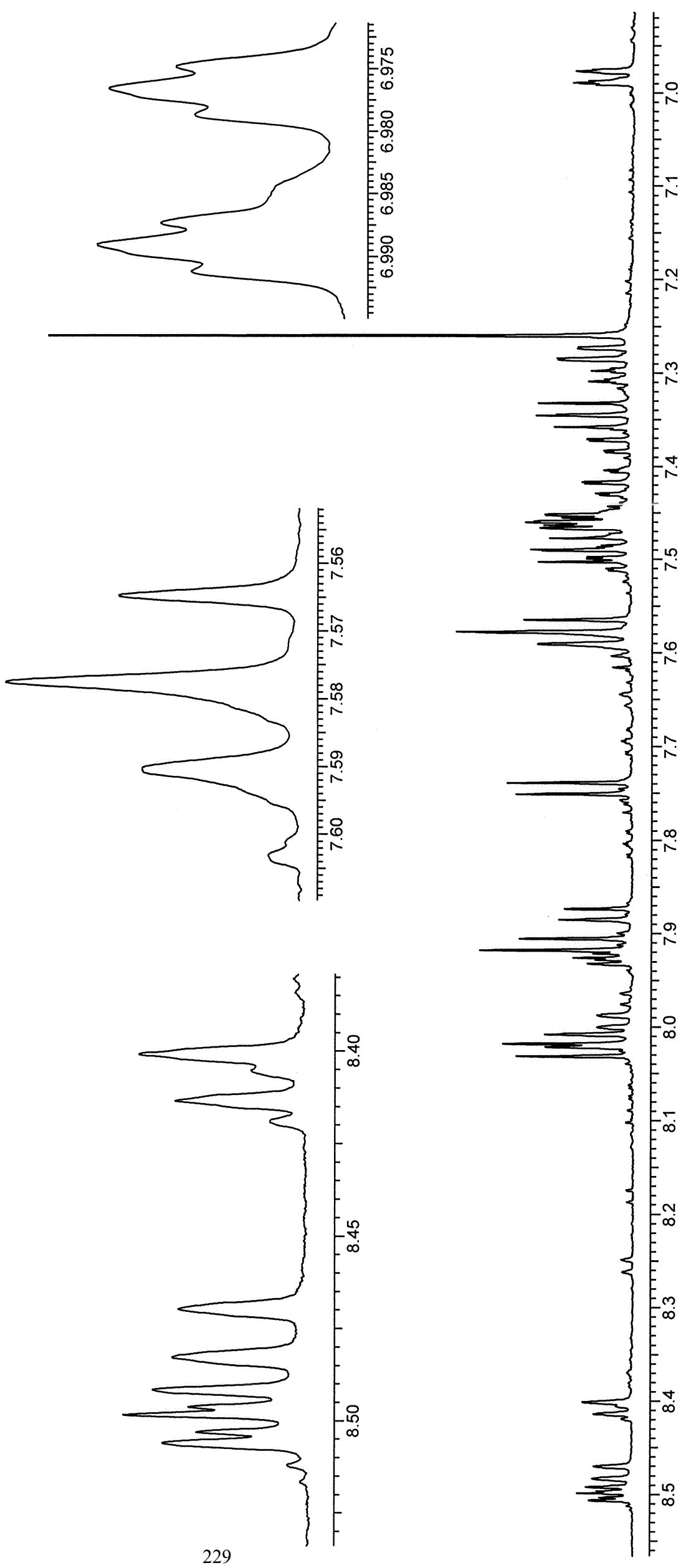




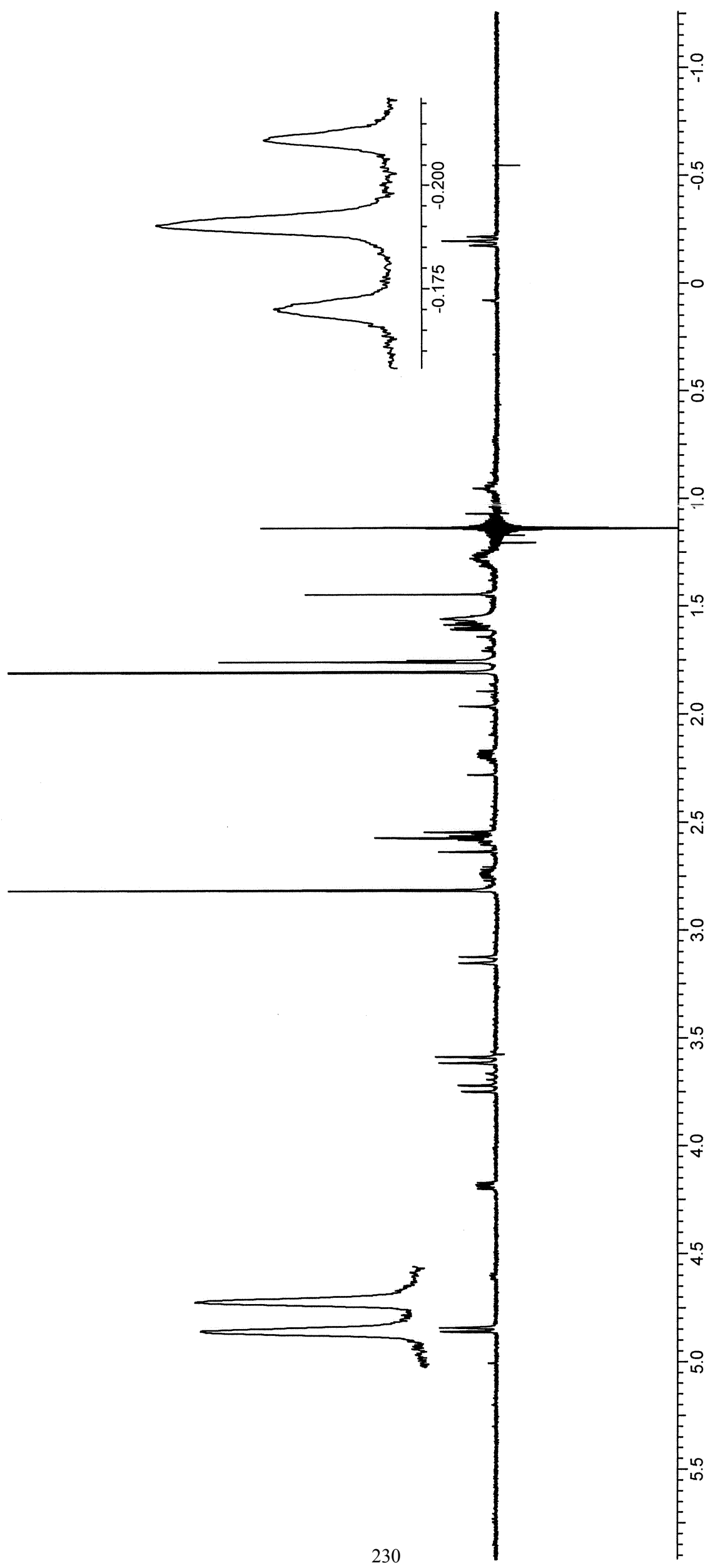




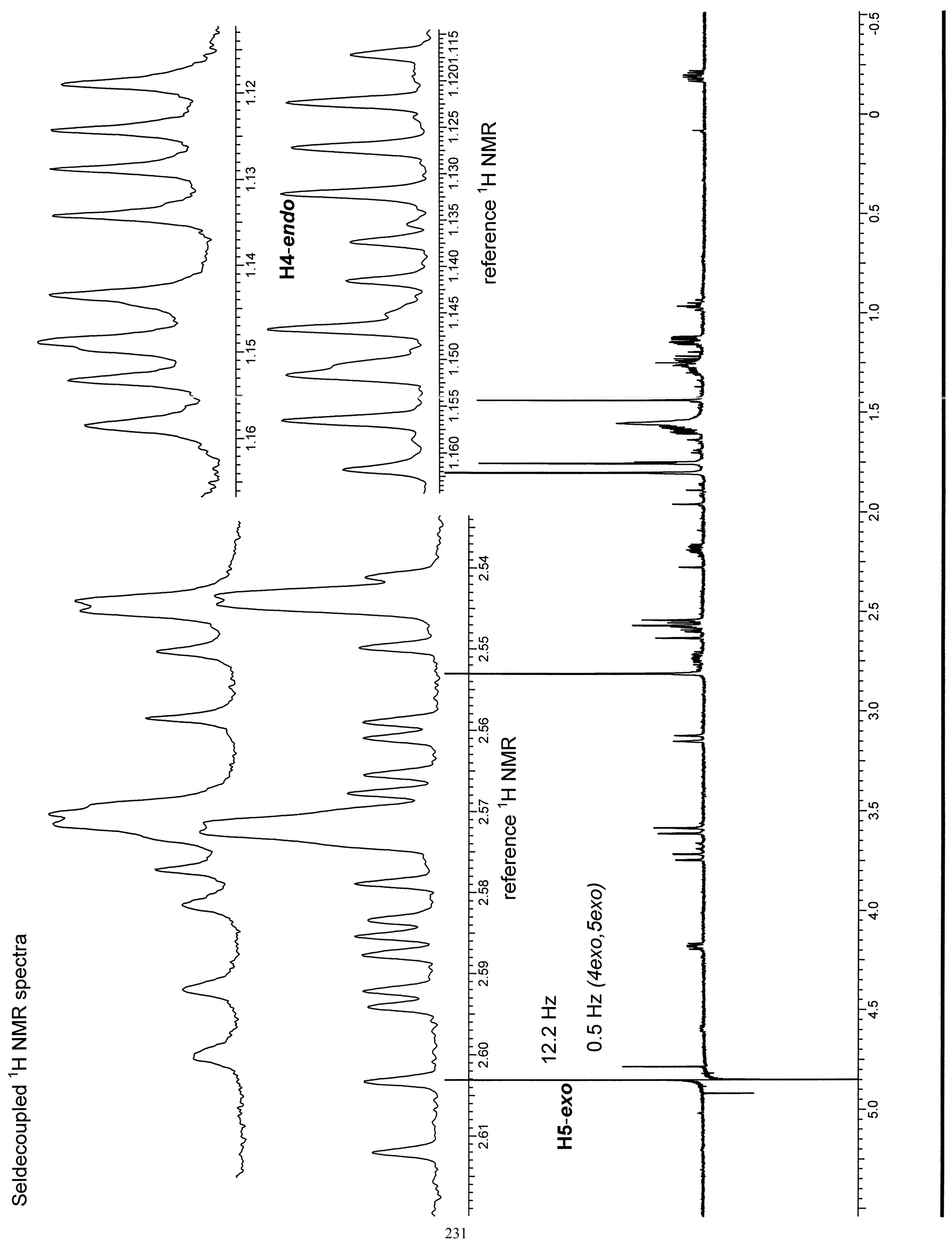



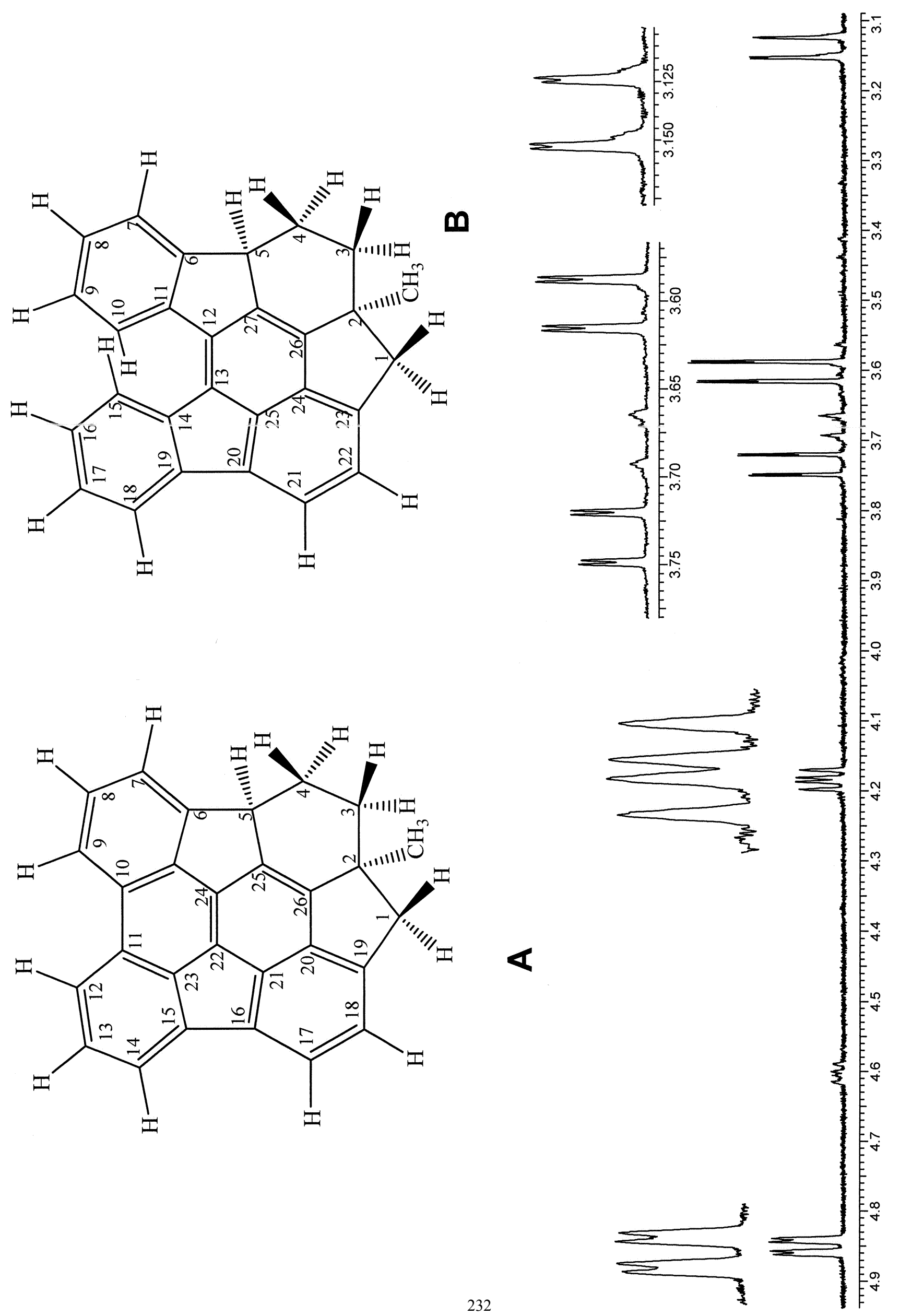


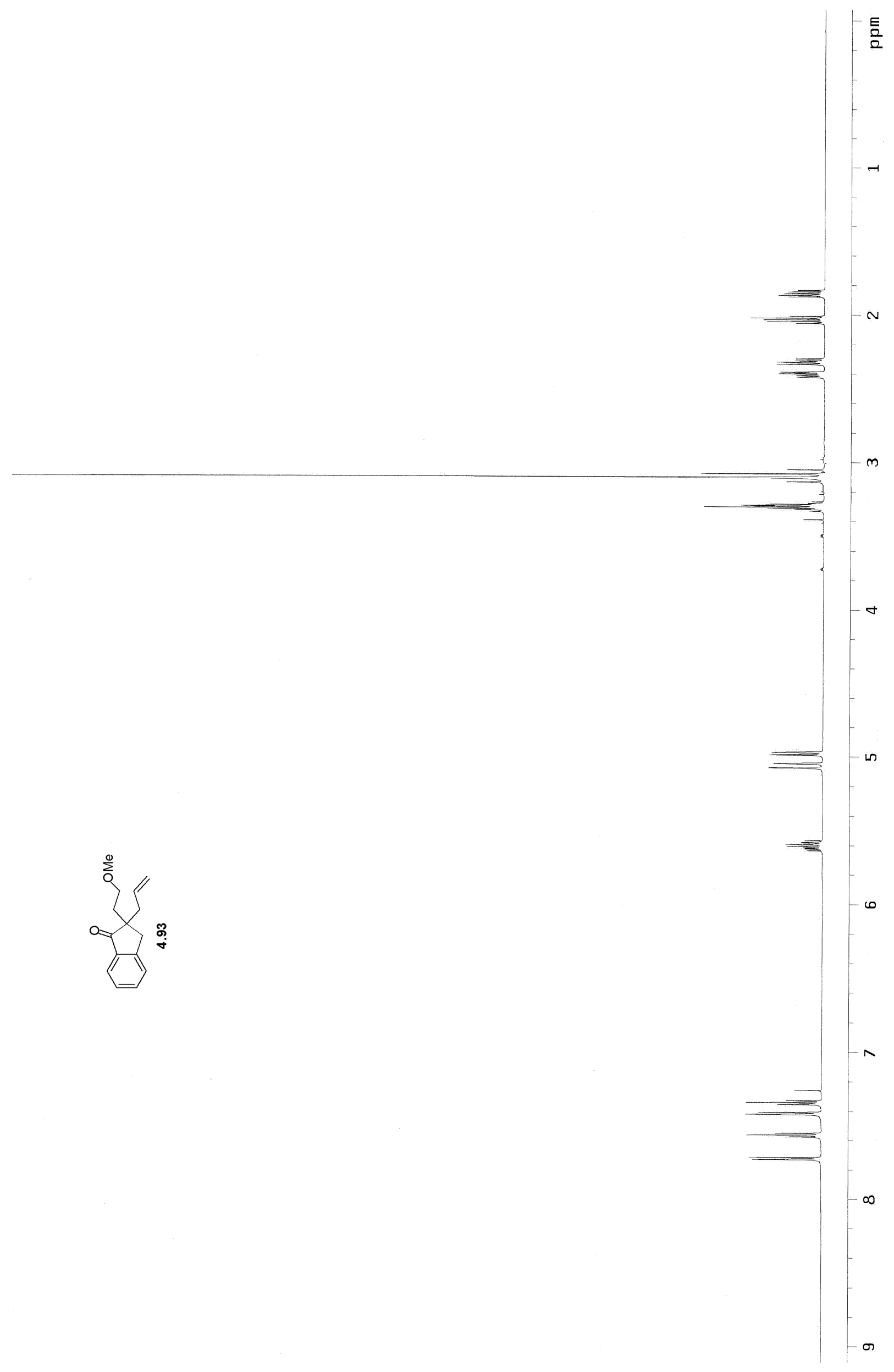




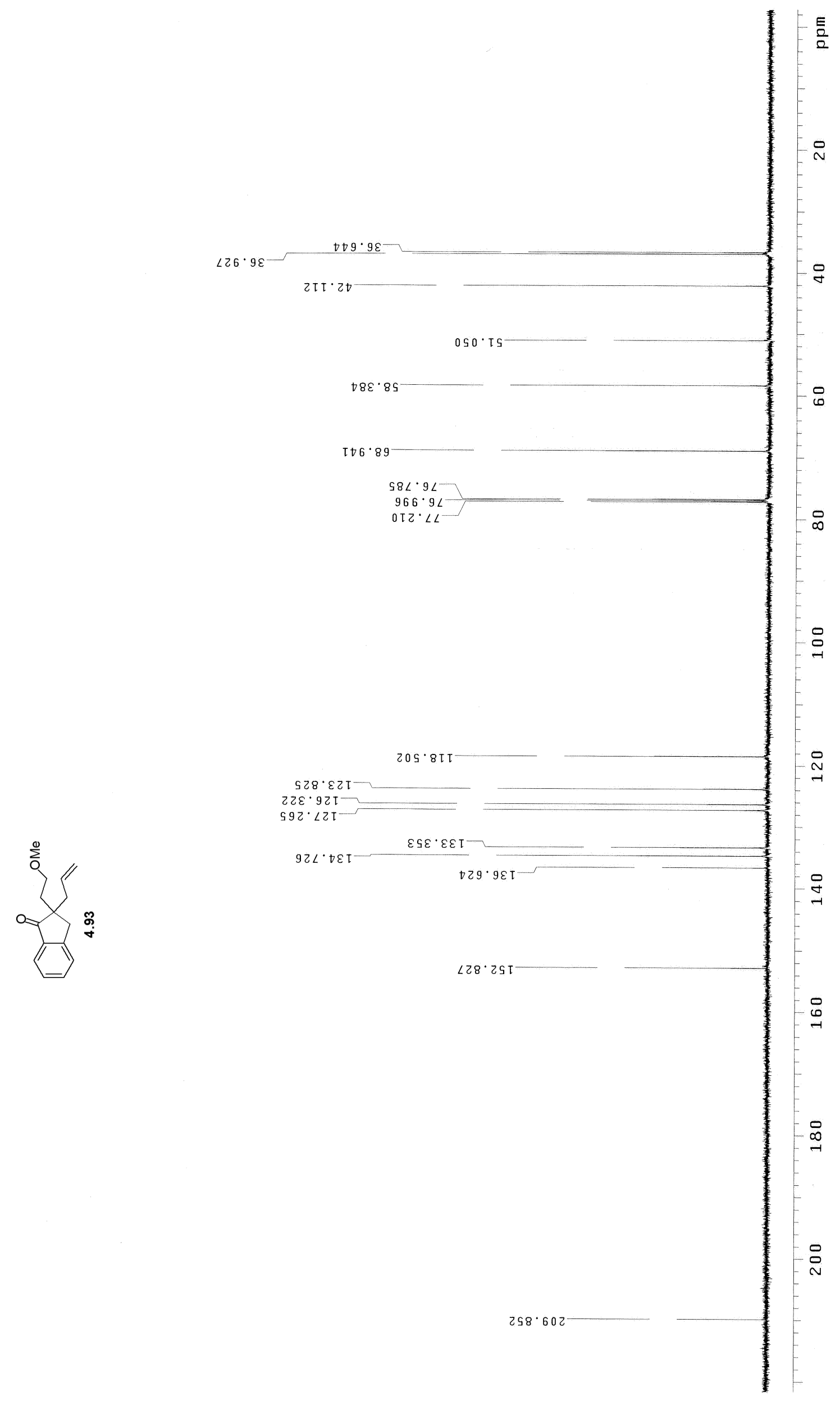




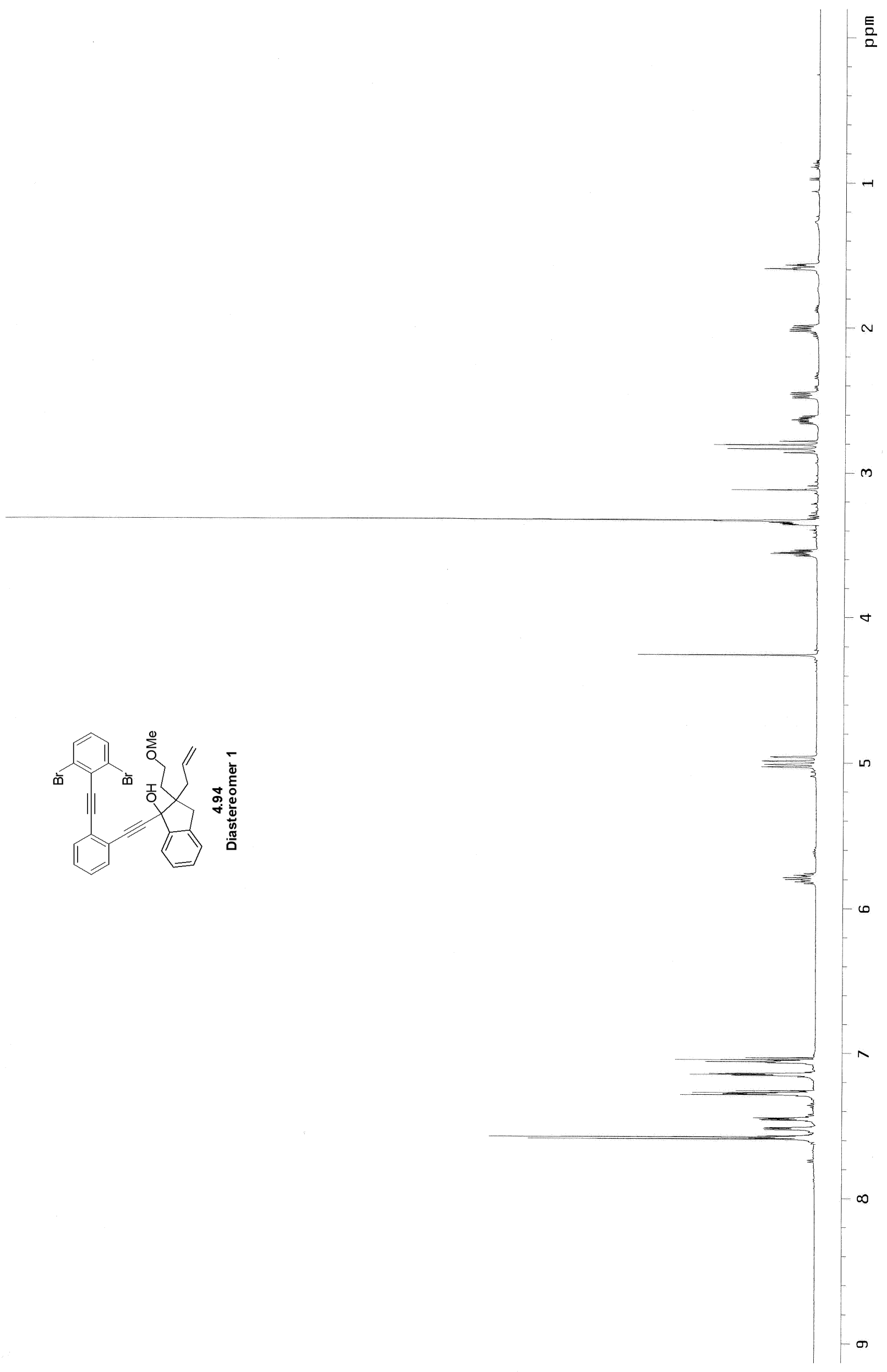



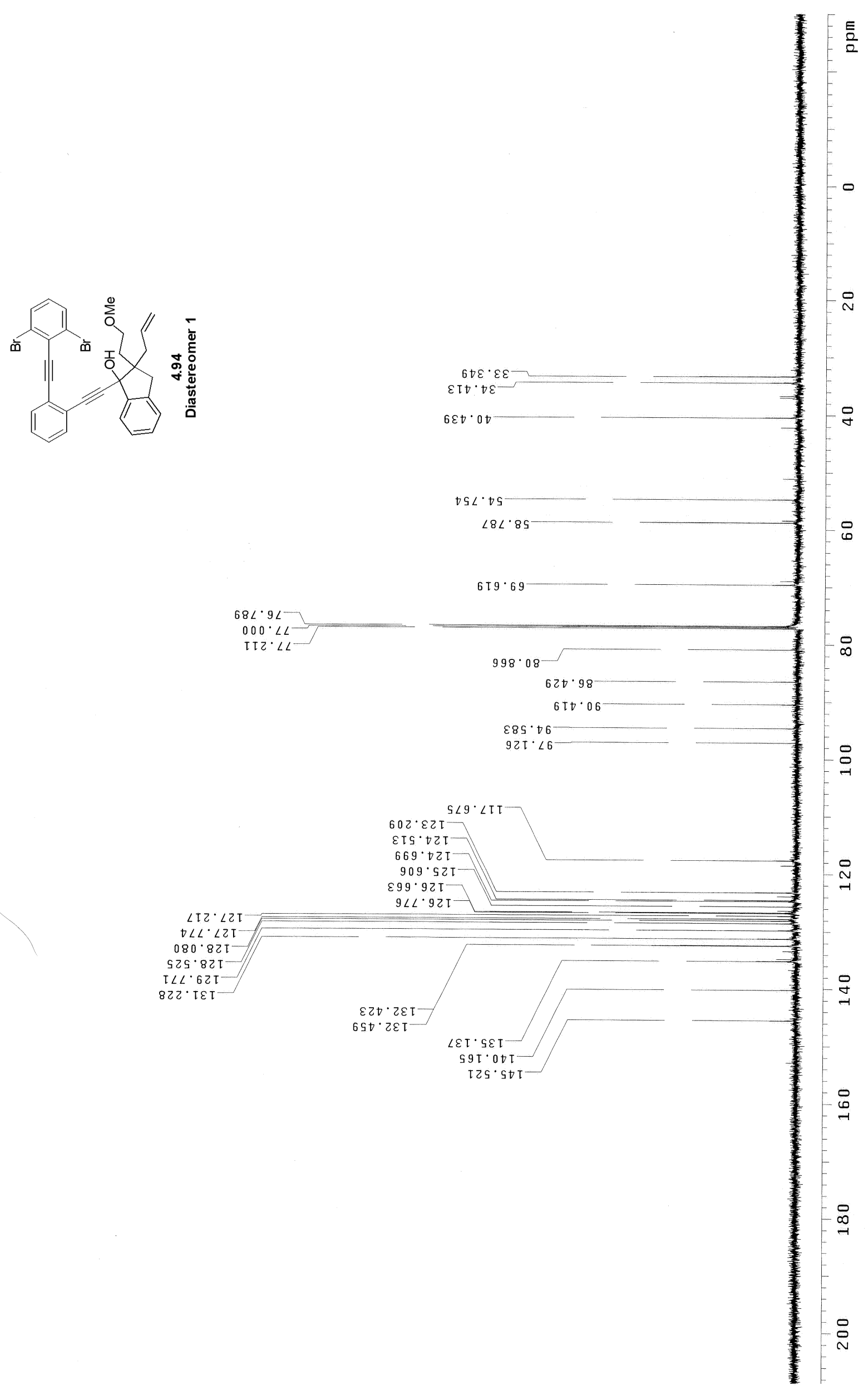


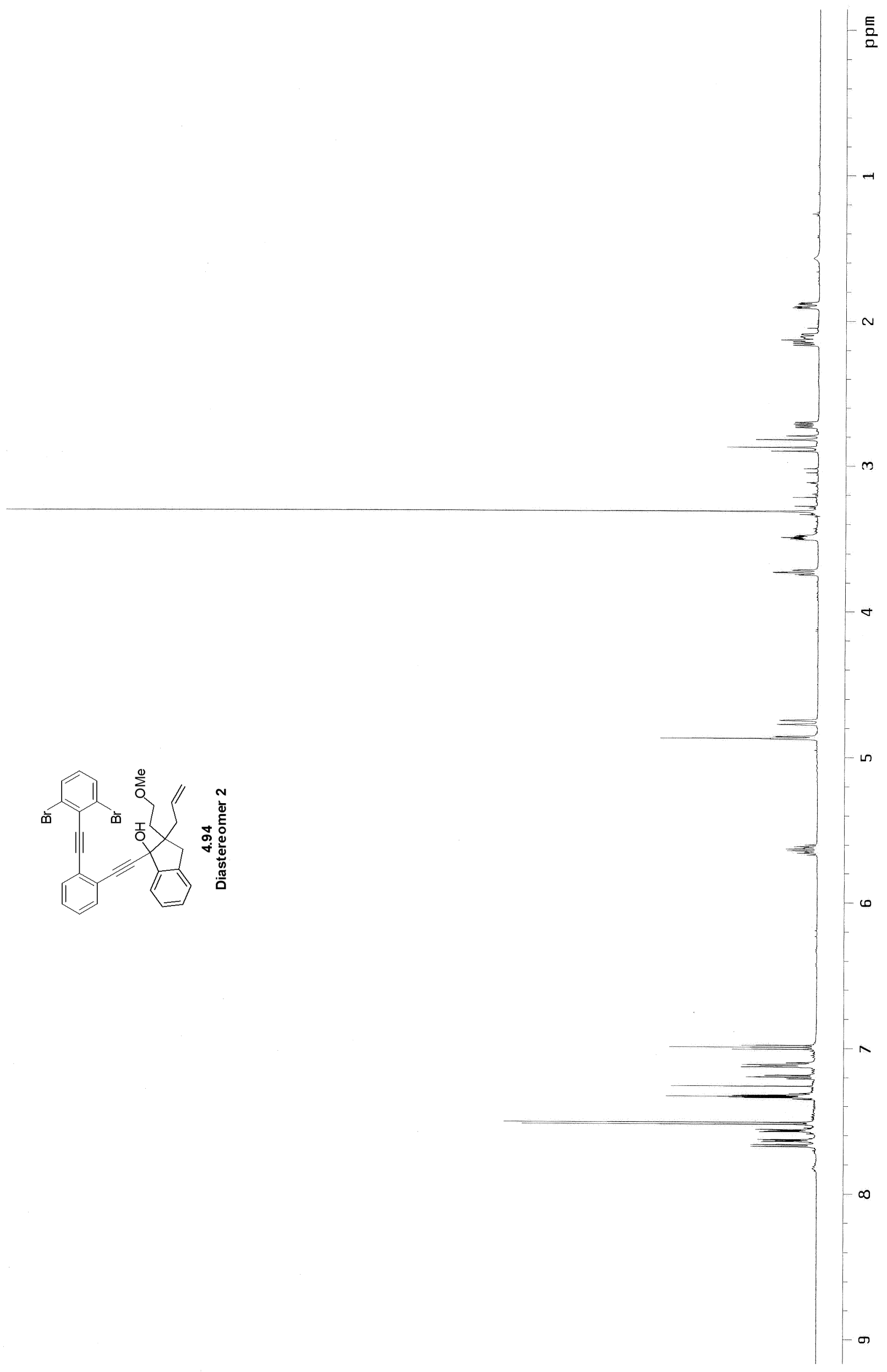




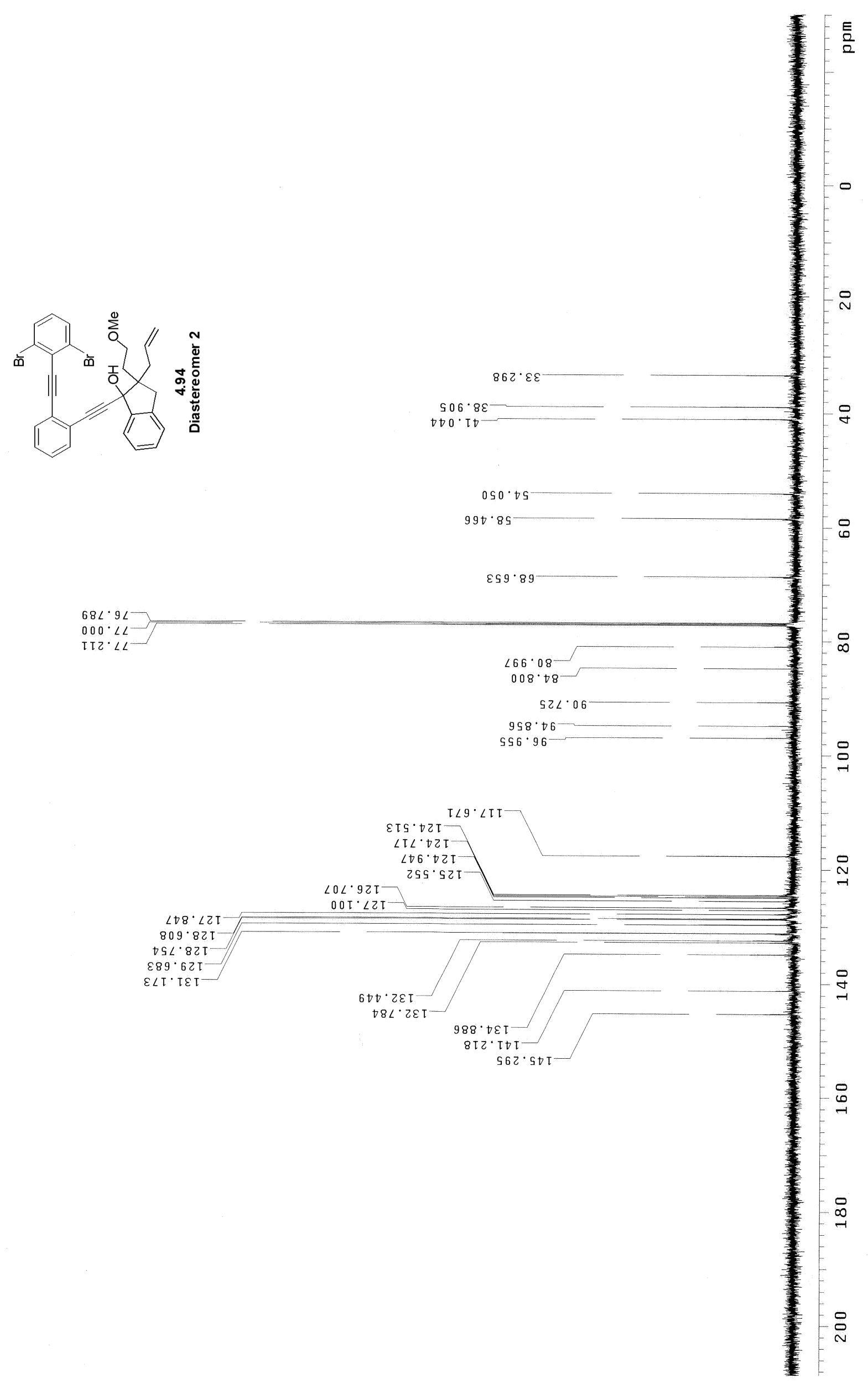




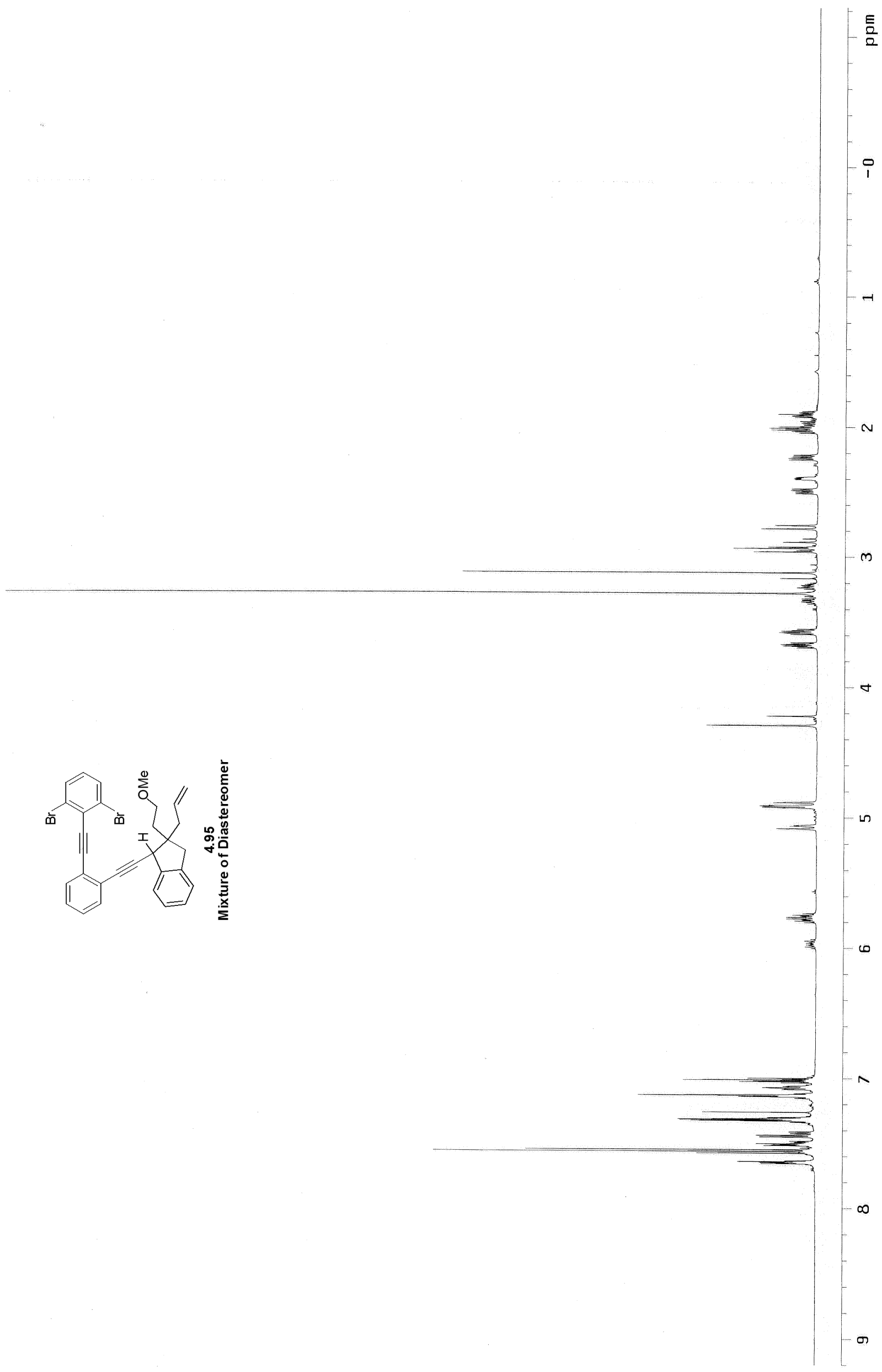



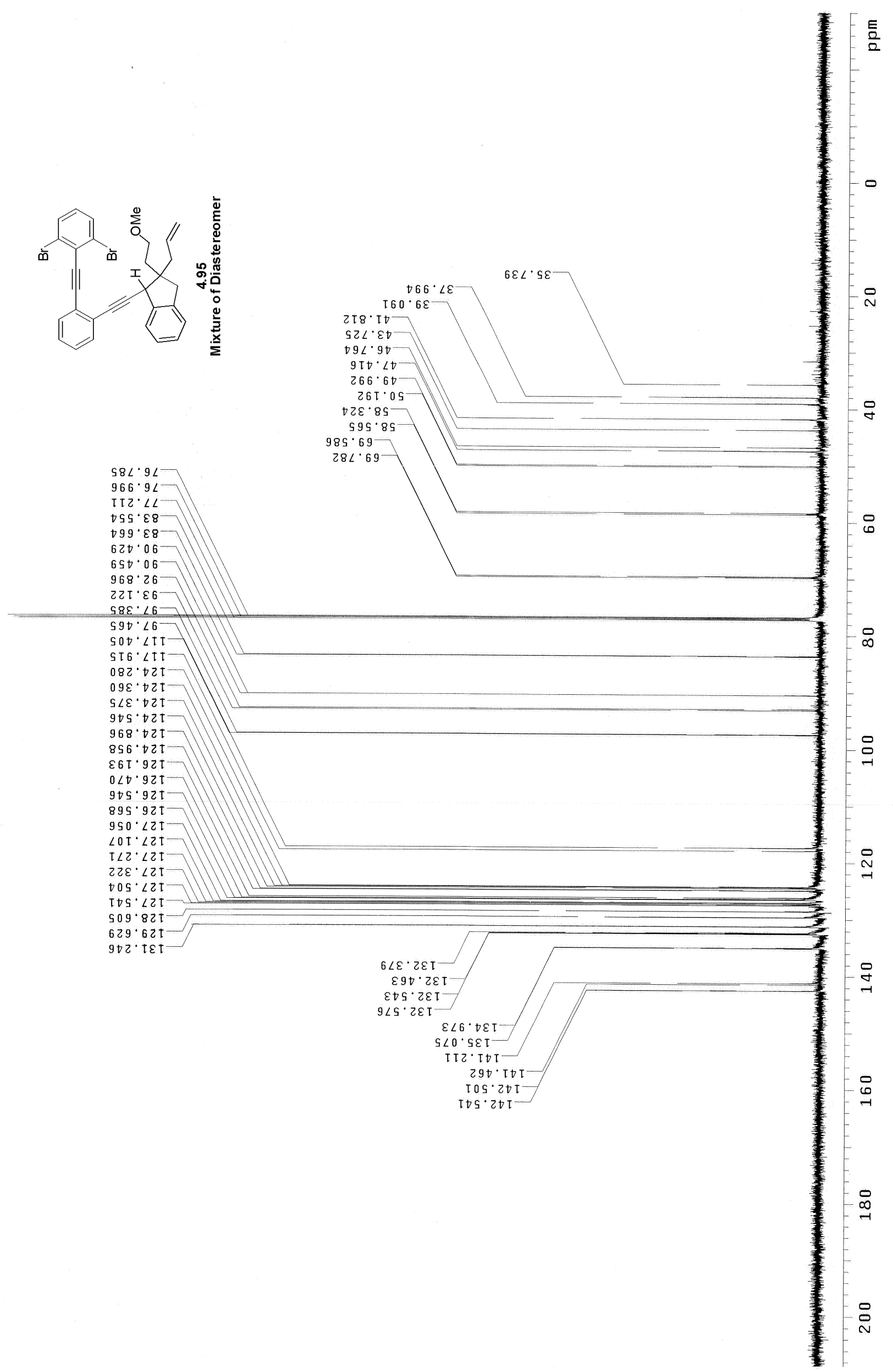


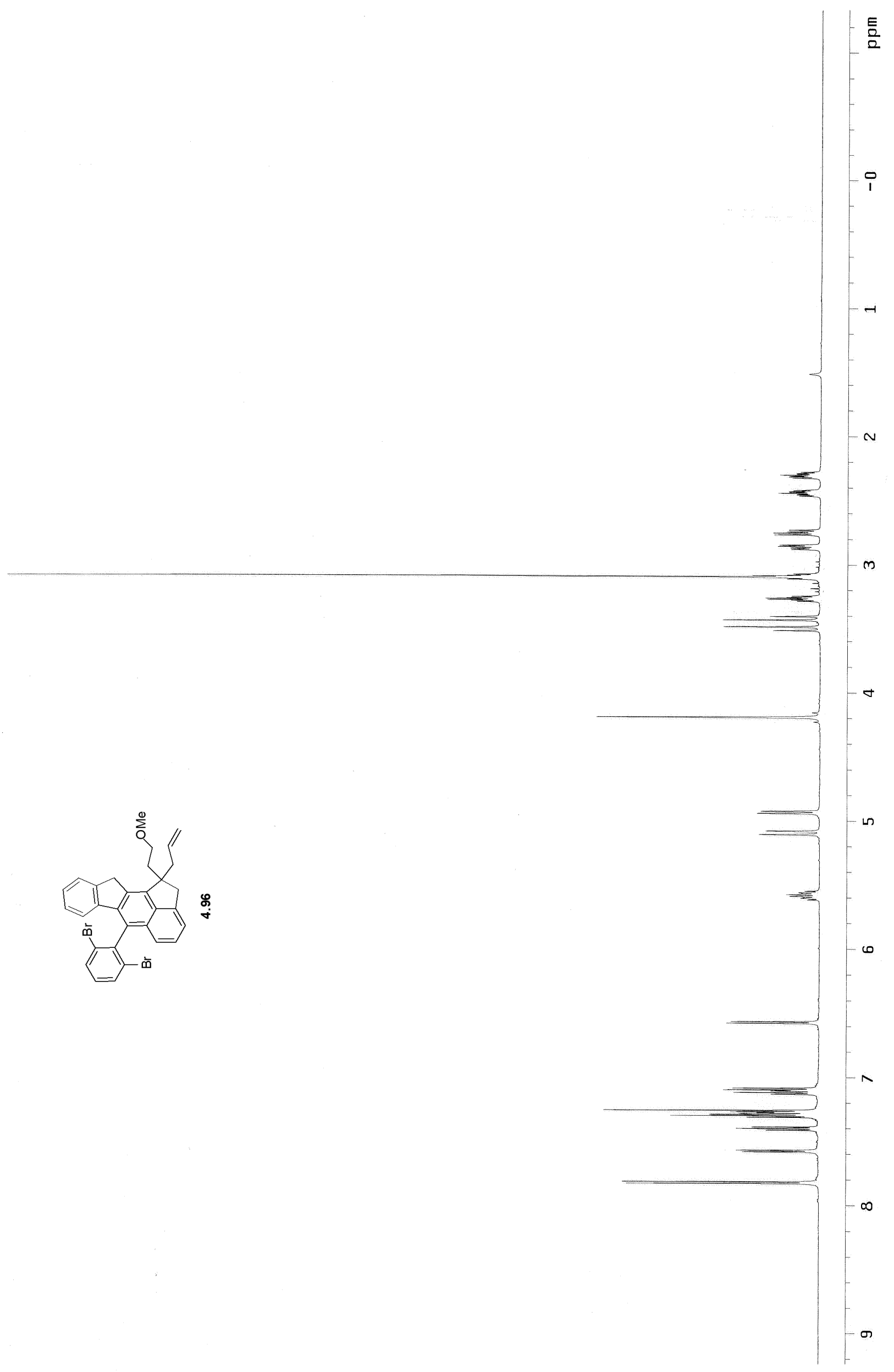




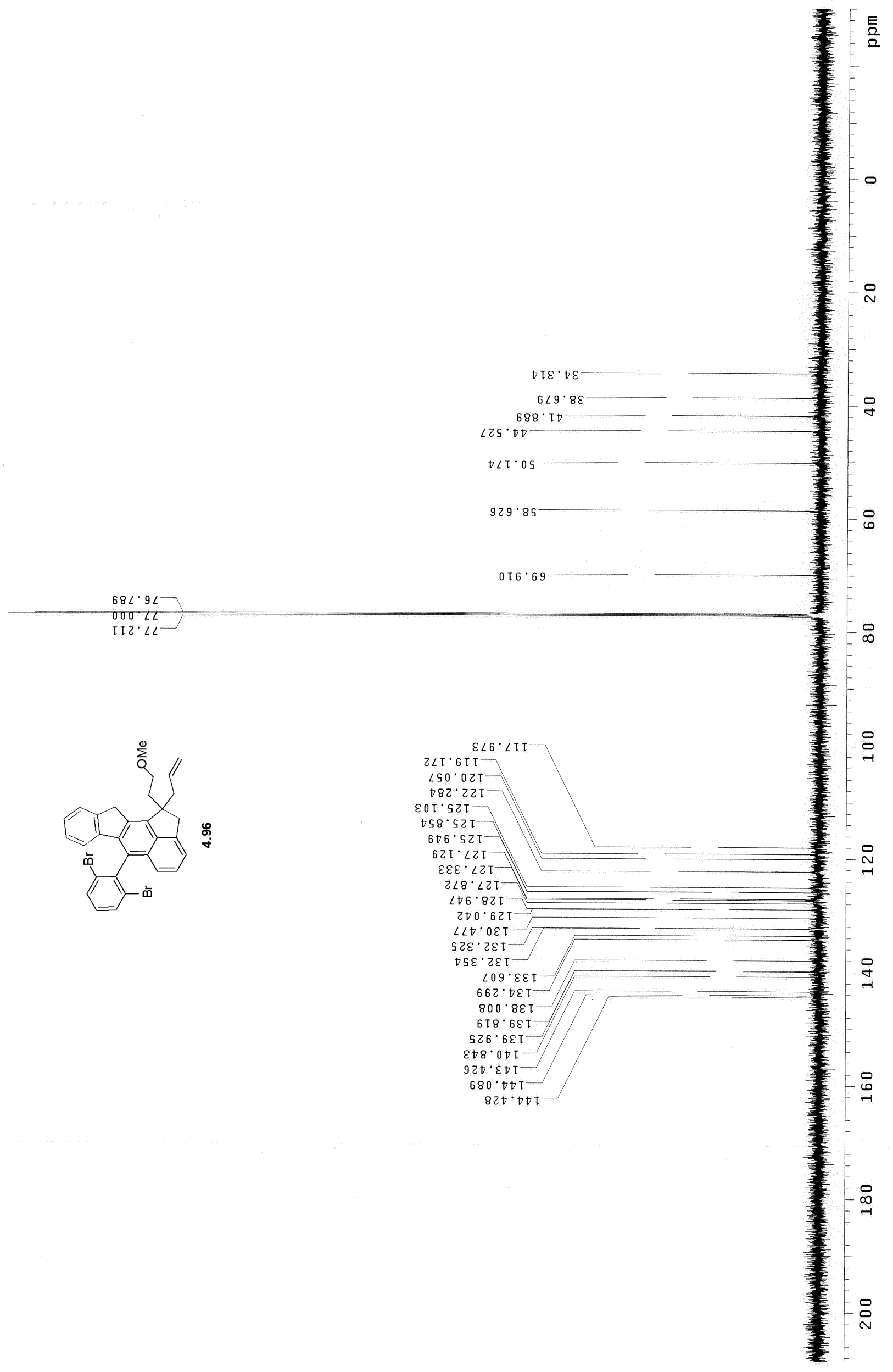




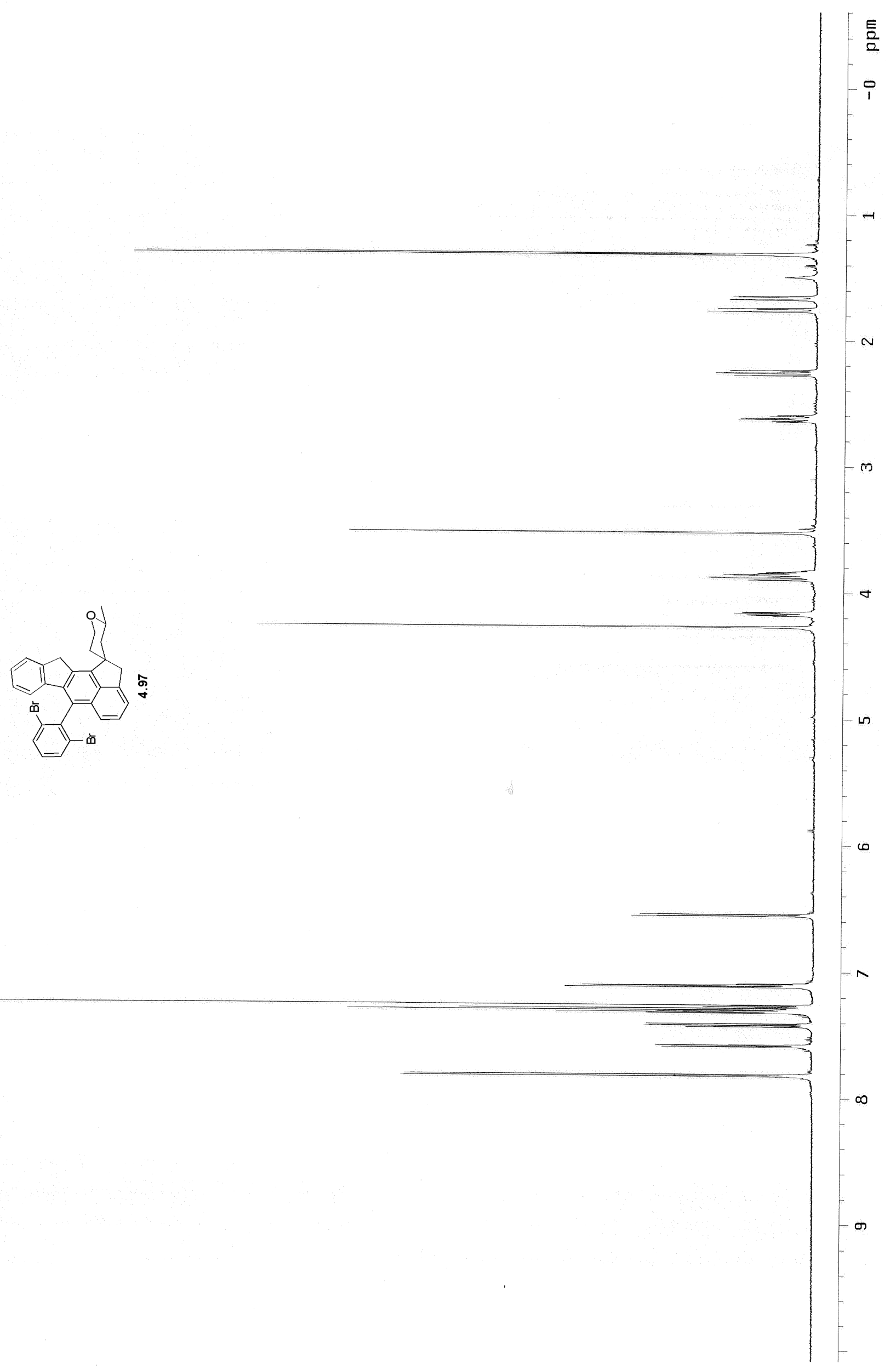




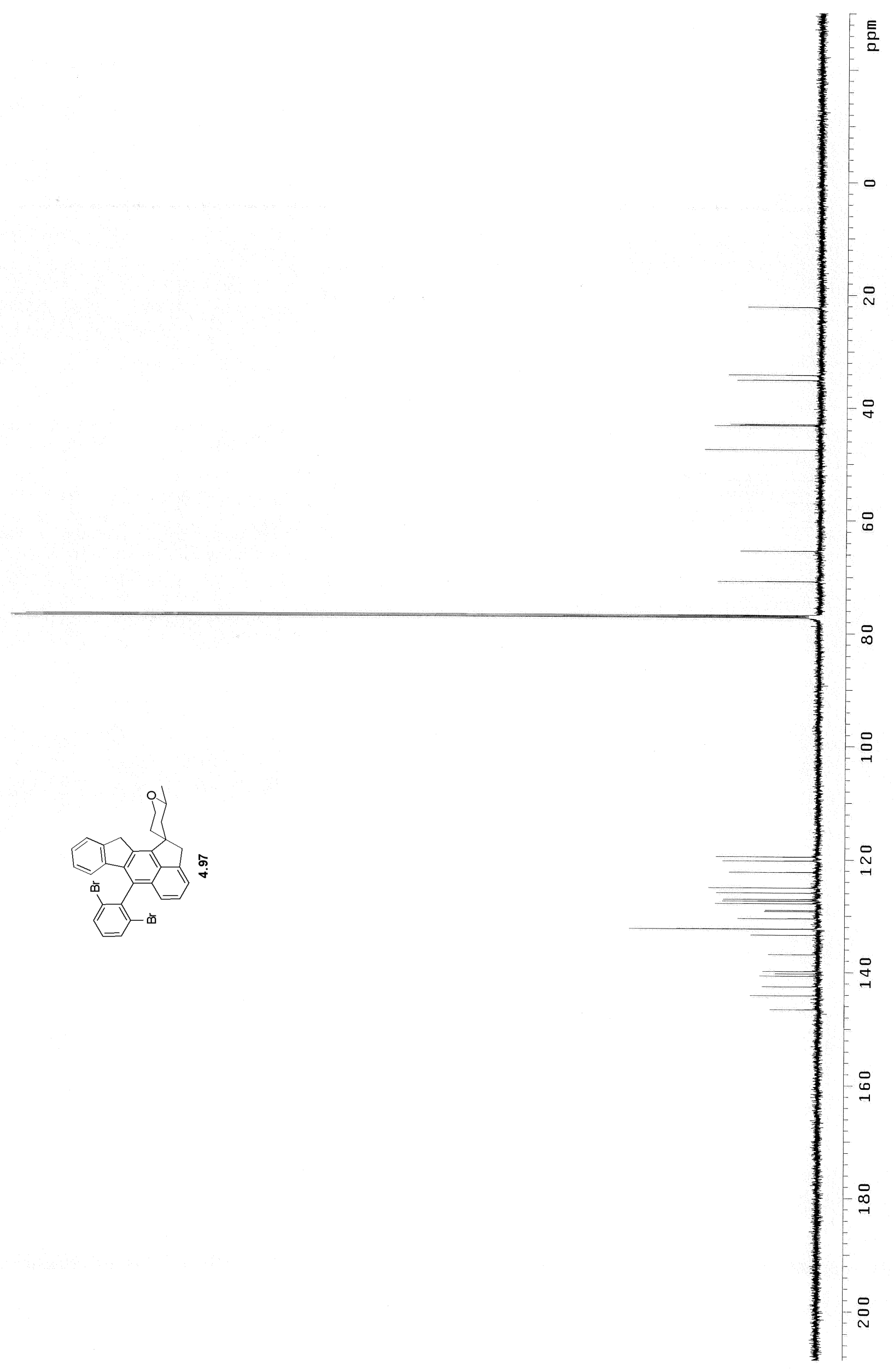




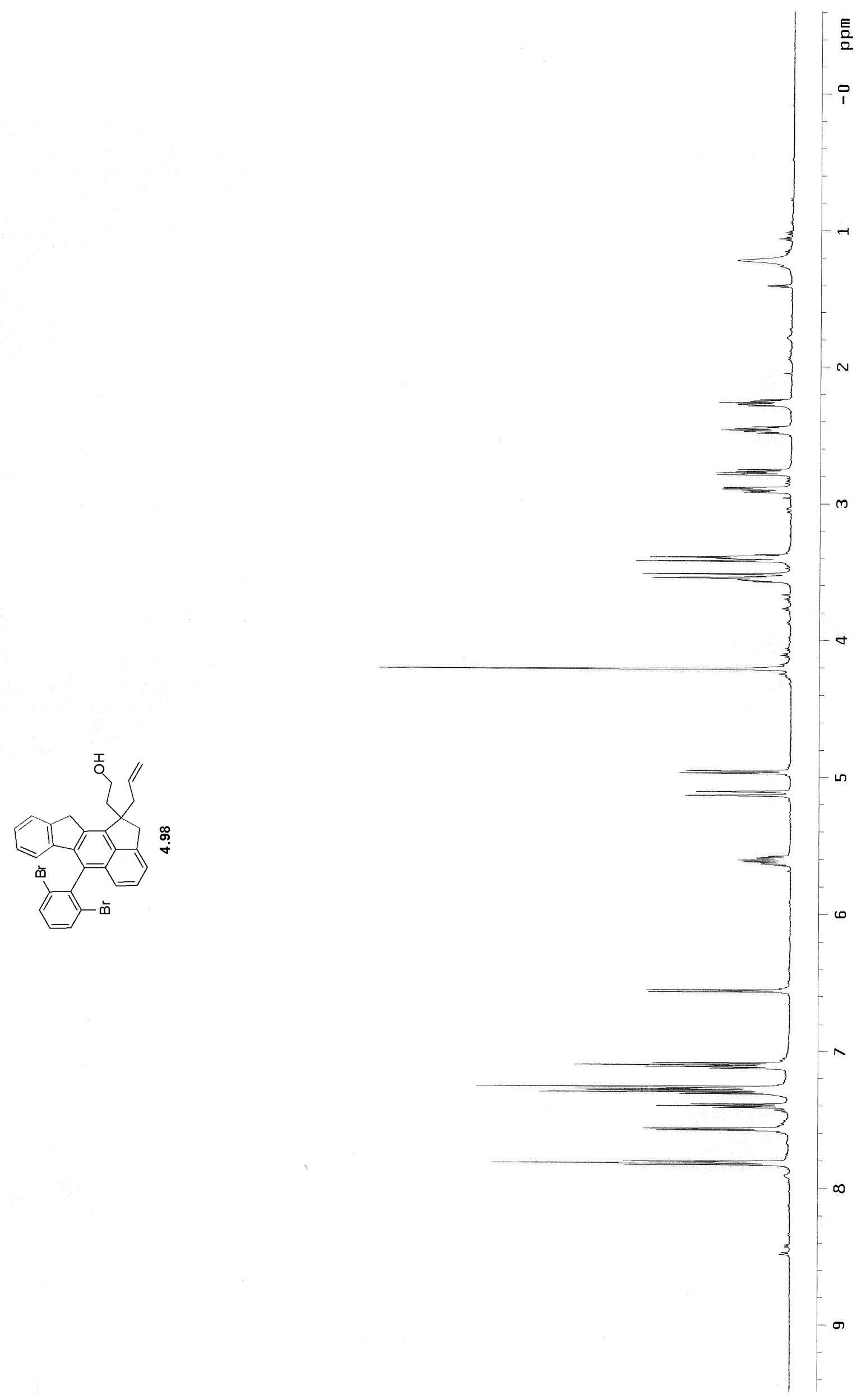




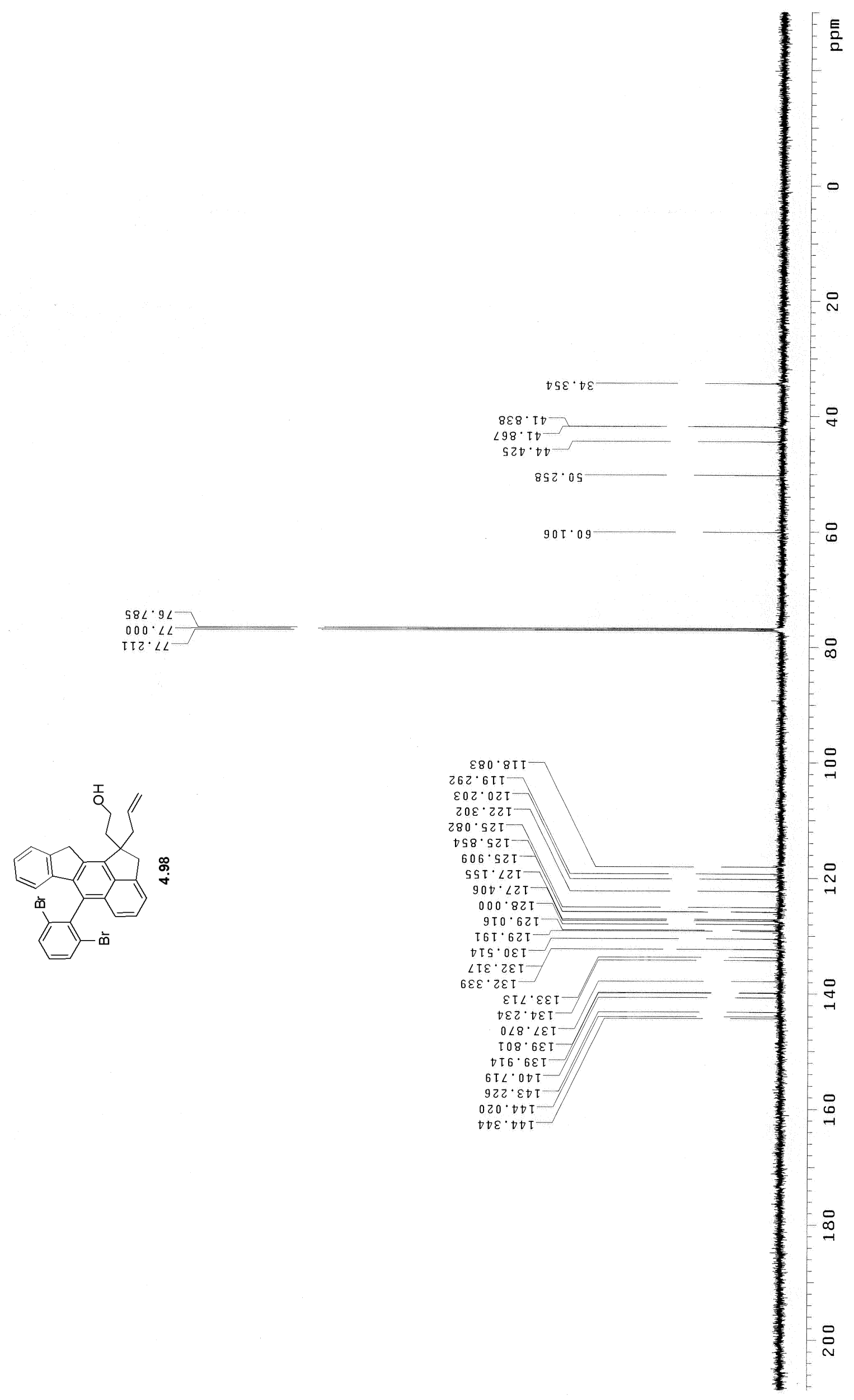




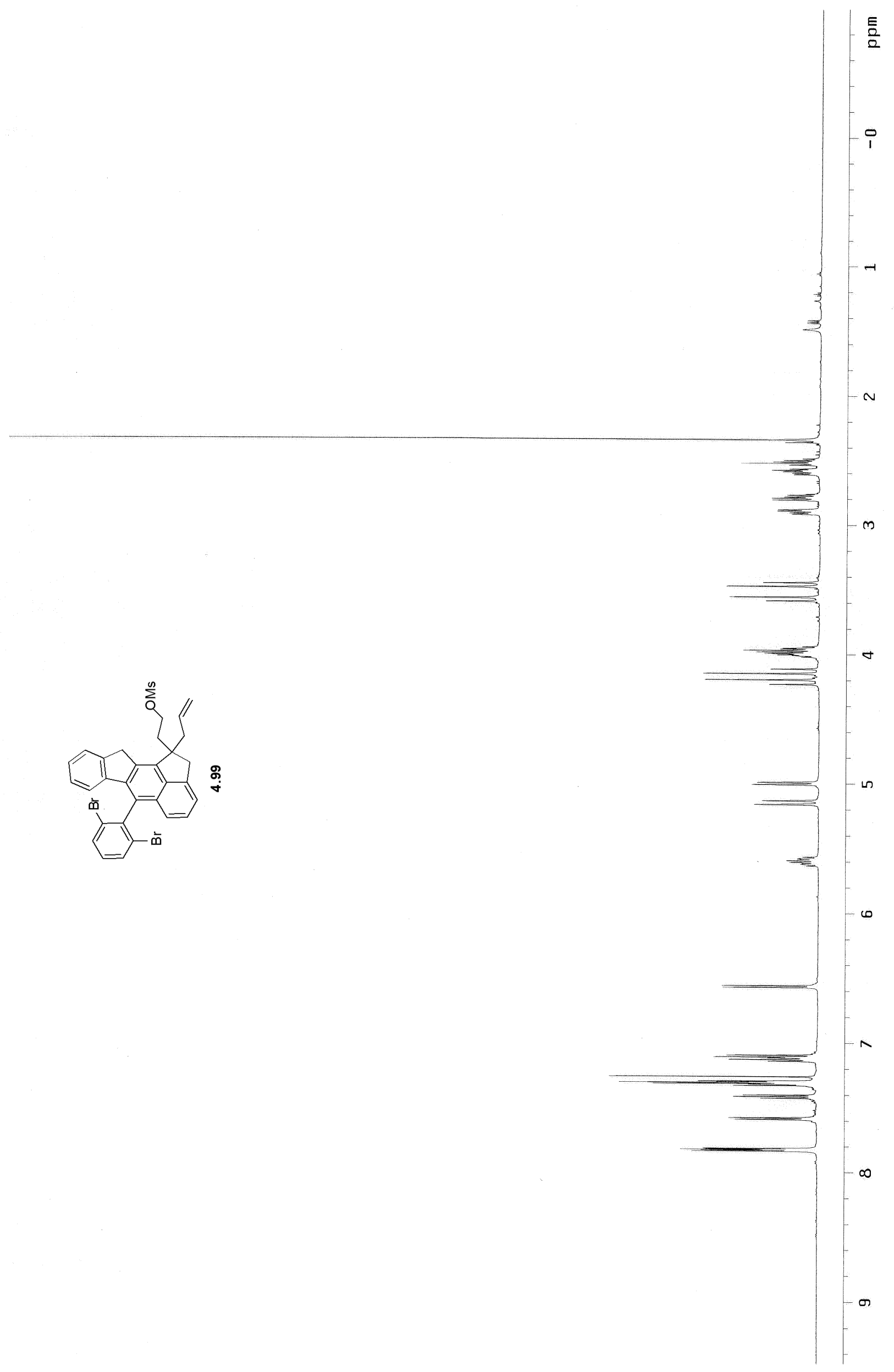




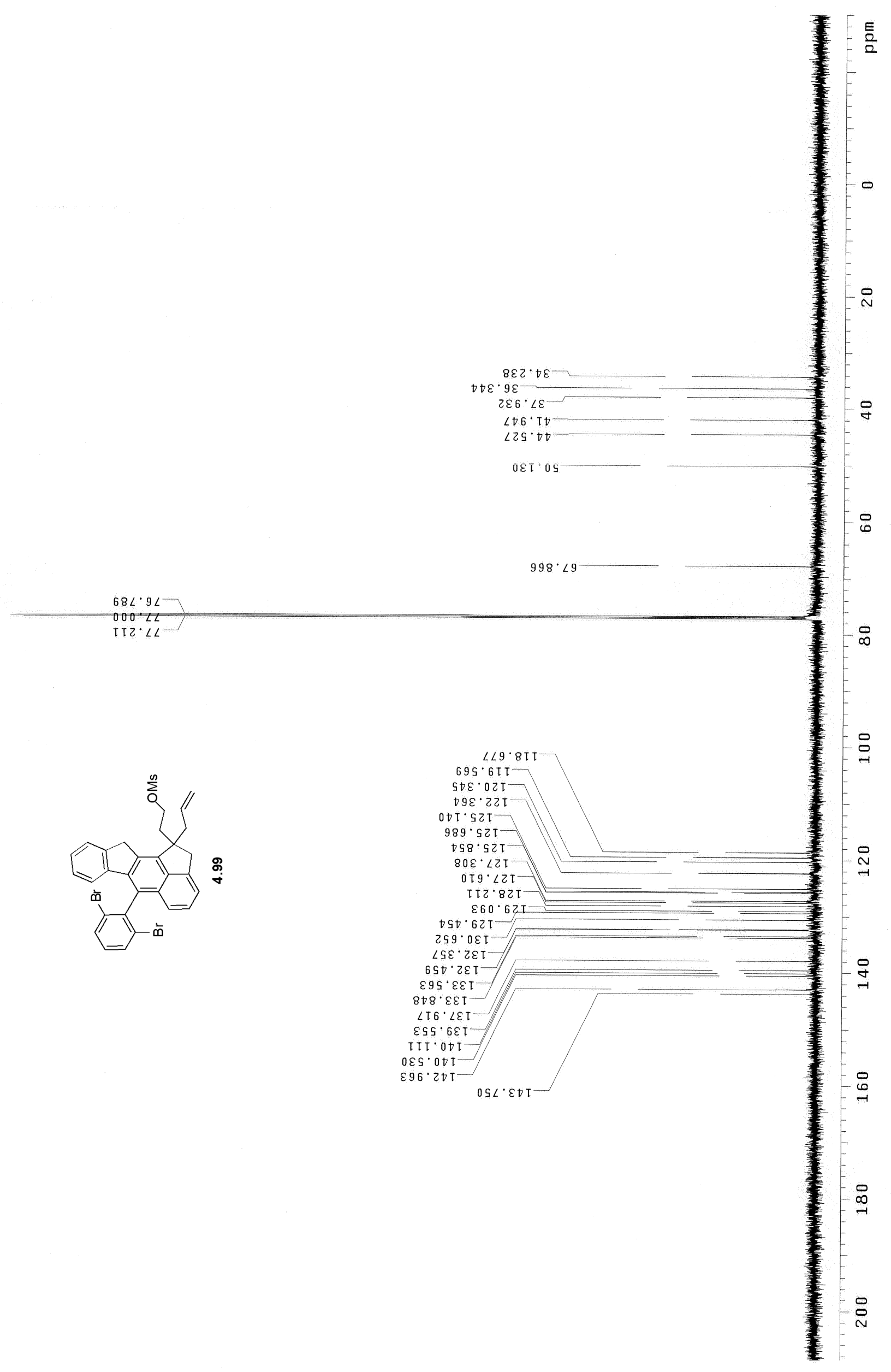




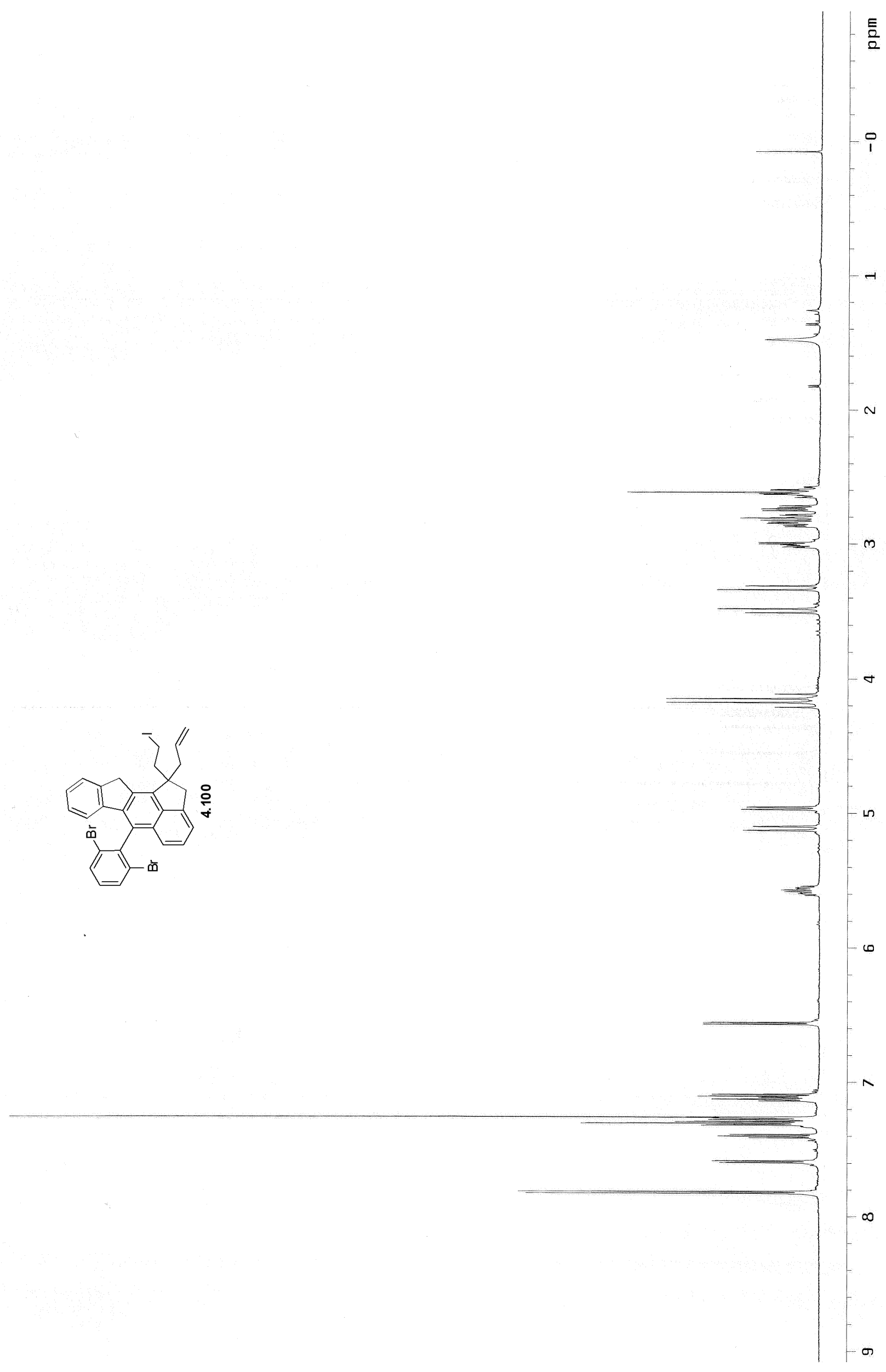




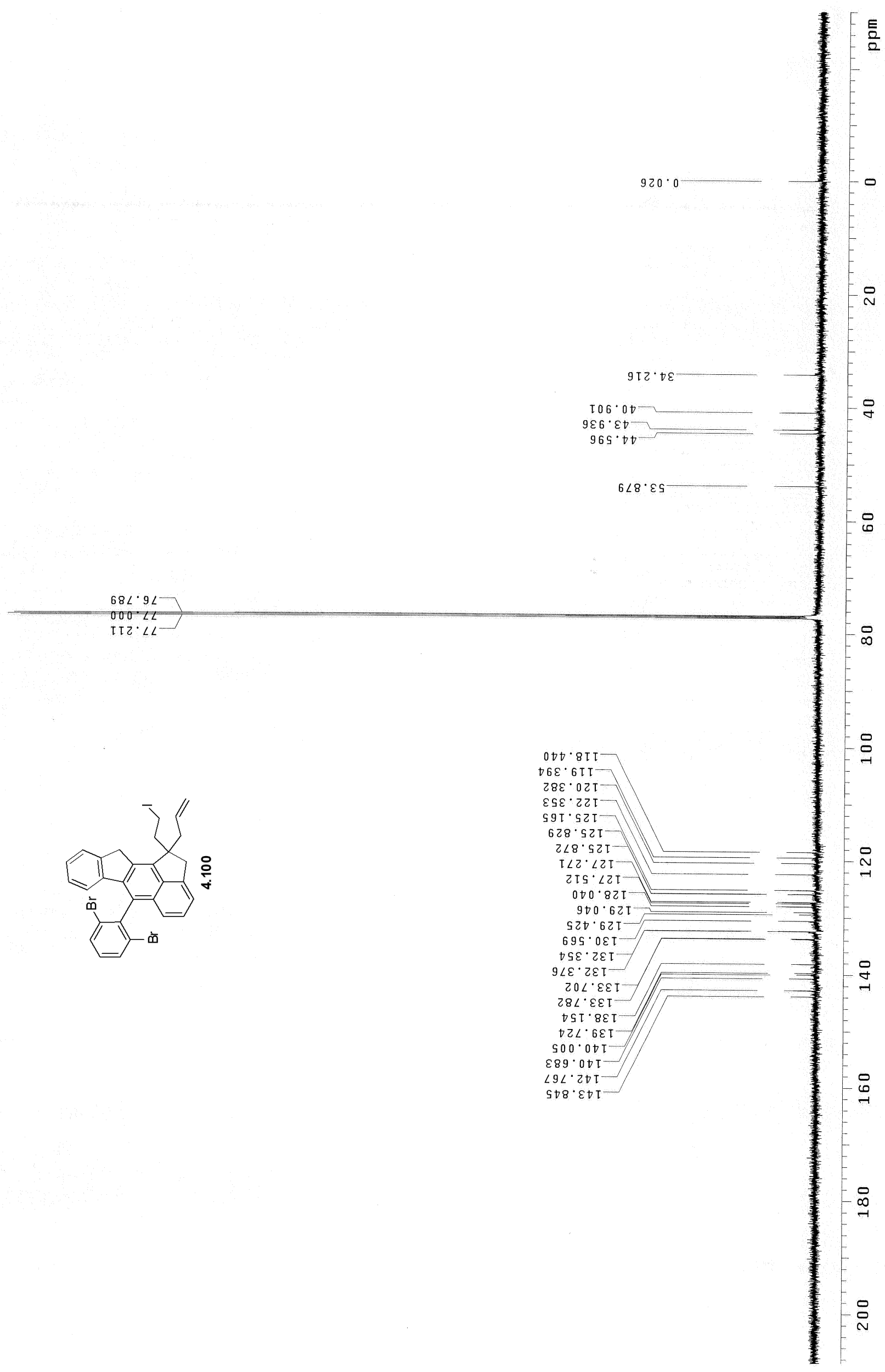




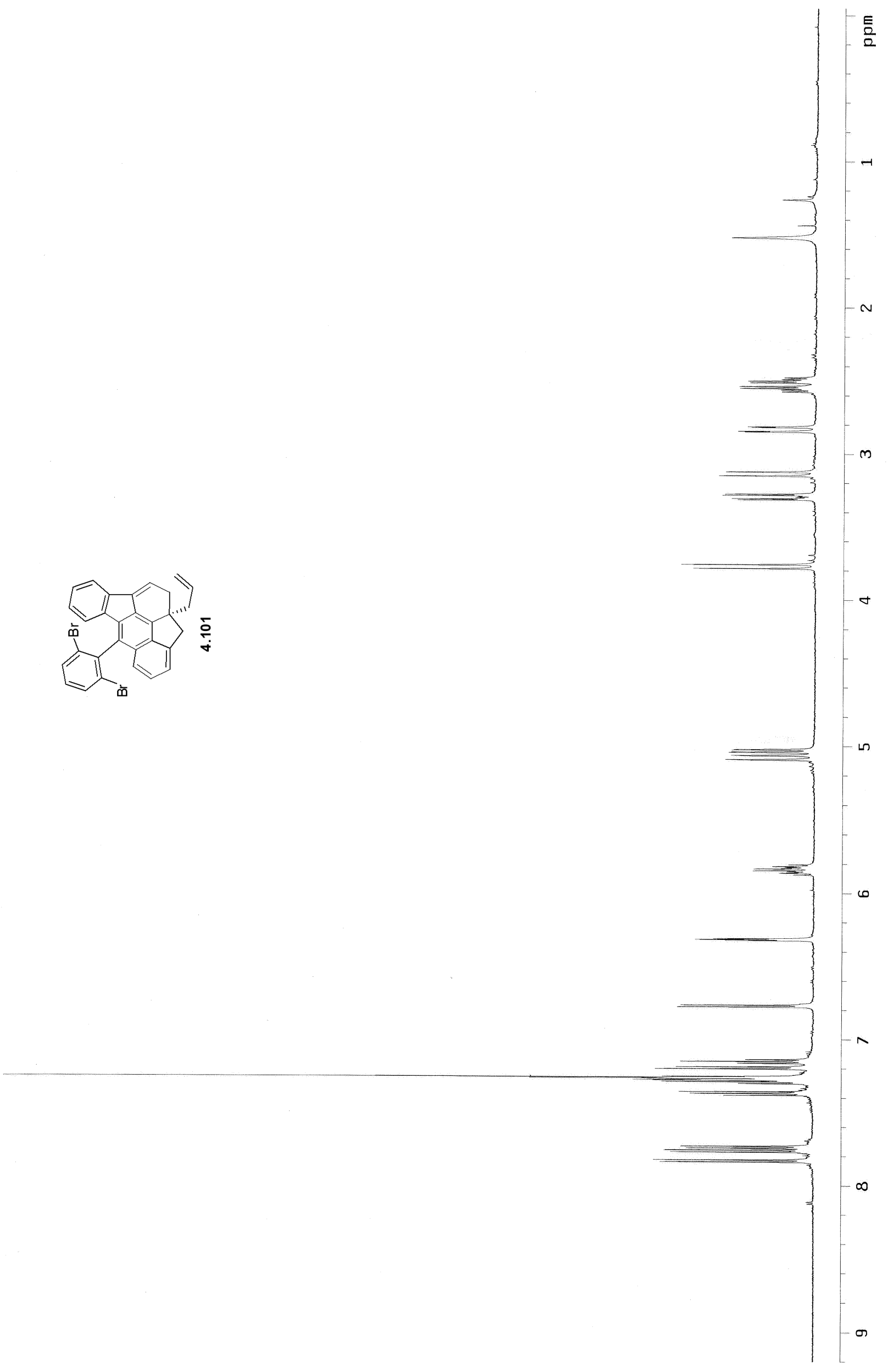




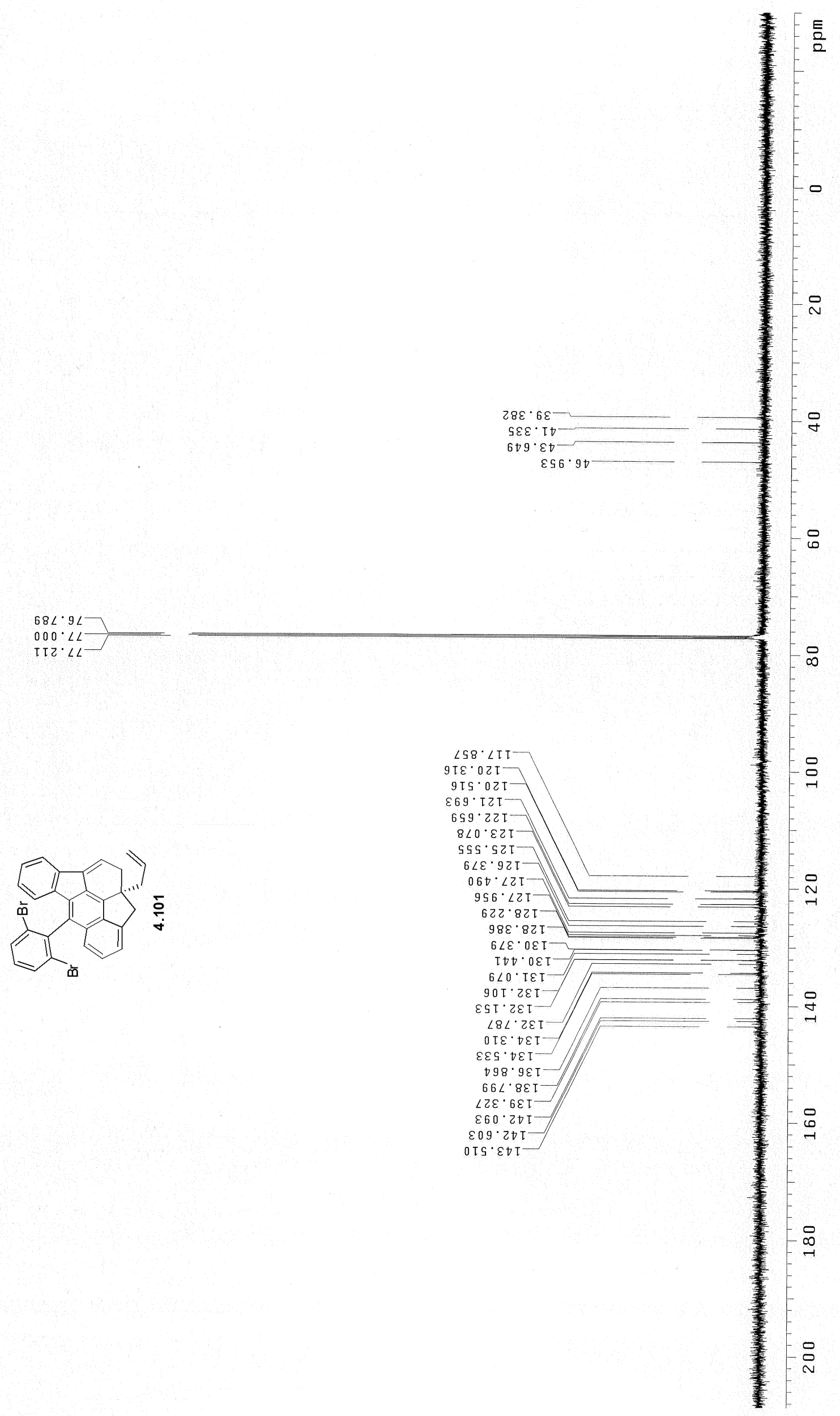




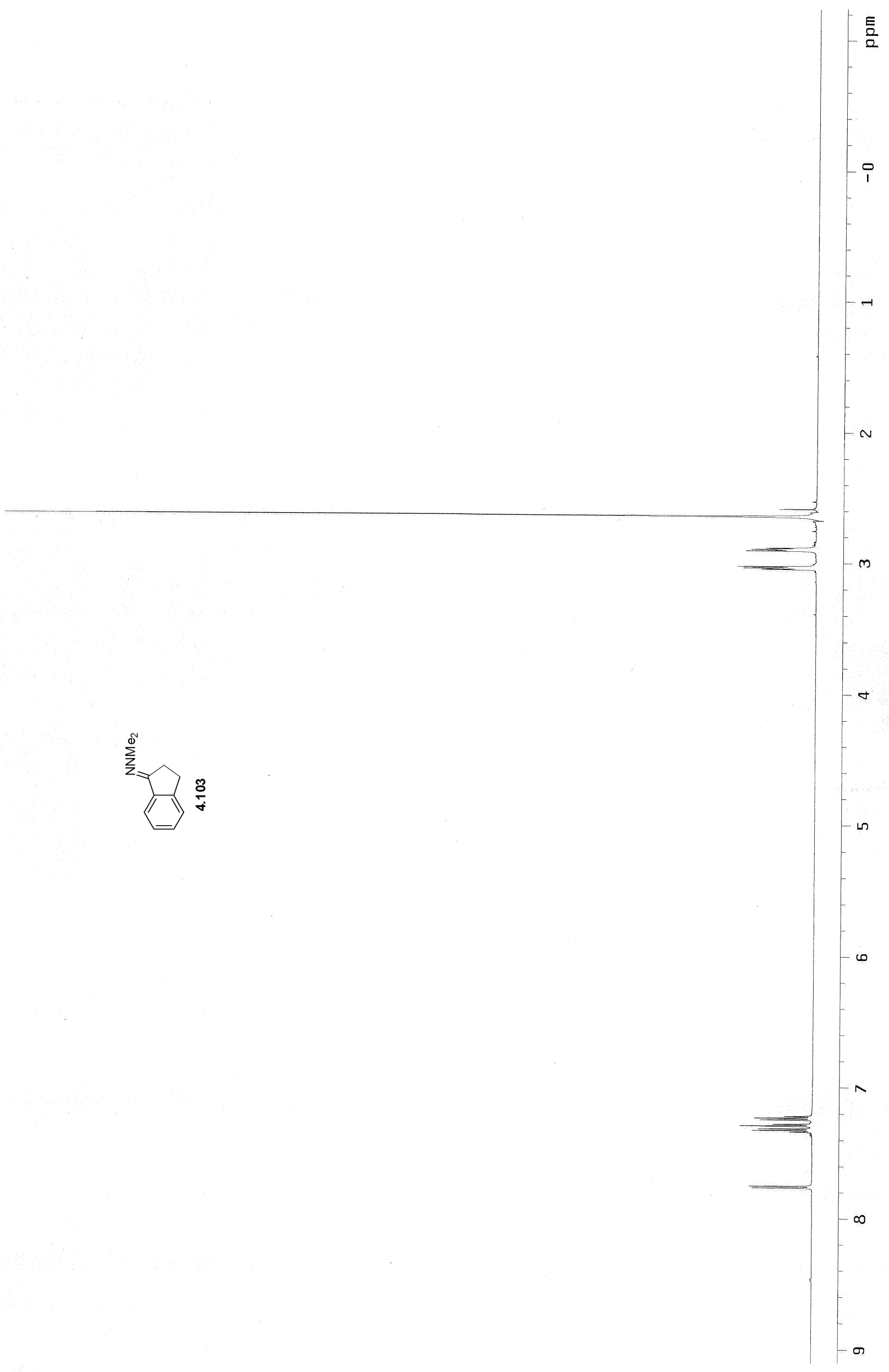




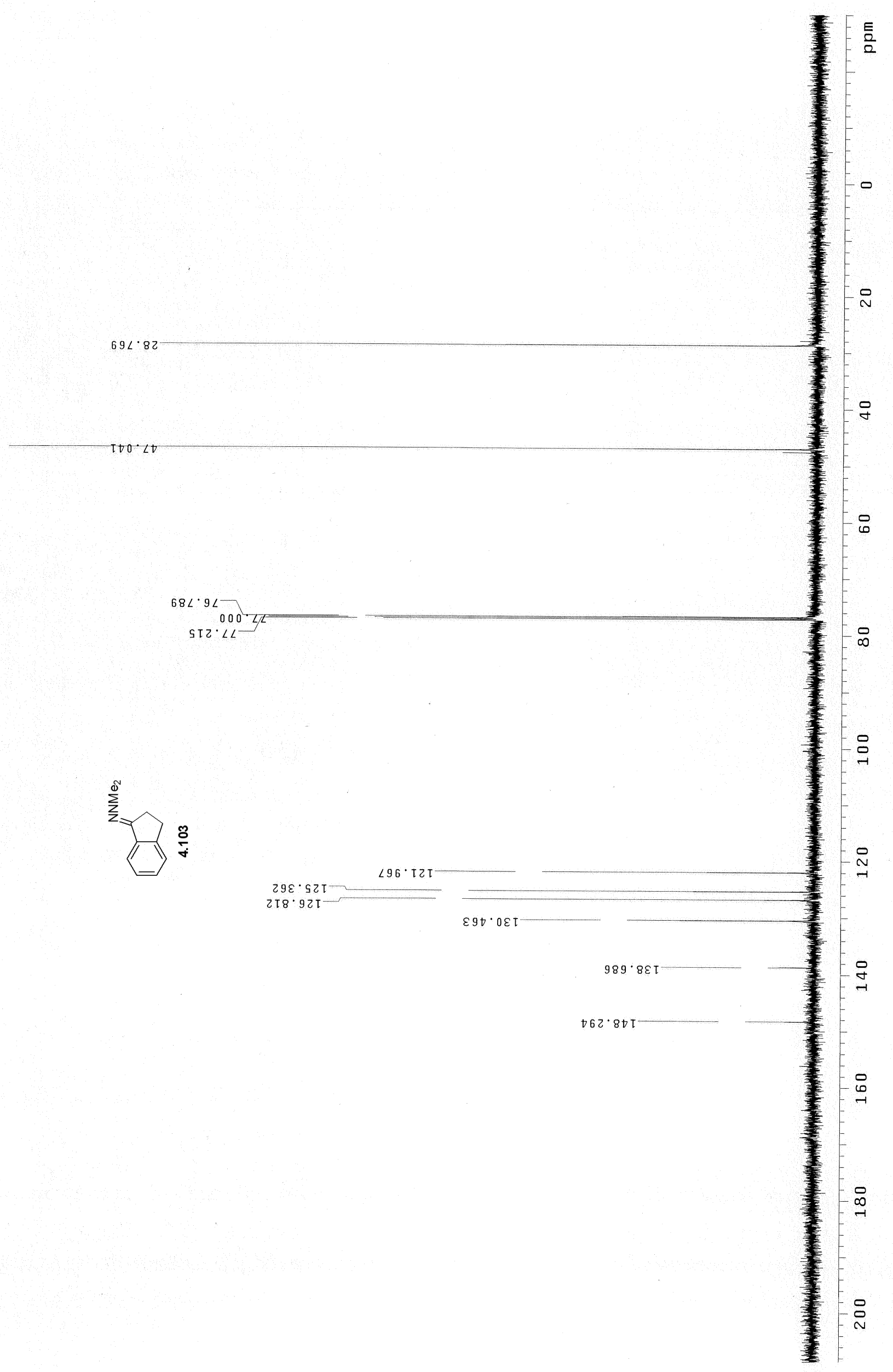




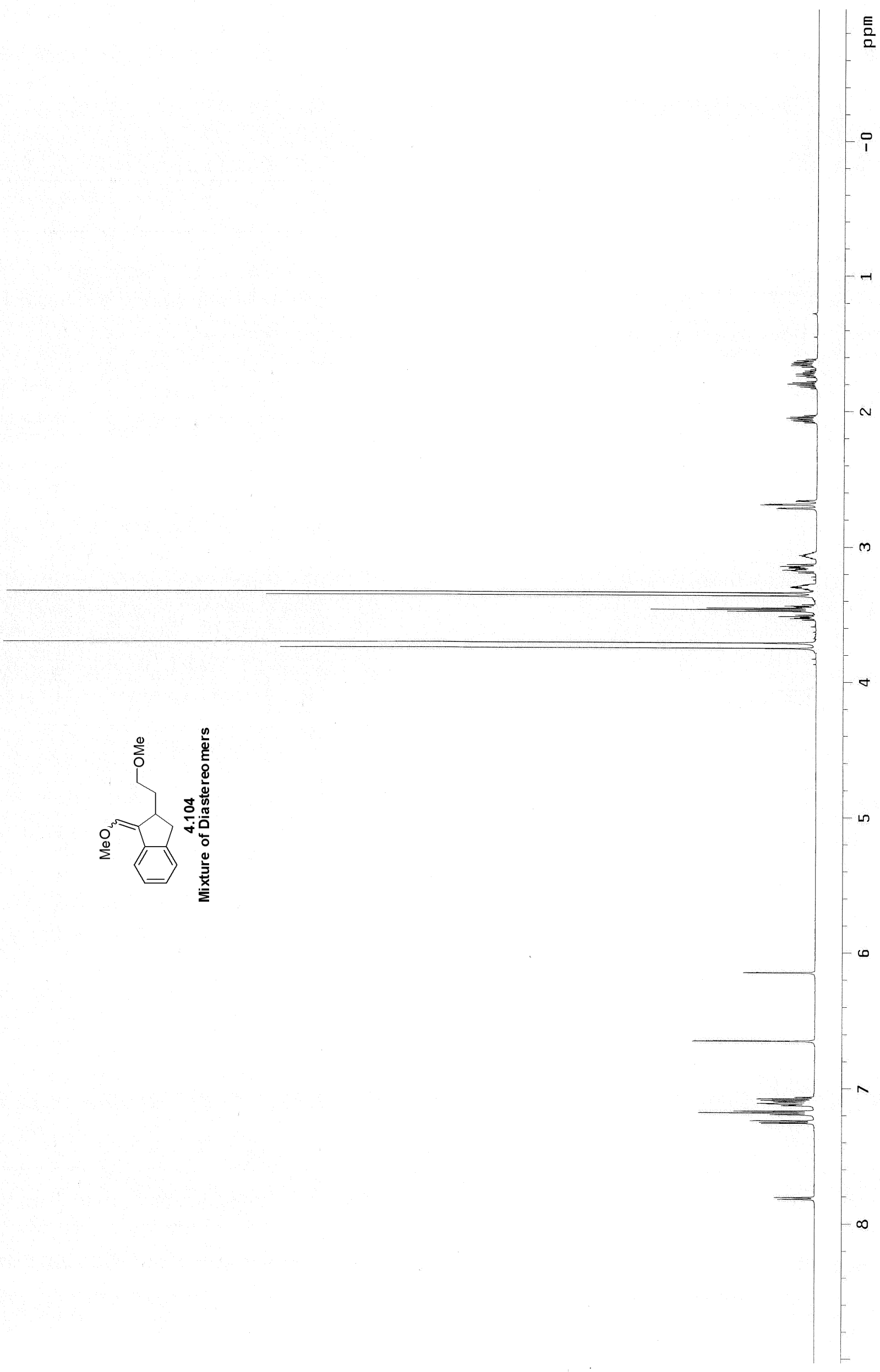




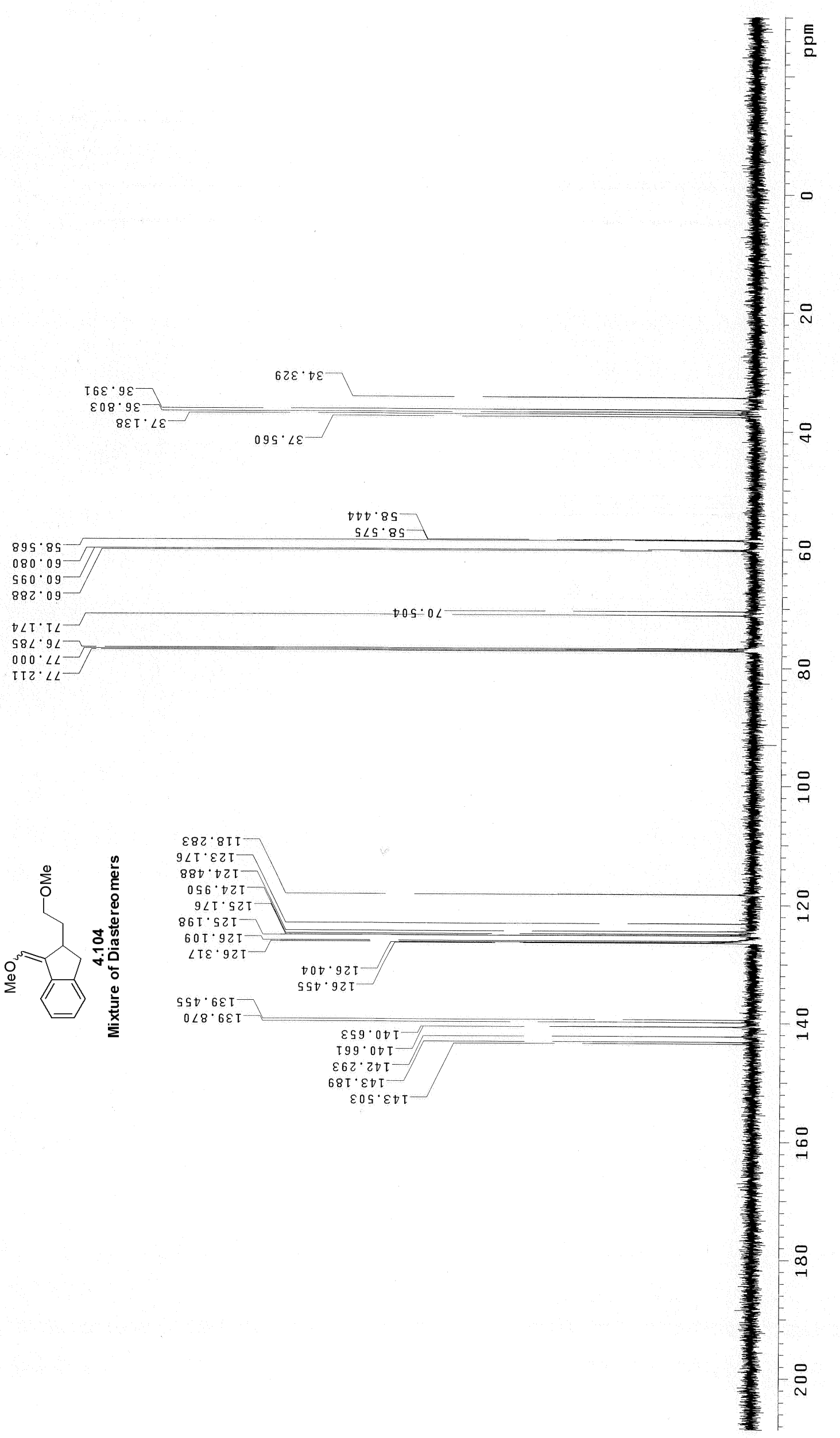




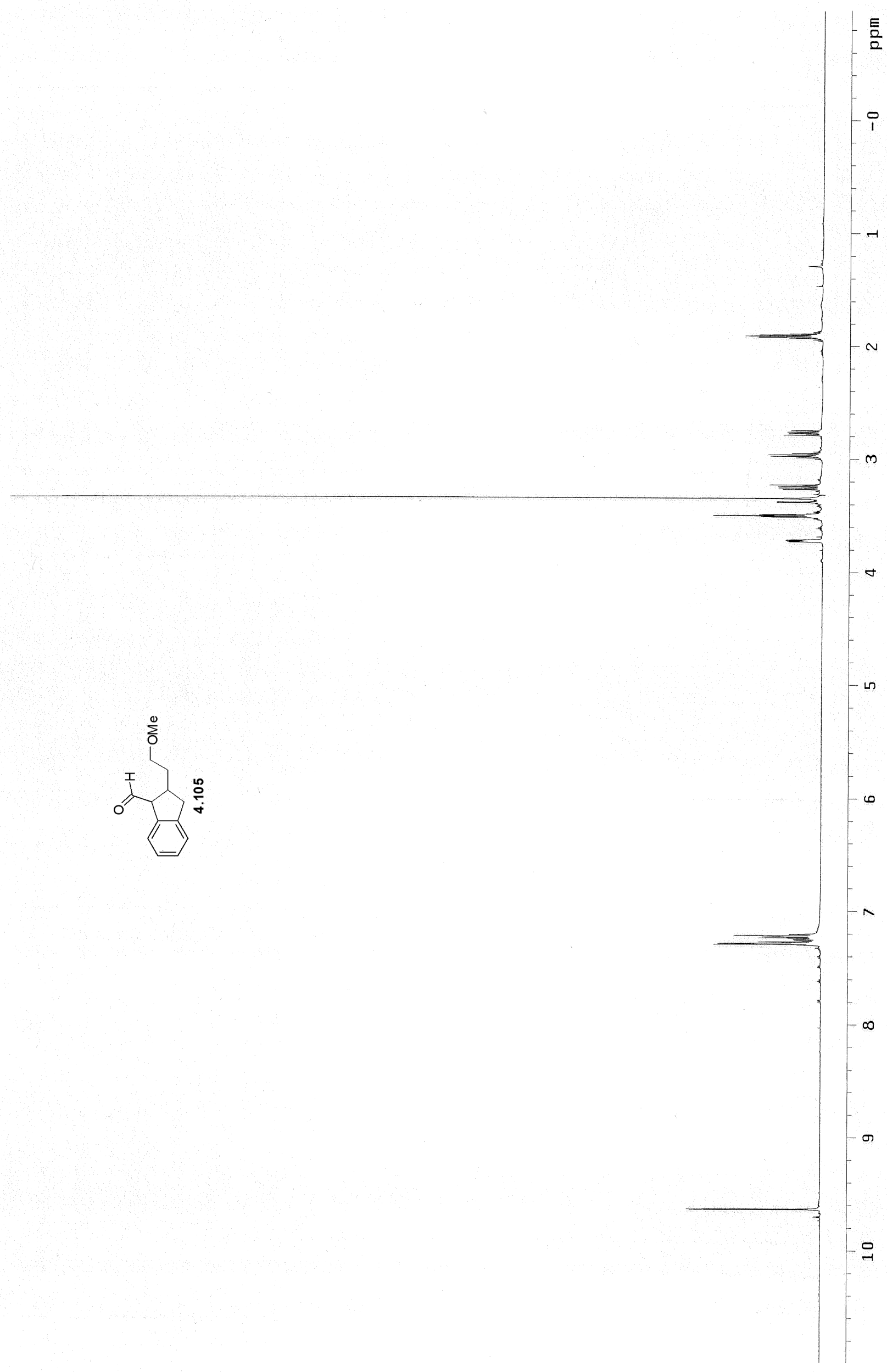




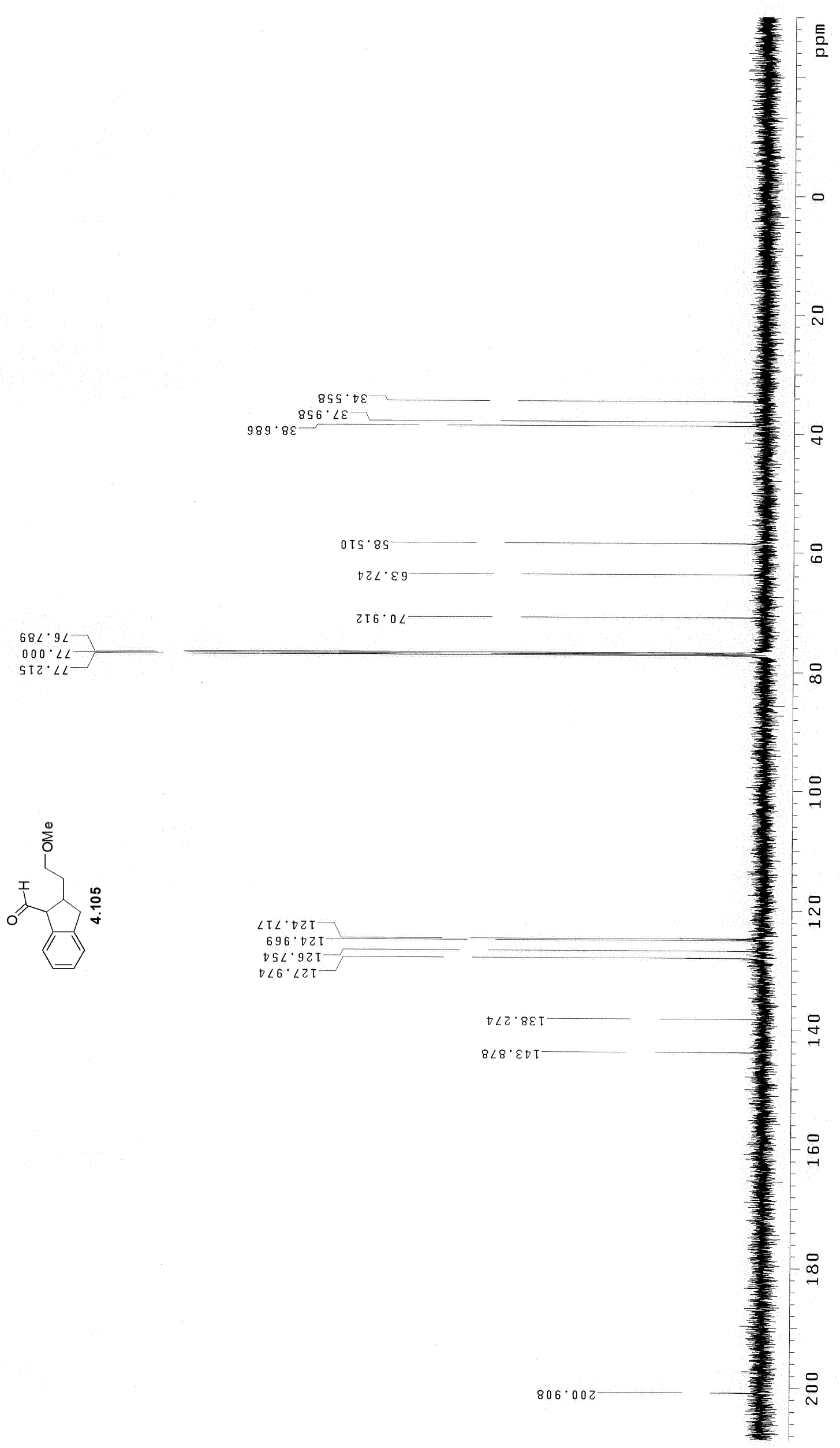




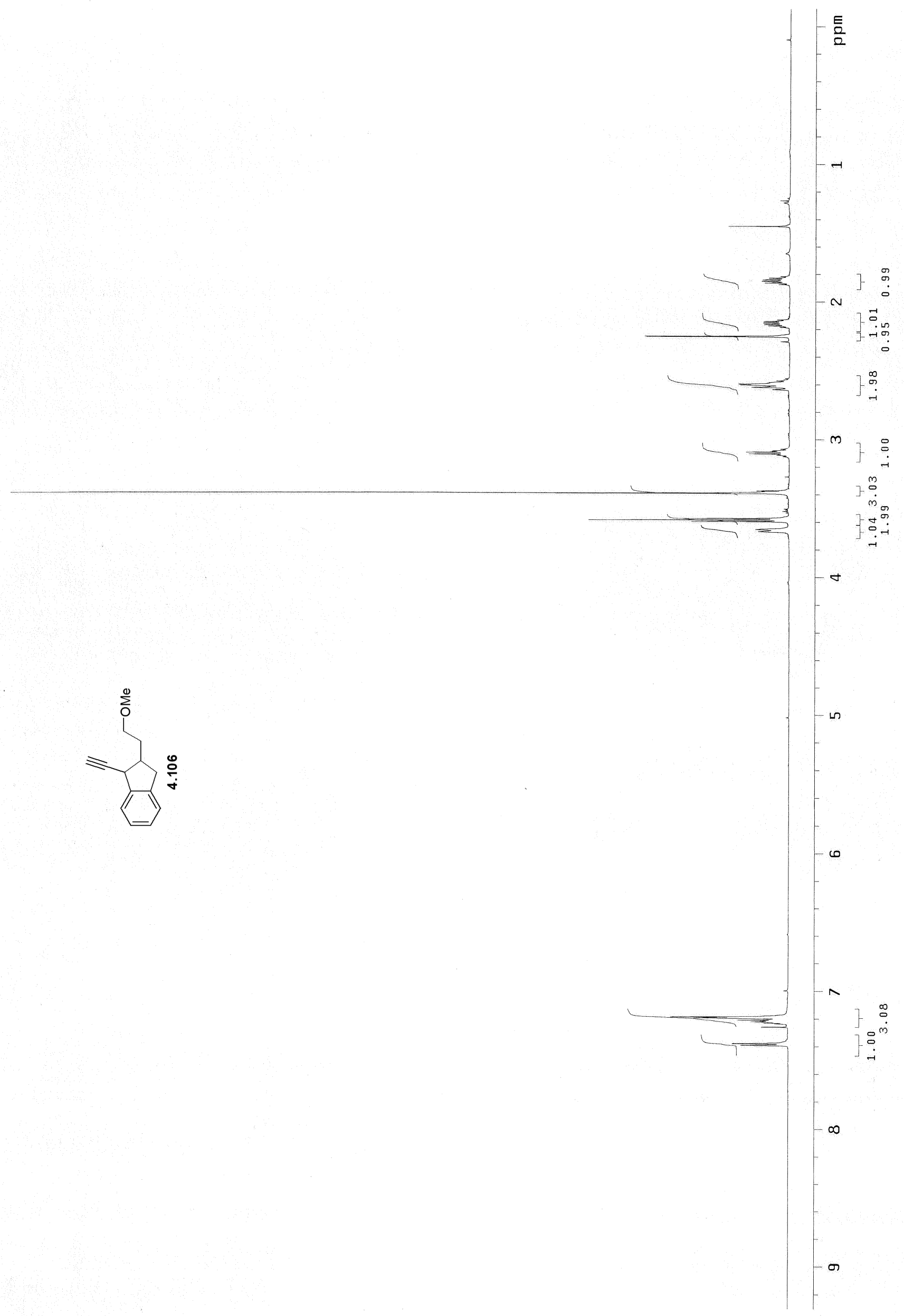




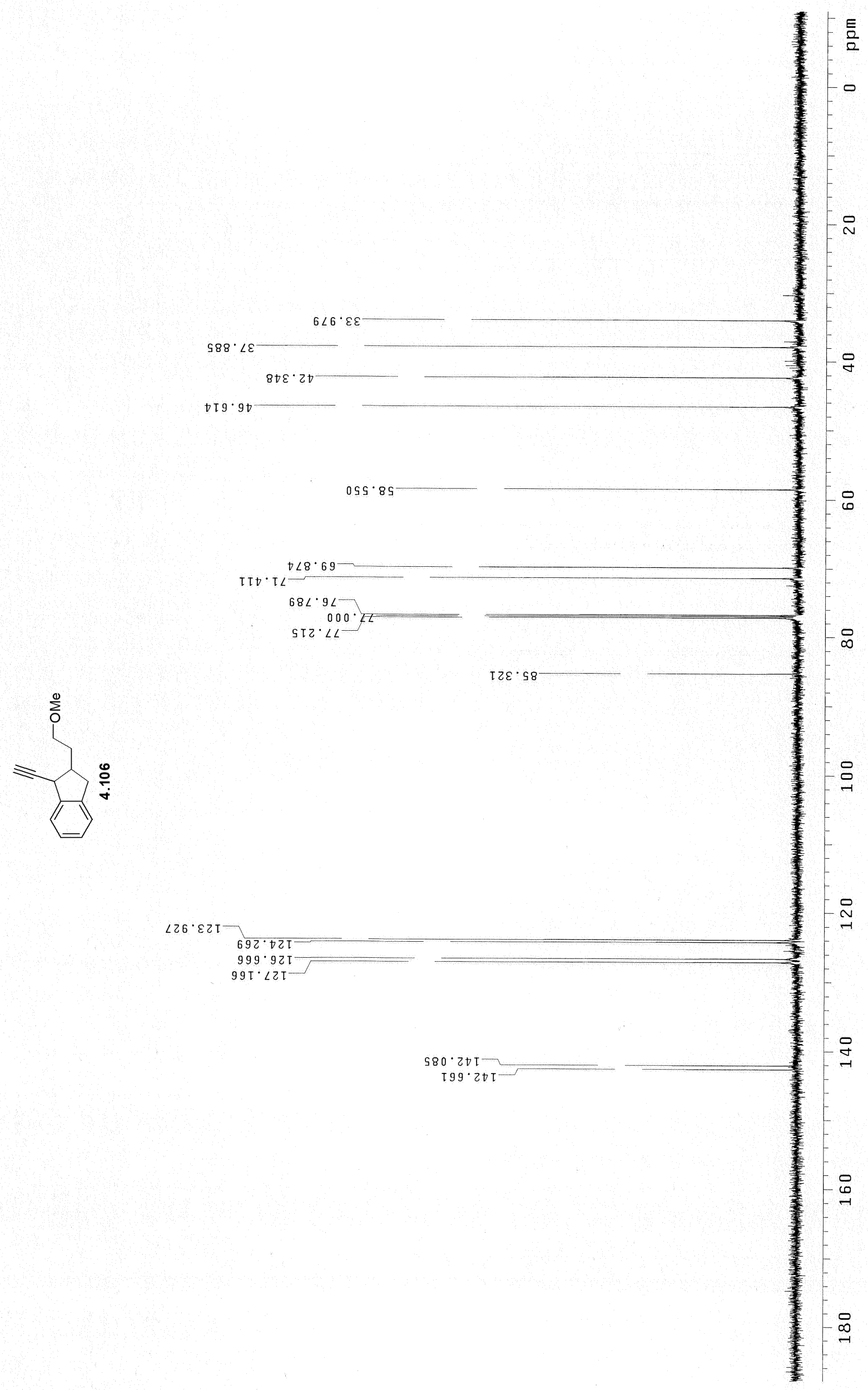




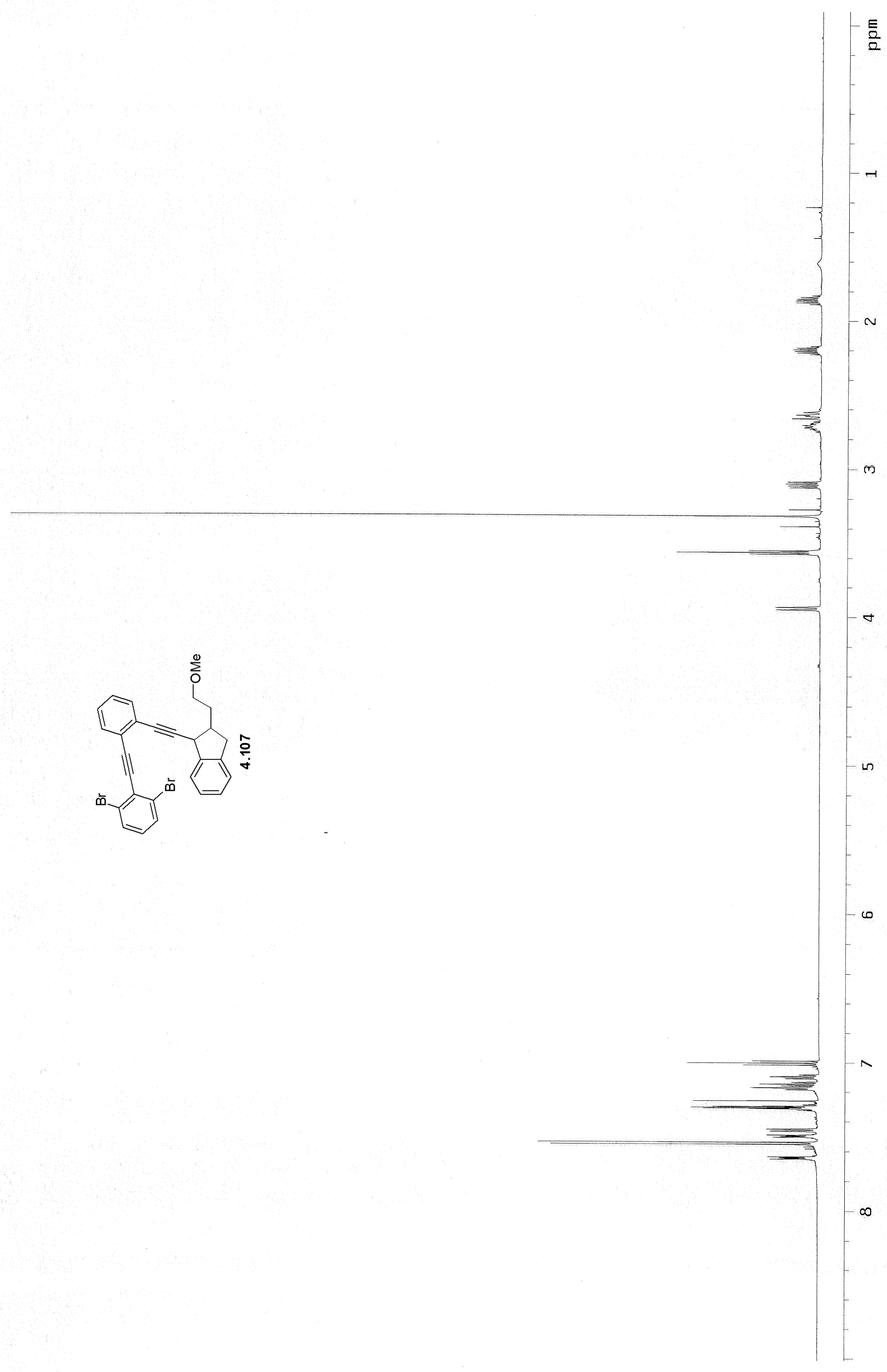




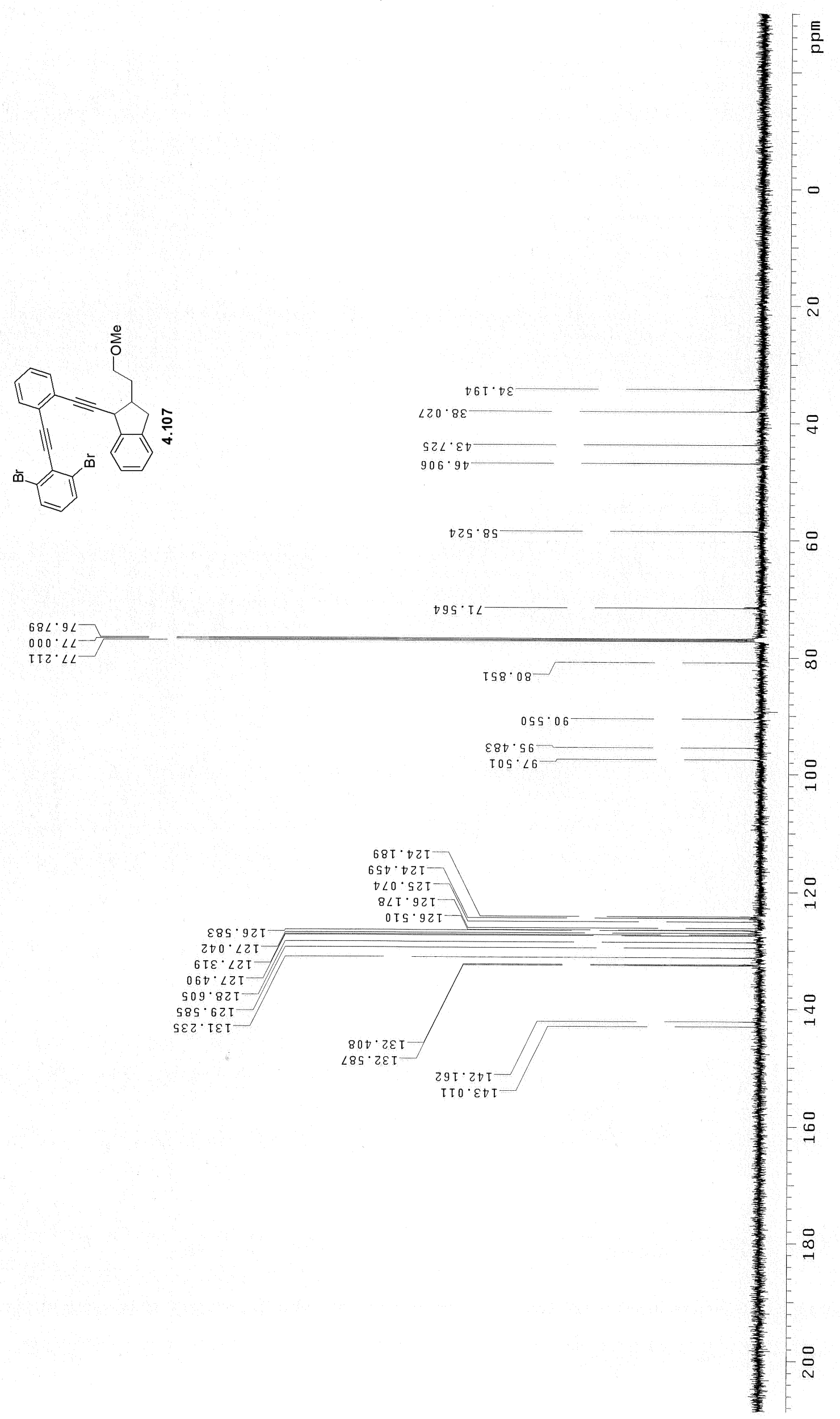




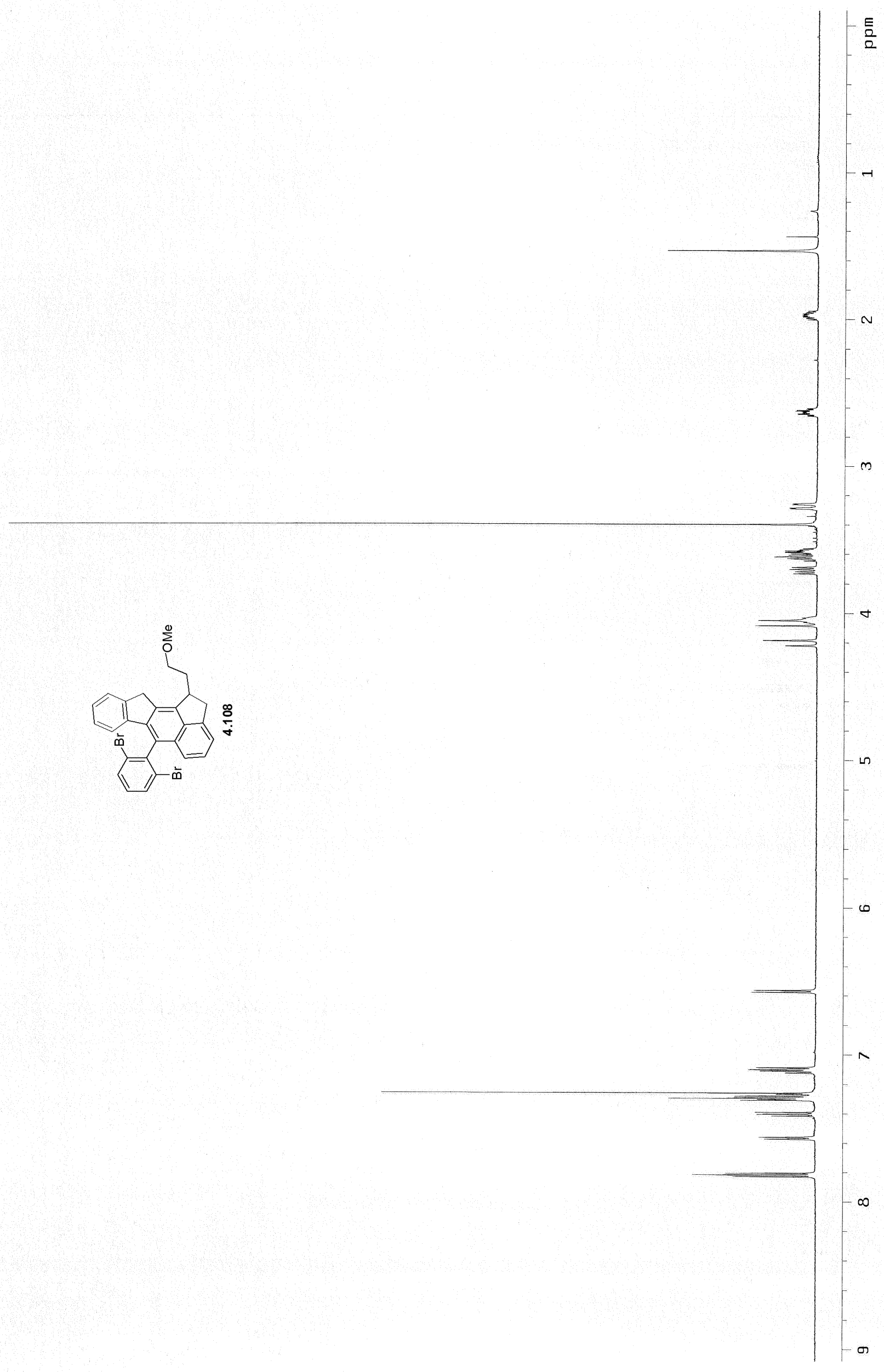




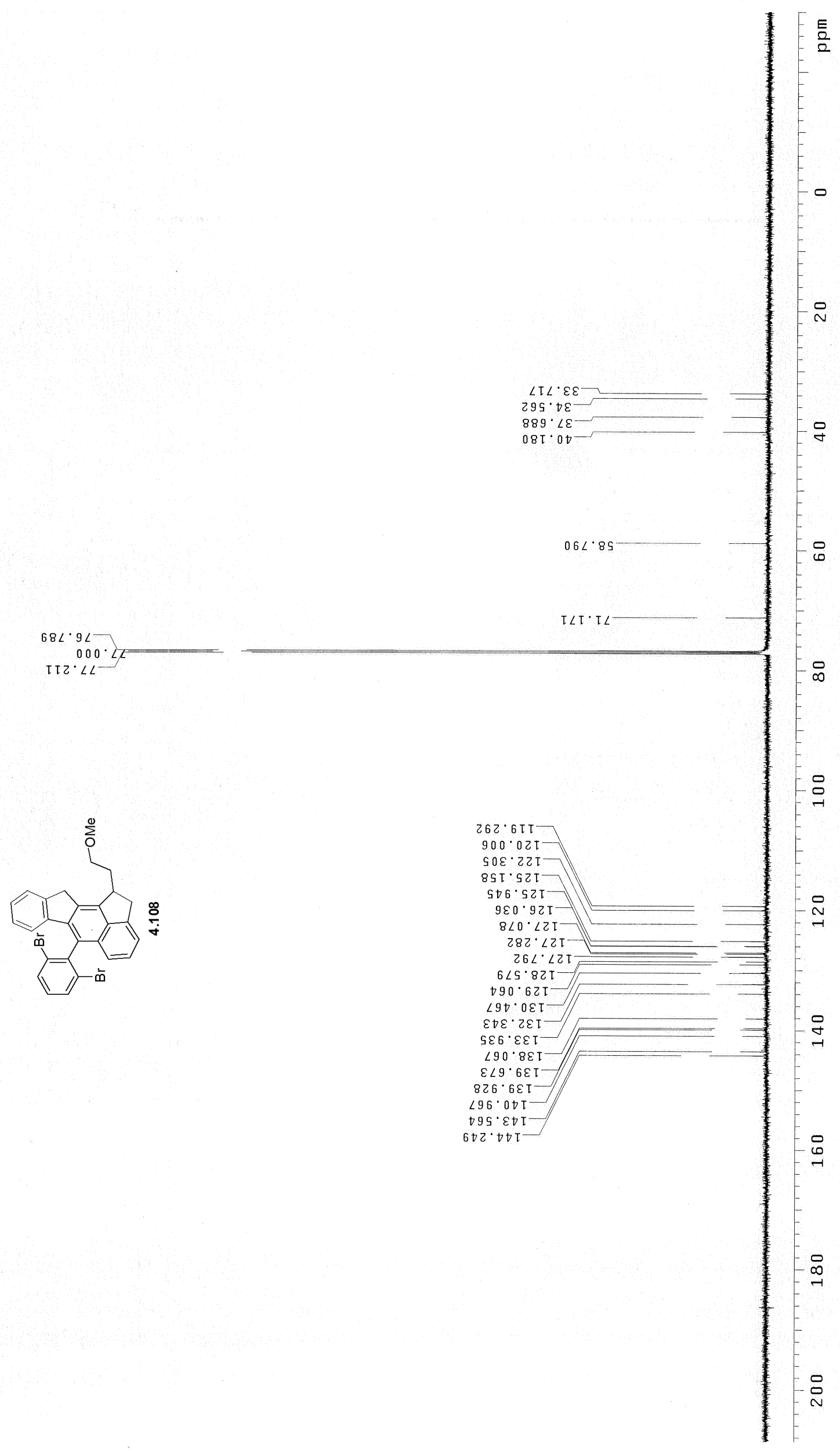




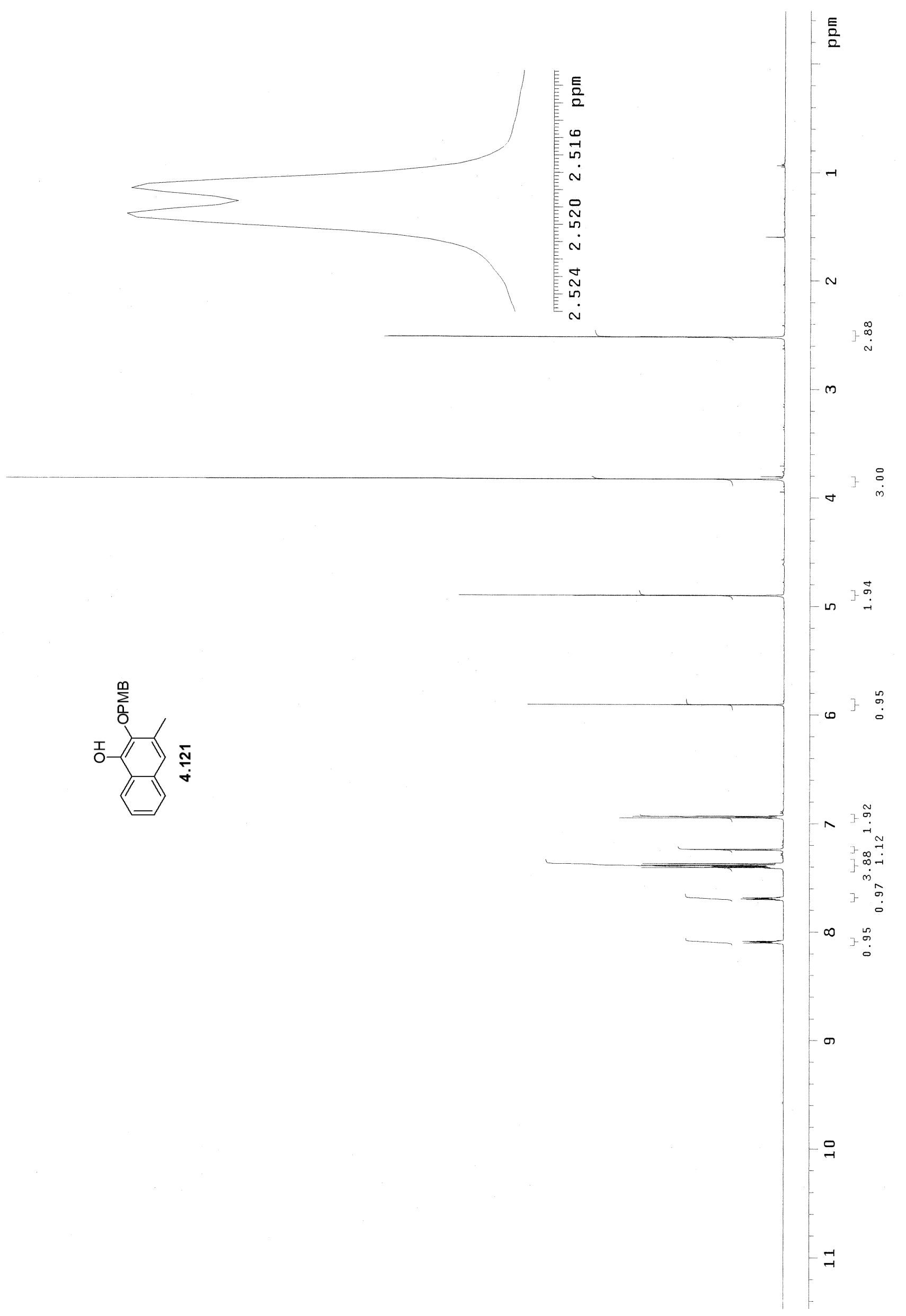




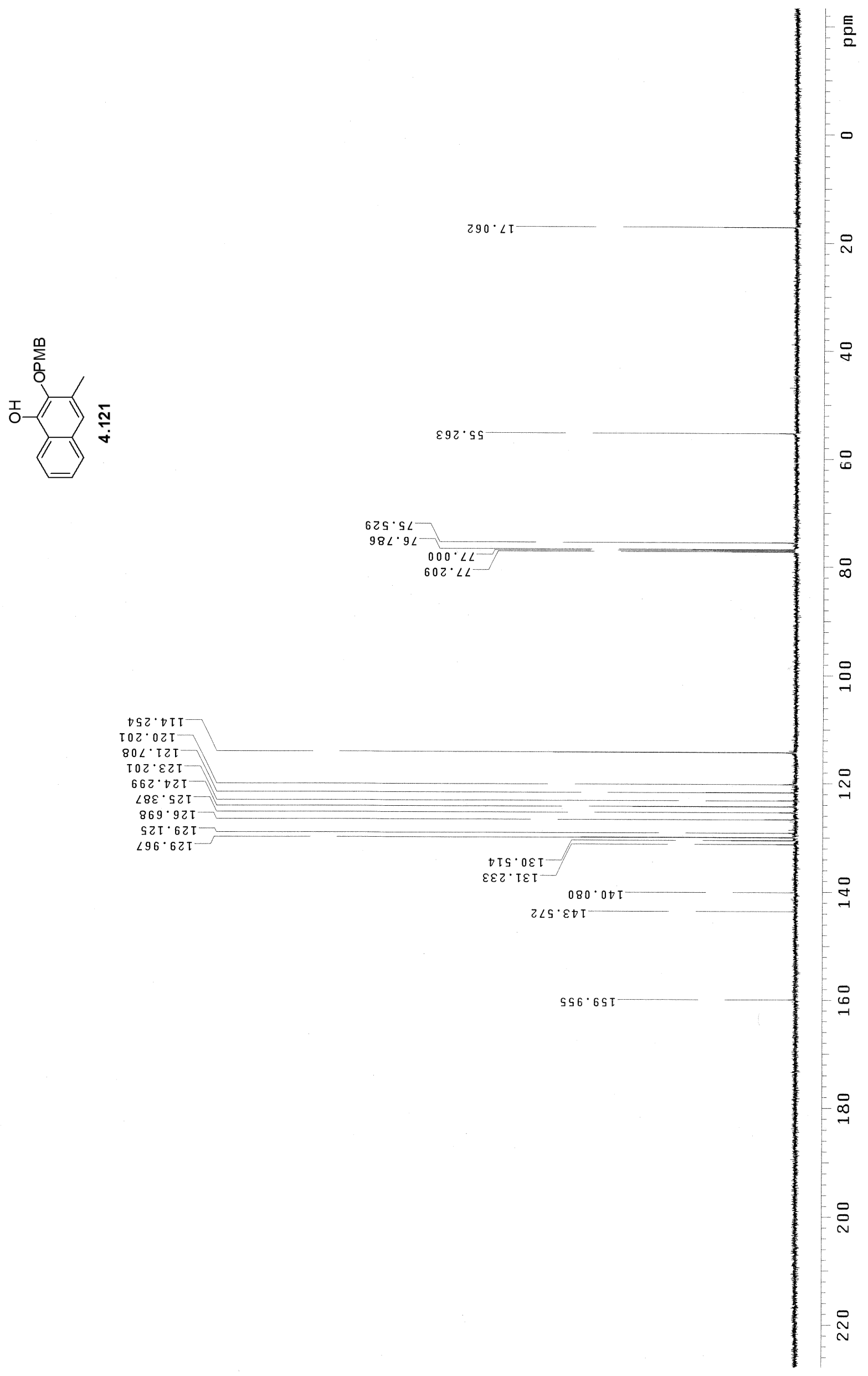




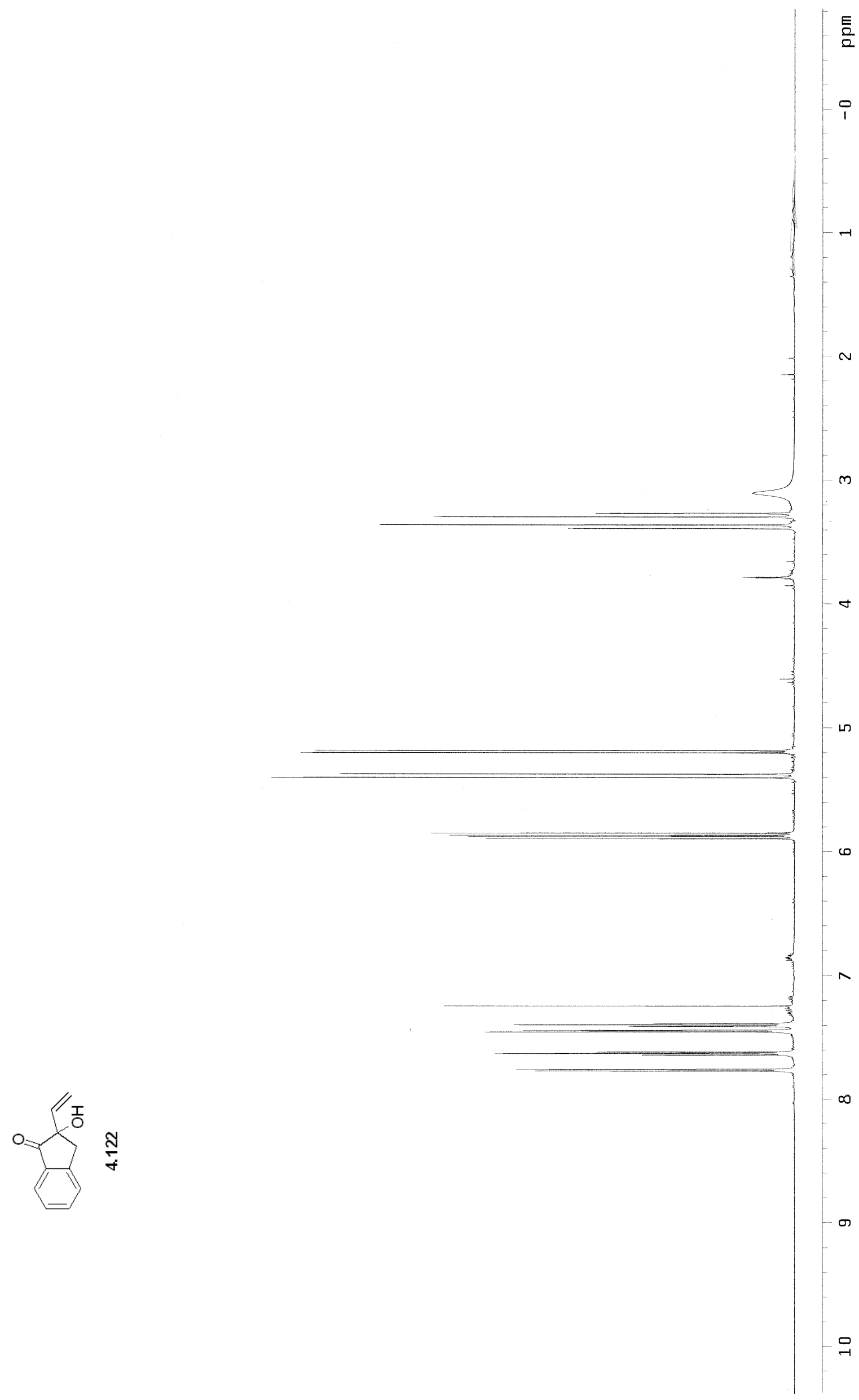




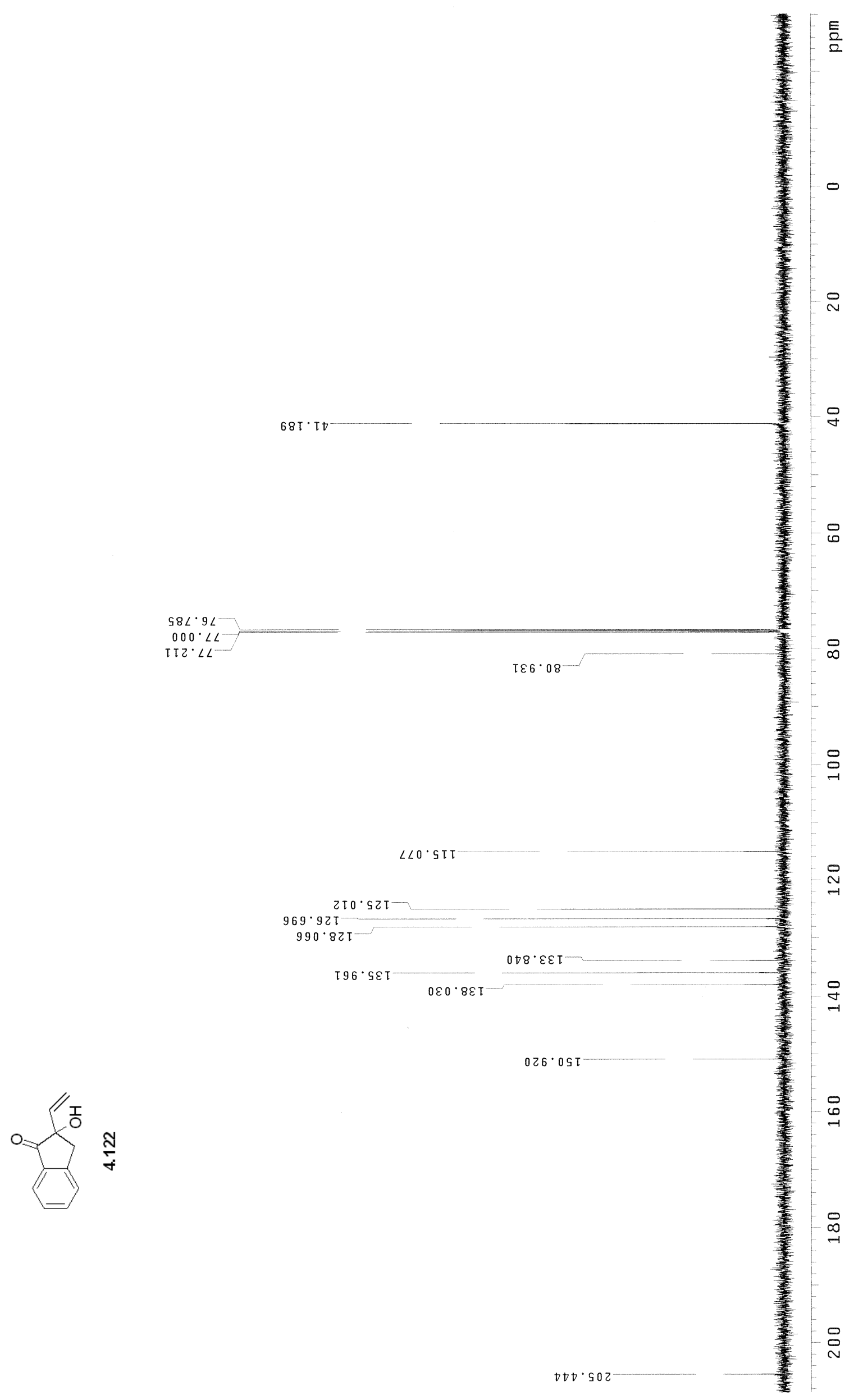




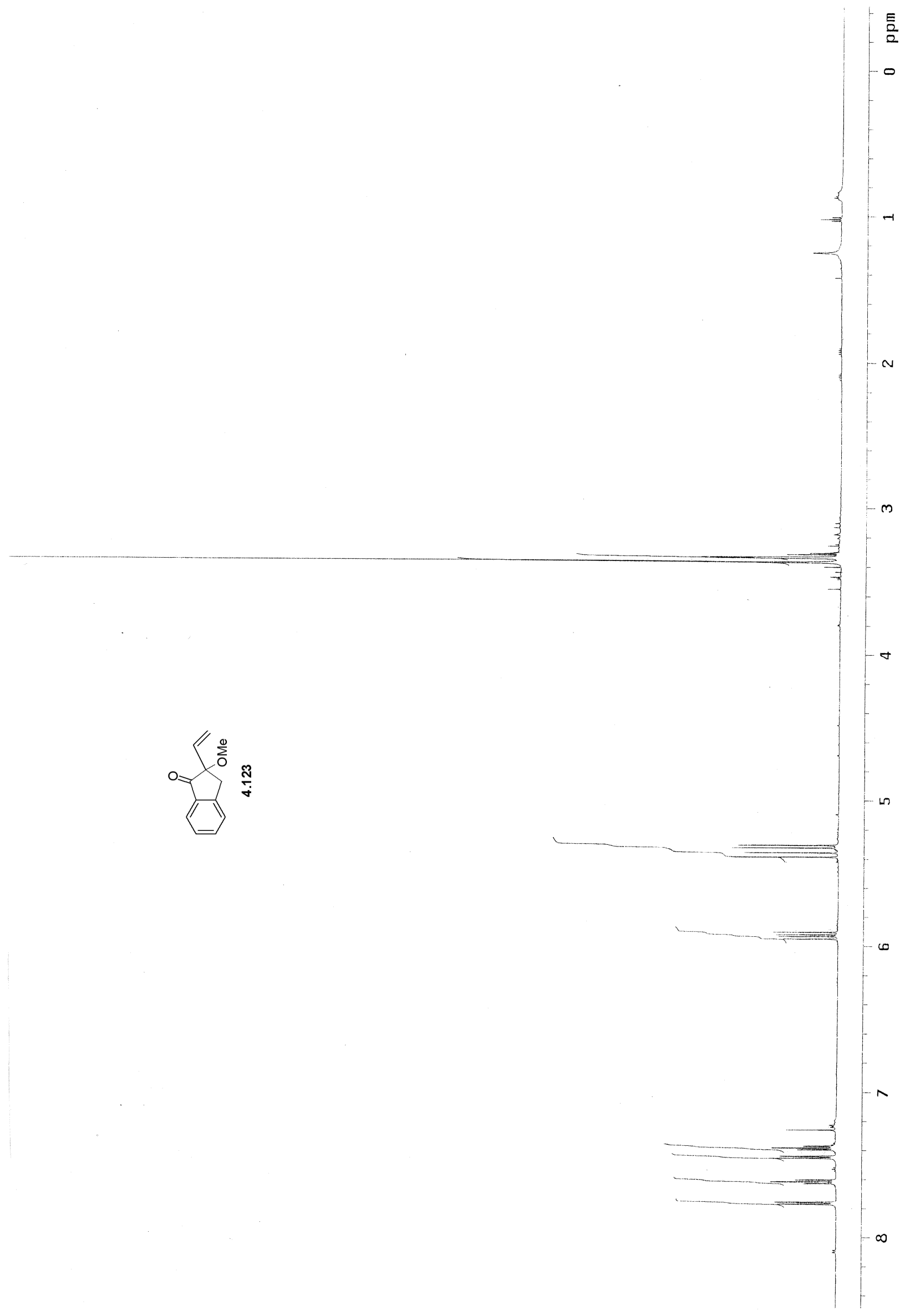




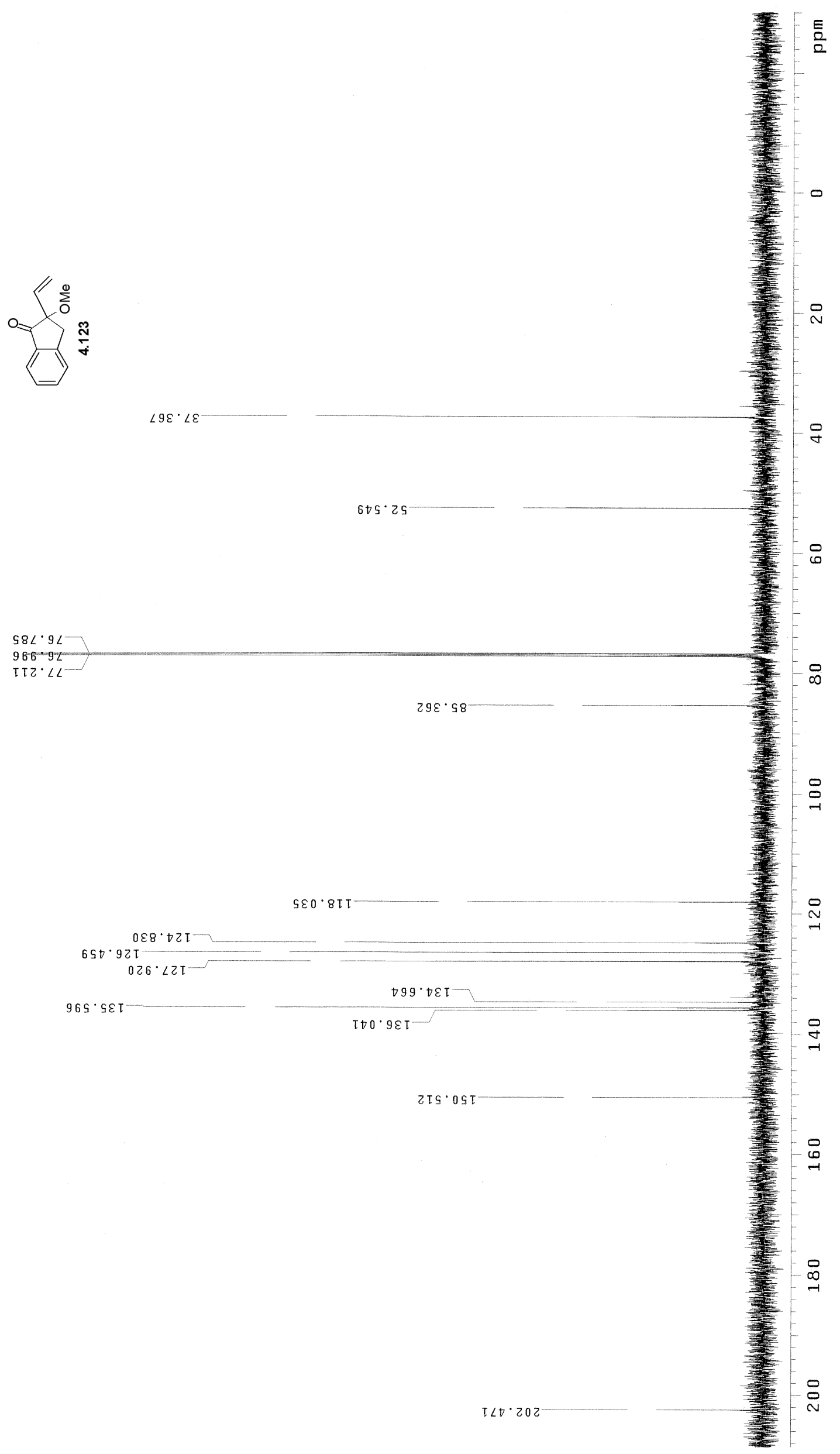




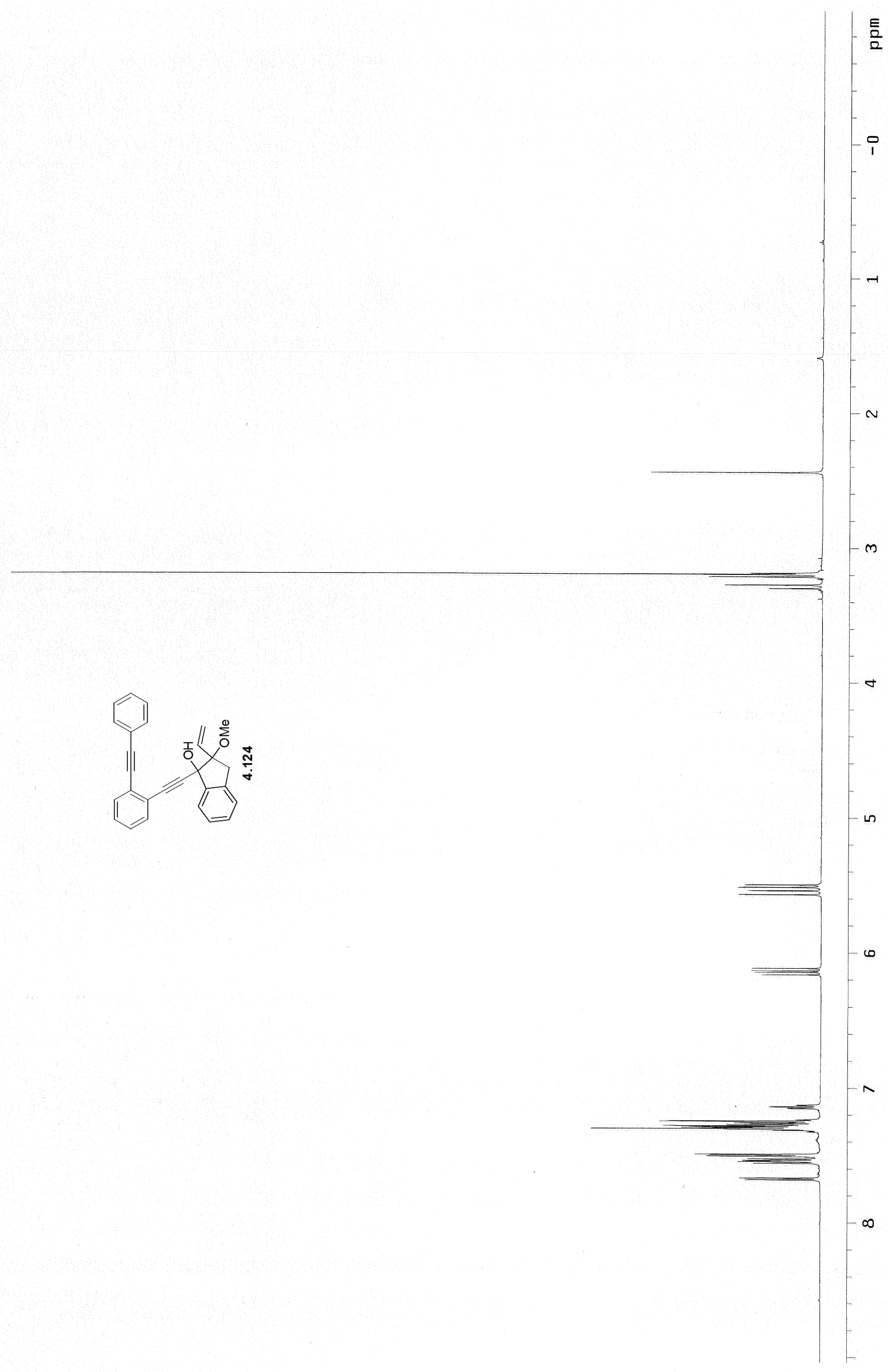




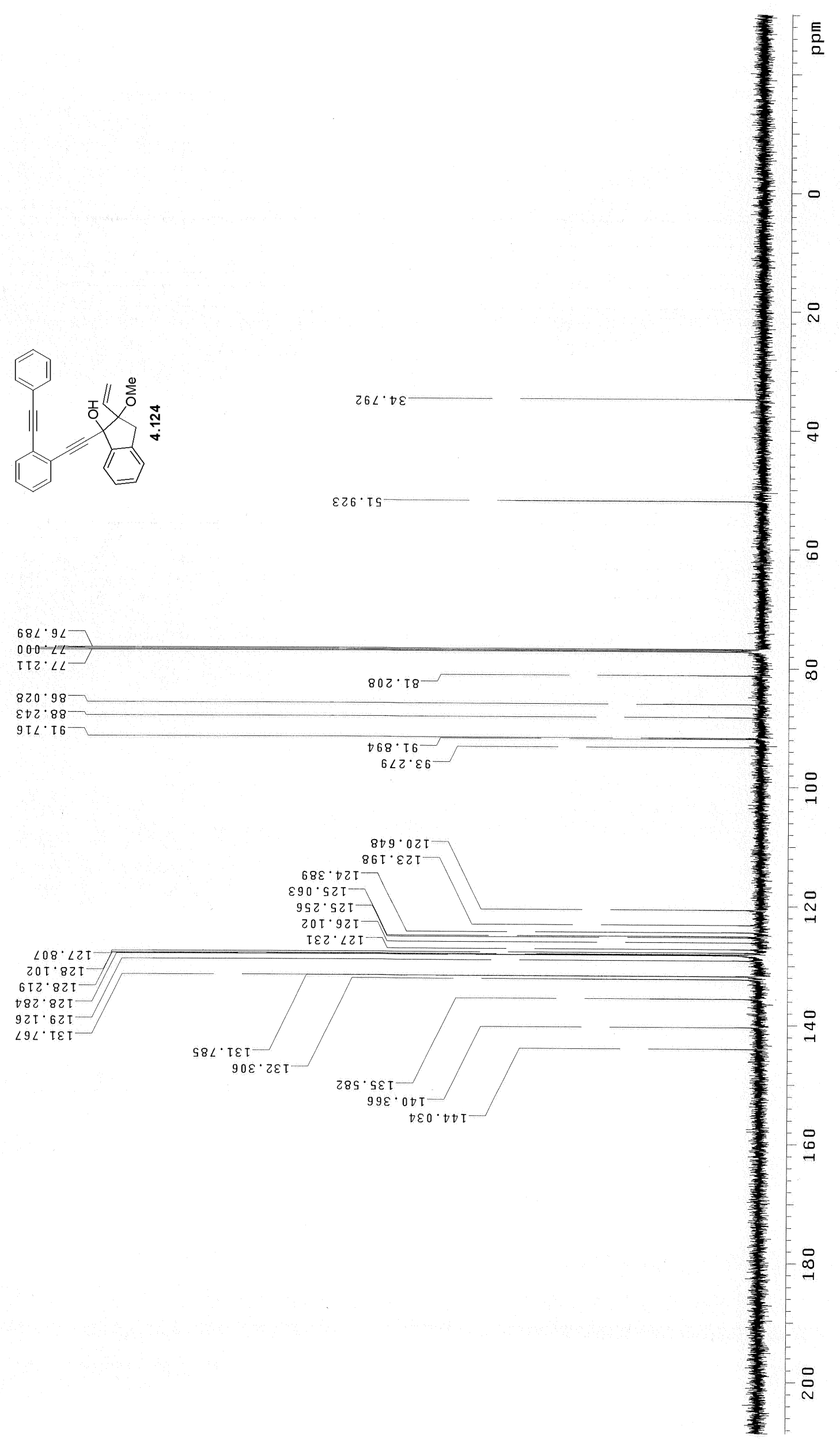




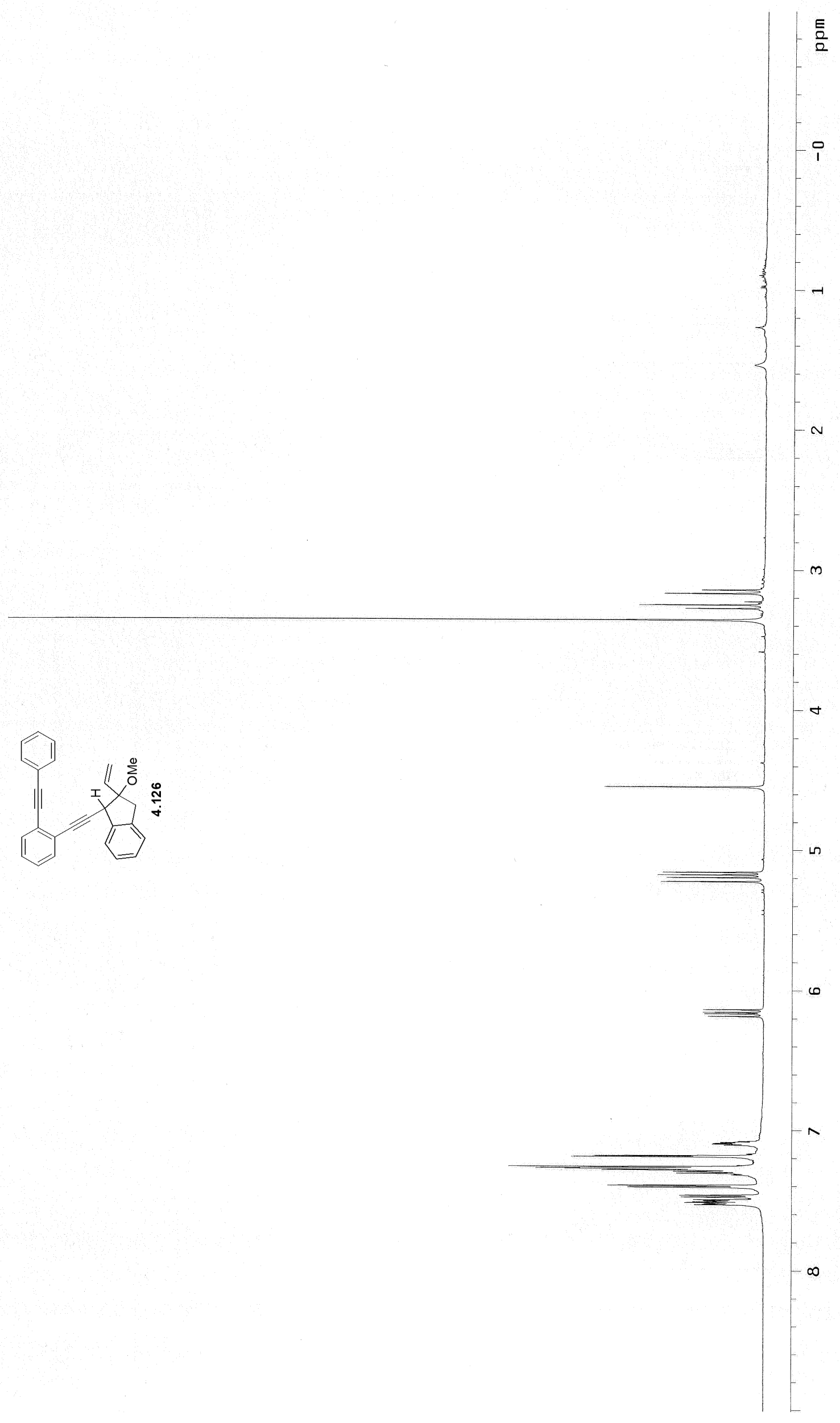




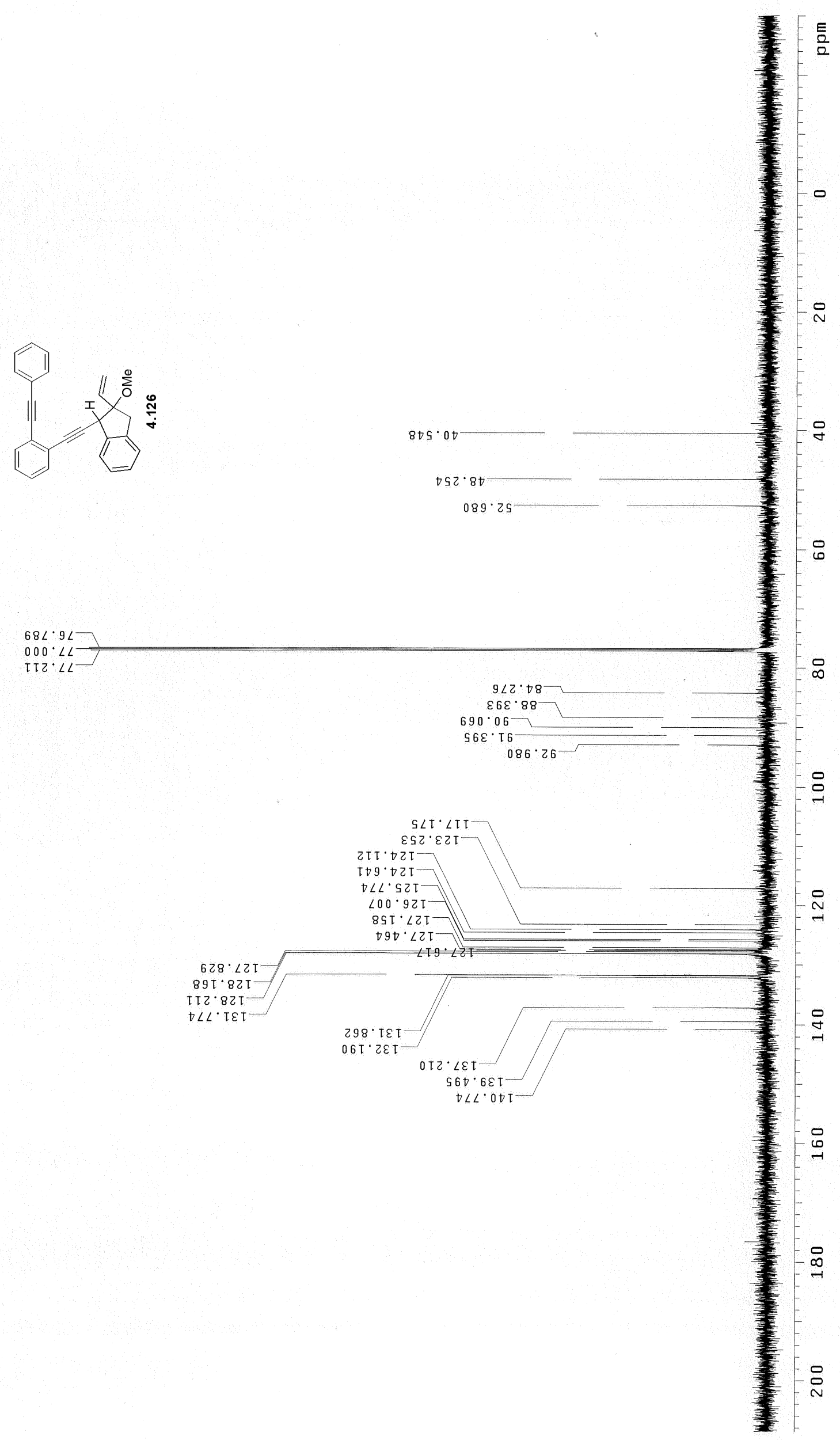




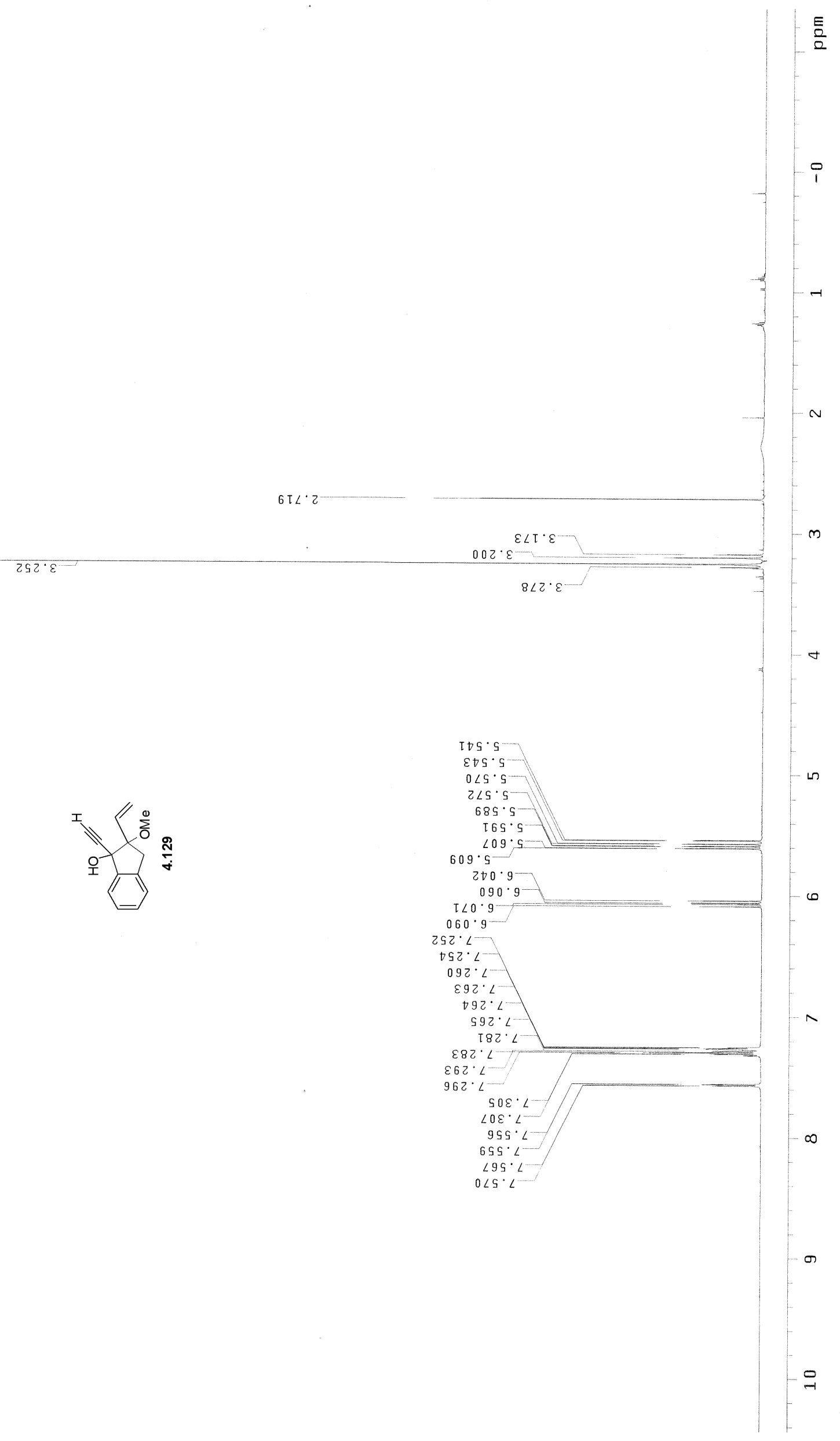




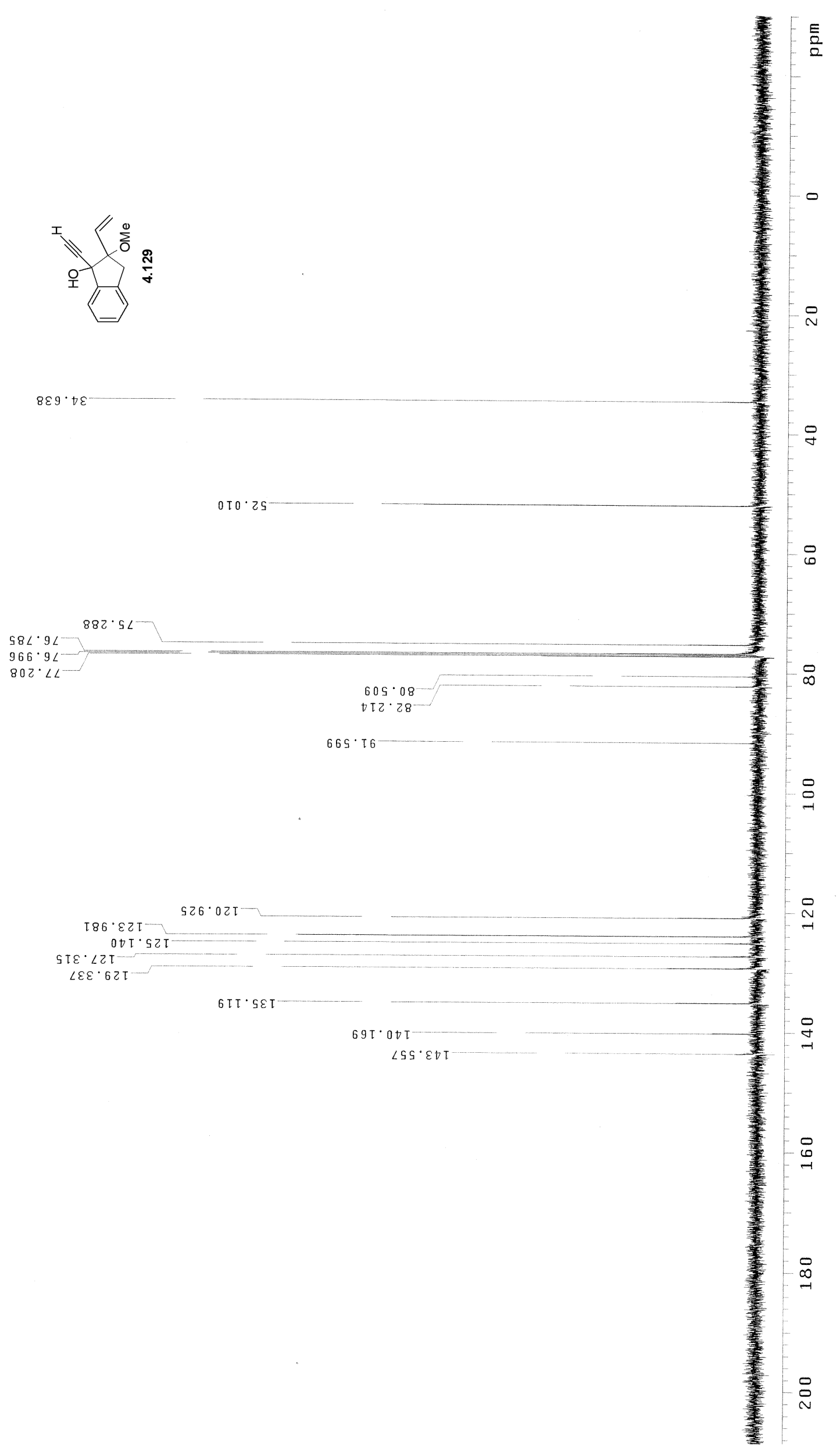




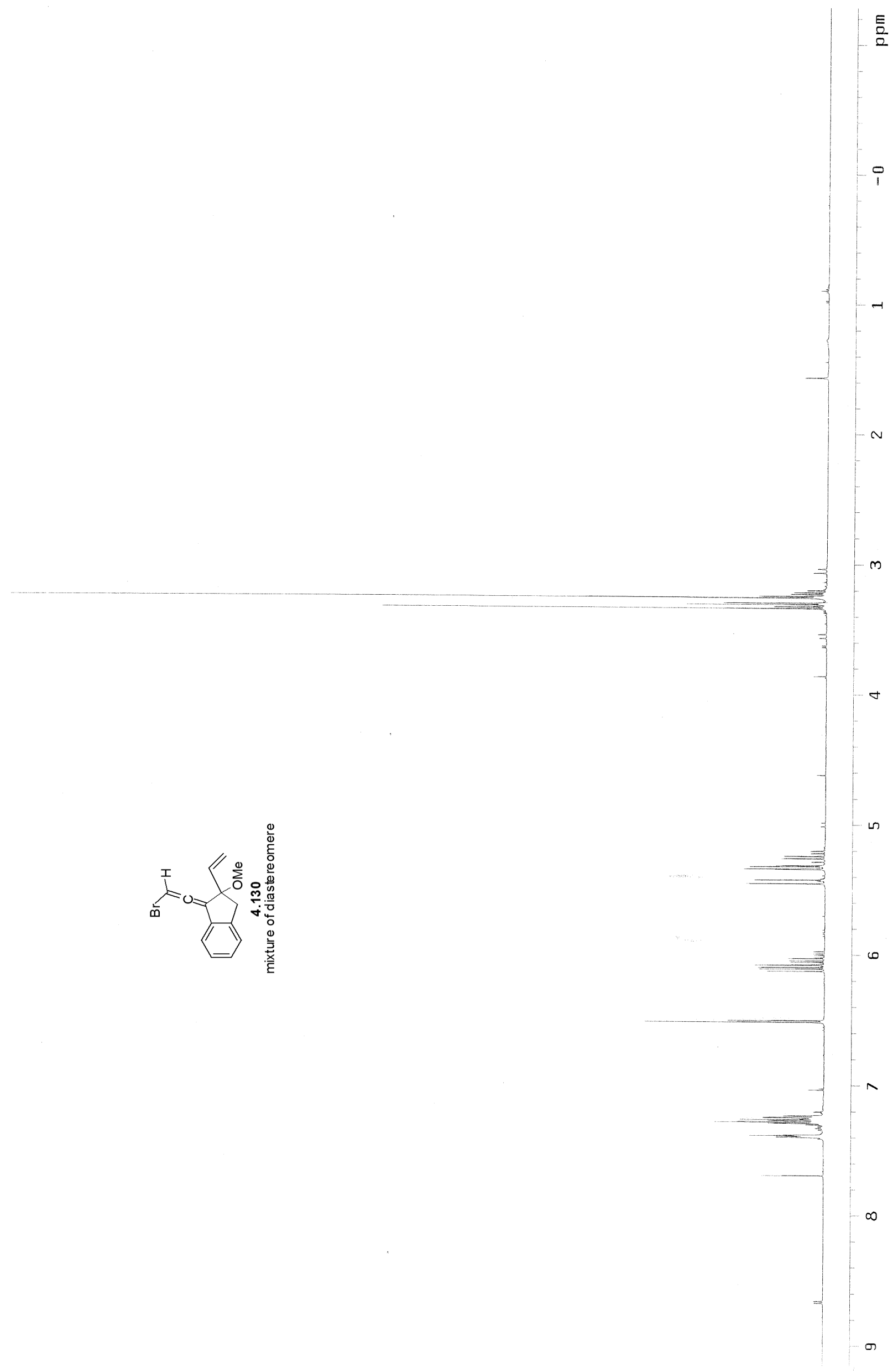




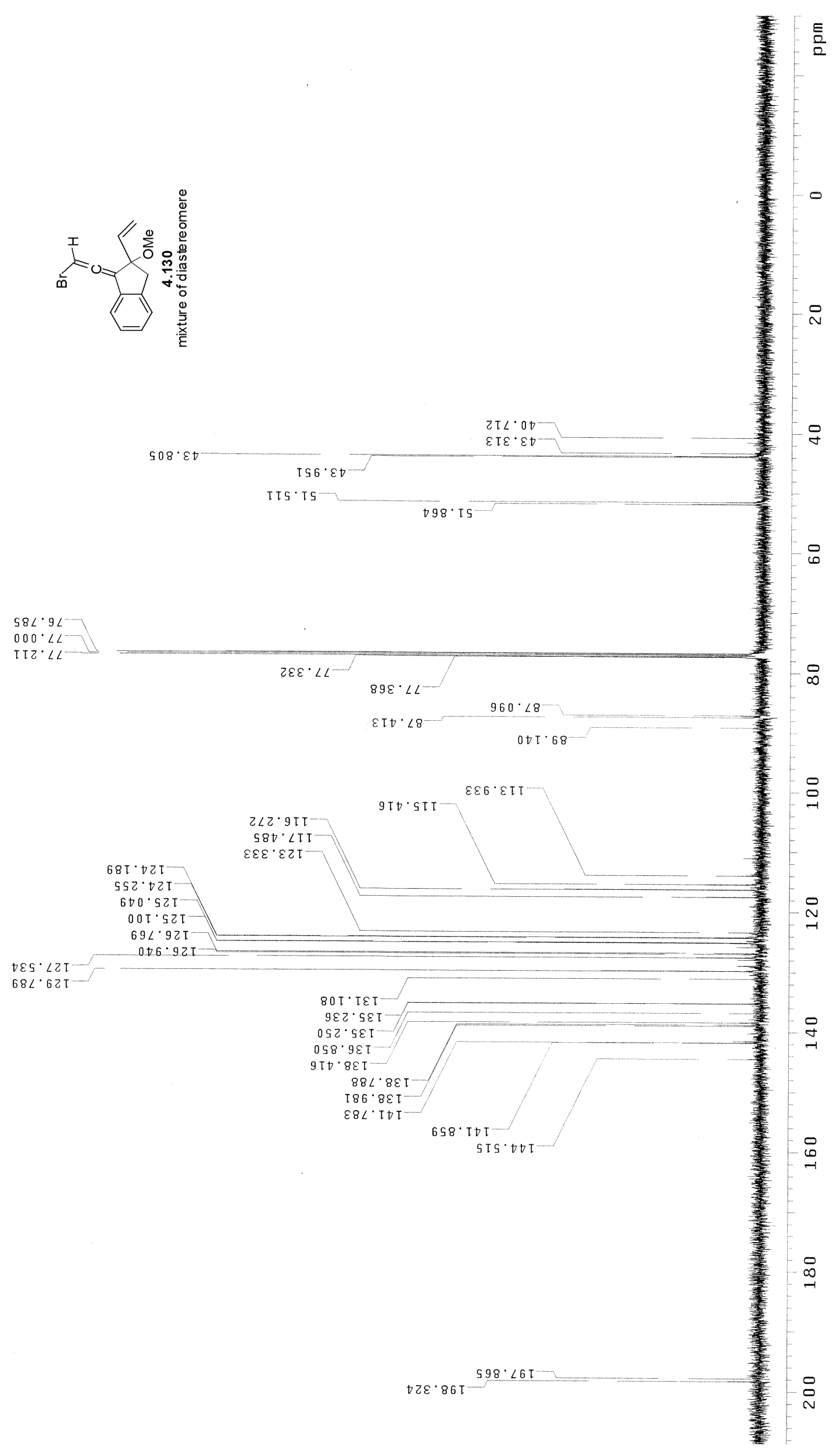




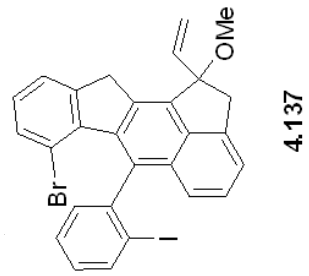




\section{Publications}

- $\quad$ Wen, B.; Petersen, J. L.; Wang, K. K. "Synthesis of 4,5-diheteroarylphenanthrenes and their dinuclear ruthenium(II) bis(2,2':6',2"-terpyridine) complexes possessing severe helical twists" Chem. Commun. 2010, 46, 1938-1940.

- Wang, K. K.; Cui, H.; Wen, B. "Synthesis of bowl-shaped and basket-shaped fullerene fragments via benzannulated enyne-allens" in Fragments of fullerene and carbon nanotubes: designed synthesis, unusual reactions, and coordination chemistry; Petrukhina, M. A and Scott, L. T., Eds.; John Wiley \& Sons, Inc, 2010, in print.

- Wen, B.; Petersen, J. L.; Wang, K. K. "Synthesis of 1,4-naphthoquinone methides via acid-catalyzed cascade cyclizations of benzannulated enediynyl alcohols" Org. Lett. 2010, Published on Web. DOl: 10.1021/ ol 102793a

\section{Presentations}

- Wen, B.; Petersen, J. L.; Wang, K. K. "Synthesis of 4,5-dihetroaryl phenanthrenes possessing severe helical twists" $236^{\text {th }}$ ACS national meeting, Philadelphia, PA : Aug 2008 .

- Wen, B.; Parbin, E. S.; Wang, K. K. "Synthesis of a partially hydrogenated $4 \mathrm{H}$-cyclopenta [def]phenanthrene via a benzannulated enediynyl alcohol" $238^{\text {th }}$ ACS national meeting, Washington, DC : Aug 2009.

- Wen, B.; Petersen, J. L.; Wang, K. K. "Synthesis of p-benzoquinone methides via benzannulated enediynyl alcohols" $240^{\text {th }}$ ACS national meeting, Boston, MA : Aug 2010. 